
Digitized by the Internet Archive in 2017 with funding from University of Toronto 



$$
(25)_{(1167 m}
$$

Tholrim

Ho Thomas Searson of the fews As a Mernorial of his Brother Villicinnsearson.

With the hind regards of

A.P.

Bordertide

Jamnany $4^{\text {th }} 1864$. 


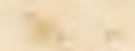

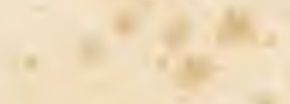

$+2$

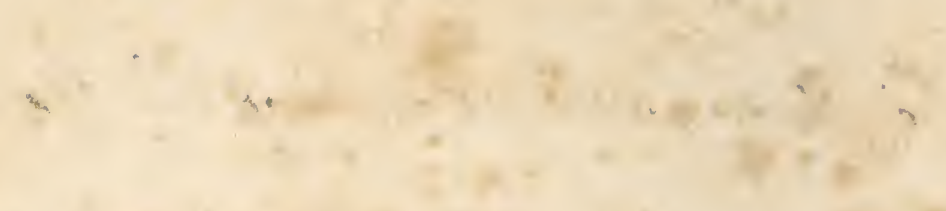

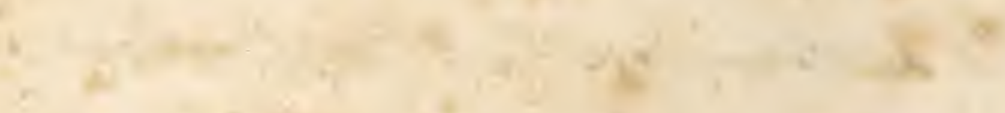

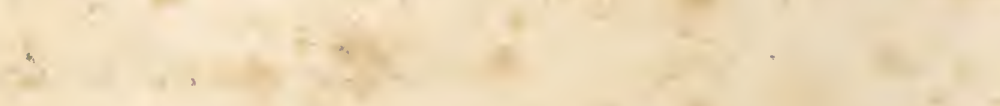

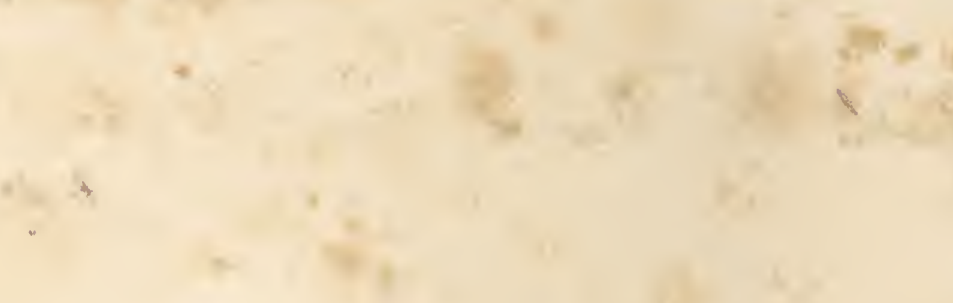

$$
\begin{aligned}
& +3 \text { is }
\end{aligned}
$$

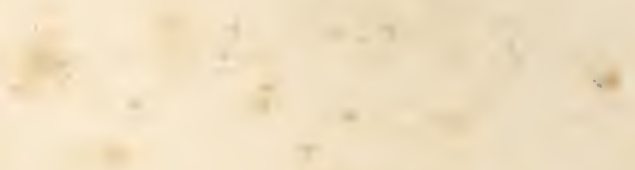

$$
\begin{aligned}
& \text { a }
\end{aligned}
$$

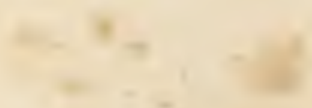

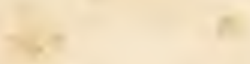

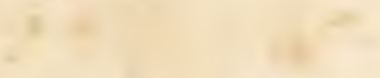

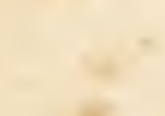$$
+4
$$$$
\cdot
$$

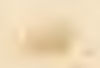

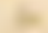

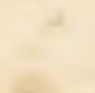

$\sqrt{2}$

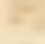


Hacosertat 


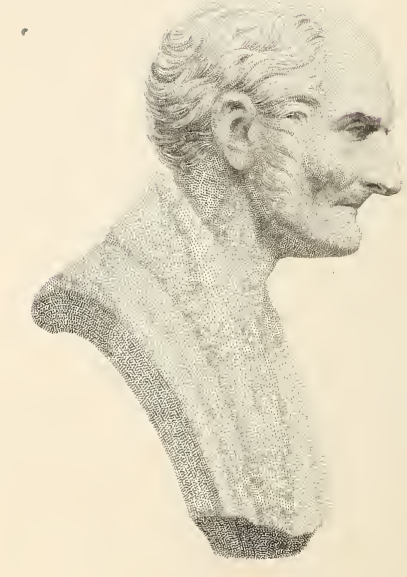

Ean faithqully sunso. Widiarton.

T Ducirect. Sculptor

W. Dickes, Engre Loncin 




\section{PAPERS LETTERS AND JOURNALS}

$\mathrm{OF}$

\section{WILLIAM PEARSON.}

III

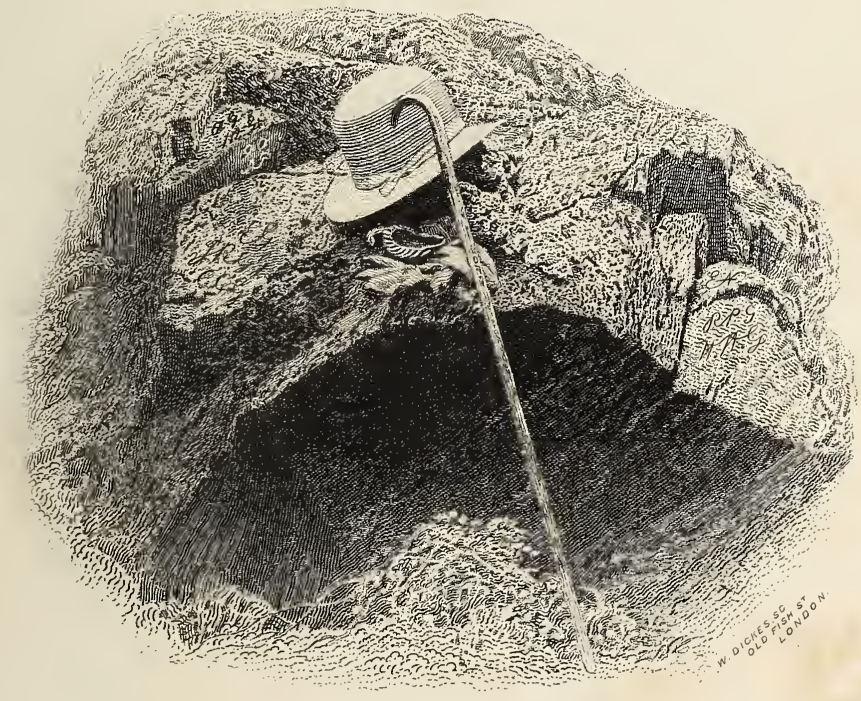

EDITED BY HIS WIDOW.

\section{LONDON :}

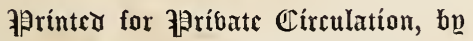

EMILY FAITHFULL,

Printer and Publisher in Ordinary to Her Majesty, VICTORIA PRESS, PRINCES STREET, HANOVER SQUARE. 


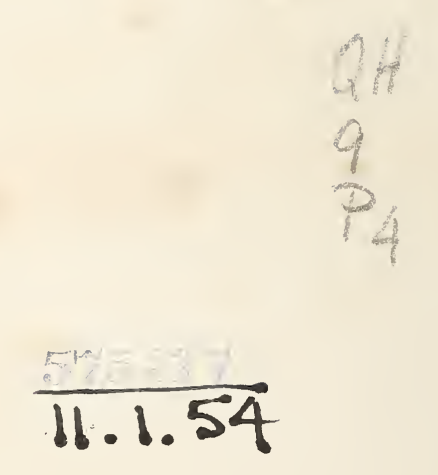$$
11.1 .54
$$ 


\section{CON T E N T S.}

MEMOIR

PAGE

Lines in Memory of William Pearson - $\quad$ - $\quad$ - $\quad$ - $\quad$ - $\quad$ - $I 75$

Sketch of some of the existing and recent Superstitions of Westmorland. I84I I

Continuation of the Subject. $184 \mathbf{I} \quad$ - $\quad$ - $\quad$ - $\quad$ - $\quad$ - $\quad 24$

Notes on Natural History, chiefly relating to a few of the Wild Animals and Birds in the neighbourhood of Crosthwaite and Lyth. I839 - - -

On Certain Changes that have taken place of late years in a part of the Lake District. I844 - - - - - - - - - - - 7

Notices on a few subjects in the Natural History of Crosthwaite and Lyth; with an Allegory. I849 - visit to firtyerland

A few Notes in Natural History, with Sketches of the Character and Habits

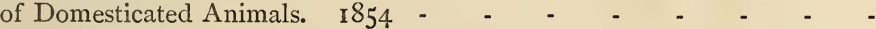

The Partridge, I846, and a Letter to $\mathrm{Mr}$. Gough, containing some Notices of Wild Rabbits, Cais, \&c., Le iter from _G hanles. Watertion. - I44

The Squirrel. I 846 .

\section{races conts}

The Wood Grouse. 1850

- IGI

The Hag Worm. 1852 - $\quad$ - $\quad$ - $\quad$ - $\quad$ - $\quad$ - $\quad$ - 164

A few recent Notices in Natural History. I855 - - - - - - 167

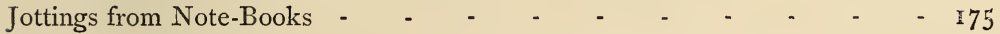

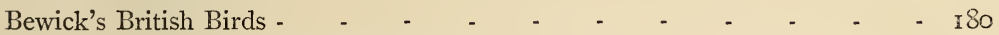

Walton and Cotton's Complete Angler - - - - - - - $\quad$ - 85

An Account of a Pedestrian Tour through a part of Derbyshire. 1817 - - 195

Some Account of a Journey into Scotland. I822 - _ _ _ - _ . - 234

Kean's Hamlet - $\quad$ - $\quad$ - $\quad$ - $\quad$ - $\quad$ - $\quad$ - $\quad$ - $\quad$ - $\quad$ - $\quad$ - 272

Sketches from short Journals, between the years I82I and I854 - - $\quad$ - 274

Wordsworth's Protestantism. I854 - - - - - - - $\quad$ - $\quad$ - 295

Letter to John Davy, Esq., M.D. I856 - - - - - - . - 300

Conclusion of a Paper on Glaciers. $1845 \quad-\quad$ - $\quad$ - $\quad$ - 306

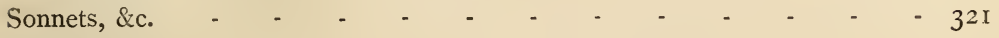

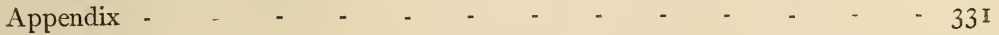





\section{P R E F A C E.}

IN this attempt to give a more permanent and accessible form than that of manuscript, to some of the papers and letters of my dearly beloved Husband, I have found encouragement in the thought, that this volume would prove a source of interest and enjoyment to his Brothers and Sister; and that to the younger branches of the family, it would be not only a Book to be loved, but also, a means of culture ; by the sweet pictures of Nature it would place before them,- the tenderness of feeling it would disclose-and the stimulus it would give to thought, by the new ideas it might impart.

I could not however, have gratified my cherished wish of reproducing these Letters and Papers in print, had I not felt a strong assurance, that my dear Husband's sanction would not have been withheld; and in this conviction, I recognised my warrant to carry out the project as soon as circumstances should allow. A most welcome and unlooked-for incitement to proceed with the work was also accorded to me, and it likewise came with the weight of an additional authority. This was the opinion expressed by two valued Friends, that the Papers and Letters ought to be published, and their estimate of them, I may here allow myself the gratification of recording.

Mr. Thomas Gough of Kendal, my Husband's dear and esteemed friend, in whose love of the animal creation he largely participated, and who as a genuine field-naturalist, and a devoted scientific observer, is well qualified to judge of the worth of the letters on subjects of Natural History,- - urged on me the desirability of publishing them. He pronounced them to be "well worthy of publication for their beautiful, simple style," and added, that "they rank with those of Gilbert White, which cannot be said of any others since his day."

The Rev. Robert Perceval Graves, of Dove-nest near Ambleside, another friend greatly endeared to my Husband, through many years of delightful intercourse, by similarity of literary tastes,-and more, much more, by congenial sentiments and aspirations-expressed to me soon afterwards, the same wish. He thought it would be matter of regret and loss, were compositions so marked by a rare simplicity and beauty of style, to be allowed to fade away at once into oblivion; and he also suggested that a brief Memoir should accompany them.

The conclusion arrived at, was to print a volume for private 
circulation-thus it will go forth, endowed with a domestic character, to attract to itself domestic love; and let this gather around it!

To a few of the more intimate circle of my Husband's friends, I fondly believe this Volume will be welcome. They who still tread this lovely Earth, with the same admiring, loving, trusting, adoring spirit, will perchance recognise in it, a living bond of union with him, who peacefully sleeps in its bosom.

In the capacity of Editor, I have confined myself chiefly to making a selection; and I have, besides, omitted passages, and in some parts, changed the arrangement a little, in order to bring together portions that treat on the same subject; this, with a few verbal corrections, where incidental errors called for them, leaves the "Papers, Letters and Journals," substantially as I found them.

A. P.

BORDER-Side, May 5th, I863.

"Let us in His sight accomplish our petty, particular doings." 


\section{MEMOIP OF WILLIAM PEARSON.}

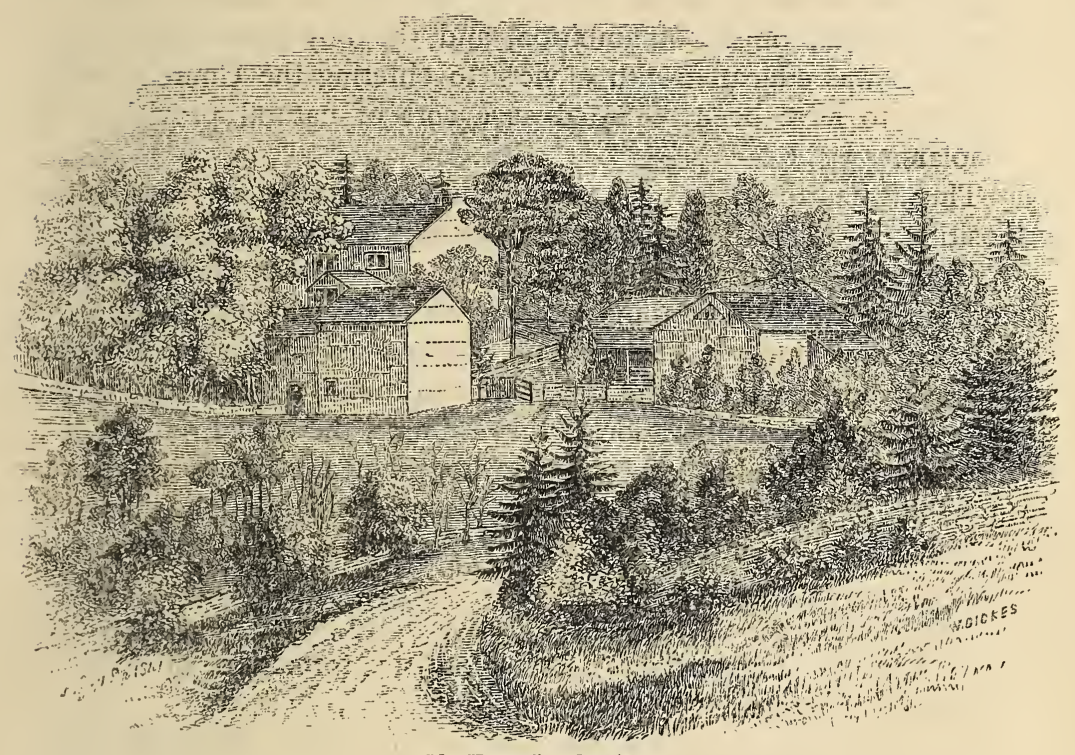

The Yews, Crosthwaite.

\section{CHAPTER I.}

The Yews, the patrimonial estate of the Pearson family, is situate in the central part of the township of Crosthwaite and Lyth, Westmorland; here, in the old house, which stood in the present fold, William Pearson, the subject of this Memoir, was born on the 9th of October, I780. His father, John Pearson, who was an only child, had eight children; the eldest, a daughter, died before the birth of William, who was the second child, and named after his paternal grandfather.

The family takes its position in the rank of Yeomen, or, to use the local term, Statesmen - a class that is gradually lessening, which fact, as tending to the extinction of a valuable and beautiful link in the social chain, is much to be deplored. Modern usages, which insinuate themselves into the most secluded valleys, are not without their hurtful influences; and of the simple manners and primitive mode of life of the forefathers, few examples are now to be found. The little holdings which had for generations descended from father to son, and which had thus served to nurture a self-respecting, manly, and 
independent spirit, pass by degrees into the hands of the larger landed proprietor. The primitive Statesman had a good deal of shrewd intelligence, derived from the necessary transactions of market and fair, and a sufficient amount of cultivation, to fit him for taking a share in parochial business; and in this part of the county, scholarship-either for itself, or for its results-seems to have been an object of ambition, and the boy who was " a good learner," was educated with a view to entering the Church, which appears to have been regarded as a sort of natural provision for scholars.

Thus, when the habits of the individual were sober and steady, the position of the small Statesman was far from being a mean one; and William was wont to remark, that the transmission of the few prized acres from father to son, indicated some sterling qualities-and the writer here willingly testifies to a prevailing sense of honour, as a trait of the labouring part of the population all round, on this edge of the county ; and in corroboration of this estimate, the casual remark of a clergyman of standing and repute, who, for nearly twenty years, was in habits of pastoral and friendly intercourse with the inhabitants of a wide-spread country cure, hard by, suggests itself- "The poor people in this part are all gentry."

This digression, at the very outset, is introduced as setting forth what had no unimportant bearing on the formation of William Pearson's character.

His Father was a peace-loving man, of quiet and retiring habitsnot prone to censoriousness, but regarded as one who spoke no evil of his neighbour. His natural abilities were above the average, and his thirst for knowledge impelled him to devote all leisure moments to reading-moments emphatically, for small leisure has the farmer. At meal times, his habit was to take up the ever-ready book; neither household noises, nor domestic movements distracted him-but as the warm weather advanced, the chair by the hearth-fire in the house was deserted, and he withdrew to his bed-room. He had a natural aptitude and an irrepressible inclination for the study of medicine, and read such books on the subject as he had access to. This predilection, guided by his practical bias, and aided perhaps by a prudential feeling, directed his mind to the veterinary branch of the science, and he acquired a theoretic knowledge, as well as practical skill, which sufficed for the treatment of his own stock, and was at the command of his neighbours.

His reading was not however confined to his favourite subject; he was a member of a Book Club established at Kendal, and without the stimulating influence of educated associates, and only by means of selfdenying frugality obtaining the benefit of books, this worthy student 
acquired a power of clear thought and expression, of which examples will be supplied from letters, treasured up by his son William, to whom they were addressed.

He had a long-established habit of going out to gaze on the heavens, before he retired for the night; the infirmities of age at length deprived him of this elevated enjoyment, which was, with him, an expression of devotion, as well as a means of sustaining it. Three years before his death, a stroke deprived him of the power of walking, and from that time, he could only move about as wheeled in his chair by one of the family. He died in March, I840, when William sent the following notice, for insertion in the Kendal Mercury.

"Died on Friday, the 2oth inst., Mr. John Pearson, of the Yews, Crosthwaite, near Kendal, aged eighty-one. For the last three years of his life, he had been very infirm; but he showed the greatest patience and resignation to the Divine Will. We could say more,much more, but

The lingering dream of their departed lives
To oral record, and the silent heart,
Depository faithful ; and mankind ,',
Their fondest Epitaph

William's mother, whose maiden name was Little, was a Cumberland woman-from the Border. Her father and grandfather were born at the Hollowes near Brompton, which was her birth-place also; and her family, like that of her husband, were farmers.

She was well-versed in folks-lore, and William never forgot the fascinating power of her fairy-tales, which would lose nothing of their charm from being heard along with the murmur, which the Poet tells us, was

$$
\text { "Soft as a Dorhawk to a distant ear," }
$$

For the mother span on the flax-wheel,

$$
\text { " To household virtues Once so dear }
$$

The imaginative element in her nature, did not, however, by any means overbear the practical. She was quick, intelligent, and remarkably energetic, and when between seventy and eighty years of age, had not given up attending the market; and many a time, though the horse ready saddled, stood at the door, she would take up the butterbasket, containing from 20 to 3 olbs. of butter, and ejaculate, "nay, hang it, I'll never fash with it," and set off on foot to Kendal, a distance of six miles, and after standing the market, and shopping, would walk home again with her purchases. Sometimes she admitted she was tired, yet after tea she was ready to walk up the hill to Hubbersty Head, to talk over the markets at her son John's. 
The following memorandum of her death is copied from William's Note-book. "Friday, I 8th March, r842. On this day my dear Mother departed this life. The complaint that caused her death appears to have been brought on by cold. She became unwell about Christmas, and gradually became weaker. Although we do not know her age exactly, yet when I was in Cumberland in 1834 , I was informed by my uncle Archy's widow, that she was at that time upwards of eighty, so that if this be correct, she must have been in her eighty-eighth year."

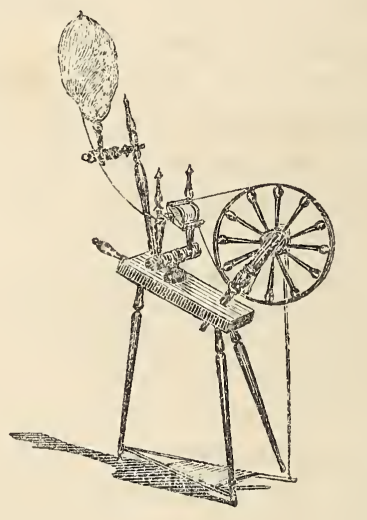

CHAPTER II.

WILLIAM appears to have partaken of the temperament of both parents, and the home-atmosphere nourished in him inherent capabilities, which in after life were developed into a marked individuality.

No childhood is so unconditionally surrendered to the training of Nature, as that of a rustic boy. Unreproved, he is permitted to follow the instincts that lead him to this true, faithful, gentle instructress-and with open arms she welcomed the little William, breathing over him silently, that benison which was, ere many years had passed over his head, to find utterance in lyric strains, poured forth by the Bard of the coming age, for all those who should have ears to hear.

\footnotetext{
"This child I to myself will take;

$\mathrm{He}$ shall be mine; - with me The boy, on rock and plain, In earth and heaven, in glade and bower, Shall feel an overseeing power, To kindle and restrain."
}

Inspired by her inward promptings, he wandered with Nature through all seasons of the year, and at every hour of the day-ay 
and of the night too, on occasion-unconsciously feeding a deep, secret spring, from which, to the last, was to well out perennial joy, according to his need.

When advanced in life, and lamenting, as sometimes he would, his want of classical learning, the system of compensation was operative even for this case-for would he ever have consented to relinquish " the world of wealth" which Nature had bestowed, in exchange for the treasures of "all the Sages"? No! assuredly no! for through all the years of his lengthened life, the spirit of earnest deprecation that breathes in this animated line, was his,

"Think not of any severing of our loves!"

Only regard that tiny boy intent on capturing Trout, wriggling through the covered drain which conveys the runlet across the road at High Birks - and then contemplate in the latter half of the following century, that slight, supple, erect figure, stealing down the path from his cottage on the rock, and wending his way, pannier on shoulder, rod in hand, to his ever-loved Winster-see him doff shoes and stockings and wade the beck to disentangle his line-and own the wonderful power of that spirit to shed a precious blessing on childhoodto transmit a precious privilege to old age!

The freedom of range afforded by the unenclosed commons, which stretched for miles in some directions near to the Yews, must have greatly fostered the spirit of boyish enterprise. His introduction to Windermere made a lasting impression on his mind. The walk, in company with his father, over Cartmel-fell, not yet enclosed and planted - the boat, the oars, the passage across the lake and backall the adjuncts of the expedition, combined to form an epoch in his young life.

But he is to be brought into contact with still more stirring influences, calculated to reach beyond the senses, and to touch the moral and religious feelings. He is to be his mother's "one companion child," on a visit to the Cumberland relations. The journey is to be performed on horseback - the time, probably, after the harvest, but before the days were yet too short.

Let us attend the pair up the pastoral valley of Troutbeck, with its elevated groups of antique dwellings, and its beck, as it gushes among the tumbled blocks, or sparkles over the sandy shallows, sending up its voice in the cool morning. This beautiful variation of the homescenery, would cast a spell of wild contrast, over the bald, precipitous Red Skrees, and the desolate gorge of Kirkstone pass-but before entering the defile, once more the boy descries Windermere-now seen in all its amplitude, winding far away sea-ward.

But they must not linger-proceeding northward, their route-never 
far distant from that feeder of Broader Water which takes its rise in the Pass-is now shut in on both hands, by the lofty mountain boundaries of Patterdale; and the boy, joyously as the wild stream itself, bounds along, crossing it from side to side, or stands to look into the pure water, where, breaking against the fretted rocks, it bears onward myriads of bubbles into the still, blue pools, that indent its margin.

Then, the grotesque transformations of the mists as they sweep along the tops or the flanks of the mountains; or the race of the cloudshadows passing over the little fields which they are approaching, would attract his wakeful observation-and the rippling, transparent, and now classic Goldrill, would usher mother and son, into that vestibule, which brings the boy for the first time, face to face with the august mountain-temple, of which Helvellyn is the High Altar;-and as his eye wanders up the solemn and mysterious coves of the mountains, who may weigh or measure the undefined feelings and ideas that are moving confusedly within-yet, destined by future processes, to be blended with his habitual consciousness.

But now we lose sight of the fellow-travellers, and consign the boy to the soothing inspirations of Glencoin and Gowbarrow-though not without the assurance, that his "heart will leap up" at the sight of that vision of splendour which spans the narrow lake with many coloured arc-or that he will be moved to ecstasy by that novel and startling sight-a herd of Fallow Deer, as the timid and graceful creatures glance away beneath the trees. Some at least, of these speculative possibilities would be realities to William; in after life, to be lighted up by the magic of imagination, into pictures of more than earthly beauty.

It is not clear whether it was before or after this journey, that the wholesome restraints of school, were first brought to bear on his ad libitum way of life-but Crosthwaite school, at that time not held in much repute, was that to which he was first sent-and the following account of school life, written by him for the Lonsdale Magazine, was doubtless that of his own boyish days at this school. (Mr. Southey, who was ever prompt to encourage meritorious men like Mr. Briggs-pointed out to him with commendation, some of William's contributions to his Magazine.)

He writes, "As to the reign of — it is so far removed into the mists of antiquity, I can recollect little, save only the memorable day of my first going to school; the noise-the number of boysbut above all, the awful master, arrayed in his wig and three-cornered hat. This day I can never forget. Bashful and rustic boys have here in learning to write, formed their first hay-crooks-have here studied the sublime science of "two and two make four"-and bit their nails over the mysteries of the multiplication table. I see all my 
light-hearted, rosy school-fellows-our out-of-door, and our in-door diversions-our social noisy scampers at Black-thorn or Bandy, or foot-ball! or the indescribable interest of scun-cap-our quieter games, such as marbles, copy-crown, \&c., our bargainings, and barterings of marbles, knives, apples and pears, of which last, many a fine one have I had from the lasses, for solving their questions in arithmetic-a dry business, at which I have observed female heads are not apt! We had also catch, prison-bars, and a game called 'getting up to th' King.' Many a Saturday have we gone a birdnesting; poring along the sides of the hedges-sparing the young birds when we found any, and placing the eggs on strings, like beads-making beautiful variegated rows, to be hung up at home. We found books, which we read, not as a task, but for pleasure; and became versed in the leading facts of English History-and there was an old soldier, with whom we used to talk of the exploits of our Edwards and Henrys. He lent us the 'Memoirs of a Cavalier,' a work of Defoe's, which in later life, I took care to purchase. In this there was mention of Oliver Cromwell, a hero whom the old soldier admired not a little. In fact he knew so much about his achievements, and was so often talking of him, that he got the name of ' Old Oliver.'

"A young man lent us the Conjurer's Magazine, and our young imaginations were wonderfully set afloat by its marvellous stories of robbers, ghosts, \&c., and our wits exercised in solving its riddles and charades. But the book of all books, with one of the boys, was Robinson Crusoe. Many a bold vessel did we construct, from the gallant three-masted ship, skimming before the breeze with canvas or paper sails-to the little boat with its feather stuck upright, for mast and sail at once. With these we navigated the mighty bounds of a tarn thirty or forty yards in diameter. I had never seen the sea, or a ship, so this boy and I set off one Saturday morning, our pockets well stored with bread and cheese, that I might be gratified with this glorious sight. We arrived about noon on the summit of a promontory," (Whitbarrow) "overlooking a noble estuary, the Bay of Morecamo. It was filled with the tide-the expanse of water lay beneath us, white and smooth as a mirror. A stately vessel was sailing out of it,

on a gentle day,

In sunshine sailing far away,

A glittering ship, that hath the plain

Of ocean for her own domain.'

"It was only a sloop, but it seemed to me, as grand and magnificent as a three-decker of the British navy!" 
Indications of one trait of William's character, were manifested whilst he was at Crosthwaite school; he stood up bravely for the oppressed little boy, in whose defence he did not shrink from fighting in right good earnest, the big tyrant. This sense of justice was predominant in after life, for it seemed a necessity to him, to combat by all the means he possessed, or could command, whatever he regarded as unjust or overbearing, especially if the evil of it lighted on his head, who had none to help him. It would be easy to cite abundant instances of this.

From Crosthwaite school William was removed to that of Underbarrow, where the Rev. Thomas Hervey, who had gained a widespread reputation as an excellent teacher, was the master. Under his instruction William applied to his studies assiduously, and acquired (a somewhat unusual accomplishment for a country school,) considerable facility in writing short-hand, the use of which, he never entirely laid aside. Assiduous too, was his devotion to sports and frolic, nor may it be irrelevant to name some of them, as supplementary to his own account.

"A ministration of their own, was theirs."

In the garret, a seclusion which he shared with White Owls, its usual occupants-he devoured the obsolete romances of Amadis de Gaul, and Roncesvalles, lent to him by a school-fellow! here also, he conned his tasks, and through the small opening which admitted air and light, he fired, as from an embrasure, on the unsuspecting rooks which settled within reach of his antiquated gun.

At school, during dinner-hour, the boys used to bathe, and William learnt to swim in a shelving pool of the beck, near Greg Hall. One of their pastimes, was the royal game of war. The boys enlisted and divided into two bodies. Each bound to be loyal to its own generalFrench or English-during the campaign. Battles were lost and won-skirmishes enacted, and even a siege undertaken-one noon, the neighbouring Dame's school was beleaguered and capitulatedthe terms offered and accepted, being, that the Dame should set free her fair young troop to enjoy a half-holiday!

For weeks before the 5 th of November, in those days so gloriously commemorated,- - there was the cutting of Whins and Savin, which had to be tugged to the Bon-fire-rock-and when on the eagerly anticipated night, the crackling fuel shot up huge tongues of flame, uproarious were the shouts and huzzas of the capering throng; whilst like beacon signals, answering fires blazed on neighbouring heights.-A pursuit he much delighted in, was snaring Wood-cocks :- 
66

'twas his joy

With stores of springes o'er his shoulder hung,

To range the open heights, where Woodcocks run

Along the smooth, green turf. Through half the night

Scudding from snare to snare, he plied

The anxious visitation-

In his copy of the "Prelude," there is a marker placed by his own hand, where these lines occur; and with an interest delightful to witness, he would talk over those moonlight nights of his boyhood, and tell how he "rose whilst it was yet night," to get the start of marauders, and secure the well-earned spoil. Nor was the artful imitation of tu-whit tu-whoo, a forgotten feat, even in his old age-when with lad-like skill and glee, through the crossed, hollow palms of his hands, he would send into the still air, "Mimic hootings to the silent Owls."

Dancing, almost the only accomplishment of rustic life, is rarely neglected, and William was sent to the dancing-school-Christmas too brought its round of visits and dances-and as the sweet spring advanced, the dressing of flies, and the nice art of angling, were bewitching occupations. This too was the season for bark-peeling, when school duties were intermitted, in order that he might earn a little money for himself.

This favourite and arcadian occupation begins in May and extends through the "leafy month of June," and as its term is limited, the bark. peeler rises whilst yet the little birds are twittering in their nests, and in the "sweet hour of prime," takes his way by lane and by field, to the scene of his labours ; and there surrounded by pure air, fragrant scents, rural sounds, and a flush of verdure and flowers, he pursues his work till nightfall. William's sensitive nature was delicately susceptible of these charms, and at the distance of half a century, this episode of his youthful days, was a sunny and unfaded picture in his memory. One of his associates at Underbarrow School, whose disposition and tastes in many respects resembled his own, was the Rev. John Kirkbyas Chaplain on board a man of war, Mr. Kirkby became acquainted with many foreign parts, and was familiar with life in Brazil; and when visiting his family in Underbarrow, meetings were arranged between him and William that gave pleasure to both, but especially to William, who found delight in listening to his friend's accounts of other lands. Mr. Kirkby afterwards held a Government appointment at Sheerness, until the infirmities of age claimed repose.

Altogether, William's boyhood and youth may be regarded as having been a happy and productive time; all his bodily powers and all the faculties of his mind were, during that period, brought into 
vigorous action; and though for a time this natural and salutary interchange, was partially interrupted, it nevertheless kept open sources of enjoyment, which contributed to secure to him a tranquil and green old age.

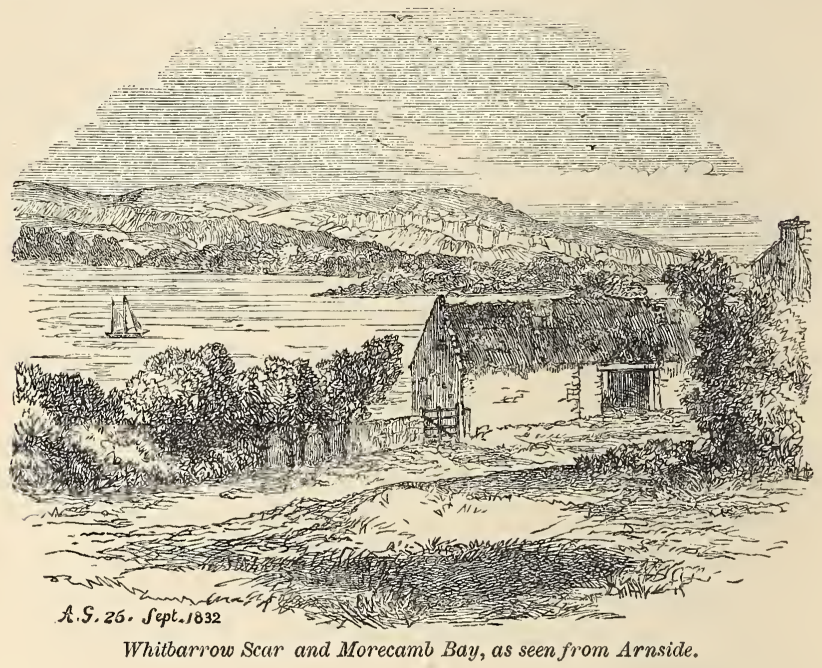

CHAPTER III.

His first stated occupation was teaching the humble school of Winster. Here he did not remain long, but engaged himself as tutor to the four children of a widow, Mrs. Dodgson of Swallow Mire, in Cartmel-fell. At the end of two years he gave up this situation, in order to learn a business, and went into the employ of Messrs. Simpson and Harrison of Kendal, - grocers, and wine and spirit dealers. The junior partner, Daniel Harrison, had been his neighbour and compeer; their path in life, however, very soon diverged. The one became a prosperous wine and spirit merchant, in Kendal-the other a banker's clerk, in Manchester; but friendly regard continued; and agriculture, to which they both addicted themselves when past the meridian of life, furnished topics of mutual interest in their occasional encounters.

To William the year spent in Kendal was an important one. The development of the religious feelings, and the training of his moral nature, appear to have kept pace with his advance to manhood: but during his residence in Kendal, his attention was directed in an especial manner to the doctrines of the Episcopal Church in which he had been reared. His mind was not so constituted as to imbibe passively, what was presented for its acceptance, and 
his earnest, questioning nature, became solicitous, that his belief should not stand in the traditions of men.

Happily, the air of sectarian controversy had never been breathed by him, nor could the seeds of bigotry have taken root in his mindand he approached the momentous subject, with calm feelings, and a reverent love of truth, to which vigorous mental perception, and an honest and dauntless spirit, were not at all antagonistic, and after careful reading and study of the Sacred Scriptures, along with the best helps he could obtain from other books, the conviction he arrived at, was, that the teaching of Moses and the Prophets, as set forth in the Hebrew Scriptures-and that of Jesus and his Apostles, as transmitted to us in the Christian Scriptures, are alike based on the fundamental truth, of the sole unity and deity of the Father, as distinguished from the triune oneness of Father, Son, and Holy Ghost; and it may seem needless to add, that with the Athanasian view of the Trinity, its cognate doctrines must either stand or fall.

There is not a vestige to favour the supposition that theology was made a subject of discussion at home-yet the father had previously arrived at the same doctrinal views, as those which William now embraced, and by the same means-and he sometimes went to Kendal on Sundays, in order to worship with Unitarians, in the old Presbyterian meeting-house. This quiet, secluded building, though situated in the heart of the town, is overshadowed by trees, beneath which rest many worthies of departed times; one of whom, James Patrick, was the prototype of the Wanderer, in the "Excursion." A plain mural slab, outside the east wall of the chapel-which was his spiritual home-bears the following inscription.

Near this place are buried

John Patrick of Barnard Castle,

Who died May Ioth, 1763 , aged 51 years.

Margaret, the daughter

Of James and Mary Patrick,

Who died November 2oth, 1767 , in her infancy.

James Patrick of Kendal,

Who died March 2nd, I787, aged $7 \mathbf{1}$ years.

When staying in Kendal with his friend Mr. Thomas Cookson, Mr. Wordsworth himself, was an occasional worshipper along with the family at this chapel; and thus became acquainted with the minister, the Rev. John Harrison, and with one of his congregation, the well-known blind mathematician and botanist, Mr. John Gough, with the delineation of whose remarkable powers and character, the poet enriched his "Excursion;" and in turn, has, by the touch of genius, imparted to them a lustre that will not fade, whilst English literature shall endure. 
After remaining a year in Kendal, William repaired to London, where his cousin William Little was already settled, and where he is still living, at an advanced age. $\mathrm{He}$ took with him excellent testimonials from Messrs. Simpson and Harrison, and warm attestations in favour of his character and qualifications, from Mr. Harvey and Mrs. Dodgson, as well as commendatory letters, from the clergymen of Crosthwaite and Cartmel-fell. $\mathrm{He}$ at once obtained a situation with a grocer in the city, but the loss of the pure country air, and the unwholesome accommodation provided for sleeping, (his dormitory was the shop, where he had a berth under the counter!) undermined his health, and at the end of three months, he found it necessary to return to the Yews.

The failure of his health, which had blighted his prospect of success in London, did not discourage him however, from persevering in the course he had marked out for himself; so that when health and strength were restored, he once more determined to make trial of a town life ; but the leading which was now given to his plans, involved a change of occupation. His father had an acquaintance who was in a bank in Manchester; for such a situation William was wellqualified; and besides this, the comparatively short hours of business in a bank, was a point of material importance. In the hope, therefore, of meeting with an engagement, he once more quitted the paternal roof, and arrived at Manchester on the I6th of March, I803.

The next morning he presented himself to his father's friend, and that same day, took his place at the desk, in the bank of Messrs. Jones, Fox, \& Co., in King St. ; and at this desk he remained during the next seventeen years.

Manchester at this time, possessed only two banks ; Heywood's, and the one in which William was now a clerk. Its head, Mr. Jones, was a Unitarian, as was also his son-in-law, Mr. Lloyd, (the father of Lord Overstone) who, in the early part of his life, had been a Unitarian minister; but his real vocation was in a widely different sphere-his fort was banking, and he was taken into partnership with his wife's father.-A great number of clerks were employed in Jones's bank, which had a sort of monopoly of the merchants' and manufacturers' banking transactions, and etiquette ruled, that they should be dight in ruffled shirts and white neckcloths!

William's lodgings were near the Infirmary, at that time not so remote from the green fields, as at present; and he generally secured a walk into the country, before the hour of business, nine o'clockoften, before breakfast; in the middle of the day, at which time nearly all classes then dined, he had the walk to and from his lodging, and as the Bank closed at five o'clock, the remainder of the day was at his own disposal. He was now in his twenty- 
third year, and in this large town, cut off from kindred, and without friends, his position was not without peril ; but he possessed discernment and strength of character, and the tone of his mind, as well as the fibre of his moral being, at this juncture of his life, may be judged of by part of a letter addressed to James Watson of Kendal, a friend of the family. It was in answer to one he had received, which touched on various subjects of mutual interest, particularly on the state and prospects of their Book Club-and contained also, a little fatherly counsel, imparted with modesty, as well as with earnestness and affection.

"DEAR Sir,

"I have received your esteemed favour, and have to thank you very sincerely for your information and advice-advice, which can only be agreeable and effective, from a persuasion of the sincerity with which it is offered; and give me leave to say, that I have a firm conviction, of your being really interested in my welfare, and that you would be very sorry, to hear of my falling into vices, which might make me forfeit the good opinion I presume you have formed of me.

"My dear sir, I hope this will never be the case; indeed it seems impossible to be so, so long as I am in the possession of good principles, and cultivate a virtuous and enlightened acquaintance, which, I trust, as it is at present, will ever be my highest ambition. I cannot say that I have been particularly happy in my acquaintance, since my arrival here; I mean in meeting with young men, who unite in their characters, those first of blessings, virtue and knowledge, in any high degree-I am happy when I meet with the former, though I should be much more so, to find it attended by the latter. Still, I have no reason to repine much-I have two or three friends whom I love and esteem, and who in regard to knowledge, are above mediocrity. But indeed sir, I think Manchester in proportion to its population, very deficient in young men of cultivated underderstanding-immersed in business, or carried down the stream of dissipation-slaves to Mammon, or to Bacchus-they have seldom time for the rational amusement of reading, or for the calm pleasures of reflection."

His lodgings were respectable and suited to his position, whilst his simple, frugal mode of living, without being sordid, was inexpensive. His disposition was sociable, and he allowed himself inexpensive recreations. Of books, those necessaries of life-he had his own little selection, to which he kept adding, chiefly from the book-stalls. He became a member of a good Subscription Library, and also took a newspaper, which was forwarded to the Yews-where other tokens of his affectionate remembrance, were not wanting; 
nor did he overlook the claims of the needy. He was of the same race as Wonderful Walker-for even out of his first year's salary of $£ 75$, he managed to send home a deposit, to one of the Kendal banks.

Among his fellow clerks, William formed intimacies, some of which ripened into friendship-but, with one exception, these were all merged in death, before his own. The one survivor is now a partner in the bank.

He joined a Dialectical Society, of which several of the clerks were members; and this social as well as intellectual bond, evoked a community or an antagonism of ideas and wit, that served to enliven the mechanical routine of figures; and the dead, speechless quiet, was now and then startled into life, by the quips and cranks, of the waggish ones, as they passed from one room to another, on business.

Part of a letter, written by William to a friend in London, some years later than this period, throws a little light on the meetings of this Society. He says, "I cannot be quite so particular as I could wish, in replying to some of your questions; but in whatever way the inquiries about quondam Dialectitians may fare, I can assure you, I sympathize very cordially in your affectionate regrets, and remembrances of dialectical pleasures; and though it may be questioned, whether we became much wiser for our meetings, there was amongst us, an odd mixture and contrast of charactera fearless utterance of opinion, however bold and unpopular-in some, a rather ludicrous, but I believe honest wish of bettering the State - and in most, a harmless display of vanity, in being the Orator for the evening, and (in the dream of the moment) associated with Cicero and Demosthenes of old! These meetings, with all their quirks and quiddities are alas, gone! They are gone, my friend, for you and me-for I resigned some time ago; though the Dialectical Society still exists, in name, at least ; but its meetings are no more held at the Dying Swan of ancient renown-they were removed to the Bay Horse,-and now, they are held in the room behind Mr. Barnes's Chapel! If you are a believer in the influence of climate, you will not augur much from the change of situation. . . . As I have not had the honour of the Sitting, since they left the Swan, I cannot enter into any details, perhaps luckily for your patience-but as I promised to attend, and indeed mean to do so, some night, I may, perhaps be troubling you with more particulars of the Decline and Fall of the Dialectical Society."

Though William's life, during his residence in Manchester, was little diversified in its outward bearings, beyond the ordinary occurrences of every-day experience-it was, nevertheless, lighted up by some 
circumstances, which, for himself, had a singular interest; nor was it barren of enjoyment, or devoid of those elements of progress, which arise out of the linked unity of social vicissitudes; and had his own letters addressed to his father and brother Thomas during this period, been extant, they would have presented the most correct and valuable reflex of himself. But alas, this precious repertory is gone! and the few details which must supply its place, will very inadequately, counterbalance the loss.

Although, during these 17 years, he remained steadily at the desk, as a clerk, the opportunity for entering into business which would ultimately have insured him wealth, was not wanting; nor was he without the discernment to perceive, that wealth, like the quality of mercy, may be twice blest-but the possession of it at a remote day, he did not regard as an equivalent for the absorption of his time, liberty, and intellectual powers, which in his case, must have been the condition of success. Far dearer to him, was some measure of present freedom, with exemption from anxiety, and the prospect at no very remote period, of a small competence, leading to his establishment in his native valley; where amidst useful pursuits, he might find leisure for his most prized enjoyments:

"-wandering on from day to day,

Where he could meditate in peace, and cull

Knowledge, that step by step, might lead him on

To wisdom _."

As years passed on, he associated himself with the Schools and Library of Moseley Street (now, Upper Brook Street) Chapel. Social intercourse also expanded, both among families of the congregation, and in other directions. His interest in politics was very decided, as well as in the course of public events generally. He became a subscriber to a News-room, and also gave his attention to learning the French language, in which he took lessons. In I8I8, when Henry Brougham contested the representation of Westmorland with the Lowther family, William contributed many spirited appeals to the Freeholders, on his behalf-which were greatly exulted over, by those at home, who were in the secret.

The theatre had great attractions for him, especially when illumined by the London Stars. Taking his seat in the Pit, his ideal of histrionic possibilities was realized, as only a Siddons and a Kemble - a Kean and a Jordan-could realize it ; and long after the feverish transport of youthful enthusiasm had passed away, the glow of it would kindle up, when expatiating upon some popular actor. But it was tragedy that held him in thrall, and which tempted him to try his capacity for theatrical criticism, hy a comparison of Kean and Young in the character of Hamlet. 
These general observations may be regarded as preliminary-much of what follows, will be found to consist of letters-not indeed, written by himself-for but few of his own have been recovered-but chiefly such as were addressed to him.

\section{CHAPTER IV.}

As being likely to interest some of his descendants, portions of letters from their common ancestor, John Pearson, to his son William, will be given. The following appears to have been the first he received, after his removal to Manchester.

April I6th, I803.

We received your letter, and it gives us much satisfaction to hear you have been so fortunate in getting a situation, and we wish you may have health to continue in it. Since you went from hence, the progress of mortality has been great among us. . . . . I saw a letter this day from Mr. Watson to his father, dated Chatham, 7 April. - He had gone thither on account of his health, and purposes taking a short tour along the coast, to Dover, Deal and Margate, and if he does not recover his health shortly, to return into the North. . . . Give my thanks to Mr. and Mrs. Bispham, for their attention towards you, and likewise to Mr. Machell.

Mr. J. Cartmel, and Mr. J. Strickland were soliciting for our Church, before Mr. Danson's funeral. Which of them will succeed, I cannot know at present.

\section{I remain,}

Your affectionate Father,

John Pearson.

In May his father again writes, and names 4 deaths in addition to 7 named in his former letter; and mentions the illness of whole families, in this same fatal complaint-he adds, that in Kendal there had been as many as "I 2 or I 3 burials in one day;" and he then proceeds, "pray write in a little time, and tell us what is your employment in the Bank, and whether you find it easy, or it will require time to learn it. . . . . I suppose we are to have another war, and that it will probably have a bad effect on the trade of your town. You can, perhaps, tell us something about it."

His father writes, in Jan. 1804 .

Son William,

This, with our kind love to you, hoping it will find you in good health, as it leaves us.

According to desire, we sent you by Mr. Maskew's coach . . . and shall be glad to hear you received it. We have little that is new 
in Crosthwaite. . . . The Editors of the Monthly Magazine, mention a Mr. Lowe of Manchester, who has published a volume of Poems. . . . " "he threatens us," they say, "with an Epic Poem ; sincerely do we recommend him, to return to the calling he has left for this idle trade." Can you give us any account of this Mr. Lowe, and what calling he left, for the superior gratification of writing poems?-We have no Volunteers in Crosthwaite. . . . Thomas and Richard at Mr. Simpson's, are among those at Kendal, where there was a review on Monday. There were between I, I०० and $\mathrm{I}, 200$ assembled.

\section{I am, \\ Your affectionate Father, John PEARson.}

A deep and warm affection subsisted between William and his brother Thomas, and as being likely to add to the happiness of both, and at the same time to advance Thomas's interests, William proposed looking out for a situation for him, in Manchester. This was approved by Thomas, but he thought "he had better go to the school first, and improve himself." Early in 1805 , he entered the countinghouse and warehouse, of Messrs. Thos. and David Dockray, manufacturers in Manchester. A younger brother was with them, learning the business, but his nature and his tastes, could not adapt themselves to trade. "Benjamin was always running off to the book-shops," says Thomas, who greatly respected him; and when in this neighbourhood, he showed his regard for Thomas, by calling at the Yews to see him. As Benjamin Dockray is named in a letter of William's, nothing needs to be said here, except, that in the first instance, his reflections were given to his towns-people in one of the Lancaster papers, where they appeared at intervals, in the form of aphorisms and short essays, which afterwards were published in a small volume, named "Egeria."

Thomas's health, even more than William's, was dependent on the renovating power of pure, country air ; and before he had been two years in Manchester, William became alarmed, by what he feared were symptoms of incipient consumption, and wrote urging his father to recall him.-The reply was as follows.

Aug. I 2 th, I 806 .

I am sorry to hear that Thomas has had a relapse, and we think it best for him to return, if the symptoms continue. I think it wants five weeks to the quarter's end, but if he should remain till that time, the disorder may become inveterate, so as even to preclude the hope of recovery. I would advise him to take as much exercise as he can, but on no account to stay too long; all other considerations, should give place to health. 
Thomas went home, but in 1807 , he was once more pursuing his occupation in Manchester. His health, however, again broke down, when he gave up all thoughts of adopting a mercantile life, and returned to the Yews.

William was subject to continually recurring colds, which affected the respiratory organs, and occasioned a harassing cough, and stomach derangement; and in 1808 , he was so much out of health, that a respite from work, and change of air, became indispensable; and in July, he also repaired to the Yews, where he remained for three months. Here, his steadfast benefactress, beneficent Nature, reached out to him "a hand of healing," and dispensed to him the most grateful of restoratives. Guided by her impulses, he provided himself with gun and Dog, and the protective licence-although it must be acknowledged, he lacked the qualification, required in those stringent days - and sometimes, with a companion, sometimes without, he ranged the fells, and shot over the land of friendly Statesmen; inhaling health with the common air, bracing his limbs with exercise, and his spirits with the genial excitement.

The passion for hunting and shooting, which manifests itself generation after generation, in some families-whether growing out of the contagion of sympathy, or transmitted in the blood, possesses the characteristics of an instinct; appearing to be as keen and irrepressible in the man, as in his four-footed coadjutor-the faithful, intelligent Dog. Hence, in Crosthwaite, as elsewhere, the humble sportsman chafed sorely against game-lazes and rights - and true it is

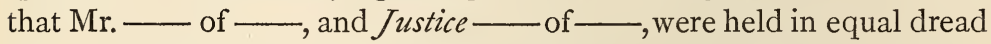
and contempt, by the unlicensed sportsman; the one, as a tyrantthe other, as the inexorable dispenser of law! Nor must it be denied, that William shared in the vulgar prejudices of his neighbours; not so much, because his own sport was interfered with(though he could on occasion grumble manfully enough, at being debarred the range of his youthful haunts) as from a conviction of the demoralizing influence of the Game Laws.

$\mathrm{He}$ could sympathize in the feelings of the labourer, who, with propensities as strong as his own, might not snare a hare, or kill a bird-nor did he wonder, that the free and easy practice of the gunner, (who must not be confounded, with the more nefarious poacher, by trade, ) was not attended by feelings of compunction-for if he were eluding the law, did not a vague sense of indefeasible right, in the wild animals and birds of the air, stand in his mind, as his justification? And how were his untrained faculties, to perceive the subtle distinctions, which to Lords of Manors, and Game-keepers, present no puzzle at all! Thus, in his eyes, the law lost its majesty-and what for him, was much worse, the boundary lines between right and wrong 
became inextricably confused. Yet, a little reflection seems to be alone necessary, to enable the labouring man to perceive as clearly, as the owner of game-preserves, that without some protective law, game would, in this country, very soon be exterminated;-whilst the ameliorations, which, during the last forty years, have been effected in the Game Laws, would seem to point to an adjustment, at no distant period, which may be equitable to the landowner and the farmer who maintain the Game, and at the same time, may not be galling to him who neither possesses, nor rents, a rood of land.

And here, there is a strong inducement to anticipate, by stating William's avowed opinions, at a later period of his life. The iniquitous and cruel operation of the Game Laws, as then framed, was matter for his earnest reprehension; and when surcharges were being scattered broadcast, among the farmers and young men in Cartmelfell and Crosthwaite-and informers were employed, insidiously to tempt suspected persons, and then to betray them-and when the Ulverstone carrier, was dogged in the night by searchers, on the lonely heights of Cartmell-fell-William, indignantly exposed the mal-practices of the one class, and pleaded the cause of the other, in the local newspaper. And when the report of the proceedings before the commissioners appeared, he, through the same medium, appealed for information on the state of the law, so strong was his impression, that it could only have been by a stretch of authority, on the part of the prosecution, that the accused could have been called on to criminate themselves.

The case of three young men, brought up for poaching, is so singular, that it shall be cited. The account was written by William and sent to a Kendal paper.

"In the wild district of Cartmel-fell during the prevalence of the late snows, three young men, brothers, were in the habit of catching Hares, without the assistance of Dog, gun, or any offensive weapon, save a knob-stick-merely by speed of foot. One of them was stationed on an eminence, commanding a view of the surrounding country. When a Hare was started, his part was to direct, when necessary, the pursuit of the other two, who acted as hounds, aided more by the eye, than the nose! Their grand manœuvre was, to keep the game continually on the move-which was effected by loud shouting, and partly, by taking near cuts, which they were often enabled to do, by the tally-ho of the keen-eyed marker, who could discern the affrighted animal, scouring across the snow-covered fields. At the close of a hard day's diversion, we will venture to say, they had enjoyed as much sport, as any red-coated Nimrod, with hound and horn. One of the trio, was seen dagassing after a Hare, within a few yards of her seat, and every now and then, shouting out to his brother hunter, at a 
short distance behind, (he knew that it was his own) 'it's a bonny hunt noow'- 'it's a bonny hunt noow !'”

In a letter sent to the same paper after their conviction, he says, " of all those that have been convicted, we most pity the Robinsons; young men who can run down a Hare, an animal that often escapes the fleetest Grey-hound! who pursued their sport without fear, in the open day, and so generously, that they left a Hare with the farmer, on whose ground they happened to take it, and whose exploits, were thought worthy of being recorded in the 'Provincial Prints' as wonderful examples of human activity and perseverance.

"These fine young men, have been made to pay $£ 3$ I3s. $6 d$. for their sport! The age of chivalry is indeed gone! The ancient Greeks, would have crowned them with laurel! but this is the age of taxation, and little men-we are 'fallen on evil days.' We only wish, the surveyor and commissioners had heard them, at their joyous sport-had heard their shouts, as we did, which made the old mountain ring again-even to Gummershow-to be echoed back, from the far-off Coniston fells!"

To go back to Manchester.-After a three months' run in Westmorland, William, in October, resumed his place at the Bank. One month out of the twelve, was allowed for a holiday-usually it was Sept. or October, and he spent it at the Yews, where his gun and Dog were in readiness : but so sturdily rebellious was his constitution, against being acclimatized to a thronged town, that besides this, he found it necessary in order to keep himself in working condition, to lodge from time to time in the country. Thomas, whose health was re-established, was wishful again to make trial of Manchester life. William refers to the subject in the following letter, which likewise shows, how warmly both of them were interested in promoting the advancement of their younger brother, Robert.

\section{DEAR BRother,}

\section{Manchester, Ist Jan. I809.}

This is New-Year's-day, and as it falls on a Sunday; I have time to begin a letter to you; had it fallen on any other day I should not-for all the last week, we have been working at the Bank, like negro slaves-Every night, till 9 o'clock! But you know 'tis common to work hard in harvest-time, and Christmas is the season of our gains ; this makes it somewhat tolerable.

I received yours of ro mo. 2 2nd duly. I am glad you are so well, and have resolved to try 'Chester once more. You must be completely tired, with having so many tyrants on every side. It would vex me not to be able to seek a Snipe or a Woodcock, without creeping as if one were going to steal something! But you cannot do 
these things without money-then come here and get it. You may then shoot either Pheasant, or Partridge, or Woodcock-or even a Jack Snipe, without being liable to a penalty of $£ 3$, or lying in the house of correction for three months! But I am sorry to say, that trade is very dull, and that I cannot promise to get you a situation, in a short time. You may hold yourself in readiness, and I shall do what I can. I spoke to Mr. Fox about a situation in the Bank; but he told me, they do not intend to take any but lads of $\mathrm{x} 6$ or $\mathrm{I} 7$, to come in as young clerks, and that they should want one of this description, in Spring. Now, I have been thinking, what a capital opportunity this might be for Robert .... He would only have to copy bills-besides, he will be able from the first to do without much assistance; and after having been three years in the Bank, would be entitled to a full share of perquisites, which is generally more than E2o per annum.

Put off his thoughts from being a joiner, he may certainly do better. Let him get forward with his learning, as fast as possible, and improve himself in writing; for it is not impossible, that I may obtain the situation for him-which you may tell him, will make a man of him.

Jan. II. - I have deferred finishing my letter, that I might send a little money in it. I enclose a bill by David Dockray, on Maude \& Co. You see, in spite of the badness of the times, I contrive to spare a little every Christmas. I wish I could save ten times as much in the same time! then I need not be obliged to stay in this sordid town! Yet in some respects, I should like it pretty well, if I could only contrive to have better health; but I am seldom quite well, and this is enough to make any place disagreeable .... I think living in the country, with the walk to dinner, has been of service to me. I feel stronger and expect to have a better Spring than I had last, and last but one. I am glad you push my father forward with improvements. He need not want work in that way. However, I would not like you to lose your writing and figures, and whilst you have the opportunity, improve Robert as much as you can in both. If I do not procure him a situation in our office, I may, by-and-by, elsewhere, which, as he is a quick lad, will be likely to do much better, eventually, than a mechanical trade.... I hope you receive the newspapers pretty regularly. You must write to me in a week at farthest, and tell me Robert's age. Be sure to send a long letter. I shall pay the postage of this, as it is on my own business.

I remain, dear Brother,

Yours affectionately,

WM. PEARSON. 
The plans which in this letter, are so hopefully dwelt on, were not to be realized. Whilst the brothers were acting on William's suggestion, a circumstance apparently trivial, lifted the direction of the future, entirely above their control. William's father wrote to him as follows, on the ist Jan. I8ro.

"We are all well except Robert, who has a bad cold, caught by getting wet in going to school. He has a bad cough, and is much indisposed, but we hope he will be better in a little time."

This hope proved vain-the cold ended in a lingering and very painful illness, which caused his death.

About this time, Thomas, who like his father, had a predilection for the veterinary art, was encouraged by him to adopt a new plan of procedure, and he decided on commencing such studies, as were preliminary to entering upon a course of regular education; and William received from his father an outline of the plan he thought it advisable for Thomas to pursue. He proposed that in March, Thomas should be placed with $\mathrm{Mr}$. C - in Manchester, and afterwards should go to London, where he was to obtain his diploma- " in the meantime I would have him read such authors as he can procure, so as to gain some knowledge of the theory of medicine, the art of discriminating disease, and the nature of the different articles in the Materia Medica." He then enumerates those books which he considered as most suitable ; and goes on to say, "you mention having seen in a Review, an account of the publication by Ed. Pearson. His cousin Edrington in Kendal, tells me he believes he lives in London. If he be a collateral branch of our family, he might be of service to Thos., especially when he learns his grandfather's name. . . . . If I knew his address I would write to him, and I should find by his answer whether he appeared to be a friendly man, and in what estimation he holds his relations in the country." $\mathrm{He}$ then names having proposed Mr. Pearson's pamphlet for their library, "but it was not ordered," he therefore commissioned William to get it, "as the price was only 3s.," and proceeds : "Mr. Clark too, might be able to gain some information about the author, for a publication of that nature, could not fail to excite some curiosity in the public mind. The title of the pamphlet, is 'Remarks on the Dangers that threaten the Established Religion, and on the Means of averting them, in a Letter to the Right Hon. Spencer Perceval.'

"I remain,

"Your loving Father, "John Pearson."

In March, Thomas wrote, " your parcel came to hand on Saturday. I am extremely well pleased with the book and the letter. It is one 
of the best publications I have seen on the subject, it treats so much at large, on the nature of diseases, and how they originate. . . My father has not written to Coleman yet." Again he writes in April, "You will think we are very neglectful, after all the kindness you have shown, in sending one parcel after another. Robert's age is fifteen, . . he practises arithmetic and is very quick; he also reads a good deal. . . . It will require a very good education, to prepare for going to the Veterinary College; . . . those who study anatomy so minutely, go into the military service. No person can give his mind more to this art, than I do."

Prelusive to relinquishing this cherished project, was its postponement-the father says in a letter written in June, "with respect to Thomas's going to Mr. Coleman, I think it had better be deferred, both on account of Robert's indisposition, and because we are at present engaged in enclosing Gelridding Lot, so can badly spare him." In the end, the plan which had been so thoughtfully arranged, and which Thomas had so heartily entered into, after being indefinitely delayed, was finally abandoned.

Robert's acute sufferings, occasioned by what was regarded as rheumatism-notwithstanding the best medical advice that Kendal afforded-became at times so torturing, that his father desired William to see the "Whitworth doctor" (an uneducated practitioner, famed for the savage roughness of his manipulations, and for the wonderful cures they effected), and to report his opinion, as to the practicability of effectually resetting the hip joint, which the rheumatism had displaced. He thought Robert had strength for undertaking the journey-but as the poor lad never went, it may be inferred, that the doctor did not hold out the prospect of success.

The hopeful spirit of youth, and intervals of comparative ease, and apparent convalescence, made it long before Robert despaired of recovery. When he was able to occupy himself, his own tastes pointed out pursuits. His mechanical turn, suggested little jobs of domestic utility - and he likewise made a flute, and a fiddlestick. $\mathrm{He}$ cultivated his love of music, and his self-taught skill in playing on the violin, both amused himself, and pleased the household. All these little matters were duly reported to William, as interesting domestic news. A box arrived from Manchester, and "the new fiddle, gave us a night of continued music, until a late hour-I believe if you had given him $£$ roo, he would not have been more pleased at the time."

During his better intervals, Robert taught his younger brother, and his brother John's children, and also advanced his own acquirements. Thomas was the examiner, of both tutor and pupils, and reported progress to William. But suffering and weakness at length vanquished 
even hope-and Robert wrote despondingly to his brother. He had "never tried to draw" since William's last visit-he was "too weak to play on the violin"-and "So thin of flesh, that he got cold every time he went out"-and he seldom rose before mid-day. "But when at the worst of all, the only pleasure I have, is thinking, that the more I suffer in this world, the better it will be for me in the next.* I have a good father, and a good mother, and a good home, and if it please God to take me, His will must be done. . . . . God Almighty bless you, and send you good health and happiness, as long as you live, and I hope you will be rewarded for all your kindness to me.

"I ever remain,

"Your affectionate Brother,

"Robert Pearson."

The poor youth still lingered on; and it was not until after an illness of more than 7 years, that he was removed from a state of weariness and pain, to enter upon the promised rest.

In one of those unsatisfied moods, to which persons of lively imagination are more liable than others, and also coincident with some disturbing occurrences, William, beguiled by a picture of the loveliness of life, on the banks of the Ohio, had a dream of emigrating to America. At once, Thomas imbibed his ideas-and with characteristic earnestness, the brothers read, wrote, and talked themselvesnot into becoming projectors of a utopian Pantisocracy, they were too practical for that-but into a scheme by which they were to leave the crying ills of life, along with the old country, behind them-and as settlers in Kentucky, enjoy the charms of freedom-ample range, without let or hindrance, for the exercise of their favourite field-sports -and new and strange interests without limit. The picture was beautiful-but by-and-by, a cress light fell upon it, revealing some hitherto unobserved and rather ugly blemishes. Thomas writes, "I have read the pamphlet you sent, and am much taken with it. Kentucky, seems, to have the preference of this writer, as well as of the others. If we were there we might live very well-but there would be many a hard day first-which I am afraid you would not bear well, for a time-and for my own part, if I were no better than I have been, for 5 or 6 weeks past, I should not be able to stand the clearing away of wood. We will leave the subject of America, for discussion when you come over, which I hope will be in the back end." This prudent suggestion, gave time for their ardour to cool-resolution flagged-and in the end, the scheme was relinquished.

On account of the interest which attaches even to trivial matters,

* " Having been a little chastened, they shall be greatly rewarded."

Wisdom of Solomon. 3 ch. 5 v. 
when associated with an illustrious or an honoured name, a few passages from letters received by William will here be given. The writer, Mr. Preston, a man of cultivated tastes, addressed a series of admirably descriptive letters to William, written whilst on a visit of several months at Paris, just after the Peace of $r 8 r 5$.

In I8I 2, Mr. P. writes, "Just returned from a visit to an eminent artist, Mr. Dawe, I sit down to discourse a while with you. I wished for your company, you would have enjoyed the conversation so much. We talked of the Arts-of Coleridge and of Wordsworth, with whom he is intimate. He repeated a poem of Coleridge's, from which he has painted a large picture-also one of Wordsworth's, 'Lines written under a Yew-tree.'-(Lines left on a Seat in a Yew-tree?) 'The Mad Mother' (in later editions, Her Eyes are Wild), he admires so much, as to speak of it only with enthusiasm.

"The picture he is now engaged on, is very large $-9 \mathrm{ft}$. high ; the subject, a mother on the mountain top, rescuing her child from an Eagle's nest-figures as large as life. Wordsworth admires it muchbut Coleridge is quite warm upon it. Mr. Dawe means to have 300 guineas for this picture-Coleridge thinks it deserves 500 ! He has gained two prizes at the British Institution, and a gold medal at the Royal Academy, for the best historical painting. A few months since, he painted a portrait for which he received 180 guineas.

"You should inform my uncle, that Mr. Dawe will be with him at Ardwick on Sunday next. What do you think? he wants me to proceed with him to London, to spend a few months with him-but then you know there is expense, \&c."

In a letter written in September of the same year, he says, "a few weeks ago, we had a grand wrestling match, between the Cumberland, Westmorland, and Lancashire lads, for 5 guineas, and a belt ornamented with a silver plate, on which was inscribed 'The Hero of the North.' A young man from Cumberland, who was that day twenty, bore away the prize.

"Wordsworth sat within reach of me, next to him, Rogers, author of the 'Pleasures of Memory.' Another Poet was there-Wilson, whose demeanour since his marriage, has less of fire and furor. Rogers, is a respectable-looking, toothless old gentleman, with it is said, an imagination full of youthful vivacity."

In I8I3, Thomas and his brother John, who had been balloted into the local Militia, had to attend at Kendal, in the Spring, for I4 days' training. The parades speedily placed Thomas on the sick list, and he wrote, "I have nothing to do, but to walk about and to read. . . Mr. Wilson of Elleray is a private in the Militia, and he assumes the character of a private, never associating with the Officers; giving as the reason, that all Officers ought to 
rise by merit." At this time, in compliance with regulations, Mr. Wilson had his fine, flowing hair cut quite close; and when the loaves which were dealt out to the privates, were distributedhe, like his comrades, stuck his loaf upon the point of his bayonet, until the moment arrived when "he held with his glittering eye," the mortal, whom he destined to be its happy recipient!

To return once more to William-whilst in Manchester, amidst all vicissitudes, his first love both cheered and saddened his heart: for oft in his lonely walks, his oppressed spirit turned with indescribable longing, towards his native valley; when gazing toward the North, the language of the Psalmist would involuntarily rise to his lips, "I will lift up mine eyes to the hills, from whence cometh my help."

\section{CHAPTER V.}

IN passing under review, the period of William's residence in Manchester, two incidents may be singled out, which appear to have been more conspicuously influential, upon the whole of his after life, than any others-these were, his introduction to the poetry of Mr. Wordsworth, and the commencement of a friendship, true, pure, and fruitful, with Thomas Smith, a Gorton Silk-Weaver.

William appears to have been early acquainted with the "Lyrical Ballads," for his copy is the Edition of 1805 ,- - and his copy of "Poems by William Wordsworth, the author of Lyrical Ballads," bears the date of 1807 , when the two volumes were first published. As an admirer of "the sweet-souled poet of the Seasons"-of Cowper -and perhaps, more than of either of these, of the genius of Burns, -it may not at this day, seem to be any way remarkable, that he should have read Wordsworth's poetry with admiring and loving appreciation.

In order, however, justly to estimate the quality of his critical acumen, it must be borne in mind, that $5 \circ$ years ago, the taste which should without a sneer, allude to Wordsworth as a Poet, had yet to be created-" to admire Wordsworth in those days, was to be kicked at," as with picturesque originality, was affirmed by one who bore an honoured name. Moreover, it is pretty certain, that the opportunity would not be wanting, for such criticism as was then in vogue, to infect his mind with its pernicious bias-neither ought it to be forgotten, that the first 20 years of his life, were passed in rustic seclusion, and the few years besides, which he now numbered, had afforded but slender facilities for mental culture-even the native vigour of his own intellectual tendencies, was kept in check by 
the distractions of a town-life, to which he could ill accommodate himself.

Regarding him then, through the medium presented by these facts, there is no wavering-the mind at once takes the attitude to admire his pure poetic taste and judgment, as avouched by its accordance with that of the highest contemporary genius, as well as with that of the Masters in Literature of these latter days-whilst by years that might be counted in decades, it anticipated that more thrilling verdict, breathed forth from hearts soothed, and souls elevated, in every land where is spoken

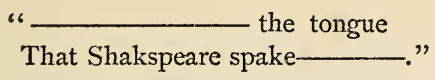

And the fact is significant, that in after years, when William was privileged at Rydal Mount, to listen to manuscript readings, Mr. Wordsworth, who on this point was eminently chary, would deign to ask his opinion on some point, to his own poetical conceptions, still resting dubious.

But in the outer circle of these his earlier years, William's high estimate of Mr. Wordsworth's poetic genius, and exalted moral altitude, inspired him with a reverence so profound, that like the Poet's own Emmeline, "dreading tho' wishing," when the coveted introduction was first within his reach, he experienced in kind, and with the same result, those feelings which in identical circumstances, overcame De Quincey-overpowering veneration, and consequent self-abasement, caused him to retreat from the Poet's threshold, awestruck and abashed. Whilst after he had numbered his three score years and ten, in the freedom of fire-side chat, he reverted with innocent gaiety to these Manchester days, playfully making his boast, that as a true believer, he had here and there indoctrinated one, and so saved him from the ranks of the scoffers! and he felt an honest selfcomplacency, that his own loving admiration, had had its birth anterior to the wide-spread homage, now yielded to Wordsworth, as the Poet of universal humanity.

An oddly characteristic incident, was the prelude to William's introduction to Thomas Smith; a friend of William's, whilst walking along Market St. in conversation with another gentleman, happened to speak of a Scotch author, just then coming into notice-when (as if one of the interlocutors,) a working-man walking near them, impulsively ejaculated, "and did you know-? ? The question itself and the eagerness with which it was put, contrasing so strangely with the exterior of the man, not only elicited an answer, but also inspired John Houtson, the gentleman addressed, with a feeling of interest and curiosity, which led him to seek the 
man's acquaintance; who was no other than the Thomas Smith, to whose cottage, William was shortly after conducted by his friend. And many years afterwards, when, cut off from kindred and country, John Houtson was consigned to the grave in tropical Africa, William had not only the remembrance of past friendship to cheer his heart, but also a living memorial of great price, in their mutual friend Thos. Smith.

Whilst in Africa, J. Houtson's kind offices to Belzoni, are named by the author of "Fruits of Enterprize, exhibited in the Travels of Belzoni, in Nubia and Egypt;" from which volume, the following extract is copied.

"On the night of Nov. 24th, I823, Mr. Belzoni left us with Mr. Houtson, for Gato. On the 3 rd Dec. I received a letter from Mr. Houtson, requesting me to go to Benin, as $\mathrm{Mr}$ Belzoni was lying dangerously ill, and in case of death, he wished another person to be present. On the 5 th I had a second letter, with the particulars of Mr. Belzoni's end, and one from himself, dated and Dec., almost illegible. At the time of Mr. Belzoni's death, Mr. Houtson had arranged everything with the King of Benin, for his departure."

This circumstance is alluded to in a letter of T. Smith's, written in Sept., I824; he says, "You have doubtless seen our friend Houtson, mentioned in the papers, in connexion with Belzoni, as being the only European, with that celebrated traveller when he died. Belzoni could scarcely have had the good fortune, to meet with a more useful, polite, and good-natured man; we both know, he would do what he could for him, with great pleasure. One feels proud that one can say, Mr. Houtson was my friend."

In I826, J. Houtson himself died. He was unmarried, and when his brother James had to attempt the recovery of his property, he found himself beset by difficulties. In this emergency, T. Smith's thoughts at once turned to William (then settled in Crosthwaite, and on a friendly footing with the family at Rydal Mount), to whom he wrote, suggesting that Mr. Wordsworth might possibly, be able to do something in the matter. The following letter shows the result.

"Crosthwaite, April, r82 7.

"How could you think for one moment, that I should consider it a trouble, to do anything on behalf of poor Houtson. I was glad you thought of Mr. Wordsworth, in connexion with the affair. I called on him the day after I received your letter; he felt greatly interested, and quite ready to do anything he could in the business. It was fortunate too, that he has a friend, Mr. Taylor, in the Colonial Office, to whom he immediately wrote a note, which I lost no time in enclosing to James H-. Mr. Taylor wrote shortly after, to Mr. W., 
apprising him of Mr. Houtson's visit, and of the advice he had given him, as to the best mode of proceeding for the recovery of the property. From James I have not heard, but if he have any prospect of succeeding (though I fear there is not much), I hope I need not say, how happy I shall be, to do anything in my power to assist him; as well on his own account, as on that of his kind-hearted, enterprising brother, now alas, no more !"

Thomas Smith was two years younger than William, and at the time they became acquainted, was living with his mother at Gorton, a village about 4 miles distant from Manchester. Their cottage was a neat, cheerful dwelling; open to the fields, and with a south aspect, which ensured the best light-a matter of much importance for silk-weaving. There is no clue by which to trace their acquaintance to its commencement-but they were in habits of intercourse in $18 \mathrm{r} 3$.

T. Smith's mental powers, seem to have been subtle and active, rather than powerful and deep. He had an insatiable and keen delight in Nature and in books - the sweet quaintness of the old Poets, was very captivating to him, and he was familiar with the range of English poetry, generally.-His was essentially the poettemperament-imaginative, sensitive, emotional, with affection deep, ardent, and clinging - and if this made sharper the troubles of life, and caused the hardships of his station, to press the more heavilyit could likewise waft him into "a world both pure and good," into which the ills of life did not intrude.

He appears to have been reared with care, and the principles of religion were operative in him through life; kindling into praise and gratitude in his happy hours, and sustaining him under the crowning sorrow of his life, as well as under the searching trials peculiar to his calling-and which during a season of extreme depression in trade, were aggravated almost to the verge of despondency.

\section{CHAPTER VI.}

OF the last six years of William's residence in Manchester, there is scarcely a trace to be found, except in such casual allusions, as are to be met with in T. Smith's letters, which also furnish a key to the succeeding twenty-two years.

A reverent desire has been felt, to establish a posthumous association between the friends, by means of these letters; in fact, by their introduction, to constitute this, a sort of double memoir. Yet, a misgiving naturally arose, as to how far this course might be justifiable-the following considerations weighed in favour of its adoption. 
Such a record as these letters present, of the joys, trials, and sufferings of our brothers and sisters in humble life, not only as experienced, but as registered by one of themselves, must of necessity be rare; perhaps these letters may even be a solitary example; and as such, it might be blameworthy to suppress them. Therefore, instead of simply sifting out of them what might be serviceable to this Memoir, it is proposed to use them freely, in the way of extract. Nor has this course been decided on without a pause for thought, on the nature and claims of confidential correspondence; the obligations of which, will cause some of the most eloquent outpourings of the heart to be withheld. As to the rest, it may be added that the letters are in themselves, worthy of being read, on account of the feeling, ability, and cultivation of mind, which they evince; and as coming from a man, whose daily bread depended on his application to his loom, and who had had to bore for himself, a passage into the mines of Literature, they are truly extraordinary.

They will indeed disclose much material distress, and many a sore abrasion of the heart, and

“It were

Severe reproof, if we were men whose hearts

Could hold vain dalliance with the misery

Even of the dead; contented thence to draw

A momentary pleasure, never marked

By Reason, barren of alr good.

But we have known, that there is often found

In mournful thoughts, and always might be found,

A power to virtue friendly___.

To go back to the period of William's Manchester life. In the Spring of $\mathrm{I} 8 \mathrm{I} 7$ he made a pedestrian tour into Derbyshire, accompanied by T. Smith; who up to this time, was unacquainted with any scenery beyond the limits of a Sunday-walk, or of his accustomed rounds when in search of work. To him, therefore, in an especial degree, the expedition was replete with enjoyment, and the excitement of rapturous emotion.

In the Autumn of 1818 , they explored together the interesting country in the Deanery of Craven, in Yorkshire, and ascended Ingleborough. On both occasions, William kept a journal-the Derbyshire Tour, will be found among the Papers.

The larger wisdom gathered from an enlarged sphere of observation, and from the interchange of ideas with men of diversified attainments and views-did not blend incongruously, with the plain manners, and simplicity of character, which during his residence in this busy town had not passed away from him-" "the angles were rubbed down"-but "the picturesque of man" was not effaced. 
In Sept. 1820, he gave up his situation in the Bank, and returned into Westmorland, and for a few years, the Yews again became his home. In the Oct. of this year, he made a pilgrimage to the Valley of the Duddon, and visited some of the Lakes; as usual, keeping a Diary.

In a letter of the $24^{\text {th }}$ Dec. $1820, T$. Smith after expressing his joy on having received a letter from William, and his regret that his own in return was so worthless, adds, "yet I have no reason to think you will be dissatisfied. Our correspondence, like our general intercourse, is very similar to our European travellers' manner of trading with the South Sea Islanders, when they give them rusty nails, beads, and other baubles, in exchange for good fat hogs, and other rich commodities. This being the case, have I not cause to lament your being taken from me? Yet your departure was much to be desired, for the renovation of your health and spirits-breathing your own sweet mountain air-and enjoying the endearments of friends and kindred-these things, my friend, I hope you are enjoying plenteously. Yet after all, I must say your departure has made havoc amongst us." His next letter is dated,

Gorton, I8th Feb. I82 I.

MY DEAR FRIEND,

Your very elating letter, although dated I 2 th Jan. I did not receive until the $5^{\text {th }}$ inst., it had lain a week at the toll-gate before I heard of it. . . . . I must say something about your letter, but I know not what-the high regard, and warm affection, you have bestowed so liberally and fervently on your poor friend, exceed his powers of adequate acknowledgment-to thank you, is to say nothing -I feel my heart struggling to bless you-I bless you again and again.

You wish me to say something about myself-all that is necessary, I can soon say. My health is good; my spirits often very low. I feel desolate without parent-without friend-my heart has had those taken from it, that it loved. . . . It gives me great pleasure to hear your health is firm; you say nothing about your fishing exploits, which I claim as my due, being half a fisher myself.-Have you no news about Wordsworth and his poetry? . . . . . I desire you to write soon, and by post, never think about the postage, ${ }^{*}$ it appears to me, when paid for one of your letters (to use a phrase we heard at Gisborne) fair a thing of nowt.

I remain yours affectionately,

T. Sмrith.

* The postage of a letter at that time was $8 \mathrm{~d}$. 


\section{MY DEAR FrIEND,}

Gorton, I5th April, 1821 .

I will not flatter you by saying I broke open your letter in transport, the moment I received it-no, no. I will speak the truth and say to you boldly, that I received it with as much bare-faced indifference, as if it had been a fragment of waste paper. It was not always thus; but things have taken a change. I am grievously suspected, and in fact have been seriously and openly accused, of being over head and ears in love. This charge was preferred against me, by a grave discerning matron, who receives from the Manchester postman, letters for the Gorton district, which she keeps until called for. She founds her charge on having observed, that when your friend applied to her for letters, he opened them instantly, and devoured their contents with eagerness and emotion; having noted this different times, she at last challenged your innocent, unsuspecting friend in these words. "I think your letter must come from a woman." I told her she was mistaken- "Indeed?" she replied, with significancy of tone and manner, "but I have not forgot your reading a letter here before!" I found I was quite condemned, therefore, all I could say, availed nothing-I then began to reflect about reading the other letter, and brought to mind that it was on a Sunday evening, and that there were on a visit to this female commentator, several welldressed, giggling young lasses, who, I have no doubt, were highly amused with the spectacle your friend exhibited, and whose ideas metamorphosed him into a sighing Inamorato! Now if they happened to be novel-readers, they must have been greatly edified, to find that even in these degenerate days, the true, romantic race of lovers is not quite extinct-but that here and there one may be found, fit to sigh by a purling stream, under a shady grove, \&c. \&c. Matters being come to this pitch, I thought it high time to prove myself free from Cupid's wounds, by deeds, as words had no effect; which I have done, by receiving your letters with assumed indifference-I suspect, I rather over-act it.

Your tidings about Wordsworth, (I will not call him Mr., he is too great for that) were good tidings indeed-his "Excursion," I have been longing for, ever since it was first published, but the price has been an insurmountable obstacle to a weaver-it now may be got over, " particularly at the Booksellers' price, for which we are both indebted to Wordsworth, and I, to you also. The cheapness of the book is of little moment to me, compared with the manner in which it comes to me-the hands through which it passes, will to me, impart the soul-knitting quality of a relic.-I am quite jaded with 
writing, yet have not half unbosomed myself; this expressing of my thoughts and feelings with pen and ink, is as imperfect and chagrining, as giving water to a man, raging with thirst, in a tea-spoon. If you do not come to Manchester soon, I have a scheme which may be put into execution, and will answer far better than always writing, it is simply this; meeting each other now and then, about half way between Gorton and Crosthwaite, which we can do any day. This has been a favourite scheme with me, ever since you went. It would answer for me, much better than a long visit into Westmorland, as it would not take more than three days at a time; and out of these we should have two nights and one whole day, for conversing together. In this way we could meet several times in a year, which would take no more time than one long visit-it would seem much longer, and would be more convenient on different accounts. If you do not come over soon, draw out a plan and send it ; fixing time and place, contriving to have a Sunday included for my conveniency . . . _ desired me to mention a fere things - we turned over scarcely so many as would fill a quire of paper! Whilst writing the last line, W. W. tapped at my window, he is coming from Denton on horseback. He says I must tell you his family and brother are well-but by all means let you know, that young Crib has been bitten by a mad dog, and is made away-this comes in luckily as a grand climax, therefore I conclude my epistle sublimely and affectingly, with the biting of young Crib.

\section{Yours,}

T. Smith.

Either write or come soon-think of this meeting plan, it is not much more than a long Sunday's walk. Farewell, my dear friend, and God bless you.

Dear Friend,

Gorton, 23rd Sept. 182 r.

Your kind and liberal invitation to come and see you, in your beautiful and poetic country, has made my pride to "kindle like a fire new stirred," and excited other feelings of a tenderer, and perhaps, better nature. Judge then my sorrow and mortification, when I find my circumstances such, that I cannot without great inconvenience, and risk to my humble domestic concerns, gratify myself and my friend, with a pleasure of all others, the most dear to my heart-a pleasure I have enjoyed so often, and in such full perfection with you, that it makes it doubly hard to decline; yet it must be so-therefore I have done.

I thank you for writing so much about Wordsworth, and your conversation with him. I hope I need not say what I felt on his 
inquiring after your friend. One would like to see the verses by the Richmond youth, that he speaks so highly of.*

I hope his encouraging you to write will have its proper effect upon you-he has seen some things you have written, is a great judge, and too wise to flatter. Think on this, and act accordingly. I think it shows great good nature and esteem for you, to offer you and your friend copies of the last Ed. of his Poems, so much under the selling price. When first I learnt this, I was quite warm and keen of availing myself, of this fine opportunity to supply myself with so great a desideratum-but, alas! since that time, short as it is, what an unfavourable change has taken place, in what so materially affects the comforts of a working man-the price of his daily bread, and the state of trade. . . . What a ramble I have taken from Wordsworth and his Poems, which but for this dark prospect, I had intended securing by your influence. I must give them up for the present, although I look on them "with love and longings infinite.". . . .

This is a strange botched letter, yet I look for one in return; your letters give much pleasure to

Your true and loving Friend,

T. SмrTH.

Gorton, 2nd Feb. 1822.

DeAr Friend,

I have put off writing until now, anxiously expecting to have had the pleasure of seeing you in Manchester, ere this ; what can be the reason that you have not come? It has been a sorrowful disappointment to myself, as well as to Mrs. Shawcross and Mr. Whitehead. Mrs. S. was so good as to send me your letter and the Derbyshire Tour. This Derbyshire tour of ours, being one of the most memorable and pleasant portions of my life.

I have often, and ardently wished to compass a copy of your very faithful, yet very animated narrative; but somehow or other, I had wished so long, and so seemingly in vain, that $I$ had nearly given it up in despair-consequently as soon as I opened the packet, and cast my eye on the Tour, I was flushed with a feeling

\section{" Kn Known to those, who after long And weary expectation, have been blessed With sudden happiness beyond all hope."}

My friend, when you and I, in a state of high excitement, saw and felt all that is recorded in your book, I think we may fairly say, we enjoyed the very quintessence, of whatever is sublime and beautiful

* "Methinks it is good to be here," by Herbert Knowles. 
in Nature, or superb and venerable in Art-by looking on this book, we may in some measure, enjoy this again-some of the images, not so vividly perhaps, but upon the whole, time has taken nothing from its general interest; in fact, when I take up the book at certain times, and in certain moods-on a Sunday, after reading Wordsworth, for instance, I have found it so thrillingly affecting, that I have been under the necessity of laying it quietly down, and creeping out of the house into the open air, for a while-auld lang syne-my friend being in Westmorland-my Mother in her grave-myself aloneGod bless you my friend-pity me.

A short time since, I received two "Guardian" papers, I conclude by your order. One containing The Hedgehog, the other an Address to a Yew Tree. I perceive by this printed copy, they have made havoc of the Hedgehog-they have improved your lines, as Moses Brown improved the taking simplicity, and plain dignity of Walton. of your lines

What is become of the humorous, earnest simplicity

"Then come away, and leave his house alone,

His house and him, now Bob I do desire."

If the Yew Tree has been lopped and pruned, as unmercifully, as the Hedgehog has been "tormented, worried, killed," I should like very much, to see a correct copy of the original. Your lines on the Yere Tree have stirred me, as only genuine poetry always does stir one; perhaps the Stanzas that please me most are . . . the IIth, I think much impaired in dignity and effect by the last two lines. They are too familiar, and have neither simplicity, dignity nor point. You see how easy it is to become a critic, and give oneself airs, and condemn what one cannot equal. . . . When did you see or hear from the great Bard? What do you think? What do you feel? Tell me, I conjure thee. Truly, I hope this will find you in good health, I have had my fears on this head.

Yours sincerely,

T. Sмiтh.

\section{CHAPTER VII.}

INSTEAD of visiting his friends near Manchester, William had been occupied in negociations for the purchase of a farm, and had become the owner of Border Side, or, as it is also styled in the writings, Balder Side. 'This small estate lies in the valley of the Winster, but is included in the Township of Crosthwaite-lying on its Western extremity, and adjoining Cartmel-fell, from which it is separated by the river Winster. 
This acquisition gave the promise of work in abundance, in the way of improvements. The buildings were old, and dilapidatedmany of the fields, sown with boulders-swampy ones needed draining-small ones had to be laid together-the beck, along its whole line of boundary, required embanking, to prevent its encroachments - the site of a new and large orchard had to be grubbed and cleared of blocks-new fences to be set up, both in the fields and on the allotments-and a new barn, and other farm-buildings had to be erected.

He began by letting the farm, in May, 1822 , for 5 years-intending to employ himself in carrying out these improvements. When T. Smith was apprised of William's purchase, he wrote as follows.

\section{DeAR Friend,}

Gorton, 14th Mar. 1822.

My part of your letter to _ I had the pleasure of receiving on Shrove Tuesday-the letter to myself, dated the Ioth inst., last Tuesday - it perhaps surprised me more, than if you had come into the house yourself, for I had been anxiously expecting you, day by day. The reasons you give for your delay, are weighty indeed, and as my fears suggest, may be lasting.

My imagination has dwelt on the topic very much-he has business enough now, as he says. He is become a Statesman-a landlord-tremendous titles to many.-Statesman-Weaver-" no more, let me not think on't"-yet he long and truly, has been philosopher and friend. "The estate capable of great improvement." $A y$, there's the rub. One would like to know whether in beauty or utilityperhaps, in both; if so his hopes of it may run high. Now "the food of hope, is meditated action," consequently, his brain is now reeling with ideas of rich wheat-lands, meadows, pure streams, woods, \&c. \&c., but

"O ye Fountains, Meadows, Streams and Groves,

Think not of any severing of our loves."

But why be jealous of your sweet influences, that

" Never have committed

A crime, against the weal of man or brute."

On this side, I am safe-but there is lucre, filthy lucre! yes, if Mammon lead him on, destruction to our loves; for where your treasure is, there will your heart be also. Ay, this is more dangerous to friendship, than "the sleep that is among the lonely hills."-Well, but did he not withstand the infectious air of Manchester-even the pest-house of Mammon, a Banking-house? Let me try himunsuccessful effort in trade-Derbyshire-Yorkshire-Books-rent- 
sick Mother-and-but enough, it is becoming too solemn, and I am afraid fulsome; yet, I assure you there is-but I have done pray have patience with me.

I have now lying on the table, a number of Gold's London Magazine, for Feb. 1821, it contains an article on the Edinburgh, and Quarterly, from which I copy a passage that has pleased me, and may you. . . . Thanks for all you say of Wordsworth's conversation, and his new works. I expect very much from his Sonnets,* the subject is interesting and important, in a very high degree, added to which, his wonderful talents as a writer of Sonnets, raise one's expectations, very high indeed. Thank you again. These things comfort and refresh me much, and have not seldom, enabled your affectionate friend to String

Not scantily, bright moments on a thread, Of keen domestic anguish___."

My dear friend, do not think me querulous when I say, that at this moment, I have occasion for some cordial or opiate for the heart. You no doubt remember my niece, a blooming girl, that lived several years in our house, prior to the death of my mother, and waited on her in her last sickness. She has been so much with us, that I feel her to be as a sister, or a daughter. The last Spring she was obliged to leave me, and go to her father, on account of the great change made in his family, by the marriage of one daughter, and the death of another. Still, she came at nights to my house, and did what she could for me. She is eminently possessed of the valuable virtues of a modest and faithful tongue-a neat, frugal management, considering her years-and an honesty that renders her worthy of unbounded trust. I often look on her, as the last lingering remains, of that halo of domestic comfort, that gleamed around my humble hearth, when lighted up by the tender feelings of a Mother. It is nearly over with her now, she is "wearing away," her physician has given her up, "to hopeless wasting, root and stem." This is touching when one knows it of any-but how much more so, of a harmless young creature, just arrived at womanhood, for she is truly Wordsworth's

\footnotetext{
" Bashful maid,

Smitten, while all the promises of life

Are opening round her."
}

A near relative too, and one that has done kind offices in the family-O for a living faith, that the darts of anguish fix not. Forgive me for saying so much.

* "Ecclesiastical Sketches," published first in $\mathbf{1 8 2 2}$. 
Do now, if possible, come over soon ; if not, write me a long letter, the first opportunity-yet I would much rather hear your tongue, than see your writing. Trade is bad at present.

I remain yours truly,

T. Sмгтн.

DEAR FRIEND,

Gorton, I9th May, I822.

I have received great pleasure from your kind and pressing invitation, mingled with very much pain-pleasure, to find you are still anxious to see me, and pain, because I must disappoint you. When first reading your letter, I was even then convinced that it would be improper, to indulge myself, so far as to comply with your warm and friendly request. This hurt me much, but I believe that my reasons will have effect on you, who have always been so tender to my domestic interests. I will not enumerate them, but give one of a different, but decisive kind. For these last 15 or 16 days, I have had so bad a rheumatic pain in the loins, that I have been hard put to it, to walk to Manchester, and though it is something better, if I had been, as I am at present, I could not have gone with you into Derbyshire. . . . . . . Tell me something about your "plaguy farm,"-its size and capabilities ; I want to know everything about it. You have no idea of the quantity of intense thought and feeling I have had about you, since you left the Bank . . . . My niece was taken from this beautiful and troublesome world, about the middle of last month; the latter part of her illness was very severe; she bore it with great meekness and fortitude, young and tender as she wasbut she was strongly and comfortably supported, by hope and trust in her God. I was sitting with her a few days before she died, when she said to me, "I dreamed a few nights since, that Mr. Pearson was come to see me, and had brought me some black currant preserve." It affected me exceedingly. . . . . I heard a rational and energetic discourse on the Atonement, preached by Mr. R-, it reminded me of you, and of your great friend, the Bard. When did you see him-God knows when $I$ must see you-I think never much again; but I desire you to write very soon. I am very lonely, and begin to think about marriage in cool blood. Now, deprived of you, I read more intently Taylor's " Marriage Ring." Tell me everything about yourself.

Yours affectionately,

T. SмIтн.

Gorton, July 2 Ist, I 822.

MY DEAR FRIEND,

After being so deeply moved by your kind and affectionate letter, (how weakly words, common-place words express one's feelings, 
owing to the insincere complimentary use of them-so that one feels a kind of shaming dissatisfaction, whilst using them-) I ought, and indeed had intended, to have written several weeks back. Of your pressing goodness I will say nothing ; but that your friendship appears almost unearthly-how hard upon your poor friend, that he can make you no better return, than saying his thankfulness of heart, is strong and deep.—I was much alarmed, and very sorry to hear of Mr. Wordsworth's accident,* and am still anxious to be satisfied, whether he is perfectly recovered. Be so good as to let me know every particular about him. Perhaps you have read the Tour [Miss Wordsworth's] since you last wrote, if so, tell me something about it. . . . . I think you can write soon, if you will-you cannot be so busy as I am. How do Latin and draining go on ?-I have some poetry for you, and must begin to copy it. . . . . I have read little, lately, but I think much-chiefly on times past-times and things. O my friend, what I feel-what I now at this moment feel. God bless you. Farewell-

\section{T. Sмith.}

During the summer of 1822 , William planned a journey into Scotland, and in August set out for a month's ramble; Mr. Wordsworth having furnished him with the following route, which is evidently an outline from memory of his own first journey into Scotland; throughout which, his Sister was his companion, and in the earlier part of it Coleridge also. William as usual kept a journal.

\section{DeAr Sir,}

The weather having been so bad, you will scarcely have set out on your Tour, therefore I hope these few notes will be in time to be of service to you.

We were pleased with the vale of Nith-The ruins of Lincluden Abbey or Priory, are near Dumfries, on the road up the Vale; but little of them remains. Drumclanrig, the mansion of the late Duke of Queensbury, which is a long way up the Vale, we did not see,turning off to Lead Hills, a village inhabited by miners; thence nothing interesting to Lanark,- - at Lanark, falls of the Clyde and Mr. Owen's establishment. Beautiful country to Hamilton, where in the Duke's palace, a fine collection of pictures. Thence to Bothwel Castle,Glasgow,-Dumbarton,-Loch Lomond,--Luss-fine view of the islands of Loch Lomond from the top of Inch de Vannoch, Tarbet, Arroqher,-Glen Crow, Inverary,-Kelchurn Castle on Loch Awe, very striking; Dalmally. Thence we went to Loch Etive,- - to Port-

* He had been thrown from his horse, and had received a cut on the head, while staying at Lowther. 
nacraish on Loch Linnhe, interesting all the way up to Ballahuilish, from hence we went up Glen Coe and back to B-. Glen Coe very sublime. By Fort William, Fort Augustus to the Fall of Foyers, very fine; and so on to Inverness, from whence, fifteen miles north to some beautiful Saw Mills, upon the river Bewley, the scenery of which is very romantic.

Homeward, by the main coach-road to Blair Athol,-a little before reaching it, you cross the stream of Bruar below the waterfalls, interesting on Burns's account,-Killicrankie and Fascally on the way to Dunkeld, very striking; Dunkeld also interesting. The narrow glen a pleasing solitude. I have omitted Kellin at the head of Loch Tay and the Trossacks, as they lie in the country between the two main roads; but the Trossacks are very fine, and Kellin a striking situation. Stirling and Edinburgh; and I have nothing more to say, unless I mention Perth, which lies low, in a beautiful valley.

The letter you sent to the Gazette was just the thing, and I hope would produce some effect. Wishing you fine weather and a pleasant journey,

I remain, dear Sir,

With very sincere regard, Yours,

Ist August.

WM. WORDSWORTH.

On his return from Scotland he received a letter from T. Smith, who after naming his own indisposition, goes on to say, "I am now, thank God, in a state of good health, one of the greatest blessings God ever bestowed on his creatures; indeed most others wither when it is gone. One cannot wonder that the more feeling and grateful among the Heathens, erected altars to Hygeia and Ceres,for what was it but saying, 'deliver us from evil,' and 'give us this day our daily bread;' requests replete with true wisdom, and suited to the nature of weak, yet sublime humanity, in all times and in all places.

"I was much pleased when I heard of your projected "trip to Scotland.' You said you did not like the idea of travelling alone. You liked it as well as your friend did, I am sure, who would most enthusiastically have prevented it, had he been possessed of the means; yet I promise myself no little pleasure, from your account of this far-famed, picturesque country, with its intellectual, musical, poetical, and virtuous inhabitants.

"You surely have kept a journal; I shall be greatly disappointed and blame you much, if you have not. I lent your Derbyshire Tour to some bookish acquaintances, who have been greatly delighted with it. If you are capable, as has been acknowledged, of giving by your 
writing, pleasure sprinkled with instruction; never let indolence, or an excess of modesty, prevail on you to withhold it.

"I was much pleased to hear that you had shown your zeal for the great object of our idolatry, by repelling the attack with your pen, made on him in the Kendal paper. I should like to see the article, and your reply. It appears Mr. W. was satisfied with your answer, yet you mention the fable of the Lion and the Mouse.-When the mighty philosophic Bard expresses a wish to see your humble friend, it is at once elevating, and overwhelming-it makes me proud-but very humbly proud; one sinks into nothing near such a being. I am glad to hear he is got quite well; I hope too you are quite well,indeed you have been little out of order lately; your general health seems firmly established. You must receive much benefit from your outdoor exercises, amidst such a profusion of pure air. I am not surprised you are delighted with agriculture-as a recreating employment; I know nothing like it, so pleasant, useful and honourable. I wish your determination not to shoot so much, still holds out; it is a very unintellectual and dangerous diversion. Poor man! Mr. S has lost his child. Such things make one hesitate about marriage. Your castle it appears is come down-nothing strange-the friend and the poet were too visible in its construction. It was a 'glorious pile' my friend, but the materials 'such stuff as dreams are made of.' - My affection and esteem for you are as strong as ever-there is a better foundation for them to rest on, than you give your castles.

"How long have you been back from Scotland? Did you see any of Burns's relations? Give me a few particulars of your tour, soon.

"Yours truly,

"T. SмIтн."

In January, I823, Mr. Mitchell, one of the proprietors of the Nerecastle Magazine, presented William with a set of that periodical, and expressed his desire to have him as a contributor to its pages. Mr. M. stated that "its circulation and correspondents were of the first respectability," and he "might add with truth, that in these respects, it was not equalled by any provincial periodical in the kingdom," and that William's "talents might be thus exerted, in conjunction with others; with whom he would not think it discreditable to be associated."

Probably he went on in the old track, as there is not anything remaining to lead to a different conclusion.

Early this year William visited Manchester, and during his stay tried to influence T. Smith to change his occupation, which had now become by the fluctuations in trade (so rarely beneficial to the operative), most anxiously precarious. But 'T. Smith's nature was too con- 
servative-too much bound up with the old and familiar, to be disengaged from it, without a wrench, such as he was not prepared to encounter; and William prevailed not-though his efforts had not been restricted to words alone. So desirous was he to effect the object he had at heart, that on his way home he wrote to his friend; and again when he reached the Yews-these letters elicited the following.

\section{MY DEAR FRIEND,}

I have received two letters from you since you left Manchester, and great pain and pleasure I have from them; that written at Preston, strongly revived a matter that had given me great uneasiness. As soon as I had read your well-intended letter, it set my thoughts and feelings a working most painfully again. I named to two or three friends what you had written, who advised me (conscientiously I believe) to remain at my old occupation; yet we all at the same time felt and acknowledged your warm purity of intention, and felt much regret at thus seeming to thwart you. It is hardly worth while to write my reasons for my decision, as you say you are satisfied, whatever conclusion I may have come to; thank you my kind friend, as that is all I wanted. Yet after all, I may be acting against myself-I mean against my worldly interest; indeed, to confess the truth, that is a thing I have never paid the greatest attention to; perhaps much less than I ought to have done, and at times (in fact frequently of late years), I have suffered severely, it may be, for not having done so-not but that I have done something like my best, with the occupation I have had-I feel little self-reproach on this head, and the time has been, that it made all our household comfortable. But that state of my irade is, I fear, for ever gone by. However, I must risk that, and make the best of it. If I can walk through life and perform its most important duties, with becoming sympathy, uprightness, and gratitude, and at the end of my journey be able truly to say, "I am a man more sinned against than sinning," I shall not have lived in vain. The former part of your letter, and indeed all of it that relates to myself, did me much good. I must have been callous and ungrateful if it had not.

My dear friend, I deal not in common-place condolence, but instead, give you my sincere regard, and daily sympathy, in whatever appertains to you, whether in mind, body or estate. I wish I could give you other proof than merely saying so. After reading the causes of your disquiet, these lines immediately came into my mind.

"Alas, how oft does goodness wound itself, And sweet affection prove the spring of woe."

These lines will apply, I am sure, directly to yourself; but think, 
my friend, how common a lot it is, to be troubled by the conduct of relations. I am sorry you brought such bad tidings from Mr. Wordsworth's, but hope things have taken a favourable turn; let me know when you write.

\section{Yours ever,}

\section{T. Sмiтн.}

Towards the close of 1823 , affairs of the heart were drawing to a crisis in the cottage at Gorton; and in a letter to his friend, T. Smith writes, "I have much to say, and but little to write, . . . . I have been agitated and troubled in this business exceedingly, . . . . marriage is a hazardous thing, and is sure to produce a great alteration either for weal or woe. . . I have boldly resolved to venture on the 'state unknown,' and we have agreed to share each others' joys and griefs, on this side the grave, by the great bond of wedlock. . . . but you know 'the course of true love never did run smooth'-it is liable like other tender and delicious things, to be ruffled by so many accidents - and ours, 'sickness did lay siege to it ;' her father fell sick, which made it inconvenient, and even improper for her to leave home; therefore, she staid till he got something better, when she became very unwell herself, and remained so a long time; she is now somewhat better. After learning this, I hope you will forgive my not writing sooner. . . . . . I am sorry your tenant is such a plague to you, but if this Rob Roy of yours remain obstinate, I know of no way but one of dealing with him, however unpleasant it may be to you-you will be forced to have recourse to the 'Statutes and their Shelves,' and convince him perforce, that 'he is come an age too late.'

"Have you no literary intelligence? What do you read, anything besides Latin? And what do you learn from reading? When did you see Mr. Wordsworth, or hear from him? It would give me great satisfaction to hear of his publishing more of his Recluse-the work makes one proud, as an Englishman.

"Yours sincerely,

" T. Sмiтн."

In $\mathrm{x} 824$, T. Smith writes, "how are you getting on with your farm and farmer? I am very sorry you ever met with such a man; his character reminds me of Thomson's spider, 'cunning and fierce, mixture abhorred.' I hope you are well rid of him; let me know particularly, it has troubled me much. I hope you are comfortably and prosperously situated on your own farm."

William's fraudulent tenant had run off their agreement, and shirked payment of rent; this was met by the seizure of some barley, which was thrashed and sold, to the amount due. The man then brought 
the matter to a trial at Appleby. Brougham was counsel for the defendant, in whose favour the jury returned their verdict. After this, the man was ready enough to give up the farm, and leave the neighbourhood ; and in reply to T. Smith's inquiries, William wrote, "I quitted my farmer last May-day; during the summer built a new barn, \&c. and now have the estate in my own hands." - In I 824, he also established himself in the old farm-house, which continued to be his home till the close of $184 \mathrm{I}$.—As a settled resident, he now bore his part in Township business, and likewise in dispensing the funds of various charitable endowments connected with the Township ; of one of these he was a Trustee.

During the mayoralty of Mr. Richard Raws, in Kendal, in I832-33, he originated and succeeded in obtaining a reform in the fruit market; where by prescriptive usage, its sale by measure was the law. The measure used (with its subdivisions), was a kind of basket of a peculiar make, called a pannier, not very unlike a fishing-pannier in form; I6qts. was the measure of its contents. Obviously, this system admitted of unreasonable demands on the one hand, and of evasive tricks on the other - and there were other evils, causing much inconvenience and sometimes loss to the farmers, which it is needless to set forth. - William drew up a petition, praying for a redress of these evils, by changing the law from sale by measure to sale by weight, and further praying the Mayor to use his authority for enforcing its adoption. - The petition was adequately signed by the orchardists, and presented for the Mayor's consideration, who granted the prayer of the petitioners, and thenceforth sale by weight became the law of the Market.

Amidst his various active occupations his literary tastes were in no danger of extinction; he contrived to keep up some general knowledge of what was passing in the world of Letters : and among his pastoral enjoyments, his Orchards were his great delight-his joy-and truly his Large Orchard became a charming retreat. It was screened to the North by a belt of tall Oaks, with an irregular undergrowth of Hazels ; and beneath these again, nestled Primroses, Violets, the Celandine, Wood-anemone, Star-wort, and many a little flower besides-and beneath the young flourishing fruit trees, the sunbeams glancing between the boughs, played among the curls of the luscious Hyacinths, which stretched away beyond ken, on the one hand-whilst on the other, those most jubilant of flowers, golden Daffodils, the glory of Spring - sentient, if ever flowers were sentient-came forth in March, and lingered into May.

Long after the bloom of novelty had been brushed away from this chosen spot, the following Idyl flowed from William's pen.

"On rising this morning, I walked into the Orchard. How 
beautiful were all things! It brought to mind the lines of the old Poet,

$$
\text { 'Sweet day, so calm, so pure, so bright, }
$$

The bridal of the earth and sky!'

And with the Seer of Rydal, I felt

'The innocent brightness of the new-born day
Is lovely yet-'

"I cannot give you 'Each rural sight, each rural sound,' but they were delightful! There was the blushing red and white Appleblossom, grateful to sight and smell; the Cuckoo shouting from the adjoining hill-its note 'by distance made more sweet'-even the homely language of our Ducks and Hens in a kind of under-tone, was agreeable, for it was the expression of pleasure.

"But what I was most delighted with was the antics of my little favourite the Willow Wren-running along the branches of the fruittrees-upside and downside, as if it could not contain itself for joyand every now and then, clapping its little wings for a minute or two-ever so long-as if to fan itself-or rather through its 'tipsy jollity!' I wish you could have been with me.

"I fear it is too true, that it often requires adversity to make us devout; but how much better it is to feel love and gratitude to the Great Giver, at the sight of the beauty and enjoyment He bestows on His Creation."

In the following extract some of his troubles peep out.

"Happening to look into White's 'Selborne' to-day, I popped upon a passage which shows that that accurate observer, has anticipated me in some degree, in my notice of the Fly-Catcher shielding its young from the burning rays of the sun. It is strange that neither Mr. Gough, nor I, nor any one present when the paper was read, should recollect this passage in a book so well known. I knew that I had read of something of the kind, but thought it was of the Swallow. White's notice is only a sentence or two, I hope to have the pleasure of showing it to you sometime.

"Though to-morrow's fair may put money in my pocket, it is far from a pleasant business. I have to sell two or three Cows of my own breeding. You may think it laughable, but I seldom like to sell a Cow. One does not like to part with things that one has been used to, particularly living beings that one has known from their introduction into the world. Moreover these said kine, were intended to be part of my summer stock of Milch Cows, and ought to have calved in the pleasant month of May-what are called Spring Calvers-but the gods unluckily decided otherwise, and I had to lament their premature delivery - an unfortunate dispensation both in 
feeling and in purse.-In fact, if I were to keep them through the Summer, their milk (as farmers say) would not be worth their meat.-So I can't indulge my feelings but at the expense of my purse ; and profitable farming I suppose has nothing to do with feeling. There now, I have given you one view of my Arcadian profession."

Elsewhere he writes, "I have been busy all day gathering fruitmy two young men have been among the potatoes-charming weather for both employments. You suppose we shall have gathered all the fruit-we have not yet got all the summer kinds (then there are the keepers), nor do I regret it, for they make money. If on a marketday they produce 2os. and the butter basket as much, it is still acceptable. It is singular that the Blackbirds this year, have been very destructive to both Apples and Pears, pecking them upon the trees till there is little left but the skin-like a mouse getting into a cheese! They take them I suppose as a quit-rent for their songs in Spring, and therefore I do not shoot them. They are very numerous about Border Side this year-perhaps there is a dearth of their usual food.

"The other day my young chaps had a journey to Patterdale, and made a pretty good trip, bringing back $24 \mathrm{~S}$. - I could almost have wished to have gone myself, that fine valley would be so beautiful in its autumnal hues.-Indeed this weather is so delightful that I feel the desire for travelling returning upon me rather keenly.

"Will you read the Critique on H. C. Robinson's tract, in defence of Clarkson against the Wilberforces? Crabb I have a notion will prove to them sour! It is praised highly, which does not appear more than it deserves. One can hardly expect anything poor, from one who was the friend of Charles Lamb, Wordsworth, and Clarkson."

In another letter he says, "Contrary to expectation, I had a beautiful night for travelling home. The moon shone out fullorbed. . . . . . Wordsworth says one may 'form dear friendships with the Woods and Groves,' and he speaks the words of truth and soberness. One may become attached to a tree that one has planted, and whose increase in size and beauty one has yearly noticed-I have felt regret enough I am sure, from the destruction of some of mine. . . . . . It is allowed that we shall preserve our identity in the future state, and what is that but our recollections and present sympathies? It would be mournful to the friendly living soul, to be eternally separated from those kindred spirits to whom it has been attached in this present state of existence. This would appear to interfere essentially with happiness. I would fain hope we shall not only know all who are dear to us, but the good and great of all past ages. It is not a selfish feeling that 
induces us to yearn after future communion with those we love -it is quite the reverse, or language has no meaning. But it is time I should conclude. Be assured I shall ever love you. Here and Hereafter, if it may be."

\section{CHAPTER VIII.}

IN September T. Smith writes, "Now for a little about myself. I am still unmarried. I have been in almost continual trouble, for some time past. The father of my intended wife died a few days ago, of a lingering complaint of the liver. $\mathrm{He}$ has been dutifully and affectionately attended, during his infirmities, by the object of my long esteem, and warm affection, whom I soon intend taking to myself, with the hope of enjoying something like domestic happiness - at the least, of loving and being beloved, in humble quiet. I sincerely wish that these things, my dear friend, may fall as plenteously to your lot, as to my own-few, I know by experience, have hearts so capable of enjoying them, as is yours. Write soon I beg of you. Good night, and God bless you. One word more-how is Wordsworth? tell me largely."

On the rgth of October, I824, T. Smith married Elizabeth Willan. Their age was the same, 42 years. Brief, alas! was the weal-the woe which followed, most pitiful! The death of his wife came upon him like a thunder-clap, on a clear, serene day! Seized with apoplexy on the Wednesday, she never spoke more, and died on Saturday the 9th July, 1825. A few words from Thomas himself, told William how sorely he had been smitten-the treasure of his life taken from him.

In September or October he quitted his desolate home, and found at Borderside, all the solace that friendship could bestow. His earthly wishes were now centred in one object-that an epitaph composed by Mr. Wordsworth, should commemorate his departed wife. This wish William undertook to communicate, and the following letters were written on the subject.

\section{DEAR Sir,}

September 2 Ist, 1825 .

I will endeavour, as you requested, to give you some particulars of the character of that amiable and interesting woman, the wife of my friend Smith, and whose loss he has so much reason to deplore.

I am undertaking a task, for which I feel myself but ill-qualified, but if I can enable you to understand the general features of her character, it will I hope be sufficient, for the purpose my poor friend has so much at heart. Mrs. Smith had been endowed 
with considerable intellectual power, and her mind had been directed to subjects of knowledge, I may say of science, to which the attention of her sex is not often devoted. Without crying her up as a prodigy, it can be truly said, that her skill in Mathematics, such as Geometry, Algebra, \&c., enabled her at any time, to take her father's place in his school. Yet these rather unusual acquirements, did not make her vain; her modesty and retiredness of disposition, were truly feminine. She was mild and gentle, and fearful of giving offence to any human being. She had besides, great sensibility to the charms of poetry, particularly the old Ballads, numbers of which she could repeat. Perhaps I ought to mention, that she was neither ignorant of household duties, nor unwilling to practise them, and that her personal beauty was rather remarkable._- Poor Smith could hardly have expected to meet with such a wife; I believe they were made for each other. He says, she was his superior. They had only been united nine short months, when she was taken away! for so willed an inscrutable Providence. Her father was schoolmaster at Gorton, for upwards of fifty years, and was highly respected not only for his professional ability, but also as a man. The Willans were of North-country derivation, her grandfather being a native of Millum in Cumberland; and what is by no means singular, the family retained a strong predilection for the land of their forefathers. Mrs. Smith had an uncle said to be an excellent Mathematician, who was, for some time, an assistant in an eminent academy in Liverpool: at the head of which was a gentleman of the name of Wordsworth. The pupils were sons of the first people in the neighbourhood; amongst whom were those of General Tarlton, the late member for the town.

If there be no impropriety in the request, I am sure that anything you may write, will be most gratefully received by her sorrowing husband-indeed it is what he has set his heart on, as the only, and the greatest thing he could do for her.

With my best respects to your Sister and Mrs. Wordsworth;

I remain, dear Sir,

Yours very truly,

W. Pearson.

He received the following reply.

MY DEAR Sir,

My brother is much interested by your simple and affecting report, concerning the character of Mr. Smith's deceased wife, and desires me to say, that he is not hopeless of being able to throw off a few lines at some time or other, in contemplating so interesting a 
character; yet he can by no means promise for himself. There are however two points which you have omitted to name, and which are essential in the composition of an epitaph-namely her age, and the date of her decease; therefore be so good as to inform us of these particulars by the next post after your receipt of this. The day of my brother's departure is not fixed; but I think it will not be later than Thursday, and I very much wish to hear from you before that time, as during his journey, it is not unlikely that his thoughts may take the turn, which might lead to the accomplishment of his, and your wishes. . . . I must not omit to tell you, that we have read your journal with great pleasure. There are two or three passages which throw light upon some imperfect recollections of my own, which I shall, with your permission, take the liberty to copy. . . . and believe me,

\section{Dear Sir,}

Yours respectfully,

Rydal Mount,

D. WORDSWORTH, Senr.

Sept. 3 oth, 1825 .

In answer William wrote, "I regret much that I should not have received your note of the 3 oth ult. before yesterday, especially as I fear Mr. Wordsworth will have taken his departure before this reaches you. However, I lose no time in making you acquainted with the two points I had omitted. Mrs. Smith's age was the same as her husband's, 42, and she died on the $9^{\text {th }}$ of last July. They were married on the 19 th of the preceding Oct.-I should not have omitted the two essential particulars you point out, but from an impression that my friend only looked to your Brother for the poetical part of the Epitaph. But in this I may have been mistakennay, I am now convinced, that it is more desirable that the whole should be of his composition, if we can be so fortunate as to procure it."

He shortly after received the following on the same subject from T. Smith.

Gorton, 13th Nov. 1825.

MY DEAR FRIEND,

I have received your letter to-day,-and I need not say I had been anxiously waiting for it; yet not with uneasy impatience, for I was sure your kind-heartedness would be assiduously at work to serve and comfort me; this I have experienced so often and so regularly, that I have not unfrequently looked for its appearance, as confidently as for the morning sun, and with something of a kindred emotion.

I am sorry you did not receive Miss Wordsworth's plain, beautiful 
letter sooner. What goodness, what talent, all in motion to serve poor me-I cannot muster words to express thanks such as my heart is now giving-Wordsworth-Friend-Wife-how can I express the deep and blended feelings, inseparable from these names?

You hint the want of a friend to dissipate your gloom; alas! my dear friend, I fear my sad and querulous demeanour during my stay, must have given proof how little can be effected by the most exalted friendship. . . . God bless you.

Yours affectionately,

T. SMrTh.

Again in Feb. 1826 , he writes "you are very good to me-in truth you are the greatest good I have left on Earth. I ought to be thankful that I have you still-you have been a blessing to me ever since I knew you. In your character and hers that is taken from me, I always found something to enjoy.

The sketch you have given of her is beautiful and correct-it is a likeness full of life and truth-I am highly satisfied with it. If I were requested to give her leading characteristic-truly and peculiarly speaking-I should say it was a willingness, or eagerness, or more properly speaking still, an anxiety to oblige, and a great fearfulness of giving offence-all combined with tender firmness and mild dignity. Let me hear from you soon. I must take this to Manchester to-night, therefore must conclude. I should be glad of the heads of Mr. Wordsworth's invaluable conversation. God bless you.

Yours very affectionately,

T. SMiтh.

Again he writes.

$$
\text { April I } 3 \text { th, } 1826 \text {. }
$$

I am painfully desirous of hearing from you, and am sometimes fearful all is not well with you. God grant that my fears may be groundless, for I have already more sorrow, than I can muster fortitude to bear as a Christian . . . . . . If I had you near me as I once had, I think my mind would not brood so intensely on the excellent woman I have lost-night and day-at home and in the open air, my loss is present and always speaking to me. All I see and all I do, bring to my mind the beauty and goodness of my departed wife. . . . . But she is now in heaven, and I am lingering here-here lingering in this foolish, selfish world, with not a congenial eye to beam upon me. Without Christianity I should hardly be able to live. . . . . I am thankful to God for sparing to me 
a congenial heart. . . . I saw James Houtson a few weeks ago-as hearty as ever in his inquiries about you.

Yours affectionately,

T. Sмітн.

Again he writes in August, I826-“ I had J. W. and W. W. yesterday. J- showed me a letter from you, inviting him to shoot with you on the ist September. He seemed much pleased, and intends setting out to-morrow for Crosthwaite, and to arrive at your sweet, pastoral home, on Thursday. How gladly would I go with him, had I the means, as he has-or even such as a weaver had, twenty years ago-woeful change--dreadful in the sum total of its effects upon human comfort. I received your kind and valuable letter of the I 9 th ult., which I had intended answering ere this, but I was laid by two or three Sundays, and other days I have been too busy; it pains me to neglect you, ever. My dear friend, you have tenderly advised me as a support, and a relief to my suffering, to reflect and to read on the goodness of God; and as an auxiliary, to ' $m i x$ a little more, with those who are more at home in the world, than we are.' I have tried both. I have been reading Paley's ' Natural Theology,' 'Sermons,' \&c., and have mixed a little with a few clever and obliging musical acquaintances, in, and about Stockport. F- junr. and a Mr. G- came to see me one Sunday. They tried to persuade me to play a little, but somehow, I cannot-I have not once sounded my flute, since my wife was taken from me. They then kindly offered to call a musical club together (of which they are members), an hour earlier than the usual time, if I would go over and hear them play some of their best music. I felt grateful for all this, and went. They played well, and behaved politely-paying great-far too great respect, to your friend's taste and judgment-the meeting was prolonged to a late hour, and four of them set me more than a mile -all this was kind and good, and I prized it much-yet I felt not half the pleasure at the time-nor real satisfaction and good accruing from it, afterwards, that I have so richly experienced in rambling through the common air, with you-enchanted at times, with the beauties of nature scattered around, but always more--deeply and more, with the greatness of the human soul-the emanations from yourself, always pouring out before me, either in speech or feature. $\mathrm{O}$ for another world, to have these things for ever!

"I said I had been reading Paley-he is one of the clearest, fairest, most satisfying writers I ever read. I was induced to purchase his sermons from hearing Mr. Wordsworth speak a few words in their praise-I have received comfort from parts of them. After all, it is difficult to gain hope and fortitude, especially when most wanted. I 
wish you had been born near Manchester, or I near Kendal; but I am thankful you are alive and write to me, it has been a great support. My dear friend, it is a heart-breaking thing to have a wife like mine, I say my friend again, like mine, taken away. She was truly, what Poets feign-Una, Juliet, 'the gentle lady married to the Moor,' all in one - it cannot be my friend, but that hearts like yours and mine, will bleed at such a severing. God give me strength, or take me to where she is.

"J. W. has this moment come in. Farewell.

$$
\begin{aligned}
& \text { "Yours ever, } \\
& \text { "T. Smith." }
\end{aligned}
$$

Whilst Mr. Wordsworth was preparing a new Edition of his Poems in 1826 , William received the following autograph note.

$$
\text { Rydal Mount, Monday. }
$$

MY DEAR SIR,

(Post-mark, Mar. 6, 1826.)

If I am not mistaken, I lent you some time ago, a copy of my little Tract upon the Lakes, which contains a corrected copy of a Sonnet upon Long Meg and her Daughters. These alterations I want for the new Edition of my Poems. I should be glad if you would be kind enough to copy them for me, and send them.

Ever most sincerely yours,

W. WORDSWORTH.

William wrote in reply.

MY DEAR SiR,

From not having a post through to our out-of-the-way place, your note did not reach me till this day. In answer, I hasten to say, that I believe I am not possessed of the copy of your Tract that contains the corrected sonnet on Long Meg and her Daughters; nor have I any recollection of your having lent it to me, nor even of having seen it. I have been just reading the Sonnet in question, in my copy of your Description of the Scenery of the Lakes, [given to him by Miss W.] but it has no alterations or corrections with the pen. I should have been glad to have copied them for you; and hope you will yet be able to recover them in time for the new Edition of your Poems.

I am happy to hear of your being engaged in preparing this new Ed., chiefly - [the remainder is unfortunately wanting.]

An interval of many months without a letter reaching him from Borderside, caused T. Smith many uneasy thoughts; and when at length one was received, his sensitive nature imagined it written with less cordiality than was William's wont, and he unburthened his mind 
in his next letter; mentioning various matters, one or other of which he fancied might have produced the "coolness."

My DEAR FRIEND,

Gorton, r4th April, 1827 .

I received your letter of the 7 th inst. yesterday-it was brought by J. S. I took the apple grafts directly to J. W., who was pleased with them, and said they were good ones. He sent his respects to you and Mr. Tyson, and thanks for sending them.

A few minutes before I got your letter, I had been walking in the meadow near my house (as I sometimes do after my solitary meal), to enjoy the air and look upon the distant hills-to hold communion with you and the "days of other years"--fourteen Good Fridays back from this, my friend and I were walking near yonder hill-then I thought, how long it is since I heard from him-becoming agitated and sad, I hurried home, taking a thrilling glance towards the churchyard, where my dear affectionate wife sleeps in the cold gravewhat a preparation for reading your letter, which for months I had been longing for . . . . . . . my trade-my poverty-my want of spirits, with many other things that I could talk to you, but cannct write on this paper, press heavily upon me, yet I am at present more depressed with your cool letter, than all these. One thing, often flashes on my mind, when about concluding a letter to you the awful uncertainty of human life; I have had it most deeply impressed on me. If you have any regard for me write soon, and explain all-. . .

Yours very truly,

T. Sмiтн.

His next letter is dated-

MY DEAR FRIEND,

Gorton, Ist July, I827.

I have received two letters from you (dated April 22d and June gth) since I last wrote to you. They have given me much pleasure, and much sorrow; pleasure to find your heart, kind and true as ever-but their main tenour relative to your own affairs and self, is sorrowful indeed, and has given me deep and lasting uneasiness. I have at times mused on you and your untoward affairs, until I have been fit for nothing. My dear friend, how many misfortunes have been attacking you. I am a judge of your fortitude, and of your sensibility-though you bear like a man, you feel like a man-bear up my friend, and if possible banish unpleasant thoughts-but if melancholy will at times prevail, unbosom yourself to your friend, and let him (I hope the request is made with becoming delicacy), confine and lock your troubles in his own breast, till they are either 
killed, or healed. The advice I can muster for you is slender, but pure ; I can say more for my sympathy, it is affectionate and deep as ever man gave to man-it is something like your friendship for me, which ever had something not of earth about it-the friendship of Books and Romance, realized.

"Gentle to me, and affable, hath been

Thy condescension, and shall be honour'd ever,

With grateful memory__."

I have no particular news-as to myself, no alteration for the better, in mind or spirits-I have passed two miserable years.

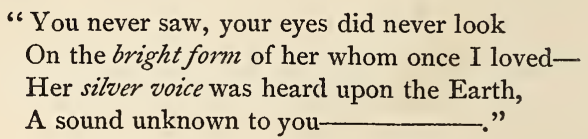

When I have lost my memory my friend, I may escape from anguish. I am often sore beset with "hauntings from the infirmity of love," tears come and give relief, else the heart must either wither, or break, " a consummation devoutly to be wished," if it would take me where she is-and you to follow. . . . . When can you come over? do your best to come-I know you would scheme hard, to find a time to write, to one, that so highly values anything that speaks of you-a pencil-mark in a book, or a snatch of translation made by my absent friend, has not unfrequently moved me to tears-no other being ever had the like power over me, SAVE ONE-if I could write a year, I should not have half done-now come, or write soon.

Yours affectionately,

T. SмIтH.

Towards the end of the year William received the following proposal from Mr. Prentice, to whose paper he had long been a literary contributor.

MY DEAR SIR,

Manchester, I3 Dec. I827.

If you are inclined to have an employment which would not be very slavish, and would be in accordance with your literary likings, I think I have an opening for you.-I have now established the "Gazette" on a firm and respectable footing; but in doing so, I have impoverished myself: I am at present in the situation of a farmer, who, after having laid out his money in draining and manuring, is in danger of losing it altogether.-I have friends here who would set the paper on a footing that would to a certainty make it prosperous, provided I had some one to undertake the management of the business part of the concern. I have mentioned your name, 
and I think that with you, there would be confidence to help us both on, prosperously and easily. Pray let me hear from you immediately, -or if your inclinations are at all for the employment, perhaps you might come over here, for a day or two.

Dear Sir, yours truly,

Archd. Prentice.

\section{William's reply.}

MY DEAR SiR,

Crosthwaite, I 7 th Dec. 1827 .

Your letter of the ${ }^{3} 3^{\text {th }}$ inst. I received yesterday.-When I inform you of my present circumstances, you will judge how far I am in a condition, to accede to the proposal with which you favour me. I am not sure whether you are aware, that about five years ago, I purchased a small estate in this Township; and that for the last two years, I have had it in my own occupation.

Had this opening occurred before I commenced farming, it might have given rise to some consideration-but I am sure that since then, I have employment more than enough-little profitable-but still healthy-which I fear from former experience, would hardly be the character (to me) of any situation in your town.

I feel obliged to you, my dear Sir, for the favourable opinion that has given rise to this proposal, and had I been at liberty, it might have been more agreeable to my feelings, than a mere mercantile situation. But had the offer been still more tempting, I must have declined it. I am fixed here so firmly that I cannot move. Since I bought this farm, I have been at considerable expense in improvements, to say nothing of the cost of stock, \&c., when I became occupier,- so that to give up now, would be losing the only chance of even a partial remuneration, for the outlay and trouble.

The increase of advertisements, and the more extended circulation of the Gazette, since under your management, gave me the pleasure of concluding, that it had become a profitable concern. I am sorry to find this is not the case. The ability, and public spirit, shown in the conducting of it, deserved a better reward. Still I am happy to presume, that your repute as Editor, as well as the part you have taken at public meetings, must have procured you many friends,-friends who are able, as well as willing, to assist you in this emergency. I wish I had been in a condition to take a few shares in your paper; but the truth is, I have no ready money. During the season of fallacious prosperity, and tempted by the high rate of interest, I was so imprudent as to lay out all my spare cash, to the amount of some hundreds, in the purchase of South American bonds, which cost me upwards of $£ 80$, and for which I could not 
now realize $£ 30 !$ - and still worse, the dividends have not been paid for some time! This unfortunate affair I mention to very few. It has docked me of half my income. I grieve that at present, I can make so poor a return for your generosity, in sending me the paper for so long a time. . . . . I cannot consent to receive it any longer, on the present footing; you must put down my name as a subscriber, from this time. When you pass through our part, I shall be happy to see you, for as long a time as you can spare, at my poor domicile. I live here, somewhat in the manner of the back settlements, in America, in a kind of rude plenty-with few of the luxuries of life, but with health and tolerable contentment. What I miss chiefly, is the society and friendship of a few, whom I esteemed, in your town; among whom, believe me, I shall always reckon yourself. But this world is no abiding place for any of us. With best wishes, I remain, dear Sir,

Yours sincerely,

W. Pearson.

Among others who suffered a diminution of income from the nonpayment of interest to the Bond-holders, was a near relative of $\mathrm{Mr}$. Wordsworth's. This stirred up a feeling of sympathy which led to many discussions on South American prospects, and affairs. It was not till $\mathrm{r} 84 \mathrm{I}$ that the payment of dividends was resumed.

Gorton, Jan. $13^{\text {th }, ~} 1828$.

MY DEAR FRIEND,

This has been a long, sadly too long silence. Your last letter is dated roth Sept. I was about writing to you, my dear and excellent friend, two months ago, when I received a letter from informing me you were expected in Manchester; on hearing this, I gave up writing, hoping day after day, to have the pleasure-rapture, is a truer word here-of seeing you and hearing you speak once again-but this has been like other hopes one has cherished, till the fond heart could scarcely live without them, which have come to nothing-or worse than nothing-for they have not left a blank merely, but pain. I love you my friend, and my heart will unfold itself to you-it cannot to anybody else.

You will oblige me very much by writing as soon as possible. Your leaving Manchester has been to me a serious misfortune indeed. It has taken from me hundreds of happy hours-nothing could supply your place . . . . there is no exaggeration here; it is a tame recital of facts. Great God of this fleeting and beautiful world, I thank Thee for thy signal goodness to me, in bringing my heart and mind into contact with two of the dearest, noblest beings, 
ever created-O that good and evil dwelt not so near togetherthe extremes of a tender heart, when happy, or unblest

I thank you for your last kind and instructive letter. I say nothing of particulars, but all is treasure to me. I have read but little these two or three months-I have been perplexed and embarrassed in my employment. Write soon, we are uneasy-tell me all. God bless you.

Yours,

T. Sмiтн.

\section{MY DEAR FRIEND,}

Gorton, 24th Nov. 1828 .

I have received two letters from you since I wrote last. Your kindness is great and delicate-it overpowers me with gratitude when I think upon it-yet poverty, and untoward circumstances, nail me to my "peculiar nook of earth," and render it almost impossible to gratify my own ardent desire of seeing you once again, and having a most cordial interchange of joys and griefs-you have always taken a large portion of my troubles to your heart, willingly, not to say eagerly; let me express my thoughts and feelings just as they are-death may come to-morrow, or sooner, and there is no speaking from nor to the Grave. . . . . . . I have walked with you many a Sabbath-day, with genuine esteem and affection-" in glory and in joy"-and at night returned to my cottage and my aged mother; she proud I had been with so excellent a man. Your letters are to me, invaluable-they are full of wisdom, elegance, and what my soul delights in, sincerity of heart, and deep affection-your consolations and sympathy, relative to my wise and beautiful, and tender and loving wife, have my grateful thanks. When our worthy and lamented friend, Houtson, made us acquainted with each other, it was an important incident to me indeed-my future life, my thoughts and feelings, took a lasting tinge and were modified by it-you became my model, my admiration, my friend and benefactor. . . . . . I have said nothing of my amusements-my chief is reading-next walking a little in the open air-but I practise both too scantily, for I am often busy. I am now waiting for work, and have been about three days, but expect having it to-day; trade is bad. I have been once at the theatre during twelve months, to see Othello-Young the Iago. I went once to the Musical Festival-bought one book last summer, because I had heard our dead friend, Houtson, praise it; Sermons by R. Morehead, A.M., of Edinburgh. They are good. Since my wife died I have read Shakspeare little-Burns less-Spencer and Milton more than ever-Wordsworth most of any-Paley very. much. I flute none. Let me know what you do.

Yours,

T. SмITH. 
MY DEAR FRIEND,

I received your kind and interesting letter dated 20 th March. I ought, and intended to have written about a month since. We should by all means write oftener to each other. . . . . . . I have had to struggle, and am still struggling, with another sorrowful dispensation. Death has been in my house again-all, all now are gone, except my poor self; and I am alone day and night. George Wood, the quiet and worthy person, so many years a lodger with me, died about three months ago. $\mathrm{He}$ was sick only a few days. The doctor said it was inflammation of the liver. I assure you my dear friend, I feel the loss severely. We had been very intimately acquainted, and much together, ever since I was a boy. He was about 62 years of age when he diedby trade a hatter. He had served, too, part of an apprenticeship to a tailor, and could use the needle very well ; this made him useful in the neighbourhood. He had but little scholarship, yet by means of a very retentive memory he became a knowing botanist, and often gathered herbs for his sick neighbours, gratis. He was particularly fond of music, and often heard the most eminent performers; he had also a liking for the drama, and had seen many good plays, well acted; but above all his other pleasures, it was his delight to ramble through the fields and woods, and smoke his pipe "beneath the greenwood tree." He passed scores and scores of days in this manner. - Whilst others were at the ale-house or fair, George was in the wood at Denton or Reddish, and when returned at night, with a few curious plants or wild flowers, "elate of heart," then would he sit down by my hearth and delightedly tell me "his travel's history."

I have not told you half his sterling worth, nor must I attempt it. We were distant relations. He never had either wife or child, but has two brothers and a sister, still living. He was more careful of the house, perhaps, than I myself; as I am situated, you may form some idea of my loss. . . . . . I thank you for all the information and kindness in your letter. How cordially I agree with you on the value of Christianity-religion is indeed, all in all, to uswithout it, man is little more than a "walking shadow." I strive, but cannot attain the heights most desirable. Can you come to Manchester and see me, I have nobody, now, to leave with the care of my house; I wish I had come to you, while I had so trusty a friend.

Trade remains very bad-never was so bad, for $m e$, as it has been for five or six months. I hope this will find you well. I have said nothing about the riots; you have it all in the papers. God bless you.

Yours truly,

T. SMITH. 
I still read a little, nothing can keep me from that. I have been reading "Essays on the Principles of Morality and Natural Religion," by Lord Kaimes. In particular parts it is a beautiful work; the author had evidently great goodness of heart, and a high veneration for the Deity.

\section{Gorton, 2 Ist Aug. 1829.}

MY DEAR FRIEND,

I sit down with a heavy heart to write to you ; things have been pressing hard upon me since my last. I duly received your kind letter enclosing_-I never more earnestly desired to see you, yet I cannot with comfort or even propriety, come over to Borderside. . . . . Contrive if possible to come over here, if it be but for a few days, or a week-it would be a blessing to me. I must try to mention a few matters, in a brief, homely way. I have nobody to leave with my house, and it would be imprudent to leave it alone; besides my waiting for work-low, ruinously low wages, have made dreadful havoc with my circumstances. A house with a quiet fireside, is what I have had all my life-I have doted on it. I have sacrificed money and pleasure, and other valuable things, and laboured hard for my "wee bit cot," and "bits o' traps ;" but all will not do now; I have lived to see all things belonging to my trade, come to nothing, and it is likely to remain thus. During this "time of trouble," I have had bad work, and waited much for work.

In other storms, I have often done pretty well-in this, I have suffered severely; and in truth, am so lonely, and so overpowered, with a keen sense of the worthlessness of life, without affection given, and received, that I am often fit for nothing-cannot labour-cannot sleep. In these trying moments, "how often has my spirit turned to thee." O my friend! that you and I had never been divided. You do not know, nor cannot judge accurately, how badly I am fixed. I sit alone-all my domestic ties rent asunder-my means of earning an honest livelihood, at present gone. . . . . . One thing I have not yet mentioned, which must have hindered me from leaving home at present, if nothing else had. My brother-in-law has been ill, and considered in danger for some months; his complaint is an abscess in the breast . . . . his will has been made perhaps 3 months, and he requested me to become his sole executor, or trustee, which I assented to-all this time, he has been very ill, sometimes, not likely to live many days. You will see the impropriety of my leaving home, under these circumstances. He has neither wife nor child, brother nor sister, and has willed his little property to his niece, except $£{ }_{5}$ for my trouble, as executor; it is not likely to give 
me much trouble. His illness adds to my gloom, being my wife's brother. Somehow I think matters are coming to a crisis with me. Come and see me once again.

Yours very affectionately,

T. SмIтн.

Notwithstanding the smallness and uncertainty of his earnings, his desolate feelings, and the want of a woman's guidance and management in his domestic concerns, craved relief, which he sought and found, in obtaining the affections of a discreet and industrious woman, whose kind, and dutiful services, to her mother and family, were full of promise for the future comfort of his own fireside; and in June he wrote to his friend giving an account of his prospects. "Besides all this, I have been carrying on business of far greater moment . . . I have been for several months assiduously courting . . . . and somehow, your friend has been so fortunate in his suit, that he can marry any day.

" My dear friend, you see a little of my state and case; it is likely I shall marry again, and soon. Thank you for your kind invitation, you are every way good to me. It is hardly likely I can come, for you see how I am fixed-my situation is critical. I ought long before this, to have given up house, or else to have taken a wife. God bless you to the last ; write very soon."

The marriage took place soon afterwards, and he wrote, "I hope I have been fortunate in my marriage this second time. I certainly have in one pleasing respect, my wife hears with pleasure, all my talk (and it is not a little) about you, and our long and ardent friendship. She sends you her best respects. She is quite a woman, that is, she can make good tea, and is no politician! She sometimes laughs at her uncle and me, for talking politics so earnestly; by-the-by, her uncle is a sad radical, and so was her father, and her grandfather also. I tell her jocularly, I could do better with her if she was not such a terrible Jacobin!

"I have been reading Byron and Sir Egerton Brydges on Byron. Sir Egerton writes well, and boldly on poetry; he values Wordsworth highly. Have you read Byron lately? he certainly displays great power in his best pieces.

"When did you see Wordsworth, and what does he think of these menacing times?*

"I wish things were well settled, and quietly. ,By the Lord, Horatio, 
these three years, I have taken note of it, the age is grown so picked, that the toe of the peasant comes so near the heel of our Courtier, he galls his kibe.' When shall I hear from you? Let it be soon. Once again God bless you."

\section{CHAPTER IX.}

For many years William was in the habit of executing sundry commissions for the family at Rydal Mount, which gave occasion for numerous short despatches; some of them of more than passing interest. The greatest number of these missives, were from Miss Wordsworth, few of them bearing any date except the day of the week-others, the day of the month also-but very rarely the year. In some cases the dates have been completed by William; in others, the topics being likewise subjects introduced in the "Memoirs of William Wordsworth," the dates have been traced.

These letters are here brought into view, as conferring a distinction on the recipient, somewhat analogous to the badge of an Order -yet not solely for this; other and less unworthy reasons for introducing them could be assigned, if necessary.

\section{From Miss Wordsworth.}

\section{MY DEAR SIR,}

I am exceedingly obliged to you for the Book, and happy to say I was not the least the worse for our walk (to the top of Fairfield,) which has left behind some pleasant remembrances.We will read Lockhart's Life of Burns, before next Tuesday, when we shall be very happy to see you.

This morning we had a letter announcing my Brother and Dora's safe arrival in London, in good health.

William returns a thousand thanks for your kindness in sending over the Dog. He had intended despatching a boy for it, to-morrow morning.

In haste, believe me

\section{Truly yours,}

D. WORDSWORTH.

I - shall be very glad before the Summer and Autumn are gone by to have another mountain walk with you.

Sunday, roth August-

When a boy, William W. had spent a little time at Borderside; perhaps he there gained a liking for handling a gun; at least, he took delight in going into the fields with one. 
The preceding note and the two following ones, are without the year; they must, however, have been written before Miss Wordsworth's serious illness in 1829-probably several years earlier.

\section{From Miss Wordsworth.}

\section{MY DEAR SIR,}

I was very sorry to find you had not seen my Brother at Mr. Tilbrook's, when you were last here, and that you were gone when I inquired for you. It was indeed very unlucky that you should have come at a time when so many strangers were gathered together at Rydal Mount.

I now write for two reasons. In the first place, to say I hope to ascend Helvellyn with you before my departure to Whetwick-and in the second, to request that you will bring with you my Scotch Tour, when you come; if you have not an opportunity of sending it before, by some individual whom you can depend upon for leaving it at Rydal Mount-one who will give it into the hands of one of our servants, or other person of the family, to be delivered to Miss Wordsworth, Senr.

We are at present in want of the Journal-but (it not being here) there is no need that you should trouble yourself to send it purposely. A week or two now will make no difference.

Next week, we expect company. But after that time, my Brother and I will be at perfect liberty to climb Helvellyn with you, any fine morning, when you may happen to arrive. Come by half-past 8 o'clock, and if on a Keswick-coach day, so much the better, as we could go on the coach to Dunmail Rays-Mondays, Wednesdays and Fridays, are the days on which the coach goes to Keswick.

I shall depart towards Leicestershire, about the first week in Novr., therefore the sooner you come, the better, after next week.

With kind respects from all the family, and my Brother especially, who much regretted he did not see you,

\section{I remain,}

\section{Yours truly,}

Rydal Mount,

D. WORDSWORTH, SENR.

Thursday, 25th Sepr.

\section{From Miss Wordsworth.}

\section{My DEAR Sir,}

The weather seems now to be taking up; but I am sorry to say we cannot ascend Helvellyn this week, on account of engagements; and next week also, we are engaged for Thursday, 
Friday, and Saturday; but should Monday, Tuesday, or Wednesday, prove fine, we should be glad to accompany you on any one of those days, for we give up the coach scheme, and intend to take the pony chaise as far as the Nag's Head.

I am, dear Sir,

Yours respectfully,

Rydal Mount,

D. WORDSWORTH.

Tuesday, 9 th October.

\section{From Miss Wordsworth.}

MY DEAR SIR,

My niece desires me to request that you will be so good as to procure for her a supply of straw, which I believe you kindly promised to do in case she should want it. I suppose she and you settled about the quantity, as she has left me without directions on that point-however, for your guidance, in case nothing was said on that score, I will remind you, that we have two ponies; and I suppose she wants enough for the winter.

You have been so much interested concerning my health, that I must not close this note, without telling you that I am now perfectly well ; but, in order to keep myself so, I avoid exposure to cold, which in one or two instances, has been injurious. I therefore do not go out in the frosty weather, at all; and this confinement agrees with me, as well as air and exercise used to do ; and I trust that in Spring, I shall be able in degree, to resume my old habits.

You will be glad to hear that my Brother and Sister, and the rest of the family are well. Two Miss Hutchinsons are with us, and my nephew John also, who after spending a week at Rydal, is going to Oxford to take his Master of Arts Degree. He is much pleased with his situation at Moresby.

I hope it will not be long, before we have the pleasure of seeing you at Rydal Mount.

Of one thing you may be secure, that you will never now, find the house emptied of its inhabitants; for I am always at home, except indeed, for an hour or two in the mornings, when the air is mild. I then, always go out in the pony chaise.

My Brother and Sister, join with me in sincere wishes, that you may spend the coming year happily.

Believe me, dear Sir,

Your obliged and sincere Friend,

D. WORDSWORTH, SENR.

Rydal Mount, Jan. $5^{\text {th }, ~} 1830$. 


\section{A part of William's reply to this letter.}

\section{MY DEAR MADAM,}

The sight of your letter gave me great pleasure, and I am truly happy to find you continue well, but fear you are a little too sanguine, when you say perfectly well. At any rate, I hope you do not forget your resolution of keeping within doors, during the prevalence of the present keen wind.

I am aware that the straw should have been sent before Christmas, and am rather fearful, Miss Dora may have thought me a little remiss about her commission. But I am sure I-shall convince her to the contrary, when I have the pleasure of seeing her, and you all, which I hope will be in the course of a few days.

In the mean time, I am glad at length, to be able to send three cart-loads of wheat straw-which I hope, will yet arrive in time to prevent much inconvenience, and it may, perhaps, prove a sufficient supply for the winter-I think too, I have met with it at a reasonable rate.

\section{From William to Miss W-}

My DEAR MADAM,

I should have written on Saturday had I considered the little I was able to learn of $\mathrm{Mr}$.__ of sufficient importance to communicate. . . . . . . . Pray inform your Brother, that I have been endeavouring to learn something more, of the character, and habits, of that poor, persecuted animal, the Hedgehog, from our neighbours the Gipsies, and I have been twice at their camp for that purpose. The first time I was there, one of them (a youngish man) gave me a terrible account of it. He said he had seen Partridges' Eggs-their young ones-and even the skins and bones of Rabbits, in their nests, or rather dens! What carnivorous propensities! This poor creeping thing, a beast of prey ! - a Liona Tiger!

Still I was incredulous. I went again, and I am glad I did so. This time, I was in another tent, and saw two or three other men, one of whom mentioned (as it were accidentally) that he had that day seen an Urchin's nest, which had been occupied by a Foulmartthere was a heap of dung in it. Further, I understood that these vermin frequently take possession of the Hedgehog's warm abode; and hence, the circumstance of these carnivorous spoils being found there, might still more have blackened the character of this innocent, harmless creature ! Indeed I could not learn that there was proof of the Hedgehog's killing and eating any thing, except clocks, or black beetles, the remains of which are sometimes found, on taking out its entrails. To this I fear it must plead guilty-to 
nothing more. Its food, besides grass, or perhaps a little corn sometimes, they said was wild fruits, such as hips, haws, blackberries, and crabs occasionally. They had found a small crab sticking in the throat of one!-It strikes me I have somewhere read (is it in Shakspeare ?) of their taking crabs to their nest, stuck upon their prickles! but of this I am not confident.

A strong proof of its harmless disposition, was a circumstance mentioned by one of the oldest of the Gipsies. He had seen a Partridge sitting on its eggs, and an Urchin on its nest, at the same time, within a foot of each other! It generally goes about in the night, to procure food, and returns to its nest in the day, summer and winter; the winter nest, being made much thicker, and of course warmer.

If an Urchin be met with stirring in the day, it is always in poor condition. Its nest is composed of withered grass, moss, and dead leaves ; and it covers it over like the Wren's. They breed twice in the year; at Midsummer, and at Michaelmas, and have from 3 to 5 at a litter. The young ones, are at first, naked, like the young of a mouse, but soon acquire prickles, which are soft and pointless. They remain in the nest till they are able to travel about. When a young one is met with in the fields, it does not coil up at the sight of man, but keeps walking on.

The Gipsies informed me, they had known persons, who said they had seen them suck cattle; but they themselves, never observed any appearance of such a thing; they thought their being frequently seen in the neighbourhood of Cows, might be accounted for, by their seeking for Beetles, which are often found in the dung of Cattle. I do not recollect anything more at present, and am afraid it is only a meagre account, after all; but I am sure Mr. Wordsworth will be glad with me, that the circumstance of the Foulmart's sometimes taking possession of its nest, clears it from the imputation of predatory, and carnivorous habits. Had I been satisfied with the first story, the rascally Foulmart, might have robbed the poor Urchin, not only of its house, but also of its "good name."

$$
\begin{aligned}
& \text { I remain, dear Madam, } \\
& \text { Yours sincerely, } \\
& \text { W. PEARson. }
\end{aligned}
$$

From Miss Wordsworth.

$$
\text { 25th March, (1830) }
$$

Rydal Mount.

My DEAR Sir,

Though I have been so slow in acknowledging your kindness, I assure you it has not been because I was insensible of it. 
My Brother happened to be from home, when your letter arrived, which prevented my answering it (according to my usual custom) immediately, and thus from day to day, I have delayed.

My Brother was much interested by the information you had gathered from your vagrant neighbours, the Gipsies; so was I, and every member of this family, and we sincerely thank you for it, and for the readiness with which you complied with my Brother's wishes. He intends, if you have no objection, to send the account to be inserted in the "Naturalists' Magazine" if the matter be thought new, or sufficiently important. To us, as I have said, it was very interesting.

You will be glad I know, to hear that we are all well. My niece has been with Miss Southey a fortnight, at Keswick, and if weather permit, her Brother purposes riding over to $\mathrm{K}$ - from Moresby to-morrow, to conduct her back with him, and he hopes for her company during a whole month-a great loss, to the Father at home!

As you were so kind as to interest yourself concerning Mr.- I must tell you, that he dined with us last Sunday, was in good spirits, and very agreeable ; and is now comfortably settled in most respectable lodgings at Grasmere.*

I hope when fine weather tempts you again to Rydal, that my Brother may be so fortunate as to be at home. This happened the last time; but how often it has been otherwise!

My Brother, and Sister unite with me in kind regards.

Believe me, dear Sir,

Yours sincerely,

DOROTHY WORDSWORTH.

\section{To Miss Wordsworth.}

My dEAR MADAM,

I am again venturing on your indulgence with a line or two which your constant goodness and humility, will I trust excuse.

I find that Mr. Coleridge has been publishing lately, a work "On the Constitution in Church and State." This I should have been glad to purchase, but of late years, unfortunately, I have found little money to lay out in books. I have therefore pleased myself with the hope of procuring the loan of it, through your kindness. You will

* With Dinah Fleming, at Town End, no doubt. This excellent woman had the tender care of a mother for her inmate; and in appearance, feelings and courtesy of manner, was truly a gentlewoman. She was a charming specimen of what her class once were! It is a delight to dwell in memory, on her kindly aspect, and pleasant speech. 
most likely have a copy of it at Rydal Mount, but should you not, or if it be not at liberty, may I indulge the hope of obtaining it through your instrumentality from Mr. H. Coleridge.

Anything Mr. Coleridge writes must be interesting ; but more so to me, what he writes on religious subjects, from his once having belonged to that "laxest sect of semi-Christians," as Mr. Southey rather unkindly calls them, to which I myself may come nearer in my creed, than to any other.

You will rejoice with me, that the weather is changed so much for the better. The Cherry, Plum, and Pear blossom are in full blowand the Apple just bursting out. The late heavy and continued rains, were quite unfavourable for us poor farmers, and retarded the spring work very much. The weather is now favourable for everything - the grass growing apace.

I shall be most happy to hear from you, and that you are well. One of your delightful little Epistles, is always a great pleasure to me to receive.

Do you continue quite stout, and can you bear to walk, as you did before your illness? I should be very glad to learn that this is the case. For my own part, I have this Spring, been visited by my old enemy; a cough; brought on by repeated colds. Though not attended with danger, it is troublesome and harassing enough, and sets the medical art, as far as I have tried, completely at defiance.

\section{From Miss Wordsworth.}

MY DEAR SIR,

My Brother would have had great pleasure in lending you Mr. Coleridge's new work, had he possessed it-I am sorry to say he does not; nor has Mr. Hartley Coleridge, yet received it. I hope the book may find its way hither in course of time, and then you will have an opportunity of reading it ; so pray do not put yourself to the expense of buying-much as I wish for the prosperity and sale of my friend's writings, I should be very sorry to hear that you were a purchaser.

My Brother intends sending the "Hedgehog" to the "Naturalists" Magazine," and probably, I should think, with a few words from himself. After it has appeared there, it might be extracted for the Kendal Papers, but better not insert there, first. This reminds me, that when I wrote to you, and also when I saw you, I forgot to ask (as I had intended doing) for a sight of the little poem, which you said you had written, on behalf of that poor, injured creature, many years ago. I hope you will not refuse to let us see it, however much you may be dissatisfied with your performance. 
My Brother intends joining his Son and Daughter, at Moresby, before the end of this week; and as he purposes to remain with them a fortnight, you had better defer your visit a little while. Indeed, I think you would hardly be certain of finding him at home, even within three weeks, from this time, as he talks of making a little tour with his Daughter, on their way to Rydal. Indeed, the time of my Brother's return is so uncertain, I will, on second thoughts, write you a line to say when he arrives, and when you are likely to find him disengaged; for I should be sorry that you should again be disappointed.

The new Terrace will be finished to-morrow-much to our satisfaction. It is a beautiful walk, and we hope the draining will be found complete. We have much enjoyed the late fine weather, living almost the day through in the open air.

You will be glad to hear that my Niece's health is, we hope, improved. She is in good spirits. I am quite well.

$$
\begin{aligned}
& \text { I am, dear Sir, } \\
& \text { Yours truly, }
\end{aligned}
$$

Rydal Mount,

D. WORDSWORTH.

May 5 th, 1830.

\section{From Miss Wordsworth.}

MY DEAR SIR,

I promised to write to you on my Brother's return from Moresby; but alas! he brought his Daughter home in such a weak state, that I could not possibly say, when we could look forward with pleasure to seeing you at Rydal.

She was seized with a bilious fever a few days before the time fixed for her return, detained by it at Moresby, and at length, returned to us sadly shattered; and we were long very anxious; though all disorder, except from weakness, had left her, and she has had no return. The weather has been very unfavourable for an invalid - so extremely cold - yet she has gone on gaining strength, though very slowly; and I trust that she may, now, make more rapid progress, if the air becomes in the least summerlike. Her spirits are excellent, and her looks beginning to improve.

As far as Dora is concerned, we should be glad to see you at any time; but I cannot say when we shall have no company. At present our house is quite full-one of the Miss Southeys and her Brother, and a nephew of Mrs. Wordsworth's are here, and others expected when they are gone. But this fact ought not to prevent your directing your pony's head this way; when you are disposed to take a day's holiday if you can make up your 
mind, to the disappointment of finding my Brother not at home, or engaged.

We are much obliged for the copy of your verses on the Hedgehog. They are interesting, if but as a record of an incident, connected with that harmless, oppressed creature.

I can only further say, that you are always welcome at Rydal Mount, but that it is impossible, during "the height of the season," to fix a time when the family will be left to itself, or other engage. ments are not pressing upon us.

My Brother begs his best regards.

I remain, dear Sir,

Your sincere Friend,

Rydal Mount,

D. WORDSWORTH.

June 22nd, (1830.)

Pray excuse this very hasty and incoherent scrawl.

Since writing the above my Brother has met you at Fell Foot, and I find he has promised to inform you when we are without company. I am sorry to hear from hirn, that your looks were not of the best; and that you had been poorly. I have broken open my letter to add these few words, having neglected to forward it, under the idea that you only get letters on Saturdays.

\section{To Miss Wordsworth.}

\section{My DEAR Madam,}

Although I have been very dilatory in answering your letter mentioning your Brother's return from Moresby, it has not, I assure you, been from any want of a deep sense of your kindness and attention. When I have taken the liberty of visiting Rydal Mount, I have been very willing to run the risk of finding your Brother disengaged-happy when I was favoured with a few hours of his society, but sometimes, disappointed of seeing him; it is therefore kind in him and you, to let me know when he will be disengaged. I fear that I have often come very inopportunely, and taken a liberty that my demerits had no right to assume. What claim had I on the notice of a man like your Brother, to be received in his house, and honoured with his society-none-but a deep feeling of the value of his writings (which however is its own reward), and a sincere respect and regard for himself. I allude not to deficiencies of rank and fortune, which yet have their value, but to others of a more intrinsic and personal nature; and my deep sense of obligation to him for conferring on me his society, and hospitable notice, I hope I shall feel to the latest hour of my life. 
I was sorry to hear of the illness and consequent weak state of your niece, and hope that by this time, she has regained her strength, although the weather has been very unfavourable. It has been a miserable season for the hay, and has kept us watching, and expecting every succeeding day might prove fine, too generally, only to be disappointed. We have still more than half of it to house, in this neighbourhood.

But a crop of more importance is the grain, which will be in a state of hazard, if the present gloom and wet should continue. It is, however, sufficiently well-fed, but there is a want of the genial influence of the sun. We must trust in the wise and good Disposer of all things. There is no employment like that of a "tiller of the ground," for reminding us of our constant dependence on Him. I thank you sincerely for the mention of my health; I am at present quite well. You say nothing of your own, I am therefore happy in concluding you are the same. That you may remain so, and be as happy as you deserve to be, is my sincere prayer. Give my best respects to your Brother and the family.

I remain,

With much esteem and regard,

Your obliged and sincere Friend,

W. Pearson.

\section{From Miss Wordsworth.}

MY DEAR SIR,

A pannier of beautiful apples is arrived with your signature, and I lose no time in returning you Miss Hutchinson's best thanks, and my own. I have not seen such apples this year, and as our orchard has produced none, they are particularly valuable.

I am ashamed of not having written to you for so long a time. The truth is, that at any time, if you had taken your chance, you would have been welcome, and would have found some one of us at home ; but I was to write when we had no company, and no engagements. This I never could do, as we have had a constant succession of visitors, ever since we had last the pleasure of seeing you, and this served me as an excuse for not writing : and I am now very sorry it did so, as my Brother, Sister, and Niece are gone away for a great part of the winter, and they would have been happy to see you before their departure. They are now at Coleorton, and next week will go to Cambridge. Whenever the weather changes for the better, and you are disposed to take a ride, Miss Hutchinson and I will be very glad to see you.

My Brother rode into Leicestershire on his Daughter's pony, and much enjoyed the journey through Derbyshire. They are all well; 
as we are at home, and our Bride and Bridegroom are returned to Moresby in good health and spirits, after a delightful tour in Scotland.

William intends to winter at Heidelberg. His health is much improved, and he writes in excellent spirits, making light of the disturbances in that part of Germany.

Our man, James, desires me to request you, if you can, to procure us our straw, which he will be much obliged if you will send as before; and when the straw comes, we will return your hamper. James did not state his quantity, but no doubt he wishes for as much as heretofore.

I hope you have been in your usual comfortable state of health, since I last saw you and heard from you.

Lamenting that you have not, in spite of my silence, dropped in during the Autumn and Summer to take your chance,

\section{I remain, dear Sir,}

Yours truly,

Rydal Mount,

DOROTHY WORDSWORTH.

i ith Nov. (I830.)

\section{From Miss Wordsworth.}

MY DEAR SIR,

I am much obliged for the potatoes, and shall pay the man. Miss Hutchinson is not yet arrived, but we expect her to-day. All distant friends well. Mrs. Luff is still with me, but walking out, otherwise I should have a message from her.

We shall be very glad to see you whenever you come. I am going to-morrow to spend a few days with Mrs. B- $\mathrm{H}-$, Green Bank, Ambleside, and should I not happen to be at Rydal Mount when you come, pray call on me at Mr. B__ H_-

In greatest haste, with wretched pen,
Yours truly,
D. WORDSWORTH.

I am quite well, and take care of exposure to cold.

Saturday Morning.

(Dec. 1830.)

MY DEAR SiR,

\section{From Miss Wordsworth.}

I am giad to hear that you had not a troublesome journey home, and were no worse for it in health.

My Brother and Sister write from London and Hampstead, in good spirits. All three are well. No fresh news from Heidelberg or Moresby. This weather is charming for the young and strong-Moonlight and at Christmas used to be delightful, thirty years ago. I now 
enjoy a short, sharp walk in the garden, and a peep out of doors, on the Evergreens and sunshine, from a warm fire-side. Many thanks for the straw, I shall pay the bearer.

Believe me, my dear Sir,

Truly yours,
Rydal Mount,
D. WORDSWORTH.
Wednesday.

\section{From Miss Wordsworth.}

My dear Mr. Pearson,

You must have thought me very slow in writing, but the truth is, that I have waited for definite intelligence; and even yet, am not enabled to give it. My Brother reached home this day week (Thursday) in good health, and as good spirits as an anxious mind would allow of-for he is very anxious concerning the passing of this Bill. He and his Wife and Daughter left Cambridge on Monday, and grievous to relate! Mrs. Wordsworth had a wretched journey to Nottingham, where she was fast bound, by the excruciating torture of the Lumbago; and there my Brother was obliged to leave her, with his Daughter. Happily, they are under the roof of the kindest of Friends, and in the care of a most judicious physician ; but you may judge of their eagerness to be at home: however, when they wrote (last Sunday) they could not venture to fix a time for their departure. Thank God! the complaint is not a dangerous one, and she is decidedly recovering, though slowly. We are now chiefly anxious, lest they should venture too soon, and suffer a second detention, with the additional misfortune of being among strangers. It was very unfortunate that my Brother's Stamp Office business, obliged him to leave her. He reached home in good health, as I have said, and was again compelled to leave us, on Sunday afternoon. He and Mr. Carter are now at Carlisle, and are intending to go the rounds of his new district, and we cannot guess the time of their return; only, I do not expect them before the end of next week. Whether he will be preceded by my Sister and Niece, it is not possible to conjecture. My Nephew William (from Germany), arrived at Rydal last Monday.-He is quite well, and much improved by his travels, and very happy to find himself, once again, at his own home.

I will write to you again when my Brother returns, and then hope to be able to say, when he will be settled at home, and glad to see you. In the mean time, conclude, that "no news is good news."

It will please you to hear, that at his first dinner, my Brother ejaculated "What excellent potatoes!" Miss Hutchinson is well, 
and joins me in best regards. I need not add how glad I shall be to see you, after we are settled.

Thursday, 5th May (183I).

I remain, dear Sir,

Yours truly,

MY DEAR SIR,

\section{From Miss Wordsworth.}

My Nephew being particularly engaged with office business, during Mr. Carter's absence, who is keeping holiday at Liverpool, has desired me to return you his best thanks for your letter, and for all the pains you have taken to procure a horse.

As perhaps you may have heard, William and his Father set off a few days ago, to look after one, or more, of the horses you had mentioned, and fortunately fell in with the Grey and its ownerIn some respects they were much pleased with it; but the man asked for it $£ 30$, which they thought too much, and besides, he was not ready to warrant its soundness, but only said, he "would pass it." These considerations, induced my Brother, with his Son, to go to Crook yesterday, and there they actually made a bargainnot for the Crook Hall Grey, but for a bay horse, which they hope will answer their purpose.

It is an admirable walker, but unused to trotting, having only been put to carting and ploughing. We expect the horse to-day, and as soon as it has had a fair trial, it is to be sent to Moresby to bring home Mrs. Wordsworth; and soon after her return, it may possibly have the honour of conveying the Poet and his Daughter, to Abbotsford, to visit Sir Walter Scott! This visit has long been promised, but the late accounts of Sir Walter's health, having been very bad, we were fearful that the visit might never be accomplished. I am happy however, to tell you, that a friend of ours, who has just been on a visit at Abbotsford, informs us, that Sir Walter is much better at present, and quite able to enjoy the society of friends. This information has determined my Brother to think seriously of the journey; and if Sir Walter continues as well as he is at present, it will probably be accomplished during the Autumn.

You will be glad to hear, that the sea air has proved very beneficial to my Sister, and that Mrs. John Wordsworth's health is improved. Miss Hutchinson is at Keswick, and will probably remain there, till Mrs Wordsworth's return.

My Brother and William would have been very glad to call on you yesterday, but the additional three miles would have made the ride too long for him. As it was, he was a good deal fatigued, not being so clever on horseback as on foot. 
My Brother and his Daughter unite their thanks, with William'sIt is very long since we have heard of, or seen you,-I hope you have been in good health. My Brother begs his kind regards.

I am, dear Sir,

Yours sincerely,

Rydal Mount,

DOROTHY WORDSWORTH.

Thursday, October 2oth (I83r).

\section{From Miss Wordsworth.}

MY DEAR SIR,

I have more than once said to you, that we should be troubling you again for a supply of potatoes, after your last year's successful purchase of that article, and I now write (I hope in good time), to beg you will be so kind as to buy us . . . . . .

My Brother and his Daughter are not expected home before the 25 th. They will meet William at Carlisle, who will be settled there as Sub Distr. about that time. I am happy to tell you, that travelling has agreed with my Brother's eyes, and that they were nearly well about ten days ago. The last tidings that have reached us were from Callendar.

They were going to Brenane, Oben, and the Isle of Mull. Thence to Glasgow and to Lanark, and home by Carlisle-Sir Walter Scott was much pleased to see them; but I am sorry to say, his health seems to be much broken-great hopes however, are entertained from a change of climate and of scene.

It is very long since you were at Rydal-To this I can say no more, than that you have always been a welcome guest, and that it will give my Brother pleasure, to see you popping in as formerly, when he has settled himself at home; - and I am sure you will be glad to inquire after his health, and to hear of their adventures.

I am, dear Sir,

Sincerely and respectfully,

Your friend,

Tuesday.

D. WORDSWORTH.

Sunday Evening.

I kept back my letter, recollecting it might be likely, that our horse-proprietors would wish to have more straw, and no one being at hand to direct me. I find they will be much obliged if you will procure them a supply, to send along with the potatoes....

Pray excuse the trouble I give you-but I know you will, having so often experienced your kindness in that way. Mrs. Wordsworth begs I will return her best thanks for the Partridges received whilst I was staying at Belle Isle. 
MY DEAR SIR,

\section{From Miss Wordsworth.}

We are exceedingly obliged for the potatoes and apples, and are, I assure you, much too selfish to desire to part with any of the latter, to our friends. . . . It is quite a treat to look at the apples, they are so beautiful.

This fine morning has tempted my brother on a walk to Grasmere, with his friend Mr. Jones, otherwise, I should have had a message from him-but I know he will at any time be glad to see you, though we may have other visitors; - and I hope it will not be very long, before fine weather and leisure, tempt you to ride over into these parts. My Brother continues quite well, and my Niece much improved by her journey, in health and strength.

As' to the poor horse, I did not name him, because not able to give a good account, though through no fault of his. My Brother had injudiciously, put him to a journey too long, and too heavy for his years; and they were obliged to leave him, in comfortable quarters, to winter at Brenane, and to hire horses for their return. The horse, however, is a very good one; and judges pronounced that no harm had been done, and that a winter's rum, and small labour next :ummer, would make him an excellent beast.-It was a great pity, that he was so soon put upon a journey-however, the human creatures' tour was a delightful one.

Wre are daily expecting my eldest Nephew John. William is at Carlisle, and we hope very comfortable. With many thanks, I am, dear Sir,

Saturday Morning. Yours truly, (29th October, I83 I. W. P-'s date.) D. Wordsworth.

DEAR Sir,

\section{From Mrs. Wordsworth.}

Mr. Wordsworth who left for London this morning, requested me to forward the enclosed to you, as he could not but think, you would be gratified, by the reception your interesting communications had received. He expressed himself as being well pleased, and begged me to tell you so.

Considerations of business, took him from home somewhat against his inclination-but, I trust, that no melancholy cause, as last Spring, may occur to hasten his return; in which case, he will, I doubt not, enjoy much pleasure in the society of old friends, and I hope, make a long stay among them.

Our invalids continue much in the same state as when you were last here. With best compliments from my Daughter,

I remain, dear Sir,

Sincerely yours,

Rydal Mount, 9th May.

M. WORDSWORTH. 
The letter which was enclosed.

SIR,

Burneside, Kendal, May 4th, I 836 .

I have it in command, from the Members of the "Kendal Natural History and Scientific Society," assembled in Ordinary Meeting yesterday evening, to express to you, their best thanks for the evidence of your interest in the Institution, manifested by the present of "Extracts from Letters on the Natural History of the Hedgehog \&c.," addressed to you by Mr. W. Pearson. The Extracts were read last evening, and I am happy to say, elicited a long, and animated, and highly interesting discussion.

Nor was this, the only result. So much enthusiasm was kindled in the meeting, for mutual instruction, and mutual entertainment, on the habits and distinctive faculties of birds and beasts, that a Resolution was adopted, to form a Class, for holding periodical Discussions on these engaging topics.

I have been emboldened to relate these particulars, (exceeding the occasion) by your acknowledged interest for the Society, and by the hope, that being made acquainted with the high results of this first presentation, you may perhaps, condescend to make us other contributions, which would be even still more acceptable.

I am, honoured Sir,

Your very humble Servant,

W. Wordsworth, Esq.,

CORNelius Nicholson, Secretary.

Rydal Mount.

William was a member of the Society, nearly from the period of its formation, till the time of his death, and always had its welfare as a Natural History Society at heart; though for some years he could only occasionally attend the monthly "Discussion Meetings," of which there were about seven annually, commencing in Oct. and ending in April. He thought little of setting off after early tea and walking to Kendal to attend the Meetings, and when they were over, of walking home again, 7 miles each way-He took delight in those primitive discussions, which had nothing fictitious about them, certainly,their liveiy sallies made the life-blood circulate vigorously; perhaps, they contributed even as much as the Papers that were read, to keep awake among the members generally, an interest in the objects the Society sought to promote.—At a later period the Society obtained its present spacious and commodious premises-fitted up a Lecture Hall, and rooms for its valuable collection of Fossils, Shells, Insects, \&c., \&c.; and (what William always regarded as a mistake) adopted an old, half-defunct Library that existed in the town, conferring on it the dowry of its own Scientific books; so that the members, unless 
they subscribed to the coalition Library, no longer had access to the books collected for their use-Altogether, however, the new state of things added to the popularity of the Institution, and it adopted a name more suited to its new character-the "Kendal Literary and Scientific Institution."

\section{CHAPTER X.}

THE birth of T. Smith's first child, was announced to his friend in the following letter.

\section{MY DEAR FRIEND,}

Gorton, 3 Ist Aug., I831.

I received your very kind letter dated July $\mathrm{I}_{5}$ th from $\mathrm{J}$. S. himself. I wish I could express my thankfulness to my heart's content, it would give me ease ; gold is good, but rare to needy man in this strange world-pure, warm friendship, far more rare, and far more valuable--but it is needless to dwell on these truisms.

I write to you my friend, with feelings quite new to me. I am just become a father. Last Wednesday morning my wife was delivered of a daughter-a fine fat child, likely for life. I wish you were here just now to look at it, I know you would notice it for its father's sake. If this child ever bring me, but half the exalted pleasure and solid satisfaction, that I have derived from you, I am a blessed man, and ought to be thankful to God whilst I have my being. The mother seems to be doing very well, and sends her best respects to you.

You say you are aware my coming to see you, must depend on circumstances. At present, I cannot come ; yet rest assured if a seasonable opportunity occur, I shall seize on it; neither wife nor child can ever check my eagerness to see you.

Yours truly,

T. Smith.

\section{From William.}

MY DEAR FrIEND,

Crosthwaite, I8th April, I 832.

I duly received your letter and was sorry my silence had given you so much pain. I am ashamed to see how long since it is dated, and that I did not duly answer the one before that. I did certainly expect to have seen you the las Summer. You had doubtless good and sufficient reasons for not coming, otherwise, I think you would have had as much pleasure in the meeting, as myself ; and if you sinned a little against friendship, I can also accuse myself of like sins.

I am still farming - with plenty of exercise for mind and body. The employment like all others, has its pleasures and its pains; I sometimes think of giving it up, for if one do not act, as well as inspect, matters often go wrong; and perhaps with all I can do, there 
is no very good management. I am sure no great profit in a pecuniary way, though the farm may be a little improved. My orchard comes on very thrivingly, and exhibits just now, a prospect of a fine show of fruit, if there do not come, as last season, "a frost, a killing frost." My Mary Oldhams are now tall, slender trees, so that I have the hope of seeing in Autumn, the first fruit of the kind grown in Westmorland. For this I am indebted to your kindness. You would still increase it, if you could come and see them. I need not say what pleasure it would give me, if you could come this Summer for a few weeks, without any serious detriment to your worldly business. But I must leave it to yourself.

My large orchard (which was I think much of it planted when you were here), contains about 300 trees-Apple and Pear, besides a row of Plum trees, which have blossom (just bursting), for the first time. I have planted two other small orchards, with about a score of trees in each, so that you see I have been making work for somebody, and perhaps profit - at any rate, it has been a pleasure to me, and even so far, its own reward. If Dr. Johnson was correct, when he said, that the man who made two blades of grass grow, where one grew before, was a benefactor to his species, I have not of late, lived altogether a useless life. My health last Winter was not quite so good as usual, I was scarcely ever free from a cough.

I received a very kind letter a few days ago, from the daughter of our favourite Poet, with inquiries after my health \&c. You will be glad to hear that the Bard is well, and all the family, excepting his excellent Sister, who, I am grieved to say, has been in a very weak state all the Winter. She is still confined to her room, they hope, however, that as the weather gets warmer, she will gain strength. Never have I known a more amiable woman. Her understanding and judgment are of the highest order. But I need not say more, you have yourself seen something of her. I have heard Mr. Wordsworth say, that he had been more indebted to her judgment, than to that of any other person. . . . . . . You have some dreadful beings in your parts. I fear there would be awful work if a civil commotion should take place-and is there no fear of it, when the people come to be disappointed of the good effects they expect to reap from Reform? For my part, reformer as I have been, I am not sanguine of any immediate effects.

In future, though I should not write regularly, never grieve yourself, nor imagine that it proceeds from any cause but that procrastinating disposition I too much yield to. I shall never cease to think of you, but with affection and esteem.

Believe me, I remain

Yours very truly,

W. PEARSON. 
The invitation given in the preceding letter was accepted, and in the Autumn of 1832 , T. Smith visited Borderside; when he took his departure, William walked a great part of the way with him towards Kendal, where he was to sleep in order to proceed by the packet-boat, early next morning, to Preston, and the following day he walked forward to Gorton ; from whence he wrote, "I found all in health, which made me thankful. My wife had been looking for me for a week or two-my child was in raptures when I took her on my knee."

Shortly after T. Smith's visit William received a letter from

\section{Dora Wordsworth.}

Dear Mr. Pearson,

Many thanks for your most interesting letter, which gave great pleasure at Rydal Mount, especially in our sick chamber. You know what a lover my dear Aunt is, both of animate, and inanimate nature, and now, that she is compelled to rest content with enjoying her at second hand, you may guess how pleasant your little history of our favourite Robin-redbreast was, to her subdued but cheerful spirit-and so simply and prettily told! My father wishes for your permission, (if you can give it) should an opportunity occur, to send it to the "Naturalist's Magazine," or some other publication that receives like histories.

We are greatly obliged to you for the beautiful and excellent apples; thanks, too, are due for bearing in mind our stable wants; but don't put yourself to additional trouble, by endeavouring to procure the straw immediately-we can do without it for two or three weeks to come.

Now that all the birds of passage have left our mountain regions, we are but seldom interrupted by strangers, so my father hopes you will find your way more frequently to Rydal Mount, for it will be ill luck indeed, if you do not find him at this season, at, or near, home.

He and my mother, and I, passed the week before last with our friends the Marshalls, at Halsteads, on Ulswater; the weather was generally very fine, so that that very fine scenery was looking its very best, and made me, I confess, a little jealous for our vales, certainly less grand as a whole, though perhaps, in their minutix, they may vie with those of Ulswater.

Have you seen the first numbers of Mr. Hartley Coleridge's book, "The Worthies of Yorkshire and Lancashire"? - It was lent to us the other day ; I have, as yet, but just peeped into it, but it seems well worth reading, as all that comes from his pen, must be. It grieves one to think that so fine a mind should turn to so little account as 
his has done, and, I fear, will do-but genius and common-place industry and regularity, seem almost incompatible. I have said nothing about my Aunt's present state of health. I am thankful to say, she is quite in her best fashion-she moves about a good deal in her own room, but as she has no inclination to join our quiet circle down stairs, I fear there is not much strength to boast of. My Mother is, thank God, always well, and so is my Father, except for inflammation in his eyes; this, at present, he is perfectly free from. I have given you so long a family history, that it needs some apology -I think I am unskilful in escaping from such snares. I will at any rate, keep clear of making others for myself, by bringing my epistle at once to a conclusion; and begging you to accept the kind regards of all this family,

Believe me to remain

Yours very truly,

Rydal Mount, DORA WORDSWORTH.

Nov. I8th, I 832 .

\section{From Mrs. Wordsworth.}

Dear Sir,

It is so long since we have seen or heard from you, that we are apprehensive that you may not be well, and should be very glad to hear that our apprehensions are groundless.

As it is time to think of Winter stores, I write now, to request that you will do the like kind service you performed for us last year. . . - . . Should you bring any apples about Christmas, I dare say they will be acceptable both at this house, and at Dr. Arnold's. attack-and also from his eyes, since you saw him-but I am glad to tell you, he is tolerably well again, and has just returned from a visit to the Earl of Lonsdale, at Whitehaven. He joins with his Sister, who is in her usual way, in best regards, and believe me to be, Respectfully, your obliged,

Rydal Mount,

M. WORDSWORTH.

Nov. 8th.

\section{From Mr. Wordsworth.}

My DEAR SiR,

Many thanks for your kind inquiries. Since I last saw you the state of my eyes, especially one, has caused me much privation, uneasiness and distress ; but thank God, I am in a fair way of recovering the ordinary use of them ; though I cannot but feel some degree of alarm for the future, as the vessels have been much weakened by repeated inflammations during the last twenty-five years. 
The weather is so extremely stormy at present, that one can scarcely be so selfish as to invite friends from a distance, besides I have reason to look for the visit of a friend from London in a day or two, and next week we expect some of the Southey family-but as early in the week after, as would suit you, (the weather being favourable) we should be glad to see you ; and pray put your nightcap in your pocket, as I should really be sorry that you should have to go home at night. We have also a stall for your mule, or pony; and be so good, if you can spare the Corn-law Poet's book, as to bring it along with you.

Miss Wordsworth's health is tolerable for her. I am glad the "Excursion" improves upon acquaintance, and remain

\section{Very faithfully yours,}

Rydal Mount,

W. WORDSWORTH.

Dec. 4th (1833).

From Mrs. Wordsworth.

DEAR Sir,

I was about to write to you to request that you would send us, either from your own store, or procure for us, our Winter's supply of apples, when those beautiful ones you have so kindly sent, arrived, and call for our thanks for your kind attention. We are indeed much obliged to you for them, as also for the pamphlet intended for Mr. W. ; but as my daughter tells me he already possesses a copy, sent by the author, probably this may be useful (if you will allow us when we see you, to return it) to present to some other of your friends.

Mr. W. left home last Friday; business called him across Kirkstone-and as he has visits to pay also, we do not expect his return in less than a week or ten days, from this time. You will be glad to hear that Miss W. and my daughter, are in their better way.

They join me in kind remembrances, and believe me to be sincerely,

Rydal Mount, Your obliged

M. WORDSWORTH.

Sept. 2 rst.

The last of these commission notes forthcoming, written Dec. 3 rd, I 835, thus concludes: "Our invalids continue much in the same state as when you were here."

Very sincerely yours,

M. WORDSWORTH.

To turn attention once more in the direction of Manchester. The calamitous times were ever becoming worse and worse, for both masters and operatives; and the spirit of our poor friend Smith 
was crushed in him, as he sat by the idle loom, or tramped with heartless energy from place to place, soliciting for work, and waiting days, sometimes weeks, for the little he was able to obtain. In the cheerful light of day, and in the darkness of night, one fearful scene was ever visible-the wark of his all! He recoiled with horror from the dreaded reality, and, with an effort of self-conquest, appealed to William, who had the satisfaction of arresting, for a season, the dire calamity.

In a letter dated April, I835, after making some inquiries about Mr. Wordsworth and his family, and some other matters, he proceeds, "What do you think of these in-and-out politics? Peel, I hear, resigned three or four days ago. It appears we agree in our estimate of Channing. 'Corn Law Rhymes,' too, you think show great ability. 'Although steeped in poverty to the very lips,' I am literary still ; if you have any little good thing to send, as you name, direct . . . . Now for a word about myself. I am unhappy -chiefly through poverty; for I am now poor indeed. The cause, mostly bad wages, and for years, scarcity of work. I have too, another child, a girl, born on the $\mathbf{I} 2$ th of January last-my wife was unwell much of last Summer-other things besides, have injured and touched me deeply, so that I am much in debt, and very miserable. God only knows what the end will be. My mind has too much on it. God bless you! Write to me very soon

Yours truly,

T. SмIтн.

\section{William's reply.}

MY DEAR FRIEND,

Sat. morn, 25th April, I835.

You must excuse my saying much, as I am writing before going to market. I received your letter, and feel deeply grieved at its contents, and will reply more at length in a week or two.

I think it best to direct this to your friend in Palace St., as perhaps, the safest. . . . . I cannot reply to all your kind inquiries, but as to South America, you will be glad to hear there is a better prospect. My stock has risen from under 30 to about 6o. Still, there has been no interest paid for 9 years. This has been a serious loss to me, but I hope, in the end, it will turn out not such a bad concern.

I cannot conclude, without a word about what you write of your being unhappy. Read your Bible. Trust in that Good Being who gave you your existence-consider the many in your situation, who from ignorance and want of education, have not the arguments for hope that you have. . . . . only the wicked need be unhappy 
at any rate, do not despair. Let me hear from you again, and soon. If I could recover the property in the S. American funds (of which there seems now a prospect), I could easily do something for you. If you could be set up in a shop for the sale of necessary articles-could not you and your wife, manage it? Many people do well in this way, why not you? Excuse haste, and believe me,

Very sincerely yours,

W. Pearson.

\section{CHAPTER II.}

THE changed condition of T. Smith's means, and the harassing life attendant on it, necessarily changed the general tenor of his letters ; yet, there are not wanting, occasional flashes, which with "words that burn," recall the old strain. In April, I837, he writes :

\section{MY DEAR FrIEND,}

As I was coming home from Stockport, having been there in search of work, I was told the post had left me a letter. Jaded and low-spirited as I was, the news of a letter revived me in a moment, being full of hope it was from you-so it proved. I cannot express my feelings on seeing your hand-writing, once again-on opening and reading it, I felt a delirious rapture, not often felt, during one's whole life-a strengthening, weakening cordial-so it acted on your poor sensitive friend-what power the mind has on the body-just before hearing of your letter, I was hungry and fatiguedon reading it, neither. When food was put on the table, I could eat nothing, I wanted nothing, I was strong and untired. This was of short continuance, another extreme came on, and I became weak as a lamb, the hour that it is yeaned. . . . . Your South American affair is a bad one, so important-so unmanageable. I believe few persons would bear it with your equanimity. . . . . . I hope I need not say, your kind feeling towards me and my affairs, goes to my heart. . . . . alas! that I can do nothing in return.

Trade is still no better for the workman, but report says, more goods were sold in Manchester, last Tuesday, than on any day for some time past. I was there yesterday, but could get no work, nor the promise of any, at present. I have had bad luck with regard to employment, for near a year back. We had last Summer, two masters-one, Mr. - was embarrassed all the Summer and found us but little work; in the Winter, he failed and stopped; the workmen all thrown out of employ, and trade (the silk trade) bad. A few weeks before this master failed, the other, Mr. Foster, died suddenly, and the concern was broken up ; we were then thrown out of employ 
for some time. At last, we got a little work in Manchester, but about a month ago, the master stopped, and we were again thrown out of work, and remained so, till yesterday, when I got some at Stockport, that will last me about a week ; but the master said he was doubtful whether he could find me any more, till trade was in a better state. My dear friend, you will gather from what I have written, that I have been ill fixed, for some time past, and just now, I do not know which way to turn-rent troubles one worse than food, for we live plain, and pinch, and so make a miserable shift-but it will soon be, no rent-no home. It agitates me and I must conclude. My dearest friend, bear with me . . . . . I shall be glad of any books you may send-but Wordsworth's Poems, (2 Vols. I807) I have; you got them for me when you were in Manchester. You do me good and forget it. . . . . God bless you! Write soon.

Yours truly,

T. SMrth.

\section{William's reply.}

Kendal, 29th April, I837.

MY DEAR FRIEND,

Just after I had written to you, I received your letter. I am very sorry to hear of your situation, and that trade is so bad at present. I lose no time in enclosing_-and wish I had been able to spare more; as it is, you are heartily welcome.

It is our fair, to-day, therefore you must not expect many words from me. I am writing this in a public-house. I hope you have got mine of last week, when I wrote more at length. I address this to J. W.'s (to whom my best respects), as being perhaps, safer. Please to acknowledge it. Hoping I may next have a better account from you,

I remain, dear Friend,

Truly yours, W. Pearson.

In replying to this T. Smith says: My breast is full of gratitude, and thankfulness inexpressible-your prompt goodness has been to me like a reprieve to a condemned man. It has snatched me from the jaws of ruin. God bless you! and a thousand thanks. It is nearly dark, and I must take this to Manchester to-night, therefore I cannot say much more. Trade does not get much better. I went five days to Stockport last week, looking after work-it makes one thankful bread is not very dear-some other things are. We give fourteen pence for 2 olbs of potatoes, and they are not good ones.

It is a seasonable time, for planting potatoes, so that with God's good 
help, they may be cheap in a few weeks, and then labouring folks, and children, may have better dinners. It will do me much good if you write me a long letter,-nothing (except seeing you), can give me so much pleasure. I have heard, that Wordsworth is gone abroad for health. Tell me something of this if you can; we owe him much. My dear friend, excuse this short, poor letter, and believe me,

Your most affectionate, and grateful Friend,

T. SмITH.

The first part of the following letter seems inexplicable, except on

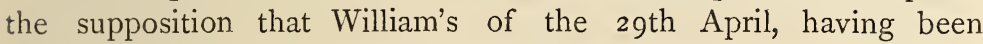
hurriedly written, to meet at once, his friend's needs, did not contain any tidings of himself.

MY DEAR FRIEND,

Gorton, 2oth May, 1837 .

Such a length of time has elapsed since I last heard from you, that $\mathrm{I}$ am fearful and troubled in beginning to write; yet I have every reason to believe, that if anything important had occurred, you would have written to me. This part of friendship's creed, rather relieves me. . . . . J. W. says, it would do him good to see you and me sitting by his fire, once again, . . . . he hopes you will excuse his not having written to you, on the occasion of his brother's death; he commissioned me to do that mournful office, but I think you have not got the letter.

J. W. wishes me to say that it would give him great pleasure, if you could make it convenient to come over to-Manchester, and its neighbourhood, to see your old friends, making his house your home, till you return to Crosthwaite. It has been the subject of our conversation many a time, sweetening for me the bitter draught of life. As an additional inducement to you to come over, J. W. mentions a rather large, private collection of paintings, belonging to a gentleman in the neighbourhood, which he thinks would please you.

My dear friend, I am forced now to begin speaking of very distressing matters. Trade, particularly the Silk-trade, in Manchester, Stockport and Macclesfield, and all the villages round about them, is in a worse state by far, than I ever knew it before; all is embarrassment, and most poignant suffering-manufacturers, some failing-others partially, many altogether stopping their works-all seems ruin.

shoals of artisans

Are from their daily labour turned adrift,

To seek their bread from public charity;

They, and their wives, and children." 
This is a true picture of what your friend sees daily, and what I know will touch you deeply my friend, is, that I myself am nearly as much in want as the worst figure in the picture-indeed, I have had worse luck than almost any of my acquaintances-my scarcity of work being of a longer standing. It is now ro months since I had a full supply, and for weeks, I have had none. I have none at this time, yet I have rambled scores, perhaps, hundreds of miles within the last month, all in vain-no work can I get. What my feelings and apprehensions are, I cannot describe. God grant me patience and resignation. My wife and children-my humble furniture-my few books-my home-I cannot without agony, think on these things. What a happy time is childhood! I hear my two children singing quite joyously in the house below. Poor things, they see not far before them; 'tis well they don't.

I must conclude this letter and take it to Manchester. I particularly request you to write, either to me, or J. W., on receiving this. I think if I could struggle on a little longer, things might mend. . . . . but, I am afraid, this storm will totally wreck me; help me if you can a little--how like a beggar I write-God help me. I am quite your unchanged friend, in any thing but appearance. . . . write soon, I pray.

Yours truly,

T. Sмiтh.

This letter was responded to, with the like commiseration as the appeal in April-but even more trying distress than the past, was fast approaching, as will be seen by the following letter.

\section{MY DEAR FRIEND,}

Gorton, 25 th October, 1838 .

I received your kind letter the fifth day after it was written I need not say, it gave me great pleasure to hear from you.

I ought to have written to you above all on J. W-'s account, as he desired me, . . . he was anxious you should know his troubles. . . . . You kindly ask me to let you know how I am going on-me and mine. My dear friend, badly indeed-it has been a dismal time with me since I wrote last-words could hardly tell you, how dismal-I have suffered, and am still suffering, very deeply-want of work, that is the thing. What a heavy time I have had these last two years; for several months we had no work but what I fetched from Presbury, near Macclesfield, at very low wages, and a very scanty supply-the distance from our place is about I 5 miles. I have often gone two, and sometimes, three times a week, poorly fed, and poorly shod, starting in the morning by 2 or 
3 o'clock-often for nothing-no work, or no money-it half killed me. What work we have had lately, has been nearer home. Still, sadly short-often, quite without for weeks together. Last Spring we were at one time, more than a month totally without-at this time, we have one loom idle, it has not got us sixpence these two months-all we have got the last fortnight, is nine shillings and four pence. One part of last Winter we had work enough, but at the time, my Wife was lame with rheumatism and could work but little.

This Summer, the children have had scarlet fever badly-they are now well, thank God!

You ask if I live in the same cottage. I do at present, but cannot long, without your kind help, which I am ashamed, but compelled to ask, or I and mine will be homeless - by all our wanderings, and all our loves, forgive me. I am sore beset; my landlord called yesterday, and told me plainly, he would put me out of the house very soon, if I did not pay the rent; and I know he will-do write as soon as you get this ; direct to $\mathrm{J}$. W-' 'S.

Yours,

T. SMITH.

The transmission of letters for want of a rural post (market-day was a sort of general post-delivery of the week's letters) was attended with uncertainty and delay, which caused poor Smith to be kept on the rack, as the expected letter did not arrive. He again wrote, with great urgency, though his appeal was scarcely more piteously moving than the preceding one. His letter was crossed on its way, by William's answer to the first.

Borderside, Crosthwaite, IIth Nov. I 838 .

\section{MY DEAR FRIEND,}

A few days ago I received your melancholy letter, and deeply sympathize with your distresses, as well as those of my friend J. W. Oh, how I wish I was rich for your sake-alas, I have lost as much as would have made you comfortable ; and if I had made you, or any other worthy person to whom it would have been useful, a present of it, what a consolation it would have been to one's mind, instead of having been cheated of it, as I have been. However, I ought still to be thankful that I am as well off as I am. Be assured, that you are sincerely welcome to the enclosed Bank of England note. I regret that it is not more, but hope that it will satisfy your landlord, for the present. If you had been situated nearer, at Kendal for instance, how many little aids I could give you (having a farm) without any inconvenience.

I send you a newspaper in which there is a little article of your 
friend's writing; it is signed It will perhaps amuse you a little; and in the same paper, you will see a paragraph which states, that $I$, as a guardian for our township, said that the provision for Paupers at the Workhouse, was more ample, than the independent labourer could afford for his own family. I did not say this-but that the expense was double. You see what it is to be a public charactermisrepresented even by one's friends-by a Paper to which I not unfrequently contribute. To show me up, as if I wished to starve the Poor ! . . . . I have been reading some Poems by Hartley Coleridge this afternoon; he is son to the great S. T. C. of the "Ancient Mariner." They made me quite melancholy. $\mathrm{He}$ is amiable, and ingenious like his father-but has a weak will, is indolent, . . . . but is a most beautiful writer of both Poetry and Prose.

I wish I could console you under your troubles. Be thankful you have not a guilty conscience-the greatest of evils. Read your Bible-read Wordsworth-Shakspeare and Milton. Do you go to worship, public I mean. You have a Chapel at the foot of the hill, join yourself to them, excuse my preaching so much, ex cathedra, and believe me ever,

Yours truly,

W. PEARSON.

Some parts of the letter dated Nov. 8th, and not received by William until after he had sent the preceding, will, not vainly, lay claim to the reader's sympathy.

\section{My DEAR FRIEND,}

I sit down with a distracted head and very sorrowful heart to write to you. I received your very kind and interesting letter dated I 2 th Oct. and have since written to you, a fortnight ago to-day, and not having heard from you (forgive, my dear friend, this unbecoming urgency; if you knew my great distress of mind, I am sure you would), although I pressed an immediate answer, I fear you may not have got my letter, or yours in reply, may have miscarried. Perhaps this weak surmising may be owing to your friend's anxiety, which I cannot help, beset as I am with such heart-rending troubles-alas, that my troubles should cause me to prey on your sympathizing goodness ; but so it is, and so it has been, for a long time, ay, ever since the commencement of our friendship-but particularly of late years. My dear, affectionate friend, I am most painfully aware, that very many of my letters to you, might with great appropriateness, have been headed "The Beggar's Petition." I am conscious it is my poverty and not my will, that has done all this-still it hurts 
me, . . . . . . at that time, I had an infirm mother dependent on me for food and home-at times, that was more than I could manage-what I fell short of doing, you did most liberallyshe was grateful, and shed tears of thankfulness on her death-bed, for your goodness - at her funeral, you came and followed her to her grave-all this is engraven on my heart-your kindness to me has been boundless, not only in warding off want, but in giving me innocent and refined pleasure-witness many good books, your gifts, which I am proud of for your dear sake-also our enchanting excursions, through the most beautiful parts; I have been blest, above all, with your conversation and affection-my Wife and Children too, have great cause to bless you-for to you they have been indebted for their home-and you, my dear friend, we are all supplicating at this moment, for one more act of your goodness, to save us from immediate ruin.--If you have received my last letter, you know our wretched, agonizing state; if you have not, I had better say a few words. . . . . . . . My Wife is a good silkweaver, and a willing, hard worker; but that you know, avails nothing, when we are without work-poor woman, she is now weaving hard on my loom, whilst I write this letter. I know she slept little last night, for she is heart-broken with the dread of losing her cottage-she is proud of it, poor as it is ; and to my Children, it is a palace and a castle - to me, it has a thousand endearments.-In this chamber, on that bed, my good mother, and my beloved wife died-and must I be banished hence ! my dear Pearson, my best of friends, if it be possible, "take away this cup from me." I earnestly beg you to write without delay-delay not an hour, my friend, if you can help it.

Yours truly,

T. Sмiтн.

William immediately apprised his friend of his having written, and the following outburst of gratitude, shortly after, was received at Borderside.

MY DEAR FRIEND,

Gorton, 2 2nd November, 1838 .

I received your kind letter enclosing . . . . our friend J. IV. brought it himself. My gratitude at this moment, is overpowering and bewildering, so that I know not what to say . . . . I wish you, however, my dear friend, to accept the warmest, sincerest thanks of a husband, father and friend, whom you have saved from ruin. Bless you-God bless you, for ever and ever.

I received the Kendal Mercury you were so kind as to send me: your article is no commonplace thing-there is a healthy raciness, 
and a peculiar humour, and humane wisdom mixed up in it, that would have done no discredit to Charles Lamb himself.

I know you will be very sorry to hear that my family is unwell. Both the children, Mary seven years old and Nancy four years, have got the whooping-cough very badly. Nancy is weakened and reduced by it, very much; a most formidable, distressing disease, it proves-very little rest, day or night, with almost convulsive struggles for breath-but I need not dwell on this, you know by painful experience, the evils attending a harassing, obstinate cough. . . . My wife is jaded; thank God, I am pretty well. Write soon, your letters were ever a cordial to me. I beg you to speak a few words of comfort to our old friend J. W., I know he will receive them thankfully. He and his sister Mrs. S., send their best respects to you. Write soon, and believe me, my dear Friend,

Very gratefully and affectionately yours,

T. Sмrтн.

\section{CHAPTER XII.}

If possible, even darker and more overwhelming still, was the Spring of 1839. Ominous the signs of the times. The people assembling in masses - the military ordered hither and thither-dismay or recklessness on all sides_-Whilst looking over, and perhaps still more vividly, whilst the hand was tracing the contents of T. Smith's letters, written during this hard time, which painfully show how a quiet and sensible man, with but a small family to provide for, was ground down by want and in the end his life sacrificed by his struggles to avert it - the mind has been impressed by the witness they bear to the clear insight of the man charged at this disturbed period, with the delicate and painful duty, of suppressing the riotous gatherings of a starving population in the manufacturing districtsthe late General Sir Charles Napier-whose tender sympathy with suffering," endued his judgment with a truth and depth far more to be relied on (though discredited in high places) than that proceeding from the instinct of fear, which referred those lawless out-breaks simply to political disaffection.-Although as clearly as others, Sir Charles could perceive that multitudes of inexperienced youths, and unattached young men, withdrawn from their ordinary daily occupations, were excited, and then played on, by self-seeking demagogues, until they became exasperated beyond the power of selfcontrol-yet with equal discernment he saw that the great mass of

* "Wisdom is a loving spirit."-Ecclesiasticus, ch. i-v. 6.

"Love furthers knowledge."-Scotch Proverb. 
these tumultuous assemblages, was composed of persons brought together by distress, starvation, and the utter lack of occupation.

The following letter from T. Smith reveals calamity upon calamity.

\section{MY DEAR FRIEND,}

Gorton, 2nd May, I839.

I sit down very much agitated and depressed, to write to you -in pure truth I am both ashamed and fearful, having appealed to your goodness of heart far, very far, too often and too much. I have said fearful, yet I have no other reason for being fearful than this-I would rather lose my life, than your affection and esteem; for from the first of our acquaintance, they have been of heavenly value to me-alas! that I am forced to use them for earthly purpose. We have, my dear friend, had much affliction in our house since I last wrote to you. Nancy, four years of age, has had the whoopingcough very badly, and is far from being well yet. In the midst of Winter, she was expected to die, daily, for a long time. For more than two months she could not stand, but lay helpless as a new-born child. . . . . My wife tended her in the day, and myself chiefly in the night. I need not say we were very poorly fed-as a husband and a father, I insisted on my wife and children having rather more than their full share, of what food we had; at length my health gave way, and I became violently ill. . . . . . I was confined to my bed a fortnight; we were obliged to call in a doctor (pay him when we could) . . . . in rather less than a month from the beginning of my sickness, I began to work again. J. W. came to see me often, and was very kind every way-sitting by my bed several hours at a time he was sitting by me when the doctor told my wife, when to go for medicine-ever thoughtful, seeing she could ill be spared from me and the child, he proposed going himself, and taking little Mary, seven years old, with him, to teach her the way (about a mile), that she might be able to go any other time. J. W. told me when he came again, that he had asked the doctor about my disorder, who said, "I am satisfied your friend's illness has been caused by an uneasy mind, and want of the common necessaries of life."

I now feel myself well, but not so strong as I was before my illness. I can follow my work as usual, and we have had enough work the last month, but very bad. I talked very earnestly one day lately, to my employer, begging him to allow me a little more for doing it, it was so bad, and underpaid. He laughed at me, and said I might leave it if I did not like it-as he could have it done at that price, without grumbling.

God help us poor weavers.

My dear friend, I beg you will bear with me. I am deeply hurt at thus troubling you so oftcn, what must, what can I do-I believe 
you do not expect so much heroism from your poor, but affectionate friend, as to let himself and family "perish in his pride." When I received your last letter I owed my landlord $£ 4$ I6s. - I paid this out of your bounty, and with the remainder bought my wife some flannel, being then, as she is at present, very rheumatic. In a few days I shall owe him $\mathcal{L}_{3}$ ros.- - which he says he will have on rentday, or he will put me out of the house, and he will make his words good-he can let it directly he says, and I know he could, and I know too, he would rather, because I am poor.-I have lived in this house 32 years-it is a very good house for us, having a capital work-shop for silk; it is warm and dry and light, my wife knows its value. I believe if we were forced into a damp work-shop, she would become a cripple with rheumatism; what will become of us, if we are forced to go, I cannot tell. We have not a shilling in the house at this moment, but I shall pad some work to-morrow, and draw about I3s.-You will be glad to hear I received 8s. weekly from my Sick Club, during my illness. I am afraid this letter shows want of delicacy, my dear friend, but what can I do, while so heavily crushed with "The king of woes, pride-humbling Poverty"-forgive me, help me if you can; if you cannot, I and my family are lost to all comfort,houseless-I cannot sleep-

Yours truly,

T. SMith.

From William.

DEAR FRIEND,

Crosthwaite, I3th May, I839.

I was disturbed to read your letter, and hoping to do more than relieve your present necessity, took the liberty of showing the letter to Mr. — who by the death of — has become possessed of a handsome fortune,-but alas! . . . . . he certainly has given . . . . . to the poor of - I send you a Bank of England note, which will enable you to settle with your landlord, and something more. This I can easily do-but still it is only temporary relief. You will be sorry to hear I yet receive no interest on my South American Stock. The scoundrels instead of paying their debts, have gone to war with Peru!. . . . .

You will excuse my writing at present at much length, as I am. just setting off for Kendal.

With kind remembrances to Mr. W.,

\section{I remain, \\ Yours truly,}

W. Pearson.

In reply T. Smith writes__ "Thanks and blessings upon you-it will relieve me and my family from other wretchedness, besides rent." 
Towards the end of August William wrote as follows :

\section{MY DEAR FRIEND,}

I wrote to you about the beginning of July, but have not had the pleasure of hearing from you since. I only returned last night from a visit to Mr.—- being the second time I have seen him since his marriage. . . . . he has surely all the external means of happiness. But however, I have better news for you respecting him, than all this. He has had the kindness to send you five pounds, which I now enclose. This he did of his own free motion, with an apology to myself for having refused me before. . . . . I can assure you, I was much gratified with his kindness, and told him I thanked him as sincerely as if it had been done to myself. . . . When you acknowledge the receipt of this, let me know how you go on. I wish it were convenient that you could come and see me. Do come, if you can without an imprudent sacrifice ; supposing work to be scarce, then, perhaps you might, for I think the expense of the journey can be no great matter, coming from Preston by the boat, and by the railway thither. Consider of it, and let me know. It would be delightful to have a ramble among the Lakes after harvest.

Yours truly,

W. PEARSON.

The visit was paid, and a little while after his return home, T. Smith wrote, "I got home speedily and safe. My wife and children were anxiously expecting me, and we had a joyful and affectionate meeting. One of the first sounds I heard in the morning, was the sound of the factory bell-one of the first things I saw, was a factory woman, partly walking, partly running, afraid of being too late. In less than an hour, she was carried home nearly killed by the machinery. I then thought on your beautiful country with its Woodlarks - and the wallers working in the open air; what a contrasthow painful. The working people in your country, are healthy, independent, and happy, when compared with ours. . . . Thank you for all the books you gave me. . . . Wordsworth is lastingly eloquent-he is the first of living writers."

In March, I840, William's father was removed by death, and he wrote to inform his friend of this event.

DeAR Friend,

Crosthwaite, 27 th March, 1840.

Thank you for your letter and all the information it contained. P'oor R—, and he is gone! and aged 53 ; but we are all getting old. We have had death lately in our family; but considering on whom it fell, we ought not to regret it ; for he was quite worn out 
with age and infirmity-my poor old Father! He had been for upwards of three years confined to the chimney corner, but he bore his sad state with the greatest patience and resignation. He would have been 82 if he had lived till May. He was always a good, quiet man, and I wish we were all as well prepared for the great and inevitable change.

You kindly inquire after my health. About a fortnight ago, I caught cold, which has brought on my old Spring complaint, a plaguy cough and shortness of breath. The worst of it is, I can seldom get any medicine that is of use. . . . . My appetite is also bad, but as the weather gets warmer, I must ride out on my pony, and that I hope will be of use.

You would see that I got credit from my Paper, read to the Society. It was local and therefore interesting. In the next Mercury after the one I sent you, were two letters in praise of it, one dated Pendleton near Manchester, in allusion to that part of it relating to the Lincolnshire Duck Shooter. Chambers' Edinbro' Journal has lately inserted my account of the Fly-catcher; but oh, lamentable, without mentioning my name! It has a circulation of from 60 to 70,000 weekly, so that it will get pretty well known, and may perhaps be copied into works on Ornithology, but still, the worst of it is, probably without my name ! You inquire after Mr._ and Hartley Coleridge. The last time I saw them was the week after my paper was read, when I was detained at Spring Cottage by bad weather, from Monday till Saturday. . . .. . I met with Hartley in going. He had been at Kendal 2 or 3 weeks ago, and falling in with the Editor of the Mercury, he had presented him with two original Sonnets. One, an impromptu on the new Postage-the other very beautiful, on Christ praying to His Father. There is lately published, an edition of Ford and Massinger, with an introduction by Hartley. It has been reviewed in the Examiner; I expect to see it, but have not yet.

I am sorry to hear of your scarcity of work. I enclose you a trifle. No doubt all who have anything to spare ought to give something to those who need. . . . . Will you remember me kindly to Mrs. Houtson, and tell her I am much obliged by her invitation. If I go to Manchester, I shall be sure to call on her.

With kind respects to Mr. W., I remain,

Yours truly,

W. Pearson.

From T. Smith.

MY DEAR FRIEND,

Gorton, I6th April, r840.

I sit down with a sorrowful heart to answer your two kind letters, and to explain my delay in answering them. 
had you constantly, day and night in my heart and mind. Your Father always seemed to me a mild, cheerful, intelligent, good man. I feel much satisfied I have seen him so lately. I know you much loved and honoured your aged parent, I know too, at times you will deeply feel your loss. Your want of health troubles me. Shun cold, avoid the night air: . . . . What I have to say about myself is bad indeed-we are suffering deeply-pinching for meat is nothing - a mere nothing. My rent day is approaching.

Your — - is still unchanged, though we have wanted meat often. The children are hearty, my wife feeble and rheumatic. I an middling.

\section{Yours truly,}

T. SмIтн.

As T. Smith's letters have shown, the approach of rent day was a periodical agony; nor was there any brightening prospect to yield a little cheer ; yet so grappled was his cottage to his very heart, that a severance was more dreaded than the most desperate efforts to retain it, and after receiving the preceding letter, William wrote, "by taking the above to the Manchester Post Office, you will receive the amount mentioned, and I hope to send you the same every year."

About this period William formed an acquaintance, destined ere long, to have an influence in directing his own future; and when in process of time his hopes and fears were imparted to T. Smith, he with characteristic ardour, entered into his friend's feelings, in what he called "the delicious but awful business of true love." And as the sunshine of his friend's happiness fell on his own tearful state, the rainbow-tinted feelings of his heart, gave brightness to a correspondence which was fast hastening to an end. His own pen shall trace his troubled career to its close.

\section{MY dEAR FRIEND,}

Gorton, 8th Oct. I 840.

I thank you for your last letter, I had been waiting for it with great anxiety; do not, my dear friencl, delay writing to me, if you can help it: I had been on the tip-toe of expectation a long time; I knew you to be in a state of important excitement, with delightful prospects and hopes, and although glorying, and hoping continually, I could not be very tranquil-I wanted to know more.

My Wife-the mother of my dear children, my two fine girls - is a very clean, industrious, home-keeping woman, and I love her warmly; but I will give up this talking about wife and children, it is perhaps too egotistical, for we are all but one at last.

Let us bless the wisdom and goodness of God, and be thankful till 
our hearts swell with gratitude. We have at present, good weather here-pleasing, mild October; I have past three Octobers, chiefly in Westmorland, feasting on rich scenery, rich intellect, rich fare, and to crown all, rich welcome. . . . . . I cannot say much is good with us, but health. We have poor trade and wages, and too often scant food, and poor spirits-we seldom have full work many days together-often have to wait a week, two, and even three. I am then constantly on the run, looking after it. If our dear children were up, we could live. We make a pinching shift for meat, but rent we cannot muster.

Yours truly,

T. Sмiтн.

At the beginning of November, T. Smith says, "I went to Stockport, taking with me the Bank of England note . . . I got it changed, and bought the following family articles which we stood in much need of-a little flannel, a pair of shoes, and a shuttle. Yesterday, we paid our rent-to-day we are comfortable. Such thanks as troubled hearts made happy, can feel, but not express, we wish to send you. . . . . . I have not yet been able to feel at all glad, that you are giving up dear Borderside, with all its plenty, and all its healthy beauty-but you should know best. I hope God will guide you to pleasantness and peace. Write to me soon, if it be but a short letter.

Yours truly,

T. Smith.

The next letter is from William.

MY DEAR FRIEND,

Crosthwaite, 5 th March, I84 I.

It is near ro o'clock, but I will just write a few lines. I wish to send you a few details, because I know you will feel interested in anything that gives me pleasure. I received a newspaper lately, for which I thank you : but I should be sorry you should buy a paper to send me. You would, I hope, get the one I sent you, not long ago, which contained extracts from a paper I lately read to our Society, on Westmorland Superstitions. I believe it afforded a good deal of amusement to the meeting. I think I must send you a Mercury tomorrow, by which you will see that I even receive compliments from Ireland! The Rev. C. Otway is a very pleasing writer-from a paper of his, I had given a quotation, and the Editor of the Mercury had sent him the Extracts from my Essay. I choose subjects that are local, and treat them in a plain, familiar style, which pleases a good many. I have to read another Paper on Monday evening-a 
continuation of my subject. I have had it to write since the last meeting, which has given me some employment. I think it will be as amusing as the last, or more so. I shall send you a paper next week, as I suppose they will beg my MS. to extract from.

I hope you will write soon-I know you wrote last. This penny postage is a blessed thing-but then one should lay hold of it ! It is getting bed-time, therefore I must conclude. I have no news. My beloved is well. So I hope is yours.

Yours truly,

W. Pearson.

\section{From T. Smith.}

MY DEAR FRIEND,

Gorton, I 2 th March, $184 \mathrm{I}$.

Your kind letter written on Friday, and the last Mercury, I received on Sunday evening. Another, about 3 weeks before. I have waited anxiously, (painfully towards the end,) to hear from you. I should have written to you, had I not been comforted by your sending me the first Mercury. . . . . . Time has been, when I saw you often, and you know how we lingered together. Then what a day was Good Friday-we were prisoners set free, roaming eagerly in quest of sweet, invigorating air-and Nature's beauty and sublimity-you remember Scout Mill-Bucton Castle-Greenfield Rocks-it was a festival, and our hearts worshipped with warm accord. . . . . . I cannot express the pleasure I feel on your Papers being noticed and applauded, on all sides. . . . . I know not what is the best feature in your Essay, but I think the humour exquisite-your account of the "Need Fire" is curious. You say nothing about your health, nor much of how you have been passing your time this hard Winter. Do you feel comfortable in your mind and affections? I would put in my claim delicately, and respectfully, for a little news of you and your beloved.

We are all healthy at present, thank God. We have waited less for work lately, but it is tedious and bad, and we can earn by hard working, very little indeed. I am just as poor as ever ; "Poor I went to sea, and poor I still remain." Poverty is a state to be dreaded, yet often healthy-children grow well in it-we have two rare fine girls. . . . . Borderside hears now, many a sweet duct, between the rippling of the Winster and the warbling of the Woodlark. Write soon-

Yours truly,

T. SMITH. 
MY DEAR FRIEND, Gorton, April 2, I84I.

I received your kind letter, and since then, another Mercury. Thank you. It is excellent, but nothing laughable can at present cheer me. . . . . . At that time we were pretty well in health, but a few days after, we had a sad, and affecting change, that has filled our poor home with misery. My beloved wife has been taken with a violent, and serious illness, which I am afraid, is likely to continue a long time. I have been obliged to call in a surgeon; he does not seem willing to state very clearly, what he thinks her disorder is; I am apprehensive of a bad fever. God grant that I may be blessedly mistaken. . . . . I am writing this at the foot of the bed. She seems asleep. . . . . Tell me something good about yourself, to cheer me a little. A month ago, I was in heaven amidst my poverty, compared with my present state-but I must not murmur, thank God, I am yet in health-if that fail, we are all lost_ at this time I am father, mother, husband, nurse, all in one.

My every way invaluable friend, you have always made my sorrows and misfortunes your own. . . Alas! that I am forced to try, so beyond all reason, that affection.

My dear Pearson, answer this as soon as you get it, for I am sore beset, with that, which rends my heart, as a father and a husbandwant, meagre want, is now grinning before my face. God bless you -I hope you are well and happy.

Yours truly,

T. Sмiтh.

MY DEAR FRIEND,

Gorton, April 8, r84.

Your short, kind letter enclosing an order for - I received yesterday, before noon. Never I think did letter bring greater, or more needed relief-our gratitude I can never expresstears, and deep sobs my friend, are our imperfect thanks. The children looked most pathetically brisk, and wondered at their father's cutting them larger pieces of bread-you can never be rewarded for your goodness by me and mine-all we can do is, to wish, and pray for you, and be thankful. . . . . . my wife is no better, the doctor says it is a fever-but not infectious, at present; he tells me, she is not in danger at present; but always adds, he cannot tell what may supervene. My hopes are distressingly waveringmy own death, would be a blessing compared with losing her, who is far more dear to me than my own life--my children had far better lose me than their excellent mother-we should be miserable, and undone without her. God grant me and our children her 
life.

Let me have a long letter from you soon. I will write again shortly.

Yours most truly,

T. Sмiтh.

His next letter contained the doctor's confident opinion, that his wife would be restored to health. In the following letter, William, after endeavouring to support his friend under his domestic affliction, gives him an account of his own prospects and plans.

My DEAR FRIEND,

Borderside, r6th April, r841.

farming. The sale is fixed for next Monday but one. Had I not been intending to marry, I should, I believe have given it up ; for in some respects, it is far from agreeable.

I always disliked change, and considering that trait in my character, it seems odd I should think of marrying. In a few weeks, I venture on that "variety of untried being." This disruption of old habits, and the great change consequent on it, I can assure you, puts me in a state of mind ili-befitting a joyous bridegroom.

Althorigh the advanced age of both, is against us, yet as we agree very much in opinion, sentiments and tastes, may I not hope we shall both be happier for the union? You will be surprised, perhaps, to hear that we are not going immediately to housekeeping, but intend to travel for a short time. Our plan is, to visit some of the Belgian towns, go up the Rhine to Switzerland, spend two or three months in traversing that sublime and beautiful country-partly on footthen, if home-sickness do not come on us, to pass the Winter in some French town, in the South, or West. However this last we have not quite concluded on. I suppose you will think all this strange; but to see the Continent, and particularly Switzerland, I have always desired; Mr. Wordsworth has advised me to it, before age renders me unfit for foot-travel.

is an excellent walker, and is quite willing to share the fatigue-and I am sure, she will share the pleasure : we mean to begin the tour of Switzerland at Schaffhausen, and end it at Geneva, seeing also some of the Italian Lakes,-to travel as economically as possible, not, however, denying ourselves any suitable comfort. We expect some trouble and fatigue, but also great enjoyment. The expense will be considerable, but as living is cheap on the Continent when you are stationary, if we stay awhile, in some French town, that will in some degree set matters straight.

I wish the sales, \&c. were well over; to sell even the cattle one has been used to, and to leave the house, poor as it is, 
that one has lived in so many years-all these changes make me feel far from joyous. Yet one ought to be happy going to be married. The last twelve months, I have been happy enough.

Let me hear from you soon, and pray I shall, sincerely, that I may have good news.

Your sincere Friend, W. Pearson.

\section{From T. Smith.}

MY DEAR FRIEND,

Gorton, 22nd April, 1841.

I have received yours of the I6th; it has overwhelmed and buried me in a flood of the deepest feeling: I would say pure, unmixed joy, if I could (and surely I ought, I believe I ought), and yet for want of true fortitude, I cannot-you, my dear friend, know I am a coward in the affairs of life-a very coward. I hope I am not wanting in truth and feeling, but the hardy, healthy virtue of courage, I am sadly deficient in-like yourself, I have been averse to changeand in addition to all this, I have a superabundance of local attachment. I wish I could banish all sadness from your true and loving heart. I am sure my own would receive great relief by doing so. . . . . You are changing many endearing things, tremendouslyand all at once-farm-beautiful old habits-your native country. . . . . . I wish your sale and other unpleasant matters were well over. . . What will become of your kind-hearted housekeeper? Give her my kind respects ; I wish she may be prosperous and happy.

Farewell, dear Borderside! thy master is a prince in heart and soul-and made thy walls by intellect and goodness, bountiful and dignified. This feeling will go with me to my grave.

I should like much to know the maiden name of your beloved-God bless and protect you both. . . . . My dear, afflicted wife remains feeble; her appetite improved, but she can only take the weaker meats, as potatoes, rice, tea and coffee, roasted apples, but not much bread. I have got a bad cold and cough, but think I shall soon be well.

Your sincere and affectionate Friend,

T. Sмiтh.

Ay, farewell. Yet one heart there is still, which loves that old farm-house; and rude as was its exterior, and bare as it was within, of any but the most homely comforts, it more than once, welcomed a most honoured guest-Mr. Wordsworth-who, by the simple act of lodging beneath its humble roof, recognised and portrayed the 
intrinsic, the everlasting grandeur of that in man, which is infinitely above position, rank or wealth-an act, which flowing from his own benign dignity of soul, dignified in degree, the lowliness of the friend he made happy by this kindly intercourse.

\section{CHAPTER XIII.}

As on a former occasion when William was about to visit Scotland, Mr. Wordsworth had given him the benefit of his own experience, so he now furnished him with a route, comprehending in its scope, the main objects of the projected Continental tour.

\section{"Mr. Wordsworth's Instructions."}

"At Mayence turn from the Rhine to Frankfort-DarmstadtHeidelberg-by Carlsruhe to Baden Baden-Strasburg-then by Hornberg or Freyburg to Schaffhausen, see Falls of the Rhinethen to Zurich-Wallenstadt Lake-up the Valley of Glarus-Altorf -Schwytz-Mt. Righi-Lucerne-Lake of Four Cantons-up the Banks of the Reuss-over Mt. St. Gothard to Lake Maggiore, Boromean Islands, Lake Lugano, thence to Lake Como, which see perfectly_-Varese-Lake Orta-Domo d'Ossola, see religious stations and cells-over the mountain to Bryg in the Valais-turn off to Gemmi Pass-to Kander Grund and Lakes of Thun and Brienz-up the Valley of Oberhasli, see Falls of the Handec at Meyringenthence to Lungern Zee-Sarnen-to Berne and Geneva by any way most promising-make the Tour round the Lake of Geneva-see Chamouny-see as many of the Passes as you can."

One of those mysterious transitions which sometimes arrest the execution of our settled projects, interposed to prevent William's marriage at this time. His friend's warm, true-hearted, "God help us all!" were the best of spoken words, and with humble trust and acquiescence, Villiam went on his way. At this juncture, T. Smith was privileged to mingle some drops of sweetness, with the medicinal bitter, poured into William's cup. He wrote, "Had I been in prosperity, I would have been with you; I know I could not have done much for you in your heavy misfortune, but I would have shared and borne as much of your affliction, as one human being can for another; sincere, loving endeavours, are seldom lost. My lot forbids my being with you, but you are in my inmost thoughts, day and night. I had been anxiously expecting to hear from you, and began to be very uneasy at the delay, fearing more affliction in one shape or other, might have come over you-these heavy, unlookedfor troubles, make one not only sad, but fearful. I shall be quite unhappy if I do not hear from you often-lighten, by writing, my heavy 
heart, which is full of the truest sympathy for all that can befall you, be it weal or woe. . . . . . . You have done wisely in taking a fishing excursion; you are in a rare district of old England, for the healing of grief. I tried it fifteen years ago, on the death of my very intelligent, and very affectionate wife. I mark affectionate, for rest assured, affection is the most valuable, of all valuable things. I can never forget the sweet complying humility of her exalted intellectand her dignified, plain, quiet, virtuous tone of feeling, charms me yet.-On my unspeakable loss, you brought me to your home, and beautiful country; and even then, I found 'that Nature never did betray the heart that loved her.' I received good from her 'soft influences, by the beneficent touch of love and beauty,' and your invaluable converse.

"I thank you for your very kind letter, and also wish gratefully to thank you, for your great goodness in sending me a Post-Office Order for - - I fear, my dear friend, you must have been in a rather absent state of mind, while in the act of sending it, as it came to me unsealed; and one might see it never had been sealed. I asked the person at the Post Office, if it was common to send Orders in that way-he laughed aloud, and said 'No-but it is well you have got your money.' This matter has made me uneasy . . . . Enjoy the scenery at your own door. Wife and children are well-but work very scarce."

In a letter from William to T. Smith, written in Aug., he says, "I returned on Friday from Langdale, having gone thither for the purpose of ascending Scawfell, but the weather unluckily changed, and so disappointed us. It was the more provoking, because there are at present, on the summit of the mountain, a party of Government Surveyors, living in Tents, with every convenience. They have a large Telescope, which it took seven men to carry up.

As you are an admirer of the Bard, I hope these quotations will not tire you. How far do you agree with —— in thinking there are persons, who appreciate other great Poets, and are yet insensible to the merits of Wordsworth? I doubt this. I am going to the Annual Meeting of the N.H. Society, and shall take this with me. Let me hear from you soon."

In Sept. T. Smith writes, "I have been much on the run and alarm about my work, for trade is slack, and work scarce and poor-yet by a sort of harassing exertion, and Providential Goodness, we have seldom been entirely without, for which I assure you, my dear friend, I am truly thankful-some of our Trade, have not had work for weeks and weeks. . . . . . Thank you for filling your letter so freely, and so well, on subjects so near and dear to my heart-Wordsworth's Poetry-Scawfell-the Task you have had set you-I do not think 
there is in the Kingdom a person more richly qualified than yourself, for writing a delightful critique . . . . . proceed without delay, and pour out your inmost heart and judgment, boldly and copiously. I never read the extracts you have been so kind as to send me, but I think of the graceful dignity of Mrs. Siddons. I hope you are still at dear Borderside, you cannot live at a more delightful place. I hope God will preserve your health and peace of mind. Keep up your spirits, and enjoy the fine, sweet scenery at your own door. . . . . tell me all. Write soon. We are all well in health."

$\mathrm{He}$ again writes in October, "I begin to be very unhappy, and make strange conjectures, why you have not written to me. I have been daily waiting for weeks, in hopes of this blessed satisfaction. . . . . . has my letter never reached you, or has yours never reached me?. . . my dear Friend, where are you-what are you doing? I have never been so easy about you, since you gave up farming. Have you been towards Scawfell again? or have you made the excursion into Wales? J. W. has often wished he could have you at his house, when you are returning from the Welsh Mountains. He says he should be happy to have you under his roof once again. Indeed, I have for years, had a standing commission to invite you. I have cause to be gratefully thankful to God, that I did not catch the fever from my Wife, which I have great reason to think, was a very bad one; before her illness, she had a very full head of hair-on her recovery, it all fell off. She is now pretty well-our children too are well. I at present am not so well, I have a cough and pain in my back - the effect, I think, of bad colds, for I have had much hard tramping after a bit of work, often, of late, in rainy weather-I have been much starved with being wet and pinched. Work at this time, is very scarce with us. My dear Friend, write very soon."

\section{Willian's reply.}

\section{MY DEAR FRIEND,}

Borderside, October 3I, I84I.

I happened to be at Kendal on the very day your letter arrived. I am truly sorry you have been made so unhappy by not hearing from me, and feel I have been much to blame. This indolence is really inexcusable, now when one may give the pleasure of a letter by a little exertion, and the cost of one penny. But I hope to amend. For the last two months, my health has been somewhat indifferent, and about the beginning of Oct. I made a journey, thinking it would do me good. I went, taking my pony by way of Kirby Stephen, over Stanemoor to Barnard Castle. It was a beautiful day when I set out, but next morning it rained as usual, and the next, and the succeeding one, so I was detained at the Inn at Barnard Castle, about three 
days, and could scarcely look out. Rokeby is about 5 miles down the Tees, near Greta Bridge. I was much delighted with the wooded banks of the river, splendid in Autumnal colours; though it rained the whole time, so that I did not enter the grounds at Rokeby. When I set out, my intention was, to go by Darlington and Stockton, to the sea-side, and afterwards return by old Durham-a place of 'many ancient associations-but the state of the weather, and of my health, made me determine to return. I went up the Tees to Middleton, Io miles, through Cotherston, Ronaldkirk, and some other villages-the scenery well-wooded, and of the richest description, but the weather was showery. Five miles beyond Middleton, is the High Force, a grand waterfall on the Tees. The cataract is divided by a high, black rock, into two streams. The river being swollen by the rains, it was a very striking and sublime scene. The weather was so bad I did not see the "Cauldron Snout," 5 or 6 miles higher up the river. I returned over the moors to Kirby Stephen, twenty-three miles, and home next day, having been absent a week. There is something sublime in these almost interminable wilds.

Some two or three weeks back, I received the letter you wrote so long ago. It had, as I suspected, lain snug in the pocket of the person by whom it had been sent from Kendal. He found it at length, and it came to hand. . . . . . My health is a good deal improved, my cough not so troublesome.

I am much concerned to hear of the trouble you have to procure work, and of the state of your health. Take care of that, I beg of you. Write again soon. In the meantime, I expect to send with this, another Order. I can do it without the least inconvenience, for I have received three payments from my S. American Stock, so long in abeyance. Let me hear from you, I beg.

From your sincere Friend,

W. Pearson.

A letter from William dated 5 th Nov. concludes thus. "Do you suppose there is any chance of abolishing the cursed Corn-Laws? Have you heard anything of a Poet at Hyde, a cotton-spinner, of the name of Prince? He has published some beautiful Verses, and there is something strange and romantic in his history. He went abroad, and in returning, travelled from Germany to England, as a mendicant, but never suffered much, till he reached the land of his nativity! See Wordsworth's 'Vagrant,' 'Near a Thousand Homes,' \&c. I am sorry to read in the papers the dreadful tales of distress. Ministers have prorogued Parliament, as much as to say, they can, or will do nothing." In reply, T. Smith writes, "Your very kind letter written last Sunday, I received on Tuesday-at the same time too, a 
P. O. Order. What a friendly and princely help. Although at this time, I feel ready to sink on my chair, overpowered with so deep a sense of obligation and gratitude, I am unable to express the pure, and mingled feelings struggling within me-yea, burning too, all over me-forgive me, my dear friend, and believe me very thankfulI feel sorry to hear your health has not been good-but as you say you are something better, I pray and hope you will soon be well. You have had weary, bad weather during your journey. You can scarcely conceive how glad I am, to find you have not sold your little, strong pony. I think it may be very conducive to your ease, pleasure and health. Make much use of it-enjoy your beautiful scenery, and pure invigorating air, as much as you can. I think you must find it one of the most beneficial things, both for body and soullook to this judiciously, I do beg of you, and depend on it, you will have good from it. I hope and believe it very possible, that things may wear a better aspect when this reaches you. That God will lead you to peace and happiness, is my most ardent prayer. Be careful of your health. I request you to write soon. We are all pretty well in health.

"Yours most truly and affectionately,

"T. Sмiтн."

\section{From William.}

MY DEAR FRIEND,

Yews, Crosthwaite, Dec. 3, I84 I.

I have within these few days changed my residence, and now live with my Mother; and indeed, it suits me better than Borderside, as I have here a room to myself, in which I can have a fire, and read without being disturbed. During the long time I passed at Borderside, most of my Books remained at the Yews-now I have them all with me, which is very pleasant, and I hope will be an advantage.

The Encyclopædia was at the Yews; I have lately had it bound, and expect to find it useful as a book of reference.

I duly received your kind answer to my last, which was written, I confess, in a state of painful feeling, and knowing how much this would grieve you, I now regret the letter was sent. However, you will be glad to learn. . . . . . I am much grieved to see by the papers, that trade continues very bad. At Stockport, in particular, the distress appears overwhelming; I suppose also at Denton, and Gorton, and all round your neighbourhood. Great exertions are made at Manchester to get rid of the Corn-Laws. I hope they will succeed, before Manufacture and Commerce are entirely ruined. I have taken for more than a year, "The Anti-bread-Tax Circular," 
and am quite of opinion, that the Corn-Laws are unjust, cruel and impolitic. Any information you can give me on the state of your part of the country, and the condition and feelings of the people, will be interesting.

. . . . Give my kind respects to J. W., and let me know how he is. I feel grateful for his kind invitation, and may, perhaps, avail myself of it about Christmas. . . . . In the meantime, with kindest wishes,

I remain

Yours truly,

W. Pearson.

My dEAR Friend,

$$
\text { Gorton-Dec. I7, I841. }
$$

I cannot express how gladdened and refreshed I was, on reading your last letter. I opened it with a sad and dreading heartbut what a gush of pleasure came, as I drank the hope, and sound comfort it contained-profound thanks to the Great and Good Disposer of all events. What a weight of sorrow is removed from the breast. Thankfulness cannot sufficiently abound in us, for this happy change. . . . . I was some hours yesterday, with our friend J.W., and one of the last things he said to me, was that I must press you warmly to come to his house, for he should be very glad to see you, and have you under his roof once again. He says his nieces, the Miss B- - also wish much to see you; they have a pleasant but imperfect remembrance of your last visit at Dentonthe social and kind-hearted Mrs. S- too, would be fain to see you, and do her utmost to make you comfortable; besides, there is J. W-'s blooming Daughter, who would be pleased to see her Father's friend. In short, you would be a most welcome and honoured guest-and as for my poor self and Wife. . . . . . You ask if I have heard of C. Prince. Our friend J. W. has spoken of him to me, and gave me yesterday some lines written by him, on "Kinder Scout;" I thought them good. Prince has a Sister living near J. W-'s at Denton, and he has told me. . . . . You are kind in asking about bad trade, and the working-man's misery-Trade with me, grows worse ; our Master says " he is glutted with goods.' We have had a very little work lately-one loom has now stood still more than three weeks. J. W., unknown to me, kindly got us some work this week--but very poor wages-bless him for his exertion.

Yours truly,

T. Sмiтн.

Gorton, Jan. 3 rd, 1842 .

MY DEAR FRIEND,

I feel sadly depressed that I am about to write to you a brief and unpleasant letter. I am unwell, and have been 
so bad for about a week, that I have been mostly confined to bed. Within this day or two, I have been somewhat better. My chief ailment is a bad cough, caused by cold I have gotten, by being much wet, and standing a long time in my wet clothes, whilst waiting for my work-It seems, I cannot stand it as well as I used to do-but I am better, and hope a week or two will set me right again. J. W. came to see me yesterday, and stayed several hours. . . . he was flat and disturbed about your expected visit, being fearful he may not be able to be at home, to enjoy your society. He wished me to say, that he is summoned to attend as a juryman, on the roth inst., at the Manchester Sessions, which will keep him engaged not less than a week-now, if you could defer your visit, till this unpleasant time is over, he thinks it would be better for you, and him, and us all . . . let me know very soon. Trade is bad with us, in the extreme-deep distress, far and wide. It is a fact, that at Stockport sour swillings-a poor sort of pigs'-meat, have been stolen for a fortnight, by a woman, for the support of herself, husband, and two children.-Write very soon.

I remain yours most truly,

T. SмIтH.

\section{William's answer.}

\section{MY DEAR FRIEND,}

Crosthwaite, Jan. 6th, I842.

I duly received, on Tuesday, your letter conveying to me the request of my friend $\mathrm{J}$. W. that I would defer my visit. I had not thought of going so soon; if I do get away, it will be at the time the great Anti-Corn-Law Bazaar is held, about the end of Jan.-I received also your former letter, and thank you for it, and for all your kind concern about me, and my affairs. I am truly sorry to hear that you have been suffering from illness. You must be more careful to guard against getting wet-if you could procure a good, useful, outside cover, to use when you go your journeys-a kind of top-coat, ever so plain, provided it would keep you dry and warm, that I think would be the best plan. If I take this to Kendal to the post, I hope to send you a trifle to purchase one.-I have a friend who sometimes sends me a Manchester paper, and it is truly awful to read of the distress around you. Stockport seems to suffer the most severely. We have distress here, but not much in country places. In Kendal they complain, but it cannot be so dreadful as with you. Convey to Mr. W. my best wishes, and my thanks for his kind invitation. I should have great pleasure in seeing him, and all friends in his neighbourhood, who may yet remember me. It is not a good season for travelling, and as one gets older, one is less inclined to move; 
yet I hope I shall come. The exact time for the Bazaar I see is not yet fixed. You will think this very short for a letter, but I hope to make up for it, next time.

Yours very truly,

W. Pearson.

The next letter brought a worse account from Gorton; it is dated Jan. Ioth.

\section{MY DEAR FRIEND,}

I duly received your kind letter, order, and papers, for which I thank you very gratefully. You will be sorry to hear I am worse than when I last wrote to you-the day but one after I wrote, I became so very ill, we were forced to call in a surgeon, living near. I have a very bad cough, and no appetite-he has ordered me to keep my bed-indeed, I had nearly done so for more than a week. He says little, except that my cough seems very firmly established. I must wait God's will. I am very sorry for my poor Wife; she is quite willing, and eager to do all she can-but she is not hard, and if she knocks up, I know not what must be done. Above all things in the world, I beg, my dear Friend, that you will take the greatest care of your health-forego anything, for the sake of your health. . . . . My ardent wish and prayer is, that you may be with your Beloved, more and more, until one event only, can part you. God bless you both-always strive to comfort one another. . . . . I long to know much of this; it would cheer and comfort me in my sickness. Write to me soon.

I remain

Yours very truly,

T. Sмiтн.

In reply to this William wrote :-

MY DEAR FRIEND,

Yews-Crosthwaite, I 7 th Jan. I 842.

Your letter dated the Ioth I received on Friday. I am truly grieved to hear of your continued illness; you have done very right in calling in a doctor. I would have written immediately, but we are so far from the post, and I have been a good deal unwell, from a cold I caught about a week ago, by standing many hours in a cold room, at the Sessions. I beg you will let me hear by the end of the week how you go on. Take all care of yourself, and attend to the doctor's directions. I enclose $\longrightarrow$, and trust that you are able to procure what may conduce to your comfort. . . . . Sincerely praying the Almighty Giver of all good, to restore your health, I remain

Very truly yours,

W. Pearson. 


\section{Thomas Smith's last letter.}

Thursday night, 8 o'clock,

My DEAR FRIEND,

$$
\text { I9th Jan. } 184^{2} \text {. }
$$

I yesterday received your very kind letter, and enclosed - I return thanks to you truly, grateful for your very great goodness to me and my dear Wife and Children-without your great kindness, we must have been miserable years ago. I cannof write much-I am sitting up in bed while I write, my dear harassed Wife holding the candle.

My disorder proves inflammation of the lungs-the doctor attends me daily, but I seem to get no better. I do not cough quite so much, but have no appetite-no, none-and am very weak and low indeed. I can perceive my friends consider me in danger-but they may be mistaken.

I have had rather a poor night, yet humble and sincere thanks to God, better than many I have had. I am very sorry to hear of your cold; take great care, I beg of you-do-do, for my illness is nothing but colds. My Friend, you show every good and kind feeling towards me-thanks and blessings on you for it. I get 8s. weekly, from my club-a great help, but no work going on-and the Doctor paid nearly as he goes on. Still, I want nothing to make me confortable. O how thankful I am to Providence, for all thisLet me hear from you very soon. Think of your own health.

I am yours very truly,

T. SмIтн.

\section{William's answer.}

MY VERY DEAR FRIEND,

Yews-Crosthwaite, 22nd Jan. I842.

Last night I received yours dated on Friday. I cannot express my deep feeling of grief, to find you still continue so ill. I did believe that your complaint was not any thing worse than a severe cold. As you have a medical man, I trust that he has employed every proper means to give you relief. I would fain hope that you have got through the most dangerous crisis of the disease, as I learn from consulting some medical books, that when Inflammation of the Lungs terminates fatally, it is generally in the first week. My most dear Friend, I have been thinking whether I should not immediately come over-but I am troubled with my Cough, and the weather is severe for travelling. But write-let me know as soon as you get this, how you go on. Yet you ought to be kept as quiet as possible, and writing will disturb you-I will write to J. W. by this post, and have no doubt he will go over to Gorton, 
and let me know how you are; therefore unless you feel much better (which God grant), I would not wish you to disturb yourself.

I am much affected by your warm gratitude for any little services I have been able to render you-I wish they had been more-but trifling as they have been, they have given me more unmixed satisfaction than anything I can look back upon. Would that all my recollections were as pleasant, as innocent, as all the circumstances connected with our friendship, and I only feel, I might have done more for you than I have done.-So long as reason and memory remain, I shall never forget the many delightful hours we have passed together, whether in reading some favourite Poet or Author, or in rambling among the beautiful scenes of Nature. I believe that seldom have two persons come together, more in sympathy than we two-and I have often felt that my separation from you, was one of my greatest losses, in leaving your part of the country.

It is useless to disguise, that I believe your complaint to be dangerous, but God is good, and I hope and trust, will restore you. The Great Disposer is good, whatever He may see fit we should go through. It must be a great comfort to you, that you have passed a harmless-nay more, a useful life-and if it has been in poverty, you have had many blessings. Assuring you, my dear Friend, of my tenderest sympathy, and praying the Almighty, that I may have better tidings of you in a few days, I am

Your sincere and sorrowing Friend,

- W. Pearson.

Yews-3rd Feb. 1842.

MY DEAR FRIEND,

I have had the pleasure of receiving a letter from Mr. W., in which he says you are somewhat better. May you go on to improve. I hope to hear again on Saturday. In the meantime, I enclose — instead of sending a P. O. Order; it will reach your hands with less trouble than if sent the other way. Your poor Wife will have enough to do, in waiting upon you. I hope she will be supported and strengthened.-Believe me, my dear Friend, it is a comfort to me, to render you any service in your sickness-as it has always been, when you were in health, and do not think it is any burthen to me. You will be glad to hear that I am much better. The snow is nearly gone, and I hope we shall have milder weather. Believe me,

I am yours very affectionately,

W. Pearson.

P.S.-Since writing, I have received Mr. W's letter of the Ist inst. I have therefore withdrawn—as I intend to set out this after- 
noon, for Kendal, and perhaps, you may see me before you receive this letter. W. P.

William reached Gorton to be at his friend's side for a brief time, before their final earthly farewell. Thomas Smith died on the $5^{\text {th }}$ of February, at the age of 60 years.

His widow is still living in their cottage near the church. It has an old-world look of respectability and comfort. In the August of r 857 , she had just laid their second and last Daughter in the Churchyard, hard by-funeral solemnities having usurped the place of anticipated bridal rejoicings. The intended bridegroom was in the Isle of Man, whither he had gone to seek the restoration of that health which the bereaved Mother feared would be his no more. She believed him to be following his betrothed, smitten, like her, with fatal disease._ Sarah Smith had a gentle, sweet, resigned expression of countenance-with which the tones of her voice and every movement, were in perfect harmony. It might have been of her, that the poet sang,

"Her words, her gestures, all present

The picture of a life well spent."

Like the women and girls in her rank of life, throughout the district around Manchester, she wore over her cap, the almost invariable kerchief; the becoming costume of girls, as well as of women; maidens wearing it on ordinary occasions, instead of a bonnet, over the smoothly braided hair. With easy courtesy, Sarah Smith asked the two strangers who had sought her dwelling, to partake of dinner. The manner and the viands (potatoes beautifully boiled, with salt, and sweet, fresh butter), were equally inviting, and they most willingly sat down to table with her. After dinner, she led the way into the Church-yard, where they stood by the head-stone of her Husband, and the grave of their two Daughters. When again seated in the cottage, they remarked on a beautiful and well-kept piece of oak furniture, at the farther side of the house, facing the fire-place-this, she said, was the Book-Chest; and on the side opposite to the low, wide window, and hanging above a cushioned Settle, was the Portrait of her Husband, covered over with yellow leno. This had been bequeathed to her by her Husband's friend, J.W.-Before parting, Sarah Smith asked each of her visitors to accept a card, bearing the name and age, \&c., of her who had died two weeks before-the little sufferer "Nancy" mentioned in her father's letters. These memorial cards have sometimes inscribed on them, a few lines of poetry or a verse or two of a hymn, in arldition to the name and date-and may be seen framed and glazed, hung up in remembrance of the departed one. So it was in this cottage; and while to indifferent persons, 
they are simply commemorative of the absent-to the sorrowing heart, they can summon an invisible, dear presence, and fill the room with the pure atmosphere of love, and holy aspiration.

\section{CHAPTER XIV.}

William was now in a position to carry out his plan for visiting Switzerland, and on the 5th of May, I842, he married Ann Greenhow.* The marriage was solemnized at Bowness Church by the Rev. John Wordsworth, and after the ceremony, William set out from Low House with the object of introducing his wife to the Valley of the Duddon. They travelled on ponies, and the excursion included some of the Lakes and the ascent of Helvellyn.—_-On their return they made the Ferry Inn their home, for the few days they remained in the neighbourhood; and whilst William attended to affairs in Crosthwaite, his wife spent the time at her Mother's. On one of these days, Mr. Hartley Coleridge called at Low House to offer his good wishes; but not finding William there, he took up a pen and addressed to him the following impromptu Sonnet.

The flower is sweetest in a field of flowers,

The mighty Oak grows tallest in the wood,

Whatever thing on earth is sweet and good,

Is good and sweet by interchange of power.

May'st thou my friend, for ever bless the hour

That saved thee from thy lonely singleness,

And gave thee her for whom thou need'st must bless

That God, who gave in her so great a dower.

A little man of solitary life,

And half an idiot too-more helpless still-

Can wish all joy to thee and to thy wife;

Thy love must be as constant as thy will.

My gentle friend, how happy mayst thou be,

That hast a wife to pray-and pray with thee.

In the allusion made to himself in this Sonnet, there is a pathos that moves the heart to its inmost depths.

\footnotetext{
"He was a dew-drop that the morn brings forth, Ill-fitted to sustain unkindly shocks,

Or to be trailed along the soiling earth."
}

William and his wife spent the latter part of May amongst their friends near Bury, and in London; and on the Ist of June left the 
Thames for Ostend. They visited most of the Belgian Cities, making themselves familiar with whatever was of interest connected with them. The sight of cattle pasturing in the charming valley of the Vesdre, between Liége and Aix-la-Chapelle, was most refreshing to William. The Rhine was first seen at Cologne-but it was indeed "to disenchant," that it was approached-for to one of the fellow-travellers, the turbid, soapy-looking waters, rudely dispelled (for the moment) the long-cherished images associated with this grand river, which here sweeps majestically between the widely sundered banks. The timber rafts which are navigated down the Rhine, presented not only a novel, but an astonishing sight. Little wooden huts are constructed upon these rafts, where the rowers and boatmen, who are sometimes accompanied by wife and children, live-poultry, pigs \&c. are also to be found there. There is often a principal raft, which is very large, with numerous smaller ones attached to it, and also small boats; the pilot commands a view of the whole, and much skill is required in rowing and steering, through straits formed by islands, and in passing eddies.

At Bonn the boasted Scenery of the Rhine begins to be very attractive, and it would seem impossible for words to exaggerate the ever varying charms of the river and its banks. Whilst at Bonn, rambling in the cool of morning and evening, between the city and the river, the air was laden with the luscious perfume of the vine blossom. Between Bonn and Coblentz the river attains its greatest width, 2000 feet, and at Neuwied, is a flying bridge. Coblentz is beautifully situated at the confluence of the Rhine and Moselle. For a considerable distance, the pure, blue current of the Moselle flows side by side with the dim water of the Rhine. From the fortress of Ehrenbreitstein, "the Gibraltar of the Rhine," which is on the opposite side of the river, there is a glorious view of city, rivers, bridges, and the surrounding country. The fortress will accommodate a garrison of 14,000 men. The magazines are large enough to provision 8000 men for to years; and cisterns supplied from springs without the walls, will contain water enough for 3 yearsbesides which, is a well sunk $400 \mathrm{ft}$. in the rock, which communicates with the Rhine; this water, however, is unwholesome.

From Mayence they turned off to Frankfort. Here, in the Cathedral, the Emperors of Germany were all crowned; and in the Kaiser Saal, or banquet-room, in the town-hall, the portraits of all the Emperors are ranged round in gothic niches. From hence passing through Darmstadt and by the Bergstrasse, they reached Heidelberg, situated close to the river, in the lovely valley of the Neckar. The grand ruins of its celebrated Castle, and many other interesting things must be passed over silently-but not an in- 
cident of rustic life, which arrested their attention at Ziegelhausen, a village a few miles higher up the river than Heidelberg: this was a herd of Swine, returning from their day's forage in the woods; attended by two swineherds, each furnished with a long whip-one, kept in the rear, the other, walked in advance, and as he drew near to the houses sounded a horn, a signal understood by both pigs and villagers-the pigs dropped off in little bands, going in the direction of their homes, and the children came running out to attend them to their respective quarters. These pigs are long-legged, long-backed, long-snouted, very lank, and have long, curling tails ; their colour is a red brown, in some cases, spotted with black; they bound along with great agility, and seemed to be on very friendly and familiar terms with their little keepers.

From Heidelberg they proceeded to Carlsruhe, which is almost surrounded by the Hardt Forest; and from thence to Baden Baden. Here, after the fatiguing pleasure of sight-seeing in large towns, they determined to rest for ten days; and William found delight and refreshment amidst the surrounding magnificent forest-scenery, which also toned the mind for the more exciting grandeur of Switzerland. Often in their woodland rambles, their steps were arrested by the sublime appearance of some individual tree-its trunk straight as an arrow, without twist or flaw-its stately shaft, immense in girth, tapering upward, and branchless to the height of an ordinary Scotch pine, the boughs then forming a verdant spire, which seemed to pierce the blue heavens.

After visiting Strasburg, they staid at Hornberg, where a market or sort of fair, brought together the country people, men and women, in their picturesque costume. Thence, by way of Tryberg (a village of the Black Forest, and the centre for the manufacture of wooden time-pieces, which it is said to export to the number of 180,000 yearly-) and Donaueschingen to Schaffhausen. At Donaueschingen they visited with much interest, the very copious crystal spring in the grounds of the Chateau ; it is enclosed by masonry in the form of a basin. Though other fountain-heads make the same claim, this spring is known as "the Source of the Danube."

The architecture of Schaffhausen is ancient, and the outsides of many of the houses are covered with paintings on plaster. Here a day was given to the Rhine-fall, which is a few miles below the town. At Eglisau, a town on the road to Zurich, they crossed the Rhine by a covered wooden bridge, of which kind of bridge, they afterwards saw many others-the most remarkable ones, being the three at Lucerne. They found much to interest them in and around Zurichamong other things, was the funeral of a young person. In one of the principal streets, the people who were to form the procession, 
were ranged in two lines, one on each side of the street; here they waited till the coffin was brought out, followed by the relatives. There was something very touching in the flower-wreath borne upon it, so tenderly did it seem to lead the thoughts of the mourners, from the cold clay, to the immortal spirit, abiding where "the roses have no thorns." Indeed the contrast between an English and a Swiss funeral is very impressive. The use of an open, raised car, in place of the loathsome hearse-the loving decoration of flowers, in place of the offensive pall-seem to proclaim a hope and trust, far more in harmony with the Saviour's words, "our friend Lazarus sleepeth," than the deceptive gloom with which the trappings of woe darken the loving heart.

From Zurich, they proceeded up the Lake to Rapperschwyl, at its head, and from thence set out next morning to walk to the Convent of Einsiedeln, the most celebrated place of pilgrimage in Switzerland; the average number of pilgrims who annually receive the sacrament there is 36,000 . The head of the Lake, where the water is shallow, is crossed by a bridge three quarters of a mile from end to end.Next day they returned, ard from Rapperschwyl proceeded to Lake Wallenstadt; and now that their experience of mountain-travel was about to begin, Mr. Wordsworth's counsel was not forgotten-and it is scarcely possible to imagine any thing more enchanting than the lower Passes which they traversed, mounted or on foot, as inclination prompted-or more sublime than the elevated ones, where the snow and ice scintillate in perennial splendour, and Nature's "cloud-capt towers" stand unscathed, save by the battling elements.

Impossible though it be, for language to depict the exquisite and rare beauty of the Flora of these regions, yet may a word or two tell, that fairy flowers of tiny forms and the most delicate tints-or bands of a somewhat larger growth, and of glowing and resplendent hues, couch amidst moss, or the loveliest of herbage, on the verge of the snow; where they receive an additional charm from the transparent atmosphere, and the deeply blue concave of heaven.__ From Stachelberg, at the head of the valley of Glarus, they went by the Klausen Pass to Altclorf, and from thence to Fluellen at the head of the Bay of Urithe highest reach of the Lake of the Four Cantons.-In summer, from ro o'clock in the morning till 4 o'clock in the afternoon a North wind blows up the Bay, it then changes to the opposite quarter, and blows much more strongly-sometimes quite furiously. During the other seasons it is very capricious and blows from different points at the same time.

About noon, with a clear sky overhead, and light clouds moving over the mountain tops, they stepped into one of the flat-bottomed boats that are used on the Lake; the boatmen row standing, at the 
hinder end, which is square ; they advance a step and then recede,propelling the boat with a kind of double stroke. It appeared laborious enough to make way against the strong wind, and the men kept at no great distance from the eastern shore-or rather, margin of the water-for very soon they approached a boundary of vertical rocks which project in frowning promontories into the Lake ; their immense height may be guessed at when it is stated, that the water beneath the Tellen Platte (a little ledge, on which is built one of the numerous chapels commemorative of Tell,) is $800 \mathrm{ft}$. deep. After landing at the chapel, behind which there is a narrow hollow, leading up into the mountains-as they doubled these promontories of rock one after another, the force of the wind increased, but the strong arms of the boatmen were equal to their work-as a class, they are said to exercise great caution, which is quite necessary, for whatever might betide, there is not the least footing to be found, for miles together.-Two little Kids were seen couching some yards above the water, on a narrow shelf where there was a little verdure, but nimble as these creatures are, it was impossible to make out any track by which they had reached their resting place. A thunder-storm approaching from the West, where the lightning shot across a lurid sky, forbade their crossing to visit Grutli, which however was seen very distinctly. At Brunnen, the port of Canton Schwytz, no time was lost in procuring a char-the postillion flogged his horse without mercy, continually looking behind-and certainly calculated the progress of the storm to a nicety, for as he stopped before the Hotel Hedegar, in Schwytz, a flash of lightning was immediately followed by drenching rain.

It is not proposed to trace, step by step, the route pursued by William and his wife, but a little more space may be claimed for a few particulars, selected from notes made at the time.

On the 28th July, we set out from Martigny to make the tour of Mt. Blanc-our route, the Great St. Bernard-Col de la Serena-Alleblanche-Col de la Seigne-Col de Bon-homme-Val Montjoie, and by Chede to Chamouni-from thence by the Tête Noir, back to Martigny. - In good weather, these high Passes are charming, and may be traversed without any cause for alarm; but should bad weather strike in, there is danger of mischance-of this, we had some experience on the Col de Bon-homme. The first night we lodged at the Hospice on the Great St. Bernard, 8,200 ft. above the level of the sea.- The second, at Cormajor, at the head of the valley of Aosta, close under Mt. Blanc, on the Italian side. Until the afternoon of the third day, the weather was all that could be desired. During that day, but particularly in the afternoon, the clouds, which are a most interesting feature of the scenery, had gathered, broken up, and been dashed by the wind, with magnificent speed, 
against the buttresses of Mt. Blanc. They then began to thicken and lower overhead, and presently to fall in rain. Fortunately, we were near a châlet, where we found shelter, and the hospitable master, who was employed in making cheese, piled more wood on the hearth-an act of generous kindness not easily appreciated, unless the difficulty of obtaining wood at these elevations be borne in mind. Presently, our benumbed limbs began to rejoice in the warmth; - he also placed before us some delicious, hot milk, in bowls, and equally delicious curd, with beautifully clean wooden spoons. - - He told us that he remained on the "Alp" for three months, leaving in September - that he had 89 cows, and made two large cheeses daily, which he could sell for 5 francs apiece-they were about 30 inches across and 7 or 8 in thickness-besides these he made a secondrate kind, which are square. The day after they are made, they are removed into another châlet, to dry. - He made but a small quan-, tity of butter, but invited us to take a little with brown, leavened bread, very much like the leavened black rye bread, in common use in Penrith and the neighbourhood. A supply for the three months' sojourn is taken up when they take the cows. The châlet consisted of one apartment; on the side opposite to the door and fire, there were a sort of cribs, or berths, fixed against the wall at a good height from the floor. The dairy apparatus occupied the farther end. Several men, apparently assistants, turned in for shelter. When the rain ceased we proceecled; it came on again, however, as we drew near to the châlets of Motet, and prefering any other discomfort, to that of getting wet through, we decided, instead of proceeding to Chapiu, to halt for the night at these very uninviting châlets.

We found the accommodation wretched enough, but the shifts we were put to were so droll, that our discomforts became matter of merriment. Whilst the room we were to occupy was being splashed over with water and then swept with a long broom of birch twigs, slightly tied together, and without a stick - we were invited by an intelligent young woman, to take seats in the room occupied by her and her companion, who had each a baby, and were come up to lodge here, for the benefit of mountain air. Our friend, with whom we had a pleasant discussion ahout the locality, seemed to be ashamed of a mistake she made in the spelling of a word, and said, apologetically, "that it was the name of a place." She had been reading, whilst a little girl was employed in rocking the cradle. When the baby awoke, instead of being taken out of the cradle (in which it was strapped), the mother placed the cradle across her knees, and in this manner the creature was suckled - the ends being reversed, to suit the mother's convenience. We harl hefore been struck hy seeing these small cradles borne on 
the head, by the women as they went along the road, and we now learnt that it is a usual mode of caring for the baby.-When the arrangements were completed, and we were shown to our room, where we had asked to have a fire, we found it filled with the pungent smoke of green wood, so that, notwithstanding the rain and cold, we were glad to sit with open window. There were three bedsteads in the room, two dirty, plank tables, and two short benches. We asked for a little straw by way of carpet (the dirt might have been scraped off the floor), when our hostess went to one of the beds and drew out a little wisp for our use. This, at bed-time, we transferred from the hearth to the bedside.- The tea equipage consisted of two brown bowls set upon plates and two leaden table spoons-no cloth to cover the table. There was also a basin of cream, and another with large lumps of sugar, so that we began to congratulate ourselves on the comforts that were to follow. In course of time the coffee was brought-literally coffee-water-little more than new milk warm.-That it might not be quite cold before we got any thing to eat, we despatched it at once; by and by, bread and butter were brought, but not the eggs ; when they arrived, it was found there was not a knife to cut the breadthat supplied, salt was wanting.- The tops of the spoons were used for the eggs; and at length, some boiling milk, which we poured upon bread, yielded a comfortable repast. During the evening, women and children kept popping into our room, and three lads brought in a young Marmot for our entertainment. It had a cord fastened round its body, and ran up the boy's arm and upon his shoulders, and crept within the breast of his coat. They all laughed heartily when the lad was asked if it slept with him. We had much difficulty in getting the bed-linen properly aired, which though clammy with damp, we were assured was only frais. There was neither bolster nor pillowand besides the sheets nothing but a coverlet. Supplying the deficiencies as well as we could, by spreading our clothes beneath and above, we slept soundly.

Next morning, at half-past four, we were called by our hostess, and profiting by the experience of the evening before, asked for boiling milk and bread. As the guide was seated by the fire, and had been desired to put the saddles on the mules, we concluded all was ready for our departure-quite the reverse-the man had not breakfasted, and not till after much delay was he ready to set out. In an hour and quarter we reached Chapiu, where we obtained a comfortable cup of coffee before commencing the ascent-but the lowering aspect of the sky caused a demur about the prudence of setting out, so that it was past 9 o'clock when we left Chapiu, and began our journey over the $\mathrm{Col}$ de Bon-homme, the top of the Pass being $8000 \mathrm{ft}$. above the sea._- Having left behind us the highest châlets, our route lay up 
what shall be named the nose of a mountain, which had on one side, a not very deep gully-but on the other a long and also very precipitous slope. The footing was slippery and insecure, the surface consisting pretty much of shale, with water oozing out and trickling over it. Up this acclivity, then, we had to ascend-the mules paused, and then summoning all their force, made a dash forward for a few yards, and again halted. This mode of advance made William prefer trusting to his own feet, and he dismounted; his mule, which followed the other, presently after, came down. After three or four more of these sallies, the guide thought he could take us to a better part, and led the mounted mule right across-to be seated upon it, with the face towards that steep declivity, which presented no obstacle to a series of summersets from top to bottom, if once the initiatory step were taken, was a frightful position-and more so still, when William called out alight:- - How, was the question-for it was a nervous business to reach the ground, even with good help.

Once safely up this ridge, though far from feeling reassured, as we anxiously watched the dull mist conceal one height after another, we again seated ourselves in the saddle, and continued ascending till the snow was reached. A sharp scattering, not of snow, properly speaking-for it never falls in flakes at these high elevations, but in fine granules, known by the name of névé-now met us, and the worst part of it was, that it obliterated nearly all the foot-prints, which would have been so useful to direct us, for as we got higher and higher, the plots of snow became more numerous. Our way now wound under rugged peaks, which were barely discernible through the encroaching mists, and then it was along a comparative level, where every now and then we had to wait, whilst the guide sought for the track-once we had to retrace our steps.-At length, blessed sight! "the firm unyielding Cross" announced that we had gained the top of the Pass, and sent a thrill of thankful joy through our hearts; but neither our fears nor our difficulties were yet at an end. We had still some distance to traverse before beginning to descend, and the mist was too dense for us to see from one to another of the poles erected in this part, for the guidance of the traveller. Twice we missed the way, and it seemed to us, not unlikely, that we might be detained for hours, beating about, which required caution; so that as we gained the friendly landmarks one after another, we were deeply thankful for the assurance thus given that we were still in the right course.

On the northern side of the $\mathrm{Col}$, there was a greater depth of snow, and we were ankle deep at every step-over one plot, about a furlong across, mid-leg deep-this was laborious, and our hands and feet were benumbed. At this place, the mules were sent across in advance, 
the human creatures following in their wake. Partial openings in the mist, now gave us glimpses of the grandeur they veiled from our sight, and which we were leaving unseen behind us, for ever.

The first part of the descent was steep, and we continued walkingbut we had now a defined mule-track, slanting obliquely across the declivity, which was of the same treacherous character as the nose. The châlets of Mit. Joie were the first we reached: here we saw Ioo mule colts pasturing together. The pasturage consists of lovely green slopes, stretching far up the sides of the mountains.-A little lower down is the fine fall of the Bourant; proceeding still lower, the region of the fir was reached, and so onwards, through a forest of pines, we approached Nant Bourant, distant from Chapiu about 8 hours. Here the mules rested two hours, and we dined.-From hence the descent to Notre Dame de la Gorge is very steep, and, being rudely paved and encumbered with blocks, difficult-the Gorge is a striking defile, particularly above and below the bridge, where the rocks approach each other from the opposite sides of the torrent. The Spruce fir is here of uncommonly beautiful growth. On the previous day we had admired some remarkable specimens of the Larch, growing amongst the morains at the foot of the Col de Géant. Two of these were, by the side any Larches we had hitherto seen, likened to Mt. Blanc by the side of Helvellyn or Scaw Fell. Their branches grew low on the magnificent trunks, and threw out other fine, large limbs, their drooping sprays, beautifully feathered with lovely verdure. The church of Notre Dame de la Gorge is very large, being a place of pilgrimage. In each of the four corners of its enclosure is an Oratory, and on the side of the road, near to it, 7 or 8 more. The top of the beautiful $\mathrm{Mt}$ : Joli was hidden in the clouds; but the wooded slopes, and sweet meadows and corn-fields along the lower part of it, with the numerous châlets, nestling among the trees, singly or in groups, were very pleasing.-We staid for the night at Contamines, where rest was indeed welcome; yet after the adventures of the day were over, we felt well satisfied that we had encountered one Pass in unfavourable weather-and perhaps, also, a little exultation over the feats of the last twenty-four hours.

Next day we stopped for a few hours at the Baths of St. Gervais, and again at Chede, to see the pretty cascade. We reached Chamouni at the close of day, as the stars one after another began to sparkle in the clear sky-rain, which had continued for a fortnight, having that day cleared off._—_ The next morning we rose at 5 , and as soon as we had taken breakfast, set out on foot for La Flegère, a mountain on the West of the Vale, and next to the Brevin, affording the best view of Mt. Blanc. It was a morning of rare beauty-the Vale of Chamouni lay in repose beneath an azure sky-all was 
silence-the silence of peace-save when the falling of an Avalanche sent a dull sound, as of distant thunder, across the valley. We reached the summit of the mountain, and here, seated on the greensward, we gazed upon the " dread and silent Mount." It was perfectly clear in its whole extent-the transparent atmosphere its "crystal shrine." Reluctantly we set forth to descend into the Vale-we crossed the plain, passing through the village of Bois, to the source of the Arvieron; then, striking directly up the mountain, through the woods, proceeded to Montanvert and the Mer de Glace-and by the time we again reached the Hotel de Londres, the stars were beginning to show themselves. Gladly would we have sojourned longer in this entrancing Vale, but the cost restrained us-for by the humane law, which interdicts the employment of any but native Guides and Mules, ours were of course useless to us, whilst the reckoning was still going on ; therefore the following morning we set out for Martigny, by way of the Tête Noir. Again and again we turned to survey the Vale, and to take another, and another look at Mt. Blanc, its Aiguilles and Glaciers-that of Argentière is finely seen from this road. The Gorge of the Tête Noir is magnificent-the high, perpendicular and rugged mountains which form the sides of the Gorge, are clothed with fir-trees of large growth-many, uprooted by storms, hang by a fang over the edges of the jutting rocks-the blanched remains of others stand firm, the greater part having been snapped sheer offand others dip their topmost boughs into the roaring torrent, far beiow the road, which is carried along the side of the Gorge, defying all obstructions. 


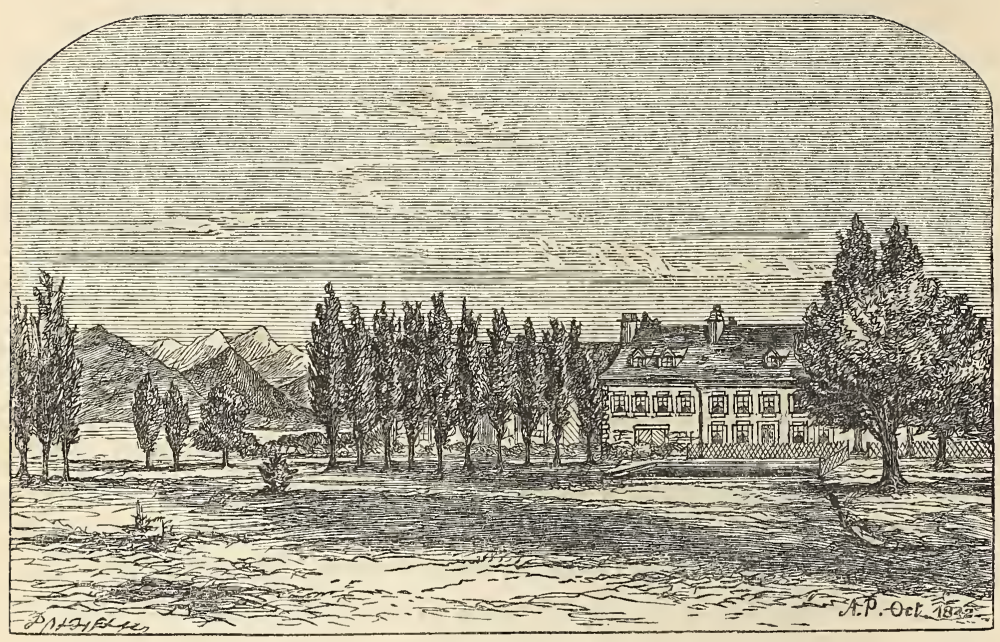

Maison Poitry.

\section{CHAPTER XV.}

From the Ist of October, I 842 , till the Ist of July, 1843 , our pleasant Swiss home was Maison Poitry, in the village of Versoix, 5 miles from Geneva, and 2 miles from Coppet. An occurrence that took place whilst we resided there, though in itself nothing very remarkable at Geneva, was to us new and strange.-On the I 4 th February our attendant, Nannette, entered the room with a grave face, and asked if we were not intending to go to Geneva. We said "Yes." She then told us, there had been a revolution in Geneva the day before, and that neither Post nor Diligence was permitted to leave the city. This was sad intelligence, for M. and Madame Poitry had gone to Geneva on the preceding day. As soon, therefore, as we had taken breakfast, we went to seek further information from their friend Madame Humel. She told us, that she had been alarmed on the previous evening, by the beating of a drum in the village, and upon inquiring the cause, had learnt that it was a summons for the soldiers of the Commune to go to Geneva, and that the soldiers of all the other Communes on this side of the City were also called thither. The workmen of the Quartier St. Gervais, who were toujours mécontens, had effected a petite revolution-she made light of it, however, and thought we need not be uneasy on M. and Madame Poitry's account. In the village, reports were less encouraging; there we learnt that there had been a collision between the soldiers and the people, with bloodshed on both sides. However, when we 
reached home, William sought up Madame Poitry's little Godson, Jimmie H., and we all walked to Coppet.-The air was balmy-the sun shone brightly-Mt. Blanc, like a spiritual presence, was grandly visible.-Gulls rose from the Lake for short flights, their silvery plumage and graceful movements as seen against the deep blue of the sky and the water, were beautiful-Wild Ducks, in larger or smaller flocks, dived and re-appeared at a distance-labourers were busy in the Vineyards-all these things spoke of peace and enjoyment; yet it was impossible to shake of the weight that oppressed the spirits; especially when our eyes rested on the massive tower $\$$ of St. Peter's, pre-eminent above the rest of the city, for we knew not what conflict might not still be going on in the shadow of that Cathedral tower.When we got back to the village we inquired of the Omnibus driver for news, he could only tell us there had been fighting during the night, and that some men had been killed. Eager for more definite intelligence, in the afternoon William set out to walk towards Geneva, Jimmie again his glad companion, who at every pause made for inquiries, with entreaty not specially needed, urged, "do go a little further-do go a little further," till at last, learning that the gates were actually open, they pushed boldly on, crossed the ramparts, and without interruption walked direct to Jimmie's home. It was late in the evening when the household again assembled at Maison Poitry. The account of the outbreak as given by Madame Poitry was this.- - She and her husband were seated in the house of a friend, on the Quai des Bergues, when they heard a great hubbub outside, and throwing open the window to learn the cause, the first words they heard, were, "aux armes-aux armes-la patrie, la patrie." They decided to go at once, to a friend's outside the city. M. P - saw his wife in safety to the bridge at the Porte Cornavin, and then ran back to look after the horses, intending to follow her immediately; but when he reached the Gate, the bridge was drawn up and in possession of the rioters. Later in the day, a Lausanne and a Paris Diligence were allowed to enter, when M. P- got across the inner bridge, but before he could reach the outer one, it had been drawn up ; between the two, he met with his friend Mons. M., who was in the same predicament as himself, fortunately,-for his errand was to look after Mons. P-. Before dark, they managed to escape and rejoin their wives. During the night, the tocsin, the hurras of the mob, the firing of muskets, and the screams of the people, by turns reached their listening ears; and it was not till three o'clock in the afternoon of the second day, that order was again established, and the city gates thrown open. The numbers killed were stated to be 27 Radicals, and 23 of the Government party, but this proved to be an exaggeration. 
The following is an attempt to describe a wonderful and beautiful phenomenon, witnessed in "That unutterable Deep which hath no shore."-_-On Thursday, March I 7 th, about 7 o'clock in the evening, Jimmie and Nannette burst eagerly into our sitting-room to tell us of a strange appearance in the heavens. We hastened to our bedroomwindow, which commanded a grand sweep of sky from E. to W. and saw a band of bright light, one end of which rested on the Jura. Its inclination, giving an angle of about $40^{\circ}$, was southerly, passing under Orion, and pointing in nearly a direct line to Jupiter-which was then very brilliant in the evenings-it did not extend so far as the zenith, perhaps two-thirds of the way. The band was perfectly defined, and the luminous matter equally diffused-no tenuity towards the edges. The upper end terminated convexly-the convex part being a little less bright than the rest. On the northern side, the heavens near to the horizon were luminous, the brightness becoming gradually fainter as the distance from the horizon increased. When the approach of the moon sent a light above the tops of the Savoy mountains, the band became less and less distinct, until it disappeared ; the part that was last to vanish, being that midway between the extremities. It was visible for three quarters of an hour from the time we went into our room.-Next evening the two came again to announce its re-appearance. It seemed to be in precisely the same relative position as on the former night, and disappeared entirely, soon after 9 o'clock, before any moonlight had spread over the sky. William believed it set. The stars were very bright._-On Saturday evening we kept watch for its appearing, and as the twilight faded a pale whiteness marked its presence; this gradually attained the same intenseness as on the other evenings, but the band had assumed a slightly curved form. It seemed to set. William pronounced it to be a Comet; and afterwards, newspaper accounts proved this beautiful object of his speculations to be identical with the tail of the marvellous Comet of $1843-$ so splendid - so transitory - and in our own dear, cloudy Island, scarcely allowing astronomical scrutiny._-At Versoix, on the fourth evening, the sky was overcast, and on the fifth, which was very clear, the trailing glory was no more to be seen; but the horizon above the Jura mountains had the same luminous appearance which had attended the visible presence of the band, or as we now ventured to call it, the tail of the Comet.

The following will conclude these desultory notices._-On a few occasions our kind host and hostess took us with them when they drove out; once we went as far as Nyons. In passing through Coppet, the Château naturally became a topic of conversation. Mons. Poitry was a native of this small town, and as a neighbour, 
had known the family at the Château. In speaking of Madame de Staël, he said she walked much, and kept much company. As many as twenty carriages might be counted in the court-yard in an evening, belonging to visitors from Geneva and Nyons-and within were the sounds of music and dancing. Madame P. related an incident connected with the period of Madame de Staël's banishment from France. The secrecy with which she had invested her marriage with Mons. Rocco, necessitated the same secrecy with regard to the birth of their son-to conceal her situation she received visitors in dishabille, and when the birth of the child was close at hand, she was very solicitous to accomplish a masked ball. She received her visitors in a domino and unmasked, but afterwards assumed her incognito. Before the guests separated, she found it necessary to withdraw, which she did without attracting observation, and attended by a confidential maid, she was conveyed to a dwelling close to the grounds of the Château, which was in readiness for her reception. Here she gave birth to a son, and was at the Château again next day.—The romance of this circumstance, imparts to it an air of credibility, rather than impugns the authenticity of the fact, which as far as we could judge, rested on testimony beyond the reach of suspicion.- About the time that we established ourselves at Versoix, Mons. Rocco, the son born under these singular auspices, died at Paris, and his remains, by his own desire, were conveyed to Coppet, to be laid beside those of his mother and Mons. Neckar, in a little enclosure situated in a grove in the grounds of the Château.

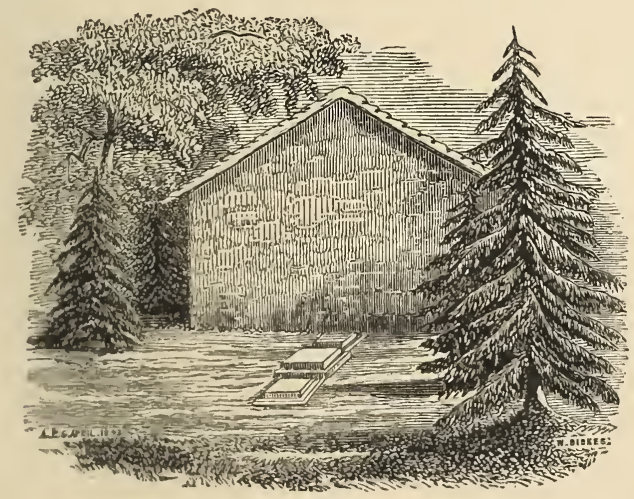

Burying-place of Nadame de Staël. 


\section{CHAPTER XVI.}

DURING the sojourn at Versoix, so many things, besides his temporary home, had become endeared to William, that the leave-taking caused sincere regrets. Scarcely could he have found a home richer in comfort and enjoyment; kind attention was unflagging-Mons. Poitry was somewhat of a Naturalist and had a tolerable collection of stuffed birds-he was a brother of the angle, and also possessed a pretty good library of French and English books, to which he gave William access. Then there were the delightful evening readings from Shakespeare and Wordsworth, in that snug sitting-room of his-with its double windows, velvet upholstery, clear, wood fire, and the luxury of a Turkey carpet - to which when the Bise, or N. E. wind, was bitter, was added a screen, behind which was placed a tambour, or portable stove; and a chauffe-pied - which is a very small stove, to be used as a footstool-was not omitted. This last named appendage is in common use among the women, who, by means of a strong wire handle, in which it swings like a bucket, carry it about with them-to church or elsewhere.

Interchange of visits with his host and hostess, afforded a wellcontested rubber at whist, and also gave an insight into the social usages of Swiss life-and sometimes, beguiled by a game at chess, the "Key-stane o' night" would be overpassed.—-The Winter was remarkably mild; only once did a sledge drive to the door, which we were not fortunate enough to see-but the Winter through we did see the women by the running stream, or village fountain, washing the linen in the cold water!

As "a man who had solitary usings of his own intellect," William ever found high enjoyment in a lonely walk; and during the Winter and Spring he explored the neighbouring district, from the Lake to the Jura,--penetrating into some of the lower recesses of the mountains; and on one occasion, in the month of April, tempted by the clearness of the air, he ascended one of the lower elevations, Mt. Murot, from whence he obtained a magnificent and complete view of Lake Leman, which stretches crescent-wise from Villeneuve at the head, to Geneva at the foot, fifty-five miles as measured along the outer curve-whilst spread out like a map, he looked over the plain South of Geneva, to its boundary Mt. de Sion. On the top of Mt. Murot, were an ancient man and a young boy, herding about $5 \circ$ goats and a few sheep.

In January, there were a few borrowed days, when we were much struck by the vernal aspect of Nature, and especially by the soft colouring of the mountains, and the spring-like appearance of the sky 
and clouds. About the middle of the month, both honey and humble Bees were very busy in the drooping, pale green flowers of the Hellibore, which, with its elegant fan-like leaves and red stems, grows plentifully in the hedge-bottoms.-It may interest some, to compare the following notes of dates, \&c. with those connected with like matters in Westmorland.

Nov. I3, 1842.- Saw one white and 7 or 8 sulphur Butterflies in the woods, each one alone.

I 7.- Mons. P. shot a Fouine this evening, which showed itself by moonlight at his bedroom window! He had shot some Wild Ducks during the day, and laid one of them on the window-sill, which he afterwards tossed to a man outside the garden wall, it had rubbed against the wall, which was a sufficient hint to the Foulmart, and the Vine trained against the house served as a ladder. The creature was warm and limp when M. P. brought it to show to William. Pity was mingled with admiration, as we looked at the undimmed eye, and stroked the full, rich, glossy fur, of the almost palpitating animal.

Jan. 30, I 843.-Heard the Skylark.-The reflection of Mt. Blancat least 40 miles distant-seen distinctly in the Lake.

Feb. I 2.- - Heard the Raven.

24.-A white Weasel, its tail tipped with black, ran across the road.-There are plenty of little grey Lizards darting in and out, on the banks by the road-side.

Mar. 4.-(This entry made by William.) Although the day has been bright and sunshiny, the Bise has blown furiously, roaring and moaning melancholy in the chimney tops. It also froze very hard during the night. William in walking along by the Canal and in the Valley of the Versoix, found a running stream nearly covered with ice, although it was afternoon. He saw a Sparrow-Hawk. The Lake has been much disturbed by the wind, its waves crested with white. The difference of colour in the water is remarkable-for the distance of about 200 or 300 yards from the shore, it is of a light hue, apparently, from the shallowness of the water allowing the waves to disturb the mud at the bottom; while towards the middle of the Lake the colour is a beautiful blue or Indigo. The Jura appears to be as deeply covered with snow as ever ; and even the dark Spruces, yesterday and to-day, are not disencumbered of the snow, notwithstanding the high wind-therefore it would seem that it is frozen to the branches.

1 2.- Saw a splendid and timid reptile on a sunny bank near to the Canal, it was basking among some briers and dead leaves. It remained motionless -its round, bright, dark eyes steadily fixed on us. I thought of the basilisk-poor, harmless Lizard! When William approached, it was out of sight in a twinkling. Its tail had been 
partly hidden by the leaves, and its abrupt flight so startled me, that I may err in saying its length was not less than 8 inches (further acquaintance confirmed this guess). Its skin looked like a series of scales, each one separately shaded in varied tints of green; the head and back of blueish, and the belly of a yellowish green-a gleam of gold over-spreading the whole.-Flora, Madame P_-'s little dog, William's close attendant, hunted these Green Lizards with exuberant life and eagerness, and then devoured them-on one occasion, we were told, she was made ill by gormandizing !

Mar. I5.-Found on the banks of the Arve, what we take to be a yellow variety of the Wood Anemone. The sides of the road near Sécheron, purple with the stars of the two-leaved Squill.

26.- Saw some Sheep which had been shorn.

Ap. 3.-Cuckoo shouts. Green Lizards plentiful.

6.- Swallows near the bridge over the Versoix. Cowslips out in profusion.-Again heard the Cuckoo, and saw a whole flock of sheep, which were shorn.

8.- The rapid progress of vegetation is amazing. Fruit-trees, except the Apple, are in full bloom-Poplars, Willows, the Horsechesnut, Elm, Lime, Beech, Sycamore, and young Ash trees-the Alder, Lilac, Dog-rose, \&c., have all burst into leaf during the past week. The air is scented with the blossom of the Black-thorn-the grass is beautifully green, and the tender brilliant verdure of the corn, delicious to look upon. Indeed, the intermixture of the varied tints of green-including the dark Firs-with the hues of the branches, twigs and boles of the trees-the brown earth of the newly dressed Vineyards-the deep blue of the sky and water, and the grand feature of the scenery, the snow-covered mountains of Savoy-form one harmonious whole, of indescribable beauty. William thinks the grass and grain here, as forward at this time, as with us, towards the end of May.

Iо.-The Woodpecker's strange note heard almost over-head, in the Oak woods-as usual, there is no catching a glimpse of the bird.

II.-A thin covering of snow.

I 4.-Gather Lily of the Valley in the woods. Barley in full ear.

I8.-Mons. P—'s imitative skill won an answer from the Nightingales, as he returned from Coppet at midnight.

20.-The Lake deeply blue this afternoon, the colour of ultramarine. The Bees in vast numbers in the blossoms of the trees. There is a constant-falling shower of snowy leaves beneath the Cherry trees opposite our bed-room window, and the twigs are kept in continual motion by unnumbered active little wings.

23. - Rye in full ear on stalks from 4 to $6 \mathrm{ft}$. high. 
26.-A prevailing tinge of green over the wide-spreading woods of pollard Oaks. The grandeur of the forest arises from its vast extent -it is the natural laboratory for the supply of fuel at Geneva-but it disturbs one to see trunks that should be the support of far-reaching limbs, and thick foliage, lopped into unsightly pollards. In the parts we traversed, fifteen feet in girth is under the average thickness of these mutilated trees-the trunks are straight and probably range from 30 to $50 \mathrm{ft}$. in height--they are bristled over with stunted boughs, so that, when in leaf, they present an array of verdant columns. Walnut trees in blossom-they begin to unfold their fragrant, dark leaves.

We hear an unknown songster in the woods, but only rarely-we take it to be the Golden onsiole, a bird we have seen but once-it was in the garden. The full bright yellow of its plumage, and its size, which is about the same as the Blackbird's, give it a distinguished appearance-and if we be correct in attributing to it the descant we hear in the woods, it is also a glorious musician. The notes are varied, clear, full and mellifluous-exceeding in richness and range, those of the Thrush and Blackbird.

30.-The luscious odours of the Apple and Bean blossoms scent the air.

May, r.-Found the Fly Orchis-plants of this tribe are in great variety - two or three are new to us.-For the first time, in the nighthave heard the Nightingale.

6.-The shout of the Cuckoo borne across the Lake-faint, necessarily.

9.-Martins congregate at Coppet, in troops of from 200 to 300. It is droll to see them alight in the vineyards by the Lake side, each one perching itself on the tip of one of the short props, to which the Vines are tied.

I 4. - Hawthorn blossom in its prime.

20.-Bees swarm. As soon as they turned out, a clatter of shovel and poker music-as with us-announced their flight. The swarm, which was very large, knit inconveniently for hiving ; immediately, Mons. P. pushed his hand gently into the midst of the living mass, and dislodged the Queen. Her next choice was not more satisfactory; and once more she had to take wing-the third proved eligible, and as soon as the Bees had knit round her, they were swept into the hive.-The same superstition prevails here as in Westmorland. If you would have your Bees prosper, on no account must you buy them! "Give in exchange for a swarm, a couple of Geese, or any other commodity, that may better suit your convenience."-Madame P. tells us, that her fine brood of young Turkeys, 9 weeks old, have been poisoned. They had got well over the three 
critical periods of the poult state, and had been allowed to go at large ; when, to her dismay, they were observed to turn over and over, and then drop down dead. With prompt decision, she undertook to cut open the crop of the only survivor-took out the grain, sewed up the wound, and had the satisfaction of seeing it recover and live.

28.- The Glede, or Melan, with out-stretched wings, came floating on the air over the Oak woods, as if from the Jura. It took the same direction as on the $23 \mathrm{~d}$., crossing the Lake into Savoy, and returning towards evening.-Mons. P. went out early in the morning, upon the Lake, to fish for Pike; he took 4 that weighed between 7 and 8lbs each; three times he had in the net, one that was not less than 25 lbs-but it escaped after all. One which was killed and brought from the reservoir, weighed between I 7 and I $81 \mathrm{lbs}-\mathrm{I} 8 \mathrm{oz}$ to the pound.

29.-The park-like field beyond the bridge which stretches from the Lake to the road, and is not less than 50 acres in extent, had 6 men mowing in it. It is dotted over with fine Walnut trees.

30.-Collected a nice gathering of ripe Strawberries under the hedges.-After a long day of rambling, Madame P. sent us up with tea, a dish of most delicate lilliputian fish-from I to 2 inches in length-there might be 50 of them. They were beautifully fried,-just as when taken out of the Lake-quite crimp, to be mumped up every morsel, head, tail, and bones, - inside and outside, altogether, and were really delicious cates !- (no note made of the name of the fish, a stupid omission.)

As Spring advanced, William followed the lovely windings of the Versoix, which is noted for the delicacy of its Trout, and

"With rod and line, he sued the sport

Which that sweet season gave,"

sometimes wandering on beyond the limits of the Canton, and trying his luck in French waters! The Trout are beautifully and profusely speckled with red. In the lower part of the river, not far from the Lake, he caught, early in June, a beautifully shaped small fish-the scales squarish, white and silvery, with a shade of green when seen facing the light - the mouth remarkably small. "Mons. P. names the fish Ombre, probably our Grayling in England," is William's memorandum.

About ro o'clock one sweet evening, we went into the garden, to listen for the Nightingales-there were a few bright stars, and the crescent moon, which was about to set behind the Jura, cast a stream of pale light down the broad gravel walk, on which fell the shadows of the trees, summer lightning danced on the edge of a mass of dark vapour, that closed the vista in the direction of Mt. Blanc. And now 
the chorus began-the Nightingales, undisturbed by day-light noises, sang in the trees, the only accompaniment, the soft, low murmur of the garden brook, which evermore diffused a cadence in harmony with all rural sounds. - It seems as if the Nightingales have favourite localities, and where they haunt, by day, as well as by night, might be heard, an impetuous out-pouring of wild, delirious notes-issuing from amidst the leaves, with a volubility that suggests the idea of the bird's being gifted with a power of throwing off an accompaniment to its own song! Both the Nightingale and the Woodpecker were more rarely to be seen than the Cuckoo.

The flora of this part is charming-many of our beautiful gardenflowers are here found wild, and every copse and grove is carpeted with the Periwinkle. Many wild flowers, new to us, were met with in our rambles; - and what pleased and impressed us very much was the industry of the children, and the simple, natural politeness of their greetings. Perhaps a little Westmorland girl would think it strange to be sent into the woods to collect and carry home the dead leaves, packed in a sheet, upon her head-yet whilst carrying this burdennot very heavy, perhaps-the little Swiss maiden will drive the Cow before her, and be knitting a stocking as she walks along, and not find herself too busy, to wish a cheerful "Good night" to the stranger passing along the road.

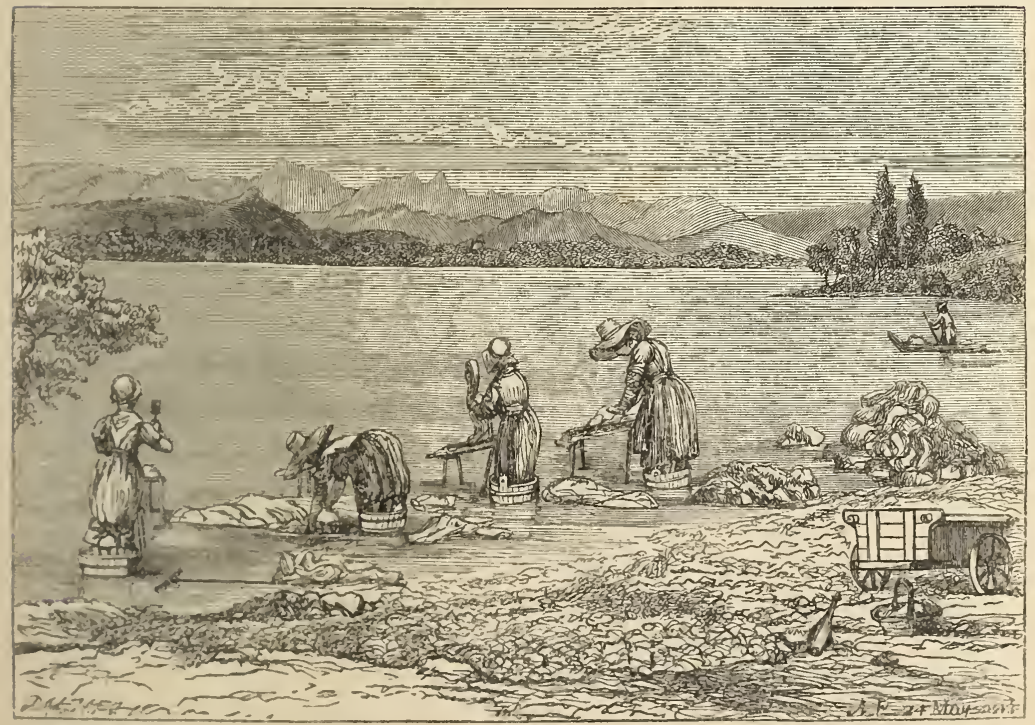

Wrshing in Lake Leman, norr Versoix. 
Before bidding a final adieu to Versoix, we made an expedition on foot to Belle-garde, in order to view that extraordinary phenomenon, the Perte du Rhone. The season was a little too much advanced to see it in its perfectness-but in Winter, when the water is lowest, the whole of the large river is engorged by a Cavern in its bed, and issues again into day at a distance of 120 yds. below. The last record of the sojourn at Versoix was from William's pen.

Thursday, June 29 th. -Went to Geneva. Took our farewell of the Valley in the evening.

Friday, 3oth.-We are again disappointed of setting out on our return, by rain coming on-the mountains are covered with clouds. On walking towards Myes, felt the air quite cool ; the Thermometer at $60^{\circ}$. Much hay-grass uncut. Heard the Blackbird.

\section{CHAPTER XVII.}

SATURDAY, July I.-The Barometer continued rising, and the morning gave promise of a fine day.-We breakfasted with $M$. and Madame Poitry ; it was our farewell. From the garden we directed our wistful gaze on the glorious Mt. Blanc, and its noble brotherhood of mountains-then followed the parting from our good Nannette, and last, from our kind friend and hostess-and as Mons. P. drove away from the door, we bade adieu to all the dear belongings. $-\mathrm{He}$ saw us on board the Aigle, at Coppet, last words were spoken, and we steamed away from the pier.—The day was one of ineffable beauty, and the passage up the Lake charming. When opposite Morges, we looked our last on Mt. Blanc.

\section{"O dread and silent Mount, we gazed upon thee."}

This view struck us as being little inferior to that from Ferney Voltaire. During our 6 weeks residence at Lausanne, the scenery at the head of the Lake had become familiar to us, which added greatly to the interest of our voyage, and we recognised with something of a home-feeling, scenes associated with previous toil, and its compensating enjoyment-Vevay, Clarens, the rocks of Meillerie, Chillon-the grand entrance to the Vallais with its noble portals, the Dent du Medi and the Dent de Morcles-and the trough through the rocks, spanned by the single arch of the bridge of St. Maurice, through which, the concentrated waters of the Rhone push onward to enter the Lake of Geneva.

In crossing the Simplon we observed many of the mountain flowers we had become acquainted with the year before, and many that, in their wild state, were new; among these was a lovely lilac 
Auricula, which grew luxuriantly on the rocks near the top of the Pass.-Our young, good-natured Postillion, pleased with our admiration, clomb the rocks like a Chamois, delighted to present us with some bunches of the clustered flowers; - and peering above the herbage of the little pastures, the delicate, white flowers of the St. Bruno Lily, were hailed with delight, as we drew near to the village of Simplon. Here we spent part of two days, steeped in pure, delicious air and sunshine ; and, as was his wont, whenever practicable, William directed his steps towards a Glacier-that of the Kaltwaser-and also explored a Morain. He was greatly interested in tracing the operations of the grand agencies of Nature, both in the minute, and the stupendous phenomena which Glaciers embrace.-To attempt any description of the scenery of the Pass would be simple injustice-but to catalogue some of the most conspicuous flowers of the Val Doveria, will occupy but a few lines-between Simplon and Gonda, on each hand, were Laburnums and the Barberry, in full bloom, May roses wreathed the over-hanging rocks on one hand, and on the other, from among fallen blocks, the Orange Lily with its yellow lining, looked up towards the sun, and the gadding stems of a broad-leafed pea, trailed along the sides of the road, displaying spikes of rosy flowers.

After leaving behind the rich golden evenings enjoyed amidst the scenery of the Lakes of Northern Italy, and the marvellous works of man, exhibited on the Splügen Pass, and in the tremendous defile of the Via Mala, we remained a couple of days at Ragatz. Here the Baths of Pfeffers and the source of the Tamina were the great objects of interest. The narrow glen down which the river foams and tosses in its rugged channel, has great beauty and grandeur. After a walk of six miles and a half, we reached the Baths, which are close to the perpendicular mass, that with a front $600 \mathrm{ft}$ high, closes in the head of the glen, which here is even narrower than below. In a rift of this precipice the river takes its rise, and at its farther end is the hot spring. The tourist is admitted into this astonishing gorge by a door, of which the guide keeps the key-the feeling of awe with which it is entered, gradually relaxes, as the gloom, the chilliness, and the roar of water become familiar. The gorge is magnificently lofty, and the water passes with a hurried rush, in a rent from 2 oft. to 3 oft. below the path of planks, which partly rests on a ledge, and is partly supported by being cramped to the side of the Cavern-it has a strong hand-rail on the side next the river. There is a general, but far from exact correspondence between the two sides-one is slightly convex, the other concave, and they approach each other more closely towards the opening. In one part an immense block is wedged in, and the foliage of pendant branches, with the strong light above them, showed a most brilliant tint of green. The gorge 
winds a little, and is nearly a quarter of a mile long. In one part a considerable portion over-head, has not been dissevered, and there is a road carried over it.-It was between 4 and 5 o'clock, and the narrow sky-lights admitted just enough light to produce the best effect,- the deep blue of the sky seen through them, was extremely beautiful. At noon, the sun-beams fall directly into the chasm. The hot spring is at the upper end, in a sort of cove, which is on a level with the platform. The cove is dark, and a candle is needed to see the spring, which is enclosed by a door, from which, when it is opened, the steam issues. The water is tasteless, and Murray states its heat to be $100^{\circ}$ Fahrenheit. The Baths were formerly taken in this cove-now the water is conveyed in wooden pipes to the Baths of Pfeffers, at the entrance of the chasm, and also to Ragatz.Beyond the cove the space contracts, and the Tamina issues out of the angular end of the gorge.

Leaving Ragatz by way of Lake Wallenstadt, we once more lingered amidst the scenery of Cantons Glarus and Schwytz, which had so greatly captivated us in 1842 . We made a short stay at Lucerne, to renew acquaintance with its queenly Lake. Passed within sight of the battle-ground of Sempach-immortalized by the patriotic devotion of Arnold of Winkleried-through Aarburg to Basle-thence, to Strasburg and Mayence-made some stay at Mayence, in order to visit friends resident at Beiberic, and to see Wiesbaden. Our next halt was at St. Goar, for the sake of its surroundings, and then we proceeded down the Rhine, direct to Rotterdam, staying for the night at Dusseldorf. On the 29th of July, embarked at Rotterdam for Hull. The wind, which was contrary, and blew rather hard, retarded all the packets for England, and after a tossing passage, we landed at Hull on the 3 ist, gladly setting foot once more on the shore of dear Old England.-The next day we arrived at Kendal-and as we drew near to Low House, the sight of the blue mountains, and of the well-known fells, and then of the dear, ivy-covered cottage itself, and the happy greetings from its beloved inmates, filled our hearts with joy and gratitude; but

"Wherefore speak of what a thousand hearts

Have felt, and every loving heart can guess?"

When in London, William had been induced to consult Dr. Southwood Smith, for his oft-recurring complaint, Bronchitis. He faithfully adhered to the advice given, not excepting the renunciation of smoking - the interdicted pipe was withstood, even in that land of Meerchaums, tobacco-loving Germany! and for five years he eschewed its use.-Change of climate also, and his mode of living whilst on the Continent, had suited his constitution admirably, and he came home in good health and full of vigour. 


\section{CHAPTER XVIII.}

DURING the stay at Low House, it was arranged that William and his wife should occupy it for the Winter, when the family would be absent in the West of England; and in the meantime, they took lodgings at Grange till November; and as no suitable house was to be had in Crosthwaite or the neighbourhood, they again engaged lodgings, to which they removed in April, I844. Their new abode at High Crag, in Underbarrow, was both comfortable and very pleasant, and also a convenient centre for William's movements; and when they could no longer be accommodated there, was left with regret.-

In the Spring of 1844 , after a visit paid at Rydal Mount, when William took his departure to walk forward to Grasmere, Mr. Wordsworth accompanied him to the door, then sauntered along the terrace-stopped-and still went a little farther; he was bareheaded, which made William uneasy, who said "Mr. Wordsworth, you are without your hat; you will catch cold." He did not seem to mind about it-but when William repeated the caution, he took out his pocket-handkerchief, and, putting it over his head walked on. It was an evening of tranquil beauty, and just that point of the twenty-four hours, when the departing day and the coming night, mingle their most lovely aspects.-The young Moon, near to its setting, hung above the ridge of Silver How, and on the "far terrace," the perfection of the scene made them stand still, and Mr. W. exclaimed "What have you more beautiful than this in Switzerland!" and then in a sort of undertone, repeated,

"But through the air I'll never float,

Until I have a little boat,

Whose shape is like the crescent moon."

As the eye rested on the two venerable men-the one, a moulding spirit of his times-the enchantment of the moment was sobered into a feeling of holy solemnity.

When William had to leave High Crag, he was fortunate enough to obtain lodgings in the valley of the Winster, at Salkeld Tenement, which was even more conveniently situated than High Crag.-In I 847, the death of a much-loved and in many respects like-minded nephew, Robert Pearson, was a sore trouble to him. He was a young man of good abilities, and of some cultivation of mind. $\mathrm{He}$ lost his young wife, about six months before his own death, and the inscription on their head-stone, in Coniston Church-yard, was written by William. It is simply a record of names and dates, with the following line beneath.

"Not without hope, we suffer and we mourn."

WORDSWORTH. 
Both whilst living in lodgings, and afterwards when settled at Borderside, it was customary for William and his wife to pay an annual visit of some length, to relatives in the neighbourhood of Bury, most commonly in the Winter season, when William could stir out but little; and there, as was the case at home, much of the day was given to reading-but when the family assembled for the evening, a rubber at Whist, of which he was fond, was a welcome recreation; and the day generally closed with the strains of the organ.-The first of these visits, however, was paid in the Summer of 1844 ; and when they left Bury, they joined Mr. and Mrs. Graves, that they might together make a pilgrimage to Bolton Abbey, Barden Tower, Gordale Scar, and Malham Cove.

During the sojourn in Winster, and also when occasionally resident at Low House, proximity to Bowness made intercourse with these valued friends, easily accessible; and the happy hours passed at their picturesque, old Parsonage-endeared as it was to so many hearts, by the catholicity of its hospitality, and the intellectual amenities of its social usages-are among the remembrances to be last surrendered by memory

William's wishes which had ever been gravitating towards Borderside, at length inspired him with courage to undertake building there ;and on the last day of July, 1848 , he, with a feeling of measureless content, "crept into the bosom" of his own cheerful cot, where, amidst the time-hallowed scenes of the past, "despising the unprofitable yoke of care," he experienced to his life's end,

\footnotetext{
"____ The little daily growth
}

Of calm enjoyment.

When living in Winster, he went through a course of hydropathic treatment-packing, followed by the cold clasp of the wet sheet, and its auxiliary processes-which was attended with such an accession of vigour, and buoyancy of limb, as made him feel youthfully alert! He had previously been a water drinker, though not a rigid one; but as a punctilio of the Water Cure, water-sipping, now appeared likely to maintain its place as a permanent institution, and his little Swiss drinking-cup became again a useful out-door appendage.-The medicinal value imputed to this wholesome beverage, imparted to "the well in the rock," at Borderside, a virtue and a charm, over and above its well-known, and long-known intrinsic value. In seasons of drought, however lengthened, its unfailing spring yielded an unstinted supply of deliciously cool, sparkling water. The well was William's delight - and everybody who cared for Borderside, took pleasure in its precious well. . Near to it, he had a small fish-pond made, which he stocked with Trout; but though a small running stream flowed into it, the fish dwindled-or escaped by the feeder-or were washed out in 
times of flood, so that it answered his wishes only for three or four years. A few Eels took possession, as voluntary emigrants, and continued to occupy it.

A pair of Turtle Doves, as had been truly foreseen by their kind Donor, were a source of daily interest and amusement-for years, they were the Cuckoo-Clock of Borderside, and when placed out of doors, their pretty cooing was heard across the Valley. In genial weather, William might be found seated under the Ash Tree, with book or newspaper-it was a chosen place also, for chat-and to under this tree might be traced a faint odour-not unpleasant-for he had indeed, once more been ensnared, by the seductive though pernicious herb! and here, after his meals, he loved to resort to smoke- he used a clay pipe, with a very small boll, which he rarely, if ever replenished.-Here, too, he delighted to sit, when his women-kind were tossing about the fragrant hay-ever ready to give a helping hand when thunder-packs were afloat ; but the stir and importance were concentrated, when John, with his following of lads and horse and cart appeared on the scene-then had William a sympathizing spectator by his side, to rejoice over the housing of their two carts of hay!

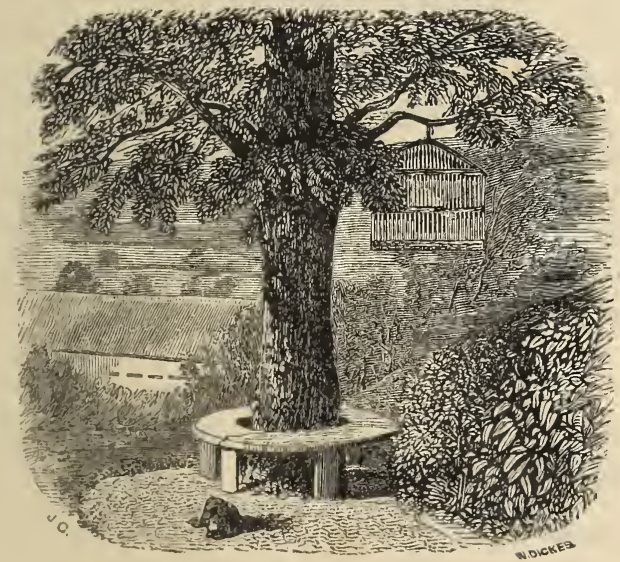

He was an early riser, and except when checked by his cough, or the weather, on going down stairs, he turned out for a walk-oftenest upon the Lots,

\footnotetext{
"Where yet the tender dew strove with the sun."
}

And when in after years this became unsuitable, the gravelled platform in front of the house, was most valuable. To the sweet influences of early morning his whole being seemed to respond, and when, as an invitation to his partner to go forth and share his bliss, he 
repeated--with a joyous devoutness of spirit not to be represented by words-

"The innocent brightness of the new-born day

Is lovely yet-

the utterance of our holy Bard, seemed truly an inspiration.

When he had friends staying with him, he loved,

"To break the livelong summer day

With banquet in the distant woods ",

or by home-rambles-or walk or ride to some favourite viewpoint; one of these which as being the most accessible, was oftenest visited, was a height above Moor How-and many a time has a tired, happy party turned in at the gate, from one of these expeditions.

The year after William had re-established himself at Borderside, he received the following short note from Mr. Wordsworth.

Dear Mr. Pearson,

Pray accept my cordial thanks for your kind remembrance of Mrs. Wordsworth and myself, and for your acceptable presents of the Print from that interesting object in Switzerland (the church on the Reghi-berg-"Our Lady of the Snow"), and for the basket of apples, an article in which we were very poor.-The Swill shall be returned according to your directions; you would have been thanked sooner, but we did not receive the Basket of Apples until this morning.-My Sister joins Mrs. W. and me in the best wishes of the approaching season.-I need not say how happy we should be in seeing you and Mrs. Pearson at any time. We are all in good health, and very sorry to hear that it has not been so with you, and the more so because Winter has yet a long course to run. With every kind and good wish, I remain,

My dear Friend, Faithfully yours,

Rydal Mount, Ist Dec. I 849.

WILLIAM WORDSWORTH.

As Mrs. Wordsworth's pen was the one accustomed to discharge these little debts of courtesy, it is not felt to be presumptuous to attribute this act of kindness, to a feeling akin to that which prompted William when far distant-at Versoix - to make this brief memorandum in his note-book, " 7 th April. Mr. Wordsworth's birth-day." - - He replied to the note as follows.

MY DEAR AND HONOURED FRIEND,

Borderside, I $5^{\text {th }}$ December, I 849.

I felt very grateful for your kind letter. On reading the first few lines, I was sorry to think how much Mrs. Wordsworth's 
hand-writing was changed; but when I found it was indeed from you, and in your own hand, the tears came into my eyes.-I shall preserve this kind memorial, and shall not part with it, till I part with every thing in this life.

Perhaps you will see in the Kendal Newspaper, that I read a Paper to our Society last Monday evening, and see also, that Paper at length. I since find that the Committee wish to print my Letters, and to send a copy to each Member. My unfledged Authorship, had hitherto never soared higher than a Newspaper or a Magazine, and but seldom so high-now I am to appear in a Pamphlet! Who knows but I may be able to send you a copy of my compositions in print-in a little book. How "honour is sometimes thrust upon one," and so unexpectedly! It is well this did not happen to me at a less sober age - as it is, my head is a little turned!- This being stated, you must not be surprised that I am emboldened to send you a little MS. (it has not yet been printed); it was written just I 2 months ago, as a kind of Christmas puzzle, for the junior members of the N.H. Society-but now "my ambition mounts higher." That you may have some of the Fishermen of the Allegory as your neighbours, may not lessen your interest in it.-We were glad to hear that you were all in good health. You will infer from my late feats, that $I$ am a good deal better-but it was thought prudent that I should go to the Lecture-room in a close carriage.- It gives me great pleasure that your Sister remembers me. Please to present to her my best wishes, and grateful thanks for her kindnesses in years gone by, when she used to lend me books I could not otherwise have procured. We thank you for your kind invitation. Of late years, I seldom stir out much in the Winter. We indulge the hope that you and Mrs. Wordsworth may grant us the pleasure next Spring or Summer, of coming to see us and our new house. As for the latter, it stands unclothed by roughcast; it exhibits, also, a goodly set of chimneys, with pretty round tops, on square pedestals-the only specimen yet in Crosthwaite of the revived good, old fashion.-Mrs. P. joins me in cordial good wishes for Mrs. Wordsworth and yourself, and believe me to remain,

My dear Friend, Faithfully yours,

William Pearson.

On the cover of the little book was the following motto-it is believed, chosen by himself.

"In common things that round us lie,

Some random truths he can impart ;-

The harvest of a quiet eye

That broods and sleeps on his own heart." 


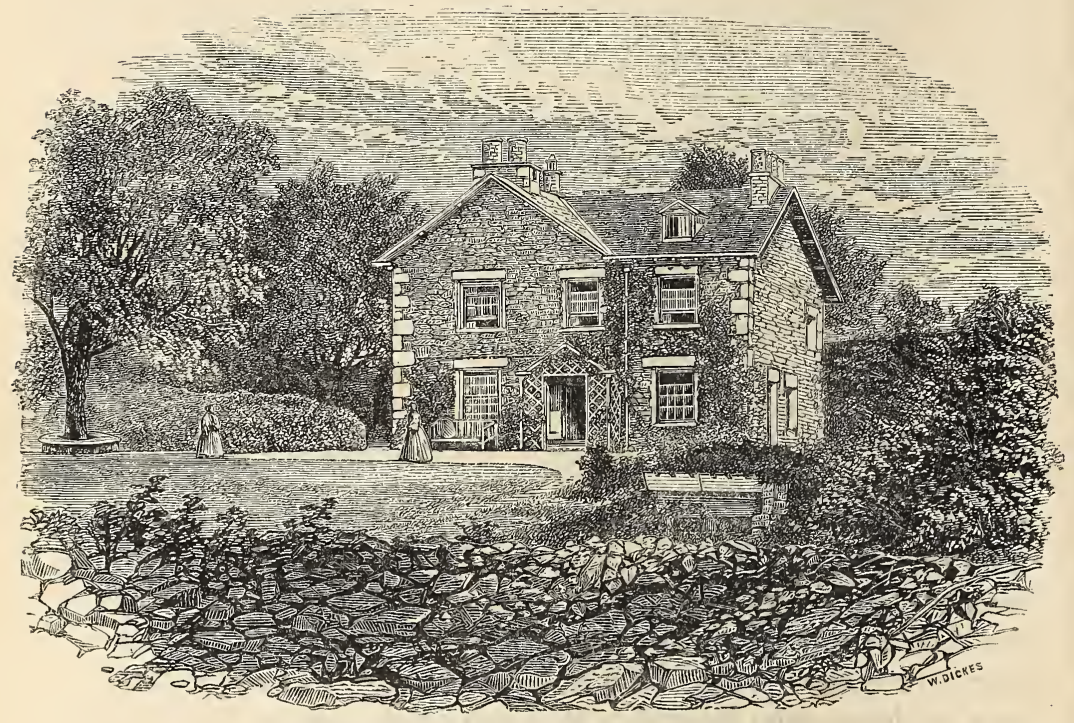

Five months later, on Saturday, the 27 th of April, 1850 , the sorrowful tidings of Mr. Wordsworth's death, on the previous Tuesday, reached Borderside, along with an intimation, that he was that day to be buried in Grasmere Church-yard. The following letter was written shortly after, by William.

My DEAR Mrs. WORDSWORTH,

Borderside, I 4 th May, I85o.

We have been deeply affected by the death of Mr. Wordsworth, and very sincerely sympathize with you under the irreparable loss. It would be great presumption in me, to offer topics of consolation to one who has so long been the bosom friend, the beloved Wife, of so wise and good a man.--No doubt every consoling hope that Religion affords is yours.- - There are few now living, I think, who have more reason to be grateful to your departed Husband than myself. Early impressed with the excellence of his Poetry-it is now more than forty years ago-it has been to me a source of the purest pleasure ever since. And then the personal intercourse I at times enjoyed-his kindness and condescension to me as a friend-if I may use the term, where there was such disparity-such an immeasurable superiority on his part. I have no words to express my sense of these obligations.-—-To the lovers and admirers of the Poet, it is a consolation, that although chequered at times with sore affliction, as is the lot of humanity; yet Mr. 
Wordsworth had granted to him by benignant Heaven, a long and happy and noble life, and at length, we must believe

"—-A death like sleep,

A gentle wafting to immortal life."

Nor can we doubt, that his divine writings will survive, to cheer and to elevate unborn generations. No genius can equal in benefit to mankind, that of the great Poet- "The vision and the faculty divine," is one of the rarest and highest gifts coming down from the Great Father of Lights.-The existence of such men as Mr. Wordsworth-as of Shakspeare and Milton-appears to me in itself to afford a strong presumption of a future and a higher life than this, beyond the grave.—-May I beg to be kindly remembered to Miss Wordsworth.

Mrs. P. unites with me, in again assuring you of our deep sympathy; and praying that you may possess every pure and high consolation,

I am,

My dear Mrs. Wordsworth,

With great regard yours,

W. Pearson.

A few months after his little book had been printed, William wrote to Mr. Waterton, requesting his acceptance of a copy, he says, " $\mathrm{Had}$ it been possible to thank all those from whose writings I have derived pleasure and instruction, I should have taken the liberty of addressing you long ago, for it is now some years since I first read your Natural History Essays, as well as your famed 'Wanderings' in the forests of Guiana. Yet, whatever delight I may have received from these, I confess that what has chiefly interested me, is not 'your hair-breadth 'scapes by flood and field'-nor even your mounting the back of the Cayman-but your having afforded a secure Asylum to poor, persecuted Birds-not merely the respectables (one may find any where, plenty of preserves that minister to the Larder), but your merit is, supplying a shelter to waifs and strays of Ornithology-to Birds of a dubious or damaged character. I dare say there is not a sly Yorkshire Jackdaw or Magpie, within many miles of your Domain, but knows where, in hard times, he can find a Land of Goshen-'a City of Refuge' - a resting-place in the Wilderness! If the Carrion Crow and the Hawk do a little mischief sometimes, what then? God has made them, and $\mathrm{He}$ would not have done this, if it had not been for some good purpose.-Birds are, perhaps, the most beautiful creatures the Author of all Beauty has created here below: I love Birds, and my kindliest feelings are drawn towards you, for the same attachment. As far as this goes our 
devotions to the Source of all Good, can never ascend amiss, if the Author of the Ancient Mariner be correct, that

' He prayeth best, who loveth best

All things both great and small ;

For the Great God who loveth us,

He made and loveth all.'

"I am here reminded, how sorry I was to learn from the newspapers, some weeks ago, that you had sustained a serious injury by falling from a tree. But as these Oracles have since been silent on the subject, as far as I know, I hope that 'no news is good news,' and that you are quite recovered. But do not, my dear Sir, repeat these adventures; remember you are no longer a boy at Stoneyhurst. You said some time ago-and the lapse of time does not renovatethat you were no chicken-therefore I hope in future you will use caution in climbing trees."

In reply to this letter, the account given by Mr. Waterton of his intense and protracted suffering, and of the remedial process which restored to him the use of his arm, is so singularly interesting, that to himself alone is any apology needed, for placing his letter before the reader.

DEAR Sir,

Walton Hall, near Wakefield, April 24 th, $185 \mathrm{r}$.

You will wonder why I have not thanked you sooner for your very interesting little present. Alas! when it arrived here, I could not peruse it; and the accompanying letter so full of kindness and interest, was laid aside to be answered (perhaps never by me) as occasion might offer.

On the I 2 th of December last, I was pruning a standard tree, and was at the top of a ladder twenty feet high. The apparatus gave way. I stuck to the ladder, which came to the ground with a tremendous crash, disabling the whole of my left arm and shoulder. Still, I was assured by first-rate surgical inspection, that no bone was either broken or dislocated. I was blooded to the amount of $30 \mathrm{oz}$. Whilst my general health was going on pretty well, a second accident in-doors, fairly floored me, and I was again blooded to the extent of $30 \mathrm{oz}$ : - -my left arm indicating that much mischief had been done. Things now went on worse and worse, although very gradually, and I was not expected to live above two hours. However, I righted again. Still, my arm plagued me sorely. On the $2 \mathrm{Ist}$ of last month, finding my nights very bad, and the pain in my arm excessive, I began to think of having it amputated. As a last resource, I had it examined on the 25 th by a common, but very noted bone-setter, named Crowther, who lives on Westgate Common, about a mile from 
Wakefield. He found the shoulder driven forwards out of its place - the elbow dislocated-and the hand much injured, and the whole arm emaciated. It took him three weeks to prepare all for the great and last operation. Each day I was put to much torment. On the r6th, by brute force, he had to smash the whole of the callosity which had formed at the dislocated joint, and had rendered the arm as stiff as a poker. This done, he threw my disabled hand up to my shoulder (which it had not touched for above four months), and said, "Now Sir, you will have as good an arm as mine." Since that hour, I have been gradually improving, and in a few weeks more, the accident will be fully and permanently repaired.

Thus, dear Sir, I have given you the outline of my sad adventure. You must excuse brevity, considering my situation. It only then remains for me to thank you again, for your kind letter and present ; -and to add, that I shall be most happy to show you the ornithological treasures of my sequestered valley, ${ }^{*}$ whenever it may be convenient for you to pay me a visit. In the mean time,

I remain, my dear Sir,

Very sincerely yours,

Charles Waterton.

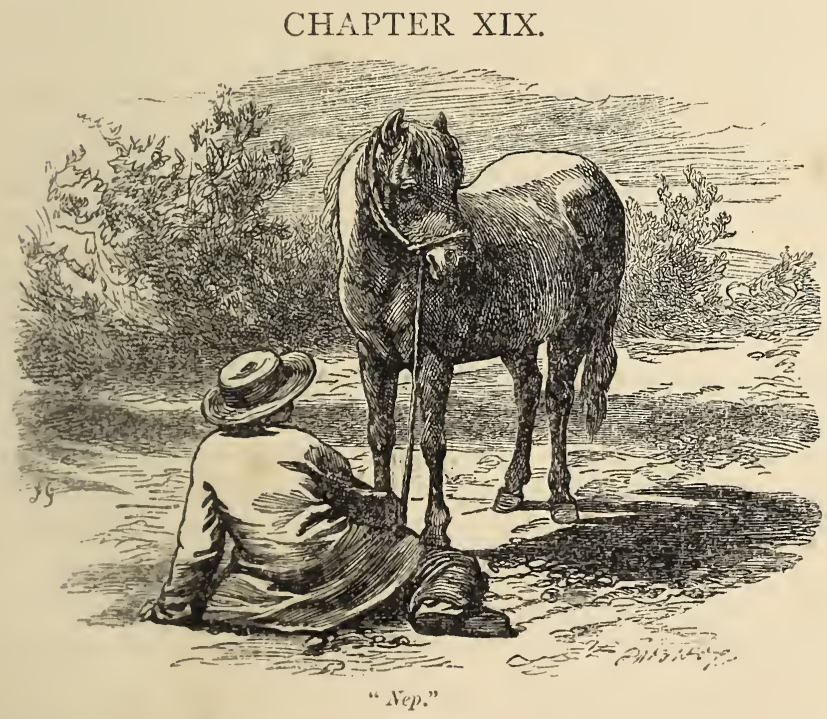

Immediately on William's return into Westmorland, his "little, strong Pony" had been taken into constant' use-except in the Winter-and largely did she contribute to the enjoyment of many 
distant rambles. On such occasions (until her foal had reached a fit age for work), Nep was equipped with a side-saddle, to which, by turn, William cheerfully accommodated himself-and the requisites for an absence of a few days, were conveyed in a satchel, slung upon the crutch.

In due time, the young pony, Camel, was taken into service, and for many years mother and daughter were true yoke-fellows. Later, when long rides became fatiguing to William, Camel was trained to draw a small pony-gig, which invaluable acquisition gave him access to friends, prolonged his enjoyment of distant expeditions, and, to the last, enabled him to visit his favourite haunts.

Nep was so intimately associated with William's pleasure, health, and usefulness, for more than one fourth part of his life, that it is impossible to pass her by without a special notice.

She was of Welsh descent, and was reared at Borderside, where she superseded her mother. Like her Master, she had a strong attachment to the place; and when sent off for the Winter to Pool Bank or the Yews, was sure to make her escape, and to be found either on the Lots, or in the lane.-In form, Nep was a perfect creature-and all but perfect, in qualifications and character;gentle, tractable, sure-footed, unwearied-when in her prime, a swift walker, and, little thing as she was, scorned to be distanced by any steed on the road: Her paces were beautiful, and the easiest imaginable-She was every way adapted to the district, and knew her rôle perfectly, and her dexterity in opening gates was something human!-And now her one defect must be told-she was easily startled-and a sudden noise or movement close at hand, would make her swerve, or even, sometimes, prance a little; which manœuvres, when her Master was ambling along with slackened rein, and with a kind of heedless thought, observing or musing-would occasionally place him in a position by no means enviable; yet her deft foot-fall had "music in it" as with measured tread, her little feet touched the ground.—-Dear, Old Nep!- she is now verging on 30 years of age, and though her teeth be not of the sharpest, she contrives to nibble a maintenance that keeps her in comely plight. In the cold season, with a coat as thick and shaggy as ever, she has the entire range of her native fields-but in May, along with Camel, takes possession of the sweet Woody Field-their own special domain. From this shady retreat she was ousted (I862) by a new-comer, a young grandson. She had then granted to her, the run of the Lots, where she had ramped airily in her own youth, and which seemed to rekindle the fire that in those early years had animated her movements, so briskly did she roam about with the farmer's horses, Charlie and Blithe. 
William was subject to severe colds, that sometimes, even in Summer, confined him to the house; and for a few years before his death, his relentless cough had become almost fixed, and on any access of cold, a truly formidable one-but far from being querulous, his gentle patience was as a glory above his honoured head. Yet, the irksomeness of close confinement when he was languishing for out-door life, would now and then betray itself by his evading ruleswhen he would steal a march, and venture forth to sun himself in front of the house.

In the Summer of $185^{\circ}, \mathrm{Mr}$. Graves went to Bardsea for the recovery of his health, and William wrote to him: "As we have now got our ponies, I feel a desire to ride over to your neighbourhood, so don't be surprised if I and my good wife pop in upon you some day. Have you any clean little Hostelry near you, where we could lodge all night-we and our ponies? . . . . . . I make bold to send you (merely as a specimen) another Heretical Newes-blatter. Don't fear that it journies on any errand of propagandism. This you may return by post, as it is not ours, but is kindly sent us by one of our non-conforming friends. Perhaps the account of the new part acting by Mr. Newman may interest you. What two singular brothers the Newmans are. I possess a book by Francis; it is a clever, serious, devout book, too-founding Religion on the nature of the "Soul," exclusively.-You will find a critique on Sidney Smith's newly published book. It had just been lent me by a friend; I thought its metaphysics shallow enough. . . . . I have just received a great treat, "Final Memorials of C. Lamb." If you have not read it I can afford you no little gratification, which I shall be happy to do. . . . I should like to know if you have made out Mr. Bigg. . . . . I confess I should like to become acquainted with him ; his love and appreciation of our divine Poet is a sufficient title to my poor friendship. . . . . I have never had higher or dearer friendships than those cemented by a common love for Wrordsworth's poetry. Alas! that he is gone." A cold frustrated this plan, and a few days later, he wrote: "It cannot be-in some unaccountable way, considering the warmth, and the time of year, I have managed to catch a very bad cold. . . . I was at Kendal on Saturday, at Crosthwaite Church on Sunday, quite well in both cases, had sore throat on Monday-but let me not enlarge on symptoms, in all cases cruel, but particularly to a dear friend who is himself, I fear, still an invalid; we should be glad to hear that he is no longer so. When you have this good news to tell-may it be soon-pray communicate it."

Writing again on the 19th of June, he, in his humorous way, alludes to his cold. 
"I ought to have thanked you before this, for sending me $\mathrm{Mr}$. B_-'s clever essay, but I am languid, and the smallest exertion out-faces me. As to the Lecture, I agree with you that it reminds one of Emerson-he is a true disciple, without being a servile copyist. . . . . I think in our highest and best moods, we are all Transcendentalists-in moments of devotion, and when the sublime and beautiful scenery of nature is most powerful over the mind. But these enthusiasts, I fear, like some of a lower stamp, make too free, are too familiar with the attributes of God. . . . We were sorry to hear that you had lost ground in consequence of the hot weather. . . . For my own part, I am almost confined to the house, which I cannot but feel rather hard, there is something so balmy, so refreshing and life-giving in the external breeze,--but Mr. Gough says, if there be the least puff of cool wind, I am in danger of catching cold. . . . . Oh, this danger of catching cold at Midsummer is the unkindest cut of all! in Winter one expects it, and can guard against it.-I see you have just a month to stay. I hope it will do great things for you and Mrs. Graves. Pray remember us most kindly to her and Miss N., and believe me,

My dear Mr. Graves, Ever faithfully yours, W. Pearson."

The distance of Borderside from Windermere Parsonage, and subsequently, Mr. Graves's removal (in I $85^{2}$ ) to Dovenest, interposed obstacles to that frequency of personal intercourse which had been practicable when they were nearer neighbours-but as visits of a few days together, now took the place of the shorter ones of former years, this change was a gain of ever-increasing value, as year after year strengthened the ties of friendship.

In the Summer of $185 \mathrm{I}$, a memorable, and exciting event at Borderside, was a visit from an American gentleman and his wife, who were making a European tour. Their too brief stay was the only drawback from a delightful interchange of thoughts and feelings. A mutual friend happened, at this time, to be on a visit at Borderside, and as from thence Mr. and Mrs. P. were to proceed to The Knoll, the party made together an excursion to the foot of the Lake, before parting at Bowness. Perhaps there is not so striking an approach to Windermere, as that by the Winster road, where the sudden turn discloses at once, the upper and middle portions.--Early in the day, it is an exquisite view; and as soon as it came in sight, Mrs. P., with a burst of delight, exclaimed, "Our own Susquehanna!"-_Mr. P. wrote :

"We were most cordially welcomed by Miss M- who did 
everything in her power to make our short stay agreeable. She drove round with us to a number of beautiful places, but the greatest treat of all, was taking us into Mr. Wordsworth's grounds, and showing us his favourite spots and walks." His wife added, "The day and night we spent with you, was such a pause in the life of restless variety we are leading, that to me it was perfectly charming. It was a privilege, too, to talk with you of the beloved ones who have left us for a little while, having well performed their mission on earth.-I often think of Mr. Pearson's remark, that separated as we are by the wide Atlantic, how closely we are united by a common Literature-and by ideas and feelings as much alike, as if we were living near to each other."

Borderside was too remote to admit of William's joining any neighbouring Book Society, and too distant from Kendal, to allow of his even snatching a sight of a new Review, or indeed, whilst it was fresh, of obtaining any other new work from the Library to which he subscribed; so that he had to rely for his reading, pretty much on his own limited resources-its range, however, was expanded to a valuable extent (as in earlier times it had been by Miss Wordsworth), by the kind thought of Mr. Graves,- - who not only gave him literary news, but also lent him many books which otherwise would have been out of his reach. The following extract may serve to illustrate this :-

Mr. G. writes, from Windermere Parsonage, in June I85I : "I have found Whately's Historic Doubts, and with it, send a sort of sequel which has been lately published: also, a little compendium of his on Christian Evidences, worth reading, as all his writings are. On the subject of the Internal Evidence, I send a little book written by W. Erskine, an Edinburgh Advocate, which I read long ago, and then thought of merit.-My uncle Dean Graves's work on the Pentateuch you expressed a curiosity about the other day. I am confident you will, if you can afford time to read it, come to the conclusion that much, at least, of its explanation and defence of the Mosaical system and history, has substantial value.-My friend Professor Butler's Sermons I send, partly because of their own remarkable power and eloquence, and partly because you will find in the Memoir a letter written by me, giving an account of that visit of his to the Lakes, on occasion of which, I remember you saw him and his fellow guest, Sir WV. Hamilton.-The 'Four Sermons,' by Mr. Myers of Keswick, I think very admirable, and trust they will interest, and to a great extent at least, meet the feelings of Mrs. Pearson and yourself-even where intellectually you may not coincide, you will find high interpretations of doctrines, respecting subjects which to all must reniain mysterious." 
When within doors, William was an assiduous reader, carefully gathering up the minutes; and at times was painfully impressed by the smallness of his gleanings from the wide-spread field of knowledge.

For some years before his death, natural science had increasing attractions for him, and he read much in that direction -but he felt a more absorbing interest, in works representing the varied thought of the age, on biblical and theological subjects. His faith in the omnipotence of Truth was unbounded, and he practically recognised what has been so well expressed in words, by one of the foremost minds of the day-that "the antagonism of influences is the only real security for continued progress ;"- and if his reading on the topics, just alluded to, exercised but a slightly modifying power on his views, it tended to deepen his conviction of the value of those Divine Truths, which are the life of life, underlaying all polemical diversity.

These important subjects, gave a leading to much interesting conversation with his friend Mr. Graves,-and here it may be well explicitly to state-what indeed may be inferred from the preceding extract-that, on some important points of Christian doctrine, their views diverged; whilst they were closely united by that Christian Grace, which is the greatest of the three that abide-and which passes from Earth to Heaven, unchallenged of

"The Shadow cloaked from head to foot, Who keeps the Keys of all the Creeds."

\section{CHAPTER XX.}

ON behoof of those who may take an interest in the topics touched on in William's latest letters, it were to be desired that the connecting links-the letters of his correspondent-could likewise be given,and that, not simply because they illustrate and render William's more complete,-but, for their own proper value, as the outcome of thought and wide mental culture: and though it be assuming a responsibility in some respects unwarranted, to interweave pretty copious extracts from them, the forbearing kindness, which over a long series of years has covered a multitude of sins, will, it is trusted, be extended to the meditated licence-. The letters which will be introduced were written between the end of 1854 and the end of 1856 . 


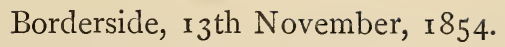

MY DEAR SIR,

Mrs. Graves's note made us sorry in more than one respect. I had pleased myself with the prospect of your viewing with me some of our sylvan scenes before the Autumn had passed away-and then the cause of this disappointment made it still worse, yours and Miss $\mathrm{N} \_$'s bad health—but we will hope for more cheerful news. .

I had thought of thanking you long ago for the pleasure and honour of meeting your accomplished friend, Sir W. Hamilton. I fear I was guilty of some rudeness of manner towards him, which I am apt enough at all times to fall into, such as interrupting, expressing difference of opinion with too little ceremony. The fact is, that Sir William's good nature made one forget that one was talking to a professor, a most accomplished man, and one accustomed to the best society. But what is not ill meant will not be ill received by a sensible man, and I trust your excellent friend looked over it.-In our solitude here, I am often in want of some literary friend to compare notes with, in regard to books I am reading.- - I have lately been engaged with Mrs. Stowe's "Sunny Memories," which has interested me more than I expected; there are so many notices of eminent persons, and these quite recent-to say nothing of descriptions of great houses, churches, scenery, \&c., that the book can hardly fail to be pleasant to most readers. One would have liked it better had there been a little more shade in the picture-it would have been so much more true to nature. . . . . . How strange that she should push on headlong to Scotland, through Oxenholme, nor "turn aside to Yarrow."- Our sweet Lakes and all their associations were nothing to her-she never gives them a thought, a word! I account for all this, by supposing her ignorant of Wordsworth-had she read and felt his poetry, which I am not quite certain she could have felt, showing as she does, such a shallow admiration of Sir Walter Scott's verses, she, like any other devotee, would have made her pilgrimage to Rydal and Grasmere.-You, I understand, think her but a poor critic of painting. Very likely she may be, in an artistic point of view, but to an ignoramus like myself, it was interesting to know the impression which certain pictures and statues made upon her. Do not most of us . . . judge by the imipression produced on the mind and feelings : and how much of this, some say all, is but the reflection of what we bring? .

As regards poetry, I have been much struck whilst reading that delightful book, Boswell's Johnson, with the difference between our judgment of what constitutes the excellence of that highest literature, and that which prevailed at so recent a period as that of Johnson.

I wish some of us, when Sir William was with us, had remem- 
bered a passage (in Vol. 3, chap. 5), where Boswell and his great oracle are discussing the merits of Hamilton of Bangour. You will refer to it, no doubt; therefore I need hardly say, curious as it is, there is not a word about that pathetic ballad, (Yarrow-in allusion to a reading at Dovenest, of Wordsworth's Yarrow, and the interesting discussion it gave rise to ;) they could both overlook the only gem in the casket! Of Johnson, admirable character as he was in many respects, as Carlyle has said, "his mind never rose into the region of poetry," therefore, how could he be a trustworthy critic in that divine art-the divineness of which, in its highest flights, he could neither feel nor comprehend? In all that constellation of talent which gathered round Johnson as a central sun, there seems to have been little appreciation of true poetry. I do not possess his "Lives of the Poets," nor ever, I think, read them. . . . . Accept my best wishes for you and yours, at all times.

$$
\begin{aligned}
& \text { Yours, my dear Sir, } \\
& \text { Very truly, } \\
& \text { W. PEARSON. }
\end{aligned}
$$

The following letter is given nearly entire :

$$
\text { Dovenest, Windermere, } 5_{5} \text { th Nov. }
$$

MY DEAR SIR,

It was a pleasure to me to receive your letter. You may free your mind from all uneasiness as to the impression made on Sir W. Hamilton by your zeal in argument. He is quite too kindly and too sensible a man to take anything of the kind ill-and he subsequently spoke to me both of the pleasure he had in meeting you, and of his regret that he could not see more of you : and as to the passage of arms between you, he was at pains to impress upon me, that he himself went no farther than to say (with Whewell), that there were no scientific grounds from analogy, to affirm that other worlds were inhabited by beings like man. He refrains from saying that the probability, on other grounds, may not be in favour of the proposition, though it is plain he feels less decidedly as to them, than you and I do.- - He would be interested in your reference to the subject of his namesake's poems. I found the passage in my Boswell, and quite agree in your opinion as to the great moralist's defective appreciation of poetry. I was glad to see that Garrick, in his own day, had the courage to maintain the same opinion, and that Boswell even has some suspicion of its truth. . . . . . I quarrelled more with Mrs Stowe's criticisms on poetry, than with those pronounced by her on the sister fine arts; her exaltation of Dr. Watts seemed to me not a little absurd. . . . . I must 
add, that however I may have differed from her judgment as to particular pictures and statues, I agreed thoroughly with regard to some, and thought her sayings with regard to Rubens, most true, bright and happy. Altogether, I like the book ; it is the sincere outpouring of a woman of genius, and the want of shade and discrimination in her characterization of living persons, may have its foundation in the fact, that all were similarly employed towards her in paying homage, and that she was in consequence naturally pleased with all. To revert to one of your observations, I must say that I certainly think good poetry does sometimes reveal to us that within ourselves, of which we had been previously ignorant. It was there indeed, but not brought out into consciousness. Therefore, we do not admire poetry merely because it expresses what we had previously taken a. delight in, or experienced with interest.

I am, my dear Sir,

Very truly yours,

Robert P. Graves.

Borderside, Nov. 30,1854 .

MY DEAR Sir,

I ought to have thanked you before now, for the pleasure I received from yours of the 15 th. - What you say of Sir William Hamilton gives me great pleasure. As to the plurality of worlds, have you seen Sir David Brewster's book? I ordered it, but it was out of print at the time. . . . . I feel obliged by your offer of Johnson's "Lives," and shall be glad to look them over. . . . . I expect more satisfaction from the good Doctor's general biography, than from his "Life of Milton," which jars sadly with my feelings and opinions-political, religious, and poetical. What a contrast is Wordsworth's noble sympathy with Milton in that grand sonnet "Milton, thou should'st be living at this hour." He felt indeed with his great predecessor in all his aspirations, except for the reform of the Church, which always seemed to me (forgive me), a sad shortcoming in the modern Bard.

I sympathize with you very strongly, as to the present aspect of the war, and of the condition of Europe generally. What is to be done with Austria? Her proceedings hitherto have been, clearly enough, favourable to Russia. Had she not held the Principalities, our brave army would not have been almost overpowered by numbers. Nothing can be grander than the bravery of our troops; the only fear is the want of intellect and judgment on the part of Ministers at home and Commanding Officers abroad. To miany of us (perhaps we ought to be more modest), they seem 
to have made some sad blunders already. Our army, instead of besieging, seems to be besieged. One is glad reinforcements are going out; but how late! But I will not pursue the subject, for doubtless you are more au fait to the matter than I, though I can do little else than read the papers, so overpowering is the interest.

\section{Believe me, my dear Sir,}

Very sincerely yours,

W. PEARSON.

\section{MY DEAR SIR,}

\section{Borderside, Dec. 9, 1854 .}

I know not whether you noticed a curious passage in the speech of a Mr. - , a travelling agent of the Protestant Alliance Society, made at Kendal, and inserted in the Westmorland Gazette of last Saturday. It accuses Mr. Wordsworth's poetry of not being friendly to Protestantism-of being, in short, one of the principal means of the revival of priestly domination in the Church of England! I would have copied the exact words, but unfortunately the paper has been destroyed. I should like to know what you think of the accusation. It struck me as something new, at least. If you agree with me, that it is in a great degree if not entirely unfounded, I should like to know further, how far, in your opinion, it is incumbent on his admirers to answer it. I thought once to have sent a protest, or a defence to the Gazette; it was better, perhaps, I did not. You would do it a great deal better. If the accusations were made only in Kendal, I do not think it would be worth while, but he is a travelling Orator, and will very likely repeat it at all his stations.-If you agree with me that something should be said, I would consent to enter the lists-perhaps the Athenæum would be the best medium. Excuse me for thus troubling you. I write in haste, for the boy is waiting on this for the post.

\section{I remain, my dear Sir,}

Sincerely yours,

W. Pearson.

As to the injustice of the charge, Mr. Graves was in perfect agreement with William, but his wider range of information dispelled his friend's impression of its novelty; and, in reply, he states, that so long ago as when Tract 90 appeared, Newman, the leader of the Oxford School, speaks of Wordsworth as one of those who gave an impulse in that direction before the Oxford men set to work. The gist of the matter is, however, comprised in the only passage in the 
letter (the substance of which is partly given above), that $\mathrm{Mr}$. $\mathrm{G}$-_'s nice sense of the requirements of composition, considered as presentable to the public, and it will be found in the reply to Mr. - under the title of "Wordsworth's Protestantism," in the "Letters and Papers." The transcript of the passage alluded to in Tract 90, was enclosed in Mr. G- -'s letter, who adds, "It is noteworthy that it was published in $\mathrm{I} 84 \mathrm{I}$, and that Wordsworth's note appended to the 'Musings at Aquapendente,' in the volume entitled 'Poems chiefly of early and late years,' was published first in $\mathbf{1} 842$. I can have little doubt but that the passage in Newman's letter, which was much commented on, had been previously brought under his notice."

Before sending his defence for insertion in the Gazette, he requested Mr. G_-_'s criticism, and wrote, "There is another point I should have liked to touch upon, as showing how much Mr.W-_ 's heart was open to what was good, even in heathen religions-his beautiful sketches of Greek and Persian, and other worship, in the 'Excursion'-had I not found it would make my letter too long. Perhaps the same objection might be urged against what you say, but yours is really too good to be omitted. Consider of it-and either give me leave to quote it, or write what you think more suited for publication."

In reply, Mr. Graves says, "I like what you have written very much. Looking at it merely with regard to its adaptedness promptly to effect its object, it may be thought that you have put forth too much in extenso, his indulgent views of Romanism, founded upon the good which he, as a man and as a Poet, saw in its actual workings; but, on the whole, I am not unwilling to neglect the polemical advantage, in order that the good lesson of that earlier part may be imbibed by its readers, upon whom it may afterwards operate with an influence mitigating their prejudices and bigotry." In another note, Mr. G. says, "I should tell you, both Dr. and Mrs. Davy were delighted with your letter in vindication of our Bard's Protestantism, both for matter and style. I have been much amused with your contributions to the $W . G$., anent the swimming pig, and I thought the charge of unnaturalist-like severity brought against you most unfounded.

Did you see that Sir T. Pasley's horse had been following the example of the pig? A more extraordinary fact of the same kind came to my knowledge-scene the same-a cat which Mr. S- once gave to the Curwens, swam back to the Parsonage" (from Belle Island to the main land), "where her kittens remained."

In the beginning of 1855 William received the following communication : 
DEAR Sir,

I am directed by Mrs. Wordsworth to inform you, that your and my old and dear friend, Miss Wordsworth, was released from her sufferings at twenty-five minutes past five, yesterday evening. She had been in her usual way till the middle of last week, and was gently and mercifully removed, after the sufferings and discomforts of an illness of upwards of twenty years.

You will be glad to know that Mrs. Wordsworth is wonderfully supported, though much shaken by the severance of a friendship of more that seventy years' continuance-Miss Wordsworth was 83 on Christmas-day.

I need not add how great a comfort it has been to us all, that both Mr. John and Mr. William arrived here the evening before her death. Hoping that Mrs. Pearson and yourself are both well,

I am, dear Sir,

Very faithfully yours,

Rydal Mount, 26th Jan., I855. J. CARTER.

In a letter of the 26th March, 1855, Mr. Graves writes, "I was sitting with Miss Martineau the other day, hearing her speak with undiminished animation, on the subject of the Slavery Abolitionists in America, their heroism, and the progress their great cause continues to make, notwithstanding Statute and Lynch Law, when she asked me if I had read her Article on the Martyr-age of Americaon my replying in the negative, she lent me the Review containing it, and I have since perused it with great interest. It is contained in the Jan. No. of the London and Westminster Review, for 1838 . What has led me to tell you this, however, is the fact, that the same number contains another Article, which will satisfy the curiosity I remember your expressing with regard to Simonides and any poetical remains of him that may have come down to us.-It supplies, I suppose, all that we can learn about him personally, and translations of the principal fragments extant. The same number contains some other most interesting Articles-one on Madam Rahel Varnhagen Von Ense, a femme d'esprit of Germany, which, from its style and sentiments, I should have attributed to Carlyle, were it not signed with the initials S. P.-There is another on Abelard and Eloise, well worth reading. I would advise you to exhume the number from the Kendal Library, or any other Book Depository-it will really give you a feast of pleasant reading.-I must not omit to thank you for the newspaper, containing your letter with the extracts from Carlyle on Red-tapeism. His eye of somewhat savage earnestness, did indeed see through the incapacity of all that system, from which we have of late so deeply suffered. It is the worst incident 
of our mode of transacting governmental affairs, that reforms must be effected, only after the community has become aware of the incapacity; and this is only when abuses have caused some serious and notorious damage. The insight and foresight of superior minds, even when their owners are in power, are, by themselves, insufficient to overcome the vis inertia of vested interests-I have with pleasure recognised your naturalist hand."

\section{Borderside, 3 rst March, I855.}

MY DEAR Sir,

I was glad to hear from you yesterday, and that you are better than usual. . . . . . . . You may be sure I should be glad to hear my defence of Wordsworth had been approved by Dr. and Mrs. Davy. . . . . . . Thanks for your news of Miss Martineau, and what you say of Varnhagen Von Ense's memoirs. The article is Carlyle's ; I have it in his "Miscellanies," and have looked at it with renewed pleasure. I should like to read the number of the Review you mention, though I fear I cannot procure it. With respect to your visit, to which we look forward with pleasure-we are expecting Mr. O. and his son for a week or two, but they, one or both, will have departed before your time arrives. . . . . . . . The Examiner has been clever lately, but scarcely can any wit or humour make the war a pleasant subject. Such heartless mismanagement. I look upon the Humiliation Day, as an attempt of Government to throw upon Providence the burden of its own misdeeds. We are not to be saved by miracles. Providence is just, and will punish us for our indolence and mismanagement.

Very sincerely yours,

W. PEARSON.

Mr. Graves having kindly obtained Miss Martineau's leave to send her Review to William, he wrote as follows:

\section{MY DEAR SIR,}

Borderside, April 9, I 855 .

I thank you for yours of the 5 th, and for sending me the interesting number of the London and Westminster Revieze. I have only yet had time to glance over it. . . . . . . I have lately had the good fortune to meet with an obscure volume, that has pleased me so much, that I have felt desirous you should have a copy-the "Egeria" of Benjamin Dockray, of Lancaster. You will receive it by this day's post, I hope. To say nothing of its intrinsic merit, it was interesting to me, from having had some acquaintance with the author in early life, at Manchester, where he should have been made a manufacturer of fustians, but an unconquerable thirst for Literature prevented this, and he returned to his native town, and seems to 
have devoted his time to solitary study, with intervals of travel. $\mathrm{He}$ has been kind enough to send me the second part in sheets (it is now at the binder's). This should have been published last July, but the bookseller said there was so little encouragement, that it was delayed. The fact is, that Benjamin is no Barnum. He neglects to advertise, and no reviewer seems to notice his book, so that it will, I fear, work its way very slowly into notice. $\mathrm{He}$ is as brave and careless about the success of his literary offspring as Shakspeare himself! . . . . . He seems to have read and reflected, so as to have become a truly liberal-minded man, and to have seen into the grounds of belief of different sects, and even religions, and to have retained his belief in the prevalence of the good and the beautiful.

Believe me, my dear Sir.

$$
\begin{aligned}
& \text { Faithfully yours, } \\
& \text { W. PEARSON. }
\end{aligned}
$$

In September, 1855 , a visit of a few days to Dovenest was preceded by a short tour, the route by Rydal, Grasmere, Wythburn, and St. John's Vale to Threlkeld, which, on this occasion, was the grand point of interest, for the sake of the shepherd-lord, and the good Sir Lancelot. $\mathrm{He}$ wished to trace out the spot where the mother had found shelter and protection for her fatherless infant. Returning by Matterdale, he crossed the moor to Lyulph's Tower, and so proceeded by the charming lake-side road to Patterdale. In the grounds of the Inn was a poor captive Eagle, chained to earth-moping there at the foot of mountain fastnesses, and with a glorious welkin over-head! In the forenoon of the 27 th, he set out to go over Kirkstone pass; the weather continued fine, and "good Camel" drew him right cleverly up the long, steep ascent, earning a rest at the hostelry on the top. He then went forward by the Troutbeck road to Dovenest. As, in boyhood, his first experience of mountain travel had led him over this pass, so, by a remarkable coincidence, it was also the last that he traversed.

The mention of the "good Lord Clifford" may fitly be made introductory to his Poet's grave,-a notice of which was sent by William to the Kendal Gazette, after the first visit he paid to it, which was not until the Summer of 1855 .

\section{"WORDSWORTH'S GRAVE."}

"I wished to visit it alone; - there was no need for a guide, for through the grassy Church-yard were two beaten tracks trodden by the feet of the numerous visitors to the Poet's Grave. It is near to the eastern wall-a simple grave-like most of its neighbours, 
covered with the grassy sod : a small dark-coloured flag placed at the foot, with a taller one at the head, on which is engraved 'WILLIAM WORDSWORTH.' On the right, lie the remains of two young children, a son and a daughter, whom he lost many years ago. A small erect slab, bears the touching words of the Saviour,- 'Suffer little children to come unto me, and forbid them not, for of such is the kingdom of Heaven.'-A more elaborately carved stone, on his left, points out the resting-place of his accomplished and kind-hearted daughter, Dora.

"There' is something extremely affecting in this simple memorial of the departed Poet. No date of birth or death, no epitaph, no eulogium, nothing but 'William Wordsworth ;'-but that is sufficient. What touching emotions will this short inscription create in the hearts of many who visit this hallowed spot!

"Nor will his admirers forget, how suitable is the place of his retirement, amid the quiet fields of that beautiful Vale, enclosed within its guardian mountains - that beloved Vale, in which he passed so many years of his life, and where he composed some of his most inspired poems.-The Bard has himself erected his own most enduring monument.

' Not marble, nor the monuments of Princes,

Shall out-live his powerful Verse.'

- More affecting than the intended monument, will be this unpretending, sod-covered grave. . . . . A ' little grave' like those of the farmers and shepherds.-How suitable for the Poet who viewed man in his simple native dignity-not as raised above his fellows by the adventitious claims of wealth or rank.- 'A little grave, an obscure grave,' with its grassy mound for the Daisy and small Celandine to bud forth upon in the early Spring, gratefully to embellish their Poet's last resting-place-and the Rotha* flowing close past the Church yard wall, over its pebbly bed, murmurs with the sweet music that was ever grateful to the Poet's ear-" . . . . P.

Until the last of that closely united band had been gathered to those gone before, Sarah Hutchinson's head-stone stood at the foot of her grave, but after Mrs. Wordsworth's death, it was placed on a line with the others.

\section{CHAPTER XXI.}

THE frugal habits of William's early years were of life-long continuance; and a predominant trait of his character was eminent unworldliness of spirit,-in the ordinary acceptation of the word, utter unworldliness.

He was prompt to forgive, seldom appearing to retain the

\footnotetext{
* Abore the Lake, its old name was Raisbeck.
} 
remembrance of what had wounded his feelings; and an unkind judgment, or an injurious word, was far from him.-His keen sense of the humorous, worked well with an earnest frankness of speech, which was further modified by its freedom from dogmatism, and his deferential bearing.

His repugnance to ostentation and all other shams, allied him to Carlyle, and operated to promote a jealous reserve in the manifestation of feeling. He was unfettered by the merely conventional; and his mien was characterised by a "refined rusticity." His reading, when he felt quite free from restraint, had an indescribable charm; and though his voice was impaired by his chronic malady, the delicacy of its intonations, and a faculty of nice discrimination made him excel in dramatic elocution. The words dropt from his tongue instinct with soul. His reading of elevated poetry possessed the power of bringing the listener's sympathies into close fellowship with the Author's-into the very empyrean of whose inspiration, he himself sometimes appeared to be caught up-when with faltering voice he would say "I can't go on"-quietly lay down the book, and leaning back in his chair, the tears would force themselves from beneath his closed eyelids.

The last year of William's life is now reached,-and with deep gratitude be it added, that it was a year "full of blessings."-His love of nature, "whether it were a whistling wind, or a melodious music of birds among the spreading branches, or a pleasing fall of water rushing violently, or a terrible sound of stones cast down, or a rebounding echo from the hollow mountains,"* or simply the "common air," + had kept wakeful in him a healthy interest in small things : and he still loved to tell of an early-blowing Primroseto bring in the first Celandine-to note the progress of the gems on the fruit trees, and the economy of the feathered tribes-to call attention to his pet flowers, the humble, brave, Poor Robin, and "the little Speedresll's darling blue;"-and to end this enumerationlooking through the window, not many days before his death, he said so cheerfully, "Another month, and we shall have Snowdrops!"

As usual, he this year made notes of what most interested him in such matters as have just been alluded to. One occurrence, of which he made a memorandum, is so closely associated with the cause of his death, that the note shall be given.

"September 8th.-Thunder in the afternoon, almost continuous, little rain. About six in the evening, a terrific crack right over head, flash and report instantaneous. J. W. when fetching the cows, noticed pieces of sod on the back of one of them, and also lying 
about at the low end of the Great Meadow. There had been an emission of the electric fluid, apparently from the dike on which the hedge grows - the surface was stripped off, and also the leaves from the hedge above, and the roots of a large Ash had the bark peeled off, and to the distance of $I_{5}$ or 20 yards, sods, with fern roots attached, were lying on the ground. The disturbance was under the tree, but not a branch or leaf of it affected. The force could not have come from the clouds, but had proceeded from the earth, probably. It had been the cause, likely, of that tremendous burst, that seemed right over the house. If a 32-pounder had been fired on the roof, it seemed that it could not have been louder, nor so loud and stunning."

His interest in intellectual pursuits never failed him-and though his bodily powers were enfeebled, he could move about with pleasure in the pony-gig, and was inspired with an unwonted desire to do so. In the course of the Summer and Autumn, he drove in every direction, leaving few places in the neighbourhood unvisitedto many of his favourite haunts, he went again and again. Little agreeable incidents, too, were interspersed, and altogether the year was rich in social enjoyment.-Death came at its close-death, which enforces the most solemn, the most searching of all separations; but it never has been nor can it ever be lost sight of, that the dreariness which he feared would attend arm-chair days (though "all things are less dreadful than they seem"), made him desire his dismissal, if it pleased God, before he should by decay of sense, be withdrawn from the ministrations of Nature: and that wish was fulfilled.

The details which yet remain to be given, though of small account in themselves, yet as having contributed to the innocent enjoyment of this last year of his sojourn on earth, it is trusted, will not be unacceptable to a few, to whom he was dear; at the same time it is anticipated, that what has still to be told, may by others be regarded as at least superfluous.

In February, he attended the meeting of the Scientific and Literary Institute, at Kendal, to hear a Paper read by Sir John Richardson; and in March, he himself read his last Paper in the same Lecture Hall, and at this time he also enjoyed a short visit to his friend Miss $\mathrm{G}$ - On the 8 th he wrote as follows to Mr. Graves :

MY DEAR FRIEND,

Borderside, March 8, r856.

I will not delay any longer thanking you most cordially, for your very acceptable present of Professor Reed's Lectures. I have read nearly half of them, and been much pleased with his 
criticisms, particularly those on Poetry. I was not, I am sorry to say, quite aware, that Chaucer was so delightful a Poet as he appears to be from the citations in these Lectures. It has struck me, however, judging him by what I have yet read, that Mr. Reed seems to have been, in one or two instances, a little one-sided and narrow. I have seen no mention of any Boston American writer-not a word of Channing or Emerson; though the latter is, I think, the most original writer that America has produced, and he certainly is a man of genius. But perhaps I am hasty in my judgment, and he might think his subject did not call for any notice of them. American writers are not often to be blamed for ignoring any kind of excellence that belongs to their country. But the late lamented Professor was Episcopalian and orthodox, and Boston, as Unitarian and free-thinking, might be tabooed in the eye of the true Church. . . . . You will be aware that we have had a great treat at Kendal, in Sir John Richardson's Lecture on the Esquimaux. . . . I think you will feel that it must be a matter of some anxiety to me that I am to succeed this truly eminent man, with a Paper of mine on Monday next. . . . . We have enjoyed, here, lately, most delightful, calm, dry weather. We hope it has been the same with you in the Emerald Isle. We trust it will remain so, till you leave it, and reach again your own snug Dovenest.

\section{I remain, my dear Friend, Very faithfully yours,}

W. Pearson.

In reply, Mr. Graves writes: "It was gratifying to me to learn that you have found Professor Reed's Lectures repay your perusal. It may be, that in one or two places, a bias, such as you speak of, is observable, but I think you are under a misapprehension, in supposing that American writers at all came within the scope of his Lectures. I conceive, that the epithet 'English' with him, as applied to Literature, is to be understood as exclusive of American: though in the last Lecture he introduces a reference, if I remember right, to some American letter-writer. He seemed to me, to be a critic of remarkably just taste (not that I agree with him in every instance), and hisstyle struck me as peculiarly pure and good."

To the same friend, William again writes :

"Borderside, March I9, 1856.

“Dear Mr. Graves,

"I was very glad to learn from your letter of the I 2 th that your journey had been so agreeable, and so beneficial to your health. I hope you got the Mercury, containing some extracts from 
my paper.

If you have a vacancy for any new reading, I have the last No. of the National Review ready for your perusal, and will send it to whenever you wish. There is an article on the present state of France, that I think will interest you, written, I presume, by Mr. Greg. It gives a singular view of the Emperor's character-a man without moral feeling, and without religion, but of deep meditative habits, and of great reticence, so that his most confidential Ministers are hardly aware of his plans. If this estimate be correct (one would think it could not), he is scarcely human. But so far, he has turned out better than most of us expected: and how events seem to favour him! This birth of a boy is a great god-send. The Parisians seem almost insane about it, particularly the poor Ladies!

"To revert to those extracts from my paper in the Mercury, there are some errors of the press, which I regret I did not correct: but the rogues have done me one service, they have marked with inverted commas, my doggrel verses at the conclusion, and so saved me from the shame of being their author. I suppose they thought they were doing me a kindness. . . . I have been reading with some pleasure, 'The last Fruit from an old Tree.' What a singular, vigorous old man, this Savage Landor is! . . . . Those Letters of Southey's, lately published by Warter, seem, from some extracts, to be very interesting."

Mr. Graves, alluding to the foregoing, says: "I was greatly diverted with your anecdotes of 'dumb creatures;' they formed a good sheaf of the 'harvest of your quiet eye,' and genial observation, and you spice them with such human pleasantness as adds greatly to the zest with which they are enjoyed. You need not be ashamed of your verses-considering their purpose, I think they were all the better for being doggrel.

Thanks for your offer of the National Review. Another friend lent it me for a particular purpose, so that I have read the article you refer to. I fear the account Mr. G- gives of the French Emperor's character is too well founded. I some time ago read in the Dublin University Magazine a very interesting article on the works of Louis Napoleon-and they certainly did appear to ignore, in a very remarkable way, all moral and religious considerations. Still, as you say, he acts well, and his good fortune is, I think, good fortune, or rather something better, for the world. I was much pleased by his taking this occasion of offering return to all the banished, on the sole condition of their declaring that they will not act in hostility to the authorities in France as at present constituted. Whether merely policy or something better, this is excellent. 
" Kindest regards to Mrs. Pearson-she knows, I believe, we meditate a long day at Borderside when Miss $\mathrm{N}$ - is with us.

$$
\begin{aligned}
& \text { "Ever, my dear Friend, } \\
& \text { "Faithfully yours, } \\
& \text { "RoBT. Perceval Graves." }
\end{aligned}
$$

On the 3 Ist, William again writes :- "I am glad my anecdotes of Animals amused you. . . . . There is no fear I shall reply to your praise as rough Samuel J. did to Hannah More's. . . . . If the poor 'dumb creatures' are more kindly looked upon from my efforts, I shall be abundantly rewarded.__ There is something curious in the number of really good and permanent books, that have been produced by unlearned writers. . . . There is Izaac Walton, John Bunyan, Daniel Defoe (a most spirited and multifarious writer), and, in our own day, Robert Burns and others. - . I have just finished reading a very interesting work, Foster's Statesmen of the Commonwealth, which has caused a revolution in my opinion of Cromwell. I had read Carlyle's Life and Letters, and from that work thought that Cromwell had been much belied, and that he was a sincerely religious and good man; and that his usurpation was a matter of necessity, to prevent all that had been acquired by toil and fighting from being lost. But I do not think so now. After all, Cromwell's is one of the most difficult of characters to appreciate. I think it much in his favour, however, that Milton seems not to have given up his good opinion of him. That he was a good son, husband, and father, and was much beloved by his servants and dependants, there is no doubt-but the mixture of hypocrisy and fanaticism is the difficulty. . . . . . J. W. brings us the news that Peace is made. One certainly ought to rejoice for the sake of afflicted humanity. That it will be permanent, one may doubt. How curious is the situation of Europe! and how little likely to continue long as it is."

In reference to Cromwell, Mr. G. writes : "In the last Edinburgh there is an admirable article on Cromwell, by whom I know not, suggested by Guizot's recent work on the subject. It left me with the balance decidedly inclined in his favour. It would be worth referring to."

In April, in consequence of an application made to him by a committee in London, William interested himself in obtaining signatures to a Petition for legislative protection to the earnings of married women; and to the credit of the district, the Petition was as freely signed by men as by women.-The Secretary (Mrs. Howitt), after acknowledging the receipt of what she styled the "Borderside Petition," says, "I have a very great love for your part of the country, 
with its strong northern character, and its Statesman population, and I rejoice to believe, that there is more justice and honour among them than is ordinarily to be found in large towns and cities, where such sad cases of marital iniquity abound."

Towards the end of May, William drove by way of Birthwaite to Reston Hall, where he spent some pleasant hours with his friend Mr. Gough (in the Autumn he again visited him); and returned home by way of Underbarrow, calling to see his friend and old hostess at High Crag, who would not allow him to depart, without taking tea with her.

In June, he spent a few days at Grasmere with a valued friend of long standing-Mrs. Cookson; and on those June evenings their thoughts travelled backward along the years, to the early days (honoured by William, with true heart homage, more than any others) of mutual friends, who in their Town End Cottage, hard by, led there a "blessed life :" and then conversation would digress into cheerful literary anecdote. One day, was made note-worthy by William's driving Mrs. C. round by Rydal, Brathay, Skelwith, and Red Bank, and so past the Church back to Howfoot. Soon after they left the door, E. C. and A. P. set out, expecting that the short cut, by "Old Corruption," would enable them to pop upon the others at White Moss, so that they might be useful by opening the gates under Loughrigg-but not even a glimpse could they catch of the two, whom, however, they contrived to way-lay at the top of Red Bank, where their appearance was welcomed._-On his way to Borderside, William called at Rydal Mount, when for the last time he saw Mrs. Wordsworth-and a note from her, when "she could not see to read over what she had written," was the closing intercourse of a friendship of forty years' growth._Mrs. Wordsworth departed this life on the I 7 th of January, I859; and the last survivor of that household circleMr. John Carter-who, after Mr. Wordsworth's death, had ministered to her comfort with tender fidelity, and especially during the period of her blindness-died on the 28 th of January, I863. Like those who had gone before, he was buried in Grasmere Church-yard._When the home at Rydal Mount was, after Mrs. Wordsworth's death, broken up, Mr. Carter had repaired to his own sweet little spot, Loughrigg Holme, where he died.

On two occasions in July, William went to Kendal, the latter time, by way of Helsington, that he might call on his old neighbours and friends, the Rev. C. B. Harris and Mrs. H._- His sisterin-law, Mrs. T. Grundy, and her two younger sons visited him, likewise in July, when a notable expedition was made to Witherslack Hall, which, with the pic-nic on the side of the scar, is held in affectionate remembrance by those who shared William's pleasure on the occasion. - He drove Mrs. G. in the pony-gig, the others rode in 
the farmer's shandry. Arrived there, the party passed through the wood, and by the ascending path over the shingle, then through the upper belt of coppice-wood, where the track is very steep, narrow, and rugged, and opens out upon a ledge beneath the overhanging cliffs. Here they lingered, as in a natural balcony, rarely embellished by the hand of Nature ; then, still ascending, by a more open and unprotected track, they fixed upon a station where to spread out their repast, the fine out-look to the sea influencing their choice.-Looking over the tops of stately trees down the narrow glade, with its few sweet, fresh fields, which are bounded on the West by the foreststeeps of Yewbarrow, and on the East by the beautifully wooded skirts of Whitbarrow-whilst beyond, in the bay, was a fine tide, with a white sail or two, and over-head a blue, but not cloudless sky-the scene might be regarded as perfect;-so it appeared on this memorable day: and as William sat on the grassy edge of the shingle, he looked so quietly happy amidst these "innocent blisses," that we all rejoiced he had had the courage to brave the climb.- The two brothers rambled off, and bore back with them treasures of limestone flowers, then in great perfection-and in the hilarity of the moment instituted the Order of the Geranium! investing each of the party with its insignia-a spray of the Geranium Sanguinium,-William pleasantly entering into the frolicsome mood of his young relatives.

As a pendant to the foregoing-though the colouring is more tenderly solemn-the sun-set light of memory rests on a group in the wood already mentioned, which girdles the lowest part of the Scar.Beneath the tall Hazels, and by the side of a rill that issues from the rocks above, two friends are seated.

\section{"They talked : the stream between them ran."}

A volume is forthcoming in this peaceful seclusion, from which the aged man has been reading-he still retains in his hand the book which belongs to the younger man, his companion.-A few paces beyond, where the rivulet crosses the path, stands a dear lady-her bonnet hangs from her arm, whilst she applies the cool water to head and face, and in explanation of the whole scene, whispers; "Do not take any notice, but Mr. Pearson has been reading the Ode on Immortality, and he read it so low!"

In August, Mrs. O. O. Openshaw, another sister-in-law, was staying at Coniston with an invalid son whom she could not leave, but his younger brother, Tom O. O., paid a visit to his uncle; and the day he returned, William drove him over the Fell to Tower Wood, from thence to be rowed up the Lake to the Ferry House. In August, also, he spent a few happy days at Dovenest. The hour for departure having arrived, the gig stood ready, and he himself was 
equipped;-but instead of taking leave, as if unconsciously impelled by some mysterious foreshadowing, he made a turn, and, oblivious of all wifely hints, again seated himself in the drawing-room. After reaching home, he wrote to Mr. Graves the following note :

\section{Borderside, Thursday morning.}

\section{MY DEAR FRIEND,}

I cannot but scrawl a line to thank you for our very delightful visit. How lucky we were (considering the precarious weather), that the showers held off during our charming Skelwith drive, as well as on our journey home, which was fair and pleasant; but in five minutes after our arrival, we had a violent thunder-shower. I hope you escaped it on your journey to Kendal.-We called on the W-'s at their new cottage, near Skelgill, and then passed down Troutbeck.-In leaving Dovenest, I cannot say my poor memory served me badly, except in not bringing away Morrell's little essay on German Philosophy, which I dare say your kindness would have spared me. However, it will do another time, on your return. Mrs. Pearson sends her love to Mrs. Graves and Miss P., and kind regards to yourself, and says her visit has given her a large supply of pleasant thoughts. I say "ditto" to all this, very cordially. We ought not to have omitted remembrance and good wishes to Mr. W.; supply this neglect if you please, and believe me,

Ever faithfully yours,

\section{W. Pearson.}

William went for the last time to Crosthwaite Church, towards the end of August.-On the 2nd of September he drove over the Fell by Stavely-brow to Newby Bridge, and returned by Tower Wood, crossing the Fell to The Wood, and so into the Winster Road.-Before he reached home an accident occurred, which, for the moment, occasioned the most anxious alarm.-From some unknown cause, when near the bottom of the steep brow at Barkbooth, down which his companion was walking, the pony began to kick violently, and taking the turn at a great speed, swept sharply round to the left with her face close up to the wall, jerking William out to the opposite side of the road.-The shock deprived him of breath for the instant, and he lay motionless and with closed eyes-but as soon as he was able to speak, he said he was not injured, and in a short time was able to rise from the ground.-It was a merciful escape, for though he lighted close to the wall, he was not thrown against it; and he fell upon a little grassy plot, with rough stones on every side.-On one temple the skin was a little grazed, and the arm on the same side bruised; and afterwards he always felt pain in the shoulder when he moved 
the arm in a backward direction.-The poor pony had stood still at once, and was trembling very much; she had one leg over the shaft, and seemed to be waiting for help, for she made no attempt to extricate it. Two men, who were reaping in a field close at hand, promptly gave their help, and William seated himself again in the gig, declining any attendance for the short remainder of the way.

He took a good deal of interest in the railway then under construction, between Ulverstone and Carnforth, and, in this month, went by way of Height-calling to see his old friends there-nearly to Grange, to take a survey of progress; returning through Lindale and up the Valley.-In October, he went to beyond the Derby Arms, expecting he should be able to drive nearly to the shore, and so to come upon the line. This, however, proved impracticable, and, in the course of a few days, he made another attempt, at Foulshaw; here he drove to within a quarter of a mile of the place where the men were at work, and made his way to them, over the rocks by the shore: and here he gained also a near view of the part which crosses the sands. The following day he wrote to Mr. Graves :

MY DEAR SIR,

Borderside, 26th October, $185^{6}$.

Although it is the good Sunday morning, I cannot delay any longer thanking you for the very acceptable loan of your two books.As to Morell's Essay, I don't know when I have read a more beautiful, clear, finished production. Though I was not quite up to the subject (no easy task), neither was I quite ignorant; I find it much clearer than Lewis's sketch, and it gives, also, a far more favourable opinion of the success of those German divings into these mystical and difficult matters-so fascinating to some minds.-I think the "Manchester Essays" do great credit to that bustling, money-getting town, so long my own place of abode. I must have these Essays. - I have also looked over Leigh Hunt. . . . . . How highly he feels the merit of poor Shelley - and how affecting his wish and expectation, that the first face he might see in an other statemight be his! May it be so, I sincerely wish.-We were grateful to hear, through the kindness of Mrs. Graves, that you had weathered the Irish journey so well-had returned, indeed, with an accession of health and strength. That you may keep this, we devoutly wish. When will you favour us with your long-expected visit? I wish it could have been a week or two ago, when you might have seen the beauty of sylvan Witherslack in great force.-Returning last night from a drive to Sandside, we found in the Mercury, the account of that horrible catastrophe of Mr. Spurgeon and his worshippers. . . . . . . He seems to delight in dwelling on the sufferings of the wicked in a future state-like Tertullian (if I mistake not), who thought one of the pleasures of the 
saints would be, to look on the torments of the reprobate! Jeremy Taylor, also, generally so tender and beautiful, administers a huge " tartarean drench," as Coleridge termed it. . . . . . Spurgeon's popularity, in part at least, is produced by addressing himself to the fears of his audience. This seems strange, fear being one of the most disagreeable of our feelings. . . . . . . However it may be accounted for, is it not too true, that to dwell on the infinite goodness of God, and the numberless indications of it, will not draw audiences like painting the dark side of the picture?

I remain truly yours,

W. Pearson.

The following is from a note written on the 3 Ist of the same month :- "Thanks for your prompt answer to my letter. We were very glad to hear so good an account of your own and Mrs. Graves's health; but had you not better eschew pulpit-services till you are more able to bear them?-I must thank you sincerely for your present of the Manchester Papers. . . . . . There is one writer (an original, humorous fellow,) who has thrown off the best defence of money-getting I have seen. . . . . . This is one of the subjects on which Carlyle would say, there is a great deal of sham among moralists and preachers. . . . . . You may be sure I should be gratified by hearing of Dr. Davy's approval of my description of the Thunder-storms. My latter letter, the more important of the two, I have had no answer to, as yet.-It was an account of what we witnessed (my wife and I), of some of the effects of that terrible avalanche of water, which occurred at Borrow Bridge, last August but one. I wished to have the Doctor's opinion whether that downfall was rain-or the sudden condensation of a huge body of aqueous vapour, that took place too near the earth, and in too great quantity, to be filtered or divided into raindrops.- $-\mathrm{My}$ wife says that it will suit her best, that your visit should be at the first date you mention, Nov. 6, Thursday, which also seems to agree best with your own convenience.

I am ever yours,

IV. Pearson.

Two drives through the woods, their "hazel bowers with milkwhite clusters hung," yielded William special enjoyment. One of them was on a sweet, mild Sunday afternoon, into the Oak grove beyond Swallow Mire. The air, the Sabbath stillness, and every object excited in him devout joyfulness of heart.-The other, was through Witherslack Park. When he reached the Hall, he walked down the steep part of the road, which commands such a fine view 
of the scar-stopping to contemplate the grand features of that favourite seclusion; it was for the last time. Then, going forward through the wood, and as far as the south end of Yewbarrow, he turned homeward, along its western side, passing Witherslack Church, and so through the hamlet of Pool Bank.

From time immemorial, he had been in the habit of visiting, annually, the neighbouring orchards for many miles roundsome of them, both when the trees were in blossom, and when the fruit was ripening. The last of these journeys was to Low End of Crook, where the orchards are very extensive, and sometimes quite a show.-It was on one of those transparent, balmy afternoons of Autumn, when the clouds rest in grand packs, apparently motionless, in the blue serene. $\mathrm{He}$ went by Crosthwaite Green. William Hartley, with his fine family of girls, was in the harvest-field, and, guessing William's errand, came towards him, jumped over the wall into the lane, and walked along by the side of the gig till they came to the gate of the large orchard. William was then going to step out, but W. H. threw the gate wide open, and insisted on his driving round! which unthought-of and charming novelty was quite practicable, the orchard sloping gently, and the trees being planted, as in the cider-growing counties, widely apart. With mutual delight, the two proceeded up one avenue, and down another, admiring and descanting - the old, crowded orchard was passed by, and they proceeded through the fold to the Skyanderanother large one, which was noted from side to side. In returning, a row of flourishing Damson trees, by the side of the beck, came in for their mede of admiration and praise-but the pride of its owner was a very large one, ensconced between two buildings, and laden even more abundantly than its neighbours, with beautiful purple fruit"That tree," said he, "our Sarah and me planted on our wedding-day!" This enduring bloom of early love put quite into the shade the very lovely, yet transient, bloom which overspread the ripening fruit.

The last drive in his serviceable, easy little gig, was through Bowland Bridge, with the intention of returning home past Wood-side ; but it was so pleasant that he was induced to prolong his ride, and going round by what at Borderside was known as the Terrace-road (below the Scar, in the direction of Church-town), he proceeded homeward by Tarnside and High Birks. This drive was only a few days before the arrival of his brother-in-law, Mr. Relph, on Friday, the I 4 th of November-who with Mrs. R. came to Borderside for a week's visit. On Sunday he received a note from the Rev. F. H., saying he and Mrs. H. intended paying him a visit in the evening. During the afternoon they were completing a round of pastoral calls before leaving the Chapelry of Winster, and it was past 
7 o'clock when they arrived. Their proposed Eastern travel, and more particularly Petra and Mt. Sinai, were topics of interest, and William was very animated. It was late when they took leave, and not without sincere regret, did he see the kind-hearted Pastor, whom he much liked, depart from the door.

On Thursday, the I8th, whilst Mr. and Mrs. R— went forward to Grasmere, he made a call at Dovenest, where he was always made to feel quite at home. Drawing up to the fire, he set his cold feet on the fender, and "at once" (as his friend described his mode of doing) "dashed with happy "into topics which his soul loved. He enjoyed this improvised visit greatly; and on the following day, Mr. Graves dined at Borderside, and staid over night.-In the evening, the party gathered round the lamp with work and book, and as was not unusual, conversation drifted to poetry; when Coleridge's sublime "Hymn before sunrise, in the Vale of Chamouni," came under discussion, which brought to William's recollection, his having, when at Versoix, met with a translation of Frederica Brun's hymn — " Chamouni at Sunrise ;"* the copy of it was sought out, and he read it aloud. The next morning-Friday, the 2 Ist of November-was clear and sunny, and after breakfast, he was observed seated outside, by the parlour window : he had only put on his hat, and no suspicion was excited of any intention to go farther: he was, however, waiting for Mr. Graves to join him in a walk down into the fields, where he wished to show him the traces of the explosion which had caused the terrific thunder-crack, in September. The walk was short, but it proved most disastrous. In returning, he met a N.E. wind, which swept over the Great Meadow, and had to encounter it unprotected by muffler or overcoat.—In the course of the forenoon, Mr. Graves took leave, and Mr. and Mrs. R- then went out for a walk. William, too, again turned out-again unobserved -and again without any extra covering. The bright sunshine seemed to betray him into forgetfulness of the need of caution. He went to the Woody Field, bound on an errand of kindness. Nep had not yet left it for the Winter, and he wished to ascertain whether there was water in the pasture, as it was apt to fail in continued dry weather.-After his return, as soon as he was seated, the symptoms of a severe cold showed themselves. - He sat down to dinner with the others, however, but ate very little; shortly after, Mr. and Mrs. R- also took their departure.-In the afternoon, he went through the processes that were generally resorted to, and with the desired result. - On Sunclay he sat up) a little while, but dir not feel so well, in conse- 
quence ; and on Monday, therefore, he did not leave his bed; but on Tuesday, felt so much better, that, well wrapped up, he went down into the parlour. It was for the last time-for it proved a sad mistake -symptoms returned that made the same discipline necessary, as at first.-On Wednesday, there was a little amendment, and he objected to have Mr. Gough sent for. He continued about the same till Friday, when he consented that Mr. Gough should be written to. Saturday passed over without his arrival, and on Sunday a letter brought the explanation-he had now given up practice entirely, except in consultation. - By this time, William had rallied again-and he began to sit up daily, keeping his room. But as a successor to his old friend, must, one time or other, be made choice of, this was thought a favourable season to effect the change, and after a little deliberation, Mr. C. was written to, and paid him two visits-he did not see it necessary to continue his visits, but desired that he might be informed how William went on.-Progress appeared to be steady, though slow - and by the week end, he sat up from about I I o'clock, till between 9 and ro in the evening. Apprehension was now abated, but not anxiety, for the attack was unusually severe, and the weather very cold, so that the most watchful care was needed.-Still, he appeared to gain ground, adopted his usual mode of procedure when confined upstairs-and occupied himself with reading-pacing the room at intervals for exercise. The household custom of reading a portion of the Scriptures was also again resumed. - Several of Robertson's Sermons were read aloud, about this time-and on Sunday, the 7 th of December, one of them was read after prayers, in the forenoon.-He kept the New Testament beside him, and his private reading during this time was some of the Epistles-he was last reading the first Epistle of St. John, where he left his book-mark.- He read the Newspapers with his usual interest -at this time he likewise read "Wordsworth, a Biography," by Paxton Hood, lent to him by his friend Mr. Lee, to whom he wrote on the I Ith, thanking him for the pleasure he had given him, and added, "as our friend Mr. Graves has not seen it, I trust you will be kind enough to allow me to lend it to him, for a week or two.- I am glad to observe in your Paper, lately, some good original articles, and able correspondence.-Some of your readers will have no doubt as to the writer of the amusing Letter on the weather, signed 'Phiz.' "

Some parts of the Biography had been very interesting to William, and in commenting on that part, where (copying from Canon Wordsworth) the Author introduces a letter written by Mr. Graves, he dwelt with interest on the fact there related, as throwing light on an obscure passage in Wordsworth's grand Ode, and taking up the words at the part referred to, he went on, repeating it to the 
end.-His brother Thomas came many times to see him, and this week he staid once or twice and took tea, which both gratified and cheered him-two or three times he brought a little game with him, and every incident of the day's sport was talked over by the brothers, and the birds greatly admired-particularly a Woodcock-the feathers of which William stroked almost lovingly, praising its beauty with his wonted enthusiasm.

On Saturday, the i $3^{\text {th }}$, he rose as usual, sponged and was rubbedbut towards 2 o'clock a great shaking seized him, and a feeling of chilliness. Such means as approved themselves were promptly used, but he objected to have Mr. C-

In the evening, the Kendal Mercury, and a book-parcel arrived;he listened to the reading of such parts of the Paper as he indicated, and named on what page each would be found. He then asked to have the parcel opened, and said which book he would like to have read-it was one of Goethe's; but it disappointed him, and after a while it was laid aside-C-On Sunday morning he felt relieved, and still objected to have Mr. C. sent for, but he consented to keep his bed. In the afternoon, his brother Thomas came about 3 o'clock, and sat with him till 7-they chatted together, and he enjoyed his company. He had a comfortable night, and felt so much as he had done before, that he got up about the usual timehe did not omit sponging, but whilst he was being rubbed he said "be quick," and repeated this. He was dressed speedily, and then seated himself in front of the fire. He read a littlebut the same sensations again came over him, and about the same time as on Saturday.-Still he could not be prevailed on to have medical advice-but Mr. C. was written to, and asked to come on the morrow-during the night fever increased alarmingly, when Mr. C. was sent for, but before he could arrive the crisis had passedthe cough had become short and faint, expectoration had ceased, and he had fallen asleep.-He told Mr. C. that during the night he had been conscious of a great change, and that he knew what it indicated: yet after his departure, William had strength to get up and walk across the room; and then back again, and to get into bed; and later, he had his desk brought, and wrote some memorandums. His strength then ebbed rapidly, but his mind was clear to the last, and the settled peace, which, as an every-day presence, bore him upward, imparted an expression of sweet, angelic beauty to his countenance.-Purely for the solace of affection, a few precious words were elicited from him,- - he expressed "his unshaken trust in God, and his hope of Immortal Life."-His breathing was as quiet and regular as that of a sleeping infant -but ever fainter and fainter.-Towards sunset, there was a 
brightening in the sky, to the West--he seemed to observe it, and turned his face to the window, and then directing his eyes as before, he moved not again - and as that day's light departed, most gently did his guileless Spirit "Issue out of life, at peace with God."

His funeral took place on the Friday following, and in accordance with the pious usage not yet obsolete in the neighbourhood, a psalm was sung at the door, before his body was carried out by near relatives, who bore it as far as the boundary gate of Borderside Farm, and as the Church was approached, this office of affection was resumed, and by those near to him, his body was borne out of the Church to the grave.

Part of a letter addressed to his Widow, by a dear friend of his and hers, will conclude this Memoir.-" For myself, the picture of himself, his life, his home in your quiet valley, is one of those in the picture-gallery of my life's experience, which I dwell on with reverential pleasure, and I was going to say, it is sore to me to miss the figure of the dear, venerable old man, with his beautiful intellect and nature, out of it-but that it is not to be missed, the memory of if as it was, is there still, and cannot be effaced-it is only lifted up and glorified, and still linked by a golden chain, to all that remains."

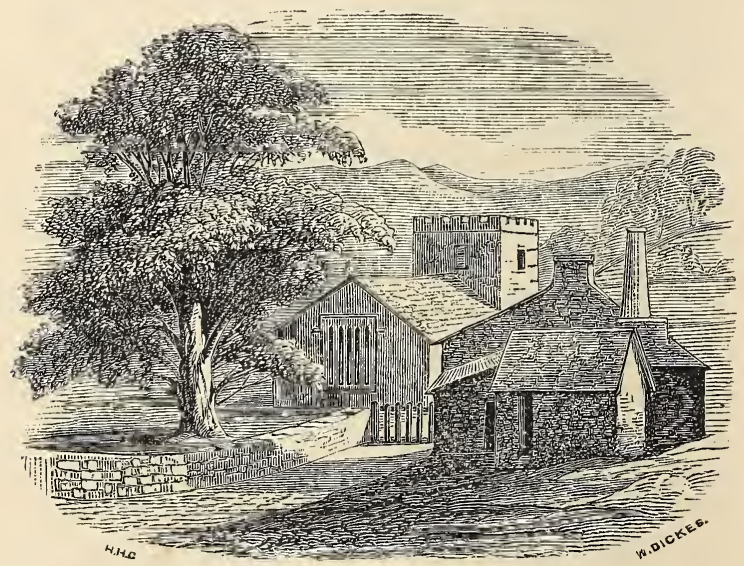

Crosthwaite Church and School-house, in 1825. 


\section{LINES}

IN MEMORY OF

W I L L I A M P E A R S O N

OF BORDERSIDE, CROSTHWAITE.

DEAR Vale of Winster! oft my heart

On vagrant pinion flies to thee;

For dear thou canst not cease to be

For what thou wert, for what thou art.

The road that takes along thy side

By copse and fell its windings sweet,

And pauses here and there to greet

Thy brook with all a sister's pride,

Leads on to where a gentle height

Uplifts towards the sunny South,

Towards the valley's widening mouth,

A cottage-home of aspect bright.

Red roses flush its native stone;

The grassy slope, the rocky mount,

Are gay with flowers; a shadowy fount

Murmurs with cool delicious tone;

Beneath, an orchard far and wide

Its blossom or its fruit displays;

Across the valley friendly rays

From neighbour-homes hail BORDERSIDE. 
How oft within its porch we've met

The welcome true of eyes and voice, That made our inmost hearts rejoice In moments they can ne'er forget !

And soon we gain'd our wish'd-for bound, The room so simple, so refined, Where flowers of earth and flowers of mind, Posies and poems, breathed around.

And when our cheerful meal was o'er, A meal which Friendship seem'd to bless, And elegance and homeliness, With charm we scarce had known before,

How swiftly flew the hours away,

As thought and feeling, deeply stored

By mind and heart, all forth were pour'd, In loving faith and lively play!

'Twas thou, calm sage of Winster Vale, My Pearson, with thy lofty brow

As marble smooth and fair, 'twas thou Whose breeze-like spirit filled the sail

Of our glad barks, whose flashing eye, And keen keen smile of arch delight, With lustre of their own made bright The riches of thy memory.

How pleased we listened to thy words

That told in careless eloquence

Of English pure, without pretence,

Choice histories of dogs or birds, 
Of Nep or Camel, ponies rare,

With genial humour fraught and love

And reverent sense of Him above,

Whose goodness fills the earth and air;

Or travel's gatherings in the land

Where Lucerne's lake and Alpine heights,

And Freedom's memories and delights,

Rejoiced thy soul, while close at hand

Moved She, who late had blessed thy bower,

And thou o'er passes mad'st thy way,

And read'st on rocks inscriptions gray

Carved by the Glacier's grinding power.

Nor thine thy native haunts to scorn;

Scawfell thou lov'dst and Windermere;

Yea, near thy home, in Winster dear,

The rocks for thee were glacier-worn.

How like the wind-harp's surging strain

Arose full oft in words of song

Thy murmured voice, and pour'd along

The music of thy heart and brain:

Some passage that had fed thy life

From Wordsworth's lov'd and honour'd lays ;

His passionate Lines in Nature's praise,

His Ode with Childhood's glories rife;

Some vigorous gush from Burns' wild heart,

As glow'd with love his being's whole;

Some verse from Shakspeare's wondrous scroll,

Or Milton's high harmonious art. 
And deepest thoughts were thine; for still

Thy questioning spirit would explore

The abyss of philosophic lore,

And search for truth with fearless will.

Yet God was ever at thy side;

His love, His word, were dear to thee;

And faith, and hope, and charity,

The blessed Three that aye abide.

No more in Winster's Vale thou'rt seen :

By Crosthwaite's Church thy cherish'd form

In peace reclines, where sun-beams warm,

And spring-flowers cheer, the turf so green.

The robin warbles at thy head,

Percht on the fond memorial stone;

And Gilpin's tuneful voice is blown

In fitful music round thy bed.

There, when a year was past, we stood,

Three friends, with Her who lov'd thee best,

And felt that grief could sink to rest

In thinking of eternal good.

How beauteous was the world to thee,

How full of glory and of God!

Here, save that sin the pathways trod,

Thou still had'st been content to be.

For new delight was ever thine

To track thy Maker's hidden skill,

To learn that deeper deeper still

Beneath thee spread the boundless mine. 
Yet doubt we not that now thine eyes New glories charm, new Nature lives Around thee brighter still, and gives Fresh marvels, ever-new surprise.

While freed for aye from sin's annoy Thy soul expands; in glowing youth

Drinks purest sireams of love and truth, And worships God with ceaseless joy.

"For what thou wert, for what thou art;"

O Vale of Winster! from thy banks

A light has gone; but love and thanks

Shall ne'er from Borderside depart,

As long as hearts that knew his worth, And Her's, not less in our esteem, His widowed star of milder beam Shall linger in this nook of earth.

\section{DOVENEST, WINDERMERE,}

R. P. G. 1862.

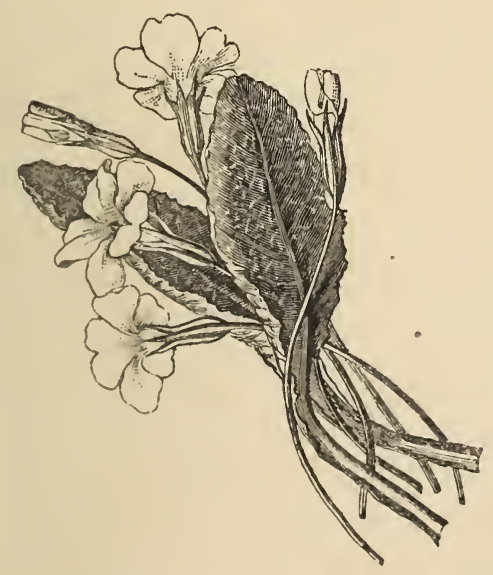





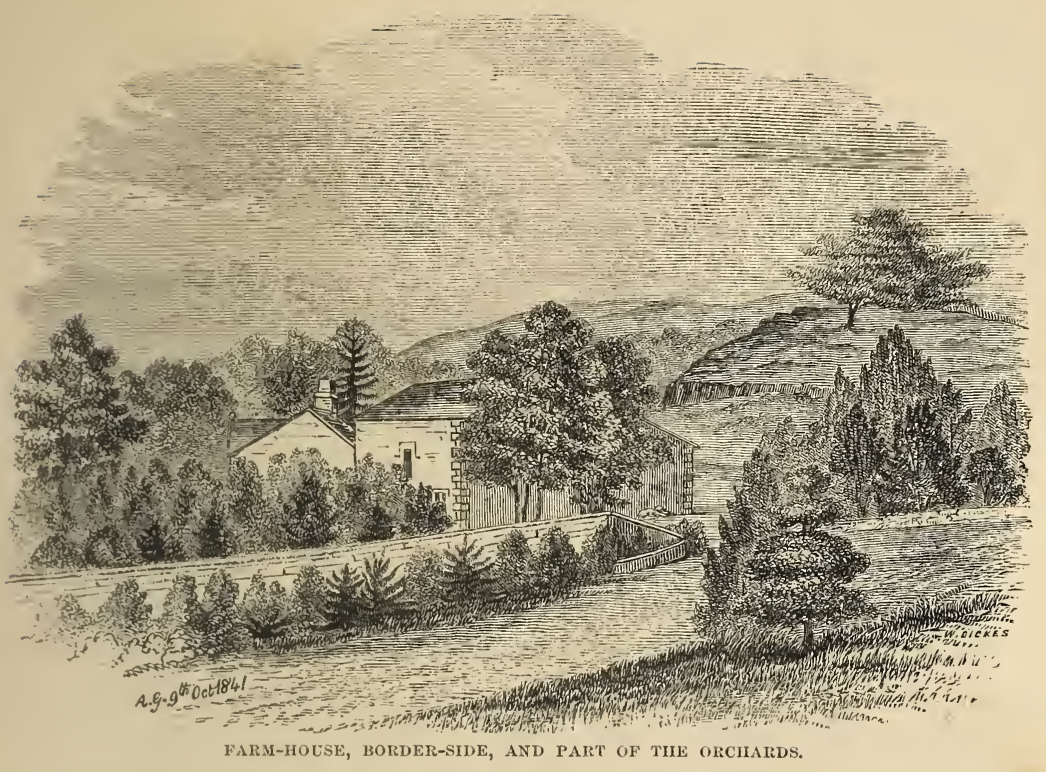

SKETCII OF SOME OF THE EXISTING AND RECEN'Y SUPERSTITIONS OF WESTMORLAND.

Read to the Kendal Natural History Society, Feb. 8, 1841.

BEFORE we proceed to the more immediate object of this paper, perhaps it may not be improper to make a few remarks on the subject of superstition in general.

As superstition arises from ignorance and credulity, so it has also a seat in the passions. Fear has been commonly considered as the passion of the human mind from which it chiefly derives its origin, and there is no doubt that more superstition has arisen from fear, united with ignorance and credulity, than from any other passion. Yet it would certainly be improper to exclude all other mental affections. Ve cannot account for the superstition of the Egyptians, without supposing that much of it arose from gratitude. They worshipped the Nile, because it distributed fertility and abundance over the land of Egypt; and they worshipped some animals, merely because they prevented the increase 
of other animals which were noxious. Thus, they adored the ibis, because it destroyed the eggs of the crocodile.

It would seem that the idea of superstition, always supposes the belief in supernatural power. It respects Grod, and beings superior to man, and extends to our religious opinions, worship, and practices, and has been defined, "absurd opinions and actions, arising from mean and defective ideas of the moral attributes of God." If this be a correct definition, it will be easily seen what a large field of inquiry opens before us, and that there are many opinions and practices connected with the different religions of mankind, not even excepting those of many professed Christians, which may be fairly described as superstitious; but I have no wish (even if I were capable) to enter upon so extensive an inquiry: besides, it would infringe one of the rules of our institution.

In addition to those superstitious opinions and practices which entirely respect our duty to God, there are others, which may be termed "Vulgar Superstitions." It is to these that I presume to direct your attention on the present occasion. These also arise from imperfect and mean ideas of the moral attributes of Grod. To believe vulgar prophecies, which are always the effusion of madness or knavery, is to suppose that God, who has drawn a veil over futurity, sometimes gives the power of prophecy for no purpose at all, or only to gratify idle curiosity, or to disclose such a knowledge of what is to happen, as is inconsistent with the free agency of man, and the moral administration of the world. Nor is it less superstitious to believe in vulgar miracles. To believe in them, is to believe that God suspends the laws of nature for the most trivial purposes; it is to receive the most extraordinary facts upon the most unsatisfactory evidence. The belief in witchcraft, in apparitions, and the second sight, may be resolved into the same principle. To suppose that God would communicate the power of doing mischief, and of 
contravening His laws, to any beings merely for the purpose of gratifying their own passions, is unworthy of that great and good Being. The same objection rises against the belicf in vulgar prophecies, and may be extended to omens, to things lucky or unlucky, to fortune-telling, \&c. As to the different devices and charms for the prevention and cure of disorders, they resemble, in every respect, false miracles.

A judicious history of superstition would be a curious and entertaining work, and would exhibit the human character in a remarkable point of view. Superstition is most prevalent among men of weak and uncultivated minds, and abounds more in the rude, than in the refined stages of society. The general features of it have been the same in all ages; but it assumes certain peculiarities, according to the diversity of character in different nations. It gained admission into the science of medicine at an early period. He who was endowed with superior genius and knowledge, was reckoned a magician. Dr. Bartolo was seized by the Inquisition at Rome, in the last century, because he unexpectedly cured a nobleman of the gout. Diseases were imputed to fascination, and hundreds of poor wretches were dragged to the stake for being accessary to them. Mercatus, physician to Philip II. of Spain, a writer, it is said, of uncommon accuracy and information, appears strongly inclined to deny the existence of diseases produced by fascination; but he is constrained to acknowledge them for two reasons, first, because the Inquisition had decided in favour of their reality; secondly, because he had seen a very beautiful woman, break a steel mirror to pieces, and blast some trees by a single glance of her eyes!

As the opinions concerning the cause of diseases were superstitious, those concerning the cure of them were not less so. Josephus relates that he saw a certain Jew, named Fleazer, draw the devil out of an old woman's nostrils, by the application of Solomon's seal to her nose, in the presence of the Emperor Vespasian. Many different kinds 
of applications were used for expelling the devil. Flagellation sometimes succeeded admirably; purgatives and antispasmodics were other modes of discharging him. Dr. Mynsight cured several bewitched persons with a plaster of asafœtida. How the asafœtida was efficacious was much disputed. Some thought the devil might consider so vile an application as an insult, and run off in a passion; but others very sagely observed, that as devils are supposed to have eyes and ears, it is probable they may have noses too !

Though superstition be generally the mark of a weak mind, such is the infirmity of human nature, that we find many instances of it among men of the most sublime genius, and the most enlightened minds. Socrates believed that he was guided by a demon. The eloquent and learned Bishop Jeremy Taylor was a firm believer in witchcraft-even the most absurd particulars relating to it, as may be seen in his "Holy Living." So was the philosopher Bacon, and so was the enlightened Cudworth, who called those who opposed the belief in witchcraft, by the name of Atheists. The predictions of Rice Evans, it is said, have been supported within the last hundred years, by the celebrated names of Warburton and Jortin. Dr. Johnson, the leviathan of literature, is supposed to have believed in the second sight.

Perhaps it may be thought, that, to an enlightened audience, it is a needless task to dwell upon the evils of superstition, and that unnecessary pains have been taken in pointing out its absurdities. Certainly, as it exists at present, it is probable that it has a beneficial tendency rather than otherwise; it may be called the religion of the uncultivated mind. Now religion is native to the soul of man. There is no nation or people, however low in the scale of civilization, which has not some ideas of religion or of superstition; and as they both imply the belief of supernatural power, they may, in this respect, be considered as nearly allied. Is not any religious or superstitious 
belief, more elevating to the soul of man than complete apathy, or a belief in nothing but what is apparent to the senses, that is to say, atheism, practical, if not theoretical? Here it may be asked, "What! is idolatry more beneficial than otherwise?" But may there not be great misconception as to this certainly imperfect manifestation of the religious principle? It is very improbable that the most stupid human being, should worship the mere materials of his idol-wood or stone. Can the human mind, the reasoning faculty, ever be so far degraded? May it not rather be supposed, that the image, the work of his hands, is the mere symbol, the visible shrine through which he strives to embody and make apparent to his senses, that invisible and supernatural power which he in reality worships? But, leaving these speculations-still, perhaps, it may be contended, that superstition, as it exists in our own county, and in our own age, may be generally beneficial. A spectre perhaps appears to point out some hidden treasure! What harm in this? Or the ghost of some departed husband is seen by his disconsolate widow, who mourns his loss, and like Rachel, refuses to be comforted. The supernatural guest is considered a messenger to abate her grief-to induce her to submit to the will of heaven-and to attend to her duties to herself and to their common children. This is eminently beneficial. And then the belief that the ghost of a murdered person will constantly haunt the murderer. What can be more salutary than such a creed, especially to a poor creature who has no principles of religion, who has never been taught any? How many lives may not this superstition have prescrved! But this subject has been finely treated by our great living philosophical poet:-

" $A$ nid those illusions, which excite the scorn,

Or move the pity of unthinking minds,

Are they not mainly outward ministers

Of inward Conscience? With whose service charged. 
They come and go, appear and disappear;

Diverting evil purposes, remorse

Awakening, chastening intemperate grief,

Or pride of heart abating ; and whene'er,

For less important ends, those Phantoms move,

Who would forbid them, if their presence serve,

Among wild mountains and unpeopled heaths,

Filling a space else vacant, to exalt

The forms of Nature, and enlarge her powers?"

Agreeing cordially with the poet, that superstition is by no means an unmixed evil, and recollecting my task to concoct an essay on our existing superstitions, I am somewhat dismayed when I come to survey my scanty materials. Nor do I pretend to give a complete view of Westmorland superstitions; but merely to note down a few that have come under my own observation, or such as I have received from credible authority; but when it is considered that my experience has been confined to the neighbourhood of Kendal, and that old opinions (and what is superstition but an old opinion?) lurk and linger longest in the most retired situations, it is almost certain, there will be not a few that have escaped my notice, and may reward the gleaner in our more secluded dells. It is no easy matter, and requires some tact, to become acquainted with the amount of superstition actually existing. Expecting little sympathy, the superstitious are shy and uncommunicative. So far from being hypocrites, they do not even boast of their faith, but rather conceal it within the sanctuary of their own bosoms. It was no doubt different in former ages: the high and the low, the learned and the ignorant, were then much on the same footing. If we could imagine the Kendal Natural History Society to have flourished some two or three centuries ago, in the reign of good Queen Bess, or bluff King Harry the Eighth; or if a conjuror's wand could remove the whole of its members for some brief space, say two or three hours, into that age of 
implicit faith and simple wonder; then, instead of addressing an audience of, I fear, incredulous sceptics, if not of downright infidels, my hearers would have been all staunch believers, myself perhaps the most orthodox of all ! And then what copious and rich materials for composing a paper on the popular superstitions! There would have been witches and their familiars, disguised demons-all believed in to be true "as words from Holy Writ." Then what stories of ghosts and hobgoblins!

\section{"Chronicle of fiends}

Strange and uncouth, dire faces, figures dire, Sharp-kneed, sharp-elbowed, and lean-ankled too, With long and ghostly shanks-forms which, once seen, Could never be forgotten;"

enough to make quail the stoutest hearts-to set the hair on end "like quills upon the fretful porcupine." But there would also have been matter of a pleasanter description.

There would have been that merry imp, Robin Goodfellow, with all his pranks and wiles; dropping a sixpence into the shoe of the cleanly and tidy maiden-while the slut or the slattern, he would pinch her black and blue Then there was that industrious fellow, Hobthrush-

"The goblin sweat

To earn his cream-bowl duly set,

When in one night, ere glimpse of morn,

His shadowy flail had thrashed the corn

That ten day-labourers could not end;

Then lies him down, the lubber fiend, And stretched out all the chimney's length,

Basks at the fire his hairy strength;

And crop full, out of door he flings

Ere the first cock his matin rings."

But, above all, there would have been those diminutive good people, the fairies, clothed in green, and dancing by moonlight. What beautiful poetry one might have 
quoted about them, from the old poets! Nor must I forget to mention that awful character, the necromancer, the astrologer, or the wiseman, who, from the starry influences, could foretell the fate of kings and empires. Oh, but it would have been easy at that time to have worked up a showy and entertaining paper! And now, of all the splendid array of visionary beings that once made part of the popular creed, how many remain to this day? Very few indeed! To be sure the drunkard will sometimes see blue devils, but teetotalism bids fair even to extinguish them! Ghosts and hobgoblins are become as rare as snow at midsummer! And as for witches, they are very scarce indeed! I never knew but one old woman who had the credit of figuring in that character. So far has the popular belief changed in this respect, that it is now generally imagined that, instead of the old, it is the more youthful and beautiful portion of the sex that are found to be the most mischievous of all witches! As for Robin Goodfellow, Hobthrush, and the Fairies, they are all gone-utterly vanished-

"They live no longer in the faith of Reason."

And as for a wiseman, I verily believe, if we sought from Stanemoor to Cartmelfell, and from Eamont Bridge to Storth, it is some hazard whether a single one could now be found in all Westmorland! Indeed, it must be confessed, that from the progress of science and literature, the number of newspapers, magazines and other periodicals, to say nothing of penny postage, which has hardly had time to work; but above all, of that gigantic power, steam, and its application to land and water carriage, and the consequent intercommunion and diffusion of knowledge, we are become so very enlightened, that there is scarcely any superstition left. So that it fares but ill with the unlucky wight, whose task it is to get up a tolerable essay on 
Existing Superstitions, and he too may be ready to cry out, that "he has fallen upon evil days; and been born in an age too late."

But it is time that we should set about seriously, to pick up what scanty gleanings may yet remain from a once plentiful harvest.

The existing and recent superstitions of Westmorland, may be chiefly comprised under the following heads; viz., uulucky days, charms for the cure of diseases, belief in quackery, fortune-telling, omens, ghosts and apparitions.

There are few country people who will begin any important work on the Friday. If hay-making or the corn harvest begin on that day, it will have an unfortunate ending-it is an unlucky day. There is another superstitious belief, though not so common as the one just named, which is, that if, on going a journey, the first person you meet be a woman, the business on which you are going will not succeed. It is an unlucky omen! No very gallant superstition certainly! I know an aged female, who was in the habit of attending the market at Kendal for a number of years. She used to say, when the market was flat, "Ay, I knew I should get a bad price for my butter to-day, for the first person $I$ met in the morning was a woman!"

I believe the owl and the raven were considered birds of evil omen in former ages. I have, however, never heard that they are so deemed in our district. Yet the magpie still retains its reputation as an ominous bird, but chiefly, I think, among the boys. Anybody almost, recollects the old distich, that says-

One is a sign of sorrow, two betokens mirth,

'Three foretells a wedding, and four is a sign of death.

The angler, if he see a couple of magpies in a morning, thinks it is a sign he will have good sport, which has been thus explained; magpies are seen flying about most 
frequently in the genial warm mornings of spring, when the weather is most favourable to good fishing. It is to be remarked that, according to the aforesaid distich, mirth is more frequently foretold than sorrow or death; for we don't often see one or four magpies, whilst, from the circumstance of their going in pairs all the year, the sight of two is of frequent occurrence. But if a single bird, or what is worse, four together should cross the path of the rambling boy, there is luckily a charm to counteract the evil portent. He immediately spits over his little finger upon the ground, and makes the sign of the cross over the place with his foot, repeating the following incantation:-

Magpie, I defy thee ! Magpie, I defy thee !

I've crossed thee out; harm can't come nigh me.

It would hence appear, that this superstition must be at least as old as the sway of the Roman Catholic religion in England.

It will sometimes happen that a cock will crow in the night. This is often considered, perhaps from being an unusual circumstance, as ominous to the family. A few years ago $\mathbf{I}$ had a servant, an elderly man, who was much disturbed, because the cock took it into his head to crow in the night-time, frequently before we went to bed. Whenever this was the case, it was perceived that it threw him into no small perturbation. He was afraid that either death, or some great calamity would occur to some of us. And what was indeed curious, a female to whom he was much attached, did indeed die soon afterwards : so that, no doubt, he is more than ever confirmed in his belief.

So it is also believed by many, that the howling of a dog indicates the death of some one of the family. It is indeed difficult to conceive what induces this sagacious animal to utter those wild, melancholy wailings; but to those who have heard them in the deep silence of night, at a solitary farm-house, it will not seem wonderful that in the super- 
stitious mind, such mournful sounds should create terror; and there really does seem to be more in this howling of dogs, than philosophy can easily find out, if we may believe the singular relation read not long ago, before the Zoological Society of Dublin, by the Rev. Cæsar Otway. The account is curious, and apparently well authenticated, for the writer says the truth of it can be attested by more than fifty persons.

[The account is too long for insertion, the closing paragraph alone will be given.]

"I tell what I believe to be true, and without drawing any superstitious or supernatural inferences from it, I can only conclude, that there may be communicated to the acute senses of dogs and other animals, as for instance, to ravens and magpies, evidences of approaching dissolution, which to us are inexplicable, and that there may be in Heaven and earth, "things not dreamed of in our philosophy."

Mankind have in all ages been very desirous to lift up the veil of futurity, particularly on that important point, matrimonial connexion; and many are the superstitious practices that have been used in the hope of attaining that purpose. We all know what a humorous account the poet Burns has given of these superstitions, as they prevail in Scotland. I am not aware of the existence of any in our district, except simple fortune-telling. About some ten or a dozen years ago, a horde of gipsies passed the winter in Crosthwaite, encamping in the open air during a very severe season, according to the practice of those singular vagabonds. There was one old sybil that reaped a plentiful harvest from the credulity of our lads and lasses-distributing most excellent rich husbands and wives, in exchange for a few paltry shillings and half-crowns.

'There were ceremonies, however, in use not long ago, of' a rather awful nature, which, for those who had the courage to use them, were said to yield the desired information without any pecuniary outlay. One was, to walk back- 
wards round a church three times on a certain night in the year, and then sit down in the porch, when the ghost of the intended husband or wife would pass before them; but if they were unfortunately not destined to enjoy the happy state of wedlock, then, how awful! they would see the apparition of a coffin! I recollect, when a boy, hearing an old man aver that he had gone through this trying ordeal, and that the apparitions of his two wives had passed before him, in the order he afterwards married them! But to walk round the sacred edifice backwards, and over the graves of the dead at the silent hour of midnight, " 0 " night's black arch the keystane," certainly shows great hardihood in the superstitious mind, or a most keen desire to pry into the secrets of futurity.

There is a method of divination that is, or at least, has been, used in Westmorland, not to become acquainted with events closed up in the womb of time, but to ascertain, when a robbery has been committed, who is the thief; at least, it was for this purpose that $I$ have known it used. It is a kind of conjuration by the use of the Bible and key. The key most likely a symbol, by which, with the aid of the Sacred Book, it is attempted to unlock the mystery which closes the secret from the knowledge of the uninitiated. I have heard of this rather profane practice being used in one or two instances. The method is this: Take a small Bible, betwixt the leaves of which, place a large key-large enough to project at both ends of the book: then the conjuror takes them in his hands, placing the ends of the key against the tips of his fingers, he repeats a few verses from the beginning of the second chapter of Solomon's Song: he afterwards says, If such a person, naming him, stole my goods or money, then Bible and key turn. If he name an innocent person, of course the Bible and key remain steady betwixt his fingers! But he goes on, mentioning two or three more, perhaps, before he hits on the name of the veritable thief- 
but so soon as he does name him, lo! the Bible and key turn, or rather slip from his fingers, betwixt which they are only loosely placed, and can be easily turned aside by the operator. It is to be hoped this kind of conjuration is not practised now-a-days, though we recollect an old man in our neighbourhood, who had used it, and professed undoubted faith in its efficacy, as a means of unmasking the thief.

There was another mode of detecting thieves, and of coming to the bottom of other occult matters, which was practised formerly-indeed, within the time of our remembrance-this was, going to consult the wise-man, as he was called.

The only wise-man that we recollect, was the renowned Isaac Atkinson, whom the village of Beathwaite Green claimed as an inhabitant, if not also as having had the honour of giving him birth. Isaac was a man who had attained some knowledge of mathematics, and, in the lauguage of the poet,

\section{"Could foretell}

By calculations sage, the ebb and flow

Of tides, and when the moon would be eclipsed,"

so at once the country people dubbed him a magician; and he, poor fellow, not being overstocked with worldly wealth, thought there was no great harm in taking advantage of their credulity. His fame was certainly very great, not only as a detector of thieves, but also in other recondite matters of a more awful nature. If the farmer's churn, notwithstanding the most strenuous and long-continued efforts, refused to yield its butter, it was clear there was something amiss - it was strange-it was unaccountable-it had not happened before-it was well if there were not something " uncanny"-it was not unlikely that the churn was bewitched! but they would know if they went to the wise-man. So off they would set to consult 
Isaac Atkinson! All this may appear very improbable as occurring in any corner of England in this enlightened age, as it is called, but nevertheless it is strictly true; and what I am stating actually took place, not many years ago, at a farm-house, not half a mile from the writer's homestead. The wise-man, when consulted, no doubt looked very grave, as wise-men are expected to do; and thus was the response delivered: That, to be sure, the churn was bewitched, but that he would teach them how to defeat all the witch's cantrips. "You must go home," said he, "and beat a large fire, shut the house door, and mind you keep it fast. Stop up every hole and cranny, through which the wind can enter; then renew your efforts at the churn-you will get butter this time." $\mathrm{He}$ continued, "As the fire kindles and burns, the witch will grow very uneasy; by and by, she can hold out no longer, she will come to the door, she will wish to come in-but don't let her, by any means." 'This is the story the man told when he got home. The fire was lighted, every little hole stopped, and the bewitched churn re-attacked with fresh vigour. Butter was at length produced, but, as may be supposed, the witch did not appear. Here it may be remarked, in proof of Isaac's sagacity, that this bewitching of the churn took place in a frost-that he was wise enough to know that warmth is necessary to the process of churning, and hence his ordering a large fire and the closing of the doors, \&c.

We have it from Shakespeare, that "there is a soul of goodness in things evil," and most assuredly a superstitious belief sometimes works beneficially; as, for instance, in the following curious circumstance, which was related to me by a country clergyman, as occurring within his own experience. It happened that the mistress of the house, at Ambleside, where he was boarded and went to school, was seized with a dangerous illness, and confined to her bed. During the time she lay sick, a five-guinea 
bank-note was missing from a drawer in her bed-room. There was no doubt but it was stolen, and suspicion at length fastened on a woman, a neighbour, who was in the habit of going to see the sick person. It was not thought proper, however, to tax her with the theft, nor to procure a search-warrant, nor to adopt any method likely to hurt her feelings, and which might be insufficient, after all, to prove the theft, or to effect, what they much rather desired, the restoration of the stolen property. So it was given out with all due importance, that the master of the house intended to apply to the wise-man. When the suspected woman heard this, it was noticed that she showed a good deal of uneasiness-asking when he intended to set out, and expressing her wonder whether the wizard knew anything about such matters. It may readily be supposed that great confidence in his deep-searching wisdom was avowed. When the important morning arrived that the uise-man was to be consulted, the master got up early, and set off before it was light; but instead of wending his way to Beathwaite Green, the far-famed seat of the oracle, he turned down the lane to Skelwith, where he remained all day with some relations, returning at nightfall. Now, although he did not consult the wise-man, yet the mere report of his being gone on that awful business, was sufficient to bring back the money. When the woman came as usual to visit the sick, she was left alone in the room. On examining after she was departed, it was discovered that the bank-note had found its way back into the drawer, from which it had taken its mysterious journey. Such was the beneficial effect of the fear of the wise-man.

It is well-known, that in ancient times, charms and incantations were much employed as a means to cure diseases. There are certainly relics of this superstition remaining in Westmorland. Perhaps some of my hearers, may have heard of persons who profess to cure burns and scalds by 
repeating certain words, or using what is properly called a charm. A person in my neighbourhood, who fills a rather respectable station in life, for he is a landlord and shopkeeper, is said to be a master of this easy and expeditious mode of surgery. A few years ago, a child at a farm-house in Cartmel-fell, happened to fall into the fire and get seriously burnt. One of the women assembled on the distressing occasion, proposed to send for the charmer. It was objected that he would perhaps be unable to come. "Oh," said another, "that is of no consequence, for he can cure it equally well by repeating his charm at home, whether he see the child or not." Very likely he could, you will think, but not exactly according to the simple woman's meaning. It is perhaps scarcely necessary to state, that in this case his charm had unluckily lost its virtue, and the good folks were obliged to send for a regular, common-place surgeon, before a cure of the poor child could be effected.

There is a charm also used for taking away those troublesome excrescences, warts, that one might think was not likely to be more efficacious than the one just mentioned. The affected person collects as many small stones as he has got warts, wraps them up neatly in paper, and goes to a place where four roads meet, throws the parcel over his shoulder, when it is supposed the unlucky wight who picks up the parcel, will have the said warts transferred forthwith to his own fingers. I confess that, when a boy, I was so unprincipled, to say nothing of the folly, as to make use of this charm, and sure enough, the offending warts took their departure soon afterwards! But why need we Westmorland folks be ashamed of such a superstition as this, when the great Lord Bacon, the prince of philosophers, relates that he was himself cured of warts, by rubbing them with a piece of lard with the skin on, and then nailing it, with the fat towards the sun, on the post of a chamber window facing the sun!

It will sometimes happen that the murrain, or other in- 
fectious disorders will prevail among cattle, carrying off numbers, perhaps, from one stock. When such is the case, it will naturally be supposed that great alarm seizes upon the farmers. The following singular ceremony, certainly in a degree superstitious, is sometimes practised. It is called the Need Fire, and is thought to preserve the cattle from catching the infection. The fire is to be procured by friction from wood that has never been in any house; nor is the fire ever to enter a building-that would entirely destroy its efficacy! The fire is to be raised in the open air, and by means of damp straw, and other materials of a like kind, a thick smoke is to be created; then the cattle are driven through and through, till they are well fumigated. As soon as this is done, a quick-footed messenger is despatched forward with the precious fire to the next farm; here the same smoking takes place as before, and then it is sent forward again; and so on through the whole township, and probably through the entire countyand even through more counties than one; for I know it to be a fact, that the last time we had the Need Fire in Crosthwaite, about seven years ago, it travelled as far as Skirwith, in Cumberland, and probably much farther.

Since the above was written, the Need Fire has again made its appearance. There is at present a rumour of a dreadful epidemic among cattle, which has shown itself in different places in this part of our county, to which it has been coming slowly up from the South, where it prevailed to a great extent last summer. On Sunday afternoon, the 15th of last November, returning from Kendal by way of Brigsteer, when I reached the brow of the hill that overlooks that pleasant village, and from whence there is a glorious prospect, I was somewhat surprised to see in Crosthwaite, two or three large masses of white smoke "rising up like the smoke of a furnace." I thought it was lime-burning, from some kilns that are not usually occupied. But when I reached Crosthwaite, I found 
myself in the immediate neighbourhood of one of these "smokes," which was rising very thickly below the Church Tower. I inquired of a young woman standing in the road, what was the meaning of all this smoke, "Oh," said she, "it is the Need Fire." Well, thought I, much as I have heard of it, I have never seen the Need Fire. I will not miss this opportunity of having ocular evidence of all its mysteries. On reaching the spot, I found the fire burning in the narrow lane called Kirk Lane, within about twenty yards of the Kirk Tower, and about half a dozen cattle huddled together and kept close to the fire, and amongst the smoke, by a number of men and boys standing on each side of them, in that narrow lane. Sometimes they drove them through the fire, and such was the thickness of the smoke, that I could scarcely perceive the actors in this strange ceremony-men and cattle. "So," said I, "you are giving them a smoke." "Yes," replied the owner of the cows, " "we wish to be like our neighbours." "But have you got the real Need Fire?" "Yes, we believe so, it came down Crook yesterday." Now I had heard that it had been at Low Levens a few days before, so that this superstitious fire was evidently moving about in all directions through the length and breadth of the land: nor do they appear to give it any rest, even on Sundays !

Yet it seems to me far from certain that this smoking of cattle may not after all, be of some efficacy in protecting from infection. That the nature of infection is very mysterious, is, I believe, confessed by the most learned and skilful physicians. I happen to know myself that letters coming from Smyrna and other parts in the Levant subject to the plague, are fumigated, so that perhaps the Need Fire may not be quite so absurd, as in the pride of our philosophy we are apt to think.

I have been favoured with one or two letters on this subject, from one of which, from Mr. Richard Herd, of Howgill, I will, with your permission, give you an extract. 
It is dated November 24th, 1840. "You have, no doubt, heard of a disease going amongst cattle: it was thought the most effectual way to stop the infection, would be to produce the Need Fire. The attempt was made somewhere in Killington, a few miles from Howgill, but it failed because some neighbour had not extinguished his fire, which is quite necessary to insure success! The fire having been produced, it was rapidly handed from neighbour to neighbour: it arrived in Howgill at a very inconvenient time for those who like sleep and warm blankets, for it was midnight; nevertheless, most of the farmers cheerfully complied, and as cheerfully forwarded the fire to their neighbours. A few, whose idleness outbalanced their superstition, remained in bed."

In a late number of the Kendal Gazette, the same statement is made, that previous to the production of the Need Fire in Kqllington, all the household fires were extinguished. This is very curious, as being analogous to a custom among the Druids; we learn from Toland's "History of the Druids," that on the 1st of May, the Druids made prodigious fires on cairns on the tops of hills, which, being every one in sight of some other, could not but afford a glorious show over the whole country. These fires were in honour of Beal or Bealan, by which name the Gauls and their colonies understood the Sun; and therefore the 1st of May is, by the aboriginal Irish, called, "La Bealtaine," or "Beltan," the day of Belen's fire.

Two such fires as we have mentioned were kindled hard by one auther, on May eve, in every village of the nation, as well throughout all Gaul, as in Britain, Ireland, and the arljoining lesser islands; between which fires the men and the beasts to be sacrificed, were to pass. One of the fires was on the cairn, the other on the ground. On the eve of the first day of November, there were also such fires kindled, accompanied, as they constantly were, with sacrifices and feasting. 
The savage nations bowed the head To Gods delighting in remorseless deeds ; Then, in the bosom of yon mountain cove, To those inventions of corrupted man Mysterious rites were solemnized; and there, Amid impending rocks and gloomy woods, Of those dread idols, some perchance received Such dismal service, that the loudest voice Of the swoln cataracts (which now are heard Soft murmuring) was too weak to overcome, Though aided by wild winds, the groans and shrieks Of human victims, offered up to appease Or to propitiate. And if living eyes Had visionary faculties to see The thing that has been, as the thing that is, Aghast we might behold this crystal Mere Bedimmed with smoke, in wreaths voluminous, Flung from the body of devouring fires,

To Taranis erected on the heights

By priestly hands, for sacrifice performed Exultingly, in view of open day And full assemblage of a barbarous host.

A few rude monuments of mountain-stone Survive; all else is swept away.

If, indeed, the Need Fire be a remnant of Druidical superstition, the last two lines must be received with some limitation. Connected with this part of my subject, there is a superstition of so horrible and cruel a character, that I hope it has not been often practised, though I have reason to believe that it has occurred in my own neighbourhood, at two places, within the memory of persons now living, viz., at Fell Side in Crosthwaite, and at Hodge Hill in Cartmel-fell; and what is remarkable, the latter; which is a large and valuable farm, was at the time in the occupation of its owner. It will sometimes occur, from some mysterious cause, that on a particular farm, the young calves cannot be reared-they all die within a few weeks of their birth. This state of things will continue for months; even, sometimes, for a year or two. Now this is a serious loss to a farmer, and naturally causes him a great 
deal of anxiety; and it is after having in vain used all rational means of cure that he can think of, that $I$ have heard of this cruel superstition being practised. A large fire is kindled in the open air, near to the farm-house, and a living calf is placed upon it, and burnt to death! Incredible as it may appear, I talked with a farmer in Crosthwaite, not more than twelve months ago, who confessed that in his youth he had assisted at one of these sacrifices; but he allowed, that so much were his feelings shocked by the moanings and cries of the poor tortured animal, that he could never again assist at such a ceremony. He added, " he did not know whether it was of any use or not!" but expressed no opinion on its folly or its wickedness.

However much we may lament the prevalence of such ignorance and superstition as could induce any human beings, bearing the name of Christians, in this country, and in the nineteenth century, to adopt such a barbarous proceeding, it is not improbable, that we may recognise in it a practice of very remote antiquity, in all likelihood derived from our heathen ancestors-British or Saxon-by whom it might have been used as a sacrifice to appease the anger of some malignant deity. I have, at present, no means of knowing to what extent this superstition may exist in other parts of England, but I am far from believing that our county is more ignorant than others, or that education is less diffused in it.*

* $\Lambda$ propos to this opinion is the following extract, copied from the report given in the Kendal Mercury, of the 30th of August, 1862, of a speech made by Lord Brougham. His lordship said, "It is my bounden duty to state that forty-five years ago, when what may be called the education movement, began, that celebrated committee, the Education Committee, sat in the House of Commons, of which I had the honour to be chairman; at that time we found Cumberland and Westmorland standing very high indeed, in point of education, in comparison with the rest of the country. Cumberland was not so high as Westmorland. Westmorland was the highest of all England, in proportion of the schools, and children going to these schools, to the population of the country. I helieve there was only one country in the world, which was part of Switzerland, that exceeded IVestmorland in proportion." 
In order that my hearers may judge how far some of our Westmorland Superstitions are derived from our Saxon ancestors, I will now give a short extract from Sharon Turner's History of the Anglo-Saxons.

"The charms used by the Anglo-Saxons were innumerable. They trusted in their magical incantations for the cure of diseases, for the success of their tillage, for the discovery of lost property, and for the prevention of casualties. Their prognostics from the sun, from thunder, and from dreams, were so numerous as to display and perpetuate the most lamentable debility of mind. Every day of every month was catalogued as a propitious or unpropitious season for certain transactions. One day was favourable for the commencement of business; another, to let blood, and so forth."

A great book has been said to be a great evil, the same, I think, may be said of a long paper; for there is not only the danger of wearying an audience, but it also limits the time for discussion, not the least interesting feature of our meetings. I will therefore reserve till another opportunity, what I have to say about Quacks and quackery, and the belief in Ghosts and Apparitions, or Dobbies, as they are termed. But, before concluding, I will add one more quotation to which $I$ have had access through the kindness and intelligence of a Kendal lady. It is from Dr. Jamieson's Dictionary.

"Need Fire," says the Doctor, "is fire produced by the friction of two pieces of wood." He gives an account of its being used in Caithness in 1788. After describing the mode of raising it, he adds, "the fire in the farmer's house was immediately quenched with water, a fire kindled from this Need Fire, both in the farm-house and in the offices, and the cattle brought to feel the smoke of this new and sacred fire, which preserved them from the murrain. It is handed down by tradition, that the ancient Druids superintended a similar ceremony of raising a sacred fire annually, 
on the 1st of May. That day is still, both in the Irish and Gaelic dialects called La-beal-tin, that is, the day of Beal's fire, or the fire dedicated to Baal or the Sun."

Here it may be remarked that Caithness is the most northern county of Scotland, and as this superstition prevailed there, it probably still exists in all the intermediate counties between that and Westmorland. Now, as the ancient Britons and the Gaelic tribes had a common origin, and as the latter were never subdued by any invaders, the Need Fire could not have been introduced by them, and may therefore boast of a very high antiquity. We may probably conclude it to be a superstition of the aboriginal inhabitants of this island; that it is a relic of the religion of the Druids; that it is at least 2000 years old, probably much older; and is a striking instance of the longevity of Superstitions, and of the tenacity with which they keep hold of the human mind; this one having survived the Roman, Saxon, Danish, and Norman invasions, the promulgation of the Christian religion, and all the influences of literature and science. 


\section{SECOND PAPER ON THE SUPERSTITIONS OF}

WESTMORLAND.

Read to the Kendal Natural History Society, March 8th, 1841.

In the paper on the Superstitions of Westmorland which I had the honour to read to the Society at our last meeting, I took occasion to dwell on omens, charms, going to consult the Wise-man, \&c., and at some length on the Need Fire. It will be recollected, that from the circumstances of the household fires being extinguished when it was raised, and from its prevailing in Caithness, the most northerly county in Scotland, and the consequent probability of its being a Celtic ceremony, I ventured to draw the conclusion that the Need Fire originated from the superstition of the Druids. If the inference be correct, it must tend to give it an interest and importance that it would not otherwise have possessed. It is true, that in these inquiries we cannot attain to demonstrative evidence, but must, more or less, rest satisfied with that of probability. I will confess, however, my satisfaction is such, from what I conceive to be the discovery of the Druidical origin of the Need Fire, that had I reaped no other pleasure from the writing of these papers, and the preliminary inquiries $I$ have been led into, I should feel myself abundantly rewarded.

I will now mention a few of our superstitions that have not yet been noticed. It is thought by many, that if a pig happen to die a natural death, (pigs don't often die a natural death !) it is very unlucky, being ominous of the death of 
cattle, horses, or some other part of the farmer's stock. I knew a substantial statesman in Crosthwaite, who a few years ago, had a pig which died; he remarked to his servant-man at the time; "I mind little for the death of the pig, if nothing else die!"

In my last Paper I spoke of charms for taking away warts. At the risk of being thought trifling, I will relate a case I have lately been made acquainted with. A young man, whose veracity I do not question, told me that a few years ago he had a great many warts. He tried remedies likely and unlikely-cauterised, rubbed them with a black snail and stuck it on a thorn, with other methods of a like description-still, they only increased and multiplied; they almost covered his hands. In this extremity he was recommended to go to a woman who was said to be able to charm away warts. He applied to her: she took a piece of thread, coiled it into a ring, with which she encircled each wart separately, at the same time muttering her spell. $\mathrm{He}$ offered to pay her: no, that would spoil the charm; when they were gone, then he might give her a trifle. No cure, no pay; that was her motto. At the end of a month, still having his warts, he reproached his friend for having sent him on a fool's errand. His friend looked at the warts, said they had a decaying appearance, and would soon disappear. And so they did, except one, which the Spae-wife, he supposed, had unwittingly not subjected to her charm! I must not omit to mention, that this notable woman lives at the village of Newton in Cartmel.

I have omitted another superstition, which, as it shows great simplicity in the poor dupes, and is sometimes attended with a heavy pecuniary loss, it may be worth while to mention. Some cunning Gypsy or other fortune-telling vagrant, when she meets with a suitable subject, will persuarle him to deposit a sum of money in some hiding-place. It is not to be visited till a certain time has elapsed : and then, by the efficacy of conjuration, or the agency of the 
Prince of Evil himself, who is always supposed to have unbounded wealth at command,- - this hidden treasure will be doubled! I hardly need add, that when the poor dupe comes to examine the deposit, it has disappeared by the nefarious conjuration. It was recorded in the Kendal newspapers, that this trick was played in Low Furness not long ago; and we learn from the same source, that an old man in Cumberland, was, about two or three years ago, defrauded by this notable scheme of $\mathfrak{E 7 0}$, and it is not more than a few weeks since it was mentioned in the Kendal Mercury, that about $£ 40$ was stolen from some poor simpleton, in the northern part of our own county, by this somewhat stale trick.

There are few things more remarkable, considering the general shrewdness of our Westmorland peasantry, in most matters relating to their own interest, than their fondness for Quacks and quackery. If they require the services of a Blacksmith or a Wheelwright, they would think it absurd to employ any one who had not served a regular apprenticeship to these useful trades. But when they are in need of a Surgeon or a Physician, they act on a different principle. Here, the result of laborious study, the acquisition of knowledge gathered from the experience of ages, all go for nothing. It was once believed that the seventh son of a seventh son, was born a Physician, and could cure all diseases! One might think, that something like this superstition lingered among our country people. If a regularly educated practitioner, and a mere pretender to the healing art, but yet who was able to cure a common wound, were to plant themselves in any Westmorland village,-if I were in the habit of laying wagers, I durst venture considerable odds, that the Quack would beat the regular Doctor hollow ! In our Township, from time immemorial, we have always had at least one individual, bearing the dignified title of "Doctor ;" and by this he was known instead of by his Christian name-though to call a person by his Christian name is still 
the good old practice with both rich and poor,-with all, indeed, who have not pretensions to the knowledge of medicine!

Perhaps it may be thought, that this fondness for quackery has no right to be classed under the head of superstitions. I am, however, of a different opinion. Is it not a remnant of the superstitious belief, that disease could be cured by spells, charms, and incantatious, at a time when the Priest and Necromancer, acted as Physician and Surgeon; when the cure was as mysterious as the disease, and the medical practitioner, instead of being qualified by education, was believed to effect a cure by some magical charm? In addition to our domestic Doctors, we have others, who seek us out in our mountain dells and retirements. They may be classed under the head migratory,-birds of passage,-wanderers from place to place, who visit us at uncertain intervals, leave their physic, and don't even stay long enough to ascertain how it may operate. For instance, there is the renowned Dr. Bennett, or there was, - I have not seen him lately, - who calls one day and leaves a bill of cures, and steps in the next, to see if anything be wanted. Dr. Bennett is a worm doctor, and his printed papers contain extraordinary accounts of the expulsion of those noxious creatures, from the minute ascurides, to the grigantic Tape, some of them measuring fifty yards in length, if I am not mistaken. Last winter, no fewer than three of these travelling gentry entered Crosthwaite in a body! A few years ago I was visited by one of these itinerant doctors; he was a tall, genteel-looking person, clothed in medical black, with white muslin neckcloth, and a broad frill to his shirt. He entered the house in a style of easy assurance, that he no doubt meant to be very prepossessing. He had a servant behind, carrying his medicinechest. He announced himself at once, as Dr. Taylor from Whitworth; thinking possibly that there could be no resisting the services of a medical gentleman who had gradu- 
ated at that famed College, and who might even be taken for one of the Professors! We entered into conversation. He offered to cure every disease " that flesh is heir to," and at a very trifling cost! I pleaded, that just at that time I had no occasion for medical services, for I happened to be well in health. Far be it from me to sit in judgment on this Dr. Taylor's medical skill! but this I do know, that he murdered the Queen's English; and that whatever authors he had studied, there was one he had somewhat neglected-Lindley Murray! This gentleman, like most of his fraternity, carried on the war on foot. Indeed, there are not many of them who, like the ancient Britons, slay in chariots. One worthy, it is said, had his winter quarters in the town of Ulverstone; in the spring he took the field, encamping with a party of Potters; at least in the campaign, in which he invaded our peaceful neighbourhood, it was in company with that Nomadic tribe. He used to call himself Dr. Cureall, though verily, Dr. Killall would have been as appropriate! I knew three of his patients, and they all died! Two of these would probably have died without his aid,-but as for the third, with sorrow and indignation I say it, there is every reason to conclude she owed her death to his ministrations. My own opinion, I am aware, ought not to go for much, in a question like this; but it was the opinion of a most respectable medical gentleman at the time. This ignorant Quack sold boxes of aperient pills, which were made from a preparation of Mercury; and, from the influence of the atmosphere, and from long keeping, they had changed to something like Corrosive Sublimate! In justice, however, to the Quack, it must be added, that his pills were in most cases taken with impunity: they were not always fatal,---but then perhaps, they had not been kept long enough!

Endless would be the task to detail all the knavery of these rambling practitioners. But I will go a little further. A few years since, one of them called on a respectable 
statesman in Crosthwaite, and was very importunate to sell him some medicine. The good man assured him they had no need for it, the family were all well,-all save his wife, who was a little ailing, but not much. When the Quack heard this, he pulled out a small bottle, which, he said, was just the thing, it would cure her in no time. So the good, easy man was prevailed on to take it. When it came to be paid for, the price was half a guinea! The statesman exclaimed against the exorbitant charge, and wished to return it. But the Quack would consent to no such thing; he flew into a passion, and pointing to the Government Stamp upon the bottle, swore he would compel him to pay for it-he would bring an action which would cost him a hundred pounds! So to make an end of the matter, the Quack was paid, and the bottle of rather dear physic might teach a lesson; - not to buy medicine again of a travelling Doctor.

A young woman who is housekeeper to a person I know, if she were to believe all these impostors tell her, has had

$$
\text { "all maladies }
$$

Of ghastly spasm

Dropsies, and asthmas, and joint-racking rheums."

One, told her she had an incipient consumption; another, that she had a dropsy coming on; and a third, with submission to my medical hearers, must have been an original genius,-he told her she had got "the windy gravel !" The best of the joke is, that she is a remarkably stout, healthy person.

Perhaps I may here be permitted to qualify an opinion I hazarded at our last meeting; that we had not a single Wiseman in the whole county. A gentleman the other Saturday, at the Board of Guardians, protested against such a derogatory reflection, so far as relates to the town of Kirkby Lonsdale-he assured me that that good town has its IViseman! and that he had lately distinguished himself by a somewhat splendid exhibition of his skill. It may 
probably be recollected by some persons present, that not long ago, a robbery was committed in the Vale of Dent, which beautiful valley is not, I believe, often sullied by crimes of that nature. A Cattle-dealer, having returned from some fair with a large sum of money in his pocket, retired to bed. Some time during the night the house was entered and the whole of his money taken away. When the Drover rose in the morning and discovered his loss, he saddled his horse and rode off to Kirkby Lonsdale for a Wiseman. When the wizard reached the scene of the robbery, whether he discovered some unexpected difficulty I know not, but he requested the aid of another Seer. A messenger was despatched to Leeds or Wakefield, (for the accounts vary,) for another Wiseman. In due time he arrived, and the two sat down in good earnest to discover the robber, or to bring back the stolen money.

In the first place, the long old-fashioned house-table was covered with numerous papers, with astrological signs and awful figures scored upon them. When the simple neighbours went in, there were the two Wisemen sitting at the table, solemn and silent; for they uttered not a word to any one. As soon as it was night, they ordered lights to be placed in every window of the house, and they continued their meditations through the nocturnal hours. It may readily be supposed, that this unwonted and serious robbery,

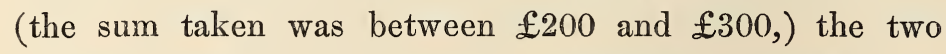
wizards pursuing their midnight conjurations, and the illuminated house, made a strong impression on the minds of the dwellers in this secluded valley, and that there were eyes unclosed by sleep during that awful night. The superstitious fears and guilty consciences of the rustic robbers (there were three of them) seem to have been thoroughly awakened;-for during the first night a pretty large sum was quietly left in the porch,-on the second, another portion of the stolen money was returned, and on

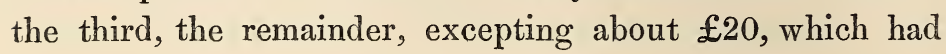


probably been expended before the magical inquiry took place.

Before I give the few details of which I am possessed, relating to Ghosts and Apparitions, I beg leave to read some remarks on the subject, by the late Mr. Briggs. They are contained in notes that he wrote on a publication entitled "Westmorland as it Was," by the Rev. Mr. Hodgson. Some of my hearers will remember the late John Briggs. He was a native of Cartmel, and brought up to the trade of Basket-maker or Swiller. He was a self-educated man, and like all of that meritorious class, had many difficulties to struggle with, on his road to literature and science. $\mathrm{He}$ established the Lonsdale Magazine, and carried it on for three or four years; and ultimately became the editor of the Westmorland Gazette. In his Magazine were many notices on the Manners and Customs, Architecture, Antiquities, \&c., of Westmorland. He was a man of quiet and amiable feeling, and of great disinterestedness of pursuit. The Magazine did him great credit, but I fear yielded him small reward in a pecuniary point of view. There appeared in it some amusing letters, descriptive of the manners and scenery of the Lake district, the matter for which he himself collected. He took journeys for this purpose, and once told me, that the whole of his expenses whilst off, amounted to the sum of $12 s$. ! I hope I shall be pardoned for introducing this short notice of a deserving man.

Mr. Briggs says, - "According to the ancient Sages of Westmorland,-the eldest and best acquainted with the Philosophy of Spirits,-no Spirit could appear before twilight had vanished in the evening, or after it appeared in the morning. Indeed there was one exception to this. If a man had murdered a woman who was with child to him, she had power to haunt him at all hours, and the Romish Priests (who alone had the power of laying Spirits) could not lay a Spirit of this kind with any certainty; she generally contrived to break loose long before her stipulated 
time. The terror of the gallows has not half the effect of this superstition. A culprit may hope to escape the gallows, but there was no hope of escaping being haunted. In common cases, however, the Priests could lay the ghosts. "While Ivy was green," was the usual term. In very desperate cases they were laid in the Red Sea, which was accomplished with great difficulty and even danger to the exorcist. In this county, the most usual place to confine Spirits was under Haws Bridge, a few miles from Kendal. Many a grim ghost has been confined in that dismal trough."

A brother of mine was once sadly frightened at this Haws Bridge. He was returning home on horseback, from some place in the neighbourhood, one fine moonlight evening, and just as he reached the bridge, he saw approaching, a strange bundle-shaped figure-

"If shape it might be called, that shape had none,

Distinguishable in member, joint or limb."

Onward the thing came,-rolling as it seemed on the road. He recollected the haunted bridge. The horse also alarmed, snorted and trembled-but he was determined to stand his ground; and when the odd shapeless mass approached him, he hailed it with "What have we got here?" "It's nobbut me," said a voice from under a heap of sheets and blankets, which were thrown over the head of a country fellow, who it seemed had bought them at an auction, hard by, and was taking them home in this odd manner.

"According to the laws of Ghosts, they could seldom appear to more than one person at once. When they appeared to the eyes, they had no power of making a noise; and when they saluted the ear, they could not greet the eyes. To this, however, there was an exception; when a human being spoke to them in the name of the blessed Trinity."

"The causes of spirits appearing after death were generally three. Murdered persons came again to haunt their mur- 
derers; or to obtain justice by appearing to other persons likcly to see them avenged. In this, however, the spirits secm to have been very foolish, as they mostly appeared to old women, or young men, with old women's hearts! Persons who had hid any treasure, were doomed to haunt the place where that treasure was hid. If any person could speak to them, and give them an opportunity of confessing where the treasure was hid, they could then rest in peace, but not otherwise. Those who died with any heavy crime on their consciences, which they had not confessed, were also doomed to wander the earth at midnight hour. These three causes are all that we have been able to discover among our Westmorland hills."

"Spirits had no power over those who did not molest them; but if insulted, they seem to have been very vindictive, and to have had little compunction for killing the insulter. They had power to assume any form, and to change that, as often as they pleased; but they could neither vanish nor change, whilst a human eye was on them."

Mr. Briggs also gives some curious particulars relating to the old belief, with respect to Wisemen. "They were supposed to have made a compact with the Devil, that he was to serve them, for a certain number of years, and then to have them, body and soul, after death. These Wisemen were such as had spent their lives in the pursuit of science and had learned too much; for conjuration was supposed to be a science which as naturally followed other parts of learning, as Compound Addition, follows Simple Addition. The Wiseman possessed wonderful power. He could restore stolen goods, either by fetching back the articles, - showing the thief in a black mirror,--or making him walk round the cross, on a market-day, with the stolen goods on his shoulders. This last, however, he could not do, if the culprit wore a piece of green sod upon his head! When any person applied to the Wiseman for information, it was necessary for him 
to reach home before midnight, as a storm was the certain consequence of the application, and the applicant ran great risk of being tormented by the Devil, all the way home. The Wiseman was compelled to give the Devil some living animal, whenever he called on him, as a pledge that he intended to give himself, at last. It was common to consider all Schoolmasters as Wisemen : and many an aching heart has the affectionate mother had, lest her darling boy should learn too far." This supplementary information is very curious, as gathered from traditions so lately extant in our mountain districts.

While treating on the subject of ghosts and apparitions, there is one tradition of so singular a nature, and so universally spread through the country, that it cannot well be omitted in a Sketch of Westmorland Superstitions. A certain eccentric Baronet, renowned for the celerity of his movements, died at his baronial mansion in this county, long, long ago; not however, at so remote a period, but that a generation not yet passed away, still remembers the event. Classical in the traditions of his native shire, is this man's name. The Baronet alluded to, was certainly no favourite while living; and the lines of the Poet might be applied to him,

"Full twenty times was Peter feared, For once that Peter was respected;"

So that soon after his demise, the night-wanderer reported strange tales, that he was "come again;" not like a poor plebeian ghost, " naked and shivering," but in a style befitting his former rank and dignity. It was solemnly averred, that he had been met in his coach and four, driving like Jehu, along the lanes near his former Seat; nay more, that like the wild Funtsman in the German legend, he would sometimes amuse himself by careering at midnight, in his aërial chariot, along the dizzy steeps of Knipe Scaur, or Wallow-cragg; a fine rock on the East side of Hawes Water. 
He also played strange pranks about the Hall. I will mention one of them. All the horses in the stables, would sometimes have their skins turned inside out! they were always, however, right in the morning! In short, as the story goes, the folks at the Hall were so teased with his vagaries, that at length they sent for a Clergyman to "lay him;"-but after trying three days and nights, the ghost was found to be beyond his power! A Romish Priest was then employed, who succeeded in laying him under Wallow-cragg, "While streams ran downwards, and hollies grew green."

There is another legend connected with my own part of the country, older than the one last mentioned. I received great part of this story when a lad, from an old man who knew both Dobby Danson and his dog. We will, if you please, call him Dobby Danson, though Danson was not his name. The pleasant appellation of Dobby was bestowed on him, because he was believed to be haunted by a Dobby. According to the story, there was an old Jew Pedlar, who was believed to be very rich, and who, when he came into this neighbourhood, was in the habit of staying all night at Dobby Danson's. At length the Pedlar disappeared; nor was he ever seen after his ill-fated lodging with Dobby Danson. Danson who before this time had been considered poor, soon began to show unequivocal signs of being better off in the world. He bought landed property, and the wonder was how he contrived to pay for it. However, there was a shrewd guess; and it was believed that the Pedlar's wealth, obtained by the most horrible means, had set ul Dobby Danson. By and by it was observed, that wherever he went, he was always attended by a little illlooking, wiry-haired, terrier dog. Tlis was the Dobby! By night or by day, at market or church, at mill or at smithy, -wherever you saw the man, you were sure to see the illlooking terrier. If some, believing it to be a real dog, wanted to handle it, and began to coax it for that purpose, 
it showed its fiendish fangs so fiercely, and its little', piercing, ferret eyes, had such an unearthly look of spite and malice, that they were fain to desist: so that in the end it was believed to be no real dog, but a Dobby, or the ghost of the murdered Pedlar, which had assumed that shape, in order to haunt and torment him all his miserable days. Yet, although this Dobby had such fear of familiar approach, it had some fun in it. Sometimes it happened, when the hounds were out near Dobby Danson's house, a fine hare would bounce out before the dogs, and lead them a fine chase, often within view, the hunters expecting it to be killed every moment; still it would hold on, till it had brought them, men and dogs, to the place from which it had started, when they would lose it most unaccountably, without knowing what had become of it. This occurred often enough to make them shy of hunting near Dobby Danson's, and they would not cast off within a mile of his house : for they verily believed it to be either the Dobly, -or "a witch yare," and what was the use of hunting "a witch yare." I must relate another trick of the Dobby, and then $\mathbb{I}$ have done with Dobby Danson. He was at an auction, and while standing among a crowd of people, such as collects at country sales, all at once, a hare jumped from his pocket to amongst the men, who began to strike at it with their sticks, but they could not hit it, though it was some time among their feet. It made its way among the crowd, and got clear off. When they considered from whence it came, it was plain enough how it was; it was their old acquaintance the Dobby, that had changed itself again into a hare!

A Kendal lady writes to me as follows: "Since we had the pleasure of seeing you, I have made inquiries after our lingering superstitions. I believe I might hear of Barguests innumerable; at any rate too numerous to introduce to your friends on Monday. There was, and I believe still is, the Brewery Barguest, in Wildman Street, which most 
frequently appears as a Pig; rattling chains and making horrible noises. One was seen in Captain French Lane a few years ago, like a Pig, with eyes as large as saucers, another used to frequent the Market Place, in the form of a headless lady, dressed in white, and having a tankard tied round her waist. I cannot learn any supposed cause of their appearance, or any use that was thought to result from it, or indeed, any effect but that of terrifying weak minds, and I think you will do a service, if you assist in laying them for ever. I regret that I am unable to give any information respecting this renowned Dobby, the 'Barguest' which haunted the town of Kendal. May I be allowed here to hazard an etymology? Is not Bar, a corruption of Burgh-a town; and Guest, the German Geist, a ghost-hence it would seem Town Ghost. I am aware I am trespassing on Mr. Nicholson's manor, and that, without either science or qualification!"

Another lady has been so good as to supply me with one or two Kendal traditions. She says, "There is living in Kendal a person who went to Dame Mills's knitting school, who firmly believes what the Dame told her. This inclustrious Dame Mills, was, as usual, sitting up one Friday night, to make up her week's work, to take in to her employer's on Saturday. About a quarter before twelve, she heard a noise like a carriage and four going down the broad walk in the churchyard, the large doors opened, the horses and carriage went into the church, the doors banged to, after it, and went in with a dreadful noise; and the Dame was so frightened, that she slunk off to bed, and never after sat up late on a Friday night. She lived in a low thatched house, which was taken down, and the Ring of Bells public house, was built on the site."

The other tradition relates to Witchcraft. "There was a woman who lived either at Beathwaite Green or Briggsteer, and brought peats to sell in Kendal. Her next-door neighbour was a Farmer. She went every morning to the 
- farmer's for fire; and the day the farmer's wife churned, she went regularly for a butter-cake and some churn-milk. The farmer's wife durst not refuse her, as they thought her a witch! But once, thinking to be even with her, the churning was put off until the day the woman went with peats to Kendal. After she had set off, they set to work to churn. Before she could have gone half way, she was back again, and as usual, asked for her butter-cake and churn-milk! One morning she omitted going for fire. The farmer went to see what had become of her: the door was locked; he called another neighbour and they broke into the house, and found the woman dead with one leg on the fire. With difficulty he got a neighbour to sit up with him during the night, as it was not thought right, that a corpse should be left in a lone house. The man who sat up with the farmer could not be kept awake. About twelve o'clock a great black cat bounced in at the window; the farmer threw his hat at it, to frighten it away, being very much frightened himself, as he could not rouse his companion. The cat went to the candle, and it burned blue! Next day. they inquired all round, who had a black cat, but could not hear of any person who had one! All in the neighbourhood believed it was the Devil in the shape of a black cat, who had gone for the Witch's Soul!"

A short time back, it was customary when a person died, to wake with the corpse. A basin of salt with a candle was placed near the body, and the watchers went every half-hour to view it. On the funeral day, most of the company used to touch the corpse. This custom was probably derived from barbarous times, when men often died from violence. It was thought the corpse would bleed if the murderer touched it. The ceremony of waking is still partly in use.

I am under great obligation to the same lady who wrote about the Barguest, for enabling me to enlighten my hearers on some mysterious rites, by which young women endeavour 
to obtain the interesting information who are to be their future husbands! I hope I shall be pardoned for unfolding these secrets to the profane ears of the male creation!

"Two young women burnt what they call a pigtail canclle, or make-weight. They sit each in a corner of the room, having each stuck a pin in her pigtail, and were neither to speak nor laugh. They made a dumb Posset, which they took in silence, then walked backwards to bed. One dreamt of coaches and horses,- - she married a coachman. The other, dreamt of a person with a drab coat, black collar \&c.,-the day after her marriage, her husband took out of his box, the said coat and other things she saw in her dream.

Two young women in Alhallows Lane would try the pigtail; a coffin appeared to one of them, the pigtail went out; she died not long after. The other dreamt she saw a nice young man walk down the aisle in Kendal Church, with red hair, and he waved his hand to her. Her husband was the exact likeness of that man. When the coffin appeared and the pigtail went out, they were so frightened they swooned away.

Another way to peep into futurity: walk backwards to bed, not speaking to any one, then set your shoes in the form of the letter $T$, repeating the following,

I set my shoes in the form of a $\mathbf{T}$.

If a man loves and marries me,

May I this night him see

In the array, he wears every day,

Not in gold or silver, or rich array,

But in the simple clad, he wears every day.

Another: Break the first egg a chicken lays, roast it upon the tongs; go backwards to bed, and lay it under your pillow, and you will be sure to dream of your sweetheart. Also, break the first egg into a glass of water, it will assume a figure that will show what trade your husband will be; if a farmer, a Plough, \&c. Another: have a glass of water; then take a hair from your head, tie it round a ring; hold 
it very steady within the glass; it will knock as many times against the side of the glass as the number of years you are to remain unmarried.

If you have a stem of clover with five leaves upon it, no Witch or Magician will be able to deceive you.

When you walk out, if you meet with an Even Ash, that is, a stalk, of which the leaves are an even number, the first person you meet will bear the Christian name of the person you are to marry.

In the richer classes, both gentlemen and ladies have a merry-thought washed, after the meat has been taken from it; make a hole in the centre with a needle, then stick it upon the nose and try and thread it; as often as you miss it, so many years you will remain unmarried. Then two persons, wishing at the same time whilst they take hold with the thumb and little finger, pull it in two,-the wish of the one that gets the larger piece, will come true. When they do these different things, they must neither speak nor laugh.

The Alphabet written in large Capital letters separately, except $\mathrm{X}$ and $\mathrm{Z}$, must be put into a large basin of water at night, and in the morning the initials of the person you are to marry, will be swimming at the top.

In a large bowl make a syllabub, with a wedding ring and a sixpence put in the bottom; with a tablespoon, fish three times for. them, if you bring out the ring, you are to be married,-if the sixpence you are to lead a single life,if both, you are to marry a rich person. This in a party of young folks.

A bride-cake is made with a ring in it, and when cut up at the wedding breakfast, whoever gets the piece with the ring in it, will be the next to be married.

On St. Agnes Eve (21st Jan.) young women fast, and make a dumb cake, walk backwards to bed, then repeat,

Good St. Agnes do me right,

And send to me my love, this night,

That I may view him in the face,

And with my arms may him embrace. 
Yarrow, thou pretty flower of Venus' treeThy true name is Yarrow-

Who my bosom friend must be,

Pray tell thou me to-morrow.

Pull the flower, and lay it under the head, and after twelve o'clock at night, you will dream of your sweetheart.

A lady informs me, that at one time, a sister of hers kept an ass. Returning from a ride, she was requested by some women to allow them to pass a child, suffering in the chincough, three times under the belly of the ass, as a cure for that complaint. The same lady, in a letter, says, "In addition to what I told you, of the use of the poor patient ass in curing whooping-cough, I learnt the following story from the mother of the child benefited. Her husband and she lived on a farm, near Brough, and were greatly distressed by the suffering of their little boy from whooping-cough, and told their anxiety to a neighbour. Their neighbour said, 'Why, you mun saddle up, an we'll tak t' barn and gang a top a t' fell, an git a lock o' asses. I'se warrant we'se git summat t' mend t' barn.' They went, and succeeded in driving several asses into an out-building-' 'when t' woman out wi her scissars an a bit o' paper, and cut as mich hair off $t$ ' crosses on t' asses' backs as she thought likely; she teed it up i' t' paper, an teed 't round t' barn's neck, an he nivver kinked efter; but what keam o't hair, hoo it gat off t' barn's neck we nivver fand out." "

It is very satisfactory to know, that the means used were so successful, that the child is now as "fine a young man as ye can leak at ony whar'!"

The same lady has kindly supplied me with a small sheepbone, in the form of a cross, which she had from a woman who was in the habit of wearing it about her person, as an amulet, or charm-something like an African fetish-to protect her from misfortune.

I have also been favoured with the following, which I 
cannot do better than give in the words of my obliging and intelligent correspondent.

"In Kendal there still lingers (under the protection and special patronage of graceful refinement), a pretty domestic usage, doubtless of venerable superstitious origin. The first time an infant is carried out of doors, it is taken to the house of a friend. There the babe is presented with a hard boiled egg, a piece of bread, a little salt, and a coin with a hole through it, the piece of money being suspended by a string, from the neck of the infant. This duly performed, thenceforward and for aye, the unwitting little stranger is provided with a charm which will secure him from all sublunary want."

I have now given, as far as I am able, a slight sketch of Westmorland Superstitions. In pursuing this fertile subject, superstition-philosophy and learning might have ample scope. The one in tracing its origin and history; the other, in exploring those principles in human nature from which it takes its rise. Although it sometimes creates unfounded fears and apprehension, and in some instances has been productive of great misery, yet its existence is by no means derogatory to man. This universal belief in supernatural beings-in a spiritual world-does it not afford a strong presumption of man's own high destination; that he is intended for a state of existence beyond this transitory life? With what interest all children listen to superstitious tales! I will give an extract from a late ingenious and beautiful writer, Charles Lamb.

"It is not book, or picture, or the stories of foolish servants, which create these terrors in children. They can, at most, but give them a direction. Dear little T. H.who, of all children, has been brought up with the most scrupulous exclusion of every taint of superstition-who was never allowed to hear of goblin or apparition, or scarcely to be told of bad men, or to read or hear any distressing storyfinds all this world of fear, from which he has been so 
rigidly excluded $a b$ extra, in his own 'thick-coming fancies;' and from his little midnight pillow, this nurse-child of optimism will start at shapes unborrowed of tradition, in sweats to which the reveries of the cell-damned murderer are tranquillity. Gorgons, and Hydras, and Chimeras direStories of Celeana and the Harpies-may reproduce themselves in the train of superstition; but they were there before. They are transcripts, types: the archetypes are in us, and eternal. How else should the recital of that which we know, in a waking sense, to be false, come to affect us at all? or

Names, whose sense we see not,

Fray us with things that be not?

"Is it that we naturally conceive terror from such objects, considered in their capacity to inflict on us bodily injury? Oh, least of all! These terrors are of older standing. They date beyond body-or without the body they would have been the same. All the cruel, tormenting, defined Devils in Dante-tearing, mangling, choking, stifling, scorching demons-are they one half so fearful to the spirit of a man, as the simple idea of a spirit unembodied, following him

Like one that on a lonesome road,

Doth walk in fear and dread,

And having once turned round, walks on,

And turns no more his head;

Because he knows a frightful fiend

Doth close behind him tread?

"That the kind of fear here treated of is purely spiritual - that it is strong in proportion as it is objectless on earththat it predominates in the season of sinless infancy-are difficulties, the solution of which might afford some probable insight into our ante-mundane condition, and a peep, at least, into the shadow-land of pre-existence."

\section{SONNET.}

Though narrow be that old man's cares, and near, The poor old man is greater than he seems; 
For he hath waking empire wide as dreams; An ample sovereignty of eye and ear.

Rich are his walks with supernatural cheer; 'The region of his inner spirit teems

With vital sounds and monitory gleams Of high astonishment, and pleasing fear. He the seven birds hath seen that never part; Seen the seven whistlers in their nightly rounds, And counted them : and oftentimes will start, For overhead are sweeping Gabriel's hounds, Doomed, with their impious lord, the flying Hart, To chase for ever, on aërial grounds !

WORDSWORTE.

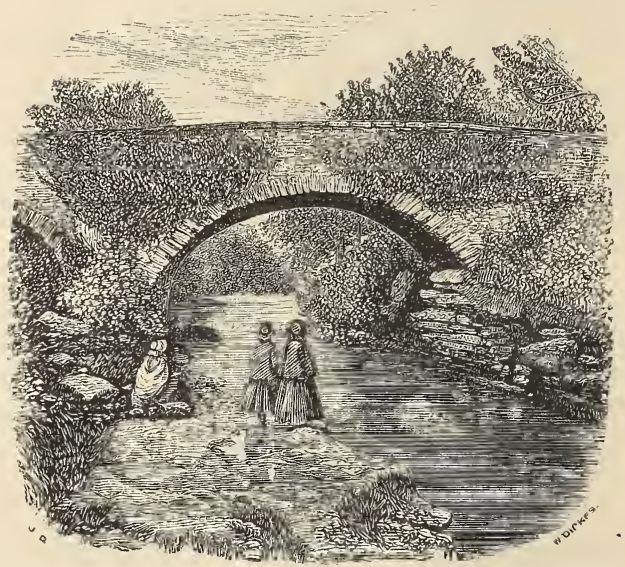

HAWS BRIDGE. 
NO'TES ON NATURAL HISTORY, CHIEFLY RELATING 'TO A FEW OF THE WILD ANIMALS AND BIRDS IN THE NEIGHBOURHOOD OF CROSTHW AITE AND LYTHE, IN TWO LETTERS TO MR. THOMAS GOUGH, OF KENDAL.

Read before the Kendal Natural History Society, Monday Evening, Dec. 8, 1839.

\section{Vear Sir,}

$$
\text { Crosthwaite, July 9, } 1839 .
$$

Knowing the interest you feel in subjects of Natural History, I beg leave to send you some account of a circumstance that has lately come under my observation.

A pair of small birds (the Spotted Flycatcher, of Bewick) built their nest lately in a corner of my bedroom window. I happened to see them when they were about beginning their little structure; but my attention was withdrawn for two or three days, and when I looked again, it was finished, so that I lost the opportunity (so seldom afforded) of witnessing the mode of building of these tiny architects. As soon, however, as the young were hatched, did these indefatigable birds feed them with flies of different descriptions, from five or six o'clock in the morning, till ten at night, and often as quickly as every minute, or halfminute. The male as well as the female took part in this labour of love; for they were frequently both present at the nest at the same time; though from their similarity of plumage, it is not easy to distinguish the sexes. There were five young ones, and when a fly was brought, it was deposited in one of the gaping mouths without a moment's hesitation; though I regret I could not ascertain the method by which they contrived not to cram one too much, while another was left wanting, for the little cormorants 
were all ready to swallow when the food came. Whether each of the parents had its own part of the offspring to attend to, or however it was managed, I have little doubt but they made an equitable distribution, and that no pets or pampered nestlings were allowed in this feathered household. I once took notice of three of them being fed in succession.

A small white-winged butterfly was brought to the young; but not having been previously killed, instead of being swallowed, it was making its escape with what speed it could muster; but was pounced upon and seized before it had got from the nest. Another time the hen (as I took it) had fed her young one; but before she flew away the cock came and sat down; when, without ceremony, she took the food from his bill and gave it to one of the nestlings herself,-as if, like a good mother, she had some doubt of her helpmate's sound discretion in the matter. She would often, after having delivered her fly, stay awhile and look round on her little family, as if to indulge a mother's fondness; or perhaps for the purpose of clearing away the excrement, which was done with wonderful dexterity the moment it was ejected. And it was curious, I could never see anything come from the young except when one of the old birds was there to remove it.

When the young were feathered, and had increased in size, they were a good deal incommoded for want of room in the nest. Indeed they filled it above the brim; and it was amusing to see two or three of these active little creatures clambering over, and sitting on the backs of the others; yet although the nest was close to the edge of the window sill, such was their instinct of self-preservation, they took care not to fall from it, which would have been almost instant destruction. After they had left the nest, they sat near it in a row, for two or three days on the outside of the window, where the old ones fed them as usual. They did not take their final departure all together, 
at the same time. On one day, two went away; on the following, another; and the remaining two, on the next. It appears as if they had immediately removed to some distance, as I have never been able to get a sight of my little Flycatchers. The last disappeared on the 1st of July.

Perhaps I ought to mention that, in order to witness the goings on in the nest, unobserved myself, I heaped up a pile of books and newspapers to form a screen, through an opening in which I could view the nest and its inhabitants.

I noticed one circumstance so remarkable that I must not forget to mention it. The nest was sheltered from the rays of the forenoon and noon-tide sun, by a projection of a part of the house; but when it came round to three or four o'clock in the afternoon, on a clear day his warm beams shone right against the corner where the nest was placed, to the great distress of the poor little nestlings. The old birds had evidently not foreseen this, for the inconvenience would have been nearly prevented, had they built in the other corner of the window.

One warm afternoon, the young ones were panting with open bills, from the great heat; and judge my surprise and pleasure to see one of the old birds (the female I suppose) seated on the sunward side of the nest, and stretching over them with wings a little extended to shield and protect them; and apparently, from her open mouth, suffering as much as or more than themselves. Here she would continue till the sun got lower. I observed them for at least three sunny afternoons; and when the young ones were suffering from heat, one of the old birds was never absentif not to shelter, to lean over with open bill, as if at least to sympathize with the distressed brood.

I have certainly read of something of the same kind, related of the Sivallow, or of the Martin; though I do not recollect where. It is an undoubted circumstance; but I shall not presume to comment upon it; yet one thing may be remarked. It is clear they could perceive the distress 
of their young; - they could infer its cause; and they took the most effectual means in their power to ward off the inconvenience. The more intimately we are acquainted with the habits of the inferior animals, the more shall we be convinced of the surprising degree of intelligence conferred upon them by their Great Creator, whether we choose to call it Instinct or Reason.

I trust you will excuse the length of my details. I shall be glad if they amuse you. I shall have no objection to this letter's being read to our Society, at some vacant time, if you think it sufficiently interesting;-nor to its being afterwards placed, with the other little notices of mine, in the archives of our flourishing Institution.

With best wishes for your health and happiness, I remain, dear Sir,

Very truly yours,

W. Pearson.

Dear Sir,

Border Side, Nov. 14, 1839.

You were kind enough to think that my letter relating to the Flycatchers was of sufficient interest to be read to the Society; but as it is much too short to occupy us a whole evening, I venture to send you a few more notices on National History, chiefly relating to that pleasing branch of it, Ornithology.

I will first mention the time of arrival of a few of our Summer Birds, as remarked by myself at Borderside, for the last two years.

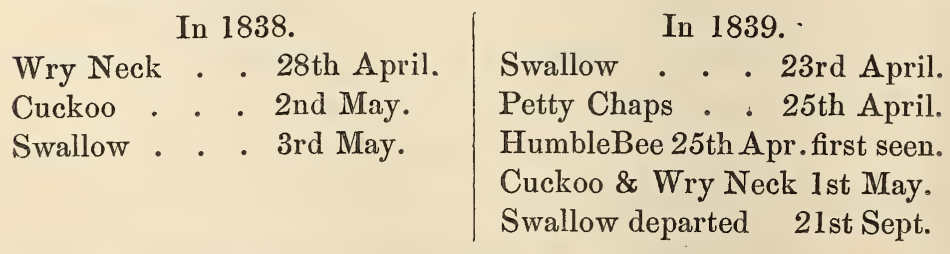

Heard the shout of the Cuckoo on the 7 th July, 1838, at Bradley Field, near Kendal. Is not this thought late? 
I will now proceed to the more immediate object of this communication.

It is well known to naturalists, that the numbers of four-footed animals, birds, insects, \&c., vary considerably at different periods in the same district. I think I cannot better fill up the remainder of my letter than with some slight notices on this subject, as well as on the habits of a few animals and birds, as far as relates to this district, with which I am chiefly acquainted, viz., the township) of Crosthwaite and Lythe; or perhaps it might be extencled to that wide valley comprehended between the bold escarpment of Underbarrow Scar on the east, and the mountain-chain of Cartmel-fell on the west-a valley of at least six or seven miles in breadth; and as it contains a great variety of soil and situation-hills of a moderate height, partly clothed with wood, among which is that striking, detached, limestone mountain Whitbarrow and the extensive breadth of Lythe Marsh, at the head of Morecamb Bay-perhaps there may be found within its confines, at one time or other, almost every variety of bird common to the North of England.

But before I proceed to the birds, I will say a word or two relating to two or three animals, some of which were once found here, though now I fear they are very rare, if not extinct. The Wild Cat, for instance, has not been met with for a long time. It is described by Cuvier as "greyish brown, with transverse waves of a deeper colour; the under part is pale; the inside of the thighs and four paws yellowish. Three bands on the tail, and the lower third blackish." I believe I once saw one many years ago. It was caught in a snare in Cartmelfell, and was a very fine animal-even larger than our pampered domestic Toms. Although it appears to be now extinct in our district, yet I have talked with a famous hunter, John Elleray (he died not many years since at the advanced age of more than ninety), who had been at 
the death of more than one Wild Cat. John lived on a small estate of his own, and was an excellent specimen of the ancient Westmorland yeoman, decorous in his conduct, moral and religious, but a keen hunter nevertheless. Hunting was his delight, his hobby. His favourite game was the Foulmart, which he hunted till he was eighty years of age, along with a companion nearly as old as himself, and as great an enthusiast for the sport. They used to kill twenty or thirty of these animals in a winter; and the skins were hung up in a conspicuous part of the house, as trophies of their prowess. This hunting being carried on in the night, would have been very fatiguing and disagreeable to any person less keen than themselves; yet after they were old men, they frequently, in pursuit of their game, have gone from their dwellings in Crosthwaite, through Witherslack, round the south end of Whitbarrow, and returned by way of Lythe, home-a distance of not less, with all its windings, than twenty miles! Perhaps you will pardon me, if I enter into some further details on the subject of Foulmart hunting, for unlike those aristocratic sports of Nimrod pursued at Melton Mowbray, these humbler huntings have seldom (never that I know of) employed the pen of any writer.

My two heroes already mentioned, John Elleray and John Bennett, hunted according to the old system; that is, they went out in the night, generally, however, when there was a moon in the sky; and they used the common terrier; two or three of which they kept for the purpose. This kind of dog not being gifted with any extraordinary sense of smell, is not able to hunt its game more than two or three hours after it has passed over the ground-hence the necessity for these nocturnal excursions. The Foulmart being an animal of small size, and not endowed with any great swiftness of foot, it might be thought by an ignoramus that when the dogs once met with him they would be able to make short work of it. But Nature has not left him 
without means of defence; for as soon as he is aware of the approach of his pursuers, he betakes himself to an old wall, or to some huge heap of stones (called here a borrow), which his long, thin, flexible body enables him easily to enter. It is then that the tug of war commences; for the enemy having entered his fortress, there is nothing else to be done but to besiege him in it. The dogs make known his presence by loud barking, which, in technical language (Foulmart hunting has it technical terms), is called setting him. As the men remove the stones and get nearer the animal, the dogs bark louder and louder. The poor Foulmart, as he becomes frightened, emits a strong effluvium which it is easy enough, without possessing a dog's nose, to perceive at some distance. You will readily guess the result, Yet it will sometimes happen, that the poor hunted animal will baffle his enemies, notwithstanding their most strenuous efforts. This is the case when the wall is thick and massy, or the borrow large. Or he is safe enough if he have time to seek shelter in a drain, which not unfrequently occurs since that mode of improving land has become common.

I need not remind you what great progress has been made of late years in all the arts and sciences. Foulmart hunting has also partaken in the general advance-a single step as it were in the " march of intellect." A new description of dog has been discovered, or bred, called a Foulmart hound, which, having the faculty of scent leveloperl in great perfection, is able to hunt its game ten or twelve hours after its run over the ground. There is, therefore, no longer any necessity to go out in the night to partake of this captivating diversion, for it can now be enjoyed in the cheerful daylight.

The Foulmart hound is a small shaggy, rough-haired dog, which like other hounds utters a cry during the chase, and this cry, to all genuine hunters, is " musical as Apollo's lute." My worthy friend, the late Mr. John Dodgson, 
possessed a small pack of these animals; but, unfortunately, they soon betrayed unequivocal symptoms of a strong inclination for his neighbours' mutton; and they were in consequence, with great regret for their untimely end, condemned to capital punishment. The on which has come within the range of my experience, was hunted by a Kendal gentleman, whose name I do not feel at liberty to mention.

The Foulmart, I believe, is seldom found abroad in the day. I have never seen him but once, at that time; and it was in my own orchard; when hearing a rustling among some dry oak leaves, I turned round, and was gratified with the sight of a very large one, arrayed in full suit of winter fur. He prudently took himself into the adjoining wall. But he did not need; I was not disposed to molest him. I was well aware of his enmity to the Hanoverian Rat (as Mr. Waterton calls it), and was therefore not at all sorry to see him so near my premises. Some years ago, a Foulmart was traced from the barn at Borderside across the Winster, into a wood on the Cartmel-fell side of the valley. From certain marks in the snow that accompanied his track, it was inferred that he had not made a bootless journey, and that he had carried a burthen of some sort or other. When his citadel was stormed, and he was forced to yield it up, together with his life, the carcase of a huge rat was found to be a principal article in his larder. His untimely fate was sincerely lamented by the farmer who occupied Borderside at the time. It may be added, that like the modern Frenchman, he is an eater of frogs, which he collects in the drains where they seek shelter: I have myself seen them among the stock of his winter provisions.

The little brown Weasel, unlike the Foulmart, may be frequently seen in the daytime. On these occasions, he generally seeks shelter in the nearest wall; but then he soon peeps out again to have a look at you. He is an active little impudent fellow, and there are strange tales circulated in the 
country respecting some of his pranks. It is averred, that when assembled in considerable numbers (small and weak as the IV easel is individually), he is not afraid to attack " the lord of the creation." I have heard of an instance of this on Troutbeck Hundreds, where a man had a severe struggle with an army of Weasels. A similar attack was made by Foulmarts at Crosthwaite Green, which singular event was recorded in the Kendal Chronicle of the time. There is little doubt that if actual assault and battery were not committed by these warlike Weasels, they at least put the human party in bodily fear. The thing is worth stating, as being a matter of popular belief. There is no doubt of the occasional assembling of great numbers of these animals. I have this on good evidence; and it is a curious inquiry for the naturalist to ascertain the cause of it. Like the Foulmart, the Weasel is an enemy to the Rat, and never meets it but they engage in mortal combat; and though, from their near equality of weight and size, there is often a severe and protracted struggle, yet I believe the Weasel always comes off conqueror. The contest is so keen and eager on both sides, that you may come close to them, and even take them up. The Weasel is also a great destroyer of mice; its long thin body enabling it to follow them through their holes in the stack, or in the corn-mow of the barn.

The Weasel is accused of a prank, which, having heard from many country people, although apparently improbable, I trust you will allow me to place on record. It is said that it will attack the Hare, large animal though it be when compared with itself. This it does by leaping upon its back, and then, like another Mazeppa, clinging to the frightened and flying creature most pertinaciously and voraciously, till it sinks down exhausted and dying, the atrocious little vermin having fixed its fangs in the veins of the victim's neck, and sucked its blood. Mind, I do not vouch for the fact, never having seen it myself, and as the newspapers saly, "it wants confirmation." If it be so, however, it is 
pretty clear the Weasel must take the Hare when seated on its form: on any other supposition there would be some difficulty in mounting! But by whatever means it acquires the elevation of the Hare's back, if it be not a most capital jockey (it is said to cling like a leech), it would assuredly be thrown off by the skelps and paroxysms of the terrified animal thus unmercifully treated.

Since writing the above, a person whose veracity $I$ have no reason to question, told me that he once met with a Hare running with great speed, and at the same time uttering a cry of distress. It shortly after dropped down dead. On going up to see what was the matter, a Weasel ran away from the dying animal. This might appear to settle the question.

I am glad, however, in concluding my remarks on this wily and courageous little creature (which have been drawn to a greater length than I intended), that I am enabled to say something in its favour. A brother of mine has one about his premises that is half domesticated. Last winter it made a nest at the side of the hay-mow; it was lined with the down or fur of mice, and other soft materials, and was altogether a very snug affair. This Weasel fills the office and performs the duty of a cat (my brother has no other), preserving his buildings clear from those destructive pests, rats and mice. As some reward for its services in this department, there is generally set for it, where it haunts, a little milk in a basin, which it always takes care to clear up before morning. It frequents an out-house that joins to the dwelling-house; this out-building communicates.with the garret by a hole in the wall, and every night before retiring to rest, they can hear this watchful little hunter taking a round in the garret. Though, as I have said, it is half domesticated, yet it was never in the hands, nor tamed by the art of man; it still retains that liberty to which it was born, going out and coming in at its pleasure.

There is another animal found in this district, and which 
it would be desirable to procure for our Museum, though I fear the chance of doing this is but small, from its extreme rarity-I mean the Badger or Brock. Yet it has been caught or killed not many years ago on Whitbarrow, in the chinks or fissures of the limestone rock. I recollect an unfortunate Badger being exhibited at a country ale-house not very many years ago, and afterwards, by our civilized and refined hunters, subjected to the not very pleasant process of baiting. How Master Brock conducted himself under this persecution, I cannot inform you, not having had the honour to be present; but as a solitary remnant of an almost extinct race, I could not but have felt for him. I am told, however, that within the memory of persons now living, he has been met with at Smithy Hill and at Townhead, in Cartmel-fell; and a friend informs me, there are still a few to be found at Humphrey Head, near Allithwaite. I hope this hint will not be lost upon our Curators.

The Otter also, though not, I believe, extinct, is become very scarce; yet I recollect one or two instances of his having been met with, ${ }^{*}$ and I have certainly seen traces of his existence in the vertebræ of the salmon or salmon trout, whose bones he had picked on the banks of the Winster. A few years ago, there was one caught alive. It was soon after put into a mill-dam, for the purpose of being hunted and worried by dogs; but, if I remember aright, it proved itself more than a match for its persecutors-biped and quadruped. I believe it escaped. The Otter will sometimes travel a considerable distance by land; for I am informed they have been traced in the snow from the Winster brook to the Crosthwaite beck, a distance of nearly two miles. *

But if the Wild Cat, the Badger, and the Otter have either become extinct in our district, or at least very greatly diminished in number, we have the consolation to know that there is another animal more than their equal in cunning and predatory habits, that has of late years increased

* There was one hunted at High Sand Side as lately as 1818. 
amazingly - I mean the Fox. Of these we have two kinds, the native and the imported. It is said we are indebted to the kind offices of some neighbouring gentlemen for this comfortable addition to the number of our useful animals! It is reported, they have laid under contribution the extensive county of York, in order to accomodate us. It is, no doubt, kind of them, and we cannot do less than express our profound obligations. But still, it would have been more polite to have first consulted some of us who help to maintain them, or, at least, to have been a little more particular in inquiring into the character of their protégés. Nor was there any great danger of the species becoming extinct; for the limestone cliffs of Whitbarrow, and the scars of Gummer's How, generally supplied us with a few breeds yearly, which were, indeed, a most respectable class of Foxes, compared with these new-comers. Our original Fox-our true Westmorland grey-coat-is of a shy, timid, retiring disposition; he has some remains of rustic modesty. 'Tis true he would occasionally abstract a hen or a goose without asking leave, but then it was done in the night, as if he were ashamed of his conduct. While, on the contrary, these interlopers, these Yorkshiremen, are a completely demoralized set, with no more honesty than a buccaneer! They will steal openly at noon-day, without the least compunction. A neighbour of mine caught one in the act of running away with one of his hens, while he was working in the hay-field. He rescued it for the time, and placed it, as he thought, securely in the hen-house; but the wily thief was not to be thus disappointed of his prize, and he came at night, and took it off. Indeed, if I were to relate the whole of their depredations, I might fill a volume. Perhaps you will ask, Why are these thieves and plunderers introduced into a peaceable country? It cannot, surely, be for the purpose of hunting them down after they have committed their robberies! I am sorry to say, there is too much reason to believe that this is the fact. There was a law in England, 
emanating from the wisdom of our ancestors, which offered a large reward (vulgarly called blood money) to the person who should be the means of a capital conviction. It was found out, however, in process of time, that it induced the thief-catcher to wink at, if not to encourage, the young delinquent in his evil courses, till he had committed some enormous crime that made it worth while to bring him to the gallows. A writer in the Kendal Mercury, who signs himself a "Foxhunter," seriously recommends these gentlemen to proceed in their useful career, and to stock the woods and wilds of High Furness with the Wolf and the Bear! How far they are disposed to profit by the suggestion, I have not heard. But of their success, if they should try, there cannot be a doubt; for it would only be a replanting or repeopling, as it were, of an expelled race in their ancient haunts! Be assured, my dear Sir, that as soon as those interesting strangers arrive, and are duly naturalized, I will lose no time in apprizing you of the circumstance, in order that our Museum may be enriched with the choicest specimens!

Of all our extinct animals, there is none whose disappearance I regret so much as that of the Kite, or Glede, so called, I am told, from the Saxon "to glide"-so exactly descriptive of his beautiful motion through the air. $\mathrm{He}$ was truly a noble bird. We have nothing left like him; the Buzzard is a mere barn-door fowl compared to him. He might have been considered our Eagle. Bewick says he measures from the point of the beak to the tail, two feet, and that his wings extend five feet; and that he is common in England. This last statement, from all that I can learn, will not correctly apply to the present day. He has not been seen in Crosthwaite for more than thirty years, and I have every reason to believe he is no longer to be found in the Lake district. Perhaps he may still linger among the Cheviots or the Grampians. But I well remember him in my youth, his forked tail, and his long crooked wings, 
which were extended without apparent motion-his easy and gentle movement through the air, which he never beat with his wings, but sailed rather on the aërial wave, as if he had been a spirit of heaven! He seemed to move by an impulse of the will, without mechanical effort, as we sometimes fancy we do in dreams. It was generally on windy days, in the late autumn or in winter, that he was abroad. He came floating away as if from some far country (the high fells, we thought), passed over our fields, and then was seen no more on that day. We knew of no dwelling-place, harbour, or haven that he had. Like the wind, we knew not whence he came, nor whither he was going; and, like the Bird of Paradise, he never touched the earth, but seemed to live in the air for ever! Such was the effect he produced on my youthful imagination, that I was never tired with gazing at him. My neighbour, Isaac Walker, informs me, that when he was a youth, some fifty years ago, and lived in Sawrey, a pair or two of Gledes built their nests among a number of tall trees, on the west side of Windermere Lake, near the Ferry Inn. These birds were most of them destroyed by some idle fellows in the neighbourhood, who shot them on the roost during moonlight. He once took away a young one from a nest containing two; it became very tame, and would sit upon his hand; and although it had long and sharp talons, it took care never to hurt him with them. He permitted it to be at liberty, and it would sometimes stay away for a day or two, but always returned. At length, however, it entered the cottage of an old woman without leave, and the illnatured crone killed it.

The Buzzard is not now an inhabitant of Crosthwaite; but a few years ago we had several. They bred at that time in the Larch Plantation at Lamb How; but such was the hostility they provoked among the sportsmen, by whom they were looked upon as inveterate poachers, that they were destroyed by all possible means, and at all times, 
particularly in the breeding season. There was one of a singular piebald appearance, that haunted the woods and wastes near Gill Head, in Cartmel-fell, a few years ago. $\mathrm{He}$ sorely puzzled our country naturalists, and was considered a rara avis, a nondescript kind of bird, and some pains were taken to secure him, but, I believe, without effect. The Buzzard is rather a sluggish, indolent bird, and will sit for hours on the stump of a tree or piece of crag, nobody knowing what he is thinking about-I believe it is mischief ! But at times he will soar aloft, wheeling round and round, high in the air, and uttering his wild and melancholy wail. Though he destroys game, yet his food is sometimes very different. I once shot one-its stomach was filled with large earth-worms. *

We had formerly great numbers of the common Wild Duck. Before the commons were divided, in 1805, the extensive marsh lying between Lythe on the one side, and Brigsteer and Beathwaite Green on the other, being then undrained and unenclosed-in many places covered with large, shallow pools of water, in which grew rushes and other aquatic plants-afforded them excellent shelter and plenty of food. Here they bred and brought out their young; and I well remember, after the broods were able to fly, the numerous flocks that used in the autumn to cross morning and evening over Crosthwaite, flying between the Mosses and Windermere. There is a tract of land, about a mile in breadth, between the Yews and Borderside, in Crosthwaite, which consists of low rocky hills, covered with fern, heath, and juniper, and contains a number of small tarns; this also was a place for their breeding. I have seen them here in flocks of forty or fifty; and I well remember going three mornings

* 'The following memorandum is copied from his note-book:-

"October 1, 1850. Saw a Buzzard, at Lindeth, sitting on a pointed rock, hy the side of the road; it rose as I approached, and flew to another crag, where it settled. I had not seen one for years in our neighbourbood, al though the last I had noticed was near the same place." 
together, when a very juvenile sportsman, along with another lad of about my own age, each armed with a gun, for the purpose of shooting them on the water. We always found a great number on the tarn; we fired together, and never returned with less than two or three. But, alas! Wild Ducks are now become scarce, and you may look or listen in vain for those large flocks in the autumn. At that time, you might have heard them soon after dusk, passing over head "with the noise of congregated wings."

For their present scarcity many causes may be assigned. One is the draining and enclosing of Lythe Marsh; another is the abominable practice of hunting out and destroying the young ducks before they are fledged. And here I would mention a wonderful instance of the early development of the instinct of self-preservation in the tender ducklings. In order to save themselves from their enemies, men and dogs, they will hold their bodies under water with nothing protruded but the point of their bills.

But the period at which the most rapid decrease in the number of Wild Ducks took place, was about twenty-five years ago. A man from Lincolnshire unfortunately found his way into our quiet solitudes; and having provided himself with a small flat-bottomed boat, he launched it upon Morecambe Bay, on whose waters, in a full tide, great numbers of Wild Ducks used to assemble. In this boat he mounted a small swivel, which he could elevate or depress, or turn in any direction he thought fit. Having loaded his gun with a pound or two of duck-shot, he stole along the shores and creeks of the bay with his devilish enginery; and, masking his hateful person, got as near as he could to his devoted victims. A single discharge is said to have killed scores. Sportsmen inform me that the poor ducks have never recovered the effects of this destructive onslaught.

Since the above was written, I have learnt some further particulars relating to this wholesale destructionisto His boat was of a very light construction; so light, indeed, 
that he was able to carry it on his back occasionally, from place to place. It was one time cut from its moorings, and floated out by the ebb-tide to the open sea. He immediately set to work and built himself another, for he was his own boat builder. After heavy rains, when the land-floods were out, and the wide expanse of Lythe Marsh was almost one extended sheet of water-then did he bring his little boat and pursue his game on the shallow waters. He also navigated the river Winster as high up as Helton Tarn, a noted haunt of the Wild Duck, and there carried on the work of destruction. It is stated that he once killed so many ducks at a single discharge, that he sold them for $£ 5$; and that with Sea Pies (a bird numerous on the tidal waters), he has been known to fill a corn-sack! Incredible as these statements may appear, my informant had them from Mr. William Saul, of Arnside, who was likely enough to be acquainted with the facts. Such was the indignation which this merciless destroyer at length excited among the neighbouring gentlemen, who were unable legally to stop his proceedings on the open sands, that they employed two or three men to watch his motions, and dog his steps from day to day, and whose business it was to scare away the simple water fowl, so that he could not come near them. The result was, that this Lincolnshire water-poacher was at length driven back to his own country. I forgot to mention that to facilitate his purpose, he had a number of artificial decoy ducks attached to his boat, which, floating on the water, assumed the appearance of living birds.

The flight of the Wild Duck is very peculiar. Unlike the confused, irregular flight of other gregarious birds, that of the Wild Duck is always in some regular figure; it is supposed, like that of a letter of the alphabet, or that of one of the numerals in arithmetic. They fly one immediately behind another. As far as my own observation goes, the figure they most commonly assume is that of the letter $>$, with the narrow part of the letter pointing forward. 
There is, however, one bird that bears up wonderfully against the hostility of man, and instead of having diminished in number, has, within the period of my remembrance, increased at least eight or ten-fold. This is the Rook. I remember when Crosthwaite and Cartmel-fell could only support one rookery; we have now no less than seven; and the one at Low Birks is a very numerous and thriving colony. This may be partly owing to the increase of the quantity of arable land, consequent on the enclosure of the commons. For if it be true that population always presses hard upon the means of subsistence, this may hold good, for anything I know, with respect to Rooks, as well as to human beings. But whatever may be the cause, it is not owing to kindness or forbearance, for he is no favourite with any one. $\mathrm{He}$ is regarded as a sable-coated plunderer, and will hardly be satisfied with a tithe of the produce. There have been naturalists who have gravely asserted that the Rook will not eat grain. Ask any farmer that question, and he will laugh in your face. During the late wet harvest, when the hattocks were obliged to be left for weeks in the field, it was a rare time for him, and you may be sure he did not neglect to profit by it. $\mathrm{He}$ is rather partial to barley; but he is not nice, scarcely any thing comes amiss. In June, as soon as the potato appears above the ground, he digs down with his great ugly bill, and flies away with the set. And as soon as the young ones are about the size of nuts, there he is, ready again to feed upon them. From morning till night, in the crop season, he is engaged in one continued breach of the eighth commandment; yet such is his sagacity, and wary sense of selfpreservation, he is seldom brought to justice. Familiar enough where there is no danger, if the husbandman is engaged in turning up the soil with his plough, he will come within a few yards of his feet; but let him take up a gun, and he is off like a crack. There is no sportsman understands better that engine of destruction; and whenever he sees it, 
he is prudent enough to keep at a most cautious distance. In addition to the misdeeds of the Rook in the corn-ficld, and among the potatoes, it may be stated, that he will eat some kinds of fruit-cherries he is very fond of; and he will sometimes steal the finest pears from the orchard, some of which I have found in the fields, where he had no doubt scattered them.

The ingenuity of the farmer is sometimes sorely taxed, in devising expedients to frighten away the Rook from his grain and other crops. Where the corn presents an open front-which is the case particularly where only a part of a field is ploughed-this bird is very mischievous, by pulling down the ears and flying away with them. Here, the farmer runs a line of yarn along the side of his grain, supported at intervals by sticks. The Rook thinks this bodes him no good, and keeps his distance. In some of our fields, chiefly those enclosed from the commons, there are rocks and small hills, near these, the soil being shallow, the grain comes up short and poor. Here, this sagacious thief having free access, is able to reach the ears of the corn, to tread it down, and almost totally destroy it. In these circumstances, the best scheme, perhaps, is to put down a number of bent sticks; which the suspicious bird, having a great horror of any thing bearing the appearance of a snare or a trap (though, after all, he does not understand trap exactly), possibly takesfor springes or sprents! Sometimes small painted boards are suspended by strings, which waving and glistening in the wind and sun, are supposed to frighten him. But the most common expedient for that purpose is the scare-crow, that is, the stuffed effigy of a man, rigged out in jacket and trousers, covered with an old hat, and sometimes in the act of presenting a rusty gun. But, as with all this parade, the scare-crow neither speaks nor stirs from the spot, the cunning bird soon learns to treat him with great contempt-ay, even to sit upon the formidahle tube! This has perhaps led some original genius 
to introduce an improvement, as he thought, and that is the female scare-crow, which I have been amused to see stuck up in the fields, and tricked out in full costume-bonnet, gown, and petticoat. But as the ingenious artist is unable to confer upon his workmanship, one characteristic endowment of the gentle sex, and she perseveres oddly enough in a most useless silence, I question whether in the long run she turns out to be better than the other. The best remedy after all, is the gun: for the Rook, like Hotspur's Fop, has a mortal antipathy to "villanous gunpowder." But as I said before, there is great difficulty in using it effectually. These plunderers, when on the feed, always take care to station a few scouts or sentinels upon the adjoining trees, which, on the least approach of danger, give warning by a peculiar cry, when the whole flock rise into the air, and flying overhead (though at a safe distance), almost deafen you with clamorous complainings of your unwarrantable interferance.

Perhaps it may be thought that I have treated the Rook harshly, and only brought forward the debtor side of the account; and that if all his good deeds were put down to his credit, there would be a balance in his favour. It may be so. It is certainly agreeable to all sound philosophy. But the farmer on this point is slow of belief. It may be stated, however, in justice to the Rook, that his mischievous pranks are apparent to all the world; whilst the benefits he confers are more concealed. Perhaps if Rooks were all banished, the farmer would soon wish for a moderate supply back again, in consequence of the increase of grubs, worms, \&c., which would overspread the ground, destroying his crops of grass and grain. Even as it is, we sometimes suffer from the Cockchafer Grub, which eats the grass roots, turning our fields quite brown; yet the Rook is a great destroyer of them, as he is also of the Bracken Clock, which, when numerous, invades the orchards and destroys the young apples. 
The river Winster has Water Hens, and Water Ouzels, or Water Crows as we name them.*

We have lately had a few couples of Starlings in two or three places, which built with us in summer, and brought out their young. These are new visitors in Crosthwaite.

That rare and curious bird the Crossbill, also made its appearance last year in the Larch Plantation at Lamb How. I never heard of it before in our neighbourhood.

Land Rails or Corn Crakes, I believe, we have always had, more or less. They may be heard any fine summer evening in the fields below Crosthwaite Church. A few years ago, we had two or three pairs in the Winster Valley, just above Bowland Bridge. Unluckily, their nests were disturbed by the mowers, and since that time they have not returned. $\uparrow$

Fieldfares, Redwings, as well as Bluebacks, whatever may be the cause, do not now stay with us through the winter. They come in large flocks about the latter end of October, and we see them again in the spring. I know that in my youth we used to have them the whole winter through, feeding on holly-berries and haws. I cannot be mistaken in this, as they were my principal game when a young sportsman.

It is well known that that rare and beautiful bird the Bittern has been killed on Underbarrow Moss; and the Red Grouse, I believe, used to breed there, as a few still do on Foulshaw and Meathop Mosses. The Large Snipe breeds in several places on that extensive marsh. But the

* I may be allowed to add the Kingfisher to the list of these Crosthwaite river-bircls. I bave seen this searce and brilliant little bird, close to the water on the banks of the stream below Durham Bridge in Lythe; ancl my nephew, J. Grundy, saw one by the side of the Winster, in the "great mearlow" at Borderside.-ED.

† Copied from William's Note Book :-

“22nd July, 1854.-Two Corn Crakes' nests. One in Alders How got out young. The otber in Long Field had nine eggs. The bird nearly had its head cut off with the scythe."

They were heard in the meadows at Borderside in 1860 also. 
progress of cultivation is narrowing his domain every year; as it is that of the Lapwing or Peewit, which was formerly found there in great plenty.

There are only two Heronries, as far as I know, in this part of the North of England; that at Dallam Tower, and the one on an Island of Rydal Mere. That large and picturesque bird has always been in the habit of coming to our tarns and brooks in Crosthwaite to fish. But I do not so often see him as formerly. I once shot two Herons in one day; but I should now be sorry to commit such an atrocity. So far from it, I sincerely wish we had a Mr. Waterton or two in the neighbourhood.

Pheasants were formerly never seen in our district. They are now not unfrequently met with by the wandering sportsman.

Of the Partridge I have not much to say. Like other game it is not so plentiful as it used to be. Indeed, a year or two ago it was so scarce, that its diminished numbers were accounted for by some persons, by the prevalence of an epidemic. I imagine the only disease that has carried them off has been the too close application of the fowlingpiece.

We had formerly great numbers of Sandpipers in the spring and summer about the beck at Crosthwaite Green. Whatever may be the cause, of late years we have few or none. On the river Winster I have never seen any.

A word or two on the Woodcock, and then I will conclude. It is well known that this delicate and beautiful bird, interesting to sportsman and epicure, was once much more plentiful than it is at present; indeed, it seems to be getting scarcer every year, so that the disappointed fowler, like Wordsworth's leech gatherer, may exclaim:-

"Once I could meet with them on every side;

But they have dwindled long by slow decay;

Yet still I persevere, and find them where I may."

One cause of their diminished numbers is said to be, that 
the peasantry of Norway and other northern countries, to which they retire in summer,* collect their eggs for sale. But is not the increased demand here, and the more prevailing practice of shooting flying, sufficient to account for their scarcity? Formerly they were sold for fourpence, now they will at least fetch half-a-crown. In the olden time they had no other method of catching them than in springes, or, as we term them in Westmorland, sprents. On moonlight nights, the Woodcock leaves the woods for the purpose of feeding on the green hills in the neighbourhood. Here he finds worms under the dung of cattle, and in other spots, of which he is a good judge, by boring into the ground with his long bill. The sprents are set in these places, and there were formerly great numbers of birds taken in this way. It is still practised, but chiefly by boys from ten to fifteen years of age. When the lad sees Woodcocks' haunts, as he calls them, he places his sprents; for the birds will come night after night to feed at the same place. These haunts are places where holes are made in the dungs by the Woodcock's bill; and where the mutings of the bird are scattered. The first thing the boy does, is to form a row of small stones, which he places side by side, called the sprent walk (and which it is supposed the simple bird will not pass over); he leaves a gap, however, of about eight inches wide. In this he places his sprent, which is a noose of horse-hair laid over a bent hazel twig, called the bridge. But woe to the unlucky bird that treads upon this bridge! For as soon as it does that, the insidious noose is drawn tight round its leg by a long elastic hazel rod, called the spelk, which having one end stuck in the ground, is fastened by the other to the aforesaid treacherous bridge.

" Villiam's mems. in 1847, gives-" May 22nd.-It it stated in the Kendal papers, that Jos. Martin had seen three Woodcocks in Tower Wood, on 17th." As respects other birds that spring, is- "April 29.-Heard Cuckoo near Wilds Castle (in Winster) first time. Heard at Borderside, 24th ; and Kendal Gazette says a Swallow was seen at Lindale, on 24th March. May 4.-Saw two at Hubbersty Head." 
Sprenting is a great delight to the rustic boy. He sets his sprents in the evening, and goes early in the morning, often before daylight, to see if there be anything caught. $O$ what delight when he finds the fluttering bird! But like all sublunary pursuits, it is not without its troubles and disappointments. Sometimes his sprents are broken, that is, the best part of his machinery is taken away, by some worthless vagabond who exercises the same craft. Or worse than that, perhaps the ensnared bird has been seized by some dishonest stripling who has been earlier on the hills. From the feathers that are left near the sprent, he infers the theft, and bewails his loss.

In some years, Woodcocks yet come in considerable numbers. A friend tells me that when he was a youth, not twenty years ago, he caught fifty in one season; and I know two sportsmen who not more than ten years since killed two hundred. Indeed, I am acquainted with a person who, about the middle of the very last December, killed ten in a day and a half! And what is curious, this year, about Martinmas, when they are commonly most plentiful, there were very few. They often shift their quarters very suddenly, and without any apparent reason. I have known them rather numerous one day, and on going to the same place the next day, there was scarcely one to be found.

A brother of mine once shot a Woodcock that had only one leg. Not I think that Nature had left it deficient in that respect; the leg had most likely been shattered by a shot, and the lower part having dropt off, the stump had healed over. Unable to find a substitute for this useful appendage, the poor bird, it seems, could nevertheless manage to do without it, for it was healthy and in good condition.

It is a curious fact that this bird, generally thought so simple, is become much more difficult to shoot than formerly. It is grown much wilder, much more alert on the 
least approach of danger; so that it not unfrequently happens, that when the sportsman finds his dog set, and expects a shot, he is disappointed-the bird has flown! As one proof of the greater difficulty of shooting Woodcocks now than formerly, it is a common practice, when two or three sportsmen go out together, as they ofiten do, in pursuit of the bird, to send one of the number forward one hundred yards or so, in advance of the place where the Cock is marked down, while the others come up and flush it, in order that some one may have a chance of a shot.

Here it would appear as if we had a beautiful provision for the preservation of the species; for as the bird becomes scarcer, its instinct seems to have expanded for the occasion.

In a short paper of mine read before the Society, soon after its formation, I maintained that the Hedgehog was not carnivorous. I am now of a contrary opinion, and as truth ought to be the object of every naturalist, it is only proper to make the acknowledgment.

A friend of mine, who has an ambition to enact the part of gamekeeper, is in the habit of setting a variety of traps, baited with some kind of flesh, for the purpose of catching Foulmarts, Weasels, \&xc., that prey upon his Rabbits. He tells me that the poor Hedgehog is not unfrequently found a captive. This is certainly a very suspicious circumstance. The next is more conclusive. Another gentleman says, that being out with his gun, he fired at a Wood Pigeon and wounded it, but the bird flew away. Returning, however, next day to the spot, he found it dead, and a Hedgehog in the act of preying upon it. The Hedgehog may be a flesheater when flesh falls in its way, but still it appears to me, that its quiet, slow habits utterly unfit it for pursuing any animal whatever. Nothing can be more lamentable than the ignorance of our rustic population in relation to this poor harmless creature. That universal butcher, the gamekeeper, destroys it because it preys on his game; the farmer, because it milks his cows; and the thoughtless boy, 
through mere wantonness. Its mangled carcass, on every way-side, bears evidence of this shocking prejudice.

That the dietary of the Hedgehog is more extensive than could have been previously supposed, and that it will sometimes feed on substances that it can but seldom meet with, will appear from the following anecdote.

I am acquainted with a little boy, who happening to be out at dusk, met with a Hedgehog. Pleased with his prize, he tied it up in his handkerchief and took it home. On going to rest, he took it with him into his bedroom, but neglecting to shut the chamber door, some time in the night the inquisitive little creature set out on an exploratory tour. It first descended the stairs to the ground floor, and then, perhaps guided by its nose, went down some more steps towards the cellar, the door of which not fitting so tightly as that of a modern parlour, it was able to squeeze its prickly back underneath it; when lo! delicately placed on clean slates laid out on the floor, were a number of pounds of butter; put there for the purpose of hardening, as it was warm summer weather, previous to taking it to market. Here was an opportunity of indulging its appetite that was not to be neglected; for it does not often happen, I fancy, that Hedgehogs have a chance of tasting butter! If it had confined its attentions to a single pound, no great harm would have been done; but, unluckily, the fastidious little epicure had gnarled holes in every pound, to the great indignation of the farmer's wife, who, you may be sure, lost no time in ejecting from her premises the unwelcome intruder.

As the Hedgehog is known to be herbivorous, frugivorous, insectivorous, and carnivorous, it may now be said (if I may coin a word), to be butterivorous also!

I am, dear Sir, very truly yours, W. Pearson. 
ON CERTAIN CHANGES THAT HAVE TAKEN PLACE OF LATE YEARS IN A PART OF THE LAKE DISTRICT, MORE PARTICULARLY IN THE NEIGHBOURHOOD OF CROSTHWAITE AND LYTHE.

Read before the Kendal Natural History Societr, at Kendal, Jan. 8, 1844.

Ix may be, perhaps, safely asserted that all things belonging to this earth of ours are in a state of continual change, and have been so, probably, from the moment the planet was first projected into the regions of space. Indeed, what is the noble and most interesting science of geology, but an attempt to unravel the history of the earth-that is, the changes it has undergone through every period of its existence. But geology is chiefly conversant with phenomena which lie hid in the bowels of the earth-the various rock formations, and their fossilized remains of animals that lived and died, perhaps millions of years before the creation of man. Whether all existing appearances are the result of the laws of nature in operation at present, is a question, I believe, not yet settled by geologists themselves; but one thing is certain, that change is continually going on, not only geologically, but also in relation to the mere surface of our planet, as modified and improved into beauty and convenience, by man, its noblest and most efficient inhabitant. These changes are more striking in proportion to his advances in civilization. While he remains in the hunting, or even the pastoral state, the surface of the earth receives few alterations at his hands. It is only when he becomes an agriculturist-a tiller of the ground,

"A planter and a raiser from the seed,"

that his dominion is most effectually displayed-that his 
dwelling-place becomes more beautiful, more healthful even, from his exertions. So much is this the case, that even in a single generation it is sometimes strikingly manifested. It is on this ground that the writer ventures to submit to the meeting a few observations which he has noted down, relating to some changes, moral and physical, that have occurred of late years in our own neighbourhood. And if he should indulge in what may appear trivial details, to those whose feelings of local attachment are less warm than his own, he hopes they will pardon it, and recollect the words of our great poet :-

"That not to know at large of things remote, obscure and subtle, but to know

That which before us lies in daily life,

Is the prime wisdom,"

But before I proceed any further with my own remarks, I will, if you please, read an extract from a small volume that came into my possession a few years ago, written by a volunteer who served in the Duke of Cumberland's army, against the Scotch, under Prince Charles Edward, or the Pretender, as he was commonly called, when he made that unsuccessful attempt on the Crown of these realms, in 1745. Any remarks made so long ago as one hundred years can scarcely fail to possess some interest. They are couched in very natural and unaffected language, without the least pomp or parade of authorship; and if they do not much instruct, they may at least amuse.

If, according to this extract, the main road was ${ }^{66}$ most intolerably bad" between Manchester and Wigan, we may naturally infer the other roads in Lancashire would be in no better state. It was about fifteen years after, in 1760 , or a few years later, that turnpike roads were first made in Westmorland. Previously, the different valleys were connected by bridle paths, and all goods were transported on the backs of pack-horses. Yet it would appear from the follow- 
ing passage in the history of the county, that at least the main, or great north road, from Kendal to Shap, admitted of the transit of carts or carriages before the time of the Scotch rebellion :-_ ${ }^{6}$ The Deputy-Lieutenants of Westmorland, on the 14th December, 1745, in obedience to the command of the Duke of Cumberland, raised a party of the county to demolish Wastell Bridge, and break up the road down to Grayrigg Hause, in order to make the road from Kendal to Shap impassable for artillery and wheel carriages." This Wastell Bridge I suppose to be what is now called "Hucks's;" but then Grayrigg Hause is on the road to Appleby, about a mile south of Borrow Bridge, consequently not likely to have been travelled by the Scotch army on their retreat from Kendal to Shap. However, be this as it may, the old road from Kendal to Ulverstone, by way of Underbarrow and Cartmel-fell, was at the time before named, first widened and probably made fit for wheel carriages.

In its ancient state, it was a mere track, from five to six feet wide, as may yet be seen in many places, particularly below the Underbarrow toll-gate, where there is a foot-path at a sharp angle of the road. Improved as the road was, it still followed the old track first marked out by the packhorses; passing over two mountains, where there were long and steep declivities-Underbarrow Scaur, and Stavely Brow, near to Fell-foot; and about twenty years ago, a new line was formed, stretching over the Mosses from Levens to Lindale, and joining the old road at Newby Bridge, then diverging from it through Backbarrow and Green Odd.

There is also another route to Ulverstone from Kendalthat through Crook and along the eastern shore of Windermere. The old and most direct road, through Crosthwaite, is now almost deserted; in fact, grass grows upon it on the summit of Cartmel-fell; you no longer see it enlivened by the smart chaise or gig, or even by the carrier's white covered cart. 
Formerly, we had two carriers passing through every week-Pickthal, and old Richard Nelson, who, as regular as the tide, faced all kinds of weather; sunshine or storm, hail, rain or snow, for nearly half a century, and died insolvent at last!

But if modern improvement has deprived Crosthwaite of passengers on one line of road, it has returned them with interest upon another; and of late Lyth Lane-indeed the whole length of road, from the Bridge Inn to Bowness, has been widened and improved,* to allow an easier and shorter transit to tourists-those birds of passage that visit our lakes and mountains. I cannot stop now, to point out all the changes that this rage for the picturesque this influx of visitors has produced in our Lake district; this would of itself afford matter for a paper; but as I have mentioned Bowness, I will just say, that it has so far swelled from a very small village into a town, as to be visited by milk-carts morning and evening; it has shops-I don't know how many - and it has two or three medical men, and as many attorneys, either in the village itself or its immediate neighbourhood. Instead of one inn and a small tavern, it can now boast of five or six ; two of them large as palaces, and dignified with the name of Hotels: one the Royal Hotel, since the visit of Queen Adelaide. The plain old English word Inn has become almost obsolete among our Lakes.

But to return to our subject. The ancient road connecting Kendal and Whitehaven, passed over Wrynose and Hard Knot; it was traversed by a gang of pack-horses, which were doubtless at that time the chief means of communication between the two towns. Indeed, till about the beginning of this century, almost all rural produce was conveyed to Kendal market on the backs of horses; apples and other fruits in panniers lashed together, two or three on

* At the time that this improvement was going on, the writer sent a jeu d'esprit to the Kendal paper, headed, "Lyth Lane," which is appended to this paper. 
each side, with the driver, man or woman, seated on the top: and it was amazing how well they sold in those days - two or three shillings a pannier, on an average, so that it was not unusual for the owner of an orchard in Lythe or Crosthwaite, to make from $£ 40$ to $£ 50$ in a season. But those halcyon times are not very likely to return, so many orchards are since planted in all parts of the country.*

How slow was the rate of travelling at that time! A journey to London, even in this century, was a serious matter. I know not how long it took the mail, but there was a "long coach," shaped like a boat, which would hold about a dozen persons inside, while, perhaps, a like number might get upon the roof, besides the piles of luggage. This heavy, lumbering vehicle set out from Kendal early in the morning (by two or three o'clock), and did not reach the metropolis till the afternoon of the third day ! - two nights and nearly three days on the road. I speak from woful experience, having then first set out on my travels. How different the case now! A gentleman of Kendal, who does not rise very early, may enjoy his newspaper at his breakfast table, published in London only the evening before; and when the railway comes, he may rise earlier and have the same indulgence.

Before quitting this part of our subject, perhaps I may be permitted to mention, that notwithstanding the great improvement in road-making, there are still many farms in the north of England, or, at least, there were a few years agn, to which there is no carriage-road, and which, consequently, possess no wheel carriages. These farms lie on the edge of Stancmoor, and in some of the Yorkshire dales. Their occupiers are obliged to drag their hay into the barns on siedgres, and sometimes pack it up in sheets on the backs of horses. The manure is sometimes carried to their steep,

* The introduction of railways has so much extended the market, that the sale of fruit is usually commensurate with the immense increase of orchard produce, varying in price according to the season. 
sloping fields in a kind of basket, called a hott, or hutt, by men, and it is to be feared sometimes by women. It is singular that a similar article much used by the Swiss peasants bears the same name. I would here, also, mention an ancient and very primitive kind of cart wheel, which was used in Westmorland within the period of my own remembrance. A strong axle of wood was firmly fixed into two wheels which had no spokes, but were solid, being made of stout planks three or four inches in thickness. They were with great propriety called clog-wheels; the cart was placed and kept fixed upon them, partly by its own weight, and partly by two wooden pins on each side of the axle, which turned round with the wheels. They were, in some respects, not ill adapted to the hilly and unlevel nature of the country, and to the cart-tracks or roads, often worn into deep ruts; for a cart mounted on these wheels could not be easily overthrown. One fault they had, it was no easy matter for the horse to turn them round without fetching a compass, for there was no small degree of friction, and they scraped upon the ground just as if they had been locked. They have long been out of use, at least in our neighbourhood. The last pair of clog-wheels I saw, was in the retired and primitive vale of Seathwaite, about twelve or fourteen years ago. If it were not for their bulk, I could almost wish to see a pair of them placed in our Museum, as a memento of our ancestors. Those famous war chariots of the ancient Britons, that were armed with scythes, and made such havoc among their enemies, were probably mounted on nothing better than $c l o g$-wheels!

Perhaps no event has produced a greater change in the appearance of our district, than the enclosure of the commons. As the ancient cultivated ground was chiefly confined to the level parts of our lower valleys, the adjoining heights and hills had been left in a state of nature, covered with juniper, heath, and brackens; and you might travel from valley to valley without let or hindrance; which 
was a great convenience and comfort to the hare and fox hunter, and to the fowler or other wanderer amid wild natural scenery. In those days, no strong stone wall rose up at every few hundred yards to arrest your steps, nor was lettered board put up, to threaten trespassers with the vengeance of the law. Thank heaven! the latter are not very common yet, in our good North Countrie.

Where the commons belonging to a township or parish lie low and warm, and the soil is of sufficient depth to admit the iplough, their enclosure may benefit the community. But on our higher fells the case is different. They are too distant, and too difficult of access, for the application of lime, and are therefore incapable of improvement. Nay, they are positively better in their unenclosed state, for in that case the cattle can have a free range, and can choose their pasture either on the dry heights, or moist bottoms, according as the weather may be droughty or rainy. It is difficult to sce what rational or honourable motive could have led to the enclosure of such commons as Troutbeck Hundreds, or that dreary waste which adjoins the Pass of Kirkstone, called Woundale. The stone walls, now thrown like chains across the fronts of these noble mountains, as if to subdue and bind down their natural freedom and sublimity, and to dole them out into petty plots of ownership-have also rolbled, utterly annihilated, that ancient barrow or cairn, which had stood there in its loneliness from the dimmest years of antiquity. But to pass over this outrage, which would be viewed as the most trifling pecadillo by many molern landowners (the rage for improvement has made sad havoc with ancient remains in many other places)-we would ask, how it could be for the advantage of the small proprietors to enclose these elevated, barren commons, for they are by the enclosure deprived of their turbary and peat grounds, and have to fence in their little allotments, which is attended with so much expense, that, it may be feared, they are tow often induced to dispose of them to 
their richer neighbours, for a trifling consideration. But still the smallest landowner had his allotment. The lord of the manor, the vicar or rector of the parish, all had their allotted shares, and often very valuable ones; yet there was one party who had a right, a privilege on these commonsoften of much service to him, whose claim was entirely forgotten-this was the poor labourer, who could have kept a pony, a sheep, or a cow upon the commons. Yet his right, his vested interest, as it would have been called, had it belonged to any other class, was completely overiooked by lord and landowner, clergyman, and every other party concerned in the enclosure of the commons. Is it any wonder that the labourer has become pauperised? I remember an old man that lived on Cartmel-fell, who actually maintained himself and family, by keeping horses on the extensive commons belonging to that township.

With respect to the commons in our own immediate neighbourhood, those belonging to Crosthwaite were enclosed in 1805; those of Cartmel-fell, a few years earlier; those of the township of Underbarrow, a few years later; those of Undermilbeck and Crook, in 1813. Considerable tracts in all these townships have been since planted, chiefly with larch, which has much varied the face of the country, if it have not rendered it more beautiful. I will mention a few. There are a good many larches planted on Whitbarrow; it is surprising how the larch will thrive-even when planted on the face of a limestone scar, where there would seem to be neither soil nor moisture to afford it sustenance. There is an extensive wood, chiefly of larch, at Lamb How, which, being in a low and sheltered situation, has already some fine specimens of that tree, although it is not quite forty years since it was planted. But it is on the heath and stone-covered heights of Cartmel-fell, that this exotic tree has been spread in the greatest profusion-to the extent of covering many hundreds of acres, certainly. The hill named Great Tower, near Gill Head, and Gum- 
mer's How and Birk-fell, the loftiest parts of that mountain range, are now one forest of larch; although the writer well remembers it, when, covered with dark heath or ling, it was the abode of Moor Fowl; of late years it has been a favourite haunt of the Woodcock. A moiety of this extensive forest was planted by the late celebrated Bishop of Landaff, Dr. Watson, who is reported to have said, "that if his laurels should fade, perhaps he might be remembered by his larches."

I am aware that Mr. Wordsworth, in his prose disquisition on the Lake district, is no friend to the larch. $\mathrm{He}$ says, "Larch and fir plantations have been spread not merely with a view to profit, but in many instances for the sake of ornament. To those who plant for profit, and are thrusting every other tree out of the way, to make room for their favourite the larch, I would utter first a regret that they should have selected these lovely vales for their vegetable manufactory, when there is so much barren and irreclaimable land on the neighbouring moors." Mr. Wordsworth's rule, in the instance I have last mentioned, has not, I think, been violated, and therefore the beauty of the landscape has not been injured. I believe it is not more than half a century since the larch, to any great extent, was introduced into our neighbourhood; but it has already become naturalized, and is spreading itself over the heaths and pastures, by the common agencies of nature, its seeds being carried by winds or dropped by birds. The largest larches in this district, I believe, are those at Rayrigg, near Bowness.

There is another circumstance, consequent on the enclosure of the commons, which has not added to the beauty of the landscape. I allude to those long straight lines of naked stone walls that divide the various allotments. How different from the ancient fences that separate the primitive fields in the depths of the valleys! If they were walls at first, they are no longer so, for wood has sprung up at their sides, and now they are hedges: they hardly keep a direct 
course for a moment, but run into all kinds of waving lines.

" "hedgerows, hardly hedgerows;

Little lines of sportive wood run wild."

Notwithstanding Mr. Wordsworth's ingenious dissertation, I can never understand upon what principles our forefathers proceeded in laying out their fields. You will never find an old enclosure of a square, or oblong, or of any regular geometrical figure. They do not appear to have thought of either saving time or materials, or to have known the mathematical truth, that the nearest way between two points is a straight line. But how much has the beauty of our valleys been increased by this happy irregularity-this want of attention to any rule!

At the time of enclosing the commons, or perhaps a little earlier, the practice of under draining seems to have come into use. The only method that was formerly practised to render a piece of low, swampy ground somewhat drier, was intersecting it with a few open cuts, or gutters as they were called. But of late years the passion for improvement is such, that some ancient tarns of no small extent, have been drained off and utterly annihilated! The most remarkable instance is that of the tarn in Kentmere, through which flowed the river Kent. It is true that a few meadows might be gained, and therefore it was a profitable scheme in an agricultural point of view; but had we been the owner of the estates on which it was seated, we should have felt very unwilling, on more than one account, to have swept it away -that ancient mere, from which the valley has evidently been named. It was prettily sheltered on the west by a young and springing wood, and was a favourite haunt of the Wild Duck; it was one of nature's fishponds, and supplied the river with Trout, and it was a spacious dam or reservoir for all the mills and factories lower down the stream; laying up and husbanding the rains that fell on the 
adjoining hills, and dealing out the water leisurely, as it was wanted; so that its extinction was lamented not by the naturalist and lover of nature only, but by the mill-owner and the manufacturer also.

Helton Tarn, through which passes the Winster, has not indeed been completely drained, but it has been much diminished, "robbed of its fair proportions," by the sinking of the river, a few years ago. The Tarn contains as well as the river, a few fine Perch and Pike, which may be mentioned, as I am not aware of any other river in Westmorland stocked with these fish. There were also some other small, nameless tarns, each enclosed in its rock basin, which, through this rage for agricultural improvement, have also been drained; often not without great labour and expense; for this silurian or argillacious rock of ours is very obstinate, and could not have been conquered at all, in many cases, had it not been attacked with gunpowder.

At Matson Ground (near Bowness), near which place I am now writing, workmen are at present engaged in sinking through solid rock to the depth of eleven feet, in order to drain a single swampy meadow of a few acres. There is one circumstance almost always attendant on these small tarns-there is peat-moss, or peat-earth, found in them to the depth of several feet, lying beneath the smooth water. Another word only, respecting this draining of tarns, or rather Lakes. It was reported, that a few years ago a scheme was in agitation to drain Grasmere Lake, and that it required all the eloquence and influence of the great Poet, who lives hard by, to prevent it. There is no doubt that mere agriculturists, who regard everything with a view to profit, and who have no eye or soul for the beautiful, would drain Windermere itself were they able.

In our neighbourhood by far the greatest alteration-I sippose it ought to be called improvement-that has been effected by changing the face of the country, is on that 
extensive Marsh or Moss bounded by Lythe on the west, and by Brigsteer and Beathwaite Green on the east. That part of it which lies on the east of the "Pool," or embanked running stream, that flows from north to south, intersecting the Marsh, has only very recently been effectually drained, while the portion on the west, belonging to Crosthwaite and Lythe, was enclosed, and much of it brought under the plough, nearly forty years ago.

As I am not writing a statistical essay, I do not even pretend to say how many acres this Marsh consists of; but I may state that it is from three to four miles in length, and from one to two miles in breadth; and as it is all rich alluvial soil, or peat-moss, it may readily be conceived, that when brought under cultivation, as much of it has been, there must have been a great increase of agricultural produce. The rising generation who have only known it in its present state, as divided into fruitful fields, teeming with luxuriant crops-as rape, turnips, or potatoes, or the tallest oats, or other grain-can hardly conceive what it was in its natural uncultivated condition, as a great common pasture, upon which every man, poor or rich, turned out his stock to graze. There was no regulation limiting the numbers, therefore it was sadly over-stocked. When you cast your eyes upon it, it seemed all alive with sheep, cows, sterks, ${ }^{*}$ and calves; horses of all sizes and ages; stags $\uparrow$ and ponies. Geese also were very numerous, being taken down to this marshy pasture in May and June, from all parts of the township, as soon as the goslings were strong enough to follow the old ones, there to remain during summer; and although they did not all return to the farmyard, yet, considering how little they were tended or looked after, far fewer perished than could have been expected. But Foxes were not numerous in those days. We were

* "Sterk," a calf after it is six or eight months old,-a local term.

$\dagger$ "Stag;" the local name for a colt or filly, from a year old till the time it is broken in for use. 
confined to our own native produce in that article! It was the good old time of restriction and protection. There was no "free trade," no importation from abroad, not even with a "sliding scale," or "fixed duty," consequently Foxes were rather scarce, and geese could walk about, and pasture and grow fat in safety-but not grow fat, I think, upon Lythe Common, for never was there pasture so bareso closely shaved-so incessantly nibbled as this!

But let us examine a little more attentively the appearance of this common, in its ancient, more primitive state. We will suppose ourselves seated on that part of the moss which lies betwixt Brigsteer and Lythe, and facing the latter. It is in its natural state, untouched by the peatdigger, and therefore swells above the adjoining marsh. That rising ground, partly wood, and partly fields, on your right hand, is named the "Holms," or islands, and is surrounded by moss, as it has been formerly by water. Now look to your left, down the Marsh, and you will see, at some distance, two green hills of limestone rock, on the Lythe side of the Pool, rising from the moss with which they are surrounded-more boldly and abruptly than the Holms. These are termed the "Heads;" they are elevations similar to Castle Head, and Humphrey Head. O how fertile was this old Saxon language in names for every description, ever so minutely distinctive, of natural objects!

This Marsh is entered on its Lythe side, by the Crosthwaite beck, or Gilpin, which is joined by the stream from Underbarrow (forming what is called the Pool). The soil on each side of these streams consists chiefly of the detritus of the slate rock, and of fine mud brought down by them in time of flood. It is by far the richest soil of the Marsh, and in its ancient state was covered by a closeset green herbage, so keenly shaved by the incessant nibbling of the numerous herbiverous animals which it had to maintain, that the woncler was how they procured a livelihood at all. Indeed, this could only be effected by the 
most unintermitting exertions. "From eve to morn, from morn to dewy eve," it was, nibble, nibble, nibble. If the poor man's horse had lost half an hour, it would have been fatal! No future efforts could have recovered the lost ground! O but this Marsh was an animated scene in the old time! We will suppose it a fine, warm, dry, sunny day in May or the beginning of June. There are the herds of cows and horses, the flocks of sheep and geese wandering about in all their pasturing activity. Then there are the peat-gravers, and their one, two, or three bearers each, going to and fro in constant motion. One part of the moss bore the name of the Whamp-nest (wasp's nest). Here the peat was very deep and of the best quality, being, when dry, black and hard, and heavy almost as coal. This part of the moss being common, that is, free to the people of the whole township-the first comers being the best served, that is, having the choice of the best dykes-it presented a scene of great activity in spring. And whether it had been named Whamp-nest, from the workers being busy as bees on a sunny day, or from the eager competition producing numerous quarrels, I know not; but such was its name.

I will here allude to a phenomenon which has doubtless been observed by naturalists, and perhaps described and accounted for, though I do not remember having met with any observations on the subject. On a dry, warm, sunny day, just over the heath, playing in the air, you might observe the "dry hop," as it is called by the rustics. It might seem as if the particles of air, generally invisible, were for the moment, from the peculiar, dry state of the atmosphere, rendered apparent to sight; or, perhaps, it may be the moisture evaporating from the earth.

On such a bright day, this wide Marsh, besides being animated by the troops of tame animals seeking their food, and peat-diggers and herdsmen, also contained at this period unnumbered pairs of wild birds, which there 
bred and brought up their young. You might hear the sublime whistle of the Curlew, high above your head. The Plover or Tewit circled round you, uttering its wailing cry. The Wild Duck was there, hidden among the sedges, or nestling on the heathy eminence. The Heron stood by the Pool or Dyke for hours-his dingy blue colour, like a piece of fossil wood, protruding from the moss, but with head lurking between his wings, and his bright hawk-like eye, showing him to be wide awake, and ready to pounce with his long bill on any unlucky fish or frog that came within his reach. Then there was the Hammer-bleater, or Large Snipe, up in the clouds, rising and falling, uttering his cry peculiar to that season, at which all the moss would seem to shake. But in a few years-indeed, it has already taken place to a great extent-not one of these birds will be found; the moss will be cut away for fuel, and its site converted into arable land, covered with green and white crops, and ministering most abundantly, but in a different manner, to the wants of man.

There is a layer of clay or marl lying beneath the peat, which, when thrown out and applied to the surface, renders it much more fertile than it would otherwise be. This argillacious deposit must have been formed long anterior to the existence of the peat, when the area of this extensive Marsh was covered with water, and probably visited by the tides of the ocean.

It has been said that one part of this moss was common for digging fuel-not all of it, however; there were some parcels belonging to different landowners. As they were deprived of them by the enclosure of the commons, it is scarcely natural that they should all have been satisfied. But there was one individual, a small Statesman, who exhibited such an indomitable spirit of opposition to what he considered an unjust law, though embodied in the decree of King, Lords, and Commons, that I hope I shall stand excused for giving a slight sketch of such an extraordinary 
character, though moving in humble life. He could never understand how it could be just to deprive him of his peatmoss. What was an Act of Parliament to him? It was but a piece of parchment-he would never submit to it. He would neither take the portion allotted to him, nor would he part with his own. In the spring he went and cut his peats as usual, on what had till then been his own moss. The person to whom it had been given by the Enclosure Act, carted them home (or, at least, as many of them as he could get), but through fear of meeting with our "Village Hampden," he carried a rusty sword, which he had worn in bygone years, when he had been a volunteer, militia-man, or some sort of soldier-a somewhat formidable antagonist one might think; but our hero, Richard, like him of the Lion Heart, was not to be quailed or intimidated; he would by no means submit. He cut his peats, sometimes getting them home, sometimes not. Matters went on in this way for years, and we fear that the King's peace was more than once broken. Recourse was also had to law, and writs were flying about. In the upshot, our rustic champion doubtless suffered in pocket, for attorneys must be paid by one side or the other, if there be the wherewithal; but like the lovesick maid who " never told her love," he mentioned not his loss. Whatever might hap to him, his spirit was never subdued, as was often shown in those democratic assemblies ycleped township meetings. It has been said by somebody, that minorities are always right. If this be true, then was Richard seldom wrong, for he was generally in the minority. Indeed, he never considered whether he was supported or not: he would maintain his opinion, though alone, against assembled numbers, like another Abdiel,

"Among the faithless, faithful only found."

At that time of day, the meetings in Crosthwaite were conducted in a very primitive manner. They had not ar- 
rived at that stage of civilization, to see the necessity of appointing a chairman, to preserve order, \&c. It therefore of ten happened, that when the ratepayers met to consider some weighty affair in public meeting, they nearly all talked and nobody listened; they called names and quarrelled, and finally parted without settling anything, leaving matters to take their own course, or, at least, to the guidance of the overseers or other officers. On some occasions, however, they were more unanimous, yet it was but seldom, indeed, that our hero ranked in the majority. "Men were so very unreasonable," he said, "they had no sense in them."

Indeed, there was one memorable meeting when he was said to have stood alone, opposed to the whole uproarious assembly. But he exhibited a vigorous "tongue fence," against the united attacks of the meeting; at length the room became too hot for him, and he retired with his pot of . ale into a small side parlour, to brood over the absurdity of mankind, and the mischiefs that were in embryo for the republic of Crosthwaite and Lythe. But it was not for long. His impatience or indignant feelings impelled him to open the door, and again face his foes, concluding a short speech with this pithy peroration: "I tell ye, ye are $o$ ' a pack of - fooals!" when, rising on their legs, with uplifted hands-

"The universal host upsent a shout,"

"Hurrah! hurrah! hurrah!" Then did our hero retreat into his lair, in a short time to sally forth, to be received with the same shouts and hurrahs!

Richard Cour de Lion (we delight to give him this appellation) is still living, though verging on the extreme age of ninety. He is still hale and hearty for his years, still walks erect, with his face looking upwards, his leg plump and well proportioned, by no means shrunk "into the lean and slippered pantaloon"-he wears "shorts" (or knee-breeches). Alack! there are few township meetings now a-days. Since 
the passing of the new Poor Law, they are few and far between, or we do not doubt Richard would still attend and still oppose the whole township, alone and unsupported, if he thought them in the wrong! May he still live many years, and may old England and the township of Crosthwaite never want kindred spirits; honest and courageous to maintain what they deem the right and the true, against all opposers, however numerous !

I have not quite finished my subject, but the paper is already too long; therefore, I will now, with your leave, conclude.

\section{LYTH LANE.}

There is a certain cross-road leading through one of our beautiful Westmorland valleys which, time out of mind, had been used only by the neighbouring farmers in the vulgar occupations of carting home hay, corn, peats, lime, \&c. ; nor had it dreamt of any higher honour. But in process of time it was discovered by two sagacious innkeepers (no doubt for the public good), who happen to live near its northern and southern extremities, that it formed a convenient line of transit for those birds of passage, who annually migrate from the more southern parts of the Island, to while away a few days in summer among, our Lakes and Mountains. Now, although thirteen or fourteen miles is rather a long stage, yet, as posting is paid by the mile, it was no doubt all for the public good on the part of these patriotic innkeepers. Then what a change in this hitherto retired Lane! Now might be seen passing along, at all hours of the day, the chaise, the gig, the barouche, and every fashionable vehicle, to the great delight of the younger part of the natives-more particularly the farmers' daughters, servant girls, \&c., who would gaze with wonder and amazement at the unwonted spectacle. What a pleasure to the postillion, in his smart cap and yellow jacket, and to the rustic maiden, to see and to be seen. This might all have been very well; but what begins pleasantly does not always go on so. This 
poor Lane was soon found by the new comers to be inconveniently narrow. What a vexatious thing for an elegant chaise, or a gentleman's carriage, to be jammed into a thorn herge on one side, and to come into grievous contact with the massy wheels of a vile and vulgar dung-cart, on the other! Application was now made to a portion of the "Great Unpaid." A mandate was issued forthwith. The tall luxuriant hedge-rows of the offending Lane are to be swept away, to be replaced by naked stone walls. Its beautiful winding vista-its alley-like line-is changing into a common, wide turnpike-road, like the outlet from some huge, manufacturing town, shining in all the glories of M'Adam. But the expenses? Doubtless, as it has been altered for the accommodation of the Gentry, they will bear the expenses? Not a shilling. But, then, they subscribed at least, handsomely? Not a farthing. Who should pay but the poor landowners, or still poorer tenants who hold from year to year? Is it not legal? O, the niggards! to grudge their dirty money for widening the roads for lakers and gentlemen's carriages! To be sure the old road might have served your vulgar purposes-to cart your lime and your peats, your hay and dung, to go to market and to church, as it served your fathers before you. And, we believe, had you lived till the age of Methuselah, to widen the Lane for your own uses would never have entered your heads. But what then? Why grudge the expense of making good roads for the gentlemen? Though you have not an inn where they can stop and spend their money; are you not well enough paid in the honour of their passing through your beggarly township? Out upon you!

Lyth Lane! thou art changed-metamorphosed. Thou art no longer the same as in our school-going days, when we loitered along thy shady alleys-gazing up at thy tall hazels, where hung thy brown nuts lurking in their ripe husks; or peeping into thy luxuriant thorn hedges, that hid the linnet and the sparrow's nest. Nor, in the orchards 
that "skirt nearly thy whole extent, can we forget the glimpses we sometimes had of the tempting apple, or still more tempting pear, at the immediate risk of a breach of morals and one of the commandments. Happy days! "The collective wisdom" had not then placed those boyish pranks, those juvenile delinquencies, in the same class with robbery and murder. Lyth Lane! thou art changed-metamorphosed-vanished-extinguished! In passing the other day thy northern extremity, we found it fenced across-interdicting all ingress or egress; and affixed to an upright post was a small card, from which we copied the following written inscription, probably the production of our erudite surveyor:-

"this Rood is stoped ites onder Repare and is thearfore onpaseble."

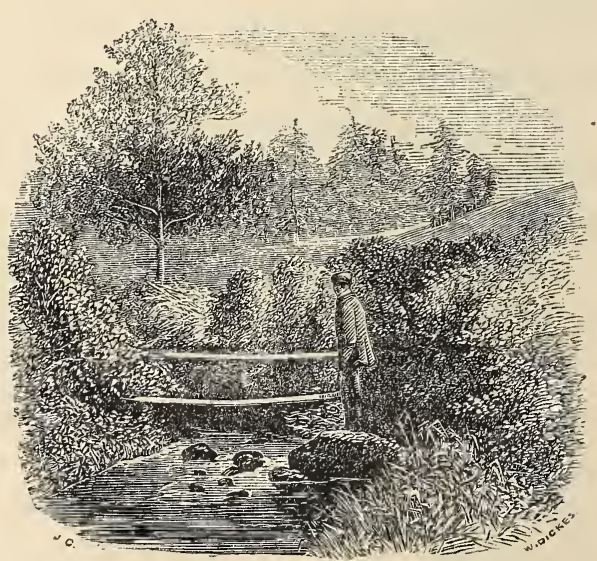

SCENETY OF THE WINSTER. 
NOTICES ON A FEW SUBJECTS IN THE NATURAL HISTORY OF CROSTHWAITE AND LYTHE, AND THE VALLEY OF THE WINSTER, IN WESTMORLAND, IN SIX LETTERS TO THOMAS GOUGH, ESQ.; WITH AN ALLEGORY.

Read to the Kendal Natural History Society, on the 8th of October, and the 10th of December, 1849.

"These lowly denizens of the earth, our fellow pilgrims on the Journey of Life, have their appointed tasks, as we have, set out by their great Creator." *

\section{LETTER I.}

Border Side, 11th April, 1849.

Mr DEAR Sir,-During one of our conversations, which I regret to say so seldom occur, I held out a promise that I would send you a few observations which I had made of late years, on some points in the natural history of our neighbourhood. I am aware that the interest you feel in these subjects, to say nothing of your good nature, will make you indulgent to what I fear other minds may consider trifling details. In two papers which I had the honour to read to our Society several years ago, chiefly on the wild animals of the district, I believe there was no mention made of fish. A few remarks, therefore, relating to them may, I hope, be excused. We have only two streams of moderate size, the Winster and the Gilpin, or Crosthwaite Beck. They rise within half a mile of each other, on the opposite sides of the hills east of Bowness; run in the same southerly direction, and fall into the head of Morecambe Bay, the one below Castle Head, the other near High Foulshaw.

* Not a quotation, in reality, but W. P.'s own thoughts. 
Through a great part of their course, they are not separated much more than a mile; flow over the same description of rock and soil, and yet, what is remarkable, contain different kinds of finny inhabitants. They are both pretty well stocked with Trout and Eel, common to all our Westmorland brooks; but, what is somewhat curious, the Winster contains both Pike and Perch, while the Gilpin possesses neither one nor the other. And yet, if I may judge from what follows, the Gilpin contains a rather uncommon denizen, that the Winster can by no means boast of. A few years ago, I had sent to me to ascertain its species, a short, bulky, whitish, scaly fish, which had been caught in the Lythe meadows, much to the surprise and wonder of the angler, who was fishing as usual for Trout. You may easily believe that my little piscatorial knowledge was sorely nonplussed -for the creature is scarce enough in our becks; however, after consulting some authorities, among the rest, good Isaak Walton, I made it out to be a Carp? But how it happened to be found there, is still somewhat of a puzzle. I have, indeed, been since informed that there are a few of this species of fish in a deep and copious spring, named Thorpel Pits, near Johnscales, in Lythe, which is fed no doubt by many a subterraneous water-course draining the eastern side of that fine detached limestone mountain, Whitbarrow. As this pit or pond runs into the Gilpin, this may go far towards solving the mystery. As to the Pike and Perch of the Winster, they are chiefly found in a pretty large piece of still water, named Helton Tarn, through which that river flows, lying west of Witherslack, near Tarn Green, although they are met with in the stream above; indeed, I have seen Pike up as high as Bowland Bridge. There was formerly a tarn near that hamlet, where they were found in great numbers. I remember, when a youth, seeing an old man placing night-hooks to catch them, baited with mice, and what, perhaps, causes me to recollect the circumstance, the mice he used were pie-bald. It may be worth mention, that I say 
"formerly a tarn," because it is no longer so, having, in the lapse of no great number of years, become comparatively solid ground, and of course the fish banished-and that not from draining, but the accumulation arising from the growth and decay of the aquatic vegetation, the natural product of the site.

The Winster, as you are aware, is bounded on its western side, nearly through its whole course, by the range of Cartmel-fell. And the mountain is intersected at short intervals by numerous small brooks, or becks, as we term them, which flow down the different hollows to feed the main stream. These are all full of Trout. I well recollect, when a young angler, the joy I felt at this discovery: it was a discovery of no small value and interest to me at the time, for when the more experienced and cunning fish of the Winster treated all my baits with indifference and contempt, these hungry mountaineers would seize them with the greatest eagerness. There was scarcely a single dub at the foot of a rock but would yield me its pretty speckled captive. Indeed, there are f'ew things more remarkable than the unconquerable perseverance evinced by the Trout and Eel, in working their way to the highest sources of the smallest streams. It is a wonder how they are supported in these scanty waters-so scanty, indeed, that they often fail altogether in a hot summer, and then you see the poor fish lying dead in the dried-up pools. The stream of these Cartmel-fell becks is often interrupted by steep rocks, where there is a waterfall of some feet in height, and which you might think the fish would not surmount; but you find them far above for all that, even at the narrow source where it dwindles into a rill. In all these becks, I know of only one exception where the Trout are not found above the waterfall. I possess a small tarn, seated high up on a rough pasture, and passing it one day, I observed a rather large Eel lying dead in the water. No doubt there are plenty of live ones besides, occupying this tarn. Now, it is a curious 
question, how they got there at first; for the stream that flows from it is so very small, and, moreover, runs over a steep rugged rock just below it, that the difficulty seems no little to account for their being there at all. I know it is said that Eels will sometimes quit the water, and make their way through the wet dewy grass on level meadows; but in this case, the difficulty would be tenfold, from the rugged nature of the ground.

You are probably aware that the Flook, or Flounder, is an inhabitant in its youth, or, at certain intervals, of freshwater streams; at least, of those which at no great distance communicate with the sea. I well recollect that, when a school-boy at Underbarrow, it was one of our sports during the dinner hour to catch these fish, which we effected by means of a common table-fork fixed on a long stick, with which harpoon we transfixed them as they lay at the bottom of the brook. They were small in size, about the breadth of one's hand, and being of the same brown colour as the mud and stones, it required all the keenness of our young eyes to detect them as they smoothly glided along, close by the bottom. Do these fish, like the Salmon, breed in the fresh water, and, like the latter, only take to the salt sea to gain strength and bulk?

Mention of the Salmon reminds me of a serious loss we have experienced of late years in our becks. Formerly small Salmon ascended the Winster and Crosthwaite becks in great numbers, in the autumn, to spawn. They were called Morts and Sprods; and although of no great sizeseldom exceeding a pound in weight-yet I have heard of some being caught that weighed twenty pounds. They were destroyed in various ways; some at mill-wears, some by nets, many speared with leisters in the night, by torch light, when they were upon the "rid." Destructive as those methods undoubtedly were-put in practice, too, at the time of the fish breeding-yet there were many that escaped, and, perhaps, more that had effected the great pur- 
pose for which they came, so that it is not considered to have contributed half so much to their present well-nigh extinction, as the detestable scheme said to have been practised near the mouth of the river near Wilson House, of obstructing the ascent of the fish by means of nets, or other engines drawn across the stream. This was indeed killing the goose that laid the golden eggs! But whatever may have been the means-and, no doubt, all have contributed-the lamentable fact is, that scarcely any of the salmonidæ now appear in our streams. The Fork-tails, or Parrs and Smelts, are gone likewise-proof enough that the Salmon are their progenitors.

What a change for the worse, from the times when the Kendal apprentice is said to have had a clause in his indentures, that he was not to have Salmon for dinner more than three days a week!

So much for fish. Perhaps, in my next, I may trouble you with a few remarks on birds, if you think it would interest you.

Believe me, I remain, my dear Sir,
Very truly yours,

W. Pearson.

\section{LETTER II.}

Border Side, 17th April, 1849.

Mr dear Sir,-In continuing these desultory sketches, indulge me with a word or two more, relating to fish. I do not know if it has ever been ascertained whether the fear that fish manifest at the sight of man is instinctive, or has been acquired from his repeated hostility. But as it is well known that the birds of uninhabited islands are so tame that they may be knocked on the head with sticks, I think it is probable that fish would be equally fearless at the approach of man, had they not learned his character from dear-bought experience. Yet inhabiting a different element, one might think they had not so good an oppor- 
tunity of acquiring that knowledge, as birds and quadrupeds. Then, again, it is a question whether fish fear the approach of the common four-footed animals which come to drink at the stream. I should think not. It is well known that birds treat them quite confidentially. The sagacious, wary Rook, that keeps at a safe distance from man, is altogether at home among sheep, cows, and horses. The Magpie will sit upon the Cow's back, and while the cunning bird is promoting its own interest, rids his supporter of a plague and a pest in the shape of a large grub embedded in his hide. Indeed, it is pretty clear that these incongruous associations are seldom owing to any sympathy or love which the parties may feel towards each other. Starlings often troop with Rooks; but is it not for what they can pick up from the latter's leavings? I was once highly amused and interested in witnessing a number of Wagtails and other small birds treading close on the heels of a flock of sheep pasturing in a field; and they appeared to reap an abundant harvest from the worms and insects that were dislodged from the grass by the sheep passing over it. This was in the neighbourhood of Geneva. But fearless as birds may be with the harmless herbivorous quadrupeds, they know how to discriminate. Let the stealthy Cat, the Weasel, Foulmart, or Fox, be seen prowling about, and then hear their cries of alarm and indignation! When the path of Reynard would be unknown to the eager hunter, his "whereabout" is made apparent enough by the noisy Crows, \&c., that pursue him, high over head, along hedgerow and thicket.

Much as the destructive instinct in man is to be lamented when carried to excess-and by none more so than by the naturalist, who has thereby to regret the entire loss of some rare bird or other animal from his district-it is pleasing to have to mention the different feeling sometimes evinced among our rural population. Here is my old neighbour, Isaac Walker, now verging on eighty, who is on such good 
terms with the Robins and Chaffinches of his garden, that he cannot stir from his door but they wait on his steps, ready to pick up the crumbs he scatters from his kind hands. He has a beautiful cock Chaffinch, particularly tame and confiding. It is odd, but he succeeds better in gaining the goodwill of the cocks than of the hens-the latter are more shy, and seldom come near. But to return to our fish:-it is well known they can be tamed, and will come to be fed. Old House Beck (one of the Cartmel-fell Becks I mentioned in my first letter) runs through the fold of a small farmhouse. The brook is there so diminutive, that it is covered in like a drain, and shelters a number of Trout, which readily come out of its mouth to be fed by the young folks of the house, and they are in no hurry to return, but may be viewed at leisure, and almost handled. The porridge pan, I am told, is sometimes placed in the brook, and the fish will enter it for the purpose of cleaning it out.*

There are one or two subjects connected with entomology, and having also a bearing on agricultural and horticultural pursuits, which I mention with a hope that your more accurate and extended knowledge of Natural History may throw more light on the matter. Our pasture lands, last summer, were much injured by the larvæ of some beetle, that ate away the grass roots, and rendered the soil so soft and friable, that one's foot sunk in on the tread. From a beautiful green, the field becomes a dead brown; this causes a serious loss to the farmer. I suspect it is not the grub of the common Cockchaffer, because we never have these in great numbers in the imago state-and our devas-

* A remarkable instance of the tameness of fish may be here recorded. In the grounds of the Kur Saal, at Wiesbaden, in an artificial piece of water, are shoals of a small kind of fish (I did not make a note of what kin(i), probably Carp, because, "except the Eel, the Carp endures most hardness, and lives longest out of his own proper elenıent." Visitor's anuse themselves by feeding these fish, which struggle and contend, jostle and push each other aside, even on the shelving bank; for they rearlily leave the water, tempted by crumbs thrown on the bare ground for that purpose. 
tators are exceedingly numerous. It is more likely to be that of the Bracken-clock, a much smaller brown beetle, very numerous, in most seasons, on our pastures, in its flying state-only the larvæ are larger than would seem to be required for such a beetle. It is remarkable, that the Rooks, of which we have such great numbers, and which feed greedily upon it both as a grub and as a fly, are not able to keep it within more moderate bounds.

Many years ago, I planted a rather extensive orchard, and as it flourished from year to year, and began to produce fruit, I took no little interest in it. But it not seldom happened, that when an apple-tree promised a full load, one's hopes were disappointed, and that in the strangest and most unexpected way. When all danger from frost and blight was passed, and the fruit was not only set, but fully half-grown, it would begin to drop from the tree in the most unaccountable manner. On close examination, I found that an apparently contemptible, but most destructive and insidious enemy had been at work. Every fallen apple was perforated from the surface to the centre; and at the mouth of the tunnel or shaft, was a heap of yellow matter, being in fact the rubbish which the invisible miner had thrown behind him in the process of his excavation. On cutting the apple, there he was, sure enough, seated in the very heart of his conquest-the core of the fruithaving dug himself a wide chamber, that he might take his ease, feast, and enjoy himself after his labour. This clever destructionist was no other than a small, tough, wiry, white-coloured grub, of about half an inch in length. When he had finished one apple, he would attack an adjoining one, for I caught him in the fact, half way along his covered passage, proceeding towards the inside. The fruit, though sorely wounded, did not drop at once, but would remain on the trees for a few days, fair to look upon. But they were doomed. How could they live when the heart was eaten out of them? They fell one by one, and lay 
thick beneath the trees, like dead men on a field of battle, a most piteous sight to a zealous orchardist. Of my ruthless enemy, I naturally wished to know from whence he came, his birth, and parentage. But it is a mystery to me to this day. I wrote to a friend at Lancaster-they had just set up a Natural History Society there-(we had none in Kendal for years after)-thinking that, as he was literary, he might, perhaps, enlighten me on the subject. But he never answered my letter. He was probably as ignorant as myself, and did not like to confess it. There was one thing curious about this mysterious freebooter, that some kinds of apples he did not attack-but those were of a coarser quality. The creature had judgment. I have observed the same thing in rats; when they have broken into an apple loft, the inferior sorts were let alone.

I had another enemy in my orchard which caused me no small trouble. Swarms of black ants would ascend the boles of the trees-spread themselves to the ends of the remotest branches, and there eat out the tender blossom buds, as they were expanding in the early spring. You may be certain I should not suffer the attacks of those ravagers without resistance. But then, how to vanquish the attacks of such innumerable hordes? There were thousands of them. I consulted my orchardist friends. I read books-eventually, I adopted several expedients-alas! for a time, all ineffectual. It may amuse you to hear of them. One was to wrap a broad leaf of the tobacco plant round the stems of the trees most numerously attacked. Then I watched the result. When the advanced files of these marauders came to the margin of the odoriferous weed, their delicate organs did not seem to relish the pungent smell, and I felt a short-lived rejoicing at the success of my scheme. They traversed the whole round of the stem, as if secking for an opening, but when they discovered none they passed boldly over it. Then a coating of tar was tried. While this remained soft and sticky, it gave 
them some trouble, but it became in a short time dry and smooth, and afforded them an easy passage. This application also injured the trees, turning the bark yellow, so that the remedy, even if it had been one, was worse than the disease. A thick barricade of sheep's wool was more effectual; and it was amusing to observe these industrious creatures toiling through the threads of this rampart-but still, through they would go-in fact, no obstacle could long impede the indomitable perseverance of these insects. In short, I gave up all these schemes; and after enduring the attacks for at least two springs, it occurred to me to examine an adjoining strip of copsewood, and there, under a large root, $I$ discovered the whole colony in a half torpid state. A tea-kettle full or two of boiling water, judiciously applied, effectually ridded me of all my enemies.

My letter has attained a full size, although I have said little on birds, as I promised. This must be postponed till another opportunity. In the meantime, I need not say I shall be glad to hear your remarks on any of the subjects I have touched upon. I ought to have mentioned, perhaps, that I kept some of the white-apple grubs to ascertain the fly they would produce, but some accident prevented the success of the experiment. I lament the unsatisfactory result of my observations.

Yours very truly,

W. Pearson.

\section{LETTER III.}

Border Side, 4 th May, 1849.

MY DEAR Sir,-I have written to you twice lately, but have not yet had the pleasure of hearing what you think of my few observations on the subjects alluded to. I need not say I shall be glad of a line when you find leisure.

I fancy our spring arrival of birds is later this season than usual, perhaps from the cold, ungenial weather we have experienced. I did not hear the Cuckoo till the lst 
May, nor see the Swallow till the 28th April, nor the Pettychaps. The Redstart a day or two later.

In noticing the manners and habits of birds, one is much struck with their various modes of incubation - the ingenious construction of some of their nests, as well as the variety of situations they place them in. How beautiful the nest of the Chaffinch-still more so, those of the Wren and the long-tailed Titmouse, the latter two covered with a dome, and provided with a side entrance into their snug interior, which is lined with feathers and the warmest materials! How different all this ingenious painstaking, from the indolence of the Partridge, Peewitt, and others, which can scarcely be said to form a nest at all, but will drop their eggs in the hollow made by a cow's foot, with scarcely a little grass to keep them from the damp ground! Then, again, some nests are snugly hid from every prying eye, concealed in the leafy hedge, or covered by tufts of grass or moss, while others are placed in trees before the foliage is unfolded, and consequently apparent to every passer by. Birds of the same species are pretty uniform in choosing similar sites for their nests, yet there are now and then exceptions. I have a Blackbird this season, that has built its nest on the ledge of a rock in a plantation of larches. The Throstle will sometimes do the same-yet it is the general habit of these birds to choose a hedgerow or bush. The eggs of birds are frequently taken away or destroyed. I should judge that one-half of them never come to maturity. A pair of Missel Thrushes have built at Border Side for a number of years, yet I do not recollect a single instance in which they succeeded in rearing their young. You know that they place their nest in the forked branches of an apple tree, near the ground; and as this is in early spring, before the trees are in leaf, the somewhat large nest is apparent to every wandering boy, or plundering Magpie or Crow that may happen to fly over it. The simple bird learns nothing from experience, but goes on from year 
to year, choosing a similar site (often the same tree), ever to lose the reward of its labours. Yet it must succeed better in its second attempt, when the more advanced season affords greater means of concealment, or the species would necessarily become extinct. While some birds seek the most retired situations for their nests, others appear as if they sought the protection of man. Rookeries are almost always near houses. Then there are the Swallow, the Wagtail, the Redstart, and, I may add, the Starling. A small colony of Starlings have shown great confidence in our good graces, for they took possession of our newly-built house, even before we entered it ourselves. There are three pairs now making their nests under the eaves, and I have been much amused in watching their proceedings. They go very leisurely about their business, only working about an hour or two early in the morning. I think they have been engaged about a month, and I am not sure that they have yet finished. It is possible that the ungenial season has caused them to be in no hurry. For a season or two they had built about the old farmhouse, but as soon as the new dwelling arose, they preferred it to their old domicile, thereby showing unquestionably their good taste. It.is odd, but we have only the same number as last year, viz., three couples. What becomes of their young brood?

The same question might be asked in regard to Swallows. Starlings are a new bird with us-at least in the breeding season-but there are now several farmhouses in Crosthwaite where this interesting visitor may be seen at this time of the year, busily engaged in the work of incubation.

A Robin had its nest in the hole of a rock, snug enough, near our house, last spring, but it was robbed for all that. This year it has placed it on the steep-side of a rock, but well fringed with ivy leaves, and therefore much better concealed. On passing, one may see the upper part of its scarlet breast, and its two bright black eyes, as they stare upon one through the narrow opening. The Redbreast is 
so general a favourite as to form, perhaps, a single instance of being sacred from that wanton destruction too often characteristic of the young gunner; and yet, I fear, he owes this privilege not to any superior innocence or mildness of demeanour beyond others of the feathered tribe. That he was jealous and pugnacious, I was well aware; that he would drive away, without pity, any poor, half-starved bird that would fain share his eleemosynary meal ; but I did not know of any serious impeachment of his honesty till the occurrence of a little incident, which I was sorry to witness, not long ago. You know what an active industrious creature the little Wren is, prying like a Mouse into all kinds of holes and corners in search of food. One of these tiny foragers entered the arch hole of a barn, and presently came out with a grub, or the cocoon of some insect in its bill. It rested a short time, as if rejoicing at its prize. A Robin, who happened to be near, beheld the Wren and its tempting morsel, and with no very honourable intention, I fear, flew towards it like a dart, but the Wren was too quick for him, and escaped with its booty. No thanks, however, to the Robin.

I have a few more remarks to communicate, in regard to our feathered friends, but as my sheet is nearly filled, I must conclude at present, assuring you,

I am faithfully yours,

Wm. Pearson.

\section{LetTer IV.}

Border Side, 4th Oct., 1849.

MY deAr Sir,-I now send you a few more remarks on the feathered inhabitants of our district.

There is one species that of late years has increased amazingly-that is the Rook. Within the period of my recollection, there was only one rookery in the whole of Crosthwaite and Cartmel-fell, and that was at Burblethwaite Hall, in the latter township. But the trees in 
which it was seated have long been cut down, and of course the poor Rooks banished; but in the place of it, in those two townships, there are at present no fewer than nine flourishing settlements of those sable birds, several of them more numerously peopled than the original one from which they seem to have sprung. I will just mention the names of the places where they are located. In Crosthwaite, at Fell Side, another at Broad Oak, one at Calmire Hall, and one at Low Birks, very numerous. On the Cartmel-fell side of the Winster, there is one at Lobby Bridge-this being at some distance from any house is rather singular-one at Hodge Hill, one at Hart-barrow, one at Lightwood, and another at Mr. Gibson's, of the Height. It is somewhat curious that Mr. Gibson had for years been desirous of possessing these noisy neighbours, and used to place Rooks' eggs in the nests of Magpies, that built in a grove of trees hard by his house, expecting that the birds thus hatched and reared, would have so much local attachment as to form the nucleus of a future rookery. But in this he was always disappointed. At length, however, the Rooks came of their own accord. To speculate on causes is always hazardous, and to account for our large increase of Rooks may be difficult. Perhaps the enclosure of the commons, the new culture of the marshes and mosses, the constant stirring up of the soil, and the great addition to our crops of all kinds (for the Rook is nearly omnivorous) - may be the chief causes. If man increases in proportion to the means of subsistence, then why not Rooks? And yet this useful bird is not always found where his food is plentiful, and where he seems to be most wanted. I remember that in the spring of 1843, in the neighbourhood of Geneva, the common Cockchafer was so numerous as to eat the leaves off the trees, and to create an alarm of famine, so that the circumstance was mentioned in the newspapers. This destructive insect had no enemy that I could perceive, but one of his own species, a most active carnivorous black beetle, that 
used to seize his brown fellow-creature in the pathways, and make a meal of him, even before he was dead. I could not but think how useful would an army of our Rooks have been here! Indeed, nothing struck me as more wonderful in the way of Natural History, than the extreme scarcity of these birds on the Continent, at least in Germany and Switzerland. I never saw more than two or three flocks of them, and these were migrators-passing on to some other district. The agriculturists sometimes seem to suffer severely from the want of them, and one might wonder what other bird is provided to keep the insect world within any reasonable limits. But there appears to be a general scarcity of birds on the Continent as compared to England, whatever may be the cause of it. Perhaps the severity of our Game Laws may bring us this good amid a host of evils. As to our own delightful district-a country of hills and woods is always favourable to the feathered creation. We seldom consider how much the face of nature is enlivened and made cheerful by their songs and varied movements; and to the lover of natural scenery, the number and variety of its birds ought to render still more dear, his beloved country.

It may safely, I think, be asserted that we have now, ten Rooks, for one in the olden time. Notwithstanding, as has been mentioned before, our pastures are sometimes sorely injured by grubs; yet to how much greater extent would the devastation reach, were it not for the numbers that must be destroyed by these useful birds ! In our fields, stones are pretty plentiful, and Rooks are in the habit of turning them over many times during the summer, for the sake of the slugs, worms, \&c., they may find underneath. It is from this practice, I think, that the short feathers near the root of the bill of the young Rook are worn off, for they are not found on that of the full grown bird. The farmer is often highly indignant when he sees some of his corn or potatoes destroyed, not being aware of the greater service rendered 
by the Rook, by keeping in check far more noxious enemies that would otherwise devastate all his crops.

The Rook being a bold, social bird, and much of his life passed in the sight of man, his habits have been well observed, so that I run great risk of useless repetition in mentioning any of his characteristics. I will just mention one I have been told of, curious enough. In a grove of trees constituting a rookery, only a few are occupied with nests; and of these, a single tree contains a number-never one tree with a single nest. There are trees quite contiguous, holding out the same convenience for nests; but they never contain one-being apparently tabooed, and kept sacred from any such vulgar purposes as nidification. If any luckless couple attempt to build in them, it is deemed a high crime or misdemeanour, and numbers soon assemble and scatter their work in the most pitiless manner.

Rooks, it is well known, live in communities, passing their whole lives in the society of each other. One might think they would somtimes grow too populous for individual comfort. However that may be, as communities, they seem averse to colonization. New commonwealths are not founded by numbers of both sexes, taking flight from the parent state, and settling down in some selected spot. No, it is some single expelled or dissatisfied couple-or at most two or three, that select a tree or grove, at no great distance, and there plant the germ of a new republic. An instance of this took place in my own neighbourhood last spring. A couple of Rooks-most likely from Hartbarrow, about a quarter of a mile distant-built their nest at the Hollins, in Cartmel-fell, in some fine oaks near the house. They were not molested by the farmer, who was rather pleased by the visit. But they had to sustain the most bitter attacks from their former fellow-citizens, as was supposed, who came in numbers, two or three times, and pulled down their work. But they built it up again, and their perseverance was rewarded as it deserved, for they brought 
out their young. And this is the foundation of a new rookery.

You see the Rooks have taken up the whole of this letter; therefore what I have to say further on birds must be reserved for another.

Yours, my dear Sir, very truly,

W. Pearson.

\section{Letter V.}

Border Side.

My DEAR SrR,-I have a few more particulars regarding the Rook, which it may be worth while to communicate.

Farmers in general are no friends to the Rook. This is not to be wondered at. The mischief he does is apparent enough; while his beneficial influence, being of the preventive kind, is seldom thought of, and, indeed,.could not be made evident without a somewhat hazardous experiment. But it is said, that, where they have been destroyed, or banished from a district, such has been the destruction of crops that has ensued, the farmers have soon found they had been persecuting their friends rather than enemies. Still, it must be confessed, the Rook will eat grain, though naturalists have asserted the contrary. Soon as the barley or wheat shoots up its first tender blade through the soil, the Rook digs down to the soft germinating grain, which no doubt he finds quite a bonne bouche. A short time before the harrest, he is still more mischievous. Many of our mountain ficlds contain rocky, barren, waste places, which cannot be touched with the plough-these afford him easy access to the margin of the ripening grain, which he treads down and strips off its ears. Nor is it easy to prevent this, though the mortified farmer uses many contrivances, such as bent sticks, to persuade him they are springes, lines of thread drawn out, \&c. But he soon finds them all to be shams, and goes on with his plunder. The newest contrivance I have noticed as a scare-crow, is an empty barrel, with one end open, and 
placed horizontally along the ground. If this answers its purpose, it must be, that, as the Rook is extremely jealous of surprise, he thinks there is a concealed enemy lurking within it. I have not mentioned that he is a great pest to the potato grounds, pulling up the sets as soon as the stems appear, and afterwards devouring the young tubers as soon as they are formed, and he is able to reach them.

It is said that Rooks, for two or three months in the middle of winter, forsake the rookery, and seek a more sheltered roosting-place in the depth of woods, sometimes at a great distance from their usual haunts. The whole of the Rooks in our valley, repair to Dallam Tower. They may be seen in immense numbers any evening in mid-winter flying over Lythe Marsh in that direction. This does not prevent them, however, from repairing next morning to their usual feeding grounds.

There are persons who prognosticate the weather, a fine or a wet day, according as the Rooks are seen to fly abroad, or not, in the morning. This, I suspect, is in a great degree fallacious; for I have often seen them feeding on wet days, and flying and sallying up and down in the air, when the wird has been high, and amidst a beating rain, evidently with no little enjoyment.

Much as the Rooks multiply in our valley, there is a good deal done to keep them under. Towards the end of May or beginning of June, as soon as the young ones leave the nest and can fly a little, a day is set, and a number of sportsmen invited for the purpose of placing a salutary check on the increase of population. Great is the noise, and great the consumption of gunpowder; and at the close of the day, when the slain are numbered, they generally amount to many dozens. The greater part of them are sent round to the neighbouring farmers as presents, and for a day or two, that savoury dish, named Rook-pie, is common as blackberries. Notwithstanding all this destruction, however, there are many that escape, and the Rooks are still a 
thriving community; and I think I may safely assert, increasing in population, not quite so quickly, perhaps, as the United States, but quite as rapidly as is compatible with the well-being of their neighbours.

But these ardent Rook-shooters are sometimes forestalled, and sadly disappointed of their sport. Bands of marauders from the cotton-spinning village of Backbarrow, or from the good town of Kendal, will descend about midnight into our quiet valley, and, when the unsuspecting inhabitants are asleep, will assail the Rook-cities, climb the trees, and seize the young in the nests, not full-fledged, and unable to fly. The robbers, however, do not always escape with impunity. A few seasons ago, a party were busy at their work in Cartmel-fell, when three stout men sallied from the house, put some of them to flight-all of them, indeed, but one poor devil whom they caught in a tree, and kept prisoner till morning. And not long since, a band of depredators from Kendal robbed in this way one of our largest rookeries in Crosthwaite. They secured a heavy booty, and 'got off without being disturbed. But the owner was not a person to sit down in quiet submission under his loss. Luckily, he obtained some clue to the thieves, traced them out, and procured a warrant for their apprehension. They were brought before a magistrate, the proof was clear of their guilt. But here, alas! a difficulty occurred. Under what statute should they be convicted? There was an assiduous rummaging of the "Statutes at large." The grave magistrate and his sagacious clerk did all that mortals could do to command success, yet, it must be confessed, all in vain. For although the statutes are in number almost numberless, none could be found, not one, relating to Rooks, or their abduction. They were not property-they were not game-alack-a-day, they were only vermin! That a robbery had been committed was plain enough. The culprits themselves confessed as much, by coming in the night. But how to punish them, when our legislators had 
neglected to provide a law? Yet they were punished, but I forget how. It could not be much, however; for there was no way for it, but to swear to the breaking of some twig-highly valued at sixpence! Now is not this a sad state of things? It is clear that Rooks have no protection! Is this to continue?. Let the legislature look to it.

I am, my dear Sir, very truly yours, W. Pearison.

\section{LETTER VI.}

\section{Border Side, 6th October, 1849.}

MY DEAR SiR,-You require information about the Ringdove and Wryneck. I will copy a memorandum regarding the former, I made last spring. "I have a small larch plantation of some twelve or fifteen years' growth. Low down, on one of its trees, a Ringdove, or Cushat, has hung 'its procreant cradle,' and in it, deposited a single white egg. The usual number is two, but she has one only." I thought she had been sitting, as I had flushed her once or twice off her nest; but she afterwards laid another. Both, however, were taken away in a short time after. You know what a poor flat concern of a nest she constructs-a few sticks laid horizontally-through which one may see the eggs. The Cushat, or Ringdove, is often named the Stockdove; but it is a different bird, and much larger, indeed it is the largest of all the pigeons. I think it stays with us all the year; but I will make further inquiry. Its cooing note, which one hears during mild weather in spring, is very pleasing. One evening about dusk, I noticed one of these doves flying with rapid wing towards the before-named plantation. I could not but believe, that it was the male bird returning to his mate, to roost at her side. We all know, that, time out of mind, these birds have been the very symbols of love and constancy.

In regard to the Wryneck, I am sorry not to have heard its note for two or three seasons. It is a bird of shy and 
retired habits, and seldom seen. Indeed, one would never be aware of its "whereabout" if it held its tongue. By the by, its local name with us is "lang tongue." I think some of our migrators don't return constantly to the same locality. In some seasons we have a few Corn-crakes in our valley; at other times not one. It may, however, be almost always heard during the season, in the neighbourhood of Crosthwaite Church.

You know how much I have lamented the disappearance from our district, of some of our largest and most splendid birds, viz., the Cormorant, from lake Windermere, the Buzzard, but, above all, the Glead. The Buzzard was pretty common with us not long ago, but I have not seen one in our valley for two or three years back. His habits were well known-his sitting motionless on the stump of a tree, or pointed rock, for an hour together. This was his season of thought and meditation. But presently he would rouse himself, and soar into the welkin, wheeling round and round, uttering his shrill whistle or melancholy wail. The last I have seen was a pair in Wythburn, three or four years ago. The Raven has, also, almost disappeared from our part. Formerly he might have been seen or heard almost any day, flying high over head, sounding his solemn cronk, as he passed from the high mountains to Whitbarrow Scar.

Mr. Wordsworth, in his prose description of the Lakes,* says, that Eagles formerly built in a precipice overlooking one of the tarns in the recesses of Helvellyn; and that they used to wheel and hover over the head of the solitary

* It is in a note to the 17 th Sonnet on the Duddon, that Mr. Wordsworth makes mention of the Eagle. This slight lapse of memory is easily accounted for. When the Sonnet first appeared in 1820 , it was in a volume entitled, "The River Duddon, a Series of Sonnets" (which Dr. Wordsworth, in his Memoir, appears not to have known; it is without the dedicatory verses). Appended to that volume is the "Topographical Description of the Lakes," which had hitherto been only made public as introluetory to some views of the Lakes, hy the Rer. Joseph WVilkinson; an expensive work. 
angler.* My recollections are not quite so sublime. But I have seen the Glead and his beautiful flight. No words, I think, can adequately describe it. It was on windy days in autumn or winter, that he generally made his appearance. Imagine a bird measuring five feet betwixt the tips of his wings! To glide along, it required, apparently, no mechanical effort, no fluttering of the wings, not the tremor of a feather. It was not flying, but sailing on the bosom of the air, as if by an effort of the will. Such ease, such grace, such dignity! Man can form no higher conception of the motion of superior angelic beings. And we are deprived of such beautiful ornaments to our scenery by the vulgar lust of game preserving. I could mention the name of a house where three Buzzards, caught in rat-traps, were seen at one time lying dead! Was it worth while to remove such noble birds from our district, in order that a few more partridges and chickens should be reared? Oh, this everlasting catering for the stomach! Has man no nobler faculties to be cherished? It seems to me, that never does utilitarianism put on a meaner face, than in these matters.

It would seem that the Glead is now seldom met with in any part of England. It has, I think, entirely disappeared from the Lake district. Yet my old neighbour, Isaac Walker, remembers that, in his youth, a pair built yearly in some lofty trees near the Ferry House, Windermere. May I just mention, that I had not seen one for more than thirty years: when entering Switzerland, near Schaffhausen, on the outside of the diligence, there was one came sailing along, as if to bid us welcome into that wild and picturesque country.

I am glad that I can conclude this letter with the mention of two or three species of birds that have lately made their appearance, as if, in some degree, to recompense us for our

* In a letter to William (written in 1811), from the late Mr. Preston, of Spring Cottage, Rydal, he says, speaking of Great Gable, "Two years ago a large Eagle was shot there, which I have seen." 
serious losses. We have a few Pheasants, but as they are generally stragglers from some preserve, and are soon picked up by the wandering sportsmen, we can hardly reckon them as a permanent acquisition. Starlings I have already spoken of, and as they are no great prize for the sportsman's bag, they will probably remain with us. But the most remarkable circumstance relating to the birds of this district, is the appearance, within these two or three years back, of a number of Black, or Wood Grouse. They have already spread to some distance. I have heard of them at Blakeholm, on the east side of Windermere, in Whitbarrow woods, in a larch plantation called Cock Hag, lying betwixt Crosthwaite and Underbarrow. And last spring, the cocks were heard crowing lustily in the mornings, in the large plantation at Lamb How, belonging to Mr. Edw. Wakefield. They have had broods for two or three seasons. This summer I noted traces of them on the naked part of Whitbarrow, in the sheep-tracks-feathers and droppings. Sportsmen, I understand, when they come within shotrange, which is not often, generally respect them, and refrain from firing. But they are wild and wary in their habits, and know how to take care of themselves. They fly high, stretching out their necks like a duck. Sometimes when they are flushed, they will approach the sportsman, as if to look at him, keeping at a safe distance nevertheless. This prudent quality of theirs, conjoined with the woody, rugged nature of the country (the woods have increased much of late years), is well adapted to their breeding and preservation. So that I think there is a well-grounded hope, that they will form a permanent addition and ornament to the ornithology of the district.

I know not whether you have heard that a couple of Woodcocks, two or three seasons ago, stayed all the summer near 'T'ower Wood, in Cartmell-fell, and hatched and reared their young. They and their young brood, four or five, were frequently seen during the spring and summer. 
The mention of the Woodcock brings to mind a singular occurrence relating to this bird, that happened at Collin Field, in Cartmel-fell. One day last winter, the farmer sitting in the kitchen with the door open, was startled by a Woodcock flying in, and resting on the floor. Had he had presence of mind to have closed the door, he might have made it a captive. But before he could do this, it flew out as quickly as it had entered. It had most likely been pursued by a Hawk, and, as the less of two evils, had sought refuge with man. Birds, I believe, not unfrequently seek the protection of man in this danger. And I have heard of foxes seeking the shelter of a building in a farmstead, when pursued by the hounds, but not often with the same lucky escape.

I think Quails do not visit our district; at least, I have not heard of them. But I remember, many years ago, there used to be a few found in the neighbourhood of Manchester. -I remain, my dear Sir,

Very sincerely yours, W. Pearson.

\section{The Fisherman,}

a character.

There is a certain secluded, pastoral valley, dividing Westmorland on a part of its western confines from its neighbour, North Lancashire. It is intersected through its whole length, of ten or twelve miles, by that pretty little trout-stream, the Winster, from its source near Bowness, to its termination below Castle Head, where it is absorbed by the great watery reservoir of Morecambe Bay. It is not our business, however, at present, to describe this obscure vale-its sweet natural woods, clothing the gigantic side of Cartmel-fell-with its green meadows and sloping fields, its simple farmhouses planted in all kinds of snug corners. 
We will leave it, like modest merit, in its own blessed retirement. It is mentioned in no Guide Book.

"The tourists know it not; it will remain Unknown to them; but it is beautiful,"

and is endeared to us by a thousand recollections. We have known it from a boy. Many a time, from joyous youth, up to sober age, have we rambled by that sweet stream, and plied " the angler's solitary trade," ensnaring the crimson-spotted, golden-sided Trout; but we must not be tempted to dwell on these charming reminiscences. Our present object is an attempt to describe a somewhat singular character, whom we met with lately on a morning walk, along the road that skirts the aforesaid stream.

We had stayed our steps as usual to contemplate, with ever new delight, the features of the valley, when we observed, moving down the stream, from just opposite to where we stood, a certain individual, who, though not strictly an angler, may be denominated a fisher of the first magnitude. We had not seen him till he moved, but he had seen us, and shifted his position about one hundred yards down the brook, by the side of which he again planted himself. We have known him long, but not intimately, for he is of shy habits, and very chary of all familiar intercourse. We could not but admire his handsome, tall figure, as he stood on the bank of the stream, looking into it, "as if he had been conning a book." He was arrayed in his constant garb, a durable sort of dress, the colour of dingy white, or rather approaching to a pale blue. The cut, or fashion of this costume, he never changes, nor does he often renew it; not oftener, we believe, than once a year, when he gets a new suit.

Your angler is somewhat of an enthusiast, and pursues his gentle craft with an absorbing interest; but, then, it is only as a pastime, and at suitable seasons, when the weather is favourable, when the spring rains have raised the brooks, and 
dyed their waters with the precious ale-colour, and the wind breathes from the mild south-and yet, after all, alas! how often does he return with an empty pannier. How different with our hero! His sport depends not on the fickle seasons, at least he pursues it in all weathers; in the bright sunshine, or when the face of heaven is overhung with clouds; in the hot days of summer, or when the wind blows from the biting north, and the ponds and streams are bound over with plates of ice; he is still at his work, fishing-evermore fishing! Indeed, it must be confessed his very living depends upon it. How often have we pitied him in winterin a severe winter. It is hard to live upon nothing but fish, and, moreover, to have to catch them before you can dine! It is hard, indeed, to be confined to one dish, and to have no other resource, for, if that fail, where are you? It is like the Irishman with his potato-when that rots, there is famine. But it has been hinted that our friend is not entirely confined to fish, and that he can occasionally eke out his scanty repast with frogs. We shall not deny it. It is probable enough. It is consoling, even to have such a resource. In this he but resembles the Frenchman.

We have said that the angler is an enthusiast, much carried away by his imagination. We have known two or three of this gentle tribe, buoyed up with the hope of sport, set off from our part of the country-walk all the way to Borrow Bridge, to try the waters of the silvery Lune, and return the same night-after fishing all day-a distance of forty miles; but, perhaps, not much encumbered by heavy panniers. But if the disciple of Walton is patient and persevering, and takes long rambles in pursuit of his pleasures, we think he is exceeded in every respect, by the subject of our description. We believe there is not a tarn or lake, still water with sedgy shore, or running brook with sandy bottom, or even dyke or ditch within a radius of ten miles from his home, that is not well-known to him, and in which he has not pursued his solitary sport. 
We have been somewhat puzzled whether to class him as gentleman or poacher, for he partakes of the character of both-a kind of hybrid betwixt the two. He resembles the gentleman in not selling his game, nor, after serving his own needs, does he dispose of it in any other way, except feeding his children, when he happens to have any, and then only while they are of tender age, for they are soon turned out of the parental shelter, and compelled to seek their own living in the world at large, like himself, by fishing. So has it been with his progenitors, so will it be with his posterity till the end of time. As in the East with the Hindoos, and in a degree with other wanderers like himself, as gipsies and potters, his family seem not to have got beyond the system of castes, which, it must be allowed, shows but a low degree of civilization. But still, as he sells not his fish, nor stoops to any kind of vulgar labour, so far, we must rank him as a gentleman. On the other hand, however, as he cannot be called the owner of a single rood of land or water, and yet presumes to sport wherever it suits him, on the property of gentle or simple, yeoman or squire, without condescending to ask leave of any man, we fear, therefore, as far as this goes, we must consider him a poacher. Moreover, like too many of that lawless profession, he is wretchedly poor, and laying up nothing for a wet day, he must be often, as we hinted before, sorely beset with his wants. There is something in his look that makes this but too probable-the same lank, meagre figure, he always was. Let the season be ever so genial-fish ever so plentiful-it makes no difference in his personal appearance; he is as thin and spare as ever, with scarcely an ounce of flesh on his bones. He is emphatically one of Pharaoh's lean kine - seems far gone in a consumption-almost like the frightful figure of death in the old pictures. It was this lean and haggard appearance, that led a fanciful French naturalist to describe him as the very type of misery and famine. We suspect, however, that M. Buffon was a little out here, 
and that our hero has more pleasure in life than he was aware of. His patient and persevering efforts must procure him many a savory meal, and though they do not fatten his ribs, they at least keep him in good working, or rather, sporting order. We trust he will long remain so, and continue to enliven our valley with his presence. Poacher though he be, we respect him for his love of freedom and independence-of nature and of fishing. We are certain, however fortune may frown upon him, to whatever straits he may be reduced for a living, that rather than seek shelter in a union workhouse, he would die of famine.

We have said nothing of his method of fishing. How various are the arts by which cunning man contrives to circumvent the finny tribe? With all deference to honest Isaak, it must be allowed, that the whole art of angling is based upon deceit and imposture. Therefore our sportsman rejects it, we suppose, on that account. And then, as to the use of nets, it has, doubtless, been copied from the villanous spider, who weaves a web from his own bowels, and hangs it before the door of his lair, in which he lurks, ready to pounce upon the unwary victim entangled in its meshes. He will have none of this. Nor does he adopt the more simple and straightforward scheme of the schoolboy and otter, by dragiging his speckled prey from under the banks and braes of the populous brooks. No; he has a method of his own. Armed with a single spear-shaped weapon, of about six inches in length-woe to the unhappy Trout or Eel that comes within its range. It is transfixed with the speed of lightning.

There is no history of an individual from which a moral lesson may not be drawn. Then why not from the character of our hero? In a poem of Wordsworth's, a fit of despondency is said to have been removed, by the patient and cheerful bearing of an old man, whom the poet met with on the lonely moors, gathering leeches. We have sometimes amused ourselves in running a parallel betwixt the 
character we have attempted to describe and the brave old Scotsman of the poet. There is no slight resemblance. Both silent and solitary in their habits. Both models of patience and perseverance, and of contentment with the calling allotted by Heaven. Both wanderers, both haunters of ponds and moors;

"From pond to pond he roamed, from moor to moor."

Yes, and on much the same errand, too, for we believe our hero could gather leeches upon occasion. Indeed, we durst back him for a trifle (were we in the habit of laying wagers) against the old man, both for quickness and tact in that employment. We have, however, no wish that the poet had substituted our hero for his, in that noble poem, for we would not alter a line or a word of it. We only beg that our Fisher may be placed side by side, as a teacher of "Resolution and Independence," with that immortal leechgatherer.

Our paper has reached a greater length than we had intended, and yet we have touched only on the character of an individual. Perhaps, we may be pardoned a few words more on the tribe to which he belongs. Like that of the gipsies and other nomadic races, its origin is involved in much obscurity. The probability is, that it came from the East; but of its first introduction into Europe, we believe history is silent, and the most learned are at a loss on so mysterious a subject. We think, however, it is pretty certain that this wandering tribe had spread widely, was perhaps more numerous than at present, before the barbarians from the North had overrun the Roman empire. Nay, if we might hazard a conjecture, it is so ancient that it dates even from beyond the Pyramids. Not, however, to indulge in useless disquisition, but to confine ourselves strictly to the historic period, we find abundant evidence that it was firmly established in our island during the middle ages, and held in much higher respect than 
it is at present. Not only were individuals of the tribe often present with the Baron in his field sports-especially that of hawking-but not seldom, in that ancient pastime, played a very active part. A still stronger proof of the regard in which they were then held was, that when the lordly Baron entertained his numerous followers on grand feast-days, the dinner would have been thought very incomplete, had they not been present, and then, not at the lower end of the long table among the poor retainers, but at the upper part, with the most honoured guests.

Like the Jews, the people we speak of, live in little knots and communities, but not, like them, confined to some dirty quarter of a city, where they can practise their moneymaking arts. On the contrary, our purer race avoid all towns-nay, like the Arab of the Desert, view them with unmingled fear and horror. Never is there one seen there, unless it be some poor captive, pining away his life for want of fresh air and freedom.

We profess not, however, to write the history of the tribe. Suffice it, that we glance at one event which has been chronicled by the local historian, and which occurred somewhat more than half a century ago. Historians, it has been remarked, fill their pages with little more than details of wars and conquests. We are sorry our episode partakes of the same character. Our fishermen had long occupied a certain territory, living in harmony with, and, as they naturally supposed, giving no offence to their neighbours. But on an ill-fated day, their ancient* settlement was attacked without notice, and with such violence, their houses being literally pulled down over their heads, that many of the junior members of the community perished in the ruins. Ejected somewhat in the style of an Irish eviction, they sought an asylum near their old neighbours, where

* We need hardly remind the naturalist, that our authority for the last-mentioned incident is the late Dr. Heysham, of Carlisle, and that it occurred at Dallam Tower, near Milnthorpe, in the spring of 1775 . 
there was room, more than enough, for both parties, and where they might have lived peaceably together, had there been a proper Christian disposition existing. This had, indeed, been the case in prosperous times; but "misery makes a man acquainted with strange bedfellows," as will appear in the sequel. It should be mentioned that the tribe near whom our exiles sought shelter in their calamity, are a swarthy, dark-hued race, by no means of respectable character; indeed, they lead a kind of vagabond life to this day, living by plunder wherever they can pick it up-even the farmer's grain in the fields, is not at all safe from their depredations. But lax as are their notions of the relation of meum and tuum, and regardless as they are of the property of others, it seemed, in this case, they were very tenacious of what they regarded as their own. For hardly had our poor piscatory friends settled down in their new quarters, before they were attacked with the greatest fury, and the habitations which they had begun to erect, pulled down, and the materials scattered to the winds. It could hardly be expected that the whites would endure, quietly, this treatment from the blacks, and submit tamely to a second ejectment. So far from it, they stood up manfully for what they deemed their rights, and the consequence was, that a most obstinate contest took place, which was carried on with various success, during the spring and the ensuing summer. We have not been able to obtain an exact account of killed and wounded, as no returns were made that we ever heard of, but they were pretty numerous on both sides. The opposing armies were, indeed, more equally matched than might be supposed, for, although the blacks are a diminutive race when compared to the whites, not, indeed, half the size of their stately opponents, yet what was wanting to them in individual prowess, was more than made up by overwhelming numbers, for they certainly outnumbered the exiles by ten to one-a great odds in any war. But, notwithstanding this, such were the indomitable courage 
and obstinacy of our fishermen, and such was the effective use they made of that formidable weapon of theirs, the pike, that they kept possession of their new domain, against every effort of the blacks to expel them. We will only mention, that the latter renewed the contest in the following spring, and another campaign was fought; but we need hardly add, with the same result as before, our dear piscatory friends coming off finally victorious. We suppose a lasting peace was eventually concluded, for from that day to this, the former belligerent parties have lived in amicable neighbourhood. May such be the end of all wars!

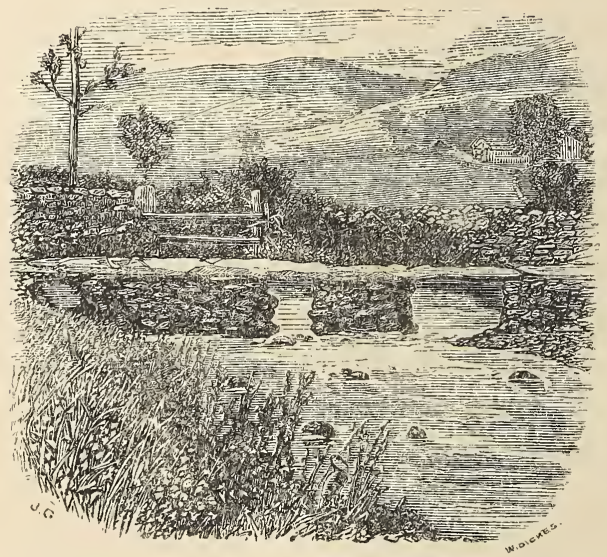

FOOT-BRIDG Q TO THE WOOD. 
A FEIV NOTES IN NATURAL HISTORY; WITH SKETCHES OF THE CHARACTER AND HABITS OF DOMESTICATED ANIMALS.

\section{Read before the Kendal Natural History Society, at Kendal, March 10, 1854.}

\section{INTRODUCTION.}

THE human inhabitants of this planet are estimated at about 1,000 millions, and it may, I think, be safely affirmed, that there are no two of them exactly alike in outward conformation, or internal character. Even in regard to mere colour, what a gradation of shade from the black Australian, Papuan, or African Negro, till you reach the white European. But in what constitutes the intellectual and moral character of individuals, the variety must be still more extensive and remarkable.

But if we descend lower, to animals below us in the scale of creation, the assertion may be considered somewhat more hazardous, that every individual of the same species differs from its fellow, as well in outward as inward character. Yet such is the astonishing variety and diversity of Nature, that the more closely we examine the subject, the more, perhaps, shall we be convinced that this is highly probable. I will mention one or two facts that seem to support this view. To a common observer, the sheep in a flock appear so like each other, that he can perceive no difference; and yet it is clear there is one, or how could the shepherd, who has to look after two or three hundred, be able to distinguish each individual, as I have been told is the case? Even the wild animals of the forest, seem to have their difference of character. Every one will remember the delightful account given by the Poet Cowper of the three 
Hares, which his neighbour sent him when they were Leverets, to tame and bring up, that they might amuse his mind, when in that state of lamentable depression that he could neither read nor write. The kind offer succeeded admirably. I need only add, that his Puss, Tiny, and Bess, when grown up, turned out different in character. Tiny he could not tame at all; the other two were interesting and playful pets. He used to have them into the parlour after supper, to play their tricks and gambols on the carpet, and the amiable Poet thought, if the sportsman knew what innocent playful creatures he persecuted, it would go far to wean him from his cruel amusement.

In a few Papers which I had the honour and pleasure of reading to this Society some years ago, on the habits of the wild animals of our district, they could only be described as they differ from each other as species; but in domestic animals, we can observe more closely, the peculiarities of individuals.

Of all the creatures that have been domesticated, none appears to have been more changed from his original character, than the Dog, both in person and habits. He seems to have been made the companion of man, long anterior to historic record. But so little is known of the origin of this most interesting and intelligent of our domesticated animals, that some naturalists think that he is descended from the Wolf; and others, with more probability, from the Wild Dog, which still exists, we are told, in the East Indies and in South America.

Some two or three years ago, I had intended to treat the subject of this Paper, in a few letters to my friend Mr. Gough; but just after I had begun, I was prevented from carrying it out; which I now regret, as the task would have been better managed at that time, than I fear I shall be able to accomplish it at present. I shall give, however, with your permission, three letters I wrote at that time, and add to them from the suggestions of memory. I fear some 
of my details may appear rather trivial, to those of my hearers who do not take a warm interest in matters of Natural History; but I can say with confidence, that whatever I state, I believe to be true, being either what I have observed myself, or have received from persons I considered worthy of belief.

Truth should doubtless be rigidly adhered to in Natural History, as in all science.

\section{To Mr. Gough.}

\section{Border Side, 19th June, 1854.}

MY DEAR Sir,-A little circumstance took place here a few mornings ago, which I cannot account for; I hope you will not think it too trivial to be made acquainted with, and thereby help me to a solution.

A couple of House Sparrows have had a nest in a hole of the wall in the south gable of our house, for a few years back, high up, under the overhanging roof. They generally manage, I believe, to rear two or three broods out of this single nest, yearly. One morning, an unfledged nestling was found dead on the gravel below; and next morning, three more-making up probably the whole number of young. Now the question is, why was this wholesale ejection made, and by what creature, quadruped or biped, was it effected? No Cat could reach the nest from the outside; and if a Rat could have made its way along the inside of the wall, it would not have been satisfied with turning out the inmates: it would have devoured them. I am, however, of opinion that this cruel ejectment was perpetrated by birds-but by what birds? and from what motive? We know no bird that is guilty of this wickedness but the young Cuckoo, and he is impelled to turn out the rightful tenants by the powerful influence of selfinterest. But he could not, in this instance, have been the agent, for no Cuckoo would have been able to drop its egg in the nest. Still, I am convinced that the 
nefarious actors were of the feathered creation; for, on the morning mentioned, quite early, I witnessed a great commotion; such moving of wings across the windows of my bedroom as I could not account for. I have now, no doubt that the tragedy was at that time being enacted, and that those flittings to and fro, were caused by the attacks of the wicked aggressors, conjoined with the efforts of the agonized parents, to prevent "the massacre of the innocents."

I remain, my dear Sir, truly yours,

W. Pearion.

To Mr. Gough.

Border Side, 25th June, 1854.

Mr DEAR Sir,-As I am not tempted into the open air this gloomy, wet morning, you will pardon me, although I wrote to you so recently, if I again trouble you with some remarks on subjects connected with Natural History.

I know not whether it is worth mentioning, that one of our two pairs of Starlings has still a brood in the nest, late as it is. The first hatch have flown several weeks ago.

There is a tarn situated about the middle of Crosthwaite, that gives a name to two or three adjoining farms, viz., Tarn Side. This piece of water is covered with reeds three or four feet high, excepting, however, a margin of clear water a few yards broad, all round. A couple of Water-hens have occupied it, at least during the breeding season, for a few years back. The oddity is, that a bird so shy and retired in its general habits, should make choice of so public a situation, where it is so much exposed to the gaze of man ; for a turnpike road winds round three sides of the tarn, and there is a smithy within twenty yards, from which the noise of hammers may be heard every hour of the day. But they seem reconciled to all these disturbances, and have become as tame almost, as their companions, the Ducks. Indeed, one can seldom pass without seeing one of the old birds swimming outside the reeds, with a 
dark-coloured chicken or two in its wake, though both mother and young soon dart away to their reedy shelter. I am told they brought out a brood of half-a-dozen this season. The neighbours, I am glad to say, protect them, being pleased, I suppose, by the confidence evinced by the poor birds, and liking to watch their manouvres-the destructive instinct being for once suspended.

Before I proceed to describe the character and habits of certain domestic, or tame animals, which I myself have kept at one time of my life, I will mention an anecdote or two of Dogs-those affectionate, sagacious creatures, of whom almost every one has something to relate. My informant is a public lecturer on temperance and good morals, and was told these anecdotes on one of his recent journeys. I do not doubt their accuracy, in the main.

Miss Wedgewood, a branch of the family so well known for their ingenuity and benevolence, attended a temperance meeting not long ago, at Market Drayton. She was accompanied by her butler, and by a handsome spotted Danish Dog, such as often attend gentlemen's carriages. Why she kept a butler, I know not, for Miss W. is Teetotal; he had probably belonged to her, in her unreformed days, and she, as a good-natured person, shrunk from the pain of discharging him. The people of Market Drayton are not the politest in the world, and very few of them, I fear, teetotallers; so that, so far from "hearing the word gladly"-I mean the teetotal lecture-they received it with shouts of derision; in short, it was a most uproarious meeting, not at all agreeable to the butler and his canine companion. Nor was this the worst, for when they retired to the inn, on their way home, some of the rudest of the mob followed, in order to treat them with a farewell shout! Notwithstanding all this, nobody was aware how much this conduct had affected the feelings of the sensitive Dog, till the next time Miss W. was driven to the town, and he set out to travel with his kind mistress, as usual. When the 
carriage had reached the cross lane which led from the main road to Market Drayton, nothing could induce him to go further, nor did he ever afterwards, it is said, enter the town.

The other Dog of which I have to speak (I regret I did not ascertain his particular kind), belonged to a young lady, was a great favourite, and of course not a little petted. He had the softest of cushions to repose on, was fed with the daintiest of tit-bits, and the kindest words and caresses were lavished upon him, when his mistress was not otherwise engaged. Doubtless he thought himself a lucky Dog, and reckoned on the endurance of such ardent affection. But, alas! neither dogs nor men know what the future has in store for them. In process of time, the young lady got married. This, of course, produced some abatement of attention to her canine favourite, but not much-he was still petted. If there were a change, he bore it patientlyhe made no complaint. But a worse thing came upon him. His kind patroness disappeared from the parlour, and took up her abode in the upper rooms of the house. An unwonted bustle was going on-much running to and fro. Every female, from the scullion wench to the lady's-maid, put on a face of importance and mystery. The poor Dog could not tell what to make of it: he had no faculty to solve the enigma. He only knew he was neglected, and received no savoury morsels or caresses as heretofore. But in due time his mistress came down stairs; now, he probably thought his troubles were at an end. Lack-a-day! they were only beginning. The changed lady carried in her arms a kind of bundle, or wrappage, that appeared to enclose a tiny, living creature, on which she bestowed her fondest words, and from which she could hardly withdraw her eyes! The Dog saw how it was: he felt he was superseded-supplanted-and by that wee, miserable object, that seemed scarcely half-alive! Could mortal Dog have patience or virtue to endure this? He was unhappy, and 
showed it by his gloomy, discontented looks. Still the fondling went on from day to day in his presence, till on one occasion, being more ardently manifested than usual, he could bear it no longer (so goes the story), when, rising on his hind legs, and stretching up towards the innocent cause of his misery, he uttered a savage bark of indignation and jealousy, and made a snap at it! After such an outrage, one need hardly say he was turned out of doors, and from that day, he was no more seen by any of the household!

I had written the foregoing when, last evening, I was gratified by the receipt of your copious and interesting epistle. At present I can only thank you. Your remarks on the Heron's foot, and on his mode of fishing, are very interesting, and, as far as I know, original. His disappearance in the winter from your neighbourhood, is curious. What can become of him? I have hardly left myself room to say that I am ever,

My dear Sir, truly yours,

W. Pearson.

[The postscript is copied from another letter, written in 1839.]

P.S.-The following anecdote of the attachment and fidelity of a Dog, which I have lately become acquainted with, I think deserves recording:-

There is a Scotchwoman of the name of Jane Stirzaker, or Jinny Tysic, as she is commonly called, who travels with a basket about our neighbourhood. She owns a small Dog, that generally accornpanies her. A few years ago she had a young child, of which the Dog was very fond, and was in the habit of lying with it in its cradle. But it so happened that the child took an illness and died. Jinny was at the time living at Hawkshead, but her infant was buried at Staveley. From the mother's distress of mind at the time, little notice was taken of the Dog; but soon after the funeral it was found to be missing, nor could any tidings 
be heard of it for a fortnight. The mother passing through Staveley about that time, visited the churchyard where her infant was interred; when, behold, there was the little Dog lying in a hole which it had scratched upon the child's grave! It was in a most emaciated state, from hunger and privation. It had been seen occasionally, for some days, in the street of that village.

\section{To Mr. Gough.}

Border Side, 30th June, 1854.

MY DEAR SIR,-I think we must acquit all the birds you mention of turning out the young Sparrows-even the Martens, the most likely of any-for this conclusive reason, that we have none at Border Side. We have two or three pairs of the common house Swallow every year; but they build about the farmhouse, and not near the Sparrows. Nor could it be the Starlings-for they and the Sparrows have been peaceable neighbours for several years, having nests within a few yards of each other. As an usurper of Martens' nests, the house Sparrow is an old offender. Gilbert White put them to death for the crime, in his day, as you will find he mentions in his 34th Letter. There is a note to that letter, in my edition of the "Selborne," by Capt. Brown, which I was quite happy to stumble on today, as it contains the apparently well-authenticated account of that grand confederacy of the Martens to punish the dishonest Sparrow, and, which, we had both of us forgotten where to look for.

In regard to this sagacious bird, I think I have an anecdote quite as good, and as well authenticated. The narrator was Jinny Hopkinson, a perfectly true, and much valued servant for many years, to one of my wife's sisters, at Bury. I will give it as committed to writing by Mrs. Pearson at the time:-

"At Tottington, a village near Bury, in Lancashire, during the spring of 1846, a pair of Swallows built their 
nest under the eaves of John Hopkinson's house, one of a row called the Wash-the height from the ground being about sixteen or seventeen feet. In due time the young were brought out, and tended by the parent birds. It happened, however, by some mischance, which neither John nor his wife could make out, that the nest was damaged, and Jinny found the young birds lying on the ground beneath. She took them up carefully, and after puzzling a little to devise a nest for them, she hit upon her son Adam's woollen cap. This she cut away to the proper size, and fastened it, as near as she could reach from the window, to their own nest. She and little Adam were delighted to observe the old birds during the day, feeding the fledglings; but great was the surprise of the family the next day, when not only the parent birds, but a company of six in all, set to work assiduously, to repair the injured nest. In less than a week the work was finished, and when Jinny and the lad made their morning observation, the cap was deserted-the young birds having been transferred to the now habitable nest. By what means the removal had been effected, they could only conjecture, but came to the conclusion that, one by one, the young ones had been taken on the back of the parent birds."

Is not this wonderful? Here there was a faculty at work, it would seem, higher than instinct. I know not how man, with his boasted reason and moral feeling, could have acted any better. I fear, many under similar circumstances would have fallen short of these teniler-hearted birds.

I need not say I shall be always glad to hear from you, whenever you find time to write. I expect sometime you will favour us with a biography of your pretty little S'guirrel.

I remain, my dear Sir, very truly yours,

W. Pearson.

The next Dog I shall mention, was one I possessed many 
years ago, when I was a keen sportsman; and if I am lucky enough to have a lover of field sports as one of my audience, he will sympathize with me, in my attempt to pay a slight tribute to his memory. His name was Blucher (the same as the fighting, Russian field-marshal), a black and white English Setter. He had belonged to a mechanic at Cartmel -an exile from Alston-Moor, from whence he had been driven, he and his Dog (it was suspected), by the prosecutions and persecutions of game preservers, for his poaching propensities. Not wishing to "buy the pig in the poke," I had the young Dog a short time on trial. But when I went again to finish the bargain, the owner, like the Sybil of old, doubled the price for him. I bought the Dog, notwithstanding, and never had reason to regret the purchase. He was, indeed, a Dog of rare excellence. His nose was so acute that no game could escape him, as his owner said in his vernacular, "they canna hide themselves frae him." Many times, early in the season, on the allotments among the tall brackens, or in the fields under the long potato tops (it was before the disease came), we used to lose him, but he was sure to be discovered set, steady as a rock, with a covey of Partridges before him; and there he would, I believe, have stood for hours, had he not been disturbed. It was likely that from so good a Dog we should wish to have a breed. But neither in shape, colour, nor character, did his progeny resemble him. It is said, that in such cases, some prototype of a grandfather, or a great-grandfather is reproduced. However that may be, the desired offspring was at length produced, and there are now descendants of his from Crook to Cartmel, that do not fall far short in their good qualities, from their great ancestor!

We have a Dog at present, called Nelly-a little black and tan Terrier; smooth-haired, prettily coloured and shaped, scarcely worth mention, were it not for some of its peculiarities. We happen, also, to possess two Ponies. Now it seems strange enough that Nelly, though kindly treated, 
feels more regard for the Ponies than for any Christian member of the family. I am one, who, in a walk, rather like a Dog for a companion. When I am setting out, Nelly will come leaping up about my heels, and showing great delight, as if at the thought of going with me on my trip. But it is all sham and make-belief! For when I have got upon the road about fifty or one hundred yards, and turn round to look for Nelly, she has slunk back, and is lying snugly in the house porch, basking idly in the sun.

But take a Pony for a ride or a drive, and then see the difference! Let one be brought to the door, and Nelly will spring up like a spirit from nobody knows where, and be ready to go with you to any distance, with the greatest delight. She will lie for hours, in the paddock beside the Ponies. Nelly has a snug kennel, is well fed, and is treated as kindly as any reasonable Dog could expect-excepting only, she is seldom allowed to enter the parlour. May not this account, in some degree, for her sympathy with Ponies? They also, are not permitted to be house-inmates-they are under the same interdict-she sees that, like herself, they are a non-privileged class; and, as such, may feel for them a more than common kindness. Nelly, notwithstanding this apparent heartlessness to human beings, is a great favourite with man, woman, and child, as well as with her own species. This, I sometimes think, is owing to a certain frank, easy assurance, if we must not call it impudence-for the Robin Redbreast is one of the most impudent of birds and yet the greatest of favourites. If you throw a few crumbs on a window-sill, he is the first comer to partake of them; if the door or window be left open, he is the first bird to enter. So, when we meet a group of children returning from school, Nelly will run forward to meet them, leap up to salute them as if she had known them for years, to their great delight-excepting the smaller fry-who fear she is going to bite them, and utter loud screams. A little 
impudence certainly goes a great way in helping on in the world, with bird, beast, and man himself.

As a proof of the estimation in which Nelly is held by individuals of her own species, I will relate an incident that occurred last summer. One fine morning, in company with Nelly, I took a ride down Witherslack. We had to pass through the hamlet of Bowland Bridge, close bywhere there is a pretty Isle of Skye Terrier, with long fawn-coloured hair, named March, being so called, because found on the road in that month, when a whelp. In passing through Bowland Bridge, March joined us, to the great delight of Nelly. The little Dogs were sometimes ahead, at other times scouring the fields, on one side or the other, but at all times going over more than double the length of the direct route. We pass through Pool Bank, and opposite, on the left, a cavern in the limestone rock, named Fairy Holes-and above it, on the edge of the steep scar, the Fairy Chapel-names interesting as relics of an extinct superstition. A little further, we enter Witherslack Park -not what might be expected from the name, but a forest covering a wide hollow between Whitbarrow and Yewbarrow, about a mile long, with large oak timber-trees scattered over it. Here my little Dogs have capital sport, chasing the Rabbits across the road and into the wood; alarming them a little, I believe, but nothing more; for without answering for his Skyeship, Nelly, I fancy, would not worry a mouse. On leaving the Park, reach Witherslack Hall, seated in a singularly picturesque and beautiful situation; but lonely as at its first settlement, for there is not another house within a mile of it. If the traveller wish to enjoy a grand prospect, let him go along a footpath in the direction of the Scar, through the wood, and slant across the "shirlings" (shingle), till he reach the foot of the stupendous overhanging cliff-then, looking south, he has the head of the Bay before him, Holm Island, Castle Head, the ever-widening sands (or water, if the tide be in), till 
the view fades away into the outline of the distant sea The present Hall is nothing but a modern-built farmhouse, perhaps, one hundred years old. One cannot but wish that the ancient mansion had remained, such as it was in the time of the Leyburnes, to whom it formerly belonged, but by whom it was forfeited, as well as Cunswick, in 1715, in consequence of the owner having joined an abortive attempt to replace the worthless family of the Stuarts on the throne of these realms. It belongs now to the Earl of Derby.

The extreme point of our journey is the Derby Arms Inn, which affords refreshment to man and horse. Here, I and my companions turn our steps homewards, taking the west side of Yerwbarrow, to diversify the scenery of our excursion, passing Halecat, snugly seated below us, on the leftsoon after, the two schools, the smart new Parsonage, and the ancient Church. I will not attempt any further description of the Winster Valley, though no pen has yet done it justice.

I will only say that we returned through Bowland Bridge, where the Skye Terrier has his home, but, although the distance we have travelled is twelve miles at the least, he stays not to rest, but accompanies Nelly half-a-mile further, to her own gate-the gallant little fellow!

The Dog is submissive and faithful, even to a brutal master; but the Cat will resent fiercely the most trifling ill-usage. Southey termed it "a democratic beast." Stroke and caress it, and it will purr with delight; but pull its whiskers, or pinch its tail, and it becomes a perfect vixen. Those soft velvet paws are transformed in an instant, into weapons armed with sharp talons, which will pierce to the bone. Yet naturalists have done it injustice, in saying that it loves places more than persons. Unlike the Dog, the Cat is but half-civilized, and, as a beast of prey, will procure half its subsistence. When kept by the farmer, to whom it is indispensable, it spends more than half its time in the 
barn, or other outhouses, or in the fields, creeping stealthily along by the side of a hedgerow; seated every now and then, to look about it, and spy out its prey, perhaps a bird, or a young rabbit or hare. I have seen a Cat cross the road before me, and quietly take a bird out of the hedge, the simple bird making no effort to escape, seeming to be overpowered with terror, or fascinated. In its field rambles, it travels on the tops of walls, or by the sides of hedges, probably in part that it may escape from stray Dogs, which it dreads, by running up a tree, which it can do with great facility by means of its long, sharp claws. I must now go back to the time when I was a farmer. The first Cat I remember anything remarkable about, was a Tom Cat, as we call them. He was given to me by a farmer, who allowed that he had one fault_-6 he was of a girt uphod," that is, he required a large supply of victuals. I thought we could manage that, as Becky, my housekeeper, was a good feeder. But we found it not so easy. The old farmhouse had an open chimney-a thing now almost obsolete. In front of this, stretched across a huge beam, which, in Wordsworth phrase, "overbrowed large space beneath," and behind which, hung hams and flitches of bacon, to dry in the smoke. The Cat, impelled by its voracious appetite, contrived to get up among the bacon, and scooped out large holes in the hams. This was a proceeding that could not be tolerated, so, being convicted of the offence, and as capital punishments were going out of fashion, he was sentenced to transportation. Being put into a bag, he was sent to within about a quarter of a mile of the farmhouse he had come from, under the hope that he would return to his old domicile. But he was not of that mind, and managed, by some unaccountable instinct, to make his way back again to Border Side, almost as soon as the messenger who had had the charge of him. The next time, he was taken on the same road, about two miles into Underbarrow, and here his instinct did not avail him, for he never returned. 
I will only mention another Cat, which was brought up by the housekeeper, and named Boaty: it grew up into a large, handsome Cat. Boaty was a male, or Tom, of beautiful white colour, excepting his tail, which was brindled. He was a Cat of respectable character, and went about his mousing and rat-catching in a creditable manner; yet there was one unfortunate drawback. He had contracted, or it had been born with him, a propensity to a vagabond life. He would disappear, and be absent, we knew not where, for a week or ten days at a time. He left home, plump, and in good condition, with a skin, white, sleek, and soft as satin; but when he returned, what a change! with a dingy, dirty coat, not smooth but lumpy, with the hair turned the wrong way; and so lean, shrunk, and wobegone, we could hardly know him: his ears and face scratched as if he had been in battle.

" How like a yonker, or a prodigal,

The scarfed bark puts from her native bay,

Hugg'd and embraced by the strumpet wind !

IIow like the prodigal does she return,

With over-weather'd ribs, and ragged sails,

Lean, rent, and beggar'd by the strumpet wind!"

The object of Boaty's vagabond excursions must be left, in some degree, to conjecture. They were perhaps, amatory, or predatory, or a mixture of the two. But if the latter, it certainly was not very successful, or he would have returned in better plight. I once came upon him very unexpectedly, when he was on the spree. I was fishing in the Winster, and met with him patiently sitting watching the hole of a Water Rat, in the banks overhanging the stream. Becky was a great lover of the lower animals-Cows, Pigs, and Poultry- " poor dumb creatures," as she tenderly called them; and as she held the commissariat department, it is not likely she would suffer them to want. (They were differently treated from our poor soldiers, in the Crimea.) Boaty, therefore, after his wars, was soon restored to his 
usual good condition.

"But Jeshuron waxed fat, and kicked." So sure as he grew sleek and fat, so sure was he to be off again. This was repeated many times with similar results. At last he went and never returned! He perished, I fear, in his sins!

I have not much to say of the Horse. I once kept a Mule-a handsome, sleek-coated animal, and an unwearied traveller. I rode it to Keswick and back, in one day-an unconscionable distance, more than fifty miles. However, it seemed not more fatigued when I reached home, than when I set out. I could not say that for myself. Having bought it of a cattle-dealer, who was no teetotaller, it had a wish to call at every public-house within ten miles round. Mules, like Pigs, are great sticklers for the rights of private judgment, and, if they were capable of religion, would be stiff Protestants.

Cows, upon the whole, are peaceable creatures, yet among themselves, they can be rather pugnacious. In every herd there is always what, by a metaphor, has been called a " master-beast." When two cows strive for mastership, they place themselves head to head, and the one that is strong enough to make the other give way, immediately attacks it in flank (a sure sign of defeat) with its sharp horns, but this is very prudently shunned by a hasty flight. A few contests of this kind, generally settle their quarrels, when, like boys at school, they know which is master. They have friendships with each other, as well as hatreds. We had two young Heifers much attached to each other. One of them had come home, with the other cattle, to be fastened up for the night, but when it should have been driven into the cowhouse, it missed its friend and would not enter, but galloped back to the pasture to seek it, when they soon returned lovingly together. We had a Calf which, from where it was kept, could see none of the Cows, excepting the one which lay next it in the Shippon, and of that one, could only view the horns and upper part of the 
head. But in the spring, when it was turned out into the pasture among the Cows, the poor Calf was observed to be always near the Cow, with which it had become so slightly acquainted.

I remember having a Cow that died just after giving birth to a Heifer-Calf; we had another Cow that was, what is termed, strip-milked, that is, yielding about half its usual quantity of milk. This Cow (a singular circumstance) would permit the motherless Calf to suck her; so, it being summer, they were turned into a field by themselves, and it was surprising how the Calf throve, became healthy and handsome-not by being favoured in breed, for its mother might have been classed with Pharoah's "lean and ill-favoured kine." The Calf, however, became excessively shy, and used to lurk in the hedge; and when one walked in the field, it suddenly rushed out, and galloped off with tail ercet, like a wild creature. I verily believe, had it been turned into one of the adjoining Wakefield-plantations, it would soon have become as wild as any primitive cattle that ever inhabited the island. As it was, it grew up into a comely and healthy Cow.

Cows have a strong feeling of local attachment. When a farmer purchases a Cow, brings it home, and places it in the pasture among the rest of his herd, it is the most disconsolate of creatures. It keeps alone, perhaps in a corner of the field; makes no effort to gain acquaintance, but utters the most piteous lowings; nor is it reconciled to its new home, till after many days.

In rural England, there are few pleasanter sights, than a herd of Cows enjoying their pasture in the fresh air and sumshine, and selecting their own food. How different in Germany-in the Phine-gau, for instance-where you may travel for miles, in that wide, fertile valley, uncheered by the sight of cattle; they are shut up, and seem to be joint sufferers with the people, from an unfeeling despotism. Cows like to be in groups, and when one sees a group of 
English cows chewing their cud, one might fancy they were ruminating on their happy lot, in having been born under the British Constitution !

I will conclude this notice of Cows, by naming a circumstance which shows their intelligence. The housekeeper, Becky-who, as I have said, was very fond of dumb creatures-when she was in the cowhouse attending to the calves, had a fondling way of talking to them, like a nurse to a child. This, doubtless, the cows had often heard. Becky happened, one day, to be in a small orchard we had in the fields; the cows were in an adjoining pasture, and, from fun, or by way of experiment, she began to talk in the fondling way she used to the calves, in the cowhouse. Presently, three or four of the Cows came up, and thrust their heads over the hedge, so eagerly (no doubt thinking there was a Calf), that she was afraid they would break through. Here is involved, if I mistake not, the great metaphysical doctrine of the "Association of Ideas," first enunciated by Hobbes-illustrated by Hume, Hartley, and others, and which forms the fundamental principle of Alison's " Essay on Taste"-which was acted upon by these horned metaphysicians! They hear the talk addressed to Calves-this suggests the idea of a Calf-they naturally conclude there is one present. How could they suspect their friend Becky of deceiving them? Becky had an aptitude for naming animals. Boaty, the white Tom Cat, had his name, I fancy, from being a fat, little lump of a kitten. There was a Calf called Kedge; another Clubby, because nature had given it a face about half the usual length. The young Pony was Nep, because it "nepped" or snapped at things. She would have pleased our first active Secretary, Mr. Nicholson, by confirming his theory about the naming of places; for although Becky knew nothing of theory, she always made her names descriptive-and original too.

It has been observed, that wild animals, in moments of pressing danger, will sometimes seek the protection of man; and it would seem somewhat analogous to this, that a domes- 
ticated animal, when alarmed by the approach of serious illness, will sometimes seek the aid of its keeper. I remember an affecting instance of this.

A valuable Cow, one day left the pasture and the rest of the Cows, when, the fold gate being open, she came suddenly before the window as we were seated at dinner. We immediately went out to see what was the matter. She appeared dreadfully ill ; almost choked-striving for breath; but, alas! we could render no assistance, and in a short time she fell down dead!

I will now conclude with a few words about that useful animal, the Pig-useful when he is dead. The Pig is not considered to stand very high in point of intellect, but I hope to show, that he has more sense than he generally has credit for. It must be confessed, he is thought to be more stupid and obstinate than any other domesticated quadruped. He certainly likes to have his own way, and is very headstrong. Hence the difficulty of getting him from place to place; or, in other words, of driving him. Pig-driving, though it cannot be termed one of the fine arts, is an art not easily acquired, from the creature's unfortunate propensity, as it has been said, "of running up all manner of streets." Sometimes, when it is wanted to change his locality, he is carted; but this method, if he have attained any size, is matter of much noise and no little difficulty; and then he must be placed under hatches, or tied down to good behaviour, or he will bolt. There is no putting bits in his mouth, and leading him about with a bridle, like a Horse; he is far too headstrong for that. But as this cannot be done, I have seen an ingenious method of getting him along, sometimes practised on our roads; which is, to fasten a strong cord to one of his hind legs, and so steer him from the stern, as a ship is guided by the helm. This, I believe, answers pretty well, for it allows him headway, which he likes above all things. It must be confessed, he is made of "opposition stuff." So convinced of this, was a driver I have heard of-quite an adept in the profession-that when- 
ever he came to a cross road, he made a pretence of driving in a contrary direction from that which he really wished to travel. The Pig of course opposed him, and he let it have its way, so both parties were pleased; the Pig thinking it had defeated its driver-while he knew that he had gained his purpose by superior tact and address.

Pigs, like many of the inferior animals, have an acute sense of smell. It is said that a gamekeeper once broke one in, for setting Partridges, and, if I mistake not, shot over it for a season or two. Behold, is it not printed in the book of "Daniels' Rural Sports," a work of some note in its day. We happened one winter to keep five Pigs. They were turned out occasionally, during the day, upon an allotment, or rough pasture, that lay contiguous to the house. Becky one day had occasion to go over this pasture, when the Pigs were upon it. They did not see her at first, but coming across her track, it was curious to observe how they hunted her out, through all the sinuosities and zig-zags of her route, as if they had been a pack of Beagles, till they overtook her. This was noticed by some hare hunters, standing on an adjoining hill, to their no little amusement. This allotment is bounded on one side by a public road, open to the pasture. Among other passers by it would sometimes happen there would be a woman; whenever this was the case, the whole little pack of Pigs would join her, and follow close at her heels, grunting out a low song of gratulation : it was their only music. She was surprised at this, but she did not need. The attention, I take it, in the dim apprehension of the poor Pigs, was because they viewed her as a reflection, or representation, of their friend Becky, their love for whom overflowed to the whole gentle sex to which she belonged. That this was the case, I think is proved by another circumstance. However many of the male portion of the human family passed along the road, the Pigs never paid the least attention to them.

It will, I fear, hardly be believed that the Pig has a sense of justice; perhaps, rather, of injustice, and, like some 
animals of infinitely more intellect and feeling, never feels injustice more acutely than when it trenches on its own interests. At our farmhouse there stood in the fold a large stone trough, a general receptacle for slops, scraps, and other kind of pig-provision. Whenever the Pigs were let out, it was the first place they visited. One morning, two of them had stationed themselves, one at each end of the trough, when the more powerful Pig began to encroach on the territory of the other. He had "seized on the principalities as a material guarantee," and was fast applying to his own use the whole contents of the trough. In this state of affairs, the weaker Pig thought it time to seek the aid of a higher power; so he straightway repaired to the kitchendoor, at no great distance, and as plainly as his mothertongue (or pig-language) could urge his claims, made known his griefs to Becky. She, perhaps, without fully understanding the complaint, knew that something wrong was going on, sallied out armed with a stout stick, when the expelled Pig, under her powerful intervention, resumed his first position at the trough, the overawed tyrant not daring again to interfere with the rights of his neighbour.

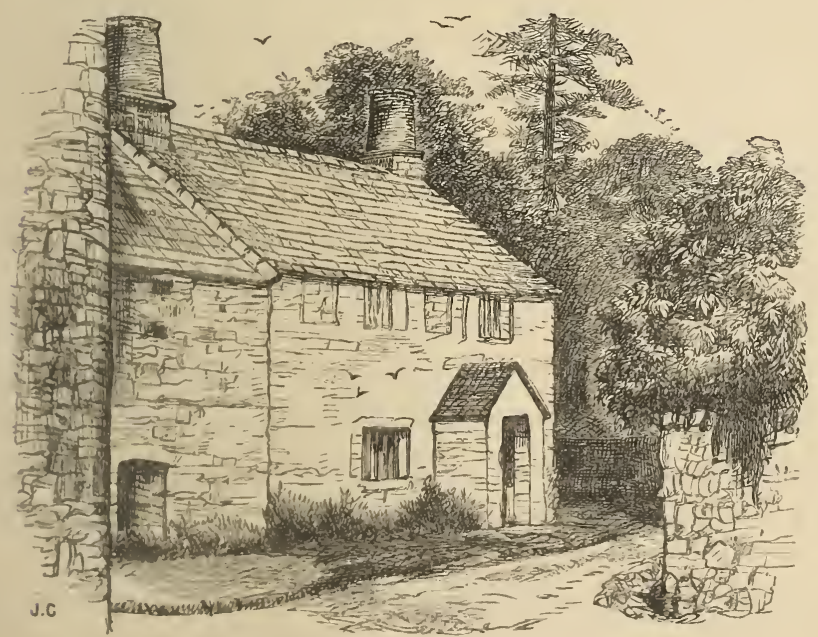

OLD FARMHOUSF, BORDER SIDE. 


\section{Letters to Mr. Thomas Gough, of Kendal.}

Winster, 15 th July, 1846.

Mr DEAR SIR,-It appears to me from what I have observed lately, that some of our birds, when placed in exactly the same circumstances, conduct themselves a good deal differently. Any one knows that if one come suddenly upon a brood of Partridges whilst they are young and unable to fly, the old birds will flutter along the ground as if lame and disabled, and this is considered a piece of parental cunning, to entice man or dog to pursue them, whilst their young ones run off, or hide themselves in the grass.

The day before yesterday, returning up the valley, through the field in which stands our pretty retired chapel,* I came suddenly on a family of young Partridges, and great indeed was the disturbance and uneasiness I occasioned. The old cock and hen ran backward and forward, hither and thither, on the grass, at some five or six yards distance, with their wings dragging on the ground (in this there was nothing remarkable), but at the same time they poured forth screams as if in the greatest distress. I looked round for the young, and saw two little creatures threading their way through the grass towards the adjoining wood.

The old birds now ceased screaming; just flew over the wall into the wood, and immediately began clucking their young to join them, as loudly and as unconsciously as if they had been a couple of barn-door fowls calling together their chickens. To a naturalist, it certainly was a most interesting little incident. In the course of my life I have disturbed many a brood of Partridges, but never before, did I witness such affection and anxiety for the young,

* Twelve or fifteen years later, this field was enclosed from the road. -Eo. 
and such unusual tameness, as were displayed by these poor birds. My impression of their singular affection is confirmed by what I saw to-day, when I again happened to disturb a brood of about the same age.

I know not how far what I have mentioned may be worth stating, but as a keen ornithologist, I am sure you feel interested in any anecdotes of birds. It may have nothing to do with the question of Instinct or of Reason, but it seems to prove (what perhaps wanted no proving) that the characters of birds, as well as of the other inferior animals, vary: some have greater or less affection for their young-more or less sagacity, \&c.*

I have met with an instance, that differs from both of the others which I sent you, two or three years ago, chiefly in the extreme tenderness of (as I suppose) the hen bird for her young. I will copy a memorandum I made at the time.

"June 19, 1848.--In walking across the upper part of the lower allotment field, at Border Side, near the wall, I accidentally disturbed a brood of young Partridges. The two parent birds, at first, sprang from the ground, a yard or two high, but immediately settled again; the cock then flew to the other side of the wall, but the hen kept in the field, fluttering along the ground, clucking and screaming; but, when she found I was too old to be taken in by this common ruse, and did not follow her, she stood quietly for a few seconds, and I had as fair a view of her, as if she had been a common domestic hen. In the mean time, I had noticed the young ones, busy hiding themselves; some in the wall, others at the root of a fine holly bush, that grew near. As to the old bird, anxious as Partridges are usually, to conceal themselves by cowering close to the ground-it was curious to see her standing near, and permitting me to view her for some

* As the Partridge becomes a topic, in a subsequent letter to Mr. G., that portion of it is introduced here, and parts of other letters on the same inlject are also brought together. 
time; indeed, till she thought all her young had got safe hiding-places. Then she flew off, over a little knoll, into an adjoining field; but I still heard her making a clucking noise. I walked in the same direction for about sixty yards, and seated myself under the hill, over which she had flown, but still within sight of the place where the young were concealed, in order to observe her return to them. She was in no hurry to do this. But after a while, I saw her head and lengthened neck, stretched up from behind a low wall, about ten yards off, peeping over to see what I was doing. She then drew back, and I saw no more of her for several minutes. At length, I spied her running along the field towards her young. Then I thought I would cross the wall, and creep quietly along the other side of it, out of her sight, till I came just opposite to where the young ones were hidden, that I might observe the manner in which she would call them together. But though I was as cautious as possible, and got near to her and her young, she was aware of my presence, and would not utter a cluck, nor collect them at all, whilst I was near; so that when I was tired of waiting, and looked over the wall, she flew away of course, and I was disappointed."

I suppose we must consider this ruse to be an instinct, for we can hardly believe that the young learn the manœuvre at that early age, and so are prepared to practise it long after, when they in turn are become brooding mothers. But, if an instinct, in the cases narrated, it seems to have been modified by a greater or less degree of affection in the parent birds. Is this difference to be attributed to a difference of individual character, or to a glimmering of understanding? Instinct is uniform; while reason varies in its adaptation of means to ends. How little do we know of the minds of the inferior animals! What a complete mystery they áre to us! Indeed, how should they be otherwise, unless we could enter into the minds themselves-in other words, become one of them. The only approach we can make 
towards a knowledge of their intellectual nature-and that must be a faint one-is by studying their manners and habits, and then drawing dark, uncertain inferences.

What a strong, active, vigorous bird is the Partridge! How full of the mysterious principle of life ! I have heard of a nest being seen in the morning in a hayfield, full of eggs, with not a shell broken, and in the evening, the young Partridges had all been hatched, and were running amongst the hay! And how vigorous the little creatures are! so that when just out of the shell, they can thread their way among rough grass, with surprising agility. The full-grown bird is so active, as a pedestrian, that it can run almost with the speed of a man; and I much doubt, whether the sportsman could ever bag his bird, when it is only winged, were he not assisted by his dog. It also flies, when fairly on the wing, with great celerity, but seldom uses its wings willingly, except when going from its feeding-grounds to roost, and back again in the morning. The place where it roosts is generally a low, wet, sedgy bottom, where the covey clusters all together-head to head, I believe. This is made apparent, by the droppings they leave. One may sometimes observe as many as half a score of these heaps, not many yards removed from each other; each having been a roosting place for a night.

This habit of theirs is attended with no little danger, on more than one account. I once heard of a poaching fellow that killed nearly a whole covey, by firing upon them when on the roost. And then the advantage it affords the poacher, in allowing him to draw the net over them, when they are pointed out by the setting dog. But, more than all must they suffer, from those vermin that range by night-the Weasel, Foulmart, and Fox-fine-nosed creatures as they are-when they happen to come to the leeward of their lodging-place.

The Partridge, like her congeners, is essentially a ground birl. About the middle of the day, it delights to bask in 
the sun, on the southern aspect of a hill; when it will spend hours, scratching and dusting itself in the loose mould. At other times, when feeding, with rounded back and head low, like a Guinea-fowl-it will creep close to the ground. It requires a fine eye, to see a covey feeding in a stubble-field. One may perceive a rounded, brown, shapeless something, perhaps: watch it, and it will become larger or smaller, or assume a different figure; if it do so, you may conclude there is a covey of these birds feeding among the stubble. But, so cautious are they, that if there be any noise, or if they can spy you, they crouch close to the earth, and become quite invisible. The colour of their plumage being in harmony with the decaying herbage, and other ground hues, this habit of theirs, doubtless, saves them from some enemies, such as Hawks, and other birds of prey. But, on the other hand, in regard to their most deadly foe, man, it is assuredly a great disadvantage; for he, being aided by his ally, the acute-nosed setting-dog, is able to come near them. The poor bird, relying on this deceitful expedient, till compelled to rise, is brought down by the inexorable gun. This misleading instinct is its ruin. Let it take a lesson from the sly Rook, the cunning Magpie, or the Jay, or indeed almost any bird of the copse: there is no good to be got by crouching, in a world of tyrants and oppressors!

What a revolution would it make, if this bird and its congeners trusted to the wing instead of to the ground! What would become of those who take delight in double barrels? Is it not somewhat curious, that this instinct, doubtless implanted for the poor bird's preservation, and which would be effective in a natural state, becomes in an era of civilization, through man's "wicked inventions," its deadly bane? But, thank Heaven, it does not always crouch!

In the beginning of the sporting season, before it has been persecuted with dog and gun, it often runs about after it has been flushed, and calls on its fellows; then it will not lie, in sportsman language; that is, it will not crouch, but 
flies, and he cannot get a shot. Like other cowards, it crouches most when most thoroughly frightened: when the covey is dispersed, and the poor birds are separated into ones, and dare not stir, the greatest havoc takes place. At other times-particularly entire coveys-will take wing at a safe distance, so that one might even think that it had learnt something, from that expensive teacher, experience. Indeed, sportsmen allege, that Partridges and Woodcocks are wilder and more difficult to come at, in our district, than formerly.

I will resume the subject in my next, and

I am, my dear Sir, yours truly,

W. Pearson.

Border Side, December, 1849.

My dear Sir,-In a good season, a brood of Partridges will number from fifteen to twenty-a great number to be hatched on the cold, damp ground, by so small a bird; but it is warm and full of life. If the weather be genial and sunny about the end of June, when the great hatch takes place, the coveys are numerous; but if it be cold and rainy, the reverse is the case, and many of the young birds perish. I have heard of a whole brood being found dead. But the covey, whatever it may number, like a loving family, always associate together through the winter, until the great pairing time in February; this, however, is delayed a little or hastened, according to the weather. It would appear, that the young couples spread off to some distance from their breeding ground, and where they feed; which never extends to an area of more than half a mile in diameter-in general, only to about a quarter of a mile. It will often happen, when a good number have escaped the gun of the fowler, that scarcely a bird will be found the following season, in the usual haunt of the covey.

Partridges are pretty plentiful in the township of Crosthwaite, as well as on the low grounds and mosses of Lythe, 
on the heights of Whitbarrow, and on other elevated spots; though I think they are seldom found higher than from 600 , to 800 feet, above the sea. A sporting friend of mine from Bury, in Lancashire, tells me that our Partridges are much larger and heavier than those of his own neighbourhood. The food they find here is probably more suitable for them, or more nutritious.

Partridges are very sociable, and when the covey is dispersed by any accident, and they are not much frightened, they soon begin to call to each other. The call-note is like the word skerritt, the last syllable strongly accented. When they have been harassed by the gun, and are in great fear, they seldom utter their call, till about dusk in the evening, when they often get upon a knoll, that they may be the better heard, or may more easily find their scattered companions.

I remember, a number of years ago, having some Partridge eggs hatched by a common hen. She took great care of the chickens, the foster-mother proving as attentive as if they had been a brood of chickens of her own. Anthills were procured for them to feed from, and they had the run of a small plantation and orchard, near the dwellinghouse. By the 1st of September, six of them were reared to full size. They were nearly as tame as the poultry, and fed among them; but about this time, they would go off into the adjoining fields, about dusk. They would return, however, next day. In a short time they would stay away for two or three days together; still, they would now and then pay us a visit, and be seen creeping about near the house. By-and-by, however, they came no more: their own wild instinct had prevailed, or else they had fallen a prey to some enemy.

Another trial was more successful, for one bird would frequently visit the fold and house, until the ensuing spring. It was the only one left out of a number, the others having been destroyed, chiefly by Rats. It was in the habit of 
feeding in some stubbles, a field or two distant from the house. Being known to the neighbouring sportsmen, when their dogs set it, it was not fired at, but suffered to fly home unmolested. It remained during the winter, and till pairing time, when it had the address to obtain a mate. It was observed one day, before the door, feeding among the hens, and at some distance, another Partridge looking on, with outstretched neck and head erect, no doubt much surprised at the boldness of its partner.

My brother had one, raised in the same way, which was still more domesticated; it remained with him the whole winter. "It was amusement for Robert, and I believe it knew him from the others, on account of his feeding it. It was well known all round, and would have been shot when among the stubbles, but for its popularity. It was seen at James Burrow's, at Crosthwaite Green, amongst their hens; it frequently went to James Cartmell's, and to Tarn Side ; and Richard Bennett's people saw it with their hens a few days since. It generally began to cry in the evening, and then took flight into the fields to sit; but it would be back again early in the morning."

I am not sure that it is mentioned in ornithological books, but it is well known to sportsmen, that the young birds may be easily distinguished from the old, even when full grown. In the old, the bill and legs are of a pale whitish colour: in the young, the bill is much darker, and the legs of a pale yellow.

My cousin, T. Little, tells me a curious anecdote of a Partridge. He once took one off its nest, and held it in his hands whilst his brother counted the eggs, twenty-six in number. He replaced it, and it continued quietly to brood, as if it had not been disturbed. How strong must have been the incubating instinct, to make it forget all sense of self-preservation. He afterwards ascertained that it hatched the whole of the eggs, and went off with the young-a great number, certainly, considering the size of the bird. 
This bird is extremely interesting to two classes, to say nothing of the naturalist. What diversion does it afford to the sportsman! What enjoyment to the epicure! There are not many dishes better than a Partridge pie, besides the many other culinary shapes in which he may be served up. But I find I am getting beyond my depth, and therefore must hold back.

Ever, my dear Sir, yours truly,

W. Pearson.

My DEAR SIR,-There were very few Wild Rabbits in our district not many years ago. Now, however, they are pretty numerous in two or three localities, where they are preserved; a task rendered somewhat difficult from the many enemies to which they are exposed. Our soil is not exactly adapted for a Rabbit warren; not being light and sandy enough for them to burrow in. They find a shelter, however, in the woods, under the stocks and roots of trees, or sometimes in dry drains, or holes in the rocks. Mr. Birkett, of Birkett Houses, has great numbers in his extensive coppice woods, from whence they issue to feed in the adjoining fields, not much to the profit of the farmers, I fancy. I have noticed in an evening more than a dozen feeding in a field, and, what is curious, one or two black ones among them. These Rabbit warrens must be a great boon to the Foxes, of which we have always had a tolerable number. I was much amused one afternoon last summer, on coming suddenly upon a Fox pursuing a Rabbit. Reynard was only a few yards behind it; he seemed more in sport than earnest, leaping gently along, with his flowing tail gracefully sweeping from one side to the other. They both disappeared in the wood.

At Pool Bank there is also a numerous colony of Rabbits. Here, in addition to their common enemies, such as Foxes, Foulmarts, and Weasels, which naturally prey upon them, 
they are subject to the inroads of the domestic Cat. Cats come even from the opposite side of the valley-from Cartmell-fell. But how they get over the Winster, which is here rather wide and deep, without wetting their feet, is a puzzle. But Pussy encounters greater dangers than crossing the river. Rabbit preservers have double-barreled guns, and do not hesitate to use them against rivals and enemies to their sports, where they can do it safely. Farmers have to lament the loss of many a favourite Tabby, whose dead body they might discover, were they to examine those Rabbit grounds narrowly. Traps, of various kinds, are also used successfully against Foulmarts, Weasels, and Cats. A box-trap, I am told, set in a path-way, was one morning found to contain a Hare, a Rabbit, a Weasel, and a Cat!- the Cat being the sole survivor, having, no doubt, killed all its fellow-prisoners. Were Rabbits not amazingly prolific, they could never keep up their numbers amid such a host of enemies. Not only quadrupeds, but bipeds, make war upon them-the human biped not being the least troublesome to the preservers. The instinct of destroying, or taking wild animals,-poaching, as it is termed, when practised by a poor man, or upon lands that do not belong to him,-is so strong, that no laws, or the severest execution of them, can put a stop to it. The respectable town of Kendal has the honour of sending among us most of these two-legged marauders; and so little are they ashamed of their pursuits, that they will not desist, unless overpowered and driven off by superior force. My brother had a few Rabbits on a small estate of his, which he wished to keep: he was apprised that a band of these plunderers were amongst them, assisted by Ferrets, nets, \&c. They saucily refused to budge, till he had raised a suficient force to intimidate them; and even then, they only removed a mile or two, as far as Mr. Birkett's more extensive preserves, to recommence their proceedings.

As to the predatory habits of our feline domestic, does 
it not form a presumption of its derivation from the Wild Cat? though I am aware many naturalists think it of a different species. The Cat does not take its prey by speed of foot, but approaches it stealthily, till sufficiently near to seize it by a spring, like its great prototype the Tiger. The Dog, on the contrary, always pursues his game and uses his nose as a guide to it. He also, I believe, sometimes poaches on these preserved Rabbit warrens. I have, more than once, noticed a Setter of my brother's, near one of these warrens, under suspicious circumstances, for he would not notice me, or acknowledge any acquaintance with me, as if he felt ashamed, and conscious he was engaged in a nefarious action; though nothing can be more friendly than his greeting, when at home. I know no business he could have in that locality, though Dogs have their business, such as it may be-for one frequently meets them travelling alone, and they are by far too sensible creatures, to be rambling about without having some object in view.

Although the Fox generally seeks his prey in the night, yet he is sometimes seen in the day. There is a cavern in the limestone rock, near Pool Bank, from which issues a copious stream, that flows through a meadow just below it. A Heron was observed fishing one day by its side. It rose, but settled again near an adjoining wood. Presently a Fox came out of it, and was seen slyly approaching the fisher, who, if he had not been wide awake, would certainly never again have had the pleasure of visiting Dallam Tower. He, however, very prudently rose on the wing, and Reynard slunk back to his cover.

Mr. Pearson, of Pool Bank, was informed one day, that there was a band of freebooters, busily engaged in a large wood of his, called How-ridding. He lost no time, but sallied out, armed with a double-barreled gun, and accompanied by his servant man with a stout stick, to defend his property. He found four men with nets, Dogs and Ferrets, making havoc among his Rabbits. Notwithstanding 
the disparity of numbers, he succeeded in making two of them prisoners, and marching them off to head-quarters. Here they were detained for some time, but no magistrate living within many miles, they were at length suffered to depart, on their parole of honour, that they would not, in future, carry on the war in any part of his territories.

Pool Bank, with the adjoining part of Witherslack, contains a greater number, and variety, of birds and wild animals, than any other part of our district, or than any other locality, I believe, in Westmorland-of the same compass. Though warred against, as in other places, they cannot be totally destroyed; the wild, and rugged character of the country affords them shelter and security. The beautiful line of Whitbarrow Scar, bulging out in places, in bold and perpendicular cliffs, as at Chapel Scar, opposite Witherslack Hall, is a roosting-place for Jackdaws, Ravens, and Hawks. The extensive woods of How-ridding, and the Park, contain numbers of Doup, or Carrion Crows, Magpies, Jays, and Stock-doves. These last, in Autumn, collect into flocks of one hundred or more, and feed in the stubbles, and turnip fields. There are Pheasants and Partridges, Hares and Rabbits, and the animals that prey upon them-Foxes, Foulmarts, and Weasels. So numerous are the animals and birds of prey, that when boys set springes for Woodcocks, and neglect duly to examine them, they are sure to find the ensnared birds eaten. Lower down, in the meadows, there are the Water Hen, and Water Rail; and in the Pool, and Helton tarn, numbers of Ducks and Divers, a greater variety than I can mention. There is the Squirrel, too; and I have omitted to mention the Black Grouse, now found in the woods on the higher part of Whitbarrow, and Red Game, at no great distance on the mosses.

What an interesting little museum would all the birds and animals of Pool Bank make, if one could collect them!

I remain, my dear Sir, yours very truly,

W. Pearson. 
'THE SQUIRREL.

Winster, 25th July, 1846.

MY DEAR SIR,-You are aware, that that pretty little active animal, the Squirrel, is rather plentiful in our neighbourhood. A large larch plantation, at Lamb How, has lately been cut down, which has had the effect of banishing a considerable number of them, into the adjoining parts. They are now met with about farm-houses in Crosthwaite, wherever there are a few trees, and where they were never seen, formerly. In going down the valley to Crosthwaite, in a part of the road free from wood, indeed, at a distance from any, I met with one; it ran across the turnpike and mounted the wall, its bushy white tail pointing upwards, or rather, over its back.

I stood still, stooping down to watch its motions. When it came near, it also stood still, and looked at me, but soon came forward along the top of the wall, passed me, and then recrossed the road, to where there were a few larches, by the side of a field. I suppose that these expatriated Squirrels, find it difficult to meet with a comfortable settlement; and one of their evils is, they are sadly tormented by mischievous boys, who can now more readily come near them. I think this white-tailed one must have been an oddity.

None of all our wild four-footed creatures is so pretty and so interesting as the Squirrel-so active and graceful in its movements; it is equally at home on the ground and in the wood, threading its way among the boughs, and leaping, from tree to tree, with surprising agility.

"Lithest, blithest harlequin,

Prettiest tumbler ever seen."

I have seen as many as three Squirrels, in a walk to Winster. If one do not make a noise, they will suffer one to approach within a few yards, and will stay, and stare at 
one, with their fine, large, black eyes; and thick bushy tail spread over their back. They feed on the young fir cones in the larch plantations. In nut time, they will travel a good distance to the hazel woods. I think there is little doubt, but that they store up nuts for winter provision, though I never saw one of their hoards, nor ever met with a person who had. Many years ago, returning from Woodcock shooting on Cartmel-fell, a Squirrel crossed the road before me, when, with the destructive instinct of the sportsman, I lifted my gun, and the discharge unluckily proved fatal. When I came up, and saw the pretty creature lying dead, with a cluster of fine, ripe nuts in its mouth, I shall not easily forget how I blamed myself, for the rash, wanton act. The provident creature was fetching nuts from the woods, and was carrying them to its home, in the larch plantation, most probably for winter use.

Before the extensive larch wood, at Lamb How, was cut down, it was full of Squirrels; and in Autumn, when the nuts were ripe, they used to leave their usual haunts, and cross the Winster beck, to fetch their favourite food from the Cartmel-fell coppices. There was one track or common road, which all seemed to travel-a short wall, which abutted against the plantation, to which was hung a heck. It is their habit to run along the tops of walls and gates in their journeyings, and I hardly ever passed that way in the Autumn without seeing one or two, crossing, or recrossing.

I have my own grievance to complain of.* The Squirrel sometimes leaves its woods, and pays us a visit in our rural retreat. It was pleasant to notice in a larch-planting, past which I sometimes take a walk, its lively motions-leaping from tree to tree, as if it were a bird. One day (it was

* This was written after he had left Winster, and was again established at Border Side. Indeed, the only portion of the original letter, here retained, is the commencement, to which detached passages on the same subject have been added, giving a continuous form to his observations about the Squirrel. 
before the frost), I looked for it as usual, but instead of seeing it as before, in all its innocent vivacity, there was its body lying on the wall, shot to death by one of those ruthless destroyers. I will not say how indignant I was ; but I do know I felt an unwonted liking for all preservers of game, and prosecutors of poachers! Moreover, this was the second of these harmless, and beautiful creatures, that had been destroyed recently, on my own land, and near our retired dwelling.

I think we have only three or four quadrupeds that form nests. The Field-mouse, makes a snug little ball of withered leaves, frequently laid bare by the mowers, in hay-time, in which one may chance to find five or six tiny, naked, young ones. This calls to mind a droll incident. A boy told me, he found a Dormouse asleep, among the feathers of a Tomtit's nest, in a hole of a rotten tree-a snug place for a winter dormitory, as the little creature must have thought, when it took possession, and which, besides, saved it the trouble of constructing a nest.

The Hedgehog wraps itself round with dry leaves, at the bottom of a hedge, or under some stock, or stone. We have a breed of these quiet animals, in the grounds, close to the house. A half-grown one will walk about in the day-time, and seems little disturbed if we go near to it. I was lately amused, on going to our spring well in the rock, to find the little Hedge-pig on the brink of it. It did not coil up, or seem alarmed, but, by-and-by, walked off into an adjoining alder bush. Hedgehogs are by no means useless in gardens; they feed on several noxious creatures that infest them. Ours have been seen rooting for grubs, in the friable soil of the grass-plots, with their little snouts, in a style that might have done credit to pigs of larger growth.

I have known Squirrels take possession of a Magpie's nest, at the top of a tall spruce fir; but they generally build one of their own, and a most snug, convenient, and elaborate structure, it is. It is not uncommonly, placed at 
the top of a pollard ash, covered and concealed by ivy. Its outside consists of green moss, inside of which are strips of bark, then a layer of dry leaves, the whole lined with warm sheep's wool. It is surmounted by a roof, or dome, like the Wren's, with two holes into it-one opposite the other; so that if an enemy approach on one side, there is a clear way of escape on the other. Here it deposits its young, to the number of four or five, which it feeds like other mammalia, till they are of size to leave this snug abode.

As to the place where the Squirrel deposits its hoard of nuts, I have read that it is in the hollows of trees. This may be the case in some parts, but does not solve the question in regard to our neighbourhood, for, as I have mentioned, the nuts are often carried from the hazel woods to the larch plantations, where there are no aged or hollow trees whatever. In removing old walls, numbers of nut-shells are frequently found, with a hole bored in the side, and the kernel extracted. This is thought to be the work of mice. Can it be Squirrels?* I am told, the Squirrel has been seen to creep into walls.

A book I have consulted, states, that there is a species of Squirrels in Wales, with cream-coloured tails. We have them also, as I have already noticed; but I can hardly believe that this simple difference can constitute $a$ species. I have often regretted, that I know so little of Natural History, scientifically. It is late on my part to set about studying it; and hitherto, indeed, if I had had the industry, I have been but poorly provided with suitable books.

It has seemed to me lately, that you could not do a greater service to our Society (you, who are acquainted with Natural History scientifically), than to point out the best methods of study, and the books that would most efficiently

* There is a large hazel within our entrance gate, from which I have observed the Squirrels run along the rock; beneath this tree, plenty of shells were to be seen, always divided, as if cut from end to end with a knife. 
assist in it. Let me beg that you will write a Paper on this subject. To the young, who wish to gain knowledge, it would be invaluable-indeed, to all of us. Hoping you will consider, and consent,

I remain faithfully yours,

W. Pearson。

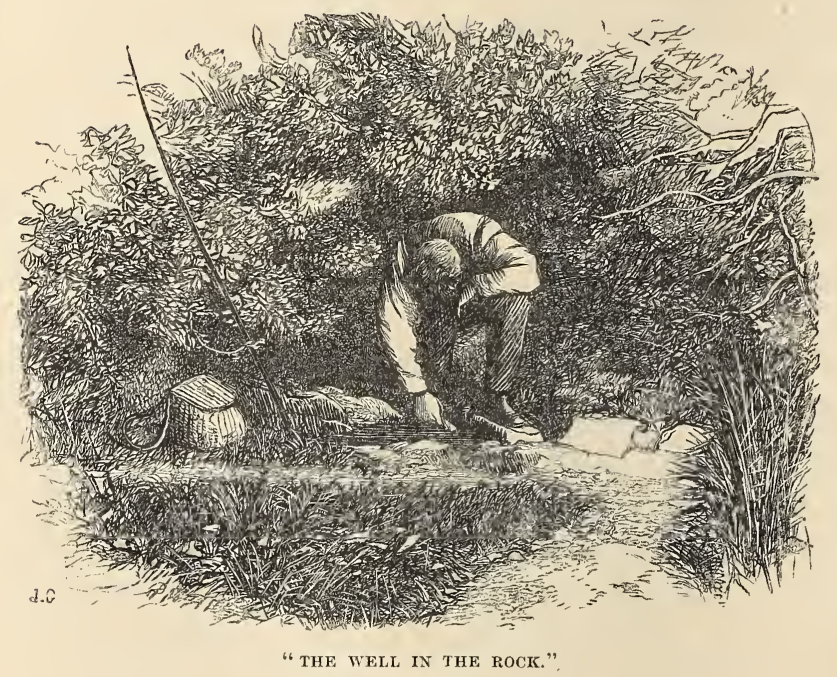


TO THE ZOOLOGIST.

Tuis part of the district of the Lakes, including both sides of Windermere, has, within these few years, been visited by a noble bird-the Wood Grouse, or Black Game, and which, from the appropriate nature of the country, as affording it both shelter and food, promises to be a permanent resident. Considering that it is only five years, since the first of them were noticed (as will appear from a letter I subjoin), they have spread themselves widely. I will mention a few of the localities where they have already been seen. In a plantation at Cock Hagg, in Crook; in another at Lamb How, in Crosthwaite; and in the wooded parts of that fine, detached, limestone mountain, Whitbarrow, which rresents such a bold, rocky scar, to the Lake tourists, as they approach by way of Milnthorpe. Here they are strictly preserved, as a gamekeeper has been recently appointed. Perhaps, they are most numerous, on the woody heights of Cartmell-fell, which is now a grand larch forest, although I remember it before the enclosure of the commons, when it was covered with heath, and tenanted by the Red Grouse. These have now disappeared, and it is curious, that from a change in circumstances, they are succeeded by the Black Game, of which, at the time of the Red, there was not a single bird in the country. They are now, as I have said, also on the west side of Windermere-on the wood-covered, rugged hills of High Furness, and even as low down as Holker, the seat of the Earl of Burlington.

Ever since their first appearance, I have felt some curiosity to know whether they were voluntary emigrants, or whether the first couple or two had been introduced by some neighbouring gentleman. To determine this, I wrote 
recently, to Mr. Wilson, of High Wray, near Hawkshead, in whose neighbourhood, I had heard, they were first noticed. His letter, which he has kindly allowed me to send to you, seems to settle the question quite satisfactorily.

"High Wray, 7 Mo., 30, 1850.

"Esteemed Friend, Wrlliam Pearson,-I have been too long in answering thy inquiries respecting the Black Game. The delay has arisen, from my wish to have my account, as to date, confirmed by another person. In the Autumn of 1845 , about 9 th mo. (September), I discovered, about a mile and half from this place, in a very young plantation, belonging to Henry Curwen, a brood of six or eight Black Game. I believe these were the first seen any where in this district. I did not know, certainly, what they were at the time, but immediately wrote a note to Braithwaite Hodgson, of Colthouse ; and his nephew, Braithwaite Hawkrigg, a day or two later, was the first to shoot two of them, which I am informed were cured, and are now in the possession of William Garnett, of Sawrey. I have never heard of their being introduced by any one here, and feel assured they came of their own accord.

"There are some now, about Colthouse Heights, and also on the lower parts of Hawkshead Moor, and probably at other places.

"The plantation in which they were discovered, was one, from which, a previous one, had been cleared, the ground having been replanted. Other birds have followed the larch plantations-instance, the Cross Bill, which, as thou probably knows, have been pretty numerous in Henry Curwen's woods, though I am not aware that they breed here.

"I have pleasure in answering thy inquiries,

And am very respectfully, "WrlliaM WILSON."

Having ascertained that they "came of their own accord," 
one is next curious to discover from whence they emigrated. But this can only be conjecture. The nearest locality where I have heard of any, is Mell Fell, a round, wooded hill, at Matterdale, in Cumberland, and more than twenty miles from Hawkshead. The rugged, and lofty barrier of the Lake Mountains, also intervening. Still, it is probable they came from thence, for we have Wood Grouse at about the same distance, to the East, West, and South of us. They did not arrive till the country was, as it were, prepared for them. Not very many years ago, the localities they inhabit would have allowed them no shelter; now, the tall larch rises at intervals, intermixed with the various native trees, such as the oak, ash, birch, alder, \&c.

It would really appear, as if Nature, like a provident mother, whenever a change occurs in her wide domains, producing a state of things, suitable to afford shelter and enjoyment to her irrational offspring, takes care to inform them of it, and thither to direct their course.

W. Pearson. 
Supplement to a Paper read at the October Meeting, 1851.

The Paper alluded to in this Supplement, is, by some means or other, missing; but in the ordinary issue of notices previous to the Meetings, the one for October, 1851, names "the Honey Bee," "the Partridge," "the Black Game," and "the Hag Worm," as the "chief subjects" of the Paper of the evening. Of these, notices of the Bee, will be found among the "jottings;" the matter relating to the Partridge, is combined with other notices of that bird, and arranged to form a distinct Paper. The Black Grouse, is treated of in "a Letter to the Zoologist;" and the Hag Worm, is made the subject of the "Supplement." Preliminary to the Supplement, a memorandum of an attempted invasion of the pantry, by a Viper or Hag Worm, will be given.

July 23, 1851.-The servant, in a great flurry, called me into the pantry this afternoon; she said, there was a Hag Worm endeavouring to get in at the window. And there it was, sure enough, raising itself straight up from the window-sill, first trying one small pane, and then another, not understanding how the transparent glass should offer any obstruction to its entrance. The window being low, it had crept over a heap of sand, lying below it. It was a beautiful creature: its small head, and two prominent, dark eyes, might have pleaded for mercy; but, notwithstanding my general habit of sparing these reptiles, when I meet with them in my walks, this one came too much in the character of a thief and a robber to be excused, so I gave orders for its speedy execution.

\section{Supplement。}

IN a paper read at our October Meeting, I alluded to a singular narrative in the Kendal Mercury, of a Viper, or Hag Worm being killed in its transit across Conistone Lake. I stated how desirable it was, that newspaper editors should authenticate the marvellous accounts they insert, on 
subjects of Natural History, by giving, if possible, the name of their authority, which would be a great comfort to sceptical naturalists. No denial of the fact was expressed, certainly; but more than doubt, was thought to be implied; for, in a week or two after, two or three letters appeared in the same paper, rather fiercely taking me to task for my non-credulity. One was a defence of the Conistone narration, but, like the others, it was anonymous. There was, however, a vein of facetiousness in it, that led my literary instinct to have a shrewd guess as to the writer, and in order to have some really reliable ground for belief in the alleged curious facts, I wrote to the gentleman, frankly, on the subject. You will, I am sure, share in my pleasure, when I add, the reply was highly satisfactory, as to the scientific fact involved, as well as in other respects, amusing and instructive. I have his permission to read the letter, he preserving his anonymity. He wraps his "cloak of invisible" tight round him; nor is it to be stript off, except by the exercise of that faculty, which I have named, literary instinct.* The writer apologizes for the length of his letter-very needlessly, I thinkand concludes with compliments on my little sketches of local Natural History, which I may be excused from repeating, although he may be assured, I am by no means insensible to the praise of one who is, himself, master of so graceful a style of writing.

It was a lucky circumstance, my allusion to that Conistone voyage of the Hag Worm, for it has brought to light evidence of two curious facts in the habits of that reptile, which, at least to me, were new, and, so far as I know, are not mentioned in books of Natural History. First, the Hag Worm's power of retaining vitality when immersed in water; and, secondly, its adventurous disposition, and its ability to cross a wide expanse of that element, with perfect facility. When we reflect on the cause that prompts this unwonted activity, in so sluggish a creature, which passes most of its time under letter.

* Want of space, necessitates the omission of this very interesting 
stocks and stones, we are sorely puzzled to account for it. What could it procure on the eastern side of Conistone water, which it had not in plenty on the western shore? Did it go to see its friends and relatives? or, like another Leander, crossing the Hellespont to visit his Hero, did it adventure like him, and, like him, perish in the gallant attempt?

Some persons may think we have dwelt too long on a noxious animal-despicable and disgusting to many; but let them remember, that the lowest of living things,

"Of forms created, the most vile and brute,"

from the worm we tread on, up to sovereign man, all have one origin-one Almighty Creator, and exist for good and noble purposes, whether we can discover them or not. We may doubt many things, but we cannot doubt this.

" Through primrose tufts in that sweet bower,

The periwinkle trails its wreaths;

And 'tis my faith, that every flower

Enjoys the air it breathes."

Our creed, may not be so catholic as this, but we may safely, I think, hold to the belief, that, in the animal kingdom at least, all creatures, high and low, have their enjoyments; different in degree, and in kind too, according to their rank, yet still, enjoyment seems inseparable from life. Even the shell-fish, fastened to its native rock, can wait patiently for the ministration of the daily and nightly tide, and enjoy pleasure that allies it to the Alderman-for is it not endowed with a digestive apparatus? If enjoyment, then, be an invariable concomitant of animal life, here we have one purpose of Creative Power, and not an unworthy one-for it bespeaks a Universal Benignity; while there may be other objects fulfilled in creation, of which we are, and must remain, ignorant.

I may conclude with the remark, that to investigate the ways and habits, of the most despised of God's creatures, will always be interesting to the devout Naturalist.

April 16, 1852.

W. P. 


\section{A FEW RECENT NOTICES IN NATURAL HISTORY}

Sent to the "Kendal Mercury," in 1855.

IN the winter of 1854-55, Mr. Gough, who was at that time resident at Grange, gratified the readers of the Kendal Mercury, by a series of beautiful letters-charming for their wealth of heart-wisdom, scientific tact, and delicate literary criticism. Simultaneously with these letters of "A Looker-Out," appeared "Notices," by "P.," and thus the Mercury became a line of communication, along which, the flash of a joyous intelligence was transmitted backward and forward, between the friends; for the intellective faculty was by no means dull at Grange and Border Side.

The sincere, and graceful tribute paid to "P." in one of the letters by "A Looker-Out," will not by him be considered misplaced here, prefixed to the "Notices":-

"The letter of your correspondent 'P.', which was published in last week's Mercury, contains many interesting and original observations, on the effects of the severe winter, on the habits and actions of birds. The value of ' $\mathrm{P}$.'s' remarks, too, is much enhanced, by the subjects of his portraitures being selected from the feathered tenants of every-day life; amongst birds, in short-whose names are as familiar to our lips, as 'household words.' Hence, another proof of the amount of novelty, which an accurate observer may glean, from living by the side of common animals; and from watching and noting all their peculiarities, their variations of habit, and their various resources to escape from difficulties. We are too apt to fancy, that because everybody knows a Crow, and because the species has been almost as often described, as seen-therefore, nothing new can arise out of a careful observation of this common bird. But to know a bird accurately, by its mere form, colour, and size, is one thing-to gain an accurate knowledge of the same bird's habits, is another. For these two facts, though we 
frequently see them associated, require a very different mental tact, to bring out in full, all the various bearings upon the history of a species; and it is to such observers as 'P.,' belonging to the White-of-Selborne group of naturalists, that we are indebted, for an increasing knowledge of the habits of animals."

Notices, \&c.

The late long-continued frost, followed by snow, brought great hardship on the feathered creation. The Rook, active and shifty as he is, in gaining a livelihood through all seasons, had persevered in the black frost, though all insects and worms, his usual food, had disappeared from the surface of the hide-bound earth. But, when universal Nature appeared to be dead, and was enveloped in a white shroud, he could stand it no longer. He struck work, cut his stick, and made off no one could tell whither. And afterwards, so long as snow covered the ground, not a Rook was to be seen in the valley of the Winster, populous as it is, with those active birds, at other times. We wish we knew whither the Rook went. We have no opinion, however, that it was to the Crimea. He is much too shrewd a fellow for that. Perhaps, he only took a trip to Sandside, to watch the flow and ebb of the tide, and see what he could pick up. Perhaps, he turned fisherman and cockler, who knows?-for probably, at a pinch, he will eat fish and flesh. Flesh, we know, he will eat, and why not fish, as "Lenten Entertainment"? But, wheresoever he went in his distress, as soon as the snow melted, and the face of the ground was bare, and somewhat soft,---sure enough, here was he to be seen again, in his old accustomed haunts, as brisk as ever.

We have another bird, in outward appearance, almost a fac simile of the Rook, though of different habits-the Doup, or Carrion Crow. When the Rook had disappeared, we noticed a couple of or two of Doups, that stood out the storm bravely; and this is more remarkable, as their dietary 
is more limited than that of their congener the Rook. They must have been sorely put to it, however, which was evidenced by an incident we witnessed. A Carrion Crow was seated on the top of a tall larch, which grows at the end of the farmhouse just below our cottage. By-and-by he descended the tree, mid-way, as if to make a nearer observation of something lying in the fold, then boldly alighted within a few yards of the porch, doubtless to secure some tempting article of food.

The unusual weather in January and February, attended by continued frost, had made water as scarce in our valley as it is in a Summer drought. The sikes, or small rivulets from the hills, had ceased to flow, and even the larger becks were almost entirely frozen over, not merely the smooth and exposed pools, but the more active running streams. No corn could be ground at the mill. Some of the farmers were obliged to cart water from a distance. Birds, therefore, of aquatic habits, such as Wild Ducks, Water Hens, Snipes, and Woodcocks, must have been almost cut off from subsistence. Indeed, a poor famished Woodcock was taken up by a farmer in Winster, too weak to get out of his way.

If birds are dear to us in Spring, when they cheer us with their songs, surely we ought not to forget them in the inclement Winter, silent though they be. For our part, like many good-natured persons who have not much to do, we strew them a few bread-crumbs on the window-sill, free to all comers. Our visitors to this dole were old acquaintances, the Chaffinch, the House and Hedge Sparrow, the Robin of course, bold and familiar as he is at all times, nor likely to be less so, when pinched by adversity. Robin is a lucky fellow, the sole sacred bird in the British Isles! Even to the murderous stripling schoolboy, when he first carries a gun, and no feather is free from danger, Robin alone bears a "charmed life." It is curious how he has contrived to gain a dignified Christian name, in all countries. 
" The Thomas in Finland,

And Russia, far inland,

The Peter of Norway boors."

We would just hint, however, under the rose, that we fear, in sober truth, he is little worthy of all this flattery. From what we have seen of him, his boldness verges on impudence: he likes the Lion's share of all divisions; he is combative withal, and quite willing to domineer over any peaceable bird he can master. He is said to have performed a pious act in the mediæval ages (see a ballad called "Babes in the Wood"), and we suspect, that his saintship arises, in a great measure, from the memory of that. What wonders poetry can effect! As some one said, "Let who will make the laws, let me write the ballads."

In ministering to the wants of our feathered friends, we were not unmindful of that active fellow, the Tomtit. But he must be provided for in a different manner. Small as he is in person, he is none of your milksop vegetarians. $\mathrm{He}$ dines on animal food, when he can get it, with a gusto and keenness that would do credit to an alderman. We possess a little network apparatus, like a purse, with open meshes. 'This, with some lard in it, was suspended from the branch of a tree, a few yards from the parlour window. It was not long before Tom found out the prize, but how, one can hardly tell. But, however this might be, it was exceedingly amusing to watch his antics. He fixed his feet to the bottom of the bag, his back downwards, and dug away in the lard with his bill, through the openings, while the bag, swinging to and fro, with the little bird hanging to it, afforded one of the drollest sights.

There are few natural phenomena, that, if reflected upon, do not partake of the mysterious, and puzzle the acutest minds. As we said, how did the little bird become aware of the prize we had set out for him? It could not be from experience, for the whole affair was new to him. The 
invention was not our own even, for it was sent by a kind lady who lives in a southern county - a better climate than our cold Westmorland. Does Tom, then, possess the sense of smell, and did he hunt out his treat by the wind? or was it by some transcendental intuition, that he made the discovery? Can any philosopher solve the problem? We pause for a reply.

We have been delighted, the last two mornings, to witness the return of birds that have been absentees during the dreary Winter. These are two pairs of Starlings. For some years they have been regular visitants in the Spring, nesting under the eaves of the house. Their return was made known by a low piping song, which we heard before we rose from bed. Their voice is soft and low, which Shakespeare says, "is an excellent thing in woman ;" excellent, too, in a bird, when conjoined with sweetness. The Starling's song, in some of its notes, resembles the Woodlark's, though certainly it does not equal that heavenly musician. In this case, one was glad to hear it, for one felt it a pleasant precursor of brighter sunshine and lengthened days - " of the time of the singing of birds, when the voice. of the Turtle is heard in our land."

March 2, 18.55.

P.

\section{Further Remarks on the Habits of the Rook.}

Mi. EnIToR,-I an certain many of your readers, as well as myself, would peruse, with much interest and pleasure, the letter from "A Looker-Out," on the habits of the Crow. That the topographical knowledge of the Rook extended to much wider circuits than the shores of Morecambe Bay, I did not doubt; nor had I less faith in his sagacity to assist, by the most judicious means, his commissariat, when it fell to a low ebb, as it must have done during the late frost and snow. Still, it is very pleasant to have one's conjecture, that he repaired to the Sands in his straits, confirmed by so competent an observer as "A Looker-Out." 
There is one peculiarity in the habits of the Rook, which, although not quite unnoticed, has not been dwelt upon by ornithologists as much as its really curious nature deserves. It is the custom of all the inhabitants of our smaller rookeries to repair to Dallam Tower, to roost during the Winter. I have watched them oft, on those journeys, with much interest, both in the evenings and mornings. Our dwelling happens to be situated nearly in the line betwixt a neighbouring rookery and Dallam Tower, so that these transits may be always observed. They form a long, straggling line, that takes some time in passing. They fly in small groups, with intervals betwixt; in larger companies of a dozen or more, down to as low as four or five-never, I think, a single one by himself. Indeed, as far as I have observed, the Rook has a great horror of solitude, and you scarcely ever remark one quite alone, either feeding or flying. In the Winter, as soon as it well light in the morning, they pass our house in the manner I have described, in the direction of the Rookery. It is curious why they should invariably assemble in the morning, at the home-quarters. Is it to consult as to the day's proceedings-where they are most likely to meet with the most profitable employment? As in the government of Rookdom, individual freedom is much abridged, and they carry on all operations in concert, and in the company of numbers; it would seem there must exist rules and laws, and even individuals placed in authority, officers as it were, to see to their execution. There must be power in some one, to direct the movement of flocks, as well as to control the irregularities of individual free-will.

As the rich and fashionable spend the Winter in the huge capital of the British Isles, so the Rooks (as if in imitation of such high example), during the same season, repair to their Metropolis, a larger Rookery than common, and seated in the centre of a wide circle of not less than twenty or. thirty miles diameter. Thronging, as they must, along all 
its radii, what an immense number of those birds must be assembled at Dallam Tower on a Winter's night! And what can be the motive or cause of all this, as one might think, needless trouble? It can hardly be to obtain better shelter and snugness, for our Rookery lies low, and free from the attacks of the turbulent West wind, the prevailing one. Is it to indulge more and more their social feelings, or something even higher, a kind of patriotism, if one may so term it-a love for their tribe, and for a wider communion with them, thereby to strengthen their common interests? These speculations may seem fine, and far-fetched. But the fact is, this instinct or reason (call it what you will) appears to be common to the bird. Mr. Waterton mentions his Rooks at Walton Hall, roosting at a distance in Winter. Now, as Nature (or more properly speaking, the Great Author of Nature) does nothing in vain, there must be.a purpose. If we are in the dark respecting it, so we are in regard to many other phenomena we meet with in our daily walks. But I believe the more we know of the inferior animals-beast and bird-the more shall we be struck with their surprising intelligence, and their suitability to the situations they are placed in.

I ought to have mentioned, that the Rooks ceased lodging at Dallam Tower about the beginning of this month, for we have seen no passing, or repassing, since then. The proximate cause may be, they have at present no leisure for such journeyings, being occupied with repairing and building their nests.

As to "A Looker-Out" being foiled in his attempt to procure a specimen of these evening travellers, and how the distant rear-ranks became in their turn, aware of his "whereabout," and thereby avoided him-so long as they were within sight or hearing of those in front, there would be no difficulty; and if the interval was not too wide for their quickness of sight, would probably enable them in passing, to give a wille berth to the foe lurking in ambush. 
To revert, for a moment, to the barriers that continually rise in our approach to the secrets of Nature, and to the little we know, compared with what is unknown, I will cite an apposite passage from the "Egeria," of Mr. Benjamin Dockray, of Lancaster-a work which, when better known to reflective readers, will be highly estimated:

"Even the excellent Gilbert White, of Selborne, could say - ' I have made but slender progress in the pursuit of knowledge;' in like manner, Newton considered himself 'but as a child that finds a chance shell, or coloured pebble on the sea shore, compared with the infinite of truth that lay before him.' The admiration produced by advancing knowledge, is continually accompanied by a still greater admiration of the extending prospect. The delight of discovery, is never without the excitement of newly awakened curiosity. The unknown appears the more extended, and the more inviting, with every extended step of research. The extending circumference of knowledge is also an equally extending contact with the unknown."

March 25, 1855.

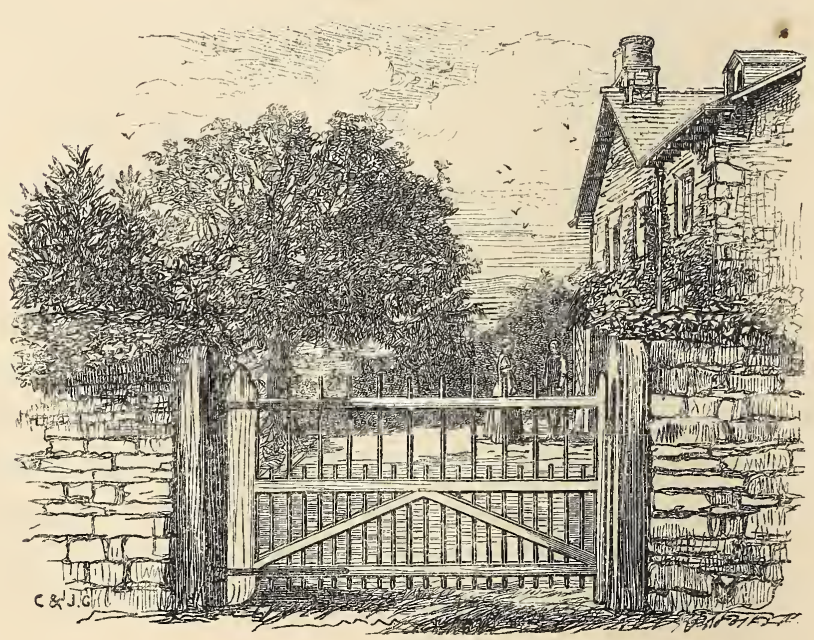




\section{JOTTINGS FROM NOTE-BOOKS.}

\section{7.}

May 3.-Found a Throstle's nest on the top of a steep crag, a ling bush spread over it. There was one last year in the same place, from which the young were hatched and flew. It seems that birds, when they find a secure situation where they are not disturbed, will make choice of it for several successive years. The late Birkett Elleray knew a Blackbird place its nest for many years on a stone in a quarry, where it was sheltered and concealed by a piece of overhanging earth.

\section{7.}

June 29.-A. and her sister S. went to Blackpool. The weather was very fine, sunny and warm, and has continued so till

July 27 , when we had some heavy rain. On going to Kendal, in Crook, between seven and eight a.m., I saw that beautiful and somewhat rare phenomenon, a Parhelion, or mock sun; or rather two, one on each side of the real luminary, and at equal distances from it, to the $\mathrm{N}$. and $\mathrm{S}$. There was a ring round the sun at the time, faintly marked in the thin, hazy clouds that covered the sky, and the mock suns were just within the line of its inner circumference. They shone very distinctly through the cloud vapour, and were faintly tinged with the prismatic colours on the side next the real sun. In half-an-hour, or less, they were obscured by a mass of dark clouds from the South, and some heavy rain came on.

1849.

Dec. 18.-A "Second Speckled Diver" shot on the mill dam, below Rowland Bridge.

\section{0.}

A pril 26.-We have a Chaffinch's nest in the holly on the left of the steep step-walk; a Blackbird's a little below, on the side of the rock-same place last season; a Robin's in the ivy on the rock side-the same place also as last year. The Blackbird has 
been sitting about a week; the Chaffinch two or three days. The Robin has one egg.

May 1.-Robin sitting on five eggs.

May 2.-Heard Cuckoo at Low House. Two pairs of Starlings. They have been busy making their nests for a few days; thought they had been sitting. Three or four pairs seen to-day.

May 3.-Blackbird's eggs taken.

May 5.-Saw the first Swallow flying across the allotment. No Cuckoo yet at Border Side. Thomas tells me there is a Black Cock calling in the mornings in Lamb How plantation. 9th, heard it.

May 6.-Heard the Cuckoo at Border Side.

May 10.-Weather cold; not heard the Cuckoo again. Saw a Magpie searching the holly and alder bushes in front of the house for birds' nests. It went through and through.

August 4.-I have been told a curious circumstance respecting Bees. Joshua Robinson, of Tower Wood, on the eastern side of Windermere, has this Summer three hives of Bees that cast swarms on the same day, one close after the other, all knitting together in one large heap on the bough of a pear tree. This bough spread out into two branches, and in the fork was a Chaffinch's nest, with two young birds in it. The Bees settled just at the fork, crawled over the nest and the poor young ones, completely covering and hiding them, to the sore annoyance of the parent birds, which kept flying near, pouring forth the most anxious chirpings. When Joshua arrived, he placed his ladder to the tree, sawed off the bough, brought it down with the huge swarm attached to it, then gently thrusting his hand among the dangerous insects, he took out the nest and its young, which, for the present, were placed on one side. Then he slivered one branch from the other, and as each had a portion of Bees attached to it, shook them into two hives, thereby dividing the mass of the three swarms into two, and, what is singular, the industrious creatures were satisfied with the new arrangement, settled quietly in the quarters, making no change, that he could percieve, though they were far from being divided equally.

The Chaffinch's nest was placed in the tree it was taken from, the young fed as usual by the old birds, and brought out. 
I have seen the Bees above mentioned; one lot in a hive, and the other in a large barrel.

Another singular anecdote relating to Bees, was told me by my cousin, T. Little. His brother, who lives at Blencowe, in Cumberland, had a swarm; they were hived and remained apparently contented, for five or six hours, in their new habitation: they then left it, rose into the air, and flew over the fields to the distance of about a mile, where they settled on an old, decayed, but not hollow tree. They remained here a short time, then rose, returned on their former track to the hive they had just quitted, entered it, and have quietly occupied it ever since. My cousin, who related this fact, was himself the person who followed the Bees over hedge and ditch, in this their singular excursion.

May we not fairly infer, that their first compulsory dwelling had not suited them in some respect or other; that they fancied they knew of one more eligible, one of their own choice, that would suit them better; but on a more exact examination, this was found not to be the case, so, like wise insects as they are, they resolved to return, and put up with the lesser inconvenience?

1851 .

June 4.-With Mr. and Mrs. Graves to Witherslack Hall. Weather delightful-white cumulous clouds, blue sky, a cool breeze. Went under Chapel-Scar Rock : beautiful prospect. A couple of Jackdaws about their nests. Sparrow Hawk flying near the rocks. On our return, saw Wild Rabbits, a Squirrel, and Wild Pigeons in the park.

July 4.-Very dry, sunny, and clear. A Goose, belonging to J. W., has set herself on the allotment, and brought out three Goslings about a week ago, on the top of a rocky knoll. The rest of the flock (seven) seem to take great interest in this second hatch, unusual among Geese. They used to go and sit near, several times a day, during incubation, and cheer her with their gabble. And now that she has brought three young ones out of her ten or twelve eggs, nothing can equal the care and pride they show in leading them about, and protecting them. One day, watching them from a distance. I saw something of a black colour run through the fern, from where the Geese were pasturing - the Gander, with out-stretched neck, pursuing. I thought it some 
four-footed animal, but it was a Crow that had approached nearer than the guardian of the flock thought it prudent to permit. I was much of his opinion, deeming the impudent rogue (who would not $f y$, he would only run) a Doup, or Carrion Crow, which wished slyly to pick up a Gosling. I watched further proceedings, but witnessed no attack on the juveniles. It was probably only an innocent Rook, that had too much sense and spirit to be driven from his feeding place by a swaggering Gander.

1852.

April 18.-I was much interested yesterday evening, in being shown two young Hares, which the farmer had found during the day, couched side by side under a tuft of heath, on a rough pasture near the house. They were very young, not more than six or seven inches in length, much to young to leap, or attempt to get away. It was dusk when I saw them; they had then separated a few yards from each other; we placed them together that they might keep each other warm through the night. But when I went this morning, they had again parted company. For some time I could only find one of them; at length, I discovered the other, at least ten yards distant; both, however, snugly concealed under decayed brackens. I left them this time, undisturbed, under the protection of their own instinct.

It is curious how little care seemed to be bestowed by the maternal Hare. Dropt on the ground where it may chance, she leaves them; only going at intervals to suckle them, chiefly at night. One might think they would either perish from cold, during the frosty nights of early Spring, or fall a prey to Dog, Cat, prowling Weasel, or other vermin. Even birds may pick them up, such as Hawks, Carrion Crows, or Magpies ; and there are, doubtless, numbers destroyed before they acquire any considerable size. Still many escape, owing their safety to their habit of couching close on the ground, of which they are nearly the colour, so that they are not easily discerned by their keen-sighted enemies.

March 23.-About nine o'clock in the morning, saw a numerous flock of Wild Geese flying up our valley towards the N. They were in the form of a large triangle, the point, or apex, in front, and the two sides spreading gradually outward. I counted the birds on one side to more than twenty, so that, I should sup- 
pose, the whole "airy caravan" numbered fifty or sixty. Our attention was drawn to them, by the continual cries they pour forth on their flight.

Dec. 26.-High wind all night, which lasted till about twelve on the 27 th (Monday). The moon being about full, and the wind blowing from S.W. and W., there was a higher tide than ever known in Morecamb Bay. Three farms at Foulshaw inundated; eleven cows, and ninety-five sheep drowned at Webster's.

A. measured an oak tree,on right-hand side of road, near Graithwaite, fifteen and a half feet round, at about one foot from the ground.

1853.

May 20.-Saw a 'Tom-'Tit's nest in a flower-pot, in the garden at High Berks. The pot is about one foot across, and rather more than one foot I think, in height. It was placed on the ground, bottom upwards; no entrance but the small hole in the bottom of the pot, about two inches across, through which the birds had entered, and covered the floor with a soft carpet of wool, moss, \&c., two or three inches thick, on one side of which was the nest, containing seven eggs. J. C. tells me, that they had a nest in the same place last year.

May 28.-Three birds' nests in small, planted trees, on East of house, by the side of the wall, viz., a Throstle, in a yew; a Hedge Sparrow in ditto, brought out its young; a Chaffinch in laurel; a Wren's nest in a crevice of the bole of the large yew; two Starlings, as usual-and several House Sparrows, in the walls of the house.

June 4, Saturday.- Set off, A. and I, for a journey to Low Furness. Reached Bardsea that evening; rested there next day. On Monday, through Dalton to Furness Abbey ; from thence through Ireleth, to Broughton, where we remained all night ; then by way of Conistone home. Very dry, hot weather; some signs of rain ; it did not come.

1854 .

April 4.-Returned from Bury after a visit of three months. Dry weather.

May 27.-Drove to Staveley, returning through Ings and Birthwaite, and Winster. There had been two hours' heavy rain in Winster; wone at Border Side. 


\section{BEWICK'S BRITISH BIRDS.}

" $O$ ! now that the Genius of Bewick were mine,

And the skill that he learned on the banks of the Tyne."

WORDSWORTH.

Date, about 1813.

THERE are few persons who are in any degree readers, but to whom some particular books are greater favourites than others. It has been said, "show me your friends, that I may know your character ;" perhaps it might almost as truly be said, "tell me the books you read, that I may ascertain your ruling passions, feelings, and propensities."

Among the books that have to myself "been dearer than the rest," I would mention the well-known "British Birds," which owes its existence to the genius of Bewick. And yet I am no ornithologist, strictly so called. I am not even master of the technical terms, by which these beautiful creatures are described. Often as the work has been in my hands, I have not attempted to learn them. I have never read even one-third of the letter-press. Indeed, it is not as a book exactly, that I love it; but rather as a series of delightful pictures-not of the birds either (beautiful and correct to nature as they are), so much as for those exquisite tail-pieces-those little chapters from the great book of Nature, or from the many-coloured history of human life. I came to the work as a child; the language was little or nothing, the pictures everything. I speak in the past tense, because the book is not quite so interesting to me now. But I was at the time,

"Brooding within the fierce confederate storm Of sorrow, barricaded evermore Within the walls of cities."

Perhaps, there is no one whose mind is awakened to a 
feeling of the beautiful and sublime in the external universe, who is fully aware of the depth and intensity of his love, if he have not at some period of his life, been an inhabitant of one of our large trading towns. The imaginative power, with which, as a lover of nature, he is necessarily endowed, will never be more vigorous, nor its exercise attended with greater pleasure, than employed, as it will be, on the impressions of his earlier years; calling them up as with a magician's wand, before his " mind's eye," in successive pictures of transcendent beauty. Wearied and exhausted by the "busy hum of men," the eternal discordant noises of the street, grating harshly on his ear, he will recur with tenfold delight to the recollection of rural sounds-to the cries of animals and the songs of birds, - to the fall of waters, whether murmuring gently in the "trotting brooks," or dashing fiercely down the rocks; - to the sounds drawn out by the winds in their endless courses-whether sighing and whispering among the leafy woods, or whistling and roaring in their strength. On the greater liveliness of imagination under apparently unfavourable circumstances, Rousseau has a striking passage :-

"It is very singular that my imagination is never excited to a higher pitch, than when my position is the least agreeable; and that, on the contrary, it is the least buoyant when all around me is joyous. If I would paint the delights of Spring, I must wait till the Winter has set in; if describe beautiful scenery, stone walls must keep it out of sight.

"I have a hundred times said, that I never could have depicted liberty, if I had not been shut up in the Bastile."

But, to return to Bewick. After escaping from the monotonous routine of the counting-house, in which one has been " cribbed and cabined" all day, how pleasant to turn over the lilliputian pictures; to smile at their broad humour, or to be soothed by their sweet sketches of rural scenery, and of healthful and innocent country anusements! Verily, Bewick, thou hast been to me as a poet! It is sometimes 
not so much what is shown to the eye, as what the mind conjures up and creates for itself, from these visual representations, that constitutes their interest. For instance, the old man (at page 193, Vol. I.) hanging his Cat, is the very portrait of Jooasy Fallowfield, whom I knew in my youth. He was a farmer of the old school, careful and steady, but hating innovation like a Tory. He would neither grow, nor eat a potato, but always had some excellent "barley wine," to which he bore no lukewarm attachment. Happy Jooasy! thou departedest this life, at the beginning of these revolum tionary times of green crops and potato growing, and before the ancient constitution of British farming had been entirely subverted and overthrown.

Some of Bewick's sketches are pathetic, and give rise to serious reflection. There is the old blind man, but hardy and stout of limb, carrying the shrivelled pantaloon on his back-the dog-guide, with collar and disengaged string, walking before; his master, for the time, making use of his rider's eyes. On the next page, two veterans shaking hands, not having seen each other for years; the one with hod on shoulder, with which he officiates at the adjoining building,the other with a wooden leg, bearing the beggar's pokeboth still decorated, with the soldier's long coat and cocked hat-but, alas! tarnished and worn out, like the wearers, and "fallen from their first estate." In another part of the book, we see the ruins of an ancient Abbey in the distance, with a man that seems almost as ancient, leaning on his crutch, reading the inscription on a gravestone, "Vanitas vanitatum, omnia vanitas ;" while close behind him runs a careless little boy, trundling a hoop.

As a contrast and relief to these, there are pieces of broad humour, and sometimes, like other geniuses, Bewick has been a little coarse, if not vulgar. I have seen his lady admirers passing these, their delicate fingers turning over to the next page. What a face is that of the termagant kitchen woman, lifting the gridiron to brain the luckless dog she has 
caught stealing her chops! It is impossible that that face can have ever smiled. Among his humourous sketches, is the good housewife hanging out her clothes to dry, while two tramps (her back being turned) have passed through the gate and left it open; the hen and chickens,-the "sow and her nine farrow,"-have entered in, and are busy among the clothes spread on the green. You can imagine what a storm will rise as soon as she turns round. Then there is the canister tied to the dog's tail, by the shoeless and stockingless urchins - the old, brawny, aproned blacksmith laughing as heartily as any of them. There is another picture, of a large river, with a bridge of six arches, a waggon passing over, and at one end a toll-gate; below the bridge is a fellow, with a true Elves'-countenance, holding by the tail of the cow, which he is compelling to ford the wide stream, rather than pay the toll; but if he have saved his money, he has lost his hat, which is sailing down the river. One cannot particularize all; still I must mention the beautiful little sketches of fishing and shooting-shooting in all its varieties, from the farmer who takes his long gun (to' scare the sable plunderers of his fields), and who is seen creeping and cowering behind the hedge, that he may have a shot at them sitting; to the regular gentleman-sportsman, who, with belt-encircled shoulders, and his elegant pointers, is traversing the stubbles, or the woods-the scenery amidst which he moves, the trees, hedges, rocks, even to the benty grass beneath his feet, all so minutely and exquisitely represented.

But, above all, I have been delighted with his fishing scenes. Take, for instance, that one at page 61 , or 238 , of the second volume. Look at the rocks rising from the margin of the river, and the wood fringing their sides, and crowning their summits; the trees bending down their branches as if to kiss the pure waters, still flowing coyly on. You see the rocky shelf, over which the river is breaking and tumbling (you may hear its murmur), and fondly passing away into that curly surface, so grateful to the eye of a fly- 
fisher. Ay, but look at the angler himself! how calm and quiet, and contemplative he is-a perfect Izaak Waltonone who has no care or anxiety, or wish, but for a wet night, and a south wind on the morrow. You may see at once, that he has not a grain of gall in his composition; - that neither avarice nor ambition disturbs him; - that he has never thought of raising himself in the world, but only how he might raise Trout!

M. N.

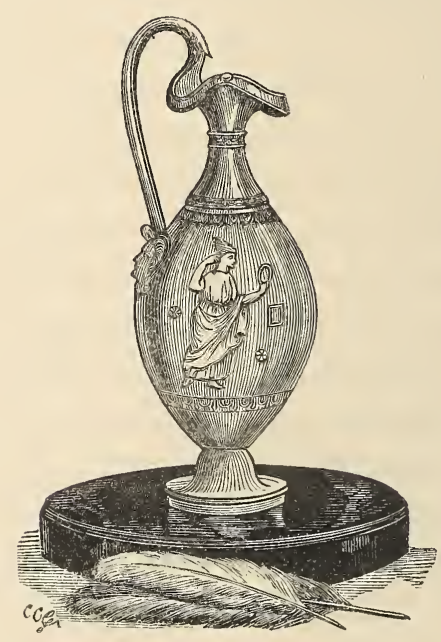


WALTON AND COT'TON'S COMPLETE ANGLER.

"Dreams, books, are each a world; and both we know Are a substantial world, both pure and good:

Round these, with tendrils strong as flesh and blood, Our pastime and our happiness will grow.

There do I find a never-failing store

Of pastoral themes, and such as I love best;

Matter wherein right voluble I am :

One will I mention, dearer than the rest."-WordswortH.

Among our most favourite books is the "Complete Angler," of Izaac Walton. It is not merely as a "brother of the angle" that we admire it, for its instructions in that solitary sport, though good as far as they go, are the least of its merits. Its peculiar excellence is of a higher kind. Dr. Johnson placed it in a list of works which he recommended to the perusal of a young clergyman; and, if we remember correctly, said it was one of the few books, that having once taken up, he never willingly laid down again till he had read it through. Yet we think its chief attraction for the Doctor could not consist in its style, for never was there a more complete contrast between its extreme simplicity, and the pompous and measured march of his own balanced and artificially constructed periods. When we read Walton, there is such a want of all author-like pretensions, that we seem as if conversing with a friend who is speaking from the fulness of his heart, and when he begins a sentence, neither thinks of the words he shall introduce, nor how he shall end it.

Izaac Walton was born in 1593, and died in 1683. Though living in an age remarkable for ability of all kinds-

"Great men were then among us, better none"-

near to, if not entirely in, the earliest and most vigorous 
period of our literature; though probably unacquainted with any language but his mother tongue, yet has he attained a permanent station among English prose writers. As well as for his book on angling, he is eminent as a biographer; having, as is well known, written the lives of the judicious Hooker, Bishop Sanderson, Dr. Donne, Sir Henry Wotton, \&c., most of them his intimate friends. Indeed, there is nothing seems more wonderful to us now-a-days, nor places the eminent persons of that age in a more amiable point of view, than so many of them having not only taken notice of, but entered into habits of close intimacy with, a man neither distinguished for learning nor rank; for honest Izaac was, by profession, a shopkeeper, and but a small one (despise him not, gentle reader), for when he occupied a whole shop, "it was but seven feet and a half long, and five wide;" and when he followed the trade of a linendraper, the house was in the joint occupation of himself and another, so that half a shop was sufficient for the business of Walton. Yet, according to Hawkins, " in the number of his intimate friends were Archbishops Usher and Sheldon; Bishops Morton, King, and Barlow; Doctors Fuller, Price, Woodford, Featley, Holdsworth, Hammond; Sir Edward Sandys, Sir Edward Bush, Mr. Chillingworth, Michael Drayton, the poet, and Dr. Donne; not to mention Cotton, who, conformably to the custom of the time, was honoured by the good old man with the title of son; and Cotton, to show his reverential attachment, most commonly alludes to him as "my father Walton." In short, he was in habits of friendly intercourse with those who were most celebrated for their piety and learning. Nor could he be deficient in urbanity of manners or elegance of taste, who was the companion of Sir Henry Wotton, the most accomplished gentleman of his age.

But our object is not to give an account of Walton's life, but a description of his book. We think it almost unequalled for display of personal character-the harmless 
and good-humoured jocularity of its author peeps out in every part of it. His trust in God, his goodwill to man, and a quiet conscience, made him ever ready for all innocent enjoyment. Indeed, his legitimate and cheerful piety forms a striking contrast with that of our modern puritans, who think they praise God by libeling his creation. On the contrary, honest Izaac thought he could not show his gratitude to the Master of the Feast, better than by partaking, in moderation, of the good things spread before him, with a thankful heart, "using the world as not abusing it;" to be merry and wise, this was his maxim.

He not only tells you how to catch a fish, but instructs you how to cook it when it is caught; and after having, with becoming seriousness and great particularity, let you into the "secret" of preparing for the table in the best manner, an overgrown Pike; and "how he is to be often basted with claret wine, and anchovies and butter, mixed together,"-it is rather laughable to read his conclusion. "This dish of meat is too good for any but anglers, or very honest men; and I trust you will prove both, and therefore have I trusted you with the secret."

As a pastoral writer, his descriptions of the milder features of Nature are excellent.-After retiring in an evening from the smoky, foggy atmosphere of our delectable town,-after being almost deafened with the din of carts, and wearied with them "whose talk is of cotton," and whose thoughts are about money-getting when they rise up, and when they lie down, and when they walk by the wayside,- - how delightful to leave these, and take up an author like Walton-to be transported into the scenes of our youth, to walk with him in meadows carpeted with flowers, amid the song of birds, the odours of Spring, and the murmurs of the pure waters; and to feel that there are exquisite enjoyments provided for " meek and contented" natures, though they may not be worth a hundred thousand pounds, and may be obliged to exercise their own limbs in the freedom 
of the open air, instead of being pent up in a close vehicle, and drawn along by two horses! But as this pleasing book is not so well known as it deserves to be, we intend to gratify such of our readers as have not seen it, with some extracts, and, at the same time, justify our own encomiums. As published in the last two editions, with the portraits and plates, it is in every sense of the word a very beautiful book, but too expensive to be within the reach of the majority of readers. Why cannot a work of such charming morality, equally aloof from irreligious licence and gloomy fanaticism, be printed in a cheaper form, and so made accessible to all? Our first quotation is a specimen of his pastoral descriptions :

"But turn out of the way a little, good scholar!" (it is written in the form of a dialogue) "towards yonder high honeysuckle-hedge, there we'll sit and sing, whilst this shower falls so gently upon the teeming earth, and gives yet a sweeter smell to the lovely flowers that adorn these verdant meadows.

"Look! under that broad beech tree, I sat down when I was last this way a fishing. And the birds in the adjoining grove seemed to have a friendly contention with an echo, whose dead voice seemed to live in a hollow tree near to the brow of that primrose hill. There I sat, viewing the silver streams glide silently towards their centre, the tempestuous sea; yet sometimes opposed by rugged roots and pebble stones, which broke their waves, and turned them into foam. And sometimes I beguiled the time by viewing the harmless lambs, some resting securely in the cool shade, whilst others sported themselves securely in the-cheerful sun-and saw others craving comfort from the swollen udders of their bleating dams. As thus I sat, these and other sights had so fully possest my soul with content, that I thought, as the poet has happily exprest it-

" ' I was for that time lifted above earth, And possest joys not promised at my birth.' 
"As I left this place, and entered into the next field, a second pleasure entertained me: 'twas a handsome milkmaid, that had not yet attained so much age and wisdom, as to load her mind with any fears of many things that will never be, as too many men too often do; but she cast away all care, and sung like a nightingale; her voice was good, and the ditty fitted for it: it was that smooth song made by Kit Marlow, now at least fifty years ago. And the milkmaid's mother sung an answer, which was made by Sir Walter Raleigh in his younger days. They were oldfashioned poetry, but choicely good; I think much better than the strong lines that are now in fashion in this critical age."-We would gladly have inserted them, but we must not trespass too much on the indulgence of our publisher, especially as we have other extracts. The next one is in praise of angling :-

"No life, my honest scholar! no life so happy and so pleasant as the life of a well-governed angler; for when the lawyer is swallowed up with business, and the statesman is preventing or contriving plots, then we sit on cowslipbanks, hear the birds sing, and possess ourselves in as much quietness as these silent silver streams which we now see glide so quietly by us. Indeed, my good scholar, we may say of angling, as Dr. Boteler said of strawberries, 'Doubtless, God could have made a better berry, but, doubtless, God never did;' and so, if I might be judge, God never did make a more calm, quiet, innocent recreation, than angling."

The next is in a more moralizing strain, but beautifully interspersed with allusions to natural objects:-

"But, master! first let me tell you that very hour you were absent from me, I sat down under a willow tree by the water-side; and considered what you had told me of the owner of that pleasant meadow, in which you then left me-that he had a plentiful estate, and not a heart to think so; that he had, at this time, many law- 
suits depending; and that they both damped his mirth and took up so much of his time and thoughts, that he himself had not leisure to take the sweet content, that I, who pretended no title to them, took in his fields; for I could there sit quietly, and, looking on the water, see some fishes sporting themselves in the silver streams, others leaping at flies of several shapes and colours; looking on the hills, I could behold them spotted with woods and groves; looking down the meadows, could see, here, a boy gathering lilies and lady-smocks, and there, a girl cropping culver-keys and cowslips, all to make garlands suitable to the present month of May; these and many other field flowers so perfumed the air, that I thought that very meadow, like that field in Sicily, of which Diodarno speaks, where the perfume arising from the place, made all dogs that hunt in it to fall off and to lose their hottest scent. I say, as I thus sat joying in my own happy condition, and pitying this poor rich man that owned this and many other pleasant groves about me, I did thankfully remember what my Saviour said, that the meek possess the earth, or rather they enjoy, what the others possess and enjoy not: for anglers and meek, quiet-spirited men are free from those high, those restless thoughts, which corrode the sweets of life, and they, and they only, can say, as the poet has happily exprest it:-

“ ‘ Hail, blest estate of lowliness!

Happy enjoyments! of such minds As rich in self-contentedness,

Can, like the reeds, in roughest winds, By yielding, make that blow but small, At which proud oaks and cedars fall.'”

We have sometimes thought of making the inordinate pursuit of wealth, the subject of one of these our weekly lucubrations, by which we endeavour to correct the taste, 
and improve the morals of our fellow-citizens of this provincial metropolis.

However new, startling, or paradoxical it may seem to our commercial readers, yet we believe there are, in all the various ways in which the human faculties can be exercised, nobler objects than the acquisition of wealth; and, moreover, we are of opinion, that there are greater blessings in the world, than even the possible of unbounded riches. Although we hope we could prove both these positions and opinions to the satisfaction of every rational mind, yet we think, at least for the present, rather than give our own reasons, however cogent, it will be more modest on a subject of such difficulty, to adduce respectable authorities, and these, thank Heaven, are numerous, both Christian and heathen. With the most weighty of the former, we have no doubt most of our readers are already acquainted. But, setting aside the sacred writers, we think there are few more engaging moralists than Walton; we shall, therefore, subjoin another and concluding extract, which more immediately relates to the subject just mentioned :-

"Well, scholar! having now taught you to paint your rod, and we having still a mile to Tottenham High Cross, I will, as we walk towards it in the cool shade of this sweet honeysuckle-hedge, mention to you some of the thoughts and joys that have possest my soul since we two met together. And these thoughts shall be told you, that you also may join with me in thankfulness to the Giver of every good and perfect gift, for our happiness. And that our present happiness may appear to be greater, and we the more thankful for it, I beg you to consider with me, how many do, even at this very time, lie under the torment of the stone, the gout, and toothache, and this we are free from. And every misery that I miss, is a new mercy; and therefore let us be thankful. There have been, since we met, others that have met with disasters of broken limbs; some have been blasted, others thunderstrucken. And we have been 
freed from these, and all those many other miseries which threaten human nature. Let us therefore rejoice, and be thankful. Nay, which is a far greater mercy, we are free from the unsupportable burthen of an accusing, tormenting conscience-a misery which none can bear. And therefore let us praise Him for his preventing grace, and say, every misery that I miss, is a new mercy. Nay, let me tell you, there be many that have forty times our estates, that would give the greatest part of theirs, to be healthful and cheerful, like us-who, with the expense of a little money, have eat, and drank, and laught, and angled, and sung, and slept securely; and rose next day, and cast away care, and sung, and laught, and angled again; which are blessings rich men cannot purchase with all their money.

"Let me tell you, scholar! I have a rich neighbour that is always so busy that he has no time to laugh. The whole business of his life is to get money, and more money; - that he may still get more and more money, he is still drudging on, and says that Solomon says, "The diligent hand maketh rich;' and it is true indeed; but he considers not that it is not in the power of riches to make a man happy; for it was wisely said by a man of great observation, "That there be as many miseries beyond riches, as on this side them.' And let God deliver us from pinching poverty, and grant that, having a competency, we may be content and thankful. Let us not repine, or so much as think the gifts of God unequally dealt, if we see another abound with riches; when, as God knows, the cares that are the keys that keep those riches, hang often so heavily at the rich man's girdle, that they clog him with weary days and restless nights, even when others sleep quietly. We see but the outside of the rich man's happiness. Few consider him to be like the silkworm, that when she seems but playing, is, at the very same time, spinning her own bowels, and consuming herself. And this many rich men do; loading themselves with corroding cares, to keep what they have probably unconsciously 
got. Let us, therefore, be thankful for health and a competence, and, above all, for a quiet conscience.

" $\mathrm{He}$ (the meek), and he only, possesses the earth as he goes towards that kingdom of heaven, by being humble and cheerful, and content with what his good God has given him. He has no turbulent, repining, vexatious thoughts that he deserves better, nor is vext when he sees others possest of more honour, or more riches than his wise God has allotted for his share; but he possesses what he has with a meek and contented quietness-such a quietness as makes his very dreams pleasing both to God and himself.

"Well, scholar! I have almost tired myself, and I fear more than almost tired you. But I now see Tottenham High Cross, and our short walk thither shall put a period to my too long discourse; in which my meaning was, and is, to plant that in your mind with which I labour to possess my own soul, that is a meek and thankful heart. And to that end I have showed you, that riches without them (meekness and thankfulness) do not make any man happy. But, let me tell you, that riches with them, remove many fears and cares, and therefore my advice is, that you endeavour to be honestly rich, or contentedly poor; but be sure that you justly get, or you spoil all; for it is well said by Caussin, 'he that loses his conscience, has nothing left that is worth keeping.' Therefore, be sure you look to that. And, in the next place, look to your health, and if you have it, praise God, and value it next to a good conscience; for health is the second blessing that we mortals are capable of - a blessing that money cannot buy-and therefore value it, and be thankful for it. As for money, which may said to be the third blessing, neglect it not; but note, there is no necessity for being rich, for I told you there be as many miscries beyond riches, as on this side them; and if you have a competence, enjoy it with a meek, checrful, thankful heart, which Almighty God grant to me 
and to my honest scholar! And so you are welcome to Tottenham High Cross."

But we must here leave them..

And now, in our admiration of the book, we trust we may calculate on the sympathy of all who have a feeling for the beauties of nature, and what is amiable and excellent in human character. We hope we need not be ashamed to confess, that in a pedestrian journey through a part of Derbyshire, which we made last Summer, in company with a friend of congenial sentiments-one of its principal objects was to visit Dove Dale, and Beresford Hall, once the residence of Cotton, the Poet, and the friend of Walton; and to see the remains of the little fishing-house erected by the former, on the banks of the Dove.

As it may, perhaps, be gratifying to the admirers of Cotton and Walton, to become acquainted with the present state of these places, we may, probably, in a future number, give an extract from that part of our journal relating to these interesting localities ; for, like other great travellers, we have written an account of our tour. We are aware, however, of the hostility of one of our learned colleagues to the whole tribe of tourists, and we are conscious we exhibit no little temerity, in thus hazarding a castigation from his satirical genius. But we trust he will regard this petit morceau, as a tub to the whale, and reserve his whole critical indignation till the appearance of our entire work-to be published in a splendid quarto, and adorned with numerous engravings, the price not less than five guineas!

M. N.

This delightful Essay proved an inspiring topic to Mr. Wordsworth, and suggested the Sonnet, "Written on a Blank-leaf of the "Complete Angler ;" a manuscript copy of which, the Poet presented to M.N. 
AN ACCOUNT OF A PEDESTRIAN TOUR THROUGH A PART OF DERBYSHIRE.

WE set out on Tuesday evening, 25th May, 1817, in order, as it were, to steal a march, and be able to start next morning on the very borders of Derbyshire. The weather had been fine in Manchester during the day, but a thick darkness in the sky, in the direction of Stockport, with two or three loud claps of thunder, between four and five o'clock, made it appear that heavy rain was falling in that quarter. Thunder packs, beautifully enlightened by the sun, were extended along the line of mountains beyond Ashton, tossed into fantastic shapes, but silent and stationary as the very hills they rested on. Although a late Spring, many of the trees being bare as in Winter, the oak with scarcely a leaf-yet the fields were green, and "refreshed the eye;" the birds were singing, and there was more mildness and summer-feeling in the air, than had been experienced for some weeks, so that we began our Journey under happy auspices. We intended to reach Mottram that evening, and went by Hooley Hill, as a much nearer way to it than through Staleybridge. When near Dukinfield Hall, and puzzled about the road, a good-natured man came to us and set us right. He told us that his home was eleven miles from Manchester; he had been at Salford Fair, where he had been " maundering up and down." "And are you not tired?" "No, not he; he reckoned nothing of a journey like that;" he had been a great traveller in his time; "he had been as far as Leeds and Hull, and down the Winyets to Castleton," at the Devil's _-, \&c. "W Well, and in all your journeys, were you never afraid of damp beds?" "No, not I; I knew how to manage that. If I thought the sheets were damp, I whipped 'em off and threw 
'em at top; one had th' same weight, you know." He lived just under the hill top, facing the West, above Dukinfield, in a house which, he said, had been inhabited by the farnily above two hundred years. In taking leave, he was particular in giving directions. There were two roads to Hayfield; the lower of which, through the valley, he advised us to take, though a mile further than the other, which went by Charlesworth over' the mountain. On this lower road were two public-houses; if we did not stay at Mottram, we might very likely be received at the "Gun," but, at any rate, they would take us in at Bedlam ! about a mile further. As we did not feel much desire either to run the risk of the Gun, or to take up our abode at Bedlam, we looked about us at Mottram for a lodging, where we found accommodation at the "Angel." While supper was getting ready, we chatted with our host, whose round face, fat cheeks, and little eyes, did not announce an overstock of intellect. An Englishman's first subject is generally the weather. Though the fertilizing showers had not to-day visited Mottram, our landlord was not without comfort; vegetation, he still thought, would be much promoted, as " the thunder had well shaken the ground." Next morning, started at five o'clock, passed over Broadbottom Bridge. We ascended the mountain through Charlesworth, a poor, naked, straggling village, in a high and bleak situation. We had a fine view on our left into Glossop dale, which is extensive, apparently two or three miles wide. The morning sun shining through the mist had a beautiful effect: the mist flying along the sides of the mountains in their long fragments, put us in mind of Ossian's Ghosts. After passing this dreary moor, about six miles from Mottram, we entered a beautiful valley lying on the right of the road, divided chiefly by stone walls, which in some places stretch high up the mountains. The houses are of stone, well built, and appear comfortable habitations. On rising the mountain beyond Hayfield, the sun shone out, and the 
clouds passing with rapidity, threw their shadows on the fields in the valley below us, which, following each other in quick succession, had a beautiful and novel effect, especially to iny companion, who was not accustomed to mountain scenery. Ardent lovers of Nature in her wildest retirements-at every turn, new and beautiful objects arrested our attention; we walked forward on this delightful morning, with vigorous steps; the Lark was our constant companion, cheering us overhead with his song-the fresh air of the mountains bathed our cheeks-there was freedom from care, and the feeling of liberty-

"When the fretful stir

Unprofitable, and the fever of the world

Hung not upon the beatings of our hearts."

We felt something of

"That blessed mood,

In which the burthen of the mystery,

In which the heavy and the weary weight

Of all this unintelligible world

Is lightened: that serene and blessed mood

In which the affections gently lead us on."

We went by the old road to Castleton from Chapel-leFrith, ascending the mountain to the East for a mile or more. 'The road is now neglected, and much worn by the rains. When we came to the village of Sparrow Pit, consisting of a few poor, unsheltered cottages, high on the moor, at the meeting of the old ard new roads from Chapel-le-Frith to Castleton, we inquired for the famous ebbing and flowing well. We were told it was about a mile down the brow, close to the side of the new road from Chapel-le-Frith, near a farm-house. We had gone perhaps two hundred yards towards Castleton, before we determined to turm back and see it, judging from the usual exaggeration in these cases, and from its acknowledged irregularity in ebbing and 
flowing, that there was some hazard whether the sight of it would repay us for our trouble. On going down the hill, we overtook a young country girl, with a sweet English countenance. We inquired for the well: she pointed it out at some distance, but added, with an arch smile, we might probably wait half an hour and not see it flow, as it was very uncertain. She spoke in a delightful tone of voice, -the uncultivated gift of nature. It is a tone not to be described, but was certainly possessed in no small perfection by this pretty mountain maid. It is the sweetest of all music. Its magic is perhaps most powerfully felt, the least able to be resisted, in early life ; but its power is never lost on the feeling heart, at any age. Our fair charmer left us rather suddenly, and tripped up a footpath to the left, leaving us to pursue our journey to the well. We found it near a large ash tree, with a farm-house about one hundred yards above it. We saw an irregularly shaped pond, such as cattle drink at, five or six yards broad, and from one to two feet deep. It seemed quite stationary when we came up, but in looking more closely, we gladly perceived that a stone, that lay near what appeared to be the spring, was yet wet, as if recently covered with water. My.companion placed a leaf on the stone close to the water, and we found that in a short time, the water had left it two or three inches, and consequently that the well was ebbing. A little after, we perceived a slight motion of the grass on the surface; but what was our joy, when we saw the water boil up in considerable quantity from the clefts in the rock, and in one place run as from a drain, soon filling the basin, and running out on the side nearest the road, over a stone placed edge-wise, to the height of four or five inches, into a channel made for it, about a foot and a half in width. It flowed four minutes, and then began to ebb; the water in the basin certainly appeared to decrease more rapidly than could be accounted for, by its visible discharge through the ditch under the road. We then proceeded, highly gratified 
with having witnessed this singular phenomenon, and leaving wiser heads to explain its cause.

"Contented, if we might enjoy

The things that others understand."

About a mile beyond Sparrow Pit, we passed a few houses called Perry-foot; and ascended a mountain about half a mile to the right, on which there appeared a small eminence, as of loose stones thrown together, Eldon Hole being about two hundred yards on the other side of it. On reaching this place, we saw immediately below us, a circular enclosure, as of a sheepfold. This was the terrific Eldon Hole. On looking over a part of the wall on the North side, which had fallen, we saw a tremendous chasm in the limestone mountain, of from thirty to forty yards in length, and ten or twelve in breadth. We threw in several stones, which, passing from one rock to another, or from the sides of the cavern, continued to fall for several seconds, sending forth a hollow sound, as it were, from the heart of the mountain. It extends longitudinally from East to West. At the western end there is a gate, the key of which is kept at a farm-house in the neighbourhood. We passed with some caution along the narrow space betwixt the wall and the cavern, to that end of it near the door, when we perceived that lower down, the hole grows narrower, the extremities, in particular, approaching nearer to each other. We had not expected to find this terrible abyss had inhabitants, but our approach disturbed a number of Jackdaws, that flew out by twos and threes. Had we lived a few centuries ago, and not in this " unimaginative age," it is possible we might have believed this chasm to be one of the portals of Erebus, and these birds to be demons, issuing out on errands of mischief to mankind. Water appears here to be scarce, if we may judge from some reservoirs paved with stone, and formed in the hollows, for the reception of rain-water, to supply the herds and flocks. On crossing the hills, we observed some 
circular holes, twenty or thirty yards in diameter, and about half as many in depth, as if the strata on the surface had sunk on some cavern beneath. We took a north-east direction from Eldon Hole, expeciing to meet with the road to Castleton at no great distance; but after walking for some time, the clouds lowering, and the mist rolling along the heights not far from us, we became rather uneasy, suspecting we were in a wrong direction. At length, we were glad to meet with a large farm-house, in a lonely situation, which seems to have been felt by its inhabitants; for the house is surrounded by a wall at least three yards in height, with a lofty gate into the yard, which we observed was capable of being well secured. A young woman, with a complexion made fresh by the mountain air, showed us the way down a cart-track, to the main road, which we reached in a short time. On looking behind, on that part of the mountain we had just crossed, we observed it to be completely covered with mist. If we had been delayed ten minutes, we might have found it both difficult and dangerous to have found our way. This part of the Peak is not so "barren and disgusting" as it has been described. Consisting of limestone near the surface, these mountains bear a short but sweet grass, very suitable for sheep-pasture, and have a very green appearance. It was not without an emotion of pleasure, that we met with one of our garden flowers growing here wild, beautifying these hills for miles-thick on the ground as daisies! Heartsease, or Pansy (from the French, pensée, a thought), the favourite of the poets, and it would seem the general favourite, from the many endearing names that have been conferred upon it; such as, "Jump-up-and-kiss-me," "Heartsease," \&c. Shakespeare alludes to it in some beautiful lines in the "Midsummer Night's Dream," in which he calls it "Love in idleness."

Soon after we reached the road to Castleton, we came to where a new one has been made, which goes to the left, passing close by the base of Mam Tor. We took the old 
road, and went down a steep and long declivity, called the Winnets, or Windgates. And never could name be more appropriate; for the road running between high mountains that rise abruptly on each side, the wind as it comes from below, being here compressed, meets one with great force, and was, even at this season, extremely cold. "Dark, rugged, and naked precipices heave their unwieldy forms on each side of the road, and frequently presenting themselves in front, threaten opposition to all further progress." The descent is about a mile, which brought us to the town or village of Castleton, a small place, which derives its support from the mines, and from the money spent in it by visitors who come to see the "curiosities," as they are called, in its neighbourhood. On entering the place, we looked out for a house where we might probably procure substantial fare, at a reasonable rate (we had heard tales of the exorbitant charges at Castleton). We were directed to a decent-looking house, a little beyond the stream from Peak's Hole. We inquired of our hostess, "what she could get us to eat." "She had nothing but bacon and eggs." " Nothing better," we rejoined. "Your Derbyshire bacon is excellent; let us have it as soon as possible." Really, it may seem somewhat vulgar, and beneath the dignity of a sentimental tourist, to touch on such common affairs as eating and drinking. We can assure that friend, however, who may do us the honour to peruse "this notable history," that though as great admirers of the picturesque as even Dr. Syntax himself, there was no view we had seen to-day more attractive than the prospect which the table of our old hostess afforded, set out with its homely appendages, and with a quart of excellent home-brewed. But it will need few words to convince him of this, if he have ever been a pedestrian himself, journeying among the mountains dinnerless, as we had been, till near four o'clock. Of course, we went to see Peak's Cave and the Castle; but as our survey was very rapid, we shall despatch them with few words. The mouth of the Cave is 
said to be a hundred and twenty feet wide, and forty-two in height; there is a distance of ninety feet, when a door interdicts all further passage, without the assistance of a guide. This awful and sublime entrance is sadly disfigured by some miserable-looking beings, who have converted this magnificent Hall of Nature into a shop for twisting packthread! Some of them actually live in it, having built their poor hovels just at the entrance. To judge from their thin and sickly looks, their abode in the cavern, with its damp and want of sunshine, must be as unfriendly to their own health, as it is disagreeable to all visitors of true taste. The usurpation of which we thought them guilty, did not put us in the best humour to listen to the appeals for charity with which we were assailed. One of the most pressing of the applicants was a young woman, who, under better circumstances, might have looked beautiful, having regular features, and, as far as we could judge, a good complexion, but which would have received manifest improvement from a due application of the clear water that runs from the cave. As it was, she was certainly no angel-we may call her, "6 the swart fairy of the mine." The Castle must have been impregnable before the invention of gunpowder, as there is no approaching it but from the North, and that by a steep ascent from the village. Some parts of the wall are yet in tolerable preservation. A square tower (probably the keep) stands almost entire on the West side of the area, overlooking the tremendous entrance of Peak's Hole, which is a great way below. The wind was blowing strong, but we ventured to look out on the rugged brow of the rock, which impends, it is said, two hundred and forty feet over the mouth of the cavern. We saw Hawks and Jackdaws seeking their nests, which they build securely in holes on the face of the precipice. The walls of the keep are three yards in thickness; the facing, of grit stone. They had not swerved a hairbreadth from the perpendicular, and in general, to our unantiquarian eyes, the Castle had a more modern appear- 
ance than we could have thought, from its known antiquity. It is mentioned in Domesday Book, and is of Norman origin at least, if not older.

It was five o'clock when we set forward to Hathersage, six or seven miles distant down the valley to the East, and as it rained nearly the whole of our walk, we saw this beautiful vale to great disadvantage. It is from one to two miles in breadth; its sides, in some places, covered with wood, in others, affording sweet views into other dales; but its peculiar beauty is, that its fields are generally divided by hedgerows - " hardly hedgerows, little lines of sportive wood run wild;" and these, indeed, are a rarity in this county, judging from what we have seen. About two miles from Castleton, we passed through the village of Hope. It has a church, with a spire steeple. Contemptible as the spire appears when contrasted with mountains for its neighbours, it is a piece of bad taste which seems not to have struck the architects here, as we met with more of them in other parts of this mountainous district.

A little trout-stream, the same that issues from Peak's Cavern, was our companion down the valley, never leaving the road far, either to the right or left, till it is absorbed by the Derwent, coming from the mountains on the left, but which here bears the name of Bamford, as we were told, on crossing the bridge.

After walking in the rain two hours, we at length reached Hathersage, snugly seated in a mountain hollow on the North side of the valley-the hollow forms a steep descent to the Derwent. Having been recommended to the George Inn, we were glad it was the first we came to on entering the place. We found one side of a blazing fire already occupied by three pedestrians, stripped of their coats and stockings, which were hung up near them to dry; we entered in better plight, having been protected from the rain by our umbrellas. Two of them were shoemakers, 
we understood; and the third, a tall young man, a farmer's son, whom they had persuaded to accompany them. He seemed much fatigued-leaned his head on his hand, just looking up now and then to inquire if his bed was ready: in short, he appeared "quite knocked up." He had strained his ankle just above the instep.

Our landlord might be between sixty and seventy years of age, with thin features and serious aspect-a man of few words and simple manners. It appeared he kept sheep on the mountains, for we noticed, in the house, a shepherd's dog of the genuine breed. Having observed the deplorable condition of the young pedestrian in silence, he rose from his seat, and without words of condolence, or making any parade of his humanity, walked to a distant part of the room, and said, gravely, "Walk this way, young man." $\mathrm{He}$ obeyed silently, put down his stocking, while the old man applied some of the contents of a bottle to his leg, which, we understood, was considerably better next morning, when he and his comrades set out on their journey.

We ought not to forget, as one of the worthy family of the George, the daughter of our venerable host. She was graceful and modest in her behaviour, and appeared to have a good understanding. We had a small tract, descriptive of her native county. She had the curiosity to look at it, and peruse it for some time to herself; but coming to a passage respecting the foundation of Depedale Priory, she read it to us aloud, with "good emphasis and discretion." In short, she seemed to possess a mind capable of being delighted with literature; and we could not help regretting not having it in our power to supply her with a pleasure, which, from the scarcity of books in this retired situation, she may probably experience to but a very limited extent.

We rose next morning (Thursday) at five o'clock, and went to see the grave of Little John (the companion of Robin Hood), who, according to tradition, was buried in the churchyard of this place. We found two rude stones, 
just rising above the surface, with many modern gravestones not far from them. The distance between these stones was something more than four yards; and this was the length of Little John, as one was placed at his head, and the other at his feet! On leaving the churchyard, we met a man who said, "What, you have been to see his grave!" "Yes, and a famous size it is." He told us that some years ago, the ground was dug to some depth between the stones, when the skeleton of a man was found, the thigh bone of which was thirty-one inches and a half in length! These bones were placed in the custody of Colonel Shuttleworth, of the Hall, adjoining the church; but finding that so long as he had them in his possession, none of his affairs prospered, or, as the man expressed it, "he had no luck," he was glad to consign again to the earth, these illustrious remnants of mortality. Another account we heard was, that Colonel S. being in Scotland, on some military business, met with somebody who was sceptical as to their size, when he ordered them to be packed up and sent to him, which was done; but what had since become of them he did not know, they had never been returned. One person told us the thigh bone was thirty-six inches!

There are many who would think these tales not worth repeating; but they are curious, at least, as showing the prevailing belief that men were once much larger than at present; a belief not so absurd, whether we consider the enervating effect of luxurious indulgence; or the evidences of the fact, which are said to exist, some of which appear to be well authenticated. For our part, we were struck, on the first day of our journey, with the tallness of the women near Hayfield, so different from our fair ones in Manchester, whether reared in the hot-bed of rich houses, or stunted by the pestiferous atmosphere of a factory.

Soon after leaving Hathersage for Chatsworth, we crossed the Derwent over a stone bridge of three arches. There was a wind blowing about us, and a sky overhead, both of 
which would have been perfectly seasonable in December, yet the fields were green on every side, and the lane ran between quickthorn hedges, so that in this beautiful vale every aspect was not wintry. The scenery now assumed a new character. We entered a wood, which covered the mountain to a great height on our right, chiefly consisting of oaks, still leafless, with a few larches in their earliest and freshest green, and here and there a birch, graceful and light-leaved. On our left was the Derwent, at seldom more than one hundred yards distance, its banks fringed with bushes and trees. It had that quantity of water from the late rains, the sight of which rejoices the heart of an anglerflowing gently, yet active and murmuring, somewhat between the noisy turbulence of the young mountain stream rioting among rocks, aud the silent, sluggish, mature-aged river of the plains. On the other side of the Derwent were corn and grass fields, woods, and farm-houses, while, beyond all, rose the mountains, barren and craggy, dark and precipitous. This fine wood extends for perhaps two miles, with the river still on the left.

While in the lane, a little beyond Grindleford Bridge, we heard a shout from behind, and, on looking round, saw $\mathrm{Mr}$. A., from Manchester, with his fishing-rod. After a cordial shake of the hand-a little more so than if we had met in our smoky town-my friend and I agreed to step a little out of our way to see him commence his angling operations. However, he had scarcely wet his flies, before a man, in a fustian dress, came posting down the lane, and inquired if he had asked leave to fish. " $\mathrm{No,"} \mathrm{said} \mathrm{Mr.} \mathrm{A.,} \mathrm{"I} \mathrm{under-}$ stood the river to be free; but if it be not, I shall give over." He said this with a very quiet and resigned tone, considering that he had come more than forty miles on purpose to angle; but his lips quivered with agitation. The man then told him that he need not lay by his rod, it would be a pity to hinder him, after coming so far. He was gamekeeper to the Duke of Rutland, who owned the left 
bank of the river. Some cotton spinner, who lived at Stoke, a large house near the bridge, laid claim to the right. The coldness of the day was very unfavourable for angling, and I fear Mr. A. would not reap much advantage from the permission.

We did not reach Baslow till near ten o'clock, when we breakfasted on coffee and eggs. We were in excellent condition to do justice to a good breakfast, having walked more than eight miles. The house we were at is near the bridge, and is kept by good-natured people, who did all they could to oblige us. Some fear having arisen that there would not be a sufficient supply of eggs, the landlord-a fine, tall, but rather corpulent man-said he'd rob every hen-roost in the place ere we should fall short! We here heard more news of Little John. Our host informed us, there were two rocks in the neighbourhood, that went by the name of Little John's stride-they are twenty yards asunder, yet he is said to have stepped from one to the other when his enemies were in pursuit of him. We said we were willing to yield all due credence to tales of the feats of heroes, but when it came to strides of twenty or thirty yards, it was certainly going a good step-it rather staggered one. "Yes, but," said our landlord, with quite a grave face, "consider the size of the man!"

We asked the landlady, apparently a sensible old woman, how many bells belonged to the Church, which stood close by. She said she did not know whether there were four, or five, though she had lived in the village all her life !

From hence to Chatsworth, a well-known seat of the Duke of Devonshire. We shall attempt a slight sketch of what we saw in this magnificent house. The great Hall, which we first entered, contains-painted on the walla representation of a heathen sacrifice, by Verrio; and the "Assassination of Julius Casar." On ascending a grand staircase, we entered the gallery of the Chapel. The altar, behind the pulpit, and facing the gallery, is of variegated 
marble; on the left, a painting of "Christ Reproving the Incredulity of Thomas;" on the right of the pulpit, "Christ taken from the Cross." A fine female figure had so much the appearance of reality-started so much from the canvas-as, at least, to look more like a statue than a picture, from where we stood. Statues of Faith and Justice stand on each side of the pulpit, with Hope and Charity on the left of the Chapel. On the ceiling, the Ascension; Christ supported and surrounded by groups of Angels; these painted by Verrio. The gallery during Divine service is occupied by the Duke, visitors, and family; the servants fill the area below, which was furnished with cushions for kneeling, and chairs of an antiquated appearance.

The communion gallery has its walls hung with numerous sketches or outlines, by the great masters-Carracci, Claude Lorraine, Rembrandt, \&c. All the rooms have painted ceilings, the subjects, in general, from the mythology of Greece and Rome, consisting of groups of heathen deities, \&c. "The Fall of Phæton," was particularly impressivethe chariot and horses falling topsy-turvy-the affrighted look of Phæton himself. By the way, it seems a subject peculiarly suitable to its situation. Among the family portraits, we recollect one of the first Duke of Devonshire, and the long-armed Duke, whose right arm was of such a length as to allow him to place the palm of his hand on the cup of his knee, standing upright. Also a portrait of the late celebrated Duchess, in a playful attitude, with her first child, an infant, the present Lady Morpeth-by Sir Joshua Reynolds. Portraits of Henry VIII., and a young Cavendish killed in the civil wars of Charles I.; two Earls of Pembroke, and several others. Of paintings by celebrated masters, we may particularlymention, "The Sleeping Shepherd;" "The Rape of the Sabines;" "6"Andromache chained to the Rock, Perseus coming to her Rescue"-the figure, attitude, and expression of Andromache, very striking; "Michael and the Fallen Angel," by Raphael; 
"Christ and Mary Magdalen," by Titian ; two pictures of "The Rape of Proserpine," by Rubens-one of them remarkable for powerful expression, is an exquisite picture; there is great beauty in the limbs of Proserpine.

Among the busts, we remember a small, but beautiful one of Napoleon, placed over the chimney-piece in the music room. But the most remarkable was one of C. J. Fox, occupying a situation in the library, with the late Duke of Devonshire on his right, and the Duke of Bedford on his left.

In the new library, lately finished, we noticed a first edition of Shakespeare's Plays, in folio, 1623; another, 1632 -both containing fine portraits of the inimitable bard. The books were chiefly of the folio and quarto size, some of the latter the largest we had ever seen. There were a great number of large and splendid copies of the Bible, in different languages, and of various dates.

We now came to the state rooms; in one of them is the bed in which George II. slept, when at Chatsworth; in another, the one in which he died. The latter is of rather plain appearance; and was claimed by the then Duke, in virtue of his office, he being at the time Lord Chamberlain.

The suite of rooms called "Mary Queen of Scots'," is said to correspond in situation, and to be of the same dimensions, with those inhabited by that beautiful and farfamed Princess, when a prisoner in the old house, at Chatsworth. Thirteen years of her long captivity were passed here; and from this place she wrote her second letter to Pope Pius, bearing date 31st Oct., 1570. We were shown the bed in which Mary slept; the hangings are of crimson velvet, bordered with gold fringe. It has a splendid appearance, though the coverlet is rent in several places, probably from age. Two antiquated chairs, one on each side of the bed, are said to have been used by the unfortumate Queen. My friend, who is somewhat of an enthu- 
siast about Mary, and a believer in her innocence, approached the bed, and, with a serious, if not reverential air, touched the hangings and coverlet. His reflections, if expressed, might have graced our tour-but what they were can only be guessed at; for, on some account or other, while in these rooms, he was more silent than usual. It is a strong proof of the general sympathy felt for this Princess, that both here, and at Hardwick Hall (another seat of the Duke's), where she was imprisoned, the rooms she occupied, the bed on which she slept, the very furniture even, as chairs, \&c., are shown to visitors, as kept in the same state as during her imprisonment, though 250 years have passed away since that event.

We ought to have mentioned that, in the state rooms, we saw the two chairs used at the coronation of the present King and Queen. In one room there is a complete collection of Derbyshire minerals, and two specimens of chain armour. On leaving the room where we saw these, we were particularly struck with a figure of Jean Jaques Rousseau. He is represented as advanced in years, wearing a wig, and a plain single-breasted coat, his left arm a little extended, holding a scroll of paper, folded so as to resemble a book. The figure is so like the portrait in a recent edition of his works, printed by Didot, that I knew him in a moment. Independent of this, from the mere circumstance of its being possessed by this distinguished family, we can hardly doubt its being a correct likeness. In looking at this extraordinary man, one is struck with the pitiable fate of men of genius. Frequently neglected or persecuted while living-idolized when dead! Poor Jean Jacques! When fleeing from the world, in which he was never happy, he sought an asylum with nature-the love of which never forsook him-persecution still found him out, drove him from one resting-place to another, and, acting on a sensibility, the characteristic of genius-its blessing and misfortune-finally drove him to madness! 
Thou passedest thy life in poverty and reproach, and now thy deathless page draws tears from beautiful eyes, and they place thine image in noblemen's palaces!

As to the situation of this noble house; it is sheltered by a tall wood behind it to the East, stands in the midst of a park five or six miles in extent, in the richest part of this rich valley; rising now and then into gentle elevations, ornamented with magnificent trees, and enlivened by herds of deer; the Derwent flowing through its whole length, and passing a short distance before the house to the West.

Two or three miles South of Chatsworth,we passed through the village of Buley; it has a neat Church with a spire; several of the houses were surrounded with little orchards, the fruit trees then in bloom. These are somewhat of a rarity, which is the more to be regretted, as, both from soil and situation, there is no doubt the apple tree might be cultivated to advantage in these beautiful vales. Here was a little Trout stream coming from the mountains to join the Derwent. The country people are left free to fish in these brooks. The next place worthy of notice on our road to Matlock, is Darley. The churchyard is full of gravestones, some of which are old-of the 16 th century. We remarked two or three in the time of the civil wars, 1642 , and upwards. The most remarkable object here is a yew tree, growing in the midst of the churchyard, with a trunk of larger circumference than any we had ever seen. My fellow-traveller measured it to be thirty-five feet and a half.

Nothing remarkable till we reach Matlock. To view its scenery, we leave the village on the left, and cross the bridge on our way to the baths. Far-famed and beautiful as it is, we could not have seen it to more disadvantage. A cold and strong North wind blew."down the valley, with a sky overcast and gloomy; it was, in short, the coldest and most wintry day we ever remember at the season. It was five o'clock; we were somewhat fatigued, and in want of refreshment; but we knew if we were once comfortably 
seated, we should be in no humour to stir again that evening; so, to save time, we walked to Cromford, and viewed the romantic cliffs, under all these drawbacks to enjoyment. It has been said their beauties cannot be described in words; it would, therefore, be presumptive to attempt it. We will merely say that in descending from the North, the baths on the right side of the river, with a number of neat and elegant lodging-houses, are fronted on the opposite side, at a short distance, by wood and rocky steeps, ascending to a great height. These cliffs extend for more than a mile, rising abruptly from the river-in some places exhibiting large masses of naked rock, but, in general, intermingled rocks and wood; the trees, tall and luxuriant, springing from clefts and crevices inaccessible to the woodman's axe. Add to this, the views are changed almost at every step, from the winding course of the Derwent, in some places settling in smooth pools, in others, roaring and tumbling among ledges and rocky fragments that have fallen into its bed. In one place, midway up the cliff, we were shown the mouth of a cavern, into which schoolboys, who come a bird-nesting in the wood, will sometimes enter, and passing through it, and under a great part of the mountain, emerge into daylight on the other side.

Willersley, the seat of Richard Arkwright, Esq., is situated at the south entrance to this delightful scenery, just above the village of Cromford. The grounds are beautiful, but we saw them only at a distance. The river appears at Matlock to be free to the angler, as we met with several boys engaged in that solitary sport-some of them having just left their work. One lad had caught a Grayling, weighing more than a pound: it was the first we had seen; we wished to purchase it, but found we were anticipated by some epicure who had already bespoken it.

We rose next morning at five; it was rather cool, but indicated a day less cloudy and more seasonable than the 
preceding. On our return in the direction of Rousley, we met two women going a milking: one of them had a large excrescence on her neck, under the chin, at least the size of an egg, which appeared between the folds of her handkerchief. We supposed this to be what is called the Derbyshire neck (the Swiss Goître)-a deformity, we understand, rather common near Matlock. We breakfasted at Rousley, a little village seated at the confluence of the Derwent and the Wye-a good station for the angler. We were told that Barbel were in such quantities in the spawning season, on the sandbanks near, as sometimes to have been seen in numbers equal to cartloads-several tons weight! We travelled along the banks of the Wye towards Haddon Hall. It was now more mild and sunny, and to look on this beautiful vale, one might have thought the world a paradise, in which misfortune and poverty, pain and sickness, could have no existence. Meeting with a woman on the road, we inquired the way to Haddon Hall, after directing us, she told us, with some hesitation, that she had been to Bakewell to see her daughter, who was lying on her deathbed; that she was a poor widow, who had come all the way from Chesterfield, where she lived, and whither she was returning, with little or no money to provide her with anything on the road. She said she had mentioned this to a gentleman on horseback, whom she had just met, who paid no attention to her tale, "people were so hard-hearted now a days." She shed tears, and appeared much affected. There was no resisting an appeal like this. She was decently dressed, somewhat thin-from poverty, perhaps, more than age; but had neither the manner nor appearance of a common beggar. A little further we crossed the Wye to the right, and procured a guide, at a cottage, to show us through Haddon Hall, a venerable mansion of the Duke of Rutland, and the principal residence of the family, till the beginning of the last century, when it was quitted for Belvoir Castle. Haddon 
Hall is said to be the most perfect of the ancient baronial residences; but we can only give a slight and imperfect description of it.

On the right of the entrance, we were shown some old boots, which reach to the middle of the thigh, have square toes, and heels three inches thick. The Chapel is of Henry the Sixth's time, although the roof has the date 1624. Here are some windows of painted glass; on the left of the communion, the Virgin and St. Ann, St. George and the Dragon, the Archangel Michael, the Crucifixion, and the Twelve Apostles; but some years ago the heads of the latter were stolen; the spaces are now filled up with common glass. There is a date in the window-Millessimo, ccccxxvii. On the left of the entrance into the Hall, there is an ancient Roman altar, which was dug up near Bakewell; it is about four feet high and eighteen inches in thickness, swells out a little at each end, and has an inscription, several of the letters of which are very legible. The Hall is a rude, uncomfortable looking place, with a stone floor. On one side is the table where the Baron and his family dined; in another part, there is one for the servants. Picture over the fire-place-Man and Horse-large as life; Game, \&c.; a portrait of Martin Middleton, aged 87, a tenant in the Peak of the Duke of Rutland's; date 1811. The rafters in the Hall are visible overhead. In the old drawing-room, Henry VII. and Queen, carved in wood, in the wainscot; very expressive. In the gallery of the Hall, there is a fine picture of the diversion of Hawking; another of Boar-hunting. On the left of the passage, at the head of the great staircase, are five or six very large semi-circular steps, framed of solid timber, leading into the long gallery, which is 110 feet in length, and 17 wide. The flooring is of oak planks, affirmed by tradition, to have been cut out of a single tree, that grew in the garden; the steps were framed of its root. There is a fine painting of the Head of Cyrus presented to Queen Tamyris 
of Scythia, over the fire-place-with numerous figures, the heads expressive of various emotion. There is a date, in glass-1589. In the dressing-room: portrait of Queen Elizabeth, and one of Charles I., on horseback, bareheaded. In the state bed-chamber: a bed, with hangings of green and crimson velvet. In a room over the long gallery, over the fire-place, is a large bas-relief of Orpheus charming the Beasts. The kitchen has an immense fire-place, with irons for a prodigious number of spits, ranges of dressers, and an enormous chopping-block, made of the root of a large oak. Dressers, consisting of thick blocks, with deep holes for mincing meat-one of the holes just worn through. In the larder, large troughs for salting meat. In a word, this ancient mansion contains two extensive courts within its walls, is of considerable extent, and, in general, in a state of such good preservation (being well covered with lead) as to convey a very vivid impression of the domestic comforts, and the hospitable mode of living, of an old English Baron.

On leaving Haddon, we passed through Bakewell. Here are some large cotton works belonging to Arkwright. When near Ashford, two or three miles farther up the Wye, we met with an angler, a gentleman from Doncaster, who had caught a Trout, more than a pound weight, with the worm. He was now trying the minnow, but without success. He had a man with him carrying a net, as most of the gentleman anglers have in this country, but whether for use or ostentation, we could not exactly determine. Whitehead, the best fisher, perhaps, among them, had none.

We were on our way to see the beauties of Monsall Dale and Miller's Dale, and suspecting we were near the former, we inquired the road of a man we met, trundling a wheelbarrow, in the village of $A$ shford. He was very minute in his directions, and seemed to be more than commonly intelligent, entering into the objects of our journey, as we fur- 
ther unfolded them, with a great deal of interest. $\mathrm{He}$ pointed out to us the road to Dove Dale. And in speaking of Monsall Dale, he said, in rather a careless manner, that he had a book which he sold, a description of it in verse, written by a native of Ashford. Being somewhat nice in our poetical taste, and, moreover, aware of the quantity of rubbish constantly issuing from the press-though prejudiced in this instance, perhaps, to our loss-we declined taking the hint, but inquired the name of the author, and his profession. To these questions he returned no answer. From some persons we met with soon after, we learnt that we had been conversing with the poet himself. Poetry was a weakness that, "for my single self," I did not suspect him of; or, perhaps, notwithstanding his hurry, we should not have parted with him so soon as we did.

We presently entered the lower part of Monsall Dale. The vale is here quite secluded - not a house to be seen; narrow, with a single field here and there skirting the Wye, above which rise elevated lands, on each side, with a gentle slope, and smooth, unbroken surface; covered with wood, in some places nearly to the top; in others, the wood only fringes the banks of the stream, which flows in a crooked, or rather zig-zag course; the mountainous banks receding at every turn, while those at the opposite side advance as much, so as to leave the dale of the same breadth, and producing an agreeable diversity of view through the whole of its winding course. Monsall Dale has a character completely its own; it has neither the wide, fruitful interchange of grass and corn-fields, woods and hedgerows, of Chatsworth vale; nor the wooded and rocky steeps of Matlock; nor the rugged and grotesque appearance of Dove Dale. Our poet of Ashford described it in two words : its character, said he, is "tranquil beauty." We here met with two more anglers, Mr. Hindley, and Mr. Thomas Hardman, of Manchester. How it would have rejoiced the spirit of good old Izaac Walton, to find 
there were men, and rich men too, who could renounce the parade and noise of a race-course, its vulgar and vicious amusements, to seek an asylum with Nature in this retired valley, with its eternal murmur of water, the chirping of insects, the hum of bees, the unbought song of birds, free as the air they fly in-its little green fields, silent hills, and the clear blue sky above all:

"Beauty, and light, and joy are every where.

There is no sadness and no sorrow here."

We saw some men cutting wood; they were old, yet ruddy. How strange, rosy cheeks and grey hairs! We pursued our journey up the Dale for, perhaps, two miles before we came to a house. There was a sheepfold near it, close to the river, in which stood a man, washing sheep, while the old shepherd, a plain worthy-looking man, superintended three or four lads, busy, active, and proud of exerting their strength in dragging the sheep to the water. Two of them were stationed as guards at an entrance, where we stood looking at them for some time. When we came up, they deserted their post, in order to assist the others, and, perhaps, display their prowess, for which desertion they were rebuked by the shepherd. The barking of dogs, bleating of sheep, laughing and shouting of the boys, made altogether a singular medley-novel, and peculiarly gratifying to my fellow-traveller. For my part, it brought to my remembrance innocent and happy days, for ever gone, in which I had myself been an actor in similar scenes. Having inquired the way to Miller Dale, a lad, who was at the sheep-washing, was sent after us; he was going some errand in that direction, and offered to be our guide. There are two or three houses in this part of the Dale; at one of them, being thirsty, we asked for butter-milk. A beautiful young woman blushed "celestial rosy red," and told us they had none. The milk is here generally made into cheese. 
We pursued our way along a track on the barren, shivery side of the limestone mountain; the Wye gliding below us to the left, skirted by two or three narrow green meadows, lying between the river and the mountainous bank rising on the other side of it. We here found, very unexpectedly, a large cotton factory, well built of stone. Our guide told us it belonged to Mr. Philips, of Manchester, who had the work done chiefly by apprentices-childrenorphans, perhaps, who are brought hither from London and other distant places. They sleep in an adjoining house provided by Mr. Philips. They are well provided with meat and drink, according to the boy's account. "Should you like to be one of them?" "No; I had rather be as I am."

The lad was apparently the son of a poor man (his brother being the sheep-washer), and, most likely, obliged to work hard; but it was in the open air, and there were variety and pleasure in it, and times of play not unfrequent. He told us, with great glee, of his going with other boys to get "Jack-a-daws' nesses" (nests), $i^{n}$ some rocks overhanging the precipice, holding by the shrubs that here and there shoot from the fissures of the rocks, pulling out the nests from the holes; though, if they were to lose their footing, they would be precipitated forty or fifty yards, and dashed lifeless on the stoney bed of the river that roars below. As we approached Miller Dale, the valley becomes more narrow and rugged. Passed under an immense rock, rising abruptly on the right, and overhanging in one part, so as to afford shelter, where there is no other, to the shepherd or solitary angler who may be overtaken by a storm. We met here with more of these "honest anglers," and, among the rest, old Whitehead, far-famed for his skill in the art. He was wading, as they nearly all do, and had caught more fish than any of his "brothers." This was near a small public-house in the narrow dell, kept by the miller, for which we had hungered and 
thirsted: it was near four o'clock, and we had not dined! While dinner was getting ready, we talked with the landlord. We found we were acquainted with some of his relations near Manchester, and we were to carry tidings that old Dakin, the miller of Miller Dale, was yet alive and hearty. After a dinner of ham and eggs, with home-brewed ale, we found ourselves in much better condition for pursuing our journey. Indeed, during this tour, we often found the truth of the old adage, "that a good appetite is the best sauce," which brings the poor more nearly on a footing with the rich (in that respect) than either of them imagine.

We still kept in the dell by the side of the stream, in a footpath which led through a wood, to a more open space of ground, which brought us to a romantic and deep hollow, where the Wye flows beneath a stupendous mass of rock, called Chee Tor, which rises perpendicularly-it is said, to the height of nearly 400 feet. The channel of the river is here confined between vast cliffs of limestone, which seem, from their corresponding form, to have been once united. In some parts they are covered with brushwood-chiefly hazel and mountain ash; in others, they are totally naked, precipitous and impending. The chasm runs in a direction so nearly circular, that the sublime Chee Tor and its dependant masses of rock, are almost insulated by the river that washes their foot. Its length is about five or six hundred yards.

We returned nearly to the wood we had passed through, and crossed the stream over a wooden bridge, and ascending the other side, we found that the country extended for miles almost on a level with the summits of the mountainous banks that enclose and hide this beautiful river. Calling at a large farm-house, to inquire the way to Monyash, we requested a drink of milk. The farmer, a respectable looking man, said we were very welcome to a draught of ale, and bread and cheese. We thanked him, and said that, not two hours ago, nothing could have been more acceptable than 
his hospitable offer, but that since we had seen the good landlady at Miller Dale, we had not the least occasion for it It was now past six, when we passed through the village of Taddington, seated on a naked limestone mountain. It is a place of no trade or manufacture. The inhabitants, farmers, deriving their subsistence from a few fields that surround it, all in grass, and which, being divided by stone walls, had a singular appearance as the setting sun shone upon them. The fields are narrow, and the walls stretching in long lines, when seen from a distance, seem close together, and have the appearance of tenter grounds. The church is singularly situated on a hillock, in the midst of one of these green fields, with gravestones standing around it, without any wall to separate the church or the yard from the rest of the field. The inhabitants are poor, and, at this time, were said to be much distressed from the high price of bread. It was dusk before we reached Monyash, our place of rest for the night. It is said to have been a market town formerly, but consists, at present, of a few houses scattered over a large plot of ground, in a barren and bare situation, surrounded with distant elevated tracts of country.

We started in the morning, between five and six, and after walking about a mile, got into the London road from Buxton to Ashbourne. We knew that there was a Druidical circle in this neigbbourhood, and made inquiry both at Monyash and on the road, but could procure no information respecting it. We had a map (Pilkington's), in which it is laid down two or three miles further South than its real situation, which had nearly caused us to miss the sight of it. Perceiving a man, near a farm, on the right, we inquired for Arbor Lowe, when he pointed to a mound, on an eminence, about half a mile to the left. We immediately went across the fields to it. This was not the Druidical Temple, as we had supposed, but a large barrow, hollow on the top, as if it had been opened. A slight bank or rampart, rising at intervals in the field, of a semi-circular 
form, seems to have surrounded and connected it with the Temple, lying about 150 yards further to the East. On first looking over the high bank, where the mysterious, if not unknown, ceremonies of an extinct religion were celebrated in remote ages, we were struck with feelings approaching the awful. The area encompassed by the ditch, is about fifty paces in diameter, and of a circular form. The stones which compose the circle, are rough and unhewn masses of limestone, lying on the ground, near the outer edge of it, with one end pointing to the ditch, and the other to the middle of the circle, where there are two or three lying together, supposed to have formed a cromlech. We measured some of the largest stones of the circle; one was about five yards by two and a half; another six yards by three, in the broadest part; most of the others were, however, of much smaller dimensions. It is surrounded by a ditch, and bank of earth, six or seven yards in height and breadth. There are two entrances, each of the width of ten or twelve yards, opening to the North and South. On the east side of the southern entrance is a barrow, standing in the same line of circumference as the vallum. It is said to have been opened some years ago, and the horns of a stag to have been found in it. The situation of Arbor Lowe, though elevated, is not so high as that of some neighbouring eminences; yet it commands an extensive prospect over what was formerly a dreary and barren waste. But it has been lately enclosed, and we observed the remains of a luxuriant crop of oats, which had grown near the circle; the bad weather of the last season having apparently prevented its being housed. Whatever might be the religious rites made use of here, by our remote ancestors, whether so horrible as is represented, or more innocent and rational, its situation seems not unsuitable to the worship of that Being, "who dwells not in temples made with hands." IVe are told that $\mathrm{HE}$ who taught the purest religion ever communicated to man, "went up into a 
mountain to pray." And is there not something in the pure air of elevated regions, where we are surrounded by the "6 everlasting hills," and can look down upon the world below, with the grandeur of the heavens above us (with which we are, as it were, in more immediate contact, and to which we tend by our immortality), far more calculated to awaken sentiments of gratitude, reverence, and humility - the essence of true Religion-towards that mysterious Being, the author of ourselves, and of all this beauty and sublimity, than those puny buildings made by our own hands, in which we are accustomed to assemble? In viewing this relic of remote antiquity, it was melancholy to think, that of the priests and the people once assembled here, and even of their religion and its rites, all record and remembrance is lost-

"And like the baseless fabric of a vision, Or like an unsubstantial pageant faded, Has left not a wreck behind,"

except this rude and simple, yet sublime Temple, which seems as imperishable as the mountain of which it forms a part.

Leaving Arbor Lowe, we walked two or three miles to Newhaven, where we breakfasted at a large and elegant inn, erected by the Duke of Devonshire for the accommodation of travellers. Previous to its being built, in 1795, there was only one mean public-house between Buxton and Ashbourne, a distance of more than twenty miles, which was considered as one stage. We pursued the London road for six or seven miles further, through an enclosed but rather bleak country, till a little beyond a toll-gate, we turned off to the right, and went down Spen Lane, which brought us to Thorp-cloud, a large green hill, of a conical shape, rising to a considerable height. The view from its summit is very extensive, particularly to the South, where below us, on the declivity, lies the village of Thorp, while beyond extends a 
wide and rich valley, far as the eye can reach, with the river Dove, like a silver thread, winding through it. Somewhat to the right, and over an immense extent of intermediate flat country, we saw a range of hills rising high, though dimly descried in the distance: these we took to be the Welsh mountains. On turning North, we had a rich and rather broad valley on our left, the upper part of the one we have just mentioned, which we had supposed to be the famous Dove-Dale. Under this impression, we descended the mountain to the side of a pretty large river, which washes its foot, puzzling ourselves as to what could be the name of it. We walked down its banks through some meadows till we came to a mill which the turnpike-road passes : here, leaving the river, we went along the road up the valley, till fortunately meeting a young man, we inquired the name of this admired river, and were told it was the Manifold. The truth struck us in a moment. We had taken the vale through which flows the Manifold, for the lower part of Dove-Dale; those only can judge our mortification, who, having a journey to perform on a warm day, of which they have finished only about half, find themselves already fatigued, yet discover, on a sudden, that they have gone wrong, and that they must retrace their steps two or three miles up a steep mountain. This was exactly our case. While on the top of Thorp-cloud, we saw a narrow glen between rude rocky-headed mountains-never supposing it was the far-farmed Dove-Dale. But thither we had to go, so we returned with the young rustic, who was going to a fair at Ashbourne. We were overtaken by three or four young country girls, smartly dressed, about sixteen or seventeen years of age, "with cheeks like cherries;" beautiful, innocent, and light-hearted! They were also going to the fair. A little further, we met a tall young man in a top-coat, though it was very warm; the liquid lustre of his fine dark eye, and his faded cheek, indicated consumption. He directed us the way to Dove-Dale, in an elegant 
tone of voice, but it was weak and hollow. He was probably a son of commerce-one of the numerous victims of the counting-house, whom the town returns to the country too late to receive any service, "but a turf for his grave." Before we reached the Dale, we overtook a woman of decent appearance, who had been at Ashbourne market, and was returning to Mill-Dale, where she lived, having, as she said, "married a man there." She was useful to us in mentioning the names of different objects.

We were now in the singular and grotesque dell; but how shall we describe it? The "little Dove" murmuring through it, with its bluish waves, the colour of a wildPigeon's plumage, from which my friend, rather fancifully, supposed it had its name; the wooded mountain on the left -its complete retiredness - its want of human habitation, or field, or other trace of man, save the path you tread, and the appearance of wood having been cut down. Woe to the shepherd lad, "or herd boy of the wood," who may cast his angle in this brook! What can sufficiently punish a crime of that enormity? Nothing less than a prison ! It was grievous to hear of the tyranny of man finding an entrance into scenes-

"Where Nature wantons, as in her prime, And plays at will her virgin fancies wild, Above rule or art."

She has formed rocks of most singular shapes; thrown them up into spires, or hollowed them into caves, or bent them into triumphal arches. What conqueror ever passed under so noble a one, as that at a little distance from the mouth of the cavern called Reynard's Hall? The rock here forms a magnificent arch, of a fine and regular curve, rising to the height of forty feet, and in width eighteen. Standing in the mouth of Reynard's Hall, and looking through this arch, we have a beautiful, but confined view of the opposite side of the Dale, covered with hanging wood, 
in the midst of which a large detached rock starts out to a great height, to which they have given the name of DoveDale Church. A little further up, we passed close under a stupendous rock, which pushes its broad front into the stream; we stepped upon some stones,-but the passage must be very difficult, if not impracticable, when the water is high. Still further, and near the head of the most picturesque part of the Dale, are two long, pointed, spireshaped rocks, rising one on each side of the river, some thirty yards distant from each other; that on the left with its foot in the stream. They stand like two gigantic sentinels, guarding the entrance to some enchanted and forbidden region. There are one or two more caves, called Fox Holes, but the dell now widens, and the mountains sink, and become less rugged. We saw, just over the stream, on the acclivity of the mountain, two countrymen seated on the grass. What a delightful place for the idler! Here we met two shepherd lads, with sunburnt, freckled faces; one stood staring at us, with open mouth, while the other directed us the way to Beresford Hall, once the residence of Cotton the Poet, and the friend of Walton.

In viewing Dove-Dale, besides the native beauty of the scenery, we had interesting associations. We were on classic ground: we knew that the venerable Izaac and his friend had here pursued their favourite sport, in delightful intercourse of heart and mind; - they had been seated under these rocks, and stood by this sweet river,- the rocks remain unchanged, and the river still flows as of old-but as for them, where are they?

We came at length to a narrow and naked part of the valley, where there are a few poor-looking cottages; it is here called Mill-Dale. Crossing the river to the Staffordshire side, a rough stony lane, of about half a mile in length, brought us to the village of Alstone-field. "What have we here-a church? As I am an honest man, a very pretty church! Tave you churches in this country, sir?" This 
is the exclamation that Cotton puts into the mouth of a stranger, on first coming within sight of Alstonefield Church. The description would suit it at the present day; for it is a neat stone building, but not very ancient. On the East, near the churchyard wall, are some large trees, occupied by a colony of Rooks, and which make the foreground of a neat engraving of the church, in the last edition of the "Complete Angler."

It is singular that a stranger, on arriving in a village, will often pay his first visit to the churchyard. Is it that man, a being " holding large discourse, looking before, and after," feels himself almost as much connected with that world of the departed dead, towards which he inevitably hastens, as with the living one, with which he holds more immediate communion? Whatever may be the cause, the sight of a country church has always been to us an interesting object. We should think it is so to man in general. He is carried thither in his infancy, soon after his eyes have first opened on this glorious world, and receives there a pledge of his high destination; there, is cemented the most important of his connexions; there, he worships weekly that Being, of whose goodness proofs everywhere surround him; it is the burial place of his fathers, and it will finally receive himself when he has finished his earthly labours. "Now get you to my lady's chamber, and tell her, let her paint an inch thick, to this favour she must come." What a history in the graves that fill this sacred enclosure! What hopes, and fears, joys and sorrows, mirth, madness, love, and ambition, lie there hushed up:-

"After life's fitful fever they sleep well." .

The simple wild flower that springs from the green sod which roofs the rustic grave, breathes the pure air, and brightens, and looks fresh in the sunshine and showers of its short Summer, but at length hangs its head, withers, and drops its leaves on the spot that gave it birth, is a common, 
yet not unapt symbol of " the poor inhabitant that sleeps below." We can never see one of these simple temples, surrounded as they are with the beautiful and permanent forms of nature, amid the quiet of the country; the greenness of its little burial ground unvaried with tombstones, * and not to be distinguished from its neighbour-field but by the mounds that rise here and there, in ridges, and point out the site of the graves;-we say, we can never see one of these-for the heart is here at liberty to feel as it ought to feel-without being affected with a not unpleasing sadnessnot unpleasing, because not unmingled with hope ; for where should the lead rest, but where we may be reminded by association, of their future existence? How different is all this from what we experience in the cemeteries of some of our populous towns: the receptacle of the dead is made a thoroughfare and a highway-a scene of vice and pollution. We pass over the dust of generations, we tread upon the graves of our fathers and kindred, with no more concern than if we were parading a race-course. But we find we are wandering, and getting serious; we must return to our narrative. We entered the churchyard and read some of the inscriptions on the gravestones, which are rather numerous. Among these short memorials which the hand of affection has raised over relatives or friends, were some which we thought worth the trouble of copying. They will, however, disappoint those who look for the ludicrous in an epitaph. A joke is a good thing, but we like it in its proper place. We confess we neither search for, nor expect to find one, in the neighbourhood of the grave.

\section{IST EPTTAPH.}

Praises on tomb-stones are but vainly spent:

Virtue alone's the only monument.

* In some parts of the country, more particularly in the North of England, the churchyarls are not distinguished by a single gravestone. 
2.

The blast that nipt my youth will conquer thee;

It strikes the bud, the blossom, and the tree.

Since life is short, eternity is nigh;

On many years to come let none rely :

The present time learn wisely to employ,

That thou mayest gain eternal life and joy.

3.

Parents, whose hopes are high, who fondly trace

Your future comfort in your blooming race,

Drop o'er this stone a sympathetic tear,

For what we felt, and what you have to fear.

The latter two, as may be inferred, were upon young persons. The pathos in the concluding lines of the third, we thought very touching.

We now began to look out for a comfortable publichouse: we were hungry and thirsty: it was near four o'clock, and we had not dined. Many times on this, as well as preceding days, we had forgot fatigue, hunger, and thirst, on coming to scenery more beautiful than usual;-the mind was exhilarated and felt not these bodily infirmities; still we were but men, and these vulgar wants must be satisfied sooner or later. We were directed to a decent-looking house, where the simple fare they had at hand, was as exquisite to our keen appetites as the most delicious banquet. We are sorry, for the sake of future tourists, that we can neither lecord the name, nor the sign of our worthy host; though, as to the latter, the fact is, we believe he had none; he had hit on a better method of making his house known than hanging up the image of either a Red Lion, Blue Boar, or Flying Dragon.

He very civilly walked with us some distance to point out the road to Beresford Hall. When we had passed over a green hill, we made further inquiry; we were now within sight of it, and an old farmer who showed it to us, said he 
supposed we went to see it because Squire Cotton had lived there. "Well, and have you heard of Squire Cotton ?" "O, yes, and he had read all his works."

Beresford Hall is situated on a declivity gently sloping to the West; on the East are some high and woody rocks overhanging the Dove, which there flows through a deep hollow, in which is the famous "Pike Pool," alluded to in "Cotton's Angler." The house is now inhabited by a farmer, and the grounds are entirely neglected-a few straggling trees, oaks, or sycamores, but apparently not so old as the time of Cotton, stand near it; there is neither garden nor orchard, except a few old apple trees which indicate the place where there has been one, but it is now left exposed to the incursions of cattle. The front of the house is from twenty to twenty-five yards, and seems, not long ago, for the most part, to have been built anew. The outer door opens at once, without lobby, into that part occupied by the farmer's family: the room on the right which seems to have been the hall, the walls of which are covered with good oak wainscoting, is set apart as a parlour for the young clergyman of the parish. He was, unfortunately, not at home, or they said he would have been glad to have offered his services, in showing us anything curious about the place. In passing through his room, we took a peep at some books lying about: there were several of the Poets, with Mrs. Grant's Letters on the Highlands, which made us still more regret his absence. In one of the rooms, we were told there was, not long ago, a bed that went by the name of "Cotton's bed;" it probably once belonged to the Poet : it has, however, been removed to London.

Some two or three hundred yards from the Hall, towards the North-East, where the meadow ground forms a kind of peninsula into the river, in the bend close to the Dove, stands the celebrated Fishing-house erected by Cotton, and mentioned by him in the second part of the "Complete Angler." The walls are in a good preservation: the roof, though 
somewhat injured (the laths and plaster in some places were falling off), is by no means in so ruinous a state as represented in the "Beauties of England and Wales," where it is said "to be nearly destroyed." The motto, " bus Sacrum," cut in the stone over the door, was partly overgrown by moss, but the initials of Walton and Cotton, in relief on the stone, were almost as clean and beautiful as when first cut. There is a date, 1674, on the outside, which has not been noticed by Sir John Hawkins, in the later editions of Walton and Cotton. The inside is a cube of about fifteen feet, a fire-place on the left; on one side of it, in relief, on the chimney-piece, are the letters Iz., on the opposite side Wa.- the manner in which the good old man abbreviated his name. The farmer told us he could remember having seen in it, the portraits of Walton and Cotton. The wainscot with which it was lined, and the black marble table that stood in the micllle of the floor, are both removed. We could see the marks where the two stone feet of the table had risen from the floor. The furniture and embellishments, according to the "Beauties of England and Wales," were long ago "demolished;" but we hope, and believe it is true, as we were informed, that they had been removed to London by Miss Jebb, the last respectable occupant of the Hall. This Fishing-house stands on a level part of the river, where the water runs smoothly; just above it, and not long ago, there was a wooden bridge.

We were pleased to hear that we were not the only pil= grims to this shrine of angling, friendship, and poetry. We were told of one who came not long ago, and remained two or three days, taking drawings in the neighbourhood: and of another, an old gentleman, from London, who said to the farmer, when viewing the motto and initials, "that he should like to come some night, and steal away the stone that contained them."

It was not without a sentiment of melancholy that we beheld this house, once the residence of a ${ }^{66}$ highly gifted 
man," and these grounds, beautifully situated, and once, no doubt, kept in excellent order, now entirely neglected; but, above all, we were moved to see this little edifice falling to decay, which, if not to be preserved as "sacred to anglers," should, at least, if the owner of the estate had a spark of taste or feeling, be religiously defended from all injury, as a temple devoted to friendship-to benevolent simplicity of character; and to poetic genius of no inferior degree. But if this memorial of Walton and Cotton is perishing, and in a few years will be as if it had never been, it is consolatory to think, that they have each of them raised a more durable monument in their written works.

"Communities are lost, and empires die, And things of holy use, unhallowed lie;

'They perish; but the intellect can raise,

From airy words alone, a pile that ne'er decays."

WORDSWORTH.

After leaving the Fishing-house, we went a short distance down the river, to see the celebrated Pike-Pool, of which there is an elegant engraving in the last two editions of the "Complete Angler." The Pike is a conical shaped rock, that rises out of the middle of the stream: on the East, it is overlooked by high naked rocks-a level plot of grass spreads along the bank of the river below it, on the side nearest the Hall, above which rise to a great height, rocks, with trees and bushes springing from their crevices, and surmounted by the ruins of a castle, or summer-house, we know not exactly which. The farmer informed us, that Miss Jebb had a statue, or figure of some kind, brought from the Hall, and placed on the top of the Pike; but soon after, the country people-whether viewing this fancy of the lady, as an attempt at "reviving obsolete idolatry;" or as a profanation of the simplicity and sanctity of nature; or what is more probable than either, from a pure love of mischief-assembled, soon after it was put up, and from the 
"6 tall rock," that rises above it on the East, they assailed the intruder with stones, and soon hurled it from its shortlived elevation, into the stream below. We cannot say that we regretted its fate.

We crossed the Dove, and ascended the steep hill on the opposite side. When near the summit, we could not help turning round, to behold, once more, this interesting spot. It was a mild evening, the declining sun shone sweetly on the grey rocks and the fresh verdure: the Dove was winding its way quietly below us: we thought of the two eminent persons whose memory gave its chief interest to the scene we were looking upon. On such an evening as this, we might have seen them from where we stood-these rocks, and this little stream, had witnessed their gaiety and kindheartedness: the sun had shone as brightly on that evening as at this moment; - the grass sprung up as green beneath their feet; - the air had come about their cheeks as "wooingly" as it now did ahout our own. But they have long ago disappeared from the face of the earth. How frail and evanescent is man, when compared with the grand phenomena of nature, and its undying energies! At this moment we could have compared ourselves to the tiny summer flies, that were weaving dances between us and the setting sun, and spending merrily the evening of that day, which made up the whole of their life.

We returned next day to Manchester. It is fit that our journal should terminate here; for what could we see, after this, which we should think worth the trouble of noting down? As it is, we may preserve it as a record, though faint and imperfect indeed, of what we saw, felt, and thought, during a few happy days; but which, in reality, will need no written remembrance to lie in the landscape of our memory, "like spots of stationary sunshine ;" they will be to us like a well of pure water amid the sands of the Desert, to which our souls may fly for refreshment hereafter, ${ }^{6}$ in hours of weariness, amid the din of towns and cities, 
and the many shapes of joyless daylight." How often had we felt, during our excursion, the truth of what the Poet has so beautifully expressed:

"That Nature never did betray

The heart that lov'd her; 'tis her privilege,

Through all the years of this our life, to lead

From joy to joy: for she can so inform

The mind that is within us; so impress

With quietness and beauty, and so feed

With lofty thoughts, that neither evil tongues,

Rash judgments, nor the sneers of selfish men,

Nor greetings where no kindness is, nor all

The dreary intercourse of daily life

Shall e'er prevail against us, or disturb

Our cheerful faith, that all which we behold

Is full of blessings."

Wordsworth's Tintern Abbey.

M. N.

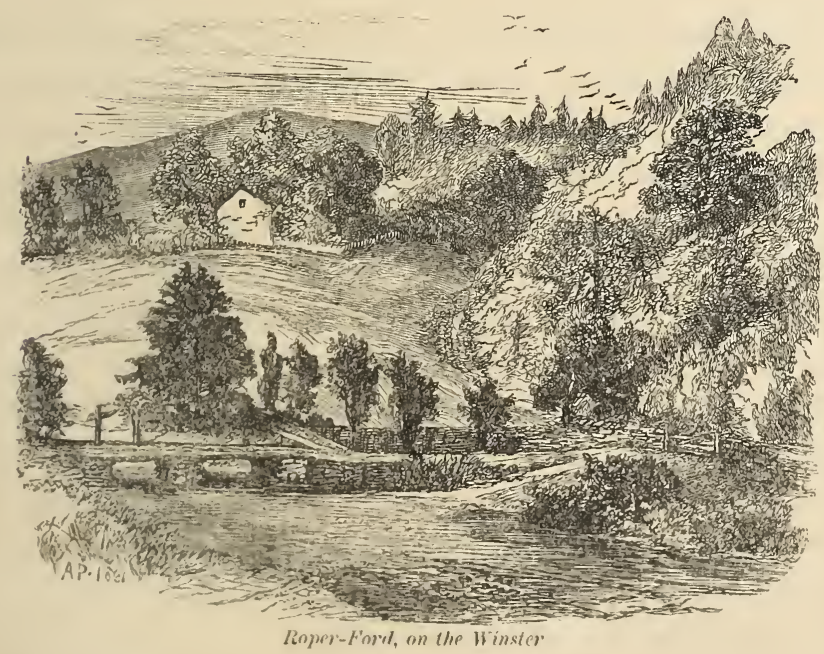


SOME ACCOUNT OF A JOURNEY INTO SCOTLAND.

ON the 20th of August, 1822, I set out, and went from Crosthwaite to Keswick that day. Examined the heap of stones at Dunmail Raise. It is about twenty-five yards in diameter-evidently artificial; a stone wall passes over the top of it. Was told by the landlord at Wythburn, who knew Mr. Gough, who perished on Helvellyn, that his dog was a little brown Cocker, but had turned grey on the back while on the mountain, and become wild. The people here were busy among the hay, although the harvest had commenced more than a week ago in Crosthwaite. Met on this lonely road, two descendants of Abraham: they were old men, with beards that seemed never to have felt the touch of steel, were natives of Poland, and travelling with jewelry.

21st.-Started about six o'clock, going along the East side of Bassenthwaite Lake. The western shore, towards the opening, rises steep, and is covered nearly to the summit of the heights with natural wood. Passed through Ireby, a long straggling village, about twelve miles from Keswick. The people busy with the harvest-the wheat all cut, and most of it housed. When I came within a few miles of Wigton, observed many coal-pits. The country rather flat, but seems to produce excellent grain. Skiddaw is in view the whole day, and is a grand object. As I approach Wigton, can discern the Scotch coast, and the mountain Criffel. Stayed all night with Cousin Barbara, at Moorhouse Hall, two miles beyond Wigton. Observed thirty-six persons employed in their harvest-field; their wages $2 s$. $3 d$. per day, men and women alike-they find themselves.

Thursday, 22nd.-Walked to Bowness, eight miles, 
through a low, flat country; the houses mean, with mud walls, and covered with thatch. Bowness consists of a few white houses and a church, on the edge of Solway Firth. I here mount on horseback, behind the guide, who takes me over the sands, a distance of two miles-his charge a shilling. The channel may be about one hundred yards broad, and took the horse up to the belly. It is about two miles, from the first touch of Scotch ground, to Annan. It was marketday, and the street full of people. There was a greater difference in their appearance and language, as well as in the houses, and the aspect of the country, than I could have previously imagined, in so short a distance as across the Firth. I observed many of the women without shoes or stockings, even though otherwise neat and welldressed.

Leaving the town, in about half a mile, cross the river Annan, which here runs through a fertile valley, $I$ then turn to the right, taking the new road to Dumfries. It runs nearly straight, through a country divided into large fields, but bleak and naked-being almost destitute of wood, excepting some plantations of fir. During part of my journey it was wet; but when within a few miles of Dumfries it cleared up, and I had a fine rich valley on my left; beyond, towards the West, a range of mountains, among which was Criffel, standing out near the sea. I reached Dumfries about six o'clock. Put up at the Royal Oak, I believe; a decent second-rate inn. Nobody at home but Mr. McLachlan, the landlord: it was washing-day, and the women all down at the river-side, according to the Scotch fashion. In an hour or two, they returned, three of them-all bare legged; yet Miss McLachlan, a lady about thirty, the landlord's cousin and housekeeper, wore earrings, and he assured me had $£ 1,500$ for her fortune! Miss McLachlan, in putting on her hose (we were sitting by the kitchen fire) exposed her delicate limbs as high as her knee -a thing which would have been thought shocking by an 
Englishwoman; yet, I have no doubt, that in all essentials, the Scottish fair ones are equally modest. Before the return of the women, Mr. McLachlan had told me much of his history. His family were from the Isle of Bute. His father had been a paper manufacturer, and had died worth $£ 26,000$, leaving his business and a few thousands to $\mathrm{Mr}$. McLachlan, who was not so fortunate as his father, for in a few years he failed, losing all his property, except some premises in the town, of which the house he lived in, formed a part. As he would not deliver these up, he was imprisoned some time, which, he said, was the happiest period of his life, as he had twenty-five shillings per week to live on, without any care! I suspect, that like many others, he had only himself to blame for his misfortunes; for his appearance was rakish-his dress shabby-genteel; a tall, pale-complexioned man, with a turned-up nose;

"There was a hardness in his face,

There was a hardness in his eye,"

not at all to my liking.

Friday, 23rd.-Went this morning along with my host and a guest of his, a young country schoolmaster, to see Burns's Monument. It is placed in the S.E. corner of the yard, belonging to the principal church in the town. There are a great number of other monuments, chiefly in the form of obelisks. The staiue of the Poet is of white marble; he has one hand resting on the plough, and is looking up to the vision of his muse, Coila, descending to crown him with holly. Though the likeness is said not to be very exact, I was much struck with the noble and manly countenance-its expression of superior intellect, calm dignity, and independence. Though there was the representation of a common implement of agriculture, which might remind you of the ploughman, yet I felt as in the presence of a being of a high rank in the scale of existence. The expression of his genius and high moral qualities in the cold marble, with the 
recollection of his misfortunes and premature death, moved me even to tears. "He asked for bread, and he received a stone."

The statue is covered by a circular dome, supported by pillars, and open to the churchyard, but defended from intrusion by iron palisades; before which are planted shrubs and flowers, among these there was the largest Scotch thistle I ever saw. 'This was very appropriate :-

"I turned the weeder clips aside, And spared the Symbol dear."

The sexton showed us the place where poor Burns was buried. He lies in the opposite, or North-East corner of the churchyard.

Such is the attraction of this monument for strangers and visitors, that, I was told, the old man makes a handsome addition to his living, from the privilege of showing it.

In a street neir this church, called Burns Street, in a neat little house, of two stories, lives Mrs. Burns, the widow of the Poet-his "bonny Jean." My host thought it strange we should have the curiosity to wish to see her"She was just a plain old body; nout else." Considering this, and the elevated and pensive feelings the visit to the monument had excited, it was perhaps no great misfortune that she was gone into the country. We did not see her.

Dumfries is a rather neat, thriving town, built of brick or red freestone, of about third-rate magnitude in Scotland, and may contain six or seven thousand inhabitants, who are said to be noted for hospitality and the urbanity of their manners. It is seated on the East side of the Nith, which is here crossed by two bridges of five or six arches each. I passed over the new one, and proceeded up the valley, which is wide and fertile, till, in a mile or two, I reached the ruins of Lincluden Abbey, seated close to the river Cluden, and surrounded by trees. Not much of it, however, remains. Its neighbourhood is said to have been a favourite 
haunt of Burns. Went along a footpath through some rich fields, by the side of the Cluden, till I came again into the main road at the bridge. Met with a decent-looking man, a carpenter, who went with me nearly to Ellisland. $\mathrm{He}$ pointed out to me, on the left, a spot of fenced ground, surrounded with trees, in which was buried a noted persecutor of the Covenanters, called " Old Lag." He was so terribly severe, that my companion said he would have shot a man, if he had found a flint in his pocket! A little further, I turned off to the right, to Ellisland-the farm which Burns occupied a short time before he settled at Dumfries. The house is about three hundred yards from the road, on a rising ground, close to the Nith, which is here fifty or sixty yards broad. 'The farmer's wife and daughter received me very civilly, and showed me the part of the house which was built and inhabited by the Poet. It consisted of three rooms in a range, on the ground floor, as is the general custom in Scotland; few or none of the farm-houses or cottages being of two stories. I was told, they had visitors from different parts of Great Britain, and even from Ireland. The old woman said she recollected Burns; he was a rather broad-set, dark-complexioned man; but, continued she, "he was just a harum-scarum fellow, sadly gi'en to women and drink. I dinna see why there should be sic a fuss aboot him!" Nearly opposite, on the other side of the vale, is Dalswinton, formerly belonging to Mr. Miller, Burns's landlord. I walked down to the side of the Nith, and on my return, the women came out of the house, and presented me with a few apples, which they said I might eat on the road. It struck me, however, that the tree on which they grew might have been planted by the Poet. So I kept three or four as relics; presenting one to a friend in Edinburgh, and intending even to bring one or two to England, but they perished before I reached home, being not so hardy as Burns's literary offspring.

Leaving Ellisland, after a few miles of straight level 
road, I crossed the Nith, over a new, handsome bridge. The vale here narrows, and becomes more interesting; fine rich land bordering the river, while the opposite side is ornamented by natural hanging woods. The day is fine, and the reapers are busy in the fields-the greater proportion of whom are women. They reap with little round hooks, or sickles, taking small rapid cuts. I observe the hay is left in many places in the fields in large cocks, which, when they have stood a few weeks, are taken to be stacked. It is no doubt an excellent method in this fickle and rainy climate, and might, perhaps, be adopted with advantage in many parts of England.

About five o'clock, I reached Thornhill, sixteen miles from Dumfries. It is a rather populous village, in a high and naked situation. It consists of a long line of houses on each side of the road; but they are low-built, straggling, and thatched. Indeed, most of the houses in the country are covered with some kind of thatch; tiles are, however, used for a few.

At the inn, which was neat and comfortable, I ordered tea. It is worth while to mention the variety of viands spread on the table. Here are cold meat, fried mutton ham, butter and cheese, eggs, wheat and oaten bread, and preserves. As I had not dined, the sight of this was very acceptable. For this, lodging, and breakfast next morning, the charge was only three shillings.

Saturday, 24th.-Took the stage-coach for Edinburgh, a distance of sixty-two miles. As the morning was wet, this is the more agreeable mode of travelling. I am the only passenger for several miles, till a young man came in, who was going from Dumfries to Biggar, to see his relations. The country becomes more barren and mountainous as we proceed. There are scarcely any fences to divide the corn and mowing land from the pasture; indeed, for miles along the road, it is common to see neither hedge nor wall between the growing corn and the turnpike-road. Hence the neces- 
sity of herding the cattle; the pastures seem eaten bare, close up to the standing grain. Reach" Dalveen toll-barthe first stage-among high green hills. Elvanfoot consists of two or three mean houses, among desolate and barren hills. My fellow traveller pointed out to me, in this lonely tract, a small enclosure, in which was a white pillar or column. Several of the martyrs who suffered in the covenanting times, when episcopacy should have been forced upon the Scotch, lie here interred-probably near where they suffered. I was glad to find that they are still regarded with veneration, and honoured with a name which they justly deserve. We have now the river Elvan on our right; it falls into the Clyde, which we have in view for some miles, also on our right. Then we have it on the left, till we come opposite Tintoff, a high conical mountain, with its top enveloped in clouds. The country becomes more fertile as we approach Biggar, which is a rather neat village, in Lanarkshire. It lies low. As we ascend the hills, we have a dreary landscape of moory and tame-swelling mountains, on both hands; large masses of poor, starved oats, without division or fence from the turnpike-road; low, darklooking thatched houses, so much the colour of the moor, on the sides of which they are planted, that they are scarcely discernible at a distance. We have this kind of scenery, with little variation, till we begin to descend towards the Lothians, within eight or ten miles of Edinburgh. When within five or six miles of it, a gentleman on the coach pointed out to me, among some dark woods on the right, where lay Hawthornden and Roslin Castle. Pass Blackford Hill, low and covered with whins, within two miles of the city. " Auld Reekie," with its castle, the Firth of Forth beyond, the Calton Hill, Arthur's Seat, and all its noble scenery, have been for some time visible. We proceed down Princes Street, a part of the splendid New Town. I deliver a letter of introduction to a gentleman in Nicholson Street, who kindly procures me private lodgings. 
On Sunday, the 25th, the King being expected to attend St. Giles's Church, I went into the High Street to endeavour to get a sight of him. The street near the church is about thirty yards wide, and both sides of it were crowded with well-dressed persons, waiting for the appearance of his Majesty. The royal carriage was preceded by three or four carriages of Scotch noblemen-the Earl of Fife's and Glengarry's among the rest. When the King came up, there was an almost general taking off of hats, but no cheers or huzzas-this being contrary to Scottish decorum on the Sabbath. His Majesty, sitting backward in his coach, was scarcely to be seen. In the afternoon, went to hear Dr. McCrie, the author of a "Life of John Knox," and a zealous and enlightened friend to civil and religious liberty. $\mathrm{He}$ has lately taken an active part in promoting a subscription to assist the suffering Greeks. I was disappointed, however. I did not see the Doctor; a young man officiated in his absence. I observed that few of the congregation took off their hats on entering the place of worship; some, even remaining covered in their seats, till the service began. This custom, I believe, is pretty general in Scotland, particularly among the older people, and probably took its rise at the Reformation, in opposition to the superstitious veneration of the Catholics for their Religious Houses.

In the evening, I visited a part of the New Town, the port of Leith, and the Calton Hill, which is on the East side of the city; the buildings of the New Town reaching to the front of it. The view from the top is very fine; looking East, you see the town of Musselburgh on the sea shore-a wide, level plain of rich country; and at a great distance, the rock of Bass, and the hill of North Berwick Law, rising like a sugarloaf. Turning towards the city, there is the ancient dark-looking palace of Holyrood, just below on the left (at the time inhabited by a King, the only instance for more than a century); beyond, a little more South, the rough and elevated terrace of Salisbury Crags, surmounted 
by the more lofty Arthur's Seat, while in front, looking over the smoking mass of the city, is the Castle, seated on its rock; more to the right, is Leith, with its harbournumbers of vessels in the offing, floating on the magnificent Frith, which here expands to the breadth of six miles-beyond, the rich shores of Fife-fields and glittering houses; the extreme distance bounded by a fine range of mountains - the Ochils and the Grampians. It is a scene, perhaps, seldom equalled on this earth, for beauty and sublimityfor a display of the works of God, and of man.

On the Calton Hill is an observatory, and a lofty circular erection, called Nelson's Monument, which has a fine appearance from several parts of the city. While $I$ was in Edinburgh, the first stone was laid by the Duke of Hamilton (as representative of the $\mathrm{King}$ ) of a superb building - a national monument, to commemorate the late victories. It is to include a church, and to be built on the model of a temple at Athens, I believe the Parthenon. When this ceremony took place, there was a grand procession of Freemasons, \&c. ; and the day being;ine, it was a very interesting sight to witness the number of well-dressed persons of both sexes, covering the extensive superficies of the hill. The cannon from the Calton and Salisbury Crags (at the time sprinkled with the white tents of the soldiers), being replied to by those of the Castle-and both answered by the shipping in Leith roads-the white smoke spewing from their sides, we could see long before we heard the report. A number of the newspapers of the day, coins, \&c., were deposited under the stone, and the Duke of Hamilton, as Grand Master, having received a cornucopia containing corn, wine, and oil, and having poured it upon the stone, said:

"Praise be to the Lord, immortal and eternal, who formed the heavens, laid the foundations of the earth, and extended the waters upon it, who supports the pillars of nations, and maintains in order and harmony the surround- 
ing worlds. We implore Thy aid, and may the continued blessings of an all-bounteous Providence, be the lot of these, our native shores; and may the Almighty Ruler of events, deign to direct the hand of our gracious Sovereign, so that he may pour down blessings upon his people; and may his people, living under sage laws, and a free government, ever feel grateful for the blessings they enjoy."

There are numerous buildings in the city which I shall not attempt to describe. I was most struck with the County Hall and Court Room, formerly the Parliament House: it is new-fronted on the model of the Temple of Erictheus, at Athens. The King was here entertained by the civil authorities. The front of the College is also very magnificent. There is a court in the inside not yet completed. The Register Office is a very elegant erection; and Oman's Hotel, and St. George's Church, and the Excise Office also. The last four are in the New Town, and are all built of fine hewn freestone, got from quarries at no great distance. The squares have a very elegant appearance-the sides of them resemble one side of a single building or templeand consist of a number of private houses.

In St. Andrew's Square there is a lofty monument to the late Lord Melville, to be surmounted by a colossal statue. The Theatre, however, though in Princes Street, in the New Town, and opposite the Register Office and Oman's Hotel, is a poor, barn-like building, utterly unworthy of the city. There is a fine equestrian statue of King Charles II. in the Parliament Close, which I was somewhat surprised at, considering how little reason the Scots had (or indeed anybody else) to respect him. I must not omit to mention that I visited the Castle. One ascends by a kind of winding road, where cannon and mortars are planted here and there. On the right, before you get to the top, is the Armoury. It contains 70,000 stand of arms, which are placed in long rooms, in regular and beautiful order. They are now browning the muskets, to save the trouble and 
expense of keeping them bright. It seems economy has extended hither, as the armourer complained heavily, that there were only six of them to keep all these arms in order. I was also in what they call the "Crown Room," where the ancient Regalia of Scotland, after having been lost for more than a century, is now exhibited to the gaze of the curious, at the rate of one shilling each. The showman and his clerk (who takes down your name) are both arrayed in antique but gorgeous suits of scarlet, fringed with lace. The crown is deposited on a splendid cushion of the same showy colour, surrounded and defended by glass from the touch of the "profane vulgar;" here are also the sceptre and the sword of state, the latter of which was presented to one of the Tameses by Pope Julian II. He told us also the names of the precious stones that embellish the crown. I only recollect amethysts and topazes. These "glittering baubles" are in a close room, hung with scarlet, and shown, though broad day, by the light of numerous lamps; so that "all appliances and means to boot" are made use of to render the exhibition striking and attractive. We were told that the money received is remitted to the public treasury, to be applied most likely to the liquidation of the National Debt! After all, I could not but look with interest on these cherished tokens of the independence of a proud and ancient Kingdom.

We were also shown the room in which the unfortunate Queen Mary was delivered of James I. in $\mathbf{1 5 6 6}$, according to the inscription. The apartment is not more than ten or twelve feet square, and overhangs the rock, down which, from a great height, the royal infant, we are told, was let down in a basket, to save him from the Queen's 'enemies. We enjoyed ourselves for some time in this once royal apartment, over a cheerful glass, the party consisting of seven or eight (as many as could be crammed into it), one half English, one half Scotch. Such are the changes time brings about! The view from the Castle was very fine. 
The sun was setting over the western Grampians. Benvenu and Ben Lomond were striking objects. The latter mountain, casts an eye over both Seas.

The presence of Royalty having hitherto prevented my introduction to Holyrood House, I fortunately happened to express my regret, when the armourer very kindly gave me permission to use his name to Mrs. Innes, the Duke of Hamilton's housekeeper, which procured me an entry, free of all expense. It is a neat and handsome building, in the form of a square. The north-west towers were built for a royal resilence by James $V$. The other parts of the building were erected during the reign of Charles II. The inner court is surrounded with piazzas. Over the principal entrance, which fronts the West, there is a handsome cupola, the roof of which exhibits an imperial crown, in stone, and beneath is a clock; over the porch, at the entrance, are the royal arms of Scotland, as borne before the Union. In the north-west angle I was shown two rooms, with a bed in each, both which, they said, had belonged to the unfortunate Mary. After going through them, we entered a small room to the right hand, from which David Rizzio was dragged to be assassinated. It has only one door, through which the conspirators entered: they drew their victim through the two bedrooms, to a spot, where is shown a dark stain on the floor, the stain of his blood, which is said to be indelible. The ancient chapel attached to the palace is at present roofless, and fast falling to ruin.

In returning to the centre of the city, is the Canongate Church, containing, in its burying ground, the monument erected by Burns to the memory of the poet Ferguson. It is a plain stone slab, fixed upright in the ground. I was pleased to see that numerous visitors had preceded me; indeed, there was a pathway leading to the simple monument, quite foot-worn. This was the case also in the cemetery of the church of the Grey-friars; there was a freshworn path to the mural monument, whose inscription says 
that fifteen of the martyrs who suffered in the reign of Charles II. for religion's sake, lie interred near that place. These, according to the inscription, are only a part of more than 18,000, who lost their lives during those horrible times, in a conscientious opposition to an unfeeling King, and an avaricious and domineering priesthood. These simple memorials, of the poet and the martyr, are surrounded by the more splendid monuments of the rich and the titled-merchants, bankers, and lords-men who were great in their day, who would have looked down with contempt on the poor poet, and the humble confessor; but "they had their good things in this life," while the latter lived for posterity, and now their memory is held in great veneration, and their tombs visited by numbers, while those of the rich, who are forgotten, "are passed by on the other side."

In the burying-ground, on the Calton Hill, I saw the monument erected to the memory of Hume, the historian and philosopher. It is rather lofty, of a circular form, and said to be in the Greek taste. The only inscription upon it are the words, "David Hume."

On Wednesday, 28th August, I had a very pleasant excursion to Roslin Castle, returning down the river, by way of Hawthornden and Dalkeith. The Castle is in a romantic situation. It is seated on the edge of a woody glen. The antique appearance of the ruins is much injured by a comparatively modern house, built within the walls. It has the date of 1622 cut in the stone of the doorway. There is a fir tree growing out of a huge mass of stone and mortar which has fallen into the area. The vaults under the Castle are still in a perfect state; some have fire-places, and all iron-grated windows. It is probable that prisoners were confined in them formerly. A farmer was now using them as a storehouse for his apples. The river below the garden very striking-having worn a passage among huge rocks in the middle of the stream. This is what is called a lin-hence, Roslin. At a short 
distance, is a curious ancient chapel, said to be one of the most perfect specimens of Gothic architecture now remaining in Scotland. Two rows of massive pillars support the roof in the inside, which is made of stone, arched over like a bridge. Down some steps, at one end, is the confessional, the window looking out towards the river. From this place I walked along a path made through the woods, close by the river-side, to Hawthornden; a distance of one or two miles. It is impossible to describe the beautiful variety of the scenery in this delightful walk. Imagine a pretty large stream flowing down a deep glen-in places, running dark and deep among rocks; in others, murmuring over stones and gravel; the sides of the glen covered with a variety of natural wood, springing from the crevices of the rocks, which sometimes appear in large masses rising from the water's edge, and crowned with heath now in flower. In one or two places it overhangs, so as to form a shelter, with seats underneath. Add to this, that, from the winding of the stream, the view is changed at every moment. The house of Hawthornden is finely situated on the edge of the dell. The buildings appear ancient, at least as old as the time of Drummond. I was, unfortunately, on the wrong side of the river, therefore could not ascertain if there were any relics of the poet, still remaining. After leaving Hawthornden, the dell becomes more open and less wooded; but there is great variety and beauty of scenery, till one reaches the village of Laswade-here there is a bridge over the river, called, I believe, the North Esk. From hence, three or four miles to Dalkeith, through a rather level, rich country. As the King was expected to pass through the town, from Lord Melville's to the Duke of Buccleuch's, crowds of country people were thronging the roads to have a sight of him - the sight of a King; so rare a phenomenon in Scotland! At length, I and many more had a glimpse, as he passed rapidly along the streets of Dalkeith. I here met with a mild, agreeable gentleman, of 
the name of Campbell, a native of Inverary. We became friendly, and he would treat me with some whisky. $\mathrm{He}$ seemed quite as curious to see the Duke of Argyll (the head of his clan), as the King. He had been to Edinburgh, but "was not certain if he had seen him" (the Duke). He accompanied me two or three miles on the road. We shook hands at parting, with mutual invitations to each other's residences, but with little prospect of ever seeing each other again. From Dalkeith to Edinburgh is six miles, through a flat, fertile country.

Friday, 30th August.-Left Edinburgh, at 4 p.m., by the canal packet, for Linlithgow-a distance of sixteen miles by the road. Past the Corstorphine Hills, pretty near; and the Pentlands, more distant; both on our left. The country is nearly level, rich and productive. No smoking allowed on board the packet, from which I infer that the smokers are in the minority in Scotland. Almost every Scotsman, however, has his snuff-box or mull. The palace at Linlithgow is a majestic ruin; it was burnt by accident in 1745 , but great part of the walls are standing. The church is a noble pile of Gothic architecture. Over the door is the following inscription :-

\section{"Mors tua, mors Christi, Fruus mundi, Gloria Cœli, \\ Et dolor inferni, \\ Sunt meditandi tibi,"}

Opposite to the town-house stands the Cross, well-built, anno 1620; from which issue about a dozen streams of water, from a variety of grotesque figures.

Saturday, 31st.-Set out early for Falkirk, eight miles distant. Face of the country swelling into gentle hills. Land rich, and lets for about $£ 2$ per acre. Cattle large, and short-horned; red and white coloured. Past through the villages of Polmont and Lauriston; the latter the birthplace of Law, the famous projector, and author of the 
Mississippi scheme. Falkirk is a pretty large town, but the houses rather mean. Near this place have been fought two famous battles-one by Edward I. and Sir William Wallace, the other in 1745. Leaving Falkirk, past the Carron river, running through a rich valley; then rising the hill, the village of Larbet and its neat new church on my left. In two or three miles further, enter the Torwood, famous as the retreat of Si: William Wallace. It is now, much of it, laid out in fields, and culiivated. Met with an old man, working on the road, quite an enthusiast about Wallace and Bruce: he was familiar with the history of their lives and actions, and pointed out to me the srot, down some fields to the North, where stood the iamous tree that afforded Wallace a shelter, during his misfortunes. It is not long, he said, since it disappeared, being subject to the depredations of patriotic Scotchmen from every part of the globe, who cut pieces from it to make queichs, or drinking cups, some of which were taken to the East Indies. Its root, I understood, was pointed out to the traveller not many years ago. I turn off to the left from the main road, before reaching the toll-bar of St. Ringins, and pass over the field of Bannockburn. In going through the village, I am shown the mill where James III. of Scotland was killed, in 1488, after having been defeated in battle, near this place, by his rebellious subjects. But Bannockburn is famous chiefly as the place where Edward II. was defeated by Bruce. I procured an old man to go with me, and point out the "bored stane," as it is here called, in which, it is said, Bruce's standard was planted during the battle. It is close to the road-side, on a gentle eminence; the hole is visible, but the upper part has been bruised and battered by curious visitors, intent upon carrying away relics; and it is clear that the stone would long ago have shared the fate of Wallace's Tree, if it had not been of harder materials. I was shown Gilles' Hill; it is about half a mile West of the field of battle, and was in the rear of Bruce's army, 
when his camp followers, the women in red petticoats, appeared upon it during the action, either by design or accident. The English mistook them for a body of fresh troops, coming to the assistance of their enemies, and fled with precipitation on all sides. By such trifling causes are the fate of nations sometimes decided. Pieces of broken. swords, \&c., are sometimes turned up in digging the ground near this place; and not many years ago, I was informed, there was found a gold ring, with the initials upon it of an English family of rank. Its fortunate possessor sold it for two guineas to a gentleman from Glasgow, a visitor to the spot. The approach to Sterling, through the populous village of St. Ninians, is delightful. The Castle on a rocky hill, the town on its eastern declivity, bear some resemblance to Edinburgh. There is a terrace walk, formed round the western side of the rock, which is here lofty and almost perpendicular. - From its extreme edge rise the Castle walls. In walking along this terrace, I have a charming prospect of the wide and fertile valley of the Forth; bounded on my right, towards the North, by the noble range of the Grampians-Ben Ledi being very conpicuous; while, far away to the West, at the head of the vale, towers the lofty Ben Lomond, never seen to more advantage. On the flat, below the Castle, are the marks of enclosures-one of which is circular-where the tournaments were held; the rock above, where the ladies of the court sat to view them, still goes by the name of the "Ladies' Rock." In turning round the northern side of the Castle, I ascend a green hill, from which $I$ have a view of the lower part of the vale, the "links of the Forth," and a part of the Frith beyond; within one of the links. or bends of the river, are the ruins of the Abbey of Cambus Kenneth, often mentioned in Scottish history. I now cross the Forth by a narrow stone bridge, on my way to the Highlands. After walking about two miles, I leave the main road to Perth by way of Dumblane, ascending the rising grounds to 
the right hand, intending to pass over "Sheriff Muir," by which I shall gain four or five miles. Many a time I turn round to gaze on the fine prospect, "and cast a longing, lingering look behind." When I had gained the summit, just on the edge of the moor, the view was, indeed, noble and extensive. Looking towards the South-East, you have the Frith of Forth, and the flat, rich country towards Falkirk; while more to the right, and below you, is Sterling and its Castle, in the midst of this finest of valleys. The fields and woods, the houses, the town and Castle, the winding river, and the shining Frith beyond, are all bright and beautiful in the clear sunshine. Yet words, poor vapid words, can never convey the impressions one receives from a delightful landscape. As I proceed along the moor, looking forward to the North, and down to the left, the mountains rise around in noble panorama; Ben Lomond still superior to the rest "for beauty and for majesty." I am here overtaken by two young men, who had been at Edinburgh to see the King. They were returning to Auchterarder, where they lived. As they were respectable and intelligent, I considered myself fortunate in falling in with them. On a lonely part of the muir, there is a small public-house; we called here, and refreshed ourselves. The shelter and simple cheer it affords, must be most acceptable to the traveller who journeys over these wilds in Winter, beset with " the pelting of the pitiless storm." It stands among a few fields, enclosed from the "heathery" waste, but without the cheerful sight of tree or shrub, or human habitation. A little to the left of this house, was fought, in 1715, the battle of "Sheriff Muir," between the Duke of Argyll and the rebels under the Earl of Mar. A mile or two farther on, we pass a small half-circle of erect stones, with one iarger than the rest, probably to mark the burying-place of some chieftain of old. We had now passed the moor, and reached the enclosed land; but the evening was coming on, and we met the reapers, men and women, 
returning from their work; by and by the moon rose over the Ochil hills on our right, "round as the shield of my fathers." I had intended to make the village of Blackford, which we now passed through, the end of my day's journey, being more than thirty miles from Linlithgow, which I had walked to-day.

"'Twelve hours, twelve bounteous hours are gone, while I Have been a traveller under open sky,

Much witnessing of change and cheer."

Yet so much is the body relieved by the excitement and elasticity of the mind, that I felt not fatigued, and the evening being fine, and my company agreeable, I stopped not till we came to Auchterarder, in Perthshire, four or five miles farther, where I was recommended by my fellow-travellers to a plain but comfortable inn. The next day being

Sunday-I attended the church at Auchterarder, where there was a numerous and respectable congregation. Though the great majority must have been mechanics and farmers, yet they were nearly all well dressed, and seemed even like gentlemen. My landlord, for instance, who is a millwright, was in klack broadcloth. I consider it an infallible symptom of a superior grade in morals and civilization, when the working-classes are more attentive to dress than to sensual gratification. How different is the appearance of the people here, from that of the dirty and squalid manufacturing population of the town of Manchester; although the latter, no doubt, earn much more money by their labour! Their superiority lies in their religious and moral character; they have, consequently, a higher respect for themselves, and a more anxious wish to appear respectalule in the eyes of their friends and neighbours. A striking proof of the state of public opinion here, with respect to decorum and morals, was afforded by my two companions on the road. As they had shown me great civility, on our parting I told them I should be glad to see them at the inn on the morrow. 
They begged to be excused, for if we should be seen, said they, in the "Change House" on the Sabbath, we should be the talk of the whole town! How different this from England! Scotland, with its economical Presbyterian Establishment, has a well-educated, moral, and religious population. I wish I could say as much for Old England, with all its expensive machinery of Deans, Prebendaries, and Bishops. The usefulness of a priesthood seems to be almost in an inverse proportion to its riches.

The name of the minister at Auchterarder is Charles Stuart. He performed the service in an earnest and fervent manner, without ranting.

There was scarcely a vacant place in the church, yet I was told it was generally more crowded in the afternoon. Many of the hearers must have come from a great distance, as they had their dinner at the inn. My bill for supper, breakfast, and dinner, was only half-a-crown (lodging too included)-by far the most reasonable charge I had met with since I set out. I suspect that not many travellers on pleasure come to Auchterarder.

In the afternoon, went to Perth, a distance of fourteen miles. Crossed the river Erne, over a bridge of four archesthrough the fruitful vale of Strathern; the road afterwards goes in a slanting direction over a wide extent of elevated ground, the top of which is covered with a large plantation of firs; this brought me to the valley of the Tay. After crossing the Erne, I had a fine view to the right, of the wide and fertile strath; but there are no rich green meadows, as in England, lying along the water-side; the ground here, as in other parts of Scotland that I have seen, being ploughed close to the edge of the stream.

It is said that the Roman soldiers, on first beholding the river Tay and its valley, exclaimed, "Ecce Tiberis!"-but they must have approached it in a different direction from mine, for I entered the town without seeing anything of this celebrated river. 
Monday, 2nd Sept.-After breakfast, I walked out to view the town. Perth is seated in a low, rich valley, having the spacious plains of the North and South Inches extending on both sides. It is regularly built, the streets running either in parallel directions, or at right angles to each other. Many of the houses are built in a style of neatness, and even elegance; it is upon the whole a handsome town, with an appearance of comfort and opulence. It contains more than 12,000 inhabitants. Perth used to be a favourite residence of the Scottish Kings. Here, too, John Knox preached his first sermon against Popery. Seeing a church of antiquated appearance, I wished to ascertain if it was the identical building, but met with no one who could satisfy my curiosity. "Perth bridge is reckoned one of the finest in Scotland; it consists of 10 arches, extending over a clear water-way of 589 feet; it is built of a beautiful sandstone, and cost more than $£ 26,000 . "$ The Tay is here a noble river in point of breadth, but runs rather shallow. It is said to discharge more water into the sea than any other in Great Britain.

Set out for Dunkeld, a distance of fifteen miles; when about a mile on the road, looking back over the Tay, have a view of the ancient palace of Scone, where the Scottish Kings used to be crowned; it is now inhabited by a nobleman-I believe, the Earl of Mansfield. It is a dark red building, seated among fine groves of trees.

The farms here are large, some of them three or four hundred acres. Land at Ochtergaven £3 per acre; this, however, can never be paid at present prices. People busy with the harvest. I observe in some fields nearly thirty reapers, the greater number women. 'They are paid $3 d$. per' threave, of twenty-four sheaves-or two stooks. I have noticed that in Scotland, almost universally, grain of all kinds is set up in stooks of twelve sheaves. Passed three pedestrian travellers, genteel young men; they were seated on the ledge of a bridge, had fishing rods, and an octavo 
book, which they were conning with great attention-it was probably a Travellers' Guide. I observe that flax is a common crop here; it is pulled up by the roots, and laid in rows to dry. The working people here, seem to wear very fine linen, at least such was the case with two or three men that were engaged in mending the turnpike road.

Just after, again coming in sight of the valley of the Tay, in going down the brow of the hill, about two miles from Dunkeld, I pass through the celebrated Birnam Wood. From the "Scotch Guide," it seems that in 1805, there was hardly a tree to be seen in it. I am happy to find, however, that it is now in a much more flourishing condition, and that it might be able even to afford a leafy covering to an army, as in the days of Macbeth. It consists chiefly of oak, and has recently been enclosed by stone walls.

Passing a little farther, I was much struck with a nest, or cluster, of low thatched cottages, lying below me on the right, close to the Tay, with a plot of holm land near them by the river side, livided into little dales of various crops; there were oats, barley, clover, potatoes, and even flax, and turnips. On the opposite side of the river, a slate quarry, and a mountain newly planted with Larches. I am now entering the Grampians, which are here, near Dunkeld, bold and lofty, but, belonging to the Duke of Athol, they are covered to the summits with plantations of Larch, of different ages. It has been stated that the Larch was first introduced into Great Britain by an ancestor of the present Duke; but I am informed by Vice-Admiral Sir Pulteney Malcolm, who was viewing the grounds and plantations at Dunkeld, that half a dozen plants were first brought from Switzerland, by the servant of a Scotch gentleman, living near Perth; four of these were given to the then Duke of Athol, and planted in the park, near his house. One of them, said to be the oldest, or first planted in Great Britain, was shown to us. It is said to measure eighteen feet in girth, at one foot from the ground, and to be twelve and a 
half feet round, at the height of four feet and a half. It was planted in 1739. The Duke's house here, is but small, but his pleasure-grounds, bordering on both sides of the Tay, are neatly kept and interesting. The wood is very luxuriant, particularly the Larches. In a part of the grounds on the South side of the river, we were introduced into a small building, which they have dignified with the name of Ossian's Hall. It stands near to a waterfall, on the river Brann, and its walls being covered with mirrors, you are startled, when you enter, with the reflected image of the white, foaming cataract. This is, no doubt, a grand and imposing spectacle in the eyes of many of the hunters of the picturesque; and as it is shown last, is probably thought the best part of the Duke's exhibition at Dunkeld. Visitors here are attended by two guides, or showmen, who, like the rest of the profession, take care that their services shall not be gratuitous. The traveller who is fond of viewing fine pictures and splendid houses, will find the money paid for seeing them no small expense. Yet, is there not something mean and commercial in this kind of exhibition for a pecuniary consideration? I was told that the Duke of Athol makes $£ 2,000$ a year, by the letting of his extensive moors for Grouse-shooting. I wonder how his grace escapes conviction under the Game Laws, as an extensive dealer in game! The poor poacher, or higgler, who sells a Partridge or Moor Fowl, is liable to a penalty of $£ 5$, and it is often inexorably exacted. But here is his Grace of Athol, who is a legislator by birth, and a great stickler for "things as they are," selling many hundreds every year, with perfect impunity, deriving no small part of his income from the sale of game! And he sells them much dearer, too, than the punishable dealer; for, according to my informant, one party had taken a tract of moor from him, for which was paid $£ 100$, and it had only two or three broods upon it! "The laws are cobwebs that catch the small flies-the great break through." "Robes and furred gowns hide all." 
Dunkeld is a neat village, the houses mostly covered with slate; it is seated on the eastern bank of the Tay, in a deep valley, among high wooded hills. Here is a fine bridge of several arches, where a few years ago there was nothing but a ferry boat. I was charged two shillings at the Duke's Arms for a very plain dinner. There is an evident design, at those places visited by travellers on pleasure, to make as much out of them as possible. "It is good for trade," as the landlord at Logierait replied to a remonstrance of mine, on the extravagance of his charge-eighteen pence for breakfast, at which I had brown sugar, and could not procure an egg! Indeed, these Bonifaces were the only description of persons in Scotland against whom I had any cause of complaint, and they were only "labouring in their vocation." I have no doubt they had two pricesone for the "natives," and another, a good deal higher, for the "Southerns."

The ruins of the Gothic church at Dunkeld are fine. I believe there is a part of the church still used as a place of worship.

I remained all night at the Inn of Inver, one mile North of Dunkeld. It is close to the Brann-quite a retired place, being surrounded by woods.

Started in the morning (Tuesday, 3rd September), before six o'clock. Went up the valley, along the West side of the Tay to Logierait, a distance of eight miles. For the first mile or two, the road lies among the woods; then I had a tolerably rich tract of cornfields, \&c., on my right. I noticed two or three orchards of large apple-trees, heavily laden with fruit. There were two or three gentlemen's houses by the road side, but chiefly thatched cottages. At one of the latter, there were placed under the eaves, on a board, the skins of several wild animals, stuffed, among which I observed that of a Wild Cat.

Logierait, which I reached about eight, is a poor-looking village, situated between the Tay and the Tummel, at their 
junction. I cross the Tay, and afterwards the Tummel, in ferry boats-the charge, a "bawbee."

An old man, who was fetching water from the brook, near one of the cottages on the road, told me an anecdote relating to the battle of Killicrankie, which had come down by tradition. A boy, who had been compelled by the "red coats" to attend them with a cart, to assist in carrying their baggage, had, from fear, during the engagement, crept under the " brae," near the river Garry. In a short time, a " red coat," who had fled from the field, came and crept in beside him; but he had not been there long, before a Highlander dragged him out; and cut off his head. The boy was sadly frightened, expecting the same fate; but when the mountaineer heard his story, that he had been compelled into the service, he pulled out of his pocket, as the old man said, "a piece of boiled hen," and gave it to the lad, telling him to go about his business.

While we were conversing together, an old woman, the man's wife, came up to us, and very civilly invited me into their humble dwelling. I accepted her invitation. They were sitting down to their morning meal, which consisted of milk and potatoes; the latter in a wooden vessel, to which the family-viz., the two old people, and a grown-up son and daughter-helped themselves with horn spoons. I was kindly invited to partake of their humble fare, which I declined as politely as I could, telling them I had just breakfasted. The old man was delighted that I would talk to him about the battle of Killicrankie, so honourable to his countrymen; he could relate many particulars of it, evidently not derived from books, and spoke much of the Highland commander, Viscount Dundee, whom he called- Clavers (Claverhouse). I inquired how they procured their living. They said they rented an acre or two near their cottage, on which they kept a cow, and grew their potatoes; as for the rest, their children, living from home in different situations, were very kind to them. This is an excellent feature in the 
Scottish character, and arises, no doubt, in part from the absence of Poor Laws.

I pass the Inn of Moulinairn, and the village of Pittochrie, having the Tummel still on my left. The weather being showery, I took shelter in another cottage. Two young women, who had been reaping, were also driven in by the weather. There were two old women likewise, one of whom was smoking tobacco. We could not, however, have much "crack," as "their few words of English speech" were soon exhausted. But they were sufficiently voluble in their own language, talking together in Gaelic, which was, to me, quite unintelligible. Nothing gives one a stronger impression of loneliness, than hearing a number of people talking together in a language one does not understand. One feels at once that one is a stranger, and far from home.

Leaving Pittochrie, I enter a wood or plantation, from an opening in which, I have a fine view looking up the Tummel, which comes winding down the rugged valley, over a rocky, sandy bed; Mr. Butter's white house seated snugly on the right; a wooded hill rising in the middle of the glen, in front; lofty and heathy topped mountains, on the right; cornfields among strips of native wood, surmounted by dark craggy hills, on the left. These few words are a poor attempt to describe a scene, which, at the time, gave me much pleasure. I fortunately found it out, and enjoyed it, before $I$ knew it to be the noted Fascally, which had been pointed out to me by an esteemed friend, whose judgment is of acknowledged eminence on subjects of taste.

I now enter the celebrated pass of Killicrankie. The road passes along the base of the mountain; the Garry roaring down the narrow glen, on my left; beautiful natural woods of birch and oak rising on each side of the stream. The rugged and narrow pass may extend about two miles. The battle was fought at the North end, on a piece of level ground, at present covered with a crop of oats. In the 
middle of the field is a stone pillar, set up on the spot where Dundee fell-the victorious leader. The English regulars, or "red coats," fled backwards over the Garry, its stream being dammed up with the dead bodies. Several of my informants agreed in this.

"Garry, thundering down his mountain road,

Was stopp'd, and could not breathe beneath the load Of the dead bodies."

The battle of the pass of Killicrankie is interesting to the lover of liberty, not so much because the better cause triumphed - as because a body of "Shepherds and Herdsmen" defeated an equal number of regular mercenaries. To quote again the same great Poet-

" 'Twas a day of shame,

For them whom precept, and the pedantry

Of cold mechanic battle, do enslave."

The Highlanders had been wandering about these mountainous wilds, poorly supplied with provisions and other necessaries, when their General heard of the King's troops entering this pass. He resolved to attack them. The result is well known. It was, indeed, more honourable to the Highlanders than I had imagined-the contest taking. place on the open plain, instead of in the rugged and narrow pass.

I now retrace my steps, turning off to the right in the middle of the pass, crossing the Garry over a bridge of a single arch, thrown from rock to rock, where the stream roars and tumbles in its deep and narrow bed. I was particularly struck with the beauty and magnificence of the scenery, at the turn where the road goes to Loch Tummel. On the left hand, at some distance down the vale, rises a heathy, purple-coloured mountain-the Garry is heard in its deep woody glen in front. The mountain beyond it has great variety in its aspect; its lower half finely sprinkled 
with birch and oak; while far above me, among the wood, but beneath the dark rocky summit of the mountain, I descry a yellow cornfield; then looking up the glen, towards Blair Athol, there is a fine intermixture of cornfields and woods; an expanse of heathy moor beyond; and in the extreme distance, high above all, and "so distant in its height," a mountain, with its dark blue conical summit. All this, seen in a glittering sunshine, just after a shower. After crossing the Garry, I travel through natural wood, thinly scattered, and beautifully intermixed with corn and pasture fields; but the whole appearance, wild and poor, and mountainous. It was now between two and three o'clock. There is no inn on the road to Cushieville, my destination, a distance of at least fifteen miles; I determined, therefore, to ask for a little refreshment at a cottage on the road-side. A man and two women were sitting by the fireside; one, a very old woman, employed in carding wool. The woman seemed scarcely to understand me, but the man could talk English very well. I had a large bowl of excellent milk and some oatcake, and when I presented the woman with a sixpence, she looked at it with some hesitation, speaking a few words in Gaelic. I inquired of the man if she considered it too little. " No," replied he; "she thinks it too much." She repeated the word "bawbee." I told her I wished to give her sixpence, though I was convinced if I had had no money, she would have made me equally welcome. It is doubtful whether she understood a word I said. But she soon produced a bottle of excellent Highland whisky, wishing me to cheer myself with two or three glasses. I drank one, and then took my leave, highly pleased with my hospitable entertainment. The "ancient woman," sitting in the ingle nook, with her carding implements, reminded me of times gone by, before the use of machinery had superseded domestic manufacture. She said nothing, but ever and anon, gazed at me with an expression of wonderment. As she lived at a distance from the com- 
mon road, and at her age could not travel, she probably saw few strangers; perhaps, scarcely an Englishman once in ten years. My appearance on this unfrequented road, my strange speech, and white straw hat, formed a vision she would probably muse on for months after. If she were gifted with the second sight, she had probably seen me months before.

After leaving the cottage, I soon came in sight of the Tummel-a dark, tumbling stream, flowing down the wooded vale. I had it on my left, for two or three miles, till I reached the foot of the Loch, which bears the same name. At the ferry-house, there were an old woman, a boy, and a young girl. On my inquiring if I could be ferried over the stream, I was told that the boat was on the opposite side, having been taken across a short time before, by a "wee laddie." Fortunately, there was the large boat lying, which they use for horses, \&c. ; this, with some difficulty, was got afloat by the boy and young woman, and as the ferry was only fifty or sixty yards broad, I was soon rowed across; but as our vessel, from its size, could not be brought close to the side, I was taken to shore, mounted on the lad's back. On looking behind me, I perceived the Celtic damsel getting over the side of the boat, immersing her smooth white limbs in the water. She waded on shore, with her shoes in her hand. She was a plump, active lass, a brunette; small featured, but not unhandsome. Being on her return home, we walked together a few hundred yards. I asked her if she would go with me to England. She smiled, but said little, her knowledge of English not extending much further, I believe, than to "Yes," or "No."

Walked by the South side of Loch Tummel, for five or six miles, along a road winding among bushes of birch and alder, thinly scattered, but wild and picturesque; not passing more than two or three houses in that distance. The opposite side is, however, more populous, there being a 
considerable breadth of enclosed land, all white with grain. The Loch widens as I proceed, extending from half a mile, to nearly a mile in breadth. At the head of it is Foss, the residence of Mr. Stuart. I fortunately met him on the road, near his house, when he very civilly directed me the way to Cushiville Inn. I was particularly struck with his good-looking, large, and manly figure, which he had enveloped in a tartan plaid. His huge size, his erect and majestic walk, I could imagine, would have qualified him for one of Ossian's heroes; indeed, before the invention of that "villanous gunpowder," no half-dozen of the sons of little men, could well have contended with him.

Soon after passing Foss, I ascend the rising ground to my left, and turning southerly, have the high mountain, Shehallion (or maiden pass), on my right. The road goes over a heathy, barren, and elevated moor. On the highest part, near the road, is a small loch, or tarn, about a mile in length. Came up with a farmer, and two or three of his men, looking after a large herd of black cattle. One or two of them wore philibegs. The farmer spoke much of the badness of the times, saying he thought all of his profession would be beggared. But in England, said he, you are better off; you are more independent; here, we dare hardly say our souls are our own! It had now become showery; and after a descent of two or three miles, with a swollen mountain stream roaring down a deep glen on my right, I reached the inn at Cushiville. It was eight o'clock, and had become dark. I had walked thirty-five miles, viz., from Dunkeld to Logierait eight miles; then to Ord, in the pass of Killicrankie, nine miles; back again, two; then four to Tummel Ferry; thence twelve to Cushiville. I was shown upstairs into my bedroom, a fire was kindled, and a cup of tea prepared, which, with some cold meat and eggs, I found a most grateful refreshment after the fatigue of the day.

On Wednesday (4th September), left Cushiville, and at a short distance crossed the river Lyon in a boat - the 
bridge having been washed away by a flood. A mile or two farther, passed Kenmore, at the foot of Loch Tay. The vale is here pretty wide and fruitful, with some woods and plantations. Taymouth, the seat of Lord Breadalbane, I observe on the declivity on the opposite side of the river. Before I came to the Loch, passed through a plantation of fine Larches ; it extends, indeed, along the river's banks for a mile or two, shutting out all view of its waters, except through some openings here and there. I am on the West side of the Loch, and find the views tamer than I had imagined they would be. Reach the village of Thlanharuah. The lofty Ben Lawers is now seen before me, on the right, its summit shrouded in mist. The Loch becomes wider, and turns to the S.E. or S. Came to Lawers, half way to Killen. It had now set in very wet, and I shelter for a short time in a miserable hovel, where they sell whisky - the only house of entertainment, I believe, from Kinmore to Killin, a distance of sixteen miles. I reach the latter place, where I remain for the night, after a wet, disagreeable day. There had been a funeral entertainment at the inn, and in the room I was shown into, were assembled some of the attendants. As soon as I entered, however-a stranger, wet and weary - they all rose to make way for me. I had before met on the road several of the funeral train returning to their own habitations. Their general dress was a blue jacket, and trousers of the same colour and material, viz., woollen-the ancient, picturesque Highland costume being in great measure laid aside. I do not recollect seeing more than one man in that dress North of the Frith of Forth, and I met him on his return from Edinburgh, where he had been for the purpose of exhibition. You see now and then, indeed, a lad in a short petticoat-the last solitary remnant of the ancient garb! While on the subject of dress, I may mention that hats are not so commonly worn as in England; the antique Scotch bonnet still maintains its ground in some places, more particularly among the old; but far more 
common is a black woollen cap, fitting close to the head, without rim or peak, but with a variegated border, which gives it a rather smart appearance. These obtain among the working classes. But the fashionables, from Glasgow, who had come for a day in the steam-boat up Loch Lomond, to view Rob Roy's Cave, were arrayed in caps, of divers shapes and materials; in short, I observed the hat was quite obsolete.

Thursday.-Set out from Killin, on my return Southward, crossing the river Dochart, which runs through a part of the village. It was much swollen with the rain, and the body of water considerable, passing over a rough, stony channel, roaring, tumbling, and white with foam ; it was an impressive sight. Indeed, a traveller, whom I met with at the inn, at Loch Katrine, said it was equal to the Falls of the Clyde. The river Lochy, coming from the North, and the Dochart, from the West, unite a little below the village, before they fall into the Loch. The mountain, Ben Lawers (4,015 feet high), the loftiest, except Ben Nevis, in Scotland, lies N.E. of Killin, but its head is at present hid in the clouds. Ben More, up the vale of the Dochhart, to the West, is a fine object. I now turn to the left, and the road has a considerable ascent. I am here orertaken by a young man on horseback, who, dismounting, offers me the use of his horse. He has a companion with a cart, into which they both enter, permitting me to ride nearly the whole day's journey, indeed all the way to Callander, a distance of, at least, twenty miles ; and for this civility, they will accept no remuneration but a little whisky! Pass through a dreary vale, called Glenogle -over which the mountains tower aloft, and on their sides lie huge fragments of rock, crossing each other in every direction. In the highest part of it, near the road-side, there is a small Loch, about a mile in length; here is neither field nor human habitation, but we observe two or three anglers plying " their solitary trade." We now descend; 
the mountains on each side, if possible, more dark, and steep, and rugged. After reaching the lower ground, pass the head of Loch Erne, leaving it on the left. Here is a rather neat and convenient Inn. We now ascend a sterile valley, a brook on our right, fringed with Alder and Birch; some fields beyond, with patches of oats, and at the base of the mountains, a few low, dark-looking thatched houses. On entering the district of Balquhidder, observe, on the right, in a solitary situation, a small piece of ground, enclosed with a, stone wall; this is the burying-place of the Mc-_'s. The vale, as we proceed, is narrow, and barren, and thinly inhabited. As we come in sight of Loch Lubnaig, Ben Ledi rises very boldly on the opposite side; the Loch making a bend round the foot of it. The road runs by the shore of the Loch, which we have on our right for five or six miles; the base of the mountains, in some places covered with natural wood. We here overtook a Highlander, driving a small black Cow to the great fair at Falkirk. It had been lost out of a large herd, and he had been sent back to seek for it. He was a native of one of the islands, and could not speak a word of English. The river, which flows from the Loch, pursues its course through the woods over a rough and rocky channel, forming, in places, cascades and water-breaks, which make the scenery very interesting. My two companions, good-looking young men, in blue top-coats, and caps of the same colour, with tartan borders, overtook a young mountain damsel, bare-legged and bare-footed, trudging on foot. She accepted their invitation to get into the cart, where, seated between them, she rode for a mile or two, not at all displeased with her company. When within about a mile of Callander, I turn off to the right, and cross the river for Loch Katrine. On inquiring of the toll-bar keeper, a facetious fellow, what kind of accommodation was to be there met with, he said that Mr. Stuart, the landlord of the Inn, " kept an excellent house, and would supply one with every 
good thing." The road has been much improved since the influx of visitors to Loch Katrine. I met two carriages on their return from it. Pass a pretty large Loch on the left. There is same cultivated land here, and the people are busy with the harvest. On entering a piece of wooded ground, in a lonely part of the road, a singular-looking being came from behind a bush, dressed in the philibeg or short petticoat, and with a kind of cloak about his shoulders; his appearance altogether wild and squalid. He might easily have been imagined one of the followers of the famous freebooter Rob Roy, whose haunts were among the rocks and fastnesses of this neighbourhood. I confess I was not quite free from alarm at the first sight of him. He came up to me across the road, and held out his open hand, but without uttering a word. I pulled out some copper, giving him two or three halfpence, on seeing which he smiled, and made a snatch at the remainder. I was told afterwards, at the Inn, that he was a poor, harmless idiot or maniac, who frequented this part of the road to beg of the passers-by. Pass the mouth of Glenfinlas on the right. The scenery becomes more interesting here, with rocks and wood. It was near dusk when I reached the Inn, which stands opposite the small Loch Acchray, and within sight of the Trossachs, and the fine mountain Ben Venu beyond. In the room where I took tea, there were four other travellers " in search of the picturesque;" this place has become a great resort of theirs, since the poet discovered the charms of Loch Katrine. Since the publication of the "Lady of the Lake," this commodious Inn has "risen like an exhalation;" its landlord, Mr. Stuart, has expanded into a portly gentleman-and even the poor of the parish feel the benign influences of the golden shower-a poor-box being kept here to receive some of the "crumbs that fall from the rich man's table." Mr. Stuart may well have a copy of the "Lady of the Lake," handsomely bound, for the perusal of his customers. If he do not erect $a$ statue to Sir Walter, the poet ought, at least, 
to be scot-free, when he comes to Loch Katrine! In the Album here you read the names of visitors from Italy and Spain, from America, from the West and East Indies, from China; in short, from every part of the globe.

Friday, 6th September.-Two gentlemen from London, a Mr. Thornton and a Rev. Mr. Melville, having engaged a boat to take themselves and their luggage up Loch Katrine, on their way to Loch Lomond; I am politely offered a seat in it. We set out after breakfast, passing through the Trossachs, which are rocky hills-covered with Oak, Birch, and other natural wood-rising in the pass leading to Loch Katrine. The sky was somewhat overcast, and a few white clouds sailing over the dark face of Ben Venu, opposite which, on our right, rises the high rocky pike of Ben Ann. Soon after, we embark, pass the Island of the Lady of the Lake, lying on our right. It is not large, but rises pretty high out of the water, and is covered with wood. The western shore of Loch Katrine is wild and uncultivated; the declivity abrupt, broken in places into rugged glens, and covered with stunted wood, grey rocks, and fern, now turning yellow. The opposite side is more flat, and there are a few houses and fields. As we proceed up the Lake, the huge bulk of Ben Ledi comes into view to the South-East; while straight before us, is a fine prospect of the Alpine mountains stretching from Glengyle, and round the head of Loch Lomond. Before we land, after sailing six miles, we observe the "lofty Ben Lomond," to the South-West. We now cross the isthmus, about five miles broad, which separates Loch Katrine from Loch Lomond. It is mostly barren moorland, unenclosed, all but a few poor fields near a small Loch, where there is yet some hay standing out at this late season. The weather was gloomy and wet, which added to the dreary and forbidding aspect of the landscape. Passed a building on the right, which, we were told, was an old Fort, in ruins. In going down the declivity to Inversneyd, there are some small fields, and patches of scattered wood. 
" These trees, a veil just half withdrawn,

And these grey rocks, this household lawn,

This fall of water, that doth make

A murmuring near the silent Lake;

This little Bay, this quiet road;

In truth, together ye do seem

Like something fashioned in a dream."

We saw these,-

" The Lake, the Bay, the Waterfall ;

Not her, the Spirit of them all-

The Highland girl, who had a shower

Of beauty for her earthly dower!"

Who was met with here by the Poet, and described with such feeling and enthusiasm. But poets, like lovers, are "of imagination all compact;" whether, however, this mountain Damsel were beautiful or not, " the rough falls of Inversneyd" will be for ever interesting to the admirers of poetry, for the strain of inspiration of which, the quotation above, forms a part.

We here go on board the steam-boat, which, in Summer, at least, navigates the Lake from head to foot, conveying tourists and parties of pleasure, to view the beautiful and sublime scenery that surrounds this extensive Loch. As the steam-vessel could only approach to within thirty or forty yards of the shore, we are obliged to reach her in a boat. There was a friendly contention between a young lady, who went on board at the same time with us, and the two boatmen; she wishing to pay them for their trouble, and they refusing to receive anything from her. They had been paid ten shillings for our passage up Loch Katrine, and five shillings for taking the luggage overland-they had been treated with whisky at the head of Katrine, and here at Inversneyd-yet they charged $u s$ "to the uttermost farthing," three pence more each, for putting us on board the steam-boat. We felt we were strangers! Their tenderness 
to the young lady must have been owing, either to a national feeling-for she was Scotch, and resided in the neighbourhood-or to gallantry, for she was very beautiful; perhaps both circumstances had an influence. The mountains near Inversneyd have a fine effect, particularly to the West and North-West. We were also much favoured by the weather; alternate sunshine and showers, produced great variety of light and shade. Heavy rain falling in some of these wild glens, made them look dark as Erebus; while the shore, at no great distance, was lit up in a brilliant sunlight. On our right, we have the mountain, with a singular-shaped summit, called Ben Arthur, or the Cobbler. A stupendous mass of rock, lying in a slanting direction, and overhanging in a surprising manner, has probably given rise to its ludicrous sobriquet. We have the beautiful and lofty peak of Ben Lomond in view for a long time, on our left; its broad base rising from the very shore of the Lake. There are a considerable number of well-dressed persons, of both sexes, on board; some seated on the deck, others walking about, most of them looking at the scenery, and many descanting, in "fine set terms," on its beauty and sublimity. There is a cant about the picturesque, as well as a "cant of criticism." Had I looked out for a true worshipper of Nature, it would not have been among these fair ladies, or fashionable beaux! I should most likely have found him to be some poor pedestrian, who, seated alone, is gazing in silence on the stupendous mountains, rapt in a sweet dream, and forgetting both himself and those about him. Our deepest feelings do not readily find utterance. Mr. Melville, though by no means so voluble as his companion, convinced me by a single remark, that he had much more profound impressions from the scenery than Mr. T. "When I am most pleased," said he, "I say nothing." He complained that his friend had a custom of undervaluing all that he admired-a mountain, for instance, by saying it was a mere mole-hill beside such or such a one, in Switzerland, which he had seen; mentioning, at the 
same time, its exact height in feet! My two companions leave us opposite the village of Tarbet, on their way to Inverary. I bade them farewell, much pleased with their politeness, and indebted to their civility; for, having engaged the boat up Loch Katrine before they met with me, they would not permit me to bear any part of the expense. They were, I believe, going to Inverary, to meet one of the Judges. Towards the foot of the Lake, we pass the Islands, some of them of considerable extent; that of Inch Marion being two miles in length-but viewing them from the surface of the water, their appearance, so far from being insular, is more like the shore of the Loch. We perceived a house upon one of them, and a few fields, but they are mostly covered with wood. Pass Inch de Vannoch, which, rising pretty high, is said to afford a fine view of the Loch and its Islands.

[The "account" here ends abruptly; but from Glasgow the writer was proceeding down the Clyde, with the intention of visiting the Isle of Man on his way home, when, in the night, the vessel came in collision with another, and they had to put back. The captain was intoxicated, at the time the disaster occurred; and whether the traveller was deterred by this adventure, from carrying out his plan, or he took his passage in another vessel, is not clearly remembered.] 
[William Pearson's earliest traceable attempts at composition were poetical, but he soon discontinued versifying. For the pleasure of his younger relatives, a few of his pieces are placed at the end of this volume.

The following critique was one of his earliest attempts at prose writing, and, like "Bewick's British Birds," and "Cotton's Complete Angler," was a contribution to a series of papers that appeared in the Manchester Gazette (a paper now defunct), under the title of "Men and Books." Its proper place would have been immediately before "Bewick's Bilds."]

THOUGH an admirer of this celebrated tragedian, we went to see his performance of Hamlet, with somewhat of a prejudice against him. We had witnessed his Richard, and felt the overpowering influence of his Othello; but the powers necessary to exhibit their terrible energies, we conceived to be very different from those which would be required to give a true delineation of the mild and melancholy Prince-a character marked by feeling and thoughtalways deliberating, yet for ever irresolute. We had seen Young also repeatedly, in this character, and always with renewed pleasure; and thought, with others, that " he was the first Hamlet of the age." Kean's personation of this arduous part has, however, placed him higher in our opinion than ever. We are aware there are those who differ from us on this point. It would be impossible to particularize all the passages, in which his natural and impressive acting was marked by the applause, and still more, by the breathless silence of a crowded audience. His surprise, when he first sees the Ghost-his eagerness and filial confidence in following it-his impassioned tone and gesture in addressing it"I'll call thee Hamlet, Father, Royal Dane"-were admirable. We think there was great propriety in his pointing his sword behind, to prevent his friends from following him, when he breaks from thern at the command of his father, 
instead of holding it before, as is usually done, as if to protect himself from the Ghost. The scene with Ophelia, which appears so harsh as it is sometimes acted, and so inconsistent with the gentlemanly mildness of Hamlet's character-to say nothing of his secret love-received a beautiful softening from Mr. Kean, by his coming back from the extremity of the stage, as if from a pang of suppressed affection, to press his lips to Ophelia's hand. This was a fine commentary on Shakespeare, and rendered the scene perfectly compatible with the real tenderness of Hamlet. His delivery of the soliloquy on death, when, after the line, "for in that sleep of death what dreams may come," he raises his eyes to Heaven, and joins his hands, as if in the act of involuntary prayer, was particularly impressive, and, we believe, original and unequalled. But it was in the closet scene, where, perhaps, the power of this extraordinary Actor was most conspicuous. The tone and look of ardent admiration and reverence, with.which he dwells on his father's picture, and the burst of execration on turning to that of his uncle, were strikingly contrasted, and the effect was electrical. His expression of awe, on the appearance of the Ghost-his speaking to his mother at its request, with unaverted eyes - as if drawn by a spell to the supernatural visitor, will not be forgotten by those that were present-it was a short illusion of reality.

We wish not to make any invidious comparison between the Hamlet of a justly admired Actor and that of Mr. Kean. If we have derived a calm and uniform pleasure from $\mathrm{Mr}$. Young, we have been more powerfully moved by Mr. Kean. In the Hamlet of Young, it would seem as if sorrow had been softened by the hand of time, and he had sunk into a state of milder melancholy. While in that of Kean, he appears as if suffering from a recent calamity - he seems to feel more acutely himself, and consequently affects us more.

M. N. 


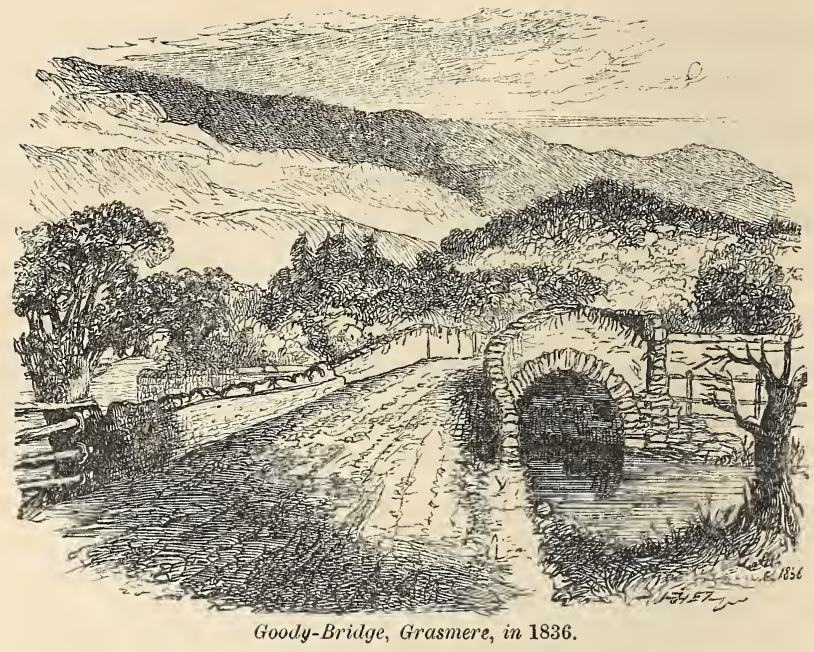

SKETCHES: SELECTED FROM JOURNALS.

From a "Visit to the Vale of Duddon." Being an Extract from a Journal among the Lakes. October, 1820.

WHEN within three or four miles of Broughton, came within sight of Black Comb, rising dark and majestic on the other side of the Vale of Duddon. Stayed all night at the Old King's Head, where I had good accommodation and moderate charge. An intelligent young man, an inhabitant of Broughton, though I was quite a stranger to him, offered to accompany me to a Druidical antiquity in the neighbourhood. At half-past eight, I set out with Mr. G., to visit the Druidical circle on Black Comb, called by the country people "Sunken Church." The Duddon here is a fine stream, requiring a bridge with three arches, up to which the tide flows. After a rather steep ascent along a rough, wooded road, we arrived at the first level of the mountain, and from a hill, had a prospect that well rewarded us; though we were disappointed in seeing "Sunken Church," except from a distance. We could perceive it in the 
middle of a field, about half a mile West of us; but a deep ravine, through which flowed a bridgeless flood, swollen by the late rains, prevented our nearer approach. The summit of the mountain beyond, was involved in clouds, but, turning to the West, we had a grand view. Broughton below, lying snugly under a grove of firs-farther South the estuary of the Duddon, filled with the tide, showed like a large lake, with two or three small vessels sailing upon it-on the other side were seen Kirkby Fell, and the fertile tract of Low Furness; and beyond, the Isle of Walney, and Peel Castle, to the South. We descended the mountain obliquely, passed Duddon Grove, and here Mr. G. and I parted. After thanking him most cordially for his attention, I proceeded alone. . . . . Pass Ulpha Mill, a new building; still travelling along the new road, with Rainsbarrow on the left. Reach the Kirk of Ulpha, a little low edifice, with only three windows on a side, and two small bells hanging side by side in the open air; no tombstones-nothing but green mounds of earth point out the graves.

It was now noon, and the sun broke out after a showery morning, and shone sweetly up the valley. I stood leaning upon the churchyard wall-the river flowing unseen on the East; by its side, two oaks, the one with dark brown leaves, the other just fading from its summer green; yellow, variegated woods on each side of the valley-a little green field on the East, embosomed in wood, with two or three Cows quietly feeding; further up and beyond-grey, rocky fells. Turning to the North, a huge craggy hill appeared to block up the dale; higher up, towards the East, still loftier mountains enveloped in clouds, their summits I have not yet seen. . . . . I pursue my way up the valley, having the Duddon still on my right-hand. Turning a little to the right, to inquire the road of a man whom I saw standing near a cottage, I was at first surprised that he paid no attention to what I said; but, as soon as he perceived 
me, he pointed to the door. I went in, and was told by his mother that he was deaf and dumb, as I had suspected; that she had two other children suffering the same privation, but that they were all able to support themselves by their industry; and had even learned to write. The young man to whom I spoke, is about thirty years of age, without anything singular in his appearance. He follows the occupation of weaving. A daughter is an apprentice to a dressmaker. It was pleasant to learn that human beings thus pitiably deprived, were able to support themselves, and become useful members of society. They had been born and had lived all their lives in this valley, but the brook that for ever murmurs near their door, has had no music for them. In the language of the poet-

"The vale, with all its streams, Is silent as a picture."

After walking about half a mile, I crossed the river by a stone bridge of one arch. No flaring gentlemen's houses-no shrubberies-no trim gravel walks-the vale still con.tinues charming from its primitive simplicity-still only shelters the "Shepherd and his Cot," amid its few green fields, and its native woods planted by the birds and winds of heaven.

I could not but stop for some time, as I came to that part of the vale opposite the tremendous chasm, of which Wallow Barrow Crag forms one side. The scenery is here so beautiful. A new white cottage on the left. Birch trees fading into yellow, thinly interspersed amongst fern and grey rocks on the mountain side-Birch, and a kind of Elm, and Alders, with a few Oaks, by the river's edge, their foliage exhibiting such beautiful variety of hues-so graceful and so wild, as to appear like enchantment.

I at length reached a small public-house, near Seathwaite Chapel, and as it was past three o'clock, and there was no 
other higher up the Dale, I determined to stay here all night.

While I was dining, I found that although a stranger, my fame had travelled before me. My landlady inquired if I had seen an old woman as I came up the Dale. I replied I had. "Yes," said she, "she called here, and said she had met with a queer sort of a man; he sometimes walked quick and passed her-then she'd come up with him again, and he asked her so many strange questions about the fells and crags, that she really could not tell what to make of him; but somehow, she thought he wasn't quite right!" I was not a little amused to find the good woman had thought me qualified for Bedlam! . . . . My worthy hostess gave me a singular proof of her simplicity and ignorance of the world-rare qualities in a person of her profession. When my bill came to be settled, she was not for charging for tea, because, she said, "I ate next to nothing!"

From "Sketch of Angling Excursion to the River Lowther." May, 1821. Contributed to the Lonsdale Magazine.

"Yes, dear to me, the angler's silent trade, 'Mid vernal peace, in peacefulness pursued, Through rocky glen, wild moor, and hanging wood, White-flowering meadow, and romantic glade."-WILson.

Set out on Tuesday, 15th May. Reached the head of Kentmere the same evening, where I was hospitably entertained, and spent the night at a friend's. Started on Wednesday morning, attended by a shepherd to direct me along the scarce-visible track which leads into Mardale, over Nan-bield. We had ascended about halfway up the mountain, when we were assailed by a shower of rain and snow, which obscured the vale and the neighbouring mountain. However, it soon cleared away, and enabled my civil guide 
to point out the sinuous path as it winds down the long hollow, lying between Harter-fell and High Street. The pass of Nan-bield, though not so high as those hills, by several hundred feet, was covered with snow an inch or two deep. I now pursue my journey alone. . . . . I have an extensive prospect, commanding a part of Hawes Water, the wide, open country beyond, towards the vale of the Eden, with Cross-fell towering high in the distance, covered with snow. Pass Small Water, a mountain tarn, said to afford" good sport for the angler; but, as the snow reached down to its margin, I did not think the experiment worth trying.

I have now a sweet view of the head of Mardale-a few green fields lying far away in the vale below; a mountain stream meandering among them, as if loath to depart-a cottage almost hidden amidst its sheltering trees, a single ploughed field near it. This lovely scene, shut out from the world on every side by steep mountains. On the right, the rugged front of Harter-fell, channeled by the fierce mountain torrents. Such is the quiet of this retired valley, that in passing a cottage, I startled the wild Pigeons from a grove of firs, close to the chimneys! I pass Mardale Chapel, a small building embowered amidst Yews and Sycamores; these latter seem the favourite tree for shelter. A few mounds of earth show the burying-place of this simple vale; no monumental stones-no epitaphs, except one on a plain slab inserted in the church wall, to the memory of the Rev. Richard Hebson, "upwards of fifty years the truly Christian Pastor of this Chapelry."

About half a mile further, I met with an old shepherd, who had most hospitably entertained a friend and myself a few years ago. We exchanged a cordial greeting, and he insisted that I should call at his house, a little farther on the road, and get some refreshment. Those who have been accustomed only to the intercourse of the great world, can hardly imagine to what extent primitive hospitality still 
reigns in these retired valleys. They place before the traveller the best fare the house affords, and would in general feel insulted by the offer of pecuniary recompense. . . . Hawes Water now opens before me, the eastern shore steep and wooded. I pass along the western margin for about two miles, the road close to the water's-edgehigh mountains rising on the left, till I reach the small village of Measand. Here are one or two good houses"learning's little tenement" is completely veiled, till you are close upon it, among its sheltering Sycamores. The lake again expands for about a mile; the declivity of the opposite shore (Naddle Forest), still finely wooded with old single trees-the green earth seen between and among them-in some places, thickly covered, - in others, in glades.

Just on the edge of the common, on the left, are some singular remains not noticed, I believe, by West, or by other authors. They consist of five mounds of earth, of an oblong shape, about a yard in height, the sides sloping from the summits, which are from two to three yards broad; their length varies from fifteen to twenty-five yards. They are known by the name of "The Giants' Graves," and extend in the direction of $\mathrm{N}$. and $\mathrm{S}$. They seem never to have been disturbed by any Jonathan Oldbuck, nor to have suffered decay or diminution, except the extremity of one, which has been trenched upon by the road, that passes close by. They are probably funereal monuments, belonging to a remote period, and raised by a people who knew not the use of letters. The vale now becomes tame and open, till I reach the plain but comfortable Inn, at Bampton, kept by honest Robin R-C. I was glad to find him "well and hearty"--displaying a somewhat greater breadth of cheek, and ampler rotundity of body; though when I last saw him, he was none of Pharaoh's "lean kine." Robin is a "brother of the angle," and dresses his own flies; of Partridgefeathers all the year round. Tom B-C, a great angler, 
used to call them his "water spiders." He fishes with strong tackle, and much need he has for it; for when he hooks a fish, he never dallies with it, but, whatever its size, hauls it out at once.

After some refreshment, I sallied out with my rod, and as the water was of a fine brown hue from yesterday's rain, I expected good sport, nor was I much disappointed. In the course of the afternoon, I nearly filled my pannier. But in angling, as in all other sublunary pursuits and pleasures, whatever Izaac Walton may say to the contrary, there is seldom wanting some bitter to dash our cup. Many a fine fish, after I had gloriously hooked him, and was full of joyful anticipation, escaped before I could draw him to the river's bank; and some, after a hard struggle, even when I had dragged them to the sandy shore, and in fancy saw them in my pannier-by one lucky leap, cleared the treacherous hook and regained their liberty. I began to think Robin's method was not so bad, after all. . . . . The next day I could scarcely kill a fish, though the river was literally alive with them, rising in all directions in the fine, large, sandy-bottomed pools of the Lowther, at a small brown fly which was creeping on the pebbly margin of the water. I tried hackle and winged flies-dubbing and no dubbing-flies of all sizes and colours, "white, black, and grey, with all their trumpery"-it was of no avail, I might as well have thrown in my hat! Neither indefatigable Joe Winne, nor even Jack Caradice, could, I believe, have tempted them, though there is only another wanting, to complete the climax! I afterwards travelled down the river to Eamont Bridge. . . . . Bampton is a station where the angler may spend a week or two with every prospect of excellent diversion. The Lowther is a fine, gravelly stream, full of Trout; pretty free, I believe, from that bane of most rivers-netting. (By-the-by, I wish all Otters and netters were sent to the - - !) Bampton is four or five miles from Ullswater and the Eamont, and two 
or three from Hawes Water (quite a pleasant walk), where the Trout is good, and a boat kept-always at the command of honest Robin.

Perhaps this world cannot afford many better things than a good day's sport by the river, or on the lake.

I have often puzzled myself to account for the pleasure that the whole of mankind, civilized as well as savage, take in the diversions of hunting, shooting, and fishing. It is said they are cruel amusements; the taking of life may be an adjunct, but it is no necessary part of the enjoyment arising from these pursuits. In many cases, I will venture to assert, it is a considerable drawback. Never will I believe that sportsmen in general, are more hard-hearted than others. How often when the bird is brought down, from his proud and apparently secure flight, by a fractured wing, and lies defenceless at one's feet, his smooth glossy plumage and bright eye showing uninjured life-how often, in that case, does it go to the sportsman's heart, to be obliged to turn executioner. He wishes the transition from life to death, to be instantaneous and unfelt. He would, if he could, always be a dead shot.

From Bampton, I set out in search of fresh streams and new landlords, but without expecting to meet with thy match, jolly Robin! Thou wast sorry, no doubt, at our parting, thou most jovial of hosts ; nor will I cynically endeavour to estimate how much of thy grief was owing to my loss, as a companion, and how much as a guest. Peace be with thee! and mayst thou never want a hearer for thy jokes, or a customer "with money in his purse." I know that thou hast had, erewhile, some that were wanting in that essential - but thou didst not send them away empty on that account. When I visit thee again, may there be plenty of water in the Lowther, and ale in the cellar, and may they be much of one colour. . . . The Lowther 
winds through beautiful meadows for about four miles, till it reaches the magnificent Park of the same name, where the declivity becomes more abrupt, and the river tumbles and roars over a rocky bed, overhung with stately trees. The church of Askham is sweetly and snugly seated on its western bank; a turretted dwelling stands near itAskham Hall. On the opposite side, the cupola of Lowther Church is seen peeping above the trees. In passing through the Park, I had a view of the castle, which was glittering in the sunshine, like some gorgeous Eastern palace, or castle of romance-for it scarcely seemed to belong to this everyday earth. Nor can I describe the noble and extensive Park-its lofty and beautiful trees-the rich and romantic scenery that surrounds it-the glorious barrier of Western mountains, seem blue in the distance; the peak of the lofty Helvellyn prominent above them all. While, on the East, the extended range of Cross-fell rises almost as high. A short distance from the path, under a fine Elm, were seated a couple whom I took to be lovers. Looking out upon these magnificent trees, hearing the songs of birds, and "the unseen river's gentle roar," sitting on the soft green grass in the gladdening sunshine, with the mild Spring air coming about them so "wooingly"--he must indeed be a poor lover who is not successful! Bachelor as I am, how could I help envying this Strephon such a scene for wooing his Chloe?

At length, emerging from the park, I passed through some fine meadows, till reaching the London road, where it crosses the Lowther, I lingered awhile on the bridge to admire Brougham Hall. . . . . Its white turrets just peep over the luxuriant trees amidst which the house is situated. About one hundred yards from the bridge, on the left, is Arthur's Round Table; a circular green area of fifty paces across, surrounded by a hollow which has probably been a ditch. In the middle of the large circle, is a lesser one, somewhat raised, of twenty-five paces. 
On inquiring of some workmen for Mayburgh-another remnant of remote antiquity-a neat young woman came from an adjoining house, and with great civility directed me by a near way to it, through the fields. I had to climb over a wall bearded with thorns. There was a ladder standing near, which she attempted to place upon it for my accommodation. Fair maiden! never will the stranger forget this simple, unaffected act of kindness-may thy goodness of heart, which is far more valuable than beauty, acquire and secure to thee, that return of tenderness which can alone bring happiness to a disposition like thine!

Mayburgh is a circle of eighty or ninety yards in diameter, surrounded with an immense ring of small stones, loosely thrown on each other, about twenty or thirty yards in breadth, rising several yards in height, and with trees and bushes growing upon its surface. In the middle of the area is a large red stone, in an erect position, upwards of three yards in height.

On my return across the Lowther, I espied a being standing by the water's edge, just below the bridge, of a most lugubrious aspect. How shall I describe his appearance and the habiliments with which he was clothed? He wore a slouched hat, waistcoat he had none-and his tattered coat was fastened over his breast by a single button-a coat or cloak, either name was equally descriptive-his lower limbs of garb were disarrayed. He was an angler. Supposing him to be fishing with the artificial fly, I civilly inquired "what colour they took this morning?" He turned up his dingy face (he was no Mahometan), and exhibiting his yellow teeth, said that "I seemed not to know what he was fishing with." I ventured to draw a little nearer, and found that he was angling with the natural May fly, one of which he drew from the perforated horn in his girdle, and impaled on his hook. I know nothing more of this character than that his name was "Jack," the appellation by which he was familiarly greeted by a town-looking beau, who stood 
on the bridge looking at his movements. He seemed to be a most killing fisher, if one might judge from the dimensions of the creel at his back. After all, I have perhaps done him an injustice; his acerbity of temper might be momentary. Perhaps the fish would not bite. He may, in his general disposition, be as quiet and as peaceable as other Anglers.

The next Notice is more recent, and merely an Extract from a Note-Book.

June 30, 1847.- Started about seven o'clock for Sedbergh. Went on Nep-through Burneside and Lambrigg. It was a warm, sunny morning, and the people were all busy among the hay. At the crossing of the railway at Garnet House, there was a train in sight, and I had to wait a few minutes. I very thoughtlessly did not dismount, when the velocity and noise of the train frightened the pony so much, that it leapt backward and forward, and had nearly thrown me off its back. I really felt thankful that it had not, in its madness of fear, rushed upon the line. Passed by a bridge over the railway at Grayrigg toll-bar; about a mile further turned to the right, and passed Docker Garths, near the viaduct of five or six beautiful, tall arches; then Mosergh Hall on my left, and came to Lambrigg Park, an inn on a wild moor. From thence to the Kendal road, about a mile. Saw a Curlew flying on the moor; it was piping its beautiful wild note, that had such an effect on the poet Burns, as to move him like strains of the highest poetry. Came within sight of the Reservoir of the canal; it looks, with its arms running up among the heathcovered hills, like a lake placed by the hand of Nature, not of man. There are plantations springing up on one sideand it has an island, I believe. Arrived between twelve and one o'clock at Sedbergh. After seeing two flag-dealers, I 
remained for the night at the Black Bull. Next morning rode to Dent. Warm and sunny, and the farmers in these fell dales all busy at the hay-induced by the weather to begin somewhat prematurely, for them. The grass thick, and other crops, potatoes as well, looking healthy and flourishing.

After a short rest at Dent, rode up Deepdale, one of the forks of Dent, to the South. The green fields almost all hay-grass. Here and there, sprinkled on the steep sides of the dale, are small barns, called hog-houses, which reminded me of the chalets in many of the Swiss valleys. Went over the pass into King's-dale. On going down the declivity, it is interesting to notice the strata of these mountains, as they lie upon each other. First, there is the limestone lying lowest; then a bed of grit, then another band of limestone; which is surmounted, if $I$ am correct, by another stratum of grit. This valley has something peculiar in its aspect, quite different from the lake valleys. It is green, but naked and treeless; two or three miles long, and rather broad and flat in the bottom; the stream that traverses its whole length, though at present its channel is almost dry, must, from its width, be a full and furious torrent in a rainy season. It had changed its course in several places. The vale is nearly uninhabited; I think there is only one solitary farm-house. I had the long ridge of Whernside on my left. Its highest part-Capel-rigg-is said to be seventy feet higher than Ingleborough. In ascending the road that leads from the lower end of King's-dale, the broad crown of Ingleborough, coming into sight over the sloping back of Whernside, has a fine effect. I should state, that in going down King's-dale, you perceive at least six terraces, one above another, on the limestone scar; they appear to correspond to each other on the two sides of the valley. On the extreme edge of the uppermost terrace, on the right, there were two or three huge Boulders, that seemed so nicely balanced, that a blast of wind might precipitate them on the 
head of a luckless passenger. They bore a great resemblance to those huge stones that sometimes rest for a short time, on the extreme edge of the lower part of a Swiss glacier.

\section{ROMAN WALL.}

Being on a journey this Autumn at Brampton, in Cumberland, I felt a great desire to view the remains of the Roman Wall in that neighbourhood. Accordingly, on the 9th of August, being a fine morning, a walk of about three or four miles on the Longtown road, brought me to the village of Newtown, through which the Wall is said to have passed. From thence to Carnbeck Hill, about a mile East, the footpath goes near the foundation of the Wall, no part of which, however, is visible - the plough having made a path where it stood. Yet the hollow of the ditch is very distinct through the fields - the lane, in one part, running along its bottom. At Sandy Sike, the house and barn are placed upon the site of the Wall. Mr. Calvert, who resides here, says many of its materials were used in his buildings. He showed me a stone in his garden wall, with the carved figure of a trident; another with an inscription, but not legible. They appear to have been Roman altars. He says, the foundation was in some places paved; in others, the Wall was built on flat stones.

Went through Walton (Wall-town), a village on the site of the Wall. Here there is a comfortable public-house. Indeed, all along, farm-houses and hamlets have been raised upon this grand monument, on account of the facility of procuring excellent stone. To this we may ascribe, in some degree, its almost total disappearance; though, in many cases, no doubt, its materials must have been removed to a considerable distance.

Just after passing the King's Water River, near a farm- 
house, the foundation of the Wall (stones and mortar) appears very distinctly in a field on the left of the road. Still the Wall could not be traced, were it not for the ditch, which forms a hollow, almost always visible, running through the fields, and along the sides of the hedges and field-fences, which are often placed on the very line of this famous military barrier.

Came to a farm-house called Garth Side. Some haymakers in a field on the East side of the house, pointed across a hollow, to a place, where I should see some remains of the Wall. And here, indeed, I was not disappointed; for along the side of the field, forming its fence on the South, for a distance of perhaps two hundred yards, I found a veritable remnant of this grand antiquity - consisting, indeed, only of the interior of the Wall-stones irregularly imbedded in rough mortar, rising in places to the height of five or six feet, with a quick-hedge on the top, the roots twisted and intertwined among the materials of the old Wall.

Thence, over an eminence, to Hare Hill; the ditch on my left, in places, newly mown, with hay standing in cocks in the hollow. At Hare Hill viewed another grand fragment, ten feet high and five yards long. Passed through Bawks, a village on the site of the Wall. Here I had the good fortune to meet with Mr. Holmes, the respectable schoolmaster of the place, who accompanied me as far as Burdoswald, and to whom I am indebted for the sight of a beautiful gold coin of the Emperor Nero, found in this village, about twelve months ago, by a labouring man, in whose possession it still remains. It is about the size of a half-sovereign, but much thicker, and the gold of a lighter colour. The impression of the head of Nero is full and distinct, and so are the letters round the border, JMP. Nero CEASAR AVG., with the exception of the first three, which have been curtailed by the blacksmith's file, into whose shop it was taken on being discovered. It dropped from a sod used for the coping of a wall. On 
the obverse is a female figure, seated, with the word salvs underneath. We are now on the turnpike road leading from Brampton to Gilsland, which has been made for several miles on the foundation of the Wall, having the ditch very distinct on its left. About a mile from Bawks, in the fields to the right, we saw two other ditches, running parallel to each other, and to the great Wall on the North. So that there had evidently been three lines of defence, formed at different periods. One of them, it is said, by Agricola. The fences on both sides of the road appear to have been made by robbing the old Wall, as pieces of mortar still adhere to the stones of which they consist.

On coming near to Burdoswald, I am highly gratified in finding more distinct remains of the Wall than any I had yet met with. For a distance of about a quarter of a mile from that place, the lower part of the Wall forms the modern fence on the right, the front or facing stones, appearing distinctly in several places; while on the other side, next to the fields, for the length of 100 or 200 yards, you see the lower part of the beautiful old Wall, at least four or five feet high, as perfect as when first erected. For this pleasure travellers are indebted to the late spirited owner of the estate, who, about twelve months ago, employed workmen to remove the rubbish, and has thereby laid bare a greater portion of its outer surface, than is elsewhere visible, through the whole of its course. I believe, indeed, there is hardly any other part, where the facing stones remain. They are here of an oblong shape-a grey sandstone-from a foot to a foot and a half long, and laid in regular tiers. These old Romans seem to have been excellent masons. The seams are what is called "broken;" that is, the upper stone is invariably placed across the interstice formed by the meeting of the two lower.

We next viewed the Camp or Station at Burdoswald (the Amboglana of the Romans). It stands upon a large plain, at the head of a steep descent towards the river Irthing. 
The Castrum forms a parallelogram of nearly two hundred paces, North and South, by a somewhat shorter length East and West. The rubbish has been here also lately removed from the South and West sides, which leaves the face of the camp wall visible, to the height of five or six feet. There has been an opening on the South, ten yards wide; and another on the West, four yards; which latter has been walled up by the Romans. The Great Wall formed its northern boundary ; close to which, and within the area of the camp, stands a farm-house, with a barn and other out-buildings. More towards the interior, are the ruins of more ancient edifices, probably Roman. There are remains of other buildings outside the camp on the South East.

We went into the farm-house, where we were shown some antique curiosities, which had been found when they were clearing the walls. There were fragments of broken pottery, a brass buckle with tongue, hammer heads and picks, horns of deer, \&c. ; but the most important were two Altars, on one of which was an inscription: we could only distinguish CUKURS IIII.

Besides this interesting and lucid description of a portion of the great Roman Wall, there are jottings which, in addition to furnishing an outline of this Cumberland journey, show also, one of the many directions taken by his mental acquisitiveness. They are comprised in a common fourpenny book, and associated with all manner of farmer's memorandums-notices of weather, ornithological scraps, titles of books, geological arrangements, \&c. \&c.

It is a pity that in connexion with the state of the Roman Wall, no year is given. The page in this book, next following, has the date 1835, and his route confirms the supposition that this journey was the continuation of one made to his relations at Ouseby, in 1834. His route was Kirkoswald.

Nunnery-upright Pillar, 1088.

Armithwaite-wear-castle-forest of Baron Wood.

Curnwhitter-Grey Yands-Dr. Circle. 


\section{Curlatton to Brampton.}

Naworth Castle-Lanercost Priory-Burdoswald-at Upper Denton a Roman Station-Gilsland-Bewcastle-Runic Pillar in churchyard-a Roman Station-in the area stand the Church and ruined Castle.

Glenwhilt, near Gilsland-Roman Wall, high enough for a man to break his neck by a fall.

At Wall Town (near Great Chester), on each side of the door stands a Roman altar, used for washing hands, \&c.; this is 2nd station in Northumberland, about six miles from Burdoswald. At a house called Hare Hill, a little west of Bauks burn, is a fragment of the Wall standing, 10 feet high and 5 yards long. This is near Lanercost Priory.

In the same Scrap Book, in connexion with a Visit to York, are the following Notes, indicating his route, \&c. :-

Sedbergh-Hawes-Askrigg-Aysgarth, 4 m. East of Askrigg -Cascades above and below the Bridge-the Force at Heaning, a curious fall of water-Hardrow Force, 5 miles West of Askrigg, ¿ stupendous cascade, 90 feet-Middleham-Castle ruins-3 miles E. ruins of Jervaulx Abbey-Redmire-village on the Urefine prospect from Preston Scar-Leyburn, on the hill on opposite side of Ure-fine prospects-Bolton Hall, Mr. Pollit'sWantley Bridge of 4 arches, beautiful rich scenery-MashamHackfall, 7 miles N.W. from Ripon, a deep and gloomy vale, grand views from some eminences-Grantley-Bremham Rocks, about 1 mile from Hackfall, and 9 from Ripon-rocking stones, largest two, weigh 100 tons each-Cannon Rocks-perforated stone, supposed to have been a rock idol, 46 feet in circumference, rests on a stone as pedestal only $1 \mathrm{ft}$. by $2 \mathrm{ft} .7 \mathrm{in}$.

Ripon-Studley, 3 miles S.W. from Ripon-pleasurè grounds among the finest in England-three-quarters of a mile from the house, in a valley, through which runs a small stream from Fountain's Abbey, 6 fine Yew trees S. of the Abbey.

Borough Bridge-The Arrows - $1 \frac{1}{2}$ mile E. is Aldburgh ancient Isurium.

York-Museum-Irish Elk found at Tramore, Waterford, by 
G. L, Fox, November, 1836-ancient busts of Cæsar-M. J. Brutus, Cato, \&c.-Altar from Delphi.

Castle Howard-Paintings-Finding of Moses; Herodius with Head of John Baptist; Adoration of Christ by Wise Men; Henry 8th; The 'Three Maries, an excellent picture-Kirkdale joins Kirby Moorside-Caves-curious old Saxon Church, year 1065-Wensleydale.

Caterick Bridge-Richmond-to Reith grand views-Pen Hill, beyond West Wilton-Swale on left-Marske, beautiful, green, wooded valley-Mr. Atwood's elegant house-fine richly wooded country-Reith.

\section{From Journal of a Short 'Tour, in Angust, 1855.}

We had (A- and $\mathrm{I}$ ), a very pleasant and interesting short journey, in our little gig, to the eastern part of our county. We set out, on the 16 th, by way of Low Borrow Bridge. On reaching Grayrigg Hause, I was struck by the changed appearance of my old acquaintance, the green, smooth-faced Carnigill, as I used to see him in former years when I came a fishing. . . . In the evening, as we could not be accommodated at Borrow Bridge, we drove on to the Cross Keys, Tebay, where we lodged. Here they were very busy with the hay, as was the case everywhere in the elevated parts, during our journey. The weather being fine, it was very pleasant to see the haymakers working with might and main-not as hirelings, but every family getting in its own winter stock. Passed Cotflat Mill, and over Orton Low Moor, where I had once a capital day's shooting. Then by Sunbiggin Tarn, and over the bare open pass to Asby. These wide, desolate moors yield a great delectation to $\mathrm{A}-$ - in which $\mathrm{I}$ cannot say I altogether sympathize! After a long descent, with continued haymaking, we reached Soulby, a well-peopled village, where we lunched-pony and humans. The beauty of our equine companion was much admired by the girls at 
the Inn, and we dare say they will talk of our visit for many a day. Thence to Little Musgrave, where we came upon the Eden; afterwards, to near Warcop; then, retracing our steps a short distance, we proceeded up a pretty, rich valley (the farms large), to Kirkby Stephen-haymaking still the chief business. Lodged at the King's Arms, Miss Powley's, a Lowther inn in former times of furious politics, which used to cause me to domicile at the Black Bull, when I came this way. But we forget all this. Miss $\mathbf{P}$. is getting old (74), a staunch Tory still; takes the John Bull, the Times, too- 6 it is so much inquired for," though she "cannot abide it."

Besides Camel, our pony, we had Nelly, our little dog, as compagnon de voyage. Nelly, at the King's Arms, was placed in the stable, as a proper lodging; but when we retired to our bed-room, a rapping on the floor was heard. This was Nelly's tail, wagged for joy, which, in her crouching attitude, hit the floor at every wag. The poor little dog had escaped from the stable, entered the inn in the dark, and not finding us below, had run up stairs and discovered our dormitory.

Next morning, travelled South, towards Mallerstang, crossing Stenkrith bridge, where the stream of the Eden is absorbed by deep clefts in the sandstone rock, and in which it has formed round holes, "potts of the linn," by whirling stones when the river is flooded. Thence, through Nateby, and passed on the right Wharton Hall (now a farm-house), once the seat of the noted Duke of that name, who died in Spain, a traitor and an exile-according to Pope, "in the worst inn's worst room," but as we were informed by an intelligent person at Nateby, in a convent. The ground about the house still appears park-like, with scattered trees, and we had the ancient park wall on our right for some distance. In another mile or two, reached the ruins of Pendragon Castle, close to the Eden. A- stayed awhile to sketch, whilst I went on to the Inn to wait for her. As 
usual, the people here busy with the hay, their only harvest-no cereal or green crops. Mallerstang is a most primitive valley, and must be little changed since the time of the Duke. As no carts could keep the perpendicular on the steep slopes at the upper part, they use sledges to house their hay, placing it in the numerous small barns scattered in the fields. The sledge-horse is often saddled, and therefore mounted both to and from the barn, so that no time may be lost. They may well work at this time, for it is the only labour, properly speaking, they have during the year. We wonder how the men pass their time in the Winter, having nothing to do but look after their cattle and sheep. As they cannot bring the hay to the cows, they must take the cows to the hay, which will cause them more trouble in Winter, in dealing out the fodder, and bringing home the milk. The people here, as in the neighbouring Yorkshire dales, are mere shepherds and herdsmen, nothing more; have much the same employment as when the valley was first settled. There is no more change than in China! Agricultural societies may meet at Carlisle-what is it to them? They are satisfied with the ways of their fathers! They are the best of agricultural Tories. They ignore all improvements; they have not even reached the era of draining, which might help their land a little, one might think, from its swampy appearance.

Secluded as Mallerstang is, strangers, in these railway times, sometimes find their way into it. We were amused on meeting two haymakers coming from their dinner, natives of the "Gem of the Sea," when, in answer to some question of A-_'s, one of them replied, with characteristic quickness, "Indeed, ma'am, I cannot tell; I'm as ignorant as yourself!" This was candid.

Went through the pass between Westmorland and Yorkshire. Here the waters divide; those to the North being carried by the Eden into the Irish Sea, below Carlisle; while to the South, they feed the head of the Ure, and flow 
into the German Ocean at Hull. Cold and stormy as this elevated pass must often be in the Winter, it has three houses of entertainment, at no great distance from each other, for man and horse; so that the traveller need not want shelter or other comforts. At the last of the three inns, The Moorcock, we turn to the right, down Garsdale to Sedbergh, ten miles.* . . . We slept at the Black Bull, at Sedbergh, a capital little inn; and returned next day home, by way of Natland, Sizergh Hall, and Helsington.

* The effects of the downfall of water in Garsdale, as also at Borrow Bridge, being related elsewhere, are left out of this journal. 


\section{IVORDSWORTH'S PROTESTANTISM.}

Perhaps no author who eventually attained such a high position in the world of letters ever passed through so severe an ordeal as the late Mr. Wordsworth. To say nothing of a hostile literary criticism, which, as a bold poetical reformer, he might have expected, rejecting as he did a vague, artificial diction, and restoring to poetry the language of truth and natural simplicity, he has been assailed even on religious grounds with undeserved reproach. In his earlier life, chiefly from that fine burst of impassioned poetry, "Lines written at Tintern Abbey," he was accused of being a Pantheist! Then a writer in Blackwood's Magazine, we believe, asserted that the "Excursion," imbued as it is throughout with a spirit of pure and elevated religion, "6 was wanting altogether in Christian doctrine." And the first of our Reviews, the Edinburgh, commenced a criticism on the "Excursion" with the pithy oracular sentence, "This will never do." We know how the prophecy has been fulfilled; it was almost as far astray as the dictum of a writer (Winstanley), who, in his "Sketches of the Lives of English Poets," said of Milton, his contemporary, that " his fame had gone out like the snuff of a candle."

These reflections have been suggested by reading in your journal, of the 2nd inst., the report of a speech delivered at Kendal by Mr. D., of the "Protestant Alliance Society," in which Mr. Wordsworth is accused of being "No special friend to Protestantism; his writings were one of the principal causes of the late great revival of ceremonial and priestly religion in this country."

Now, sir, to those acquainted with Wordsworth's poetry, and who, moreover, enjoyed the privilege of his conversation and friendship, not a word need be said in refutation of the charge. To them it is well known that when the Catholic 
Relief Bill was passed, he was warmly opposed to it, as affording increased power to a religion in its essence agressive and intolerant, and therefore he was not very likely to assist in building up a half-way house to Romanism in the national Establishment: indeed, some of his friends at the time were surprised at what they considered his exaggerated fears of Popery. But it would appear as if the poet had had a presentiment of the cloud that was coming in a few years to overshadow his beloved Church of England!

A poet who composed verses from the age of twenty, or earlier, till, within a short time of his death at eighty, would be likely to produce some of apparently, if not really, opposite tendency, according to the various moods of his mind, as well as the different points of view from which he would look at the same object. It is probable that Mr. Wordsworth, in some of his writings, is thought to feel too much indulgence and sympathy with Romanist worship and observances. But in countries where Romanism is the prevailing religion, how much better is it to perceive in it what is good-what is consolatory to the afflicted worshipper - than to close up the heart, as English Protestants, we fear, are too apt to do, and view the worship and worshippers with unmitigated contempt. Surely one may remain a true Protestant, and yet not be insensible to what is good in the belief of every Christian community. We are certain Mr. Wordsworth was such. Among his poems written during a tour on the Continent are many beautiful pieces, which, from the delightful spirit of charity they breathe, cannot but be dear to the hearts of all liberal-minded. Christians, as well as to the lovers of poetry. We think we may be pardoned if we give one or two quotations :

Composed in one of the Catholic Cantons of Switzerland.

Doomed as we are our native dust

To wet with many a bitter shower, 
It ill befits us to disdain

The Altar, to deride the fane,

Where simple sufferers bend, in trust

To win a happier hour.

I love, where spreads the village lawn, Upon some knee-worn cell to gaze;Hail to the firm unmoving cross, Aloft, where pines their branches toss! And to the chapel far withdrawn, That lurks by lonely ways !

Where'er we roam-along the brink Of Rhine-or by the sweeping Po, Through Alpine vale, or champaign wide, Whate'er we look on, at our side Be Charity! to bid us think, And feel, if we would know.

The abbey of Einsiedeln, in Switzerland, is resorted to, from a hope of relief, by multitudes from every corner of the Catholic world, labouring under bodily or mental affliction. The following is from "Descriptive Sketches of the Alps," written by Wordsworth, when a youth of twentyone :

'Mid savage rocks and seas of snow that shine

Between interminable tracts of pine,

Within a temple stands an awful shrine,

By.an uncertain light revealed, that falls

On the mute image and the troubled walls.

Oh ! give not me that eye of cold disdain

That views undimmed Einsiedeln's wretched fane,

While ghastly faces through the gloom appear,

Abortive Joy, and Hope that works in fear ;

While prayer contends with silenced agony,

Surely in other thoughts contempt may die.

If the sad grave of human ignorance bear

Ono flower of hope-oh pass, and leave it there : 
The rigid Protestant may think this too favourable to Catholic superstitions; but surely a phase of the Christian religion which has lasted so many centuries cannot be an unmingled evil. Men do not preserve institutions, civil or religious, for the evil that is in them, but for the good. Evil, as such, can preserve nothing,

To those who know Wordsworth's noble sonnets on national independence and liberty (nobler or more spiritstirring there are not in the language), it must seem the most obtuse stupidity to represent him as an enemy to civil or religious freedom. But as our chief object was to show the poet's Protestantism, we shall cite on that matter the following from the "Ecclesiastical Sonnets," and we do it the rather because a friend of the poet, writing to us a few days ago, says, "I remember well, in speaking to me on this very subject, he referred to his sonnet entitled ' The Point at Issue,' as permanently recording his conviction respecting the controversy between Romanism and Protestantism."

\section{The Point at Issue.}

For what contend the wise! for nothing less

Than that the soul, freed from the bonds of sense,

And to her God restored by evidence

Of things not seen, drawn forth from their recess,

Root there, and not in forms, her holiness ;-

For Faith, which to the Patriarchs did dispense

Sure guidance, ere a ceremonial fence

Was needful, round men thirsting to transgress-

For Faith, more perfect still, with which the Lord

Of all, Himself a spirit, in the youth

Of Christian aspiration, deigned to fill

The temples of their hearts, who with His word

Informed, were resolute to do His will,

And worship Him in spirit and in truth.

Here we cannot do better than again quote our valued friend:- "The attentive reader of this sonnet who sees 
how the poet, in it, extols the Reformation as the victory of the wise, reclaiming religion from a degrading thraldom to forms and ceremony, will scarcely think that his writings can be justly charged with a tendency unduly to exalt what is merely external. We affirm that a careful study of them all, will leave perfectly undisturbed the impression it produces, and satisfy the reader that the well-balanced mind of the bard, while seeing and feeling the beauties and affecting associations connected with the exterior of religion, and its consolatory effects on ignorant and simple-minded worshippers, yet ever assigned to its spiritual essence, the paramount importance belonging to it."

Wordsworth's fame has been a hardy plant of slow growth-

“ Never hasting, never resting,"

like the motion of the stars-surviving the roughest weather, frosts, and storms, till, like the Oak or the Yew, it has become a stately tree, to endure for ages, if not as long as the language itself in which his poems are written.

An Aduirer of Wordsworth and his Poetry. 


\section{To John Davy, Esq., M.D., Ambleside.}

Borderside, 28th Oct., 1856.

Dear Sir, - In reply to yours (dated 22nd Oct.), I have certainly no objection to your sending my account of the thunder-storm to the journal you mention; but rather, feel proud that you should think it of sufficient interest.

You would, doubtless, read in the newspapers, at the time, a notice of a very heavy fall of water, attended by thunder, that occurred at Borrow Bridge, on the Lune, on the 8th August, 1855, if I remember correctly. About a week after I visited the place, accompanied by my wife, on a journey we made to some of the eastern parts of the county. There was something so tremendous in the havoc this storm had occasioned, that I am sure you will excuse me, if I endeavour to describe some of the most prominent effects we witnessed.

At Grayrigg Hause, we first came in sight of the Lune Valley. Carnigill, East of the Lune, a mountain with a smooth, green surface, is right opposite, but it was now furrowed with numerous gutters and red streaks, caused by the sudden rush of water down its smooth declivity. In the stone wall at its foot, there was a large gap, twenty or thirty yards, at least, in width, which had been made by the impetuous flood; and in the fields below, an immense mass of earth and stones, covering about an acre of it. The road a from the house to the Inn is a long descent. There is a new stone wall on the right of the road, and on the other side, the mountain rises pretty steeply. This wall in one or two places was washed down, and the road, in part, covered with stones, soil, and gravel. In one place, a complete land-slip had occurred; a part of the mountain side, with the green sod at the top, had slid across the road, so as to 
prevent the passage of carriages, till a part of it had been removed.

On reaching the Inn, we were told the rain fell and the flood entered the house quite suddenly, when they were at dinner, after going in from the hayfield. We saw that, in running down the lane below, towards the Lune, it had worked itself a channel, about two feet deep. But the greatest havoc was East of the Lune.

After crossing the bridge, we went up a lane towards a farm-house, just under Carnigill. It was rendered quite impassable for carts-a channel of from two to three feet deep, being furrowed in the middle of the road. But what shows more convincingly than anything I have mentioned, the immense mass of water thus suddenly precipitated, was that the hedge on our left, through which the water had passed into the lane, was covered with grass and wreck to the height of at least three feet; and recollect that this body of water had flowed down the smooth side of a mountain, and had not been absorbed in the ghylls, as would have been the case in a common heavy thunder shower.

It seems to me, that if the contents of one of our small lakes (Esthwaite Water, for instance), could have been suspended over the summit of Carnigill, and then suddenly let fall, is would not have produced a heavier or more overwhelming flood. Mr. Day, the landlord at Borrow Bridge, told us, that this shower (it was a shower in the valley below, with loud thunder) did not cover an area of much more than a mile in diameter. Is it not rather strange, that this huge mass of aqueous vapour should reach the top of Carnigill before it met with a body of cold air, to change it into water, and that so suddenly? Doubtless, electricity is also an active agent in these heavy rain-falls, though it would appear that in some cases the fall is heavier than rain. The atmosphere, on the day I mention, from whatever cause, was in a state to produce phenomena very similar, at no great distance, though not so violent as at 
Borrow Bridge. On the Cross-fell range of mountains, opposite to Warcop, we were told, the downfall of water was so heavy as to come down the sides of the hills, as it were, in sheets_-"white as sheets." And in Garsdale, ten or twelve miles from Borrow Bridge, the same afternoon, there was almost as violent an inundation as at that place. We passed down Garsdale on our return, and certainly the havoc it had made, by covering the unmown grass with sand and stones, was no trifle. Here also the flood had not confined itself to the ghylls, but had swept down the bare mountain sides, and so through the walls into the fields and into the houses. Some of the narrow lanes that lead to the farm-houses on the slopes, were ploughed up by the torrents. One we noticed, that had a neat gate close to the road; this was thrown open across the road, and blocked up to the top with stones and rubbish, so that there was neither ingress nor egress till they were removed.

This storm in Garsdale did not seem to have extended more than about a mile in breadth. In travelling the length of the long valley, we went across the track of the deluge, and saw the ravages it had made on both sides.

The country people call these heavy down-fallings, waterspouts, but I think incorrectly; for water-spouts, from what I have read, besides being of a different appearance and character, take place at sea and not on the tops of mountains; neither should these down-fallings be confounded with thunder-showers - the water falls more suddenly, and in a greater body, and such down-pourings are of more rare occurrence. A brother of mine, once, coming down Kentmere on a fine day, was surprised to see a heavy gush of water descending the bed of the river, with a crest in front of it, like that of a high tide. It must have fallen suddenly on High Street, or the upper part of the stream. The most remarkable of these water-spouts (if we must call them so) that one has heard of, as having fallen in our part of the Northern Mountains, took place about a century ago, 
near the head of St. John's Vale, when a corn-mill was entirely swept away, mill-stones and all! One of which has never been found to this day; it is supposed to have been buried under a huge mass of wreck, deposited on a meadow below.

To one so little acquainted with the dark science of Meteorology, it might be more becoming to confine myself to mere narration. But one likes to inquire into the why and the how. I know not whether the common opinion, that these débâcles are water-spouts, is founded in any observed facts, though a shepherd may, at one time or other, have been surprised by one on the hills.

The question the Meteorologist has to solve is, how a fall of rain (that is, small globules of water) could so suddenly produce a volume of water of such weight and force, as to tear off the tough grassy surface of the mountain, and plough it into trenches, carrying the great mass of detritus into the fields below. Does it not seem that a large body of aqueous vapour, being lodged in clouds, touching the top of the mountain, had suddenly been condensed, and so flowed down its slopes-and other parts having to fall some depth into the valley below, became divided into drops, and so fell in heavy rain.

I would not have troubled you so much at length on this Borrow Bridge deluge, had I thought it had been noticed as much as its peculiar character deserved.

I have said but little about the devastation in Garsdale, for fear of overwhelming you with details. At the Inn where we stopped to dine, the torrent came down the road in such depth as to flow into the parlour and other parts of the house, two or three feet deep. At a cottage on the hill side, near a ghyll, the flood entered; timely help arrived, but the inmates, an aged couple, had a narrow escape of their lives.

Allow me to add a word or two as to the appearance of the thunder-storm, to near observers, as well as to those 
at a distance. Mr. Day, of the Inn, told us they had just gone in to dinner from the hayfield. Suddenly the sky was overcast, the rain poured down in torrents, and the water flowed through the house. On going out, he observed through the clouds that hung over Carnigill, a kind of opening or pale bright spot. This was singular, because the main weight of water had fallen on Carnigill, on the East side of the valley, although on the Borrow Bridge side, West of the Lune, it had come down the declivity in great force. I well remember the day the storm occurred. It was a hay-day with us, and the farmer was carting his hay, but there was a threatening, thundery appearance in the clouds. I was at the front of our house, and my attention was directed towards the East, from whence proceeded a long rumbling sound of thunder. This was at the time the storm was raging at Borrow Bridge. There was no striking appearance of blackness, but a bank of clouds, white on the upper edge, hung in the horizon over that place, which is about twelve or fourteen miles from Borderside, as the crow flies, and I suppose thunder can be heard that distance. I have omitted to state that it was our intention to travel down the East side of Lune to Sedbergh; but we were told that some of the bridges over the brooks were washed down, and the road so obstructed that it was utterly impassable.

I know not whether you will quite go my length in being impressed by this remarkable phenomenon, and I fear I have been somewhat lengthy, but I could wish there had been here a Sir Thomas Dick Lauder (who so well and minutely described the Moray floods), to employ his pen on this occasion.

I am, Dear Sir,

Respectfully yours,

W. Pearson. 
In November and December, 1845, W.Pearson read two Papers on Glaciers before the Natural History Society. They were an able compendium of the results of the most recent inquiries into the structure, movement, effects, \&c., of Swiss Glaciers. The writings of Messrs. Agassiz and Charpentier, formed the text of the papers, collated with the still later investigations of Professor Forbes. But as further and more minute research brings to light the imperfect character of hitherto accepted data, modifications in the deductions drawn, follow ; therefore the concluding part of his second Paper (as coming from himself) will alone be given. 
CONCLUSION OF A PAPER ON GLACIERS.

Read before the Natural History Society, in December, 1845.

WHEN our great dramatic Bard, by the mouth of one of his characters, talks of finding

"Tongues in Trees, Books in the running Brooks,

Sermons in Stones, and good in every thing,"

he exhibits the wisdom of the true Poet and Philosopher. There is doubtless no object in nature, but may teach a lesson to the reflective mind. But when Shakspeare, more than two centuries ago, spoke of finding "sermons in stones," he seems to anticipate modern discovery-nay, almost to manifest the prophetic spirit! For in his day Geology was not. Men had not yet learned to examine the various rock formations, nor to draw from their hidden chambers the effigies of those wonderful creatures, that, in long past ages, had walked the earth, or inhabited the depths of the sea. But if our subject have nothing to do with Rocks in situ, or their curious contents, it does seem to be connected with that powerful but mysterious Agency, which has transported those numerous fragments of rock, now found scattered over the earth's surface, so many miles away from their birth-place.

I will now endeavour to describe, as simply and clearly as I can, certain phenomena which $I$ have observed in our own neighbourhood, and in the district of the Lakes, which, although on a smaller scale, appear to be very similar in kind to those we have already dwelt upon as existing in Switzerland. We have also our erratic Boulders, though 
they are of a size in proportion to the diminished magnitude of our mountains. They seldom exceed ten or twelve feet in diameter, whilst those in Switzerland, as already mentioned, are from fifty to sixty feet. No one perambulating our beautiful country, but must have noticed those pieces of rock, strewing the plains, resting on the slopes of hills, and often, oddly enough, perched upon the top of a hillock, or ridge. A large stone in so unlooked-for a situation, has not failed to arrest the attention of the Poet, and to supply him with a simile :-

"As a huge stone is sometimes seen to lie

Couched on the bald top of an eminence,

Wonder to all that do the same espy,

By what means it could thither come, and whence;

So that it seems a thing endued with sense,

Like a Sea Beast crawled forth, that on a shelf

Of rock or sand reposeth, there to sun itself."

My knowledge of Boulders was acquired as a farmer, rather than a geologist; and to a farmer they are by no means agreeable acquaintances. Certainly, my knowledge of them was far more intimate than I liked. About twenty years ago, I purchased a farm in the Winster Valley, near Bowland Bridge. The land lies low and warm, and is fertile enough; but when I came to examine it closely, I found it terrible stocked with Boulders. They lay in a kind of irregular band across the valley, in places, thickly scattered like a flock of sheep, sparing neither ley land nor meadow, so that I might have exclaimed with Hotspur:-

"See how these cursed stones come cranking in, And cut me from the best of all my land, A huge half moon, a monstrous cantal out."

As I said, they occupied a rather wide band, covering some of the best land in the estate. There might be a few stragglers, but the main body bivouacked within the lines. They were like a horde of sturdy Saxons, who had invaded 
the fertile valley, and could not be expelled by the ancient Britons, the original possessors of the soil. It was evident they had been too strong for my predecessors, both owners and occupiers-yet they were, in American phrase, only squatters-they had no legal right whatever to the landstill they had been long in possession. What was to be done? I was determined to eject them at whatever cost. I had an advantage over my predecessors, inasmuch as I lived in an enlightened age, when the Arts and Sciences had made great progress. I, therefore, called in the aid of a powerful auxiliary - a certain dark-coloured, granulated material, manufactured somewhere near Sedgwick, and which indeed has won many battles, besides that of the Boulders! With the assistance of this potent Ally, I destroyed hundreds of them, and with their bones (or fragments) erected stone walls of such strength and solidity, that I verily believe they will be found standing as firm and erect as ever, in the year 2000-barring earthquakes! At that time I was no geologist. I did not puzzle myself as to how they had come, and from whence; my only care was how to get rid of them. I have compared them to Saxons, but, soberly speaking, they were no Saxons-not even so much as foreigners; they were from the North certainly-some of them from the high mountains; these, being far-travelled, had the most smooth and polished exterior, but they were the most coarse and cross-grained within, and were, consequently, the most difficult to manage. The greater number had their corners and angles unbroken and rough, and had evidently come from no great distance; but from whence and in what manner, is still the inquiry of the inquisitive geologist.

I cannot but think, that I was indebted for this shower of stones to an antediluvian Glacier, that at the period of its retreat and decay, had, unluckily, made a halt in this part of the valley, and there unloading its broad back, had formed a terminal Morain. This is my theory. Indeed, I 
may as well state at once, that there are many phenomena in our valleys, that convince me that they have, at some former period of the earth's history, been occupied by Glaciers of greater magnitude than any that now exist in Switzerland. I have come to this conclusion, chiefly from the position of many of our erratic Blocks, from the appearance of ancient Morains, but more than all, from the numerous scratched and scored rocks to be found in our district.

It has often appeared to me impossible to account for the occurrence of erratic Slate Boulders on our limestone hills, by the agency of streams of water. If we grant the possibility of an enormous marine wave, overflowing the land to the height of 1,000 or 1,200 feet-and it must have risen to that height to have covered our limestone mountains, and have deposited the Blocks where we now find themwould it not have left them on the bottoms of the valleys, rather than have lifted them over those steep escarpments to the North and West which are found on Kendal Fell and Whitbarrow? A few years ago, there was a large Block of hard, flinty slate, lying on the North end of Whitbarrow, at no great distance from the steep cliff it must have ascended; and there is at present, on the same mountain, opposite to Pool Bank, a Boulder of many tons weight (it has been split by lightning), and it is not far from the steep, overhanging escarpment, overlooking Witherslack. Whitbarrow has some Boulders lying within a few yards of its highest point. Perhaps I ought to mention, that on Whitbarrow they are often found lying near together, to the number of five or six, apparently from the same parent rock. This is the case also in Switzerland. The position of Boulders on Kendal Fell is quite as remarkable. I will only mention those to the right of the road leading from Kendal to Underbarrow, near the lime-kiln at the top of the Scar, and near the edge of the cliff. Most of them, from their hardness and want of cleavage, have evidently 
been brought from the Middle Silurian region, and could only have reached their present site by ascending the steep escarpment that rises to the North and North-West. The same may be said of that large one, weighing many tons, which lies near the Race Course. Arnside Knot, Haverbrack Fell, the hills near Lindale-indeed, all our limestone hills, are sprinkled with Boulders from the slate rock. But I know of none more remarkable, as showing the utter improbability of their having been conveyed by water, than those on the limestone of Hampsfell above Grange, lying on the very edge of the steep escarpment to the West, and near the highest point of the fell. At the southern extremity of that range called Kirktown Fell, dividing Crosthwaite from Underbarrow, there is a wide expanse of smooth rock, on the middle and highest point of it, there is a large Boulder. It would certainly be marvellous if any stream of water could have conveyed it thither.

May I now, for a moment, draw your attention to those large, swelling hills to be found in most of our valleys. In form they are sometimes circular, but more frequently oval, or elongated in the direction of their enclosing valleys. There are several in the vale of Kendal, between that town and Burneside; also in Selside and Grayrigg. There are two or three in the Ings Valley, and in Underbarrow. In Crosthwaite there are five or six, and of sufficient magnitude to have acquired names. There are Bend How, Kirk Bank, Oak Bank, Foulhain, and Elleray. They are each of twenty or thirty acres in extent, and are divided into fields. There is in Grayrigg one very similar to these, which has been laid open by the railroad, and which I recently examined. It seems to consist of a mass of rounded pebbles, gravel, sand, and clay. It had also contained, below the surface, two large erratic Blocks of hard, flinty slate rock, rounded by friction, and which must have been brought from the Middle Silurian region. It is to be hoped, that the numerous railway cuttings will throw 
more light on the nature and origin of these round smooth hills.

With respect to those other collections of stones, gravel, and sand, generally termed Diluvial, from an opinion that they have been deposited by extraordinary currents of water-all those which I have examined seem much more to favour the conclusion that they are the result of glacial action. Their whole materials are mingled together in most " admired disorder" -without stratification or regard to specific gravity-so far from this, often the heaviest blocks lie uppermost. But whatever may have been the agent or moving power in our valleys, it has certainly proceeded from the North or North-West. I will mention two or three facts that would seem to prove this. On the left of the road leading from Lindale to Grange, there is an excavation where you find fragments of the slate and limestone rock mingled together. This could only be caused by some agency proceeding from a northerly direction, or it could not have brought the fragments of slate rock. The same may be said of a sand quarry on a farm of Mr. Wakefield's, near Sedgwick, where I have noticed a similar disorderly mixture of limestone and slate fragments. But, perhaps, the most interesting fact in regard to this part of my subjeet may be found on the left of the road from Bradley Field to Cunswick, where, in sinking to procure road materials, you will find deposited on the limestone mountain, an unmixed mass of gravel and sand from the Silurian rock, and which must have been transported or lifted over the steep escarpment to the North.

I believe it is the opinion of most geologists, that these miscellaneous collections of Drift and single Boulders are of the same age, and have been deposited by the same agency, whatever that may have been. Now, I should like to inquire of Professor Phillips, or of any other advocate of the Diluvial Theory, how it happened that the same huge 
cataclysmal wave, when it swept over the land, should leave this light sand and gravel just on the edge of the cliff, and convey that enormous Race-course Boulder half a mile further? For whatever water power may be created or called into action, we must insist upon its being regulated by the same laws of Nature as prevail at present, in our humblest streams.

Greology makes us acquainted with many strange revolutions. If this globe, with "all that it inherits," in the words of our illustrious President (Professor Sedgwick), be the effect of Omnipotent Power, with an eternity to work in, we ought not to be slow of belief in the most wonderful changes, for which we think there is sufficient evidence. And yet it does seem an amazing thing, to be told that this beautiful part of the earth's surface, our dwelling-place-these sweet green valleys of our Lake district, with their fair houses, the comfortable homes of so many human beings - to say nothing of the countless number of inferior creatures-all rejoicing in that existence bestowed upon them by their bounteous Creator-it does seem a most improbable belief, that these abodes of so much enjoyment, should at one time (and that not distant, geologically speaking) have been covered up, hill and dale, with one enormous ice wrapper! To those who have not considered the evidence, this must be thought the most improbable of propositions. So it appeared to me a few years ago. But now I think appearances are conclusive, that, at one time, this fair district of ours, with all its lakes and hills, was enveloped in a pall of ice, and that, consequently, all vegetable and animal life was non-extant.

It is curious that we may, without recognition, pass by daily, for years, phenomena that are sufficiently plain when we direct our attention towards them. The North-American Indian, it is said, can trace the footsteps of his enemies through the trackless forests, by marks only apparent to his practised eye. 
If we find in our Westmorland valleys, mounds of sand, gravel, and Boulders, similar in composition, and occupying like situations to those ancient and existing Morains in the Swiss valleys, it does not appear unphilosophical to attribute to them the same origin. I believe we have several, and will mention two or three. In Kentmere, near the bridge, where the Tarn had formerly its outlet, there are eminences with scattered Boulders on both sides of the valley, which, to my eyes, have every appearance of an Ancient Morain. There are others, I believe, in the hollow above Kentmere Hall, on the left of the road that passes over Garbourne to Troutbeck. There is a collection of large Blocks and other débris at the upper end of Underbarrow, near a farm-house called Beckside, which, in my opinion, bear's strong evidence of a glacial origin. It appears to be a Terminal Morain, and to have stretched across the valley and up the hill-side to the West, but which has been cut across by the Underbarrow beck, near to the old Malt Kiln. The same Glacier, on its retreat, seems to have left a fine specimen of a Lateral Morain, by throwing off along the edge of Bell Hill, on the East, in an irregular line, about sixty large Boulders.

I will only mention another, but which I consider exhibits indubitable evidence of being a Terminal Morain. It is near Crook Mill, and close to the road side from Kendal to Bowness. In its confused mingling of materials, it has all the character of a Morain-but it has stronger evidence than this. It has lost much in bulk from being used as a quarry to repair the road; but this loss has been a gain to the curious geologist; for in carting away the sand and stones, there has been laid bare, one of the most interesting specimens of a scored and striated rock that $I$ am acquainted with. It seems to have been immediately covered up by the falling rubbish from the back of the Glacier, and by that means preserved as in a cabinet, in all its pristine freshness and beauty. This little Morain formerly possessed 
a magnificent Boulder, reposing near its summit, but I am sorry to find it has been robbed of it lately. It has been blasted and broken up for repairs at Crook Mill. What a pity! Were there no stones in all Crook, that they must needs take this?

Before I quit the subject of Morains and Boulders, I ought to mention that I am acquainted with four instances, in my own neighbourhood, where erratic Blocks, of a long, slablike form, are found fixed into the earth, standing erect on one of their ends. It is not easy to conceive how this could take place, on the supposition that they had been transported by water. Whilst, on the contrary, if they fell from a Glacier, they might easily take this position. There is one in a pasture field near Hollin Hall; another close to the farmhouse at High Crag, Underbarrow ; and two in Crosthwaite ; one of them in a field that was common, a few years ago, and therefore very unlikely to have been set up by the hand of man.

It is well known to those acquainted with the Upper Silurian formation, that it frequently presents rounded and smooth masses of rock of considerable extent. Tilted up, as it is in general, at a high angle, it must have been rugged and bristled on the surface, at its first upheaval from the sea. But, however incalculable the time that has elapsed since its elevation, it is clear, that the disintegrating power of the atmosphere could not have brought this rock into its present smooth and rounded condition. There can be little doubt, that it is the result of the grinding movement of ancient Glaciers over its surface ; but the grooving and stria which would have appeared on these polished surfaces have been obliterated, wherever they have been exposed to the elements. It is only where the rocks have been covered with soil, that you find this evidence of glacial action.

Not many years ago, the commons were enclosed belonging to the townships on the West of Kendal; since that time, the farmers have dug up the soil along the road sides, 
to carry to their fields, and thereby have exposed the surface of the underlying rock. It is by this means that the geologist is presented with so many specimens of polished, scored, and striated rocks. These stria and groovings are always parallel, or nearly so, to each other, and elongated in the direction of the valleys. The scorings vary from an inch in breadth, to lines as fine as if made by a graver.

I will now note down a few places where they may be seen. They may be distinctly noticed on the left of the road from Kendal to Bowness, near Bonning Chain; also not far from Staveley, on the side of the road to Hollin Hall-opposite to New Hall-where there is an extensive surface of polished rock. Also, near High Crag, at a turn in the road, and near Blake Bank, both in Underbarrow; the latter is on the elevated road leading to Red Scar, and 300 or 400 feet above the base of the valley. There are also rocks distinctly marked in Crosthwaite, near the sixth milestone on the old road from Kendal to Ulverstone; and about half a mile further on the same road; also near Green Thorn, Colin Field, and Strawberry Bank, in Cartmell-fell. Rocks, beautifully scored, may be seen also near William Robinson's farm-house, at Lindeth, near Bowness. These stria are more readily found in our valleys than in other localities of our northern mountains; but I have seen them by Haws Water ; and have been told they are finely exhibited below Coniston Old Man. I have seen them myself on the road side between Santon Bridge and Nether Wastdale, and in the gorge of Borrowdale.

As we find Boulders seated high up on our hills, it becomes interesting to ascertain how far we can discover these groovings and stria on the rocks at a similar elevation. I have observed them on Applethwaite-fell, and near Crook Hall, which latter I think is about the height of Kendal-fell. Not long ago, I was highly gratified to find these traces of Glaciers on the rock at the edge of a tarn, near Mr. I. Bolton's, Crook, and at the summit of the 
chain of hills that divides Underbarrow from Crosthwaite, and at least 700 feet above the sea level.

It would be interesting to ascertain the exact height on our highest hills, from which those primeval Glaciers have descended. One day, since our last meeting, I went as far as the East side of Windermere, with the purpose of trying to gain some light on this part of our subject. I ascended the mountain from Blake Holme, through one of the large forests belonging to Mr. Wakefield. My first piece of good fortune was to light on a large erratic Block, of about nine feet in length, six feet in breadth, and about three feet in depth, resting on a shelf of the steep mountain side, and at least 800 or 900 feet above the level of the Lake. It had a smooth surface, with corners well rounded, and was of that hard, flinty description of rock, without cleavage, belonging to the Middle Silurian region, about the head of Langdale or Grasmere. If this Boulder were transported by an enormous rush of water, it certainly is curious, how, contrary to the law of gravity, it should have been deposited on the steep side of the mountain, and not in the bottom of the Lake below. In my further progress up and over the mountain, I found two other Blocks, at a still higher elevation. But my greatest piece of good fortune was to discover, at the side of the road which runs along the upper boundary of Lutherburn Park, a rock surface, distinctly scored and striated. This is within 300 or 400 feet of the highest point of Cartmel-fell, named Birk-fell, and which, I think, must be at least 1,500 feet above the sea level. I found other scored rocks, in my descent of the mountain, on the eastern side.

It has been supposed by Mr. Lyell that Boulders have been dropped by Icebergs, and that the scores and stria upon certain rocks have been also caused by Icebergs moving over them. A fact I have become acquainted with, seems to go far to prove, that in our district it could not be the case. There has lately been formed a reservoir, high 
up on the hill-side, near Golden Rock Cottage, in order to supply Crook Mill with water. In digging away the soil from its interior, the surface of the subjacent rock has been uncovered; it is striated and scored in the usual manner. But on the South of this water basin, that is, on the side towards the sea, there rises close to it, a steep little eminence from sixty to a hundred feet high. Now, if at one time this part of the valley had formed an estuary, it seems impossible for an iceberg floating from the sea to have produced these marks by sliding over the rock, the intervening hill would have prevented it.

I might here urge other arguments in favour of the glacial hypothesis; but my Paper is, perhaps, already more than sufficiently long. I cannot conclude, however, without stating my firm conviction, that the phenomena that $I$ have enlarged upon must be ascribed to Glaciers. The notion of currents of water is, I think, utterly untenable. To only mention the Shap-fell granites; how many currents, moving in different directions, would have been required to effect their dispersion? One from nearly every point of the compass. But my business is with facts, rather than arguments, and perhaps it requires an apology for hazarding so confident an opinion, in opposition to Mr. Phillips and other eminent geologists. Mr. Phillips states that the transit of the main body of the Cumberland erratic Blocks, must have been caused by the sweep of an enormous marine current, passing over the land from the North and North-West, because the greatest number of boulders have been carried South and South-East. I will conclude with the mention of my observations, made during a short tour this Autumn, and which I think have some relation to this opinion of Mr. Phillips.

Having viewed the numerous Blocks of Syenite that have fallen from the eastern flank of Carrock-fell, and there lie heaped one upon another-on my ride from Mungrisdale to Greystock, uver that bare, open, moory district, I took par- 
ticular notice of the kind of Boulders scattered along the edge of the road, the fragments of which composed the walls that bounded it on each side. They consisted of indurated, flinty, blue Slate rock, apparently from Helvellyn and its neighbourhood. Now had they been brought by a torrent, flowing from the North-West, they should have been Skiddaw slate, and Syenite from Carrock-fell. However, I could not find one Boulder belonging to either of those rocks; therefore, the conclusion seems to be inevitable, that their means of transport had been a Glacier, resting on "the brow of the mighty Helvellyn;" or, if this will not be allowed, that, at least, the moving power, whatever it may have been, had proceeded from that quarter, and not from the North-West.

There is a phenomenon produced by Glaciers, which, perhaps, I ought to have mentioned, as it would appear we have something of the kind occurring in our district-this is "perched blocks." It often happens that Glaciers surround the salient points of rocks, and funnels are formed round these, by the melting of the Glacier. When the Glacier sinks and retires, Blocks which have fallen into the funnels are often found perched on the point of the rock which occupied its centre. When similar points of rock project above the Glacier, their flanks are clothed with Blocks that surround them on all sides, and end in forming a kind of crown about their summits, as the Glacier sinks or retires. Currents produce nothing of the kind; on the contrary, when a torrent breaks against a salient rock, the Blocks or stones it carries down, turn round the rock, and form a train more or less regular, a little way below. In like circumstances, a Block can neither stop on the top nor on the flank of a rock; for the force of the current being accelerated by resistance, the Block is carried with violence to below.

In conclusion, to use the words of Charpentier, "though 
the facts stated may not be denied, neither the conclusions drawn from them; yet many persons will find it difficult to familiarize themselves with these results; they will experience a kind of repugnance to yielding their assent to the views which have been developed-not so much because they deem them erroneous, or are struck with the want of exactness in the exposition of facts, or shocked by false reasoning or hazardous suppositions, as because the geological phenomena on which the opinions are founded, are not familiar to them, and are out of the range of those natural agencies which are daily before their eyes. Indeed, the number of persons who have seen currents of water, and have witnessed their effects-who have seen diluvium and alluvium-is infinitely greater than of those who have seen Glaciers and Morains; and, above all, greater than the number of those who have observed and bestowed upon them close attention. It is not astonishing, therefore, that all the phenomena of a diluvian epoch, and the dispersion of erratic débris, should be ascribed to water. It appears so very natural, even to an imagination not particularly lively, to create, without any effort, currents a thousand times more considerable than those now existing; and this is the more easy, because in reference to diluvian phenomena, the imagination does not disquiet itself about the possibility of such currents, in the regions which it assigns to them; neither about their origin, volume, rapidity, force or direction, still less their effect. Thus, for example, some one to account for the transit of erratic blocks, begins by imagining a formidable current or débâcle, of 2,000 or 3,000 feet in depth, without accounting for the origin of such a mass of water. Then, in order to carry blocks of more than 60,000 cubic feet, over the basins of our lakes, he endows this current with a speed of hundreds of feet in a second, without regard to its depth, or the slope of the ground;-afterwards, to deposit these enormous blocks 2,000 or 3,000 feet above the plain, he bestows on this débâcle a consistency muddy and 
thick enough to support them on its surface. In order to account for scattered blocks, he has recourse to a second débâcle, less formidable than the first; the water clearer, for it has not to form deposits; it has no other object than to free the large blocks from the finer débris, in which they are supposed to have been buried. To these same currents, on which he has conferred such an enormous volume, and such extraordinary rapidity, he ascribes also, unhesitatingly, the deposition of diluvium formed of alternating beds of pebbles, gravel, sand, and mud; beds which are often so irregular and thin, as to exclude all idea of débâcle or impetuous torrent. In short, is it anything more extraordinary, more unwonted, that there should have existed a Glacier 60 leagues long, with a surface of 200 square leagues, and a thickness of from 2,000 to 3,000 feet, such as must have been the diluvial Glacier of the Rhone, than to imagine such torrents as those of which I have spoken?"

Our Author concludes by expressing a hope, that the theory he has been demonstrating (the glacial) is neither chimerical nor absurd; but that, on the contrary, it merits to be studied and discussed by geologists and naturalists. 


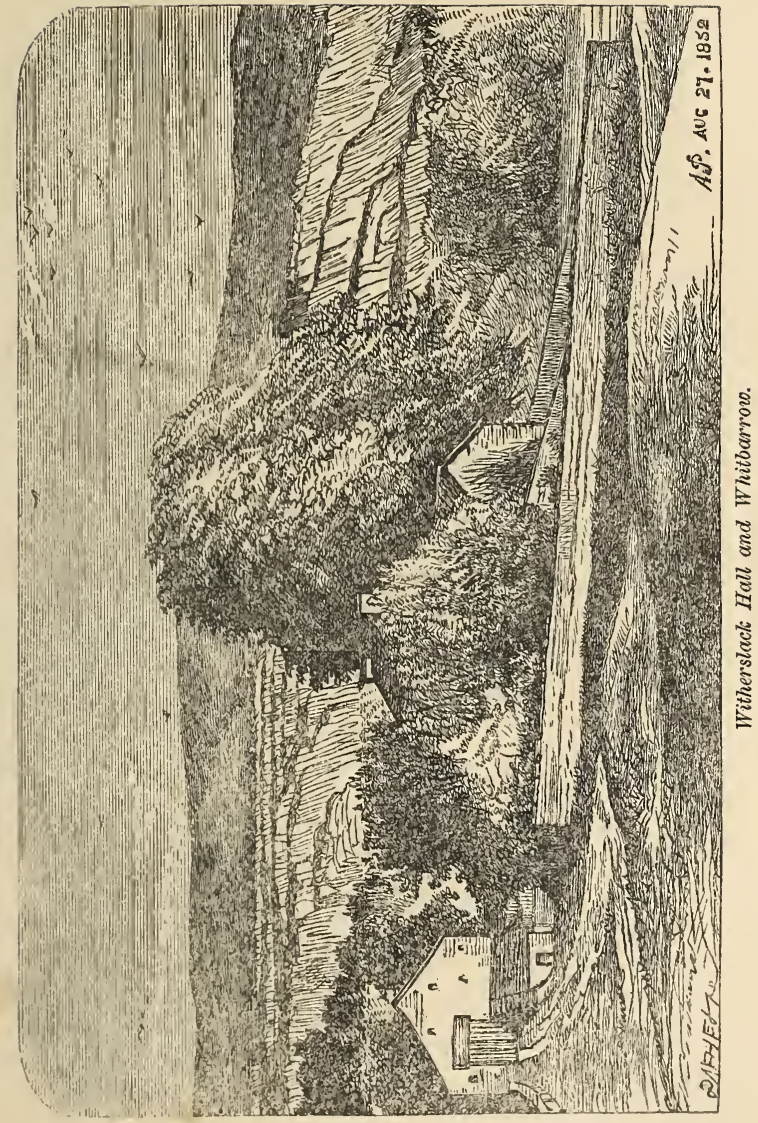





\section{SONNETS.}

WHEN faint and weary with the hum of men, Blest Fancy! I will woo thy soothing power ; My wafted spirit at the evening hour Shall seek my early childhood's scenes again; And by thy magic aid, my native hills

Shall in their rude and simple grandeur rise, Pour down their furrowed sides the foaming rills, And hide their misty summits in the skies. And see I not that sweet sequestered vale,

And the snug cot where first I drew my birth; With extacy its every feature hail,

For I shall love it till the hour of death!

O Heavenly Father! speed the time away,

That I once more among those scenes may stray. 1806.

Sweet is the calm and silent hour of eve, Just when the sun with mild and softened ray Gilds the fair landscape; then be my lot to leave The smoky town, and wend my willing way To the green fields; and like to him released

From the dim horrors of a prison's gloom To the bright light of day-so I, well pleased,

Will hail sweet Nature's influence, and the bloom That smiling Spring throws o'er her beauteous face ;-

And for those scenes of vice and wretchedness,

That crowd the haunts of man, mind eye shall trace

Thy lowely scenes, O Nature! and I'll bless Thy healing power, that to my sickened mind, Doth peace restore, when grieved for human kind. 1806. 
ON LEAVING THE PLACE OF MY NATIVITY.

As here upon this mountain's western side,

I sadly linger, with a farewell look

Cast on the expanse below,一fair Nature's book

Of hill and valley, far outspread and wide;

How many a long-remembered scene I trace!

Scenes of my sportive or my musing hours,

When Nature on the virgin fancy pours

Feelings and forms, that time can ne'er efface. And though when in the city's crowd I mix,

Dear native vale! thy simple mountain stream-

Green meads-woods-rocks-across my mind will gleam

At eventide; - yet ah ! no spot will fix

Within my heart, like yon secluded shade,

That from the world conceals Maria, lovely maid!

November 8, 1808.

ON READING IN THE NEWSPAPERS THAT BUONAPARTE HAD

ARRIVED AT VITTORIA, ON HIS INVASION OF SPAIN.

YE patriot bands! how awful is the time,

When in the perilous fight, ye must withstand,

The man who scourges with a giant hand

The nations. $\mathrm{O}$, with an energy sublime,

Truly to live resolve, or dare to die!

Bravely stand forth-arm for the God-like cause,-

Your Independence, Liberty, and Laws;

The tyrant challenge, and his aims defy!

Think of your native homes-your native fields-

Your vine-clad hills-those tender ties more near-

Friend, parent, sister, wife, and children dear!

Your children's children, should your courage yield,

Must crouch abject. Then, O ye patriots brave!

Repel the foe-or find a glorious grave!

November 26, 1808. 
ON THE SAME SUBJECT.

Methinks 'tis like the calm that reigns awhile,

Sad and presageful of the coming storm,

Which mars each fair variety of form,

And robs the face of Nature of its smile.

"Yet not for things inanimate I mourn,"

The sunny hour will soon their tints restore.

But when, to man, shall his lost joys return?

Him, on the plain, who welters in his gore?

Him, life's endearments never more shall charm,

Yet shall he live in history's ample page;

Iberia's sons, his bright example warm

With love of Liberty, from age to age!

Storms, by the tyrant raised, shall pass away,

And Freedom's sun illume a glorious day.

November 29, 1808.

\section{"THE RESTING-STONE." *}

LET kings and conquerors from the crowd obtain

The noisy plaudits that to them belong;

And courtly poets celebrate in song,

The men who load their kind with grief and pain.

For me, no idle raptures need I feign

To praise that Worthy, far above the throng,

Who raised this Stone, and made its shoulders strong,

To ease the heavy laden. Not in vain

At morn, or dusty noon, or evening dim,

This seat is ever here. The rosy maid,

With rural fare in basket neat and trim,

On market morn receives its welcome aid;

The burthened pedlar; weaver pale and slim;

All bless the hand "the Resting-Stone" that laid.

September 30, 1818.

* $\Lambda$ bout a mile from Rochdale, on the Manchester road, are two upright stones, supporting another laid upon them, and held together by strong iron bolts. The letters I. C., probably the initials of the benevolent builder, and also the date, 1755, are cut in the upper stone. 
TO WORDSWORTH.

WoRdsworth! to thee what praises shall I bring,

Or how convey the high respect I feel

For that oracular gift, that can reveal

The depths of human feeling, and can fling

A radiance o'er the common flowers of Spring;

Of doubt and weariness our spirits heal,-

And deeper griefs, we from the world conceal?

O pure and lofty Bard! do thou still sing

Those songs endeared to many a gentle breast,

As of that Lady, lone and sorrowing,

With her dumb friend in Rylstone's drear domain :

Or if thy genius would, at our request,

Of that poor, lost Recluse, resume the strain,

Out of his dread despair, to give him rest.

October 4, 1818.

THE WIDOW AND HER PONY.

A Ballad, founded on Fact.

Poon Brough! when I've seen thee return from the plough, O'erlaboured and lean, I could almost have cried, To remember the day when thou'dst nothing to do,

But bear my loved husband in gladness and pride.

Poor Brough! "that with covetous spirit I sold,"

I wish that for thee a green pasture I'd kept;

Till in plenty and ease, with thy mistress grown old,

Thou hadst sunk down in age, and then peacefully slept.

And yet in the sale, when thy lot I thought hard,

And that labour and hardships might soon make thee die,

To place thee more easy, no money I spared;

Thou art now with my farmer, and under my eye. 
And often I've stolen, when no one was near,

To see that thy rack was well furnished with hay: For 'tis often but sparely replenished, I fear;

They feed thee but poorly, whatever I say.

Poor pony! whenever I see thee I sigh,

And think of my husband and daughter so dear; And of days once so happy, for ever gone by ;

I have lost those I loved,- - and thou only art here.

'They are gone, do I say? and, alas ! thou'rt not mine!

But if money can buy thee, thou shalt be ere night; And a field I'll reserve, which shall ever be thine, Dear pony! for pasture, for ease, and delight.

Neither cart, plough, nor harrow, shall ever again Embitter with toil thy poor remnant of days;

A snug shed I'll provide, to defend thee from rain, In the sweet daisied pasture wherein thou shalt graze.

March 8, 1821.

THE MAID OF CARTMEL FELL.

A LOVElY maid has blest mine eye, Of her I dream, for her I sigh ; And yet her name I must not tell, But she's the pride of Cartmel Fell.

O what a world of magic lies

Within her blue and heavenly eyes!

I know on whom she's cast a spell, This charming maid of Cartmel Fell.

How sweet and modesí is her smile;

It would all care and pain beguile!

I'd happy be in hermit's cell,

With this dear maid of Cartmel Fell. 
Let others seek for wealth or fame, For honours bright, or sounding name; No tongue I wish my praise to swell, But thine, fair maid of Cartmel Fell.

If I but once could gain thy love, No earthly care my soul would move; For I in Paradise should dwell With thee, sweet maid of Cartmel Fell. 1821.

TO THE RIVER WINSTER.

Thovgr small thy stream, and all unknown to fame, To me more dear than those of prouder name, Derwent, or Duddon, or renowned Dove,Clear-flowing rivers, which the Muses love. Nor can I think upon my early days, And all their harmless joys, but thee I praise. While yet a child, I've chased the butterfly Along thy meads, thy current murmuring by; Or in the woods that rise above thy banks, I and my boy-companions played our pranks; There did we hunt the Con* with merry glee, Quick glancing, like a bird, from tree to tree. O harmless hunting! ours had all the joy, Without the deaths that other hunts alloy; For if we shouted loud, we had been taught, The timid Con, through fear, would soon be caught. We shouted loud enough, till we were hoarse, But still the Con held on its airy course.

And then on holidays, with what delight We sought birds' nests, from morning until night, In Spring's sweet season: and O, what joy to see At length the Crow's nest, in the timber tree, 
Upon its topmost bough, high hung in air ;

What could poor school-boys do, but on it stare?

But soon a stone, sent with direction true,

Would rouse the Crow, and show the nest was new.

$\mathrm{Oh}$, now for courage, skill, activity,

To mount up high, to climb the lofty tree!

With many a tug and strain behold him rise;

He gains the top-he sees the longed-for prize.

Now in his pocket placed, the brittle ware,

A safe descent requires his utmost care;

But not so much the breaking neck or limb,

As breaking eggs, is what perplexes him!

Then see him landed, after all his pains,

And mark the blameless glory that he gains !

And in the heary time of after life,

When buried in the midst of noise and strife

In trading towns; if intermission sweet

I sought from my dull toil, my fancy fleet,

Was straight amid thy vernal meads and flowers,

Thy hanging fields, wild woods, and leafy bowers.

Nor could I think of beauty on this earth,

But still 'twas seen with thee-as if thy birth

And mine had been together.

Now at ease,

And free to wander wheresoe'er I please,

What charms I find along thy simple stream,

Beloved Winster! such as I may not dream

To seek, where tender bards have spread a glory,

By elegy, or song, or pastoral story.

Than Nith or Yarrow thou art yet more dear!

Nor must I now forget, that it was here

Where first I learnt to lure the sposted fry,

With taper rod and "well-dissembled fly;"

And even now I love the lonely sport,

As in the years gone by; and oft resort 
To thy loved banks, when vernal rains imbue Thy sweeping current with the choicest hue. Befits it then the angler's skill to uphold, Which tempts the Trout to show his sides of gold Soft gleaming through the wave.-Consuming care And purblind fear forgot. Meanwhile the air, Balmy with smell of fragrant leaf and flowerThe river's changeful murmur-all hath power To cause a sweet oblivion of past years Of vexed unrest; of pain; of worldly fears Which wisdom never sanctions.

\section{I indeed}

Must praise thee, gentle river! for the meed Of many gifts ; but chiefly for the sense Of rural pleasures, and the influence Of natural beauty on the mind and heart. And though in early life compelled to part From thee and thy sweet scenes-amid the mass Of moneyed worldings, all unfit to class ;Yet still for this I loved thee even more, Yea, far more deeply than I knew before; And when from weariness I sought to flee, Sweet sylvan stream, my spirit turned to thee.

And now, fair river! if thy poet may His parting benediction on thee lay;May busy manufacture never dream To raise his prisons on thy pastoral stream, Nor taint thy waters with unwholesome stain ; But when discoloured, let it be with rain Of heaven-which onward bears a fresh supply Of various food, to all thy sportive fry. Still may the rosy urchin of the vale Be free to ripen in the untainted gale; Here still the youthful angler's skill be tried, And rustic lovers wander by thy side. 
IMPROMPTU,

On receiving a Snowdrop, enclosed in a Letter, from Dorothy Openshaw.

"WEE modest flower!" the firstling of the Spring, What could induce thee thus so far to move?

A silent messenger, yet quick to bring Glad tidings of an absent Sister's love!

6th February, 1846.

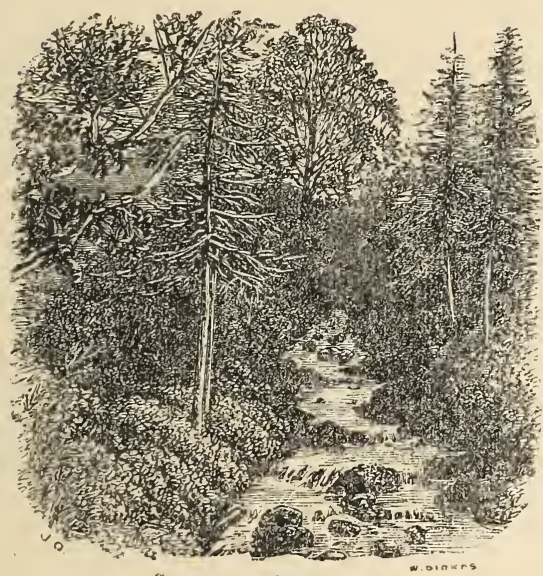

scenery on the minster. 



\section{A P P E N D I X.}

\section{A (Memoir, p. I I4).}

Ann Greenhow was born at High House, Stainton, in the parish of Heversham; she was the eldest daughter of John Greenhow, one of a firm of five brothers, woollen manufacturers in Kendal. Her mother, born Ann Relph, was a native of Penrith, and contemporary with Dorothy Wordsworth and Mary Hutchinson, who were her associates in girlhood.

Ann Relph was descended on her mother's side, whose maiden name was Atkinson, and who was born at Spout, in Crosthwaite, from Thomas Cartwright, Bishop of Chester-and through him, it the authority of Chalmers and other writers may be relied on, from Thomas Cartwright, "the Father of English Puritanism," or, as Fuller styles him, "the chief of the Nonconformists."

Bishop Cartwright was born at Northampton, September I, I634. "His father was for some time, master of the endowed school of Brentwood, in Essex, and appears to have been educated in the religious principles that prevailed among the anti-episcopal party. His son Thomas was entered of Magdalen Hall, Oxford, but removed to Queen's College by the parliamentary visitors in 1649 . He became Chaplain of this college and also Vicar of Walthamstow, in Essex." In I659, he was made domestic chaplain to Henry, Duke of Gloucesterprebendary of Twyford in the church of St. Paul ; of Chalford in the church of Wells - afterwards a chaplain in ordinary to the King, and rector of St. Thomas Apostle, London, and created D.D. though not of standing for it. To these were added, in $6_{672}$, a prebend of Durham, and, in 1677 , he was made dean of Rippon. In the reign of James II. he succeeded to the bishopric of Chester, "for boldly asserting in one of his sermons, that the King's promises to Parliament were not binding!" "The most remarkable event in his life, was his acting as a commissioner in the memorable attempt made by James to control the President and Fellows of Magdalen Hall, Oxford, when they rejected a popish President intruded on them by the King."

Upon the Revolution he went to France, where he officiated as chaplain to the Protestant part of James's household-and he was also 
made titular Bishop of Salisbury on the death of Dr. Seth Ward. "He accompanied James to Ireland, where he died of dysentery, April I5, I689, and was sumptuously interred in the choir of Christ Church, Dublin."

The following outline is inscribed to Cuthbert Cartwright G-

In strong relief with the career of the Courtier is that of his more noble-minded ancestor, the Confessor,-Thomas Cartwright, whose name is inseparably connected with one of the most remarkable and important periods of English ecclesiastical History.

He was born in Hertfordshire in 1535 , one year before the birth of Queen Elizabeth. Early indications of unusual abilities led his father to send him to Cambridge, where at the age of ${ }_{5} 5$, he was entered as a student of St. John's College. On Queen Mary's accession, the Master, 24 Fellows, and many of the scholars, among whom was Cartwright, were forced to quit the University. He then became "a clerk to a counsellor-at-law, of Lincoln's Inn," but continued to prosecute his favourite studies. This barrister, happening to be in company with Dr. Pilkinton-who on Elizabeth's coming to the throne was made Master of St. John's-named to him his clerk's strong attachment to Literature, and his studious habits. Cartwright was introduced to Dr. Pilkinton, "who, convinced of his great abilities and attainments, offered to take him back to St. John's, to which his master consented." Soon after he was made a Fellow-and three years later, one of the Eight Senior Fellows of .Trinity College, and afterwards Lady Margaret's Divinity Reader."

"From the commencement of his academical pursuits, he formed the habit of intense application, to which he adhered all the rest of his days, and he allowed himself only 5 hours sleep, through the subsequent stages of his life." - - As Professor, the students flocked to his lectures, and "he became so famous as a preacher, that when it came to his turn to preach at St. Mary's church, the sexton was obliged to take down the windows, on account of the multitudes that went to hear him." When Elizabeth visited Cambridge in ${ }^{5} 5_{4}$, "in the philosophy act" for which "the ripest and most learned men " were appointed, (the questions to be discussed were "Is Monarchy the most Eligible kind of Government," and "Is the frequent change of laws dangerous"-) "Cartwright and Preston, men memorable as the leaders of the two great schools of thought, were rival disputants before the Queen."

It was not long, however, before Cartwright's Presbyterian tendencies brought upon him, as might be expected, the reprobation of Elizabeth, and also of the Primates and many of the Bishops. His 
great opponent, Dr. Whitgift, who was made Vice-Chancellor of the University in $\mathrm{I} 57 \mathrm{I}$, caused his removal from the Professor's chair, and afterwards he was excluded from the pulpit.-The testimony borne to his great virtue and learning, by an appeal on his behalf drawn up and signed by eighteen members of the University, in high repute for learning, and presented by them to the Chancellor, Lord Burghley, obtained from him an order to rescind the sentence, but it did not restore Cartwright to the free exercise of his office as Professor of Divinity-and by means of drawing up a new code of statutes, which was confirmed by the Chancellor, and afterwards turned to uses he never contemplated, Whitgift deprived him of the Senior Fellowship of Trinity College and banished him from the University. Being thus cut off from active usefulness, he withdrew to the Continent, and there cultivated the acquaintance of the most celebrated Protestant divines. Beza writing to one in England said, "here is now with us, your countryman Thomas Cartwright, than whom, I think, the sun doth not see a more learned man."

When negotiations for the Queen's marriage with the Duke D'Alençon were pending, Cartwright was urged by his friends to return "to aid them in averting so imminent a danger." He obeyed the summons; and the Lord Treasurer consulted him as well as other divines-about the marriage ; the question he put was "whether it was lawful for one professing the gospel, to marry a Papist." About this time Cartwright wrote the "Seconde Admonition to the Parliament." (The First Admonition was falsely attributed to him.) Both were answered by Whitgift. Cartwright then wrote a "Replye to an Answere made by M. Doctor Whitgifte againste the Admonition to Parliament." "The Bishops were alarmed. The Queen was indignant ;" and a command was issued to "every printer, stationer, bookbinder, merchant, and all other men who may have the custody of the said books, to bring the same to the bishop of the diocess, or to one of her Highness's Privy Council, within twenty days after he shall have notice of this proclamation, on pain of imprisonment and her Highness's further displeasure." Not a copy was brought, though Strype remarks it could not be doubted that several thousand copies were dispersed in the city and diocess.-Grindal wrote to Parker, Archbishop of Canterbury, to inform him that Cartwright was concealed in the house of Mr. Martin, a wealthy goldsmith in Cheapside; but before the Star Chamber could make

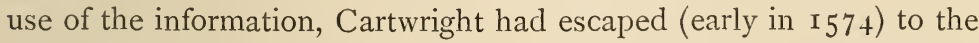
Continent. After staying a year or two at Heidelberg, he repaired to Middelburg and Antwerp, and was chosen minister, at both these places, of the English congregation.-In 1574, came out "The Defence of the Answere to the Admonition against the Replye of 
T. C." This was soon after followed by "The Second Replie of Thomas Cartwright against Maister Doctor Whitgifte's Second Answere touching the Church Discipline," and about two years later, followed "The rest of the Second Replie."-Whilst living at Antwerp, he was invited by James VI. to the office of Professor in the University of St. Andrews; and in 1576, himself an exile, he was invited by the Protestant refugees in the islands of Jersey and Guernsey, to assist them in drawing up their system of Ecclesiastical discipline. After his return from Guernsey to Antwerp, he married the sister of $\mathrm{Mr}$. John Stubbs, a barrister of Lincoln's Inn; who, for writing and publishing "The Discovery of a Gaping Gulf, whereinto England is like to be swallowed by another French marriage, if the Lord forbid not the banns;" had his right hand smitten off on the public scaffold, with a butcher's knife and mallet, and was then committed to the Tower. A severe illness and the labours and anxieties of his position had so shaken Cartwright's constitution, that his physicians recommended his return to England, and he wrote to Lord Burghley praying him to use his influence with the Queen, for his safety; and also he wrote to the Earl of Leicester, and to the Privy Council. Yet no sooner did he reach his native shore (in I 585), than he was cast into prison by Aylmer, Bishop of London. This stretch of power brought upon the bishop the Queen's displeasure, which was conveyed in a rebuke through Lord Burghley. The leaning of many of the nobles to Puritanism, caused Cartwright "speedily to find many friends amongst the most eminent laymen; and the names of the Earls of Warwick, Huntingdon, and Bedford, Lord Bacon, Sir Francis Knollys, and Sir Francis Walsingham, appear among his foremost friends and patrons." The Earl of Leicester tendered him his friendship, and appointed him master of his recently founded hospital at Warwick, which was not within episcopal jurisdiction. At Warwick he undertook the writing of "an elaborate refutation of the Rhenish translation of the New Testament." The most learned members of the universities urged him to undertake the work ; and Beza, "to whom the Queen had applied, as if the Church of England possessed no man powerful enough to cope with the chosen champions of Popery-referred her to Cartwright as far abler to defend the Protestant cause; and Sir Francis Walsingham, Secretary of State, seconded this recommendation by an urgent appeal to Cartwright to begin the work," and he enclosed $£$ roo to assist him in purchasing such books as he might need. No sooner did Whitgift learn the extent of the design, than he forbade him to proceed with it ; and Cartwright, disheartened, desisted.

He ventured, however, to preach frequently in St. Mary's church, Warwick and occasionally in neighbouring churches. The Earl of 


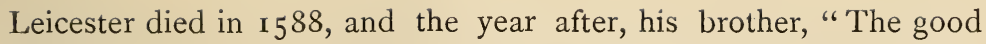
Earl of Leicester" died also — and Cartwright was now cited before the Star Chamber. Burghley contented himself with the private expression of his disapprobation, stated in no stinted terms to Whitgift. Cartwright, for refusing to take the oath, was thrown into prison. He petitioned for release, stating that he was afflicted with gout and sciatica, which the cold, damp cells of the prison greatly increased. In I59I, after having been more than a year in prison, he and his fellow-prisoners prayed to be released on bail. The Archbishop refused his concurrence, " unless they signed a submission expressly renouncing their opinions"-and they were retained in durance, till the fear of coming into collision with the Lord Treasurer, and other persons of eminence, induced Whitgift to yield. When the Queen understood he was restored to his hospital, where he now gave no cause of offence, she refused her allowance of his preaching, without subscription. He then accepted an invitation to go to Guernsey, where he met with a friendly reception from Lord Zouch, the governor of the island. About 1598 he bade adieu to his flock at Castle-Cornet, to return to his charge at Warwick, and passed the remainder of his days here in peace.

His work on the Rhenish question lay neglected for some time, but encouraged by an honourable lord, he resumed it, and at the time of his death, he had completed it as far as the fifteenth chapter of the Revelation. At his death it was thrown aside, but came forth in I6I8, some defect in the edition being excused by the printer, inasmuch as the copy had been "mouse eaten." Cartwright survived the Queen only three months. He died suddenly on the 27 th of December, 1603 ; having preached on the previous Sunday, from the text, "Then shall the dust return to the earth, and the Spirit shall return to God who gave it." 


\section{B (MEMOIR, p. I 45).}

\section{BRITISH BIRDS.}

\section{TO THE EDITOR OF "THE TIMES."}

Sir,-All lovers of nature owe The Times a great debt for its advocacy of the protection of our native birds. May I ask you to give me space for a few words on the subject?

The facts which Mr. Waterton is able to exhibit at his most interesting seat, are sufficiently conclusive to prove that we may protect our native birds without serious loss or injury. I spent the zoth of this month at Walton Hall, and once more had the pleasure of seeing what its venerable owner calls "the ordination of nature," which is simply the result of protection and non-molestation; whatever is to be there seen, is perfectly natural to this England, and might be enjoyed to a far greater degree, by the owners of many a beautiful domain.

Notwithstanding that some thirty pairs of herons are building close at hand, the fine lake abounds with pike and eels of the first quality, nor does the protection of every bird of prey, prevent the presence on this water, of hundreds of wild fowl, neither the constant residence of fourscore carrion crows, with magpies and jays in plenty, deny to Mr. Waterton as much game as should satisfy any reasonable man.

The white and brown owls abound, and, while the latter inhabit a grove of noble spruce hard by, the dovecote, to which they have free access, yielded last year above ninety dozen of young birds.

A telescope, from the drawing-room window, covered at one sight on the margin of the lake, this unusual group-four herons, three mallards, two wild ducks, three widgeons, five lapwings, two carrion crows, and a water-hen.

Now, every one who visits this place is delighted at the sight of the life and manners of these creatures, but we are in danger of making such a scene impossible.

Our country gentlemen spend large sums in the adornment of their pleasant homes, but would not these have an additional charm if more peopled by our feathered friends?

The magpie, so beautiful and gay, is always an amusement; the woodpecker, with its golden green back and crimson crest, wili, if not scared, soon become half tamed, and search even the lawn for ants; while the graceful and most useful kestrel would be almost ever on the wing. 
Yet we are fast destroying the materials, without which the History of Selborne could never have been written; and unless we take heed in time, it will be impossible for the most observant and accomplished author to produce a book of like character. I rejoice to think we are growing somewhat wiser, and beginning to see that bird life is no mean element in the charm of an English country home.

Our gratitude is especially due to Mr. Waterton, for that he has ever taught by precept, and shown by example so convincing, how this varied life may be enjoyed. Our country gentlemen have the matter in their hands.

A few words to the keeper, and to their tenants, and many inhabitants of our woodlands, now so rare, would soon again be common, doing their appointed work in nature, and giving pleasure to all intelligent observers.

I am, Sir, yours faithfully, Alfred Ellis.

Belgrave, near Leicester, March 27, 1863. 
APPENDIX.

C (Memoir, p. I 7 I).

CHAMOUNI AT SUNRISE.

FROM THE GERMAN OF FREDERICA BRUN.

From the still shadows of the tanné grove, Trembling I mark thee, as I gaze above, Eternal Mountain, dazzling summit, whence

My vaguely wandering sense

Departs, upon its world-o'erpassing flight

Soaring aloft, away into the Infinite.

Who fixed into the earth

The old millennial pillar, fast and deep,

Which in the lapse of centuries

Hath borne thee since thy birth?

Who hath uptowered along yon azure steep,

Thy bright, bold aspect, glorious to the skies?

Who poured ye out, ye jagged streams that roar

In your descending course, from the abode

Of Winter, all unchangeable and hoar?

Who hath pronounced abroad

The voice of the Omnipotent behest:

Here let these surgy shapes for ever rest!

Who gives its march unto the Morning Star?

Who wreaths the borders of eternal frost

With tenderest blooms? to whom still near and far,

O Arveiron, while around is tost

Thy wave-like anarchy-to whom arise

The accents of thy dreadful harmonies?

Jehovah! yes, Jehovah sounds aloud

When the tall iceberg's massy form is rent,

And where the toppling Avalanche is bound,

There o'er the thundering mountain's steep descent, Jehovah rustles in the bright green trees, And murmurs in the brooks and in the breeze. 


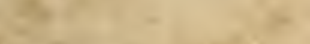
$x_{2}+2$
$577^{2}$
$r^{2}+2$

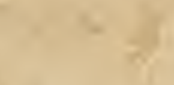

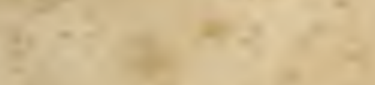

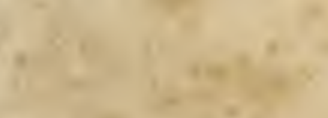

$64+2=-2$

$x+13=1$

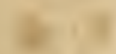

$2+7 x+2=0$

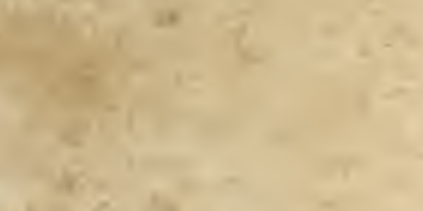

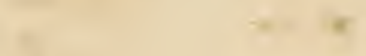$$
+2-2
$$

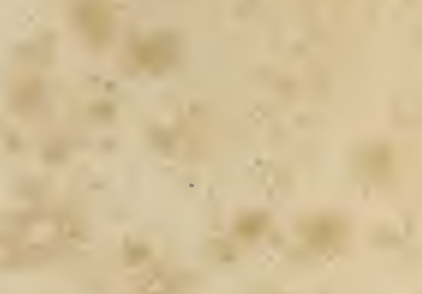
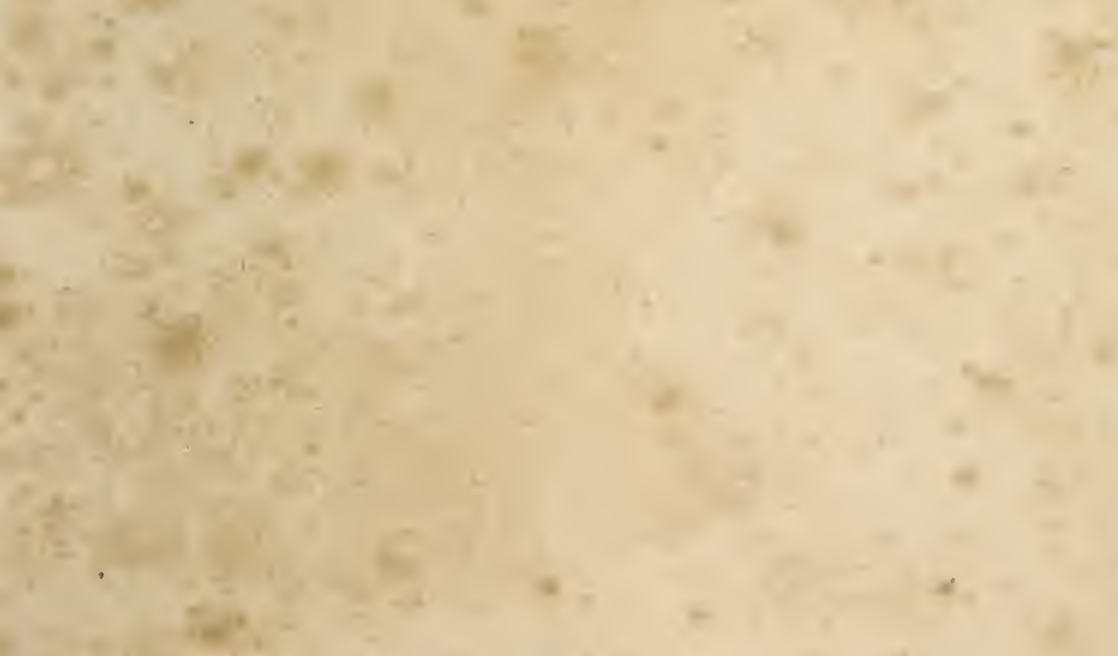


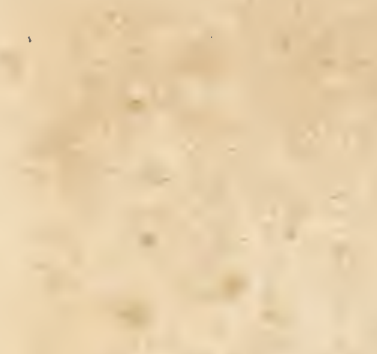

$+$

$+$

$w^{2}+2 x+5$

$+$

$\sqrt{2}$

$-1+2$<smiles>C1CC2CC12</smiles>

$-$

1

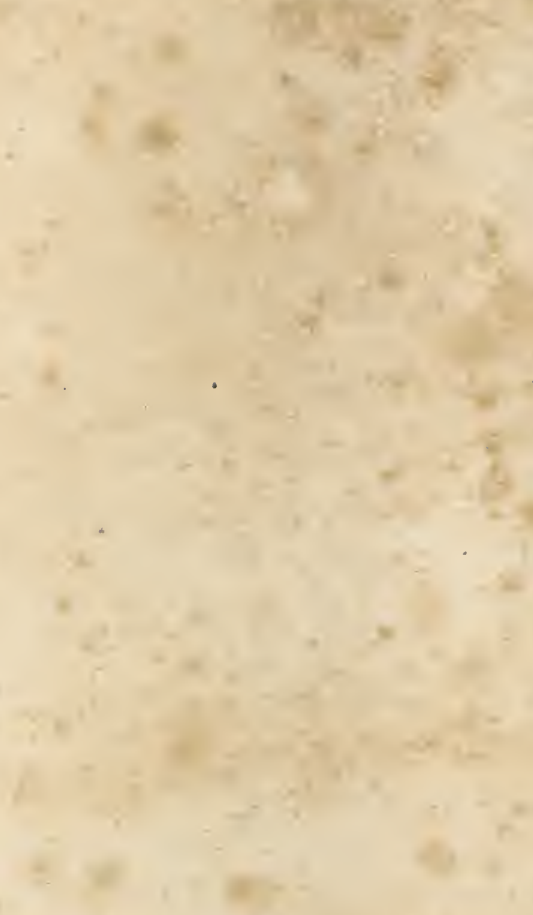

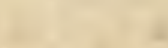

.

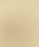
-

$$
\text { - }
$$$$
+2+2+2+2
$$

$-$ 

